


\section{TRABAJOS Y TRABAJADORES EN AMÉRICA LATINA (SIGLOS XVI-XXI)}

Rossana Barragán Romano (coord. y comp.)

Amaru Villanueva Rance y Cristina Machicado Murillo (orgs.)
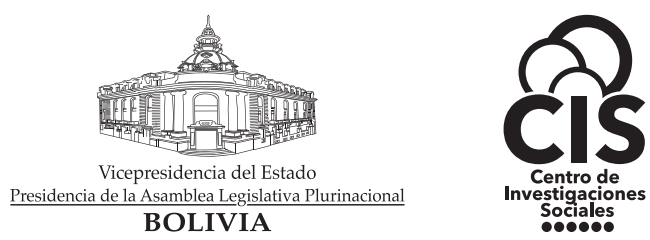

Sociales

1 2 Ministerio de

UDE INTERVENCIONES

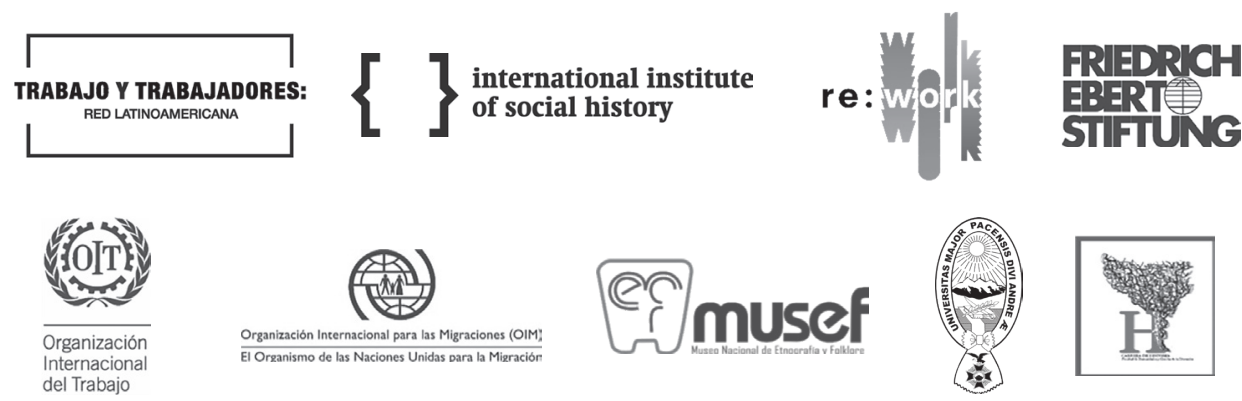


Trabajos y trabajadores en América Latina (siglos XVI-XXI) / coordinación y compilación de Rossana Barragán Romano / organización de Amaru Villanueva Rance y Cristina Machicado Murillo - La Paz : Vicepresidencia del Estado Plurinacional de Bolivia, 2019.

578 p. ; il. ; $24 \mathrm{~cm}$ - (Historia laboral)

ISBN 978-99974-77-84-2 (versión imprenta)

ISBN 978-99974-77-85-9 (versión digital)

Contiene : Prólogo / Rossana Barragán Romano, Amaru Villanueva Rance.

1. América Latina - Género del trabajo/no trabajo 2. América Latina - Historiografía del trabajo 3. América Latina - Trabajo y coacción 4. América Latina-Conflictos y luchas laborales 5. América Latina - Informalidad y precariedad I. Barragán Romano, Rossana, coordinación y compilación II. Villanueva Rance, Amaru y Machicado Murillo, Cristina, organizadores III. Vicepresidencia del Estado Plurinacional, ed. IV. Título.

Director general del CIS: Eduardo Paz Gonzales

Gestión editorial y revisión de pruebas: Claudia Dorado Sánchez

Edición académica: Rossana Barragán Romano , Paola Villarroel Oyanguren

y Cristina Machicado Murillo

Edición y corrección de estilo: Patricia Montes Ruiz

Composición de portada: Valentina Delgado Torrez

Diseño y diagramación: Gabriel Sánchez Castro

Gestión de derechos de autor y registros editoriales: Ernesto Flores Ayala

Gestión administrativa: Betty Márquez Lecoña

Derechos de la presente edición, agosto de 2019

(c) Vicepresidencia del Estado Plurinacional de Bolivia,

Centro de Investigaciones Sociales (CIS)

Calle Ayacucho esq. Mercado № 308

La Paz - Bolivia

$+591(2) 2142000$

Casilla N ${ }^{\circ} 7056$, Correo Central, La Paz

www.cis.gob.bo

ISBN: 978-99974-77-84-2 (versión impresa)

D.L.: 4-1-300-19 P.O.

Primera edición

500 ejemplares

Impreso en Bolivia

Las opiniones expresadas en esta publicación son de exclusiva responsabilidad de sus autores y no necesariamente representan la postura de las instituciones que han contribuido a su financiamiento, producción o difusión.

"Esta obra ha sido beneficiada del Programa Intervenciones Urbanas del Ministerio de Planificación del Desarrollo del Estado Plurinacional de Bolivia."

Este libro se publica bajo licencia de Creative Commons:

Atribución-NoComercial-Compartirlgual 4.0 Internacional (CC BY-NC-SA 4.0)

Esta licencia permite a otros crear y distribuir obras derivadas a partir de la presente obra de modo no comercial, siempre y cuando se atribuya la autoría y fuente de manera adecuada, y se licencien las nuevas creaciones bajo las mismas condiciones. 


\section{CRÉDITOS}

\section{AUTORES}

Mirta Lobato, Verena Stolcke, Maria Ullivarri, Fernanda Wanderley, Sabina Di Marco, Cristiana Schettini, Diego Galeano, David Mayer, Paulo Drinot, Larissa Rosa Corrêa, Fabiane Popinigis, Paulo Cruz Terra, Laura Caruso, Lucas Poy, Andrés Stagnaro, Victoria Basualdo, Paola Revilla, Christian G. De Vito, Beatriz Mamigonian, Felipe Castro, Paula C. Zagalsky, Isabel M. Povea Moreno, Francisco Quiroz, María Luisa Soux, Norberto O. Ferreras, Gabriela Scodeller, Sergio Serulnikov, Carlos Illades, Rossana Barragán R., Huascar Rodríguez García, Pablo Ferreira, Renán Vega Cantor, Luz Ángela Núñez Espinel, Gioconda Herrera, Dasten Julián Vejar, Cristina Vega y Lucrecia Saltzmann

\section{COORDINADORES, COMENTARISTAS Y COMITÉ EDITORIAL}

Laura Caruso, Larissa Rosa Corrêa, Felipe Castro, Christian G. De Vito, Gioconda Herrera, Carlos Illades, Mirta Lobato, David Mayer, Beatriz Mamigonian, Paola Revilla, Gabriela Scodeller, Julio Pinto, Lucas Poy, Verena Stolcke, Sergio Serulnikov, Andrés Stagnaro, María Ullivarri y Cristina Vega

Otros integrantes del Comité EdITORIAL

Gabriel Di Meglio, James Dunkerly,Sergio Grez y Carmen Soliz

Colaboradoras

Paola Villarroel Oyanguren y Cristina Machicado Murillo 



\section{Índice}

Presentación 11

$\begin{array}{ll}\text { Prólogo } & 13\end{array}$

Rossana Barragán Romano y Amaru Villanueva Rance

1. Género del trabajo/no trabajo 21

Introducción $\quad 23$

Mirta Zaida Lobato / Verena Stolcke / María Ullivarri

¿Qué es trabajo? Las fronteras conceptuales entre trabajo y no trabajo 33

Fernanda Wanderley

Los "sin trabajo" antes del "desocupado". Socialistas y anarquistas

en la construcción de un problema social a fines del siglo XIX

Sabina Dimarco

Una historia verosímil de la Princesa de Borbón: trabajo, género

y sexualidad en América del Sur, 1905-1919

Cristiana Schettini / Diego Galeano

2. Historiografías sobre trabajo

Introducción

Larissa Rosa Corrêa / Paulo Drinot / David Mayer

Historiografia da escravidão e do trabalho e no Brasil:

avanços e desafios

Fabiane Popinigis / Paulo Cruz Terra

Los mundos del trabajo en la historiografía argentina: sindicatos, izquierdas y género, una mirada de conjunto

Laura Caruso / Lucas Poy 
8 Trabajos y trabajadores en América Latina (siglos XVI-XXI)

Para una historia de la Organización Internacional del Trabajo y América Latina: perspectivas, problemas y trabajo colaborativo

Laura Caruso / Andrés Stagnaro

Dictaduras, trabajadores y sindicatos en la segunda mitad del siglo XX: propuestas para un diálogo entre los casos de Argentina, Brasil, Chile, Paraguay y Uruguay

Victoria Basualdo

3. Trabajo y coacción

Introducción

Paola Revilla / Christian G. De Vito

Un mundo diverso: una panorámica sobre los trabajadores mineros coloniales a partir del análisis de casos en los virreinatos de Nueva España y del Perú

Paula C. Zagalsky / Isabel M. Povea Moreno

Aprendiendo juntos: indios, negros libres y esclavos en talleres de la Lima colonial

Francisco Quiroz

Yanaconas, colonos y arrenderos: contradicciones entre la ley y la práctica en el trabajo rural durante los siglos XIX y XX en Bolivia María Luisa Soux

La discusión sobre el trabajo forzado en Brasil y Argentina en diálogo con la Organización Internacional del Trabajo

Norberto O. Ferreras

4. Conflictos y luchas

Introducción

Gabriela Scodeller / Lucas Poy / Sergio Serulnikov / Carlos Illades

El "bien público" del trabajo compulsivo en entredicho: contrapuntos de voces y acciones en Potosí (siglos XVII-XVIII) Rossana Barragán R. 
Índice 9

Pícaros y ladrones. Robo campesino y bandidaje en el Valle Alto (Cochabamba, 1880-1930)

Huascar Rodríguez García

Los lugares de la política plebeya en Montevideo, 1806-1817

Pablo Ferreira

Los trabajadores petroleros en el enclave de la Tropical Oil Company:

formación, cultura y resistencia (1920-1948)

Renán Vega Cantor / Luz Ángela Núnez Espinel

5. Informalidad y precariedad

Introducción

Gioconda Herrera

Sociedad precaria en Chile: la "tragedia" de los 33 mineros

Dasten Julián Vejar

Protagonismo femenino y construcción de la ocupación. La apropiación del espacio urbano por parte de las vendedoras minoristas en la Martha Bucaram (Quito, Ecuador)

Cristina Vega / Magali Marega / Lucrecia Saltzmann 



\section{Presentación}

Pocas cosas modelan los contornos de una sociedad de modo tan determinante como la organización del trabajo. A la vez, las relaciones y las características concretas del trabajo resultan decisivas de la experiencia vital de cada sujeto. El trabajo es, pues, un eje estructurante que va de lo macro a lo micro y que es distinguible en cada momento histórico bajo las marcas propias de su tiempo y su ubicación. Trabajos y trabajadores en América Latina (siglo XVI-XXI) es un libro que da fe de esa diversidad y riqueza. Nos lleva por las indagaciones minuciosas que desentrañan las características del trabajo forzado en el mundo colonial hasta las formas contemporáneas de trabajo precario en las metrópolis. Nos lleva desde cruentas formas de explotación hasta las formas de resistencia de los trabajadores, sus formas de organización y su demanda de derechos. Hombres y mujeres de distintas clases y etnias son retratados en las actividades en las que plasmaron sus vidas a fin de mostrarnos con lentes novedosos los perfiles del trabajo, de trabajadores y trabajadoras, de sus actividades, sus relaciones y sus luchas.

Para el Centro de Investigaciones Sociales (CIS) de la Vicepresidencia del Estado Plurinacional de Bolivia, la publicación de este libro marca un punto de llegada -aunque sea solo momentáneo- en el que se valora a los compañeros de ruta. Desde la organización del Congreso de Trabajo y Trabajadores en 2017 hasta el cuidado de la edición de este texto, el CIS ha compartido este trayecto con instituciones que en las personas de sus representantes se han portado generosas con el proyecto. Igualmente, la pluralidad de enfoques sobre el tema debe su riqueza a más de 30 autores que con rigurosidad y talento han sabido plasmar sus reflexiones en las páginas que siguen. Merecen un agradecimiento especial, en tanto artífices, Rossana Barragán y Amaru Villanueva, motores en el centro de esta empresa. Este entramado de relaciones interinstitucionales y personales nos recuerda que la producción de conocimiento es una tarea colectiva que hace brotar sus mejores frutos en el intercambio, el diálogo y el debate. Es en el contraste y la comparación que las rupturas muestran su sentido más profundo, así como las continuidades se hacen más comprensibles.

La publicación de este volumen reafirma el compromiso del CIS con los estudios sobre el mundo del trabajo y de los trabajadores. La centralidad del tema y las enseñanzas de este texto abren vetas prometedoras que de ningún modo se agotan en los artículos aquí presentados. Hay mucho por indagar 
12 Trabajos y trabajadores en América Latina (siglos XVI-XXI)

sobre las relaciones que vinculan a los trabajadores de modo continental, tanto por las relaciones de mercado como por los intercambios de naturaleza política. En otro filón encontramos todo un territorio de fronteras porosas entre lo que consideramos trabajo y aquello que en un pasado muy reciente no se lo consideraba como tal, como el cuidado o las tareas reproductivas. Igualmente hay un énfasis que nos lleva a recuperar la agencia de los trabajadores para revertir una imagen maniquea en la que aparecían desprovistos de recursos e iniciativa. Solo tres apuntes, inventariados rápidamente, para mostrar la agenda de investigación que un libro como Trabajos y trabajadores en América Latina (siglo XVI-XXI) nos deja para profundizar en la reflexión

Eduardo Paz Gonzales 


\title{
Prólogo
}

\author{
Rossana Barragán Romano \\ Amaru Villanueva Rance
}

\section{ATRAVESANDO TIEMPOS Y FRONTERAS}

El trabajo es una experiencia multifacética que nos constituye desde nuestra cotidianidad. Atraviesa los tiempos y, sin embargo, la "historia laboral" se ha restringido a la de los obreros de la industria (desde fines del siglo XIX), olvidando el amplio universo de los no asalariados permanentes y de los sujetos a diferentes grados de coacción, como también el de las mujeres y sus múltiples modalidades laborales retribuidas y no retribuidas. Las reflexiones sobre el trabajo atraviesan también las fronteras, aunque las establecidas entre los académicos del sur con los del norte pueden ser más habituales que las existentes entre los propios países de América Latina. El trabajo es transversal también a muchas disciplinas aunque se limita muchas veces a miradas muy específicas, cortándose de las aproximaciones de historiadores, sociólogos o antropólogos, entre algunas de las perspectivas de las ciencias sociales. El libro Trabajos y trabajadores en América Latina (siglos XVI-XXI) busca sobrepasar esas limitaciones para repensar qué es trabajo, y cuáles son sus fronteras, sistematizar las tendencias historiográficas existentes, revisar los conflictos en torno al trabajo, así como analizar la informalidad y la precariedad laboral. Son estos cinco ejes los que estructuran los aportes y las reflexiones de más de 30 estudiosos de distintos países latinoamericanos, gracias a un largo esfuerzo colectivo de instituciones y de investigadores.

\section{EL CONGRESO DE 2017: SUMANDO ESFUERZOS PARA ESCUCHARNOS}

Esta publicación es la concreción de un amplio y vívido congreso que se llevó a cabo del 2 al 8 de mayo de 2017 en la ciudad de La Paz (Bolivia), en el que participaron al menos 89 personas de 17 países, además del público asistente. Todos convergieron en actividades que incluyeron dos mesas redondas, dos conferencias magistrales y siete paneles o sesiones temáticas en las que se presentaron 47 ponencias que se programaron de forma secuencial (y no así paralela), con el fin de permitir a toda persona poder asistir a las distintas sesiones y escuchar investigaciones sobre la dinámica laboral desde el siglo XVI hasta la actualidad. Su particularidad fue, además, que no se trató únicamente de un debate entre académicos, dado que entre los participantes se contó también con actores sociales que forman parte de la vida pública, incluyendo autoridades de Estado, representantes institucionales y trabajadores vinculados al ámbito agrario y sindical.

Dar curso a esta iniciativa no fue tarea sencilla, pero el desafío resultó gratamente asumido por varias instituciones y las personas que las constituyen. $\mathrm{La}$ 
idea fue concebida en el Instituto de Historia Social (IISG por su nombre en holandés), y se sumó como coorganizador el Centro de Investigaciones Sociales (CIS) de la Vicepresidencia del Estado Plurinacional de Bolivia. No tardaron en adherirse instituciones que encontraron esta iniciativa en sintonía con sus propios objetivos y facilitaron el traslado a La Paz de decenas de personas de distintos países. La Fundación Friedrich Ebert (FES) se sumó dada su misión institucional relacionada con la reflexión sobre sindicatos y trabajadores. Dos oficinas del sistema de Naciones Unidas en Bolivia también expresaron su interés por acompañar esta iniciativa: la Organización Internacional para las Migraciones (OIM), que coincidió con el planteamiento de varios panelistas acerca del estrecho vínculo entre los fenómenos migratorios humanos y las relaciones laborales; y la Organización Internacional del Trabajo (OIT), a la que no le faltaron razones para apoyar de manera transversal. Considerando la dimensión internacional de este congreso y sus propósitos, Re:Work, de Alemania, igualmente ofreció su apoyo y representación.

Una vez programada la realización del congreso, el Museo Nacional de Etnografía y Folklore (MUSEF) abrió sus puertas a los asistentes y se constituyó en un espacio ideal para la realización de un encuentro de esta naturaleza. Por su parte, la Carrera de Historia de la Universidad Mayor de San Andrés (UMSA), cuyos alumnos participaron del evento, brindó un espacio propio para la presentación de publicaciones. Finalmente, el Ministerio de Planificación, mediante el Proyecto de Intervenciones Urbanas (PIU), añadió parte de sus recursos al "aptaphi" para hacer posible la impresión de la presente publicación. En suma, fueron al menos nueve las instituciones que colaboraron generosamente de distinta manera para llevar adelante esta iniciativa y su posterior materialización en formato de libro.

La iniciativa de todo este proyecto partió de historiadores trabajando temas afines a la historia socio-laboral, que vieron la pertinencia de sumar investigadores de otras disciplinas como la sociología, la antropología, la economía y la geografía. Esto confiere una innegable característica transdisciplinaria al esfuerzo conjunto, la misma que es cada vez más necesaria para estudiar los mundos del trabajo, no solo desde el ayer de sus instituciones y relaciones interpersonales, sino desde el presente y mirando posibles futuros. La estructura resultante está constituida por cinco secciones generales: "Género del trabajo/ no trabajo", "Historiografías sobre trabajo", "Trabajo y coacción", "Conflictos y luchas" e "Informalidad y precariedad". Cada una es introducida y comentada por investigadores e investigadoras que han sido sus coordinadores y comentaristas, y que han enriquecido el libro al encargase de presentar tanto las temáticas que se abordan como los principales argumentos y los aportes de los autores. Remitimos a leer las cinco introducciones magistrales de nuestros colegas. Aquí nos interesa explicitar cómo cada uno de los artículos, a pesar de insertarse en una sección, contribuye a pensar los temas de las otras secciones. Considerando, por una parte, que cada uno de los artículos despliega panoramas sobre la literatura de los temas específicos que aborda, y, por otra, que los 
artículos de la sección "Historiografías sobre trabajo" contribuyen también, de manera muy interesante, a pensar las otras secciones, vamos a referirnos en este prólogo a los ejes que tienen que ver con las mujeres, con el trabajo y con la coacción, los conflictos y la informalidad/precariedad.

\section{Redefiniendo el "trabajo" con las mUJeres y sobrepasando los mUROS de BerlíN}

El libro se abre con varias reflexiones de mujeres y sobre mujeres y género, y el texto se cierra también con ellas, desde las calles de un mercado abierto en Ecuador, que remite a la situación que se encuentra en muchas de las ciudades de América Latina. Este inicio y fin no es casual: si los múltiples trabajos de las mujeres a través de los siglos, fundamentalmente desde fines del siglo XVIII, fueron considerados como no productivos, y a partir de entonces fueron paulatinamente invisibilizados, son las reflexiones de las mujeres las que han permitido y permiten develar esas miradas. Las historiadoras Mirta Lobato y María Ullivarri, junto con la antropóloga Verena Stolcke, son las que introducen los tres trabajos iniciales que nos llevan a pensar, desde lugares distintos, el trabajo, el no trabajo y el género del trabajo. Fernanda Wanderley realiza un recorrido en el que delinea el proceso de invisibilidad del trabajo no remunerado y "fuera del mercado", conduciendo a marginalizar muchas de las actividades de las mujeres. Esta mirada se prolonga hasta hoy y la autora nos recuerda que la estructura de todo el sistema estadístico se ha construido diferenciando la población económicamente activa (PEA) de la población económicamente inactiva (PEI), categorías que establecen, respectivamente, la frontera entre "trabajo" y "no trabajo", y por ende el mundo de "los trabajadores" con derechos. En contraposición, "los sin trabajo" a principios del siglo XX componen la base de reflexión de Sabina Dimarco. Ella analiza cómo se fue constituyendo el concepto del "desocupado" o la involuntaria falta de trabajo, que solo pudo emerger cuando el empleo y el salario se iban generalizando, cuando surgió la cuestión obrera y cuando se generalizó la propia proletarización. La autora explora esa categoría no solo como resultado de las políticas desde los reformadores, sino más bien desde un espacio distinto, no estatal, entre los periódicos socialistas y anarquistas tan importantes en la Argentina de esa época.

Las fronteras, o más bien los umbrales borrosos o transitados entre trabajo doméstico, sexual, de género, artístico, y los puertos de distintos países (de Brasil y Uruguay), son analizados y explorados por Cristiana Schettini y Diego Galeano, con la historia y la encarnación de la llamada Princesa de Borbón, conocida, al igual que muchas otras personas, como "ladrón vestido de mujer". Estos mundos de personas transgénero son los que escapan no solo a las estadísticas, sino que develan cómo se construyó el concepto de lo que no podía ser concebido como trabajo, como el sexo/género que no podía concebirse.

Otros aportes del libro nos hacen repensar en lo que se ha denominado el "muro de Berlín historiográfico", expresión acuñada por Silvia Lara (1998) y por Sidney Chalhoub y Fernando Teixeira da Silva (2009) para designar la 
tajante división existente entre las investigaciones dedicadas a la historia de la clase obrera industrial con las investigaciones dedicadas al análisis del trabajo doméstico, esclavo y otras actividades con mayor o menos coacción y dependencia que existían entre los siglos XVI y XVIII, y que en muchos casos persistieron hasta fines del siglo XIX o persisten hasta hoy. Ese muro historiográfico está aún presente en Argentina, como en muchos otros países, tal como revelan Laura Caruso y Lucas Poy. En Brasil, en cambio, Fabiane Popinigis y Paulo Terra nos muestran cómo se ha criticado, y en gran parte sobrepasado, la estrecha identificación del trabajo con el salario y con la capacidad de organización y de movilización de la mano de obra europea de los migrantes, en oposición a la pasividad supuesta y atribuida a los esclavos. La rica historiografía brasileña ha mostrado también cómo los propios cautivos podían recibir remuneraciones y tener distintos grados de autonomía, revelando mucha más cercanía entre obreros y esclavos que lo que se había pensado en un momento dado. La historiografía laboral argentina, al contrario, como sintetizan Caruso y Poy, aunque aún se encuentra preferentemente anclada en periodos recientes e industriales, está realizando importantes contribuciones que han procedido, primero, a situar y cartografiar el trabajo de las mujeres, identificando la importancia de determinados sectores, entre ellos la alimentación y la industria textil, los servicios, el cuidado de la salud, la educación, el servicio doméstico y el trabajo a domicilio. Esta preocupación ha ampliado indudablemente el mundo del trabajo, contribuyendo también a repensar una historia social de la clase trabajadora con perspectiva de género, de tal manera que se generiza también el estudio de la participación gremial y política de las demandas obreras y de la protesta.

Pero el trabajo no solo se define y se regula local o nacionalmente, sino también en relación con el mundo. Laura Caruso y Andrés Stagnaro muestran cómo el contexto internacional y las organizaciones transnacionales como la Organización Internacional del Trabajo (OIT) fueron actores fundamentales para redefinir las condiciones laborales $y$, sobre todo, las condiciones y los derechos en muchas partes del mundo, y por supuesto en América Latina. De ahí también que se fueran construyendo instituciones estatales con potestad sobre las cuestiones del trabajo que permitieron visibilizar las demandas desde los trabajadores, implicando también la formación de burocracias profesionales productoras de conocimiento y de regulación del mundo del trabajo.

\section{LOS APORTES PARA PENSAR LOS TRABAJOS Y LA COACCIÓN}

La minería de la plata en el virreinato del Perú o en el de Nuevo México resulta fundamental en tanto espacio en el que se tuvieron las primeras experiencias de congregación de trabajadores, como no se había dado antes y como no se daba ni siquiera en las metrópolis europeas. Paula Zagalsky e Isabel Povea, precisamente, comparan el tipo de trabajadores que tuvieron las minas de Potosí y de Guanajuato en sus momentos de auge, en el periodo comprendido entre los siglos XVI y XVII, y en el siglo XVIII. Las similitudes y las diferencias son 
claramente resaltadas por sus autoras. Entre las primeras destaca el sistema de trabajo de repartimiento minero, que podemos definirlo como asignado por las autoridades a determinadas minas y a sus propietarios, la existencia de mano de obra libre o la costumbre de otorgar parte de la producción obtenida para atraer trabajadores. Entre sus diferencias, en cambio, sobresale ciertamente un mundo casi exclusivamente indígena en Potosí, en el que la intervención de la Corona y sus representantes era fundamental, frente a una diversidad de trabajadores entre mestizos, indígenas o mulatos en Guanajuato.

Es el mundo diverso que se encuentra en Lima, una de las ciudades más importantes a lo largo del periodo colonial, del que Francisco Quiroz revela el universo de los artesanos que podían "coexistir juntos pero no revueltos". El autor muestra que los gremios españoles se fueron formando frente a la competencia de otros grupos, indígenas, negros esclavos y libres (había oficiales esclavos). Fundamental resulta también la complejidad que tenían las remuneraciones, en servicios, especie y dinero, en sus más variadas combinaciones, pero, además, las grandes brechas existentes al interior de una sola categoría, la de los oficiales españoles, por ejemplo, lo que alerta a tomar en cuenta no solo la heterogeneidad de los artesanos, sino también los análisis globales sobre salarios.

El artículo historiográfico de Fabiane Popinigis y Paulo Terra contribuye también a pensar otro tema, el de la autonomía/dependencia y la coacción de los trabajadores, al recordarnos cómo los contratos de trabajo supuestamente libres podían parecer esclavizantes, porque los patrones buscaban mantener la subordinación de los nuevos trabajadores libertos, o cómo los Africanos y los indígenas libres fueron sometidos a formas de trabajo compulsorios tanto de parte de particulares como del Estado, especialmente en trabajos públicos.

El área rural y los espacios de producción de las haciendas en base al trabajo diverso de campesinos se encuentra en las investigaciones de María Luisa Soux y de Huascar Rodríguez, sobre Cochabamba (Bolivia) en los siglos XIX y XX. Soux plantea que junto al término colonial de yanacona, para designar a los trabajadores adscritos a las haciendas, empezaron a utilizarse los de colonos y arrenderos, de tal manera que se estaría frente a un contrato de arrendamiento a cambio de diferentes tipos de pago, entre ellos los llamados "servicios personales" o trabajos cumplidos en las casas de los hacendados. Fueron estas labores consideradas las más abusivas y "serviles", identificadas por los propios dirigentes indígenas como trabajos de esclavos, profundamente cuestionados a partir de 1938. Rodríguez nos revela la variedad de situaciones de los trabajadores agrarios, que intercambiaban su fuerza laboral y parte de su producción por el usufructo de una parcela de subsistencia, bajo la denominación de "colonato", pero también nos hace conocer la diversidad dentro del propio mundo indígena. El caso de los "aparceros", o pago del colono al hacendado en especies, se presentaba de ese modo como uno de los posicionamientos relativamente privilegiado, mientras que los "sitiajeros" se encontraban en el otro extremo, ya que no tenían ningún acceso a tierras de cultivo, por lo que realizaban cualquier 
tipo de servicio/trabajo en las fincas/haciendas a cambio de diminutos espacios donde construían sus chozas. El "arrimante", por su parte, tenía un subalquiler y se establecía en tierras del aparcero a cambio de pagos en especie o en trabajo, ayudando también al colono a cumplir sus obligaciones con la hacienda. Por último, estaban los "desahuciados" o campesinos que no tenían casi ninguna opción para subsistir, viéndose generalmente obligados a incursionar en actividades fuera de la ley. Una cadena muy visible de mayores y menores dependencias y arreglos de trabajo en una sociedad de alta densidad demográfica.

Los trabajosindígenas no esclavos pero tampocolibres, que se conocían como "trabajo forzado/obligatorio" en el sistema internacional y como "peonaje por deuda y especies" en el continente americano, constituyen el tema de análisis de Norberto Ferreras, poniendo en diálogo a la OIT, Argentinay Brasil. El autor nos muestra cómo los dos países latinoamericanos preferían el término "trucksystem" o pago en especies, negando la existencia de una situación laboral a la que consideraban propia de los países coloniales.

La rapidez de los cambios ligados a la explotación de recursos naturales en manos de empresas norteamericanas es muy clara en el caso del enclave de petróleo en Barranca Bermeja, en Colombia, del que nos hablan Renán Vega Cantor y Luz Ángela Núnéz. De un poco más de 400 habitantes en 1907 pasó a tener 5.000 trabajadores y 12.000 habitantes en 1927, hasta constituirse en uno de los centros de mayor concentración obrera de Colombia en 1938.

Como en un contrapunto, las mujeres en la calle, autoempleadas y autoorganizadas, constituyen la otra cara de ese mundo masculino obrero al que hicimos referencia y que en el presente, en medio de desregulación y de precariedad laboral, pareciera remitirse solo a un pasado lejano y a un grupo privilegiado. En lugar de demandas de mejores salarios, las mujeres de hoy deben luchar por la posibilidad de construir su trabajo, como nos lo recuerdan Cristina Vega, Magali Marega y Lucrecia Saltzmann.

\section{LOS APORTES PARA REPENSAR EL MUNDO DE LOS CONFLICTOS}

La historiografía brasileña es también muy rica e inspiradora para pensar lo que se denomina de manera amplia como "conflictos", porque muestra cómo los esclavos no solo eran sujetos de violencia, sino también importantes actores que tenían constantes procesos de negociación con sus amos, y cómo su lucha acumulada fue utilizada, luego, por diversos grupos de trabajadores libres y no libres para reivindicar mejores condiciones de trabajo individuales y colectivos.

Para el caso de los trabajadores de la minería de la plata, Rossana Barragán remarca cómo se buscó diferenciar el trabajo de la mita potosina de los "servicios personales" gratuitos y forzosos, cuestionados desde Bartolomé de las Casas. El carácter de compulsión temporal que tenía se justificó, en gran parte, en nombre del "bien público" de la monarquía. Fue ese "bien público" que se puso en entredicho desde arriba, con las discusiones sobre la mita entre las autoridades, 
y desde abajo, es decir desde las acciones variadas de los trabajadores, llegando a modificar, en parte, el escenario laboral.

Pablo Ferreira cubre un periodo propicio para la participación "popular" en Montevideo (Uruguay), entre 1806 y 1817, cuando se produjo la crisis política en la península ibérica, desatando una serie de movimientos en los que participaron grupos de pardos y morenos libres, propiciándose, incluso, la fuga de esclavizados bajo la promesa de libertad a cambio de su incorporación a los ejércitos revolucionarios. En síntesis, la participación política se incrementó apelando a las clases populares, las que finalmente tuvieron grados de incidencia en las decisiones, contribuyendo también al temor que suscitaron entre las élites.

Otro escenario analizado por Huascar Rodríguez es la situación de estrechez de los campesinos del área rural en Cochabamba, en el que emergieron prácticas consideradas de "robo", como el chajmeo, toleradas y/o autorizadas por los propietarios, recordando la actividad de los k'ajchas en las minas potosinas del siglo XVIII y el juqueo minero que existe hasta hoy. El chajmeo podía aparecer a los ojos de los campesinos como legítimo frente a tierras que podían ser consideradas como suyas, pero también como un impuesto de facto o un intento de redistribución por el monopolio que tenían los hacendados.

La situación que se presenta en el enclave petrolero en Barranca Bermeja resulta más clásica. Renán Vega Cantor y Luz Ángela Núñez plantean la importancia de compartir las experiencias de lazos de solidaridad entre los obreros, conformando comunidades "cosmopolitas" en términos ideológicos. El sindicato de la Unión Obrera de la década de 1920 fue capaz de desarrollar huelgas sucesivas relevantes, atrayendo la visita de importantes líderes sindicales de México, como Vicente Lombardo Toledano. La huelga de 1948 habría logrado, finalmente, iniciar el proceso hacia la reversión de las concesiones, dando lugar a la Empresa Colombiana de Petróleos en 1951.

La dimensión transnacional de las luchas y de los conflictos es analizada por Victoria Basualdo, al sistematizar las investigaciones existentes y reflexionar sobre las dictaduras y los trabajadores en Argentina, Brasil, Chile, Paraguay y Uruguay. En un esfuerzo abarcador, la autora compara y discute las políticas dirigidas a "descabezar" a las bases, imponiendo una disciplina en el lugar de trabajo, el concepto de la "resistencia" o las líneas de acción y organización de los trabajadores, así como las críticas que han ido señalando los diversos grados de consentimiento del mundo trabajador con las dictaduras.

La organización de los trabajadores, incluso como ambulantes, resulta crucial. Es lo que hacen las mujeres de Quito, que se asocian y, gracias a esa organización, se convierten en interlocutoras con las autoridades de gobierno.

LA INFORMALIDAD Y LA PRECARIEDAD DE HOY (¿O LA DE SIEMPRE?)

Dasten Julián Vejar nos conduce por uno de los países más neoliberales y privatizados de América Latina, Chile, planteándonos la existencia de una 
economía de empleos y de trabajos precarios en la minería, que es ya parte de un "patrón histórico", de tal manera que lo sucedido en la Mina San José con los 33 mineros que quedaron atrapados en 2010 no resulta casual sino, más bien, sintomático de esa economía y sociedad.

La informalidad en Ecuador, como en muchos países de América Latina, es común en la mayoría de las mujeres que trabajan en condiciones precarias, con bajos ingresos y desprotección social. Son en gran medida mujeres indígenas que crean sus fuentes de trabajo y que nos llegan de la mano de Cristina Vega, Magali Marega y Lucrecia Saltzmann. Son mujeres que ocupan las calles como modo de sobrevivencia, buscando no solo afincarse sino también preservar su autonomía frente a lo que podrían ser lazos de dependencia, orden y jerarquía, que ellas lo expresan claramente: no quieren ser "ordenadas de nadie". Allí, en la calle, donde se unen o se borran las fronteras de lo público y lo privado, del mercado y del trabajo no remunerado, las mujeres van construyendo sus territorios de trabajo.

\section{$\infty \cdots$}

\section{TRABAJANDO EL LIBRO, CONSTRUYENDO SUS EJES Y SECCIONES}

Esta compilación es producto del trabajo de varias personas que participaron en el congreso como panelistas, coordinadores y comentaristas, en base al cual se conformó un Comité Editorial. Este comité implementó un sistema de revisión de pares anónimos que evaluó los trabajos, permitiendo a sus autores contar con la retroalimentación y los comentarios necesarios para enriquecer sus artículos. El esfuerzo conjunto, que requirió ciertamente mucha energía y tiempo, hoy se ve recompensado en un resultado gratificante. Esto se debe no solo a la diversidad y a la calidad de los textos reunidos, sino a la dinámica de trabajo que ha alcanzado la Red Latinoamericana Trabajo y Trabajadores (RedLatt), que no cesa de avanzar en el presente con nuevos y diversos objetivos.

El logro de esta publicación ha sido posible gracias a cada una de las personas que ha aportado con su investigación. Nuesto agradecimiento especial para Mirta Lobato, Verena Stolcke, Sergio Serulnikov, David Mayer, Paola Revilla, Carlos Illades, Christian G. De Vito y Paulo Drinot, así como para todos los coordinadores, los comentaristas y los integrantes del Comité Editorial. Nuestras gracias también para todas las personas que participaron activamente en la organización del congreso, particularmente a Cristina Machicado y Paola Villarroel Oyaguren. Finalmente, para el CIS, especialmente para Valentina Delgado, Gabriel Sánchez y Claudia Dorado, por su alto compromiso profesional durante el proceso de edición y diagramación. 
GÉNERo del trabajo/No trabajo 



\title{
Introducción
}

\author{
Mirta Zaida Lobato (Argentina)* \\ Verena Stolcke (Alemania/España)** \\ María Ullivarri (Argentina) ${ }^{* * *}$
}

¿Qué es el trabajo? Aunque parece una pregunta demasiado simple, las respuestas son múltiples y complejas, y, como muestra este libro, existe una enorme cantidad de estudios que tratan de explicarlo. Una definición tan elemental como que "se denomina trabajo a toda aquella actividad, ya sea de origen manual o intelectual, que se realiza a cambio de una compensación económica" ${ }^{1}$ puede ser muy útil para presentar estos tres primeros trabajos del libro.

A simple vista, los tres artículos de este apartado parecen referirse a actividades y a contextos temporales y espaciales muy distintos, pero en el fondo ofrecen explicaciones complementarias que revelan de qué modo surge el contraste entre lo que se considera trabajo/no trabajo.

Así, el texto de Fernanda Wanderley, "¿Qué es trabajo? Las fronteras conceptuales entre trabajo y no trabajo", da cuenta de los debates contemporáneos en las ciencias sociales sobre las fronteras entre lo que se considera trabajo y no trabajo. Lo hace desde la sociología, y reconoce y analiza los argumentos de quienes participan en las controversias. Explora también el desarrollo del concepto de "trabajo de cuidado" y sus implicancias en la discusión pública y para las políticas públicas. De esta manera, Wanderley hace hincapié en un aspecto ideológico decisivo, con frecuencia oculto, como los criterios socioculturales y políticos de género que han ido configurando (y continúan haciéndolo) los modos de ver, entender y compensar los trabajos/no trabajos.

Hace décadas que investigadoras feministas han rescatado de su invisibilidad y carencia de reconocimiento la gran gama de labores domésticas que suelen realizar las mujeres en las familias y que eran (y son) consideradas como obligaciones “naturales”. Esa 'naturalización' como no trabajo explica y justifica la ausencia de remuneración. Como los estudios feministas han

\footnotetext{
* Universidad de Buenos Aires (UBA).

** Universidad Autónoma de Barcelona (UAB).

*** Consejo Nacional de Investigaciones Científicas y Técnicas (CONICET), Universidad Metropolitana para la Educación y el Trabajo (UMET), Centro de Innovación de los Trabajadores (CITRA).
}

1 Véase: https://definicion.mx/trabajo/ (fecha de consulta: 1 de octubre de 2017). 
mostrado más recientemente, la misma lógica se aplica al amplio campo de los cuidados de personas (niños y niñas, ancianos y ancianas, y personas enfermas), realizados "naturalmente" por mujeres.

El artículo de Sabina Dimarco, titulado "Los 'sin trabajo' antes del 'desocupado'. Socialistas y anarquistas en la construcción de un problema social a fines del siglo XIX", examina el debate político sobre el "no trabajo" en una época y en un entorno geopolítico concreto, ofreciendo un fascinante contrapunto al artículo que le precede. Mientras que Wanderley muestra que es indispensable tener en cuenta las representaciones de género/sexo para comprender lo que se entiende por trabajo, Dimarco, por el contrario, estudia los usos de categorías explícitas de clase aplicadas al no trabajo que se desarrollaron en Argentina a fines del siglo XIX e inicios del XX, en tiempos de la inmigración transatlántica masiva y de una crisis económica y política que generó desempleo. Ella analiza dos publicaciones de política y divulgación obrera de la época, El Obrero, de tendencia socialista-marxista, y El Perseguido, de inspiración anarquista-comunista, que denunciaban la falta de trabajo como problema social.

En el lenguaje obrero, a los parados se los llamaba desocupados, aludiendo a la política de despidos de los empresarios, en contraste con los diversos términos moralistas que la burguesía les confería. El punto de partida para formular los interrogantes sobre las ideas de anarquistas y de socialistas en el viraje del siglo XIX al XX es el estallido social de diciembre de 2001 en Argentina. Ese mes emergió con crudeza, aunque el problema no era desconocido, el fenómeno de la desocupación, no como una dificultad coyuntural sino como parte de una estructura económica y social que persiste hasta hoy. Dimarco filia su investigación con las reflexiones de algunos sociólogos, pero también con una tradición que relaciona la historia de los conceptos y la historia social, y que tuvo una de sus primeras expresiones en el trabajo de Reinhart Koselleck, "Historia conceptual e historia social" (1993), en el que destaca la importancia de la exégesis de los textos en la consideración y uso de conceptos, así como los momentos de permanencia y de cambio en sus contenidos (ibid: 105-126).

La insólita trayectoria de la célebre princesa de Borbón entre los puertos de Buenos Aires, Montevideo y Río de Janeiro, igualmente a inicios del siglo XX, que presentan Cristiana Schettini y Diego Galeano en "Una historia verosímil de la princesa de Borbón: trabajo, género y sexualidad en América del Sur, 1905-1919", revela toda una serie muy poco convencional de estrategias de supervivencia. Las posibilidades de trabajo remunerado eran escasas para las mujeres solteras. Así, entre aquellas que llegaban solas a los puertos sudamericanos había quienes se procuraban fuentes de vida al margen del mercado de trabajo convencional, tales como la prostitución, actividades artísticas en pequeños teatros o como sirvientas domésticas. Más allá de mostrar las diferentes actividades que existían en la época para algunas mujeres, resulta interesante en 
este estudio el papel de la intersección de estrategias de supervivencia, género y sexualidad que a menudo implicaban suspicacias que las involucraban con actividades delictivas. La designación de "ladrón vestido de mujer" que se le atribuyó en algún momento a la princesa de Borbón hacía precisamente hincapié en las prometedoras ventajas, pero también en los riesgos que podía implicar el ser o presentarse como mujer. Así, parecería que pretender ser contratada como sirvienta, cuya labor por definición significaba franquear el espacio doméstico de quien la empleaba, podía ocasionar la sospecha de robo.

En este último artículo pueden encontrarse las palabras clave que la historia social con perspectiva de género ha desarrollado en la producción académica de los últimos 30 años. Aunque la categoría de género es considerada hoy como ambigua o inestable ${ }^{2}$ lo cierto es que, imbricada con las prácticas historiográficas de la historia social y cultural, ha generado estimulantes interpretaciones sobre el pasado.

La historia, la antropología, la filosofía y la geografía pueden trazar sus genealogías respecto a los estudios que colocan como central las diferencias de sexo/género en las relaciones de poder de una sociedad y en el mundo del trabajo. Esas genealogías son constructos culturales situados en múltiples contextos de producción y en la subjetividad de los emisores. Se producen saberes conectados que enlazan experiencias, momentos históricos y formas de abordar los problemas, conformando capas cognitivas con las que se han ido pensando el mundo del trabajo, las relaciones de género, las prácticas de los sujetos y sus representaciones.

Una reflexión crítica de ese proceso de producción intelectual excede los marcos de la presentación de esta sección, pues sería necesario trazar un mapa de lecturas y sus derivas, en una suerte de historia social de la producción intelectual que supone un ejercicio de reflexión crítica sobre cada disciplina, así como problematizar y matizar nociones y análisis de los autores canónicos del quehacer científico en cada uno de los países y/o de las regiones.

Frente a la diversidad existente entre disciplinas, teorías y metodologías, se puede afirmar que el desarrollo de los estudios feministas y de género se ha multiplicado en las últimas décadas, y que existe ya una importante producción de conocimientos que permite debatir temas, cronologías e interpretaciones desde múltiples perspectivas en cada una de las regiones.

En conjunto, los tres artículos de esta sección dialogan con una profusa literatura que tiene profundas raíces en el pasado. Los debates sociológicos y económicos cuestionaron desde la década de 1960 la idea de que existe cierta neutralidad de género en las relaciones económicas, en el uso de tecnología

2 Véanse: Femenías, 2008; Santa Cruz, 1994; Santa Cruz, Bach, Femenías, Gianella y Roulet, 1994; Stolcke, 2003. 
y en las relaciones laborales. Esta tendencia puso en cuestión buena parte de la literatura específica sobre el mundo del trabajo que analizaba de manera homogénea los agentes económicos y sociales organizados en un englobante "trabajadores", lo que dificultaba avizorar las especificidades de la inserción laboral femenina. La división sexual del trabajo estaba naturalizada y la división de esferas de actuación (público/privado) ayudaba a organizar argumentos importantes para el análisis histórico. ${ }^{3}$

Los estudios sociológicos, antropológicos, demográficos e históricos han destacado de manera persistente que las mujeres participaban en la producción de bienes y servicios. Eran parte de la economía de "mercado", pues estaban integradas a las actividades en fábricas y en talleres. No eran las únicas actividades. Estaban además las costureras, que circulaban por las calles de las ciudades llevando las prendas de su casa al taller de confección; las lavanderas, las planchadoras, las chicheras, que vendían sus productos en calles y mercados; las cocineras, las mucamas y las amas de leche; las artistas, las coristas y las cantantes, que realizaban sus giras por pueblos y por ciudades; o las matronas, que atendían y cuidaban a otras mujeres. Podríamos seguir con esta enumeración, pero en cualquiera de los casos se puede afirmar que había unas labores que no estaban siendo observadas y analizadas por los estudiosos y que las tareas de las amas de casa eran entendidas en una extensa literatura de inspiración marxista como trabajo reproductivo.

Una historia global del proceso de construcción de instrumentos de medición de la población y de las actividades productivas facilitaría una mirada crítica sobre cómo se diseñaron y se levantaron censos y encuestas, y sobre los modos en que se fue consolidando la idea de la importancia de registrar las actividades remuneradas, dejando al margen otras tantas que no podían ubicarse en la categoría de trabajo asalariado. En este sentido, los trabajos realizados por las mujeres en el campo y en las ciudades fueron desapareciendo de las informaciones estadísticas que, aunque cada vez eran más complejas y detalladas, se volvían también más restrictivas en la categorización de ocupaciones. Es decir que las categorías cambiantes con las que se elaboraban las estadísticas producían distorsiones en la medición del empleo femenino y, aunque sea anticuado decirlo, la sistematicidad y la objetividad estaban y están bajo discusión, toda vez que se pone en evidencia el sesgo androcéntrico de los criterios censales. Esta observación deja al descubierto también el problema mucho más profundo de poner en debate lo que es o no considerado como trabajo.

3 Hay debates clásicos y contemporáneos sobre la división del trabajo, las estructuraciones de clase, la formación del mercado de trabajo, los conflictos, las formas de protestas, las relaciones de género, el rol del patriarcado, las divisiones y los conflictos étnicos y raciales. Un compendio de esas lecturas se encuentra en Giddens y Held, 1983. 
La novedad que introdujeron los estudios feministas y los estudios de género fue la de cuestionar esos criterios e impulsar categorizaciones informadas por estas perspectivas de análisis para comprender mejor los mecanismos puestos en juego en la división sexual del trabajo y en las relaciones de poder. El uso de la palabra 'género' constituye un intento de categorizar un conjunto más amplio de problemas que incluye la división sexual del trabajo e inscribe las relaciones entre varones y mujeres en estructuras de poder. La vasta literatura sobre trabajo femenino produjo un dislocamiento en las formas de pensar el trabajo, aunque no solo este, ya que todos los conocimientos fueron descentrados y dislocados, produciendo desplazamientos importantes en el análisis sociohistórico.

La filósofa argentina María Luisa Femenías señala, al analizar la cuestión de la mujer en el pensamiento de Simone Weil y de Simone de Beauvoir, que la división sexual del trabajo produjo una conmoción que aseguró a las mujeres la "autoridad" en la casa (con "empleo" exclusivo en "las labores" domésticas), como también la autoridad absoluta de los varones en el "espacio público" (Femenías, 2005). El gobierno de la ciudad y el gobierno del hogar se consolidaron, en palabras de Geneviève Fraisse (1991). Una derivación importante fue el desplazamiento del "derecho materno" por el "derecho paterno", la transmisión del dominio por vía genealógica masculina, lo que consolidó la estructura de dominación. Según Beauvoir, la única capacidad considerada valiosa de la mujer era (es) su función reproductiva. De aquí a la protección de la madre obrera hay un pequeño paso, del mismo modo que la distancia es pequeña para la consolidación de las ideas de "trascendencia y ambición" para el varón y de "inmanencia y renuncia" para la mujer (Beauvoir, 1987, 2017).

Las palabras de Beauvoir no eran tan nuevas, pero eran moduladas de un modo distinto. Ya en el siglo XIX, John Stuart Mill sostenía que "las relaciones sociales entre ambos sexos (aquellas que hacen depender a un sexo del otro, en nombre de la ley), son malas en sí mismas, y forman hoy uno de los principales obstáculos para el progreso de la humanidad; entiendo que deben sustituirse por una igualdad perfecta, sin privilegio ni poder para un sexo ni incapacidad alguna para el otro" (Mill, 2005: 47; Mill y Taylor, 2000). Esa dependencia fue transformando al sujeto femenino en "incapaz", se lo asoció a una minoridad eterna y, por lo tanto, se planteó que debía ser protegido y tutelado.

Destacamos a Mill porque en la Inglaterra del siglo XVIII encarnaba esa mirada que recuperaba un mundo laboral y situaciones y roles masculinos y femeninos más complejos que los que enunciaba Adam Smith. Mill, como Mary Wollstoncraft, era leído y traducido en diferentes países de América Latina por mujeres que se identificaban con los feminismos de la época. Por ejemplo, Martina Barros, una mujer de la clase alta chilena, tradujo La sujeción de la mujer, que publicó por entregas entre 1872 
y 1873 en la Revista de Santiago. Esta publicación es bastante anterior al trabajo realizado por Emilia Pardo Bazán, cuya traducción al español data de 1892. Barros fue tildada de "niña peligrosa", pues veían su iniciativa como amenazante para la sociedad y la familia (Castillo, 2009: 30). Vale la pena recordar que la idea de "peligrosa" se extendía a toda mujer que tuviera algún grado de intervención pública, y las actividades económicas lo eran, salvo para las viudas.

En Argentina, tanto Mill como Wollstoncraft fueron citados en las primeras tesis doctorales sobre el movimiento feminista, escritas por mujeres, que se presentaron en la Facultad de Filosofía y Letras de la Universidad de Buenos Aires. Elvira López se doctoró en 1901 y María Isabel Salthu en 1920. En Paraguay, Serafina Dávalos escribió su tesis titulada "Humanismo", en 1907. Algunas ideas compartidas unen esas tesis. Por un lado, cobra cuerpo la tensión entre maternidad (deber primordial de toda mujer) e independencia económica. Por otro lado, emerge el conflicto entre maternidad y participación política (en el Parlamento para hacer leyes mejores). Se entiende, de acuerdo con las ideas que circulaban en la época, que la importancia de la mujer reside en que es madre tanto del individuo como de la sociedad y que las leyes expresan "el egoísmo del hombre", que convirtió a la mujer en su esclava a través de la ignorancia, la falta de bienes propios y el confinamiento al hogar. Una idea clave es que la mujer no participó en la formación de las leyes, y que es su condición de madre y de persona instruida la que podría convertirla en "mujer diputada”, integrándose activamente a la labor parlamentaria. La mujer aportaría la cuota de humanidad y preocupación por la comunidad en su conjunto, como también una cultura diferente alejada de los vicios masculinos, pero al hacerlo atentaría contra su función primordial, que es el cuidado de los hijos.

Según estas tesis, el hijo tiene derechos sobre la madre y por eso el problema es de todas las mujeres, y mucho más de la mujer obrera, que es empujada fuera del hogar y lo descuida. Como si fuera poco, su trabajo fuera del hogar, más los trabajos de cuidado de la familia y el cansancio producto de la doble jornada, contribuyen a la expulsión del marido del hogar, lo que significa que el esposo elige el camino de la taberna y el juego o la situación lo destruye y se "afemina", transformando su "espíritu varonil". En estos textos se plantean algunas soluciones para resolver la tensión maternidad-trabajo fuera del hogar, como el establecimiento de casas cuna, jardines de infantes y escuelas hogares, que siempre se analizan como insuficientes en tanto que dejan intacto el "abandono del hogar" por parte de la madre.

Las autoras sitúan el discurso de la maternidad en el centro del destino femenino y ponen en tensión la idea igualitaria. Un siglo más tarde, esta formulación es reconfigurada de algún modo y emerge renovada entre 1980 y el presente, a partir de una revolución silenciosa que ha devuelto a la 
maternidad y a la tiranía del hijo a un lugar central, tal como lo ha analizado Elisabeth Badinter (2011).

Las tesis doctorales mencionadas definen el feminismo como una corriente que busca una "dignificación de la mujer", que no implica la "lucha de sexos", para destacar que no hay superioridad ni inferioridad de un sexo sobre otro, sino que el criterio debe ser el de la equidad. Es una forma de lo que hoy se denomina "feminismo maternalista", el cual privilegia la ética del cuidado y de la familia basada en el amor, la dedicación y la atención del otro, consideradas como virtudes maternales. Destaca la importancia de la "madre feminista" porque significa que conoce los desafíos de la época y las necesidades de la sociedad. Es una caracterización de uno de los feminismos latinoamericanos que habría que explorar en profundidad.

Estos breves bosquejos nos informan de la existencia de una problematización histórica de las raíces económicas, culturales y políticas de la desigualdad de género, y uno de los aspectos centrales refiere a la forma en que las sociedades resuelven la reproducción cotidiana de las personas y al rol que esto juega en la configuración de patrones de desigualdad.

Como venimos sosteniendo, estudiosos de diferentes disciplinas han reflexionado sobre el impacto de la categoría de género. En la disciplina de la historia, Geoff Eley (2008: capítulos II y III, y páginas 41 a 176) ha considerado los caminos de su formación académica, los impulsos y sus límites, el rol de las instituciones y las publicaciones, así como el impacto y el dislocamiento que produjeron las feministas y la formulación de la categoría de género a la historia social y laboral. Dice Eley: "Aprender de la historia era más complejo, [...] menos transparente, menos dócil, menos reducible a un conjunto de protocolos fijados o prescripciones". Pensar las formas de la historia social y de la historia del trabajo implica reflexionar sobre los procesos de descentramientos, desplazamientos y dislocamientos epistemológicos. Las ideas circulan, pero siempre teniendo como núcleo duro la producción académica europea. Las desigualdades también impregnan las prácticas historiográficas, y el trabajo académico de unos (¿unas?) no siempre goza de las políticas de traducción y legitimación de los otros (¿otras?). Los estudios que aquí se presentan ponen en evidencia que desplazar, descentrar y dislocar son estimulantes y contribuyen a ampliar el horizonte de las historias laborales. Los tres trabajos de esta sección, aunque distintos entre sí, ponen el foco analítico en las relaciones de género, en el reparto desigual del poder, en las implicancias políticas. Pero también iluminan la importancia de los feminismos para desafiar la construcción de conocimiento y analizar cuestiones de trabajo, poder, Estado, ciudadanía, raza y racismo, sexualidades y construcciones identitarias. 
30 | Trabajos y trabajadores en América Latina (siglos XVI-XXI)

BiBLIOGRAFÍA

Badinter, Elisabeth

2011 La mujer y la madre. Madrid: La esfera de los libros.

Beauvoir, Simone de

2017 El segundo sexo. Estudio preliminar de Teresa López Pardina. Madrid: Cátedra.

1987 El segundo sexo. Buenos Aires: Siglo XX.

Castillo, Alejandra

2009 "Las aporías de un feminismo liberal". En: Martina Barros, Prólogo a la Esclavitud de la mujer. Santiago de Chile: Palinodia.

Eley, Geoff

2008 Una linea torcida. De la historia cultural a la historia de la sociedad. Valencia: Universitat de Valencia.

Femenías, María Luisa

2008 "De los estudios de la mujer a los debates sobre género". En: Mirta Zaida Lobato et al., Historias con mujeres. Mujeres con historia. Buenos Aires: Facultad de Filosofía y Letras, Universidad de Buenos Aires.

Femenías, María Luisa (comp.)

2006 Feminismos de París a La Plata. Buenos Aires: Catálogos.

2005 Perfiles del feminismo latinoamericano. Buenos Aires: Catálogos.

Fraisse, Geneviève

1991 Musa de la razón. Madrid: Cátedra.

Giddens, Anthony y David Held (eds.)

1983 Classes, Power and Conflict. Classical and Contemporary Debates. Londres: The Macmillan Press.

Koselleck, Reinhart

1993 Futuro pasado. Para una semántica de los tiempos históricos. Barcelona: Paidós.

Mill, John Stuart

2005 El sometimiento de las mujeres. Introducción, estudio preliminar y notas de Ana de Miguel, traducción de Alejandro Pareja. Madrid: Edaf. 
Mill, John Stuart y Harriet Taylor

2000 Ensayos sobre la igualdad de los sexos. Estudio preliminar de Victoria Camps, traducción de Pere Casanellas. Madrid: Machado.

Roulet, Margarita y María Isabel Santa Cruz

1994 Mujeres y filosofía. Teoría filosófica de género. Buenos Aires: Centro Editor de América Latina.

Santa Cruz, María Isabel

1994 "Actualidad del tema del hombre: los estudios de la mujer". Revista Latinoamericana de Filosofía, XX. 2.

Santa Cruz, María Isabel; Ana María Bach, María Luisa Femenías, Alicia Gianella y Margarita Roulet

1994 Mujeres y Filosofía. Teoría Filosófica de Género. Buenos Aires: Centro Editor de América Latina.

Stolcke, Verena

2003 "La mujer es puro cuento: La cultura del género". En: Quaderns de l'Institut Cátala d'Antropologia, sèrie monogràfics: "A proposit de cultura", número 19. 



\title{
¿Qué es trabajo? Las fronteras conceptuales entre trabajo y no trabajo
}

\author{
Fernanda Wanderley (Brasil/Bolivia)*
}

\begin{abstract}
RESUMEN: El presente texto reconstruye el debate conceptual que se desarrolló en las ciencias sociales sobre las fronteras entre "trabajo" y "no trabajo”. Mientras las perspectivas económicas clásica y neoclásica entendieron el trabajo restringido a actividades remuneradas, la perspectiva sociológica elaboró un concepto más amplio de trabajo como todo esfuerzo humano que añade valor a bienes y servicios, incorporando formas mercantiles y no mercantiles de trabajo. La controversia en torno a qué es trabajo ha tenido derivaciones significativas en el campo de los estudios sobre las realidades laborales, y en la comprensión y explicación de un conjunto de fenómenos, tales como las desigualdades de género, generación, etnicidad y clase, el rol de diversos tipos de unidades económicas en el desarrollo y la relación entre trabajo y regímenes de bienestar social. El texto concluye con consideraciones acerca de la trascendencia de la discusión académica sobre el significado del trabajo en la formulación de políticas públicas.
\end{abstract}

Palabras Clave: trabajo; trabajo no remunerado; economía feminista; género; mercado de trabajo; sociología; nueva economía de la familia.

\section{INTRODUCCIÓN}

El trabajo es parte de la condición humana y, a lo largo de la historia de las sociedades, asumió variadas formas. En los siglos XIX y XX, el trabajo asalariado adquirió creciente importancia para la obtención de recursos y medios necesarios para la reproducción material de los seres humanos y, concomitantemente, las ciencias sociales se consolidaron en el contexto de la emergente sociedad capitalista. Los estudios sociales centraron su atención en la forma típica de trabajo de la economía de mercado: el empleo asalariado.

\footnotetext{
* Doctora en Sociología por la Universidad de Columbia, Nueva York. Instituto de Investigaciones Socio Económicas (IISEC), Universidad Católica Boliviana (UCB). Contacto: fernandawanderley38@gmail.com
} 
Otras modalidades de trabajo, al margen de la lógica de mercado, perdieron visibilidad, a pesar de que persisten hasta la actualidad. Entre estas modalidades figuran las labores en el hogar para la preparación de alimentos, la limpieza y el cuidado de familiares, la producción de alimentos para el autoconsumo, así como la artesanía y la manufactura en pequeños establecimientos. El rol social y económico de los trabajos autogenerados, no remunerados o no asalariados en actividades de producción de bienes y servicios en la modernidad no recibió la atención debida de parte de las ciencias sociales.

En la segunda mitad del siglo XX, estudios sobre género y trabajo desarrollaron una importante crítica al concepto de trabajo limitado a la lógica de mercado, el cual excluye gran parte del trabajo realizado por las mujeres en el seno de los hogares y las comunidades. Estos análisis mostraron, además, que dicha exclusión imposibilita la adecuada comprensión de las dinámicas que explican los patrones persistentes de participación diferenciada de hombres y mujeres en el mercado de trabajo. A partir de estos estudios, un importante debate conceptual se desplegó en las ciencias sociales sobre las fronteras entre "trabajo" y "no trabajo". Mientras que las perspectivas económicas clásica y neoclásica entendieron el trabajo como aquel restringido a actividades remuneradas, la perspectiva sociológica avanzó un concepto más amplio de trabajo como todo esfuerzo humano que adiciona valor a bienes y servicios, incorporando formas mercantiles y no mercantiles de trabajo.

La controversia en torno a qué es trabajo ha tenido derivaciones significativas en el campo de los estudios sobre las realidades sociolaborales, y en la comprensión y explicación de un conjunto de fenómenos como, por ejemplo, las desigualdades de género, generación, etnicidad y clase, o el rol de diversos tipos de unidades económicas en el desarrollo y la relación entre trabajo y regímenes de bienestar social. Este debate transcendió el ámbito académico con consecuencias en el debate público y en la formulación de políticas sociales y económicas.

El presente texto reconstruye el debate sobre la definición y el significado de trabajo, poniendo especial atención en la controversia entre la economía feminista de tradición sociológica y la nueva economía de la familia de tradición económica neoclásica desde la década de 1970. Delinea, asimismo, los principales ejes de discusión y sus desarrollos conceptuales más importantes. El texto está organizado en cuatro partes, además de la presente introducción y las consideraciones finales. La primera parte discute la invisibilidad del trabajo que se despliega al margen de la lógica de mercado, tanto en el campo de las ciencias sociales como en el de las estadísticas laborales. La segunda parte reconstruye el desarrollo de las perspectivas feministas sobre la organización del trabajo en la esfera del mercado y del hogar. La atención se centra en la convergencia de los estudios, sin profundizar en las diferencias entre las 
perspectivas feministas. La tercera parte presenta el debate de la perspectiva sociológica y la perspectiva económica neoclásica sobre el trabajo remunerado y no remunerado. La cuarta parte desarrolla la conceptualización del trabajo en las ciencias sociales, en la cual convergen diferentes escuelas teóricas -feminista, marxista, institucionalista e interaccionista-. Finalmente, se presentan las implicaciones que tiene la discusión conceptual sobre el trabajo en el debate público y en las políticas públicas.

\section{LA INVISIBILIDAD DEL TRABAJO NO REMUNERADO}

En la historia de la humanidad, las actividades humanas para agregar valor a bienes y servicios necesarios para satisfacer necesidades biológicas y sociales ocurrieron, en gran medida, fuera de la institución del mercado y de las relaciones de compra y venta de tiempo y esfuerzo de las personas. Los trabajos forzados -esclavitud y servidumbre- son algunas de estas formas que predominaron -y que siguen presentes- en muchas sociedades (Vallas, 2012). Con el desarrollo del sistema capitalista y la expansión del mercado de trabajo en los siglos XIX y XX, muchas de estas formas de trabajo se redujeron paulatinamente, aunque con asimetrías significativas entre sociedades $y$, ciertamente, no han desaparecido. De igual manera, una gran parte de las actividades de producción de bienes y servicios continuó en el ámbito de trabajo fuera del mercado: el trabajo doméstico no remunerado, el trabajo de ayuda mutua, los intercambios sin que medie un precio, el trabajo para el autoconsumo y el trabajo cooperativo, entre muchos otros (Tilly y Tilly, 1998). En la actualidad, el desarrollo de las economías colaborativa, social y solidaria está expandiendo nuevas configuraciones de trabajo no asalariadas (Nyssens, 2006; Wanderley, 2015).

Pese a la continuidad de circuitos de producción y circulación de bienes y servicios al margen de la lógica de compra y venta en una variedad de tipos de trabajo, hasta el presente la reflexión histórica y social se centró en los procesos de industrialización y en la emergencia del empleo asalariado. Esta atención se entiende por la creciente importancia del mercado de trabajo y del trabajo remunerado en la consolidación del sistema capitalista, principalmente en las sociedades europeas y norteamericana.

A lo largo del siglo XIX, los estudios se centraron en las transformaciones de los campesinos, los artesanos y los mercaderes en capitalistas y obreros; en la emergencia de las ciudades y en las transformaciones del ritmo de vida y de trabajo; en la reconfiguración de la vida doméstica; y en las relaciones de propiedad, poder y autoridad en la sociedad de mercado. En el siglo XX, la discusión profundizó las transformaciones de la organización capitalista del trabajo, las nuevas relaciones industriales, las culturas ocupacionales en las 
empresas, la reconfiguración del sindicalismo y de los movimientos obreros, y los cambios en la legislación laboral y la seguridad social (Sabel, 1982; De la Garza Toledo, 2000).

La sociología industrial, la sociología del mercado de trabajo y la sociología de las organizaciones son algunas de las ramificaciones de esta amplia e importante literatura. Todas ellas comparten la atención sobre el trabajo en el marco del mercado. Esta focalización también caracterizó la teoría económica hasta hace poco, cuando empezaron a aplicarse sus herramientas conceptuales y metodológicas al estudio de otras esferas sociales, como por ejemplo la organización del trabajo en el hogar. La nueva economía de la familia que abordamos más adelante es una de las nuevas tendencias de la teoría económica neoclásica (Becker, 1981).

En este proceso se consolidó la visión del "verdadero trabajo", asociado a la forma de trabajo mercantil y, en especial, a la del empleo asalariado, a pesar de las evidencias de la persistente presencia de formas de trabajo no mercantiles y de su importancia social y económica, tanto en términos del número de trabajadoras y trabajadores, como de su magnitud en tiempo y esfuerzo y de su aporte a la reproducción de la vida social (Vallas, 2012).

En este contexto intelectual, no sorprende que la construcción del sistema estadístico sobre el trabajo, a inicios del siglo XX, presentara también ese sesgo hacia el trabajo remunerado y las relaciones de mercado. Es así que a fines de la década de 1930 se desarrollaron la estructura conceptual y las técnicas de medición de la fuerza de trabajo, actualmente en uso en todo el mundo, primero por la Work Projects Administration de Estados Unidos, y difundidas posteriormente por la Organización Internacional del Trabajo (OIT). De esta manera, se establecieron normas generales adoptadas por los países, que facilitan la comparabilidad de los datos sobre ocupación. Pese a la continua adaptación de estas normas, según las transformaciones en el mundo del trabajo, no se modificó la estructura conceptual básica (Rendón y Salas, 2000).

Las categorías empleadas para la captación de datos se centran en las actividades que se despliegan en la esfera del mercado -ya sea de compra y venta del tiempo de trabajo (mercado de trabajo) o de compra y venta de bienes y servicios producidos por el trabajo (mercado de bienes y servicios)-. Es así que las categorías centrales que estructuran el sistema estadístico son la población económicamente activa (PEA) y la población económicamente inactiva (PEI), categorías que establecen, respectivamente, la frontera entre "trabajo" y "no trabajo". En este marco categorial, para que una persona sea considerada parte de la PEA debe estar incorporada a la dinámica del mercado (de trabajo o de bienes y servicios), ya sea como población ocupada o como población desocupada. El concepto de trabajo que fundamenta este indicador es la actividad de producción de bienes o servicios destinada al mercado, mientras que el 
concepto de trabajador se refiere a quien está en el circuito de compraventa de su tiempo de trabajo o del producto de su trabajo. ${ }^{1}$ De esta manera, la PEA enmarca estadísticamente la frontera entre lo que es el trabajo y los que son los trabajadores. Por lo tanto, todas aquellas personas que no están dedicadas a una actividad remunerada por lo menos una hora diaria (población ocupada) o no están buscando activamente un trabajo remunerado (población desocupada) son clasificadas como parte de la PEI; es decir, al margen de la economía. La PEI incorpora a todas las personas en edad de trabajar que están sin empleo o que no realizaron una actividad de búsqueda de trabajo. Entran en esta categoría los estudiantes a tiempo completo, los jubilados o retirados, las y los trabajadores domésticos no remunerados y todas las personas que no realizan actividades orientadas a la compraventa del trabajo o de los bienes y servicios producto de su trabajo.

De esa manera, se consolidó la marginación de una variedad de formas de trabajo en la medición de los esfuerzos que las sociedades despliegan para producir el conjunto de bienes y servicios que se requieren para su reproducción. ${ }^{2}$ Si bien se reconoce la importancia del trabajo pagado en las sociedades modernas, como también la disponibilidad de estadísticas comparables para examinar sus características, se reclama la inclusión de las actividades de producción de bienes y servicios no destinados al intercambio en el mercado y de las formas de trabajo no asalariado en los sistemas estadísticos, para la adecuada comprensión de las dinámicas económicas y sociales tanto a nivel de los Estados-nación como a nivel global. ${ }^{3}$

\section{LAS PERSPECTIVAS FEMINISTAS SOBRE EL TRABAJO}

Las ciencias sociales, en especial las perspectivas marxista e institucionalista, desarrollaron conceptos y métodos que ayudaron a comprender cómo las relaciones sociales entre mujeres y hombres estructuran los mundos del

1 La categoría ocupacional clasifica a los trabajadores por tipo de relación laboral. El que vende su fuerza laboral puede ser clasificado como obrero, empleado o trabajador doméstico asalariado; el que vende el producto de su trabajo puede ser clasificado como trabajador independiente o por cuenta propia. La excepción del criterio de mercado (de trabajo o del producto del trabajo) es la categoría ocupacional de trabajador familiar no remunerado.

2 Algunas excepciones son el trabajo agrícola y el trabajador familiar no remunerado, que son incorporados en las estadísticas laborales.

3 Estos debates condujeron a esfuerzos e iniciativas para ampliar la captación de información sobre el trabajo desplegado más allá del ámbito mercantil, como las encuestas de uso del tiempo. 
trabajo. Los estudios de género y la economía feminista profundizaron el análisis de la división sexual del trabajo dentro de los hogares y cuestionaron el concepto de trabajo limitado a la lógica de mercado. ${ }^{4} \mathrm{~A}$ pesar de que este es un campo compuesto por diferentes marcos teóricos y con importantes debates y controversias, es posible identificar un núcleo común compartido por las diversas corrientes teóricas de la economía feminista. El presente análisis se centra en estas ideas.

Una primera importante contribución de los estudios feministas ocurrió en la esfera del mercado de trabajo. Con base en las estadísticas laborales, dichos trabajos mostraron la creciente salida de las mujeres de la esfera privada de los hogares y su incorporación al trabajo asalariado. Visibilizaron los patrones persistentes y diferenciados de participación entre hombres y mujeres en el mercado de trabajo. A partir de ahí, acuñaron los conceptos segregación ocupacional horizontal y vertical, y brechas de ingreso entre hombres y mujeres.

El concepto de segregación ocupacional horizontal da cuenta de la segmentación de las mujeres en ciertas actividades y ocupaciones, mientras que la segregación ocupacional vertical se refiere a la presencia mayoritaria en los niveles más bajos de cada ocupación. Las brechas de ingreso hacen referencia a las diferencias persistentes de remuneración promedio entre hombres y mujeres, inclusive cuando se controla por nivel de formación y experiencia laboral y por tipo de ocupación. Pese a los cambios en la segregación horizontal y en la segregación vertical en muchas sociedades en las últimas décadas, las estadísticas muestran que los cambios no son consistentes en todas las ocupaciones. De igual manera, las brechas de ingreso no desaparecieron ni a nivel del Estado-nación ni a nivel de la división global del trabajo, a pesar de los esfuerzos políticos y de las políticas públicas.

Desde la perspectiva del mercado de trabajo como institución social -constituida por normas, reglas y prácticas sociales que definen las formas de incorporación del trabajador y sus trayectorias profesionales-, los estudios mostraron que las oportunidades de acceso y de desarrollo laboral, así como los salarios, no están determinados únicamente, ni primordialmente, por el criterio de productividad. Otros factores -como costumbres, prejuicios, estereotipos, prácticas y relaciones en el mercado de trabajo- son importantes en la estructuración de las oportunidades laborales. Las investigaciones analizaron cómo las construcciones de género estructuran y son estructuradas

4 Entre estos estudios están Boserup, 1970; Tilly y Scott, 1978; Treiman y Hartman, 1981; Benería y Sen, 1982; Bielby y Baron, 1986; Anker y Hein, 1986; Benería y Roldán, 1987; García Fanelli, 1989; Arriagada, 1990; Andersen, 1991; Bielby y Bielby 1992; López, Molly y Villarreal, 1992; Glass y Camarigg, 1992; Borderías y Carrasco, 1994; Wanderley, 1995; Kabeer, 1998; Wanderley, 2003; Thistle, 2006. 
dentro y fuera del mercado de trabajo. De ese modo, la segregación horizontal y vertical, así como las brechas de ingresos, son producto de prácticas y dinámicas institucionalizadas que incluyen mecanismos de discriminación que no responden a principios de meritocracia o de eficiencia. Estos mecanismos establecen oportunidades desiguales y, muchas veces, están legitimados social y hasta jurídicamente.

Una segunda importante contribución de los estudios sociológicos sobre género y trabajo fue el análisis de la organización del trabajo en la esfera del hogar y cómo esta afecta los patrones diferenciados de participación de hombres y mujeres en el mercado de trabajo. Los estudios mostraron, con sólida evidencia empírica, que la desigual distribución del trabajo entre hombres y mujeres en la familia es uno de los principales factores que explican los patrones diferenciados de participación en actividades remuneradas entre hombres y mujeres. Las evidencias sobre la resistencia cultural y social de los varones a compartir el trabajo reproductivo y del cuidado en las familias, pese a la creciente participación de las mujeres en actividades remuneradas y en la provisión de recursos económicos al hogar, dieron nacimiento a nuevos conceptos, entre ellos, por ejemplo, la doble y la triple jornada laboral. Quedó demostrada así la fuerte asociación entre trabajo remunerado y trabajo no remunerado.

Esos hallazgos cuestionaron los conceptos dominantes de trabajo y economía para explicar las realidades laborales de hombres y mujeres. Mostraron la necesidad de un marco teórico que integrara el trabajo orientado a generar ingreso y el trabajo orientado a la reproducción de las familias, para entender los factores intervinientes en la estructuración de patrones diferenciados de participación económica entre hombres y mujeres. El concepto de trabajo, desde este nuevo marco teórico, incorpora las actividades remuneradas y no remuneradas que agregan valor a bienes y servicios necesarios para la reproducción de la vida social. De este modo, el concepto de trabajo dejó de estar asociado únicamente a las actividades generadoras de ingreso y al criterio de valor de cambio. Esta redefinición se fundamentó sobre la evidencia de que ambos tipos de trabajo -remunerado y no remunerado- requieren dedicar/utilizar esfuerzo y tiempo para agregar valor de uso a bienes y servicios indispensables para la sostenibilidad de las personas, las familias y la sociedad en general.

\section{El DEBATE CON LA PERSPECTIVA NEOCLÁSICA}

El desarrollo de los estudios de género y trabajo de fines del siglo XX, siguiendo la tradición sociológica institucionalista, tuvo a la explicación neoclásica de la economía y del trabajo como a su principal interlocutor crítico. El embate teórico y metodológico entre los diferentes paradigmas produjo explicaciones divergentes sobre los factores que intervienen en la reproducción de los 
patrones diferenciados de participación laboral entre hombres y mujeres. Este intenso debate se dirigió tanto a las dinámicas dentro del mercado de trabajo como a las dinámicas del trabajo dentro del hogar.

En la esfera del mercado de trabajo, el embate no se limitó a la discusión sobre el concepto de trabajo, sino que involucró también el de mercado. Para la perspectiva neoclásica, el mercado es el mecanismo central de asignación de recursos en la economía, y es conceptualizado como un mecanismo abstracto de maximización de recursos que tiende a la eficiencia. Desde este concepto, un supuesto importante es que la posición que ocupan las mujeres y los varones en el mercado de trabajo respondería a priori al principio de eficiencia.

La perspectiva sociológica pone en cuestión el concepto de mercado de la teoría neoclásica. En primer lugar, enfatiza que el mercado no es el único mecanismo de asignación de recursos en la economía moderna. Además del mercado, están los mecanismos de subsistencia (hogar), redistribución (Estado) y reciprocidad (redes sociales y de asociación) (Polanyi, 2007). Estos mecanismos se articulan de diversas formas y configuran diversos tipos de economía. Sus pesos relativos, roles y formas son reconfigurados continuamente en dinámicas territoriales a lo largo del tiempo. ${ }^{5}$ En segundo lugar, comprende el mercado como una institución constituida por prácticas sociales entre agentes imbricados en marcos sociales y culturales que no se comportan únicamente como agentes atomizados que buscan maximizar o satisfacer sus utilidades. Hubo amplia evidencia de que las decisiones de contratación, las oportunidades de capacitación y movilidad laboral, y la definición de los salarios de hombres y mujeres en empresas no están exentas de costumbres, prejuicios y estereotipos socialmente estructurados. Las construcciones de género y las prácticas de discriminación en el mercado de trabajo explican parte importante de la segregación ocupacional y de las brechas de ingreso. Por lo tanto, revelan que las diferencias en la participación laboral entre hombres y mujeres no son solo resultado de diferencias de productividad en un modelo de mercado competitivo.

A partir de la década de 1970, los economistas empezaron a aplicar los conceptos de la teoría neoclásica para explicar la división del trabajo en la familia y cómo esta determina la participación de hombres y mujeres en el mercado de trabajo. El estudio de Gary Becker, A Treatise on the Family, fue uno de los pioneros. El modelo de Becker (1981) asume que el objetivo de la unidad doméstica es la maximización o la satisfacción de su función de utilidad. Para esto, la unidad familiar selecciona una combinación de bienes y servicios de los cuales la familia obtiene la mayor utilidad posible. Los bienes

5 Para una revisión de la perspectiva de Polanyi y del concepto sociológico del mercado, véase: Wanderley, 2015. 
y servicios son producidos por los miembros dentro del espacio familiar y comprados en el mercado con recursos monetarios de trabajos remunerados. Muchos de esos bienes y servicios comprados en el mercado requieren inversión de tiempo de los miembros del hogar para su transformación en bienes necesarios para que la familia perciba utilidades.

Al trabajar con la idea de una función de utilidad agregada de la familia, Becker propone el concepto de 'dictador benevolente', que supone que el "jefe de la familia" es altruista y que incorpora en su propia función de utilidad las funciones del resto de los miembros de su familia. Este concepto es el que más polémica ha causado porque elimina la posibilidad de conflicto entre los miembros y supone que la distribución de recursos y bienes tiende a la eficiencia de la colectividad (ningún miembro del hogar puede salir favorecido sin que alguien salga perjudicado). La teoría afirma que no importa el género del miembro que gana y controla las decisiones en el hogar, toda vez que los bienes son reunidos y distribuidos por el principio de la maximización del bienestar colectivo. Esto es, los comportamientos de los actores se pautarían por cálculos de costo y beneficio, y no por valores y normas colectivas (identidades sociales). A partir de este supuesto, la teoría predice la flexibilidad en la distribución del tiempo de trabajo no mercantil entre los miembros del hogar, siempre que existan cambios en las ventajas comparativas entre los cónyuges, predicción que no se verifica empíricamente.

El autor plantea también pensar la familia como una unidad productiva comparable a una pequeña empresa. Esta perspectiva tuvo el mérito de situar el análisis de la producción en el hogar al mismo nivel conceptual que el trabajo remunerado, cambiando la visión de la familia como espacio únicamente de ocio y recreación por la de un espacio de igual importancia que el mercado para la producción de bienes y servicios socialmente necesarios. Así, el hogar pasó a ser definido por la teoría neoclásica como un espacio que combina la producción de bienes y servicios para el consumo con el ocio y la recreación. Igualmente importante fue la idea de que el factor tiempo es limitado y que las personas deben distribuirlo entre actividades mercantiles remuneradas, actividades domésticas no mercantiles y actividades de descanso y recreación. Esta propuesta significó un avance con relación a la teoría neoclásica tradicional respecto a que el tiempo no dedicado al trabajo remunerado dejó de ser identificado como ocio. Además, la idea del tiempo como recurso escaso implica que hay que asignarlo a distintos trabajos; por tanto, la nueva economía de la familia pasó a enfatizar la interrelación entre las esferas del hogar y del mercado de trabajo.

A pesar de estas importantes contribuciones, Becker (1981), siguiendo los axiomas neoclásicos, argumentó que la distribución del tiempo de trabajo dentro de la familia, entre actividades en el hogar y actividades generadoras de ingreso, así como la distribución de los recursos y productos entre los 
miembros, responde al principio de eficiencia en la búsqueda de maximización de la satisfacción de las necesidades del grupo. A partir del concepto de las ventajas comparativas de la teoría del comercio internacional, Becker argumentó que la producción de bienes y servicios dentro y fuera del hogar es más eficiente cuando uno de los miembros se especializa en la producción en el mercado y el otro se especializa en la producción en el hogar. De ahí que el modelo de familia biparental, en el que el varón se especializa en la producción en el mercado, mientras que la mujer lo hace en la producción en el hogar, sería el arreglo más eficiente para maximizar las utilidades colectivas de la familia, en tanto que cada uno obtendría mayor retorno monetario o mayores beneficios en sus respectivos trabajos.

Los estudios sociológicos y feministas cuestionaron la nueva economía de la familia a partir de la división sexual del trabajo en esta y su efecto sobre la participación diferenciada de hombres y mujeres en el mercado de trabajo. Primero, aportaron evidencias sobre las transformaciones familiares con la pérdida de importancia relativa de la familia biparental, compuesta por un papá proveedor de ingresos y una mamá disponible a tiempo completo para proveer cuidado en el hogar. Mostraron la diversificación de los tipos de familias con el aumento de familias monoparentales con jefatura femenina, de familias biparentales donde ambos cónyuges comparten la responsabilidad de proveer ingresos y de familias con orientaciones sexuales diversas. ${ }^{6}$

Después, los estudios sobre género y trabajo evidenciaron las limitaciones de la visión del hogar como una unidad homogénea en la que no caben dinámicas generacionales y de género ni diferencias de intereses, expectativas, responsabilidades y bienestar entre los miembros. Considerar a los hogares como unidades heterogéneas permitió entender, por un lado, de qué manera el sexo, la edad y la clase son ejes estructuradores de la división del trabajo dentro y fuera del hogar, y, por el otro, la interacción cotidiana entre cooperación, conflicto y disputas de poder. Además, los hogares son espacios dinámicos que varían en el transcurso del tiempo porque sus ciclos de vida están marcados por acontecimientos (nacimiento de hijos e hijas, unión de miembros que permanecen en un mismo espacio físico, enfermedades, separaciones y muerte o circunstancias externas, como la reducción de la demanda de trabajo o catástrofes naturales). Por lo tanto, para hombres y mujeres los "beneficios y costos" de la división tradicional del trabajo en familias biparentales son mucho más complejos de lo que propone la teoría neoclásica tradicional. Se comprobaron también las transformaciones sociales,

6 Entre los estudios están Wanderley, 1995 y 2003; Paulson, 1996; Alberdi, 1999; Jelin, 2000; INEGI, 2000; Farah, 2002; Arriagada, 2004 y 2008; Abramo, 2006; Aguirre, 2007; Gutiérrez, 2007; Aguirre y Batthyány, 2007. 
económicas y familiares a lo largo del tiempo; las tensiones entre el trabajo remunerado en la esfera del mercado y el trabajo no remunerado en la esfera del hogar; y las desigualdades de género dentro del hogar y del mercado, tanto en el acceso a recursos como en el poder y la autonomía de decisión, en la satisfacción de necesidades y aspiraciones, y en las inequidades en el ejercicio de derechos, mostrando en el mercado de trabajo realidades familiares y dinámicas muy distintas de la explicación neoclásica.

La crítica más radical a la nueva economía de la familia desde los estudios de género y trabajo apunta al supuesto que subyace al paradigma neoclásico del actor económico maximizador o satisfactor de utilidades y, específicamente, su adaptación a los comportamientos diferenciados entre hombres y mujeres. De este modo, la teoría neoclásica construyó funciones de utilidad masculina y femenina: mientras los hombres orientarían sus comportamientos a la maximización del ocio y la remuneración, las mujeres orientarían sus comportamientos a la crianza, el ocio y la remuneración. Así, la nueva economía de la familia naturalizó los roles de género y no cuestionó su construcción social como relaciones de poder, ni los efectos inequitativos de la división sexual del trabajo dentro y fuera del hogar. Los estudios feministas criticaron el supuesto de racionalidad instrumental de actores atomizados y sin identidades sociales, por no permitir comprender las relaciones sociales y de poder dentro de los hogares, como tampoco los mandatos normativos que estructuran los comportamientos y la división del trabajo ni cómo la reproducción de la posición inferior de las mujeres no es producto de decisiones individuales sin limitaciones estructurales.

Muchos estudios desde la economía neoclásica sofisticaron los planteamientos iniciales a la luz de las críticas realizadas desde las distintas disciplinas sociales. ${ }^{7}$ Entre estos cuestionamientos figura la minimización de los problemas de cooperación, conflicto y negociación, con base en la suposición de que la familia funciona como un mercado interno con transacciones mediadas por el precio. Sobresalen los estudios de Amartya Sen (1990), los cuales enfatizan que las diferencias en las capacidades de negociación entre los miembros de la familia son resultado de distintas fuentes de desigualdad y de poder. El autor cita los estudios de género para mostrar la importancia de las distintas estructuras de poder en las relaciones entre mujeres y hombres dentro del hogar.

\section{EL CONCEPTO DE TRABAJO EN LAS CIENCIAS SOCIALES}

El debate llevó a la construcción del concepto de trabajo ampliamente aceptado en el campo de la sociología del trabajo. Trabajo es "todo esfuerzo

7 Entre los primeros están Manser y Brown, 1980; Sen, 1990; Blau y Ferber, 1986; Blau, 1993. 
humano que añade un valor de uso a un bien o a un servicio" (Tilly y Tilly, 1998: 22). Esta definición incluye actividades para el intercambio en el mercado, el trueque o el autoconsumo, que son necesarias para la satisfacción de necesidades sociales. Todo esfuerzo y tiempo dedicados a actividades que agregan valor a bienes y servicios disponibles a otros actores son considerados trabajo. Este concepto se funda en el valor de uso de las actividades, desplazando el criterio de valor de cambio mercantil en la delimitación de la frontera entre "trabajo" y "no trabajo". Las actividades que no califican como trabajo son aquellas que reducen la transferencia de valor de uso disponible para otros. En este sentido, se sustituye el criterio que define la frontera entre trabajo y no trabajo: se abandona el criterio de los esfuerzos fuera del mercado y se adopta el criterio de los esfuerzos fuera de las relaciones sociales, como por ejemplo aquellos orientados a la pura gratificación (ibid:: 23).

Desde este concepto, trabajo implica organización y procesos en la asignación de tiempo y esfuerzo para la producción de bienes y servicios, así como diferentes tipos e intensidades de esfuerzo y tiempo, conocimientos y tecnologías, distribución de responsabilidades y tareas, normas, regulaciones y prácticas dependientes del contexto organizacional y social en que las actividades ocurren. El trabajo, en todas sus variedades, tiene una dimensión estructural que va más allá de la dimensión psicológica. En la dimensión psicológica, se ha mostrado la relación entre patrones de trabajo y ansiedad, depresión y satisfacción. En la dimensión estructural, se enfatizan sus características relacionales y colectivas de trabajo: su inscripción en normas, reglas y regulaciones formales e informales que determinan patrones de actividades, comportamientos y experiencias sociales que restringen los márgenes de elección de los individuos sobre su trabajo.

Los enfoques teóricos sobre la dimensión estructural del trabajo divergen, sin embargo, en la atención sobre los ejes estructurantes y estructurados del mundo del trabajo. Los enfoques feministas ponen el énfasis en las construcciones sociales de género que configuran la división sexual del trabajo. Las construcciones sociales de género no se reducen al nivel psicológico, debido a que están profundamente inscritas en instituciones y hábitos que son comprendidos por los actores sociales como expresiones naturales de la condición biológica. Además, las relaciones de género están imbricadas en estructuras de poder que no solo diferencian sino desigualan las oportunidades, el desarrollo y los resultados del trabajo de las mujeres con relación a los varones. Las inequidades de género se estructuran, además, en la intersección de diferentes tipos de inequidades (clase, raza y etnicidad, religión, orientación sexual y edad), las cuales expresan disputas de poder, prestigio y derechos. Sus transformaciones requieren de movilizaciones e intervenciones activas desde la sociedad y el Estado sobre las instituciones formales e informales que regulan las relaciones sociales. 
El enfoque marxista enfatiza los patrones estructurales de las relaciones de clase en el sistema capitalista y, específicamente, la transformación del tiempo de trabajo en mercancía rutinariamente comprada y vendida. La venta del tiempo de trabajo en el mercado ocurre bajo restricciones que limitan la elección de los trabajadores sobre esta venta y sobre las condiciones de esta venta. Sin embargo -y esto es lo más importante en la perspectiva marxista-, la venta de esta mercancía no tiene como consecuencia la pérdida de control del tiempo de trabajo por parte del trabajador. De ahí deriva una lucha continua entre trabajadores y capitalistas sobre las condiciones de explotación de la mercancía trabajo. Las formas de coerción, explotación, resistencia y regulación de las relaciones de trabajo son focos centrales de esta perspectiva analítica. Además de las características antagonistas y conflictivas de la relación del trabajo asalariado, se enfatizan las instituciones que condicionan la distribución del poder en la esfera económica y que se reproducen en todas las esferas de la sociedad capitalista.

El enfoque de la vieja escuela institucional ${ }^{8}$ dirige la atención sobre las influencias y limitaciones externas, especialmente los factores legales, políticos y culturales, que estructuran la organización y la experiencia de trabajo. En este sentido, el trabajo se comprende como una construcción social imbricada en órdenes normativos y campos estructurados que ejercen amplia influencia sobre las prácticas, relaciones, significados y experiencias de trabajo, tanto en la esfera del mercado como fuera de la misma. Se conceptualiza el mercado de trabajo como una institución constituida por prácticas sociales que estructuran las formas de incorporación del trabajador y sus trayectorias. El acceso, la posición, las oportunidades de desarrollo y la valoración social y monetaria son determinadas, en gran medida, por principios sociales, culturales y políticos. Factores como costumbres, prejuicios, estereotipos, percepciones, grado de sindicalización y acción colectiva, normativas estatales y políticas públicas, y reglas formales e informales en el espacio laboral moldean el trabajo por encima de decisiones racionales orientadas principalmente por la maximización en la asignación de los recursos (en este caso, de recursos humanos).

El interaccionismo simbólico de la Escuela de Chicago ${ }^{9}$ ha puesto la atención sobre las dinámicas de negociación en el espacio del trabajo remunerado, en la estructuración de las categorías ocupacionales y en la división del trabajo. La focalización se sitúa en el ejercicio de poder en las interacciones

8 Entre los autores de la vieja escuela institucional están Veblen, 1994; Weber, 1978; DiMaggio y Powell, 1983; Hodgson, 1994.

9 Esta vertiente está representada, entre otros, por Hughes, 1946; Strauss, 1978; Becker, 1963; y Goffman, 1967. 
directas entre trabajadores y las distintas capacidades de "distinción" entre ocupaciones. Esta perspectiva elabora la teoría del "orden negociado" en espacios de trabajo como hospitales, instituciones mentales, organizaciones policiales, escuelas y restaurantes, entre otras. Esta perspectiva es especialmente apta para captar los procesos informales a través de los cuales poder $y$ autoridad son negociados continuamente en situaciones concretas, pero también la emergencia de culturas organizacionales, significados de trabajo, identidades ocupacionales y diferenciaciones de estatus entre trabajadores.

No obstante sus diferencias, estos enfoques tienen en común la comprensión del trabajo como una construcción social en complejos entramados institucionales, en contraposición a la teoría económica neoclásica, que se funda sobre los supuestos del comportamiento maximizador o satisfactor de utilidades y la noción del mercado autorregulado para explicar la organización del trabajo. Aquellos refutan también la perspectiva neoclásica de que el trabajo puede ser adecuadamente abordado como pura transacción económica, bajo una lógica de competencia y de oferta y demanda mediada por un precio entre individuos aislados y cuyo comportamiento no está condicionado por estructuras sociales. Por el contrario, el trabajo implica relaciones sociales imbricadas en contextos históricos (leyes, memorias, creencias compartidas, acumulación de conocimientos, prácticas y roles sociales) cuyas estructuras son persistentes, aunque continuamente contestadas y disputadas.

\section{Consideraciones finales}

Los estudios sobre género y trabajo en el marco de la tradición sociológica aportaron críticas importantes al concepto de economía y de trabajo de la teoría neoclásica dominante al cuestionar: (i) su visión restringida al circuito mercantil y la invisibilidad de la esfera reproductiva y del cuidado como parte de la economía; (ii) la naturalización del mercado como un mecanismo no histórico que niega la importancia de los marcos normativos, los roles sociales y las prácticas de poder y discriminación en el seno de mercados concretos; (iii) el concepto de trabajo limitado a las actividades remuneradas y el no reconocimiento de la contribución social y económica de las actividades no remuneradas para la reproducción de la vida social; (iv) la visión del hogar como espacio homogéneo y que funcionaría como un mercado interno; (v) la noción dominante de un modelo único de familia; (vi) la división entre las esferas pública y privada; (vii) el supuesto de una racionalidad-instrumental (homo economicus) como el comportamiento económico que garantiza el buen funcionamiento de la economía.

En sintonía con otras vertientes críticas, la desnaturalización del mercado como mecanismo abstracto y no histórico pone de manifiesto la falacia 
del supuesto de que el comportamiento racional-instrumental que busca la ganancia máxima sea suficiente para explicar las dinámicas económicas. La inscripción de las actividades económicas en las estructuras sociales, culturales y políticas permite superar las visiones esencialistas de la economía y visibilizar convenciones sociales y políticas que estructuran las realidades laborales de hombres y mujeres.

A partir de esta reflexión, los estudios sobre género y trabajo, en el marco de la perspectiva institucionalista, desarrollaron el concepto 'trabajo del cuidado', con implicaciones importantes en la discusión pública y en las políticas públicas. ${ }^{10}$ En términos empíricos, el trabajo del cuidado incluye alimentar, educar, curar, criar, atender y proteger. Este trabajo está en el centro de la vida social y todos los seres humanos necesitan de cuidado. Sin embargo, algunos grupos, debido a su ciclo vital, necesitan más cuidado que otros; es el caso de niños, niñas, adolescentes, personas con discapacidad o enfermas y adultos mayores. Estos grupos requieren atención a tiempo completo para que puedan desarrollar todo su potencial y tener una vida digna.

$\mathrm{Si}$ en un primer momento los estudios mostraron la desigual distribución del trabajo reproductivo y del cuidado dentro de las familias, el paso siguiente fue problematizar la desigual división del trabajo del cuidado en la sociedad. En este segundo momento, la crítica avanzó hacia el cuestionamiento de la naturalización del trabajo del cuidado como inherente a la esfera de las familias y las comunidades, y, consecuentemente, la no responsabilidad del Estado y de la sociedad respecto a la organización del trabajo del cuidado para la sostenibilidad de la vida. Con ello, la crítica feminista identificó el problema del cuidado como un problema público en el ámbito de los derechos sociales y expandió la responsabilidad de la organización del cuidado a nuevas esferas institucionales: el Estado y el mercado, además de la familia y la comunidad. Desde esa perspectiva más amplia, se visibilizó la posición desigual que tienen las familias de diferentes estratos socioeconómicos para articular trabajo reproductivo y productivo.

Estos estudios mostraron que la ausencia de corresponsabilidad en la organización del trabajo del cuidado entre familia, sociedad y Estado tiene resultados inequitativos a nivel de las familias, por cuanto son las familias más pobres las que carecen de las condiciones para garantizar que sus hijos e hijas estén bien cuidados mientras los padres de familia desarrollan trabajos remunerados. Esta situación obliga a estas familias, y sobre todo a las

10 Entre estos están: Andersen, 2006; Pautassi, 2007; Marco, 2011; Martínez, 2008; Pautassi y Zibecchi, 2010; Pautassi y Nieves Rico, 2011; OIT y PNUD, 2009; Orozco, 2010; Montaño y Magaña, 2010; Nieves Rico, 2011; Wanderley, 2011; Farah, Salazar, Sostres y Wanderley, 2012. 
mujeres, a aceptar trabajos remunerados que les permitan cuidar a sus niños y niñas (en el mismo espacio físico o trabajo a tiempo parcial), normalmente fuera de la regulación laboral y de protección social. Esto restringe las oportunidades laborales de las mujeres con responsabilidades familiares y limita sus oportunidades de formación y participación en la esfera pública.

Esta realidad sociolaboral también tiene consecuencias para la vida de los niños y niñas, debido a que muchas familias no tienen otra salida que delegar el trabajo del cuidado a los propios niños, niñas y adolescentes. Estos arreglos precarios del trabajo del cuidado y protección someten a estos miembros de la familia a una mayor exposición a riesgos de todo tipo, incluidas las actividades delictivas y de consumo de drogas, el ingreso temprano al mercado laboral en detrimento de su educación y de su seguridad física y emocional (como la violencia sexual intra y extrafamiliar), además de problemas de salud por su presencia en espacios públicos inadecuados. Otros riesgos son las deficiencias de estímulos cognitivos, físicos y sociales, el embarazo adolescente y el abandono familiar, que podrían ser prevenidos por el trabajo remunerado del cuidado en centros de atención infantil o en actividades extraescolares complementarias a la escuela, mientras que los padres y las madres generan ingresos. Y tal como lo documentan estudios feministas, estas situaciones afectan principalmente a las familias más pobres.

El debate público alrededor de la organización del trabajo del cuidado generó un conjunto de convenios internacionales y propuestas de política pública para afrontar la crisis del cuidado y la reproducción de las desigualdades de clase, género, étnicas y generacionales. Desde el enfoque de derechos, plantea alternativas de sistemas del cuidado con base en la articulación entre las esferas familiar, comunitaria, mercantil y estatal, y la revalorización social y económica de diferentes tipos de trabajo del cuidado: no remunerado en la esfera del hogar (madres/padres, abuelas/abuelos, hermanas/hermanos), remunerado en la esfera del mercado o del Estado (parvularios, profesoras en servicios del cuidado) y remunerado en la esfera del hogar (trabajadora doméstica remunerada). 
BiBLIOGRAFÍA

Abramo, Laís (ed.)

2006 Trabajo decente y equidad de género en América Latina. Ginebra: Oficina Internacional del Trabajo.

Aguirre, Rosario

2007 "Trabajar y tener hijos: insumos para repensar las responsabilidades familiares y sociales". En: María Alicia Gutiérrez (ed.), Género, familias y trabajo: rupturas y continuidades - Desafios para la investigación politica. Buenos Aires: CLACSO, Colección Grupos de Trabajo.

Aguirre, Rosario y Karina Batthyány

2007 "Introducción”. En: María Alicia Gutiérrez (ed.), Género, familias y trabajo: rupturas y continuidades - Desafios para la investigación politica. Buenos Aires: CLACSO, Colección Grupos de Trabajo.

Alberdi, Inés

1999 La nueva familia española. Madrid: Taurus.

Andersen, Jeanine

2006 "Economías del cuidado colapsadas: ¡a quién le tendría que preocupar?". Ponencia en la conferencia internacional: "Las migraciones América Latina Europa: ¿qué desafíos para el análisis y las políticas?”. Bruselas.

1991 "El sueño de la casa sin cocina”. En: Virginia Guzmán, Patricia Portocarrero y Virginia Vargas (eds.), Una nueva lectura: género en el desarrollo. Lima: Ediciones Entre Mujeres.

Anker, Richard y Catherine Hein

1986 Sex Inequalities in Urban Employment in the Third World. Nueva York: St. Martins Press.

Arriagada, Irma

2008 "Futuro de las familias y desafíos para las políticas". Serie "Seminarios y conferencias”, número 52. Santiago de Chile: CEPAL.

2004 "Estructuras familiares, trabajo y bienestar en América Latina". En: Irma Arriagada y Verónica Aranda (eds.), Cambio de familias en el marco de las transformaciones globales: necesidad de politicas públicas eficaces. Santiago de Chile: CEPAL y UNFPA.

1990 Participación desigual de la mujer en el mundo del trabajo. Santiago de Chile: CEPAL. 
50 | Trabajos y trabajadores en América Latina (siglos XVI-XXI)

Becker, Gary

1981 A Treatise on the Family. Harvard, Massachusetts, Estados Unidos de América: Harvard Press.

Becker, Howard Saul

1963 Outsiders: Studies in Sociology of Deviance. London: Free Press of Glencoe.

Benería, Lourdes y Gita Sen

1982 "Class and Gender Inequalities and Women's Role in Economic Development: Theoretical and Practical Implications”. En: Feminist Studies, volumen 8, número 1. Maryland, Estados Unidos de América: University of Maryland.

Benería, Lourdes y Martha Roldán

1987 The Crossroads of Class and Gender. Industrial Homework, Subcontracting and Household Dynamics in Mexico City. Chicago, Estados Unidos de América: University of Chicago Press.

Bielby, Denise D. y William Bielby

1992 "I will follow him: Family Ties, Gender Role Beliefs, and Reluctance to Relocate for a Better Job”. En: American Journal of Sociology, volumen 97, número 5. Chicago, Estados Unidos de América. 1241-1267.

Bielby, William T. y James N. Baron

1986 "Men and Women at Work: Sex Segregation and Statistical Discrimination". En: American Journal of Sociology, volumen 91, número 4. Chicago. 759-799.

Blau, Francine D.

1993 "Gender and Economic Outcomes: The Role of Wage Structure". En: Labour, volumen 7, número 1. 73-92.

Blau, Francine y Marianne Ferber

1986 The Economics of Women, Men and Work. Englewood Cliffs, Nueva Jersey, Estados Unidos de América: Prentice Hall.

Borderías, Cristina y Cristina Carrasco

1994 Las mujeres y el trabajo. Rupturas conceptuales. Madrid: Economía Crítica.

Boserup, Esther

1970 Womans Role in Economic Development. Londres, Inglaterra, y Nueva York, Estados Unidos de América: Allen \& Unwin. 
De la Garza Toledo, Enrique

2000 Tratado latinoamericano de sociología del trabajo. México D. F.: Fondo de Cultural Económica.

DiMaggio, Paul y Walter W. Powell

1983 "The Iron Cage Revisited: Institutional Isomorphism and Collective Rationality in Organizational Fields". En: American Sociological Review, número 48. Estados Unidos de América. 147-160.

Farah, Ivonne

2002 Hogares y familias bolivianas: trabajo de hombres y mujeres. La Paz: CIDES-UMSA / INE.

Farah, Ivonne; Cecilia Salazar, Fernanda Sostres y Fernanda Wanderley

2012 Hacia una politica municipal del cuidado. Integrando los derechos de las mujeres y la infancia. La Paz: CIDES-UMSA / Conexión Fondo de Emancipación.

García Fanelli, Ana

1989 "Patrones de desigualdad social en la sociedad moderna: una revisión de la literatura sobre discriminación ocupacional y salarial por género". En: Desarrollo económico, volumen 29, número 114. Buenos Aires. 239-264.

Glass, Jennifer y Valerie Camarigg

1992 "Gender, Parenthood and Job-Family Compatibility". En: American Journal of Sociology, volumen 98, número 1. Chicago, Estados Unidos de América. 131-151.

Goffman, Erving

1967 Interaction Ritual: Essays on Face-to-Face Behavior. Garden City, Nueva York, Estados Unidos de América: Anchor Books.

Gutiérrez, María Alicia (comp.)

2007 Género, familias y trabajo: rupturas y continuidades. Desafios para la investigación política. Buenos Aires: CLACSO.

Hodgson, Geoffrey

1994 "The return of Institutional Economics". En: Neil Smelser y Richard Swedberg (eds.), Handbook of Economic Sociology. Princeton, Nueva Jersey, Estados Unidos de América: Russel Sage Foundation.

Hughes, Everett C.

1946 "The Knitting of Racial Groups in Industry". En: American Sociological Review, volumen 11, número 5. Estados Unidos de América. 512-519. 
52 | Trabajos y trabajadores en América Latina (siglos XVI-XXI)

Instituto Nacional de Estadística y Geografía (INEGI)

2000 Las familias mexicanas. México: INEGI.

Jelin, Elizabeth

2000 Pan y afectos. La transformación de las familias. México D. F.: Fondo de Cultura Económica, Colección Popular.

Kabeer, Naila

1998 Realidades trastocadas. Las jerarquias de género en el pensamiento del desarrollo. México D. F.: Paidós.

López, Cecilia; Molly Pollack y Marcela Villarreal

1992 Género y mercado de trabajo en América Latina. Santiago de Chile: PREALC.

Manser, Marily y Murray Brown

1980 "Marriage and Household Decision-Making: A Bargaining Analysis". En: International Economic Review, volumen 1, número

1. Pennsylvania, Estados Unidos de América. 31-44.

Marco, Flavia

2011 "Los derechos al cuidado y a su redistribución: temas ausentes en las estrategias de desarrollo de ayer y hoy". En: Fernanda Wanderley (ed.), El desarrollo en cuestión. Reflexiones desde América Latina. La Paz: CIDES-UMSA / Oxfam.

Martínez Franzoni, Juliana

2008 ¿Arañando bienestar? Trabajo remunerado, protección social y familias en América Central. Buenos Aires: CLACSO.

McKie, Linda; Sofia R. Bowlby y Susan Gregory

1999 Gender, Power and the Household. Nueva York, Estados Unidos de América: St. Marin's Press.

Montaño, Sonia y Coral Calderón Magaña (coords.)

2010 El cuidado en acción. Entre el derecho y el trabajo. Santiago de Chile: CEPAL / UNIFEM.

Nieves Rico, María

2011 El desafio de un sistema nacional de cuidados para el Uruguay. Santiago de Chile: CEPAL / UNFPA.

Nyssens, Marthe

2006 Social Enterprise: At the Crossroads of Market, Public Policies and Civil Society. Londres: Routledge. 
Organización Internacional del Trabajo (OIT) y Programa de las Naciones Unidas para el Desarrollo (PNUD)

2009 Trabajo y familia: Hacia nuevas formas de conciliación con corresponsabilidad social. Santiago de Chile: OIT / PNUD.

Orozco, Amaia

2010 Cadenas globales de cuidado. ¿Qué derechos para un régimen global de cuidados justos? Santo Domingo: Instituto Internacional de Investigación y Capacitación de las Naciones Unidas para la Promoción de la Mujer.

Paulson, Susan

1996 "Familias que no conyugan e identidades que no conjugan: la vida en Mizque desafía nuestras categorías". En: Silvia Rivera (ed.), Ser mujer indígena, chola o birlocha en la Bolivia postcolonial de los años 90. La Paz: Subsecretaría de Asuntos de Género.

Pautassi, Laura C.

2007 El cuidado como cuestión social desde un enfoque de derechos. Santiago de Chile: CEPAL.

Pautassi, Laura y Carla Zibecchi

2010 La provisión de cuidado y la superación de la pobreza infantil. Programas de transferencias condicionadas en Argentina y el papel de las organizaciones sociales y comunitarias. Santiago de Chile: CEPAL.

Pautassi, Laura y María Nieves Rico

2011 "Cuidado infantil y licencias parentales". En: Desafíos, Boletín de la infancia y la adolescencia sobre el avance de los objetivos de desarrollo del Milenio, número 12. Santiago de Chile: CEPAL / UNICEF.

Polanyi, Karl

2007 La gran transformación. Los orígenes políticos y económicos de nuestro tiempo. Buenos Aires: Fondo de Cultura Económica. [1944]

Rendón, Teresa y Carlos Salas

2000 "El cambio en la estructura de la fuerza de trabajo en América Latina". En: Enrique de la Garza Toledo (ed.), Tratado latinoamericano de sociología del trabajo. México D. F.: Fondo de Cultural Económica.

Sabel, Charles F.

1982 Work and Politics. The division of labor in industry. Cambridge, Inglaterra: Cambridge University Press. 
54 | Trabajos y trabajadores en América Latina (siglos XVI-XXI)

Sen, Amartya

1990 "Gender and Cooperative Conflicts". En: Irene Tinker (ed.), Persistent Inequalities - Women and World Development. Oxford, Inglaterra: Oxford Univerisity Press.

Strauss, Alselm

1978 Negotiation: Varieties, Processes, Contexts, and Social Order. San Francisco, Estados Unidos de América: Jossey-Bass.

Thistle, Susan

2006 From Marriage to the Market. The Transformation of Women's Lives and Work. Berkeley, Estados Unidos de América: University of California Press.

Tilly, Louise y Joan Scott

1978 Women, Work and Family. Nueva York, Estados Unidos de América, y Londres, Inglaterra: Hold, Rinehart and Winston.

Tilly, Chris y Charles Tilly

1998 “Work under Capitalism”. En: Serie New Perspectives in Sociology. Boulder, Colorado, Estados Unidos de América: Westview Press.

Treiman, Donald y Heidi Hartman (eds.)

1981 Women, Work and Wages: Equal Pay for Jobs of Equal Value.

Washington, Estados Unidos de América: National Academy.

Vallas, Steven Peter

2012 Work Key Concepts. Cambridge, Inglaterra: Polity Press.

Veblen, Thorstein

1994 The Theory of Leisure Class. Nueva York, Estados Unidos de América: Dover Publications. [1899]

Wanderley, Fernanda

2015 Desafíos teóricos y politicos de la economía solidaria. Lectura desde América Latina. La Paz: CIDES-UMSA / Hegoa / Plural editores.

2011 El cuidado como derecho social: situación y desafios del bienestar social en Bolivia. Santiago de Chile: OIT.

2003 Trabajo no mercantil e inserción laboral: un abordaje de género desde los hogares. La Paz: CIDES-UMSA / Plural editores.

1995 Discriminación ocupacional y de ingresos por género. La Paz: Subsecretaría de Asuntos de Género.

Weber, Max

1978 Economy and Society: An Outline of Interpretive Sociology. Guenther Roth y Ckus Wittich (eds.). Berkeley, California, Estados Unidos de América: University of California Press. [1903] 


\title{
Los "sin trabajo" antes del "desocupado". Socialistas y anarquistas en la construcción de un problema social a fines del siglo XIX
}

\author{
Sabina Dimarco (Argentina)*
}

After its birth, unemployment continued to be the subject of a continuing gap between reality and representation, and a matter of contrasting political agendas, images, policies and struggles.

Matt Perry, Bread and work, 2000

RESUMEN: Este artículo estudia la construcción del problema de la falta de trabajo en Argentina entre fines del siglo XIX y principios del XX. Varios autores se han preguntado por la forma en que la "invención" de las categorías de desocupación y desocupado por parte de las élites reformistas de cada país contribuyó a la configuración de sociedades salariales. Otros estudios cuestionaron ese enfoque argumentando que deja en las sombras la acción de los propios desocupados y la experiencia concreta de la falta de trabajo. En ambos casos, se reconoce el surgimiento tardío -con relación al desarrollo capitalista- de la figura del desocupado y su relevancia en la configuración de sociedades basadas en la relación salarial.

Esos estudios han demostrado que la reconstrucción de la configuración sociohistórica del desocupado puede ser una valiosa entrada para indagar en las especificidades nacionales de la conformación del mercado de trabajo moderno y el surgimiento de una concepción social de la intervención pública. Sin embargo, esa aproximación ha sido muy poco transitada en los países de la región. En el cruce entre ambas vertientes teórico-conceptuales que se enfocan en el papel de las élites reformistas y aquellas otras que enfatizan en cambio el rol de los propios trabajadores, el artículo se propone analizar los primeros intentos de formulación del problema de la falta de trabajo en Argentina por parte de las organizaciones de trabajadores, socialistas y anarquistas en particular, en el marco de la crisis de 1890.

Doctora en Ciencias Sociales por la Universidad de Buenos Aires y L'École des Hautes Etudes en Sciencies Sociales de París. Consejo Nacional de Investigaciones Científicas y Técnicas (CONICET), Universidad Nacional de General Sarmiento (UNGS). Contacto: sabinadimarco@hotmail.com 
El corpus documental está conformado por sus principales órganos de difusión en ese periodo: El Obrero, en el caso del socialismo, y El Perseguido, en lo que respecta al anarquismo.

Palabras Clave: desocupación; desocupado; socialismo; anarquismo; cuestión obrera.

\section{INTRODUCCIÓN}

Desde hace algunas décadas, historiadores y sociólogos de Europa y Estados Unidos de América han iniciado una corriente de estudios que se pregunta por la "invención" o "constitución" de las categorías de desocupación y desocupado por parte de las élites reformistas como forma de comprender la configuración de las sociedades salariales. Esa línea socio-historiográfica, en la que se encuentran trabajos como los de Christian Topalov (1994), Robert Salai y otros. (1986), Bénédicte Zimmermann (2001) o William Walters (2000), analiza el modo en el que fue tomando forma el proceso de objetivación de la falta de trabajo en categorías específicas de intervención por parte del Estado.

Para que personas que no contaban con ocupación rentada, siendo capaces de trabajar (por sus condiciones físicas o su edad), pudieran ser consideradas desocupadas, tuvo que darse un proceso de normalización y generalización del empleo, es decir que el empleo regular y asalariado se convirtiera en el destino efectivo de la mayoría de la población que depende de su trabajo para vivir (Zimmermann, 2001; Topalov, 1994; Walters, 2000). Según mostraron esas investigaciones, la falta de trabajo pudo ser concebida como un problema colectivo solo como contracara de ese proceso. En esa normalización del empleo jugaron, entre otros factores, las transformaciones económicas y de la estructura ocupacional, el desarrollo de la legislación social a través de la acción reformista y las prácticas sindicales orientadas a la organización del trabajo. El "nacimiento del desocupado" (Topalov, 1994) remite, de acuerdo con esta perspectiva, al periodo que transcurre entre fines del siglo XIX y comienzos del XX en los países de temprana industrialización, afirmándose recién a partir de entonces el concepto en su sentido moderno. La definición del desempleo que terminó por imponerse contiene fundamentalmente tres dimensiones: la ausencia de trabajo, la disponibilidad para aceptar un puesto y la búsqueda laboral activa (Pugliese, 2000). Pero el contenido de esas dimensiones responde a procesos sociohistóricos conflictivos, sujetos a los tiempos y las características de las distintas sociedades, y que parecen nunca estabilizarse del todo: ¿qué es tener o no tener trabajo en un contexto de alta irregularidad del empleo y de prevalencia 
de actividades económicas no consideradas "legítimas"? ¿Qué implica estar disponible para un trabajo (¿para cualquier trabajo?, ¿en qué condiciones?, ¿con qué umbral de ingresos mínimos?)? ¿Cómo demostrar (o corroborar, de acuerdo al lado en que nos situemos) que hay una actitud activa o una intención de conseguir trabajo? Todas estas cuestiones no remiten a meras definiciones técnicas, sino a cambios en las representaciones sociales y mutaciones más generales en las concepciones del valor y el lugar del trabajo en la sociedad que están sujetas a disputas sociales y políticas por la definición del sentido. Un elemento clave -y a su vez el más conflictivo- en la definición del desocupado es el que remite a la involuntariedad de esa falta de trabajo; sin el surgimiento (históricamente situado) de la posibilidad de dejar de considerar la falta de trabajo en un sentido condenatorio y empezar a verla como una situación forzosa, no hay lugar para la emergencia de esa nueva categoría de pensamiento. Como plantea Pugliese, "el análisis histórico del desempleo muestra la difícil afirmación del principio del desempleo como fenómeno involuntario" (2000: 60).

Ciertamente, la falta de ocupación como experiencia de vida es previa a la emergencia de la categoría 'desocupado'. Es por eso que estos autores plantean la necesidad de diferenciarla de la categoría 'pobre válido' -con la que previamente se nombraban situaciones de no-trabajo-, puesto que las representaciones sociales que recaían sobre ambas figuras eran sustancialmente diferentes, como así también el tratamiento que se les destinaba. Mientras que el pobre válido se inscribía en el universo de la pobreza o el problema del pauperismo, pensar esa pobreza en términos de "desocupación" supone ubicarlo en la "cuestión obrera". En los términos de Zimmermann (2001), la formulación de la categoría desocupado se dio recién cuando la falta de trabajo pudo dejar de ser pensada como un problema de "vagancia" para incorporar la idea de que podía afectar a "trabajadores" -incluso a trabajadores calificados-.

Otra serie de estudios, entre los que podemos ubicar los de Richard Croucher (2008) o Matt Perry (2000, 2007), han cuestionado el enfoque que acabamos de presentar argumentando que se trata de un tipo de abordaje centrado en los aspectos institucionales y en la acción reformista de los expertos y/o de las instituciones oficiales, que deja en las sombras la acción de los propios desocupados. En contraposición, proponen el desarrollo de investigaciones que enfaticen la labor de estos últimos (o de sus organizaciones) puesto que entienden que son sus manifestaciones y protestas las que se encuentran en la base del surgimiento de políticas remediales contra el problema de la falta de trabajo. En diálogo explícito con la perspectiva mencionada, Perry plantea que "el desempleo no fue -como decía Salais- inventado; este existió fuese la sociedad o el individuo consciente o no" (Perry, 
2000: 2). ${ }^{1}$ Desde ese lugar, el historiador inglés se pregunta por la temprana experiencia del desempleo y su impacto en la población que lo padecía. Aun así, también él advierte que el reconocimiento del desempleo -entendido como una involuntaria falta de trabajo- fue tardío y disputado, a tal punto que todavía hoy sigue siendo materia de controversia. Quizás el punto medular del desacuerdo entre ambas perspectivas se refiere a si es posible o no considerar a esas formas de no-trabajo (jobless) como "desocupación", antes de que esta fuese establecida como categoría institucional y estadística y antes de que hubiese personas definidas por otros y por sí mismas como "desocupadas". Este punto es sustancial: mientras que desde la primera perspectiva el problema nunca puede preceder a su conceptualización, Perry sostiene que, a pesar de lo tardío de esa formulación conceptual, la desocupación antecedió a su reconocimiento oficial (2000: 19). Coinciden, empero, en que las representaciones sociales de la falta de ocupación como una condición involuntaria deben ser situadas históricamente y son materia de disputa. ${ }^{2}$ Finalmente, la primera serie de estudios se pregunta por la emergencia de la categoría y del uso del término (y algunos autores, como Walters, por su transformación a lo largo del tiempo), así como por las nuevas propuestas de intervención y los cambios en las representaciones que todo ello supone (lo que Topalov resume como el despliegue de un nuevo "sentido común" respecto de ciertas formas de no-trabajo). La segunda perspectiva, en cambio, indaga en la experiencia concreta que esa falta provoca y, lo que nos interesa particularmente, en la importancia de la clase trabajadora y de las organizaciones socialistas en el reconocimiento del desempleo como problema.

A pesar del enorme potencial que este tema tiene para indagar en la conformación del mercado de trabajo moderno, de la clase trabajadora y del surgimiento de una concepción "social" de la intervención pública, este ha sido muy poco transitado en los países de la región. Retomando los aportes de la sociohistoria, nuestro estudio se propone, en su objetivo general, indagar en los primeros intentos de formulación de la categoría 'desocupado' en Argentina, en tanto categoría social, estadística y de política pública. Esa pregunta nos llevaba, como han señalado también otros trabajos, a dos momentos de inflexión, relacionados, a su vez, con dos crisis económicas: la de 1914 y la de

1 Los párrafos citados de libros que en la bibliografía figuran en francés o en inglés son de traducción propia.

2 No debemos olvidar que la emergencia del desocupado como forma de no-trabajo legítima se configura como contracara de la vagancia. Una vasta bibliografía se ocupó del tema en distintos países (Castel, 1997; Burnett, 1994; Wadauer, 2011). En América Latina, la cuestión de la vagancia en el siglo XIX recibió notable atención, aunque por lo general se trata de estudios de casos nacionales. 
1930 (Bertolo, 2008; Daniel, 2013; Grondona, 2012; Dimarco, 2016a). Fue en ese momento cuando las instituciones públicas y los expertos vinculados a estas comenzaron a delinear el problema de la desocupación en Argentina, y cuando la categoría comenzó a perfilar sus límites y a estabilizar su sentido, aun tratándose de un proceso siempre inconcluso.

Como parte de esa pregunta más amplia, en este artículo nos preguntamos por la participación que las organizaciones que se adjudicaban la representación de los trabajadores tuvieron en ese proceso. Estudios previos nos permitían saber que la experiencia de la falta de trabajo había llegado antes que el término y su conceptualización "desde arriba". ${ }^{3}$ Nos preguntamos, entonces, cómo fue pensada y conceptualizada esa experiencia por las organizaciones que se encontraban más cercanas a los trabajadores que padecían en carne propia la falta de trabajo. Más específicamente, cómo era nombrada y explicada, a qué o a quiénes se atribuían las causas y cómo entendían las respuestas las organizaciones socialistas y anarquistas que en ese entonces tenían una presencia muy visible en el mundo obrero. Partimos de la hipótesis de que esas organizaciones habían tenido un papel importante en la formulación del problema de la falta de trabajo; concretamente, en su configuración misma como "problema" en una época en la que no era considerado de ese modo. Pero también -y este es el punto que nos interesa particularmente- en brindar un prisma de interpretación novedoso de esas situaciones. En pocas palabras, si buena parte de los estudios que se han ocupado de esta cuestión han tendido a mostrar que la elaboración de la nueva categoría social resulta de una construcción que proviene de los reformadores sociales de cada país, nuestro trabajo se propone abordarlo como un proceso de configuración más amplio, de plazos más largos y sinuosos, y que involucra a diversos actores. Las agencias públicas, las políticas - propuestas o implementadas- y los actores vinculados a estas tienen un lugar central en ese proceso de problematización, por supuesto, pero también otros actores sociales provenientes de diversos ámbitos de la vida social. En el caso que nos convoca, entre estos actores se encuentran, en un lugar nada menor, las agrupaciones políticas representativas de los trabajadores.

En un trabajo anterior (Dimarco, 2016a) nos preguntamos por el papel que los socialistas de El Obrero jugaron en ese proceso. Aquí se busca profundizar en ese análisis incorporando, para el mismo periodo, la perspectiva anarquista. Indagar en las diferencias y en las semejanzas entre dos vertientes significativas de la representación obrera nos permitirá acceder a una idea más amplia y profunda respecto de cómo era percibido el fenómeno de la falta de

3 Sobre la existencia de desempleo en las últimas décadas del siglo XIX véanse, entre otros: Suriano, 2001; Falcón, 1984; Pianetto, 1984. 
trabajo desde un heterogéneo movimiento obrero en plena conformación; y a su vez, conocer si lo que se presentaba como novedoso en el caso del socialismo era una perspectiva más extendida en el arco de las izquierdas. Se estudian estas cuestiones a partir de tres ejes de indagación: en primer lugar, el análisis del lugar que socialistas y anarquistas dieron a la falta de ocupación en el marco de la crisis; en segundo lugar, cómo concibieron el problema, esto es, la forma en que se lo definía, la atribución de causas y responsabilidades, las disputas de sentido respecto a otras representaciones de la falta de ocupación y las propuestas de resolución; y, por último, cómo eran pensados específicamente los "sin trabajo" en relación al mundo obrero. Nuestro abordaje se ubica, entonces, en la articulación entre las dos perspectivas que mencionamos: retomando, por un lado, la idea de que si bien la ausencia de ocupación como experiencia vital es previa al surgimiento y la generalización del término, el proceso de conceptualización que tiene lugar hacia fines del siglo XIX va delineando una figura nueva que amerita ser analizada en su especificidad. Pero a diferencia de esos estudios, buscamos mostrar que las organizaciones de trabajadores jugaron un rol fundamental en ese proceso de conceptualización. En otros términos, y a diferencia de la interpretación que predomina en los trabajos enmarcados en la segunda perspectiva, no consideramos que ese papel se limite al peso de las protestas y las manifestaciones para instalar el problema, sino también, y fundamentalmente, a su rol activo en la elaboración conceptual de la nueva categoría, con lo que se brinda aquí un marco novedoso de interpretación de la falta de ocupación en personas válidas.

En síntesis, el artículo propone analizar la forma en que la experiencia obrera de la falta de trabajo fue problematizada por parte de las organizaciones socialistas y anarquistas, concentrándonos en el último tramo del siglo XIX, y en particular en los ańos que siguieron a la crisis económica de 1890. Para ello, nos apoyaremos en el análisis de sus principales órganos de difusión del periodo: El Obrero, en el caso del socialismo, y El Perseguido, en lo que respecta al anarquismo.

\section{0, LA IZQUIERDA Y LA CONSTRUCCIÓN DE LOS “SIN TRABAJO"}

Los primeros ańos de la década de 1890 estuvieron signados por una grave crisis política y económica con profundas consecuencias para los sectores populares, a tal punto que esa época puede señalarse como un momento determinante en la conformación del movimiento obrero (Suriano, 2001). Se vivió entonces un importante desarrollo de las organizaciones de trabajadores y una creciente conflictividad social. Además del incremento cuantitativo de las organizaciones gremiales, ganaron terreno las corrientes socialista y anarquista, impulsadas en gran medida por inmigrantes que llegaban con 
experiencias de participación política en sus países de origen. ${ }^{4}$ La prensa dirigida a los trabajadores como público específico, en sus diferentes modalidades de diarios, periódicos, revistas y folletos, fue el ámbito privilegiado de difusión de ideas doctrinarias de ambas corrientes y, en términos más amplios, de todo el arco de las izquierdas (Lobato, 2009).

Fue justamente en 1890 cuando empezó a editarse el periódico anarquista El Perseguido. Voz de los oprimidos (EP), que tuvo una estabilidad considerable para los parámetros de la época, llegando hasta finales de 1896. Sus redactores se proclamaban anarco-comunistas y eran fervientes defensores de la propaganda violenta y contrarios a toda forma de autoridad y estructura jerárquica. El socialista El Obrero. Defensor de los intereses de la clase proletaria $(E O)$ comenzó a publicarse pocos meses después y su duración fue más breve: circuló hasta 1892. Creado a instancias del Comité Internacional Obrero (CIO), El Obrero se presentaba como órgano oficial de la Federación Obrera, aunque esta se constituiría recién unas semanas más tarde. Sus redactores adherían al socialismo científico de matriz marxista y presentaban una postura más proclive a aceptar la intervención del Estado en el ámbito laboral (Tarcus, 2007). Entre ellos figuraba Germán Avé-Lallemant, el más prestigioso referente intelectual socialista de la época, quien estuvo a cargo del periódico en un primer momento.

El mercado de trabajo argentino de la segunda mitad del siglo XIX -aquel que observaban quienes estaban al frente de estas organizaciones- se caracterizaba por la irregularidad del empleo, las colocaciones ocasionales, la escasa calificación de las tareas y la alternancia entre periodos de empleo y otros en que faltaba el trabajo. Estos rasgos estaban ya presentes en épocas previas, pero se exacerbaron con el auge de la economía primario-exportadora que requería de esos flujos y reflujos estacionales de mano de obra entre el campo y la ciudad, y entre el país y el exterior (Pianetto, 1984). Así las cosas, la experiencia de la falta de ocupación era frecuente para quienes necesitaban -cada vez más- de un salario para vivir, y continuó siéndolo a pesar del intenso crecimiento económico del último tercio del siglo. Podría pensarse, retomando a los autores citados al comienzo, que, en tanto la estabilidad del trabajo no solo no era la norma, sino que tampoco era un horizonte deseable -ni por las organizaciones de trabajadores ni por las élites argentinas de esa época-, esa experiencia de falta de trabajo, que por lo general era transitoria,

4 En las últimas décadas del siglo XIX, el mercado de trabajo se vio radicalmente transformado por la llegada de inmigrantes, en su mayoría varones jóvenes. Basta ver los saldos migratorios: de 40.000 a 220.000 personas entre 1880 y 1889 (Pianetto, 1984). Mucho se ha dicho sobre la influencia de esa inmigración en la llegada al país de las ideas socialistas y anarquistas. 
era vivida con cierta naturalidad. Se ha dicho muchas veces que para los trabajadores del siglo XIX esa irregularidad era una forma de vida que les permitía considerables niveles de libertad. ${ }^{5}$ Pero para 1880, las condiciones que hacían posible la subsistencia por fuera de la relación salarial se habían visto afectadas por la combinación de diversos elementos, como el cierre de la frontera, la extensión del uso del alambrado y, con ella, la delimitación precisa de la propiedad de la tierra, la prohibición de cazar determinadas especies - como el ñandú- y la denegación de los "agregados", ${ }^{6}$ que permitían desarrollar estrategias familiares de producción y consumo independiente. De este modo, la vida sin salario se hacía cada día más difícil.

En ese marco, tanto los primeros socialistas marxistas nucleados en torno a El Obrero como los comunistas-anarquistas que participaban en $E l$ Perseguido adoptaron el tema de la falta de ocupación como un fenómeno relevante en la Argentina finisecular. Pero, como puede observarse en las distintas notas que ambos periódicos dedicaron a esta cuestión, en esos años de 1890 la falta de trabajo estaba lejos de ser percibida socialmente como un problema local: se trataba, justamente, de construirlo como tal. Cada uno con su peculiar prisma de interpretación de la realidad social, anarquistas y socialistas -aunque con mucha más intensidad los segundos- se propusieron demostrar que la falta de trabajo era efectivamente un problema que debía ser tenido en cuenta y, en particular, un problema "de sociedad", en el doble sentido de que afectaba a un conjunto social considerable $-y$ no a individuos aislados- y que sus causas remitían al funcionamiento social -y no al carácter (a)moral de los afectados-.

“MillaRES Y MILLARES DE ObREROS SIN TRABAJO...":? DISPUTAS EN TORNO A LA EXISTENCIA (O NO) DE UN "PROBLEMA"

Los problemas sociales tienen, por supuesto, un anclaje en condiciones objetivas. En ese sentido, sería fácil afirmar simplemente que el tema de la falta

5 Topalov (1994) pone como ejemplo del apego de los trabajadores a la independencia que otorgaba el trabajo ocasional el hecho de que quienes se rebelaban contra la falta de ocupación no reclamaran empleo estable, sino ocupación temporaria en obras municipales. En el caso argentino, Mayo (1987) habla de una "actitud poco calvinista”.

6 Mayo (1987) describe para la época colonial dos formas de acceder a la tierra por fuera de la propiedad: asentarse en las todavía abundantes tierras fiscales disponibles o "agregarse" a un establecimiento rural y desarrollar la actividad agropecuaria en pequeña escala.

7 El Perseguido, 1 de enero de 1892. 
de ocupación comenzó a ser problematizado por socialistas y anarquistas porque en ese momento, y como consecuencia de la crisis, la escasez de trabajo empezó a ser un problema "objetivo". Sin embargo, como ya hemos mencionado, la experiencia de la falta de trabajo para quienes vivían de su salario no surgía por primera vez en ese momento. Se nos dirá que ese año adquirió las proporciones colectivas que lo constituyeron en "problema". Sin embargo, como hemos mostrado en otro trabajo (Dimarco, 2016a), no hay una relación lineal entre un hecho y otro. Concretamente, en 1890, esa mayor cantidad de personas que se encontraba en dificultades para ganarse la vida a través del trabajo -y que en los documentos de la época se pueden rastrear en los relatos que dan cuenta del incremento de personas volcadas a las calles en busca de caridad o que colmaban los asilos de mendigos- no fue interpretada como un problema de falta de trabajo, sino como un problema moral: un exceso de personas que, en lugar de valerse por sus propios medios, optaban por "depositarse" en la caridad ajena. La crítica a la llegada de inmigrantes con ideas anarquistas consideradas contrarias al trabajo, de "atorrantes", "falsos mendigos" o "mendigos de profesión" se inscribía en ese tipo de argumentación. En línea con esa perspectiva, las soluciones consistían en un reforzamiento de las medidas represivas y coactivas.

Ese ejemplo nos permite ver que, como señala la sociología de los problemas sociales o públicos (Blumer, 2004; Gusfield, 2014), las condiciones materiales son necesarias para entender la emergencia de un problema, pero no son condición suficiente. Tampoco permiten en sí mismas explicar la forma concreta que ese problema adopta en un momento dado. En el caso argentino, se advierte un claro desacople entre ese primer momento en que se observan indicadores objetivos de un incremento de la falta de oportunidades laborales y su problematización por parte de funcionarios y expertos (Dimarco, 2016a). Es por eso que resulta significativo analizar el proceso de construcción de la falta de trabajo como problema social que socialistas y anarquistas llevaron adelante en un momento en el que no era socialmente percibido de ese modo.

Wright Mills diferencia una inquietud de un problema; mientras que la primera remite a la esfera individual, el segundo constituye un asunto público que remite a "la estructura más amplia de la vida social e histórica" (1986: 28). Una situación puede ser identificada como un problema, dirá, cuando "se advierte que está amenazado un valor amado por la gente” (ibid.). En 1890, a pesar de que las memorias, la prensa, los relatos de viajeros y los censos daban cuenta de un incremento de personas con problemas para valerse por sí mismas a través del empleo, la falta de ocupación no era identificada como "problema" probablemente -retomando los términos de Mills- porque el trabajo (o su estabilidad) no era percibido como un "valor amado por la gente". Demostrar 
que la falta de trabajo era un "problema” en el sentido señalado fue parte de la tarea que, en esos ańos de crisis, emprendieron los socialistas de El Obrero y los anarquistas de El Perseguido. Para ello, confrontaron abiertamente los discursos de la época, denunciando una y otra vez que las interpretaciones "burguesas" cargaban las tintas sobre las personas que padecían la falta de trabajo, y buscaron refutar esos discursos. Lo hicieron no solo recurriendo a argumentos de tipo narrativo a través de sus periódicos, sino también por medio de acciones en la escena pública. Como veremos, ubicar la falta de trabajo como problema implicaba posicionar el trabajo como un valor.

Es sabido que socialistas y anarquistas se encontraban para esa época enfrascados en una tensa disputa en torno a los contenidos doctrinarios de ambas corrientes y a la necesidad de sumar a sus respectivas filas a los trabajadores sin filiación política. El núcleo central de la controversia se hallaba, por un lado, en la forma en que unos y otros pensaban el papel que estaba llamado a desempeñar el Estado y, por el otro, en los medios considerados legítimos en la lucha revolucionaria. ${ }^{8}$ Mientras que las propuestas reformistas estaban en el centro de la crítica ácrata a los socialistas, estos últimos rechazaban el uso de la violencia en la acción política por parte de los primeros. Sin embargo, en el tema que aquí nos ocupa, es posible advertir puntos de encuentro en las narrativas respecto del problema de la falta de trabajo. Un claro elemento de coincidencia es la forma en que en ambos periódicos se presentaba la visión burguesa sobre el tema.

Lo que socialistas y anarquistas consideraban la perspectiva "burguesa" de la falta de trabajo se puede rastrear a través de las denuncias al tratamiento que hacían del tema los medios de prensa tradicionales, las agencias de colocación, la Oficina de Trabajo del Departamento de Inmigraciones, los grandes hacendados y la Policía. A todos ellos se los ubicaba como los formadores de una imagen negativa del obrero sin trabajo. El Obrero, por ejemplo, denunciaba desde sus páginas que los grandes hacendados publicitaban la búsqueda de trabajadores con el único fin de "formar un ejército de reserva agricultor" en su beneficio; ${ }^{9}$ la Oficina de Inmigración era acusada de prometer trabajo a los obreros extranjeros y enviarlos al interior donde había "sobreabundancia de brazos y miles de proletarios sin ocupación", ${ }^{10}$ con el objetivo de bajar los salarios; la prensa burguesa, decían, "se queja que numerosa gente hábil para el trabajo, pierda su tiempo en la capital viviendo

8 Martín Albornoz (2015) trabajó sobre las controversias entre anarquistas y socialistas en Buenos Aires entre finales del siglo XIX y comienzos del XX.

9 El Obrero, 27 de junio de 1891.

10 Ibid. 
de la caridad pública y sin hacer nada, por conseguir ese trabajo que abunda en el litoral y en el interior"; ${ }^{11}$ y la Policía "les dará caza como a fieras, los recogerá e irán al trabajo forzado [...] sin causa, sin justicia ni sentencia de juez competente, pura y simplemente porque la santa policía así lo quiere y los declara de vagabundos $[s i c]{ }^{\prime} .{ }^{12}$ Este tipo de críticas se encontraba también en el periódico anarquista cuando, por ejemplo, denunciaba que ciertos medios de prensa ponían en duda que los obreros estuviesen atravesando un momento difícil: "[...] no cree en la crisis que atraviesan los obreros de Buenos Aires pues que cuando [sic] los solicitan para ir á trabajar á la campaña para los trabajos de agricultura y no acuden [sic] con esto prueban que hay una gran resistencia al trabajo y que más que crisis y hambre, lo que hay es una crisis de haraganes"; ${ }^{13}$ o se burlaban del comisario porque, al mismo tiempo que negaba que faltase el trabajo, aplicaba con todo vigor la ley de vagancia. ${ }^{14}$

$\mathrm{Al}$ reconstruir lo que socialistas y anarquistas percibían como la representación "burguesa" de la falta de trabajo, aparecen con mucha insistencia dos elementos: por un lado, el planteamiento de que todo aquel que no tuviese ocupación demostrable era considerado un "vago" o "atorrante", alguien que rehuía a la disciplina del trabajo; por el otro, pero articulado con lo anterior, que desde los ámbitos burgueses se buscaba mostrar que la Argentina carecía de los problemas de empleo que tenían otras sociedades en esa misma época. Por eso, en ambas publicaciones las solicitudes de empleo de las agencias de colocación o de la Oficina de Inmigración, así como las quejas frecuentes de los grandes hacendados que no conseguían mano de obra disponible, no se consideraban (como ocurre en general en la historiografía que se ocupa de este periodo) como una demostración de que el problema de la falta de trabajo no era tal sino, por el contrario, como una "farsa" que buscaba ocultar un problema realmente existente. Más allá de algunas diferencias en la forma en que se establecía la crítica en un periódico y en otro, ${ }^{15}$ ambos coincidían en lo esencial: la denuncia de una estrategia burguesa para mostrar que había trabajo en el país como una forma de responsabilizar a quienes se encontraban

11 El Obrero, 7 de noviembre de 1891.

12 El Obrero, 5 de marzo de 1892.

13 El Perseguido, 6 de enero de 1891.

14 El Perseguido, 14 de junio de 1891.

15 El Obrero, por ejemplo, interpretaba los avisos de empleo como una forma de movilizar a trabajadores a través del engaño para generar una "sobrepoblación relativa” que impulsara el descenso de los salarios, mientras que para El Perseguido no se trataba de que los anuncios no fuesen ciertos, sino que encubrían condiciones degradantes de contratación. 
desocupados. En efecto, si, como se decía, el país ofrecía posibilidades de empleo a aquel dispuesto a buscarlo, entonces las causas de la carencia recaían en las propias faltas de la persona sin trabajo (falta de voluntad, de esfuerzo, de moralidad). De ahí que dichos argumentos estuvieran en el foco de la denuncia por estas organizaciones, en el marco de la formulación de la falta de trabajo como un problema social en la Argentina de fin de siglo. Desde El Obrero y El Perseguido se recurría alternativamente a la refutación o la burla. En ese sentido, los anarquistas de este último planteaban con ironía:

Coraje trabajadores! 'El diario' nos avisa que hay trabajo para todos y demanda de obreros en todos lados de la República. Recién ahora nosotros nos esplicamos $[s i c]$ el porqué de tanta emigración para la Europa y el Brasil. Estábamos tan ignorantes de no saber que si los obreros escapan de esta República, es porque hay abundancia de trabajo. ${ }^{16}$

Mientras que en una nota titulada "Los trabajadores sin trabajo" los socialistas afirmaban:

La prensa se queja que numerosa gente hábil para el trabajo, pierda su tiempo en la capital viviendo de la caridad pública y sin hacer nada, por conseguir ese trabajo que abunda en el litoral y en el interior. El Comisario General de Inmigración, él que con tanto empeño se esfuerza de atraer más inmigración a este país, en donde cientos de miles de trabajadores están sin ocupación, y el Jefe de Policía de la Capital, se pondrán de acuerdo sobre las medidas que corresponda adoptar. ${ }^{17}$

Así pues, a través de la confrontación directa, e incluso de la ridiculización de los discursos en circulación, iban presentando una realidad social radicalmente diferente sobre la situación obrera de la falta de trabajo. Para refutar los argumentos que sostenían la inexistencia del problema, y que buscaban legitimarse en las publicaciones de ofertas de empleo, la "guerra a las agencias de colocación"18 resultaba central, en particular en la prensa socialista. Pero, además, plantear la existencia de un problema requería demostrar que no se trataba de un fenómeno aislado y marginal, sino colectivo y masivo. En este punto, la utilización de cifras constituía un recurso fundamental para pasar de la idea de un problema individual a la construcción

16 El Perseguido, 14 de junio de 1891.

17 El Obrero, 7 de noviembre de 1891.

18 Este era el título de una nota. 
de la falta de trabajo como problema colectivo, que afectaba a un número considerable y preocupante de trabajadores. El Obrero y El Perseguido recurrían a diferentes cifras - de las cuales nunca se señalaba la fuente- que eran utilizadas para objetivar el problema y demostrar con evidencia "empírica" su carácter generalizado. El Perseguido calculaba en diciembre de 1890 "más de diez u doce mil trabajadores y que será aumentado este número con los que queden cesantes para primero de año", ${ }^{19}$ y en septiembre de 1891 hablaba de "20.000 en esta ciudad sin trabajo"; algunos meses después mencionaban que había "millares y millares de obreros sin trabajo, reducidos a la más absoluta miseria" ${ }^{20}$ El Obrero, por su parte, decía a comienzos de 1891: "Creemos no equivocarnos mucho, si afirmamos que el número de trabajadores sin ocupación y fuera de trabajo en esta ciudad de Buenos Aires no baja de diez mil (10.000) hoy en día. Diez mil hombres sin trabajo, sin medios de subsistencia!" ${ }^{21}$ y un mes más tarde sostenía: "Naturalmente la intendencia nada dice, de que en Buenos Aires no deben bajar de 20 a 30.000 el número de hombres que están sin ocupación, sin trabajo, que no saben en donde $[s i c]$ buscar el pan del día". ${ }^{22}$ Estas son solo algunas de las cifras que se citaban como una forma de refutación empírica de los discursos que negaban la existencia de un problema.

En ese intento por dar entidad a la falta de ocupación, los socialistas de la recientemente creada Federación Obrera dieron un paso más organizando una acción política que buscaba ubicar a los "sin trabajo" en el espacio público de modo tal que la escenificación del número operara en sí misma como la mejor refutación de tales argumentos. En uno de sus primeros números, El Obrero publicó una extensa nota convocando al "meeting de trabajadores sin ocupación” organizado por la Federación. ${ }^{23}$ La organización del mitin respondía a un doble objetivo: por un lado, dar visibilidad al fenómeno y así "hacer presente a los poderes del estado la situación desesperada en que se halla sumida una enorme mayoría de los ciudadanos de esta capital". ${ }^{24}$ Por otro lado, la organización de esa acción se presentaba desde el socialismo como la posibilidad de brindar una interpretación diferente del fenómeno. Veamos entonces qué se buscaba argumentar por medio de la organización del mitin.

19 El Perseguido, 7 de diciembre de 1890.

20 El Perseguido, 1 de enero de 1892.

21 El Obrero, 9 de enero de 1891.

22 El Obrero, 17 de octubre de 1891.

23 El Obrero, 9 de enero de 1891.

24 Ibid. 
68 Trabajos y trabajadores en América Latina (siglos XVI-XXI)

\section{"Sufrimos sin NUEStra culpa".25 Argumentos para un nO-trabajo inVoluntario}

En la convocatoria al mitin que se difunde a través de El Obrero puede leerse lo siguiente:

Si convidamos á todos los trabajadores de todas condiciones, artesanos obreros, jornaleros simples y todos los que están sin ocupación, que concurran á un grande $[s i c]$ meeting de trabajadores baldíos es simplemente con la intención de hacer presente á las autoridades supremas, y á la clase superior, las condiciones desesperadas en que nos hallamos, decirles que sufrimos, que sufrimos sin nuestra culpa, y que les pedimos que nos ayuden, que nos den trabajo, que nos permitan ganar el pan diario para nuestros hijos, que ellos, ellos que se encuentran en posesión de la tierra entera y de todos los demás medios de producción son los que pueden y deben auxiliarnos. ${ }^{26}$

Con la organización del mitin, que se esperaba masivo, se quería demostrar no solo que se trataba de un problema generalizado, y que por lo tanto no se ajustaba al ámbito de lo personal, sino también objetar la falacia de que se trataba de un problema moral de personas que no se esforzaban por trabajar. La obligación moral del trabajo no era puesta en duda, al menos en el caso del socialismo, sino que se buscaba demostrar que, a pesar de los grandes esfuerzos que se llevaban a cabo individualmente, no había trabajo disponible. En clara oposición a lo que percibían como la idea burguesa, desde El Obrero dedicaron varias notas a mostrar a los "sin trabajo" como personas activas y esforzadas en la búsqueda de subsistencia: "[...] hallamos un gran número de trabajadores, que andan en busca de una ocupación, golpean en todas las puertas, recorren las calles de día y de noche, teniéndose por bien servido si hallan algún trabajo ordinario por algunas horas [...]”. Y cuando la prensa burguesa acusaba a los jóvenes de querer vivir a costa de la caridad y los impelía a que buscasen por medio del trabajo, "lo que encuentran en la mendicidad y la holganza", desde El Obrero respondían: "No hay trabajo" 27 (Dimarco, 2016a). De esa manera se apuntaba al corazón de la perspectiva burguesa por la falta de trabajo como un problema de vagancia.

Entre los anarco-comunistas de El Perseguido se desarrollaba una argumentación similar. También aquí aparecía con fuerza la idea de que había deseo de trabajo y esfuerzo para buscarlo, es decir que había voluntad de

\section{Ibid.}

26 Ibid.

27 El Obrero, 15 de agosto de 1891. 
trabajo y que lo que faltaba era el trabajo mismo. “¿Por qué es negada o contrastada la existencia á tantos obreros que no tienen otro deseo que de vivir trabajando y produciendo en bien del cuerpo social, es decir á ventaja suya y la de todos?”. ${ }^{28}$ En un párrafo que citamos previamente se mencionaba que un periódico burgués descreía de la crisis obrera y adjudicaba la falta de ocupación a que había "una gran resistencia al trabajo" y "una crisis de haraganes". ${ }^{29}$ El Perseguido recuperaba esa nota para criticar las duras condiciones de trabajo que hacían imposible tomar esos puestos, y finalmente concluía:

Si estos señores redactores de 'La Capital' se fijaran un poco más en el procedimiento que usan los burgueses con los desheredados, me creo que tendrían más razón en censurar la conducta de los primeros que no en maltratar á los segundos $[\ldots] .^{30}$

En esa misma línea, otra nota planteaba que solo "el que quiera trabajar mucho, comer y dormir poco y no cobrar nada" podía aceptar los puestos que ofrecía la Oficina Nacional de Trabajo. ${ }^{31}$ En este punto habría que mencionar una diferencia entre ambas corrientes, que nos lleva a la cuestión de la "disponibilidad". Desde la argumentación ácrata, el rechazo de esos puestos en condiciones degradantes era considerado aceptable, puesto que la demanda de trabajo no implicaba para ellos la disponibilidad absoluta para aceptar cualquier colocación, en cualquier lugar y bajo cualquier condición. Los socialistas, en cambio, postulaban más bien la falsedad absoluta de la existencia de esos puestos en el interior, y se esmeraban por señalar que los obreros sin ocupación estaban dispuestos a trabajar "en cualquier trabajo". En la convocatoria al mitin, se los describía como "[...] atormentados por el hambre, por la menesterocidad la indijencia [sic] propia y de los de su familia quisieran trabajar en cualquier trabajo, sea donde fuese, con tal de ganar tanto como para poder dar de comer a sus hijos". ${ }^{32}$ Cualquier trabajo, sea donde fuese, aparece aquí con un uso argumentativo claramente orientado a enfatizar lo forzoso y por lo tanto involuntario, de esa falta de trabajo.

La demostración de que se trataba de un no-trabajo forzado se articulaba con la identificación de las causas. Una vez fuera del argumento moral que

28 El Perseguido, 1 de enero de 1892.

29 El Perseguido, 6 de enero de 1891.

30 Ibid.

31 El Perseguido, 27 de septiembre de 1891.

32 El Obrero, 9 de enero de 1891. 
reducía la explicación al comportamiento individual, la pregunta por las causas adquiría otro peso. Tanto socialistas como anarquistas adjudicaban las causas de la falta de trabajo a las condiciones estructurales del sistema capitalista. En el periódico ácrata no hay, no obstante, un desarrollo importante de este tema, como no lo hay en general del funcionamiento de la economía. Solo en una oportunidad, y con la intención de realizar una crítica a las sociedades de resistencia y no de tratar de entender las causas de la falta de trabajo, explicaban los motivos de la disminución de salarios por la ley de la oferta y la demanda: "Ley que es inerente $[$ sic $]$ al organismo capitalista y sólo desapareciendo éste podrán desaparecer los malos efectos de aquella". Desde su perspectiva, la ley de oferta y demanda, "y no la unión por medio de las sociedades de resistencia como algunos pueden pensarlo", era la que explicaba la alternancia entre la baja y el alza de los salarios de la clase obrera. Al aumentar los medios de producción disminuía la cantidad de obreros necesarios, dejando a muchos de ellos sin trabajo, generando las condiciones para que, ante la abundancia de oferta de trabajo, el patrón pudiese disminuir salarios. Retomando sus palabras:

Con esto queda probado que con el invento de una máquina, de cada sesenta obreros del ramo en que se aplique se pueden quedar cincuenta y nueve sin trabajo. [Estos últimos] [...] se ven obligados a competir con aquellos obreros que han quedado trabajando y al poco trabajo que hay que hacer se lo disputan, y todos van á ofrecer su trabajo, a aquel patrón que en vez de precisar sesenta no más precisa uno. ${ }^{33}$

Pero es importante tener presente que esta explicación no se orientaba a entender la falta de trabajo como problema específico, sino a demostrar que la organización en sociedades de resistencia no generaría nada bueno para "los obreros como clase" mientras se mantuviese la sociedad "basada en la propiedad individual y en la fratricida competencia industrial y comercial", que daría lugar a nuevos inventos, incrementando otra vez la oferta de trabajo. ${ }^{34}$

En los escritos de los socialistas de El Obrero, en cambio, estaba mucho más presente la búsqueda de explicaciones vinculadas a la oferta y la demanda, así como el análisis de la funcionalidad de los "sin trabajo" para el sostenimiento del capitalismo. El bagaje conceptual aportado por las ideas marxistas se observa con claridad en la interpretación de la falta de trabajo en términos de "sobrepoblación relativa" o "ejército de reserva". Planteaban,

33 El Perseguido, 25 de noviembre de 1890.

34 Ibid. 
por ejemplo, que en tanto los "sin ocupación" constituían un ejército de reserva del capital, cumplían una función vital tanto porque aseguraban mano de obra disponible a los capitalistas (en este caso, además, fuerza de trabajo ajustable a los requerimientos fluctuantes de la economía agroexportadora) como porque presionaban a la baja los salarios:

En las provincias hay una sobrepoblación relativa, que no halla trabajo y no tiene qué comer, sumida en la mayor miseria. Estos pedidos de trabajadores hacen los gran $[s i c]$ hacendados capitalistas, para formar un ejército de reserva agricultor $[\ldots]$ ejército que provee a sus necesidades variables de trabajo, la materia humana siempre explotable y siempre disponible. [...] Por esta sobrepoblación relativa el estanciero tiene en su mano el de bajar los salarios a un mínimo terrible. Tenemos noticias de todas las provincias y en todas hay una sobrepoblación sin trabajo. ${ }^{35}$

En línea con los postulados de Marx, esa sobrepoblación relativa no era vista como mera consecuencia de la acumulación capitalista, sino como su condición de posibilidad (Marx, 2004: 786). En el caso local, los socialistas argentinos sostenían, como ya mencionamos, que esa sobrepoblación era provocada activamente por parte de los grandes hacendados, los medios de prensa a su disposición y el Estado, entendido como aparato de dominación de esa misma clase: "[...] El Estado comete un verdadero crimen, facilitándoles a estos explotadores de la miseria, su jugada infernal e inhumana". ${ }^{36}$

Ahora bien, en el caso de los anarquistas de El Perseguido, la idea de un no-trabajo forzado o involuntario y su inscripción en el marco del funcionamiento sistémico del capitalismo los llevaba a rechazar cualquier intento reformista, mientras que desde el socialismo, por el contrario, al invertirse la responsabilidad (del individuo al sistema), se pensaba que correspondía a esos "otros" -que estaban en la base de la generación del problemaadoptar soluciones: a los propietarios de la tierra y los medios de producción se les demandaba la generación de trabajo, y al Estado se le reclamaba obra pública, colonias agrícolas, la limitación de la inmigración "artificial" (a la que distinguían de la "natural"), una bolsa de trabajo y la sanción de leyes protectoras, en particular la jornada legal de ocho horas, que era pensada por el socialismo como una forma de distribuir el trabajo existente (Dimarco, 2016a).

35 El Obrero, 27 de junio de 1891.

36 El Obrero, 16 de enero de 1892. 
72 | Trabajos y trabajadores en América Latina (siglos XVI-XXI)

“EL hOMbRE VIVE, Y TIENE EL DERECHO Y EL DEBER DE VIVIR". ${ }^{37}$ ARGUMENTOS SOBRE EL TRABAJO COMO DERECHO

La forma en que se pensaba el trabajo en las corrientes de izquierda aquí analizadas es un elemento central para entender el lugar otorgado a la falta de ocupación en su cosmovisión. Sobre la base de entender el trabajo como un valor que debía ser defendido (un valor amenazado, en los términos ya citados de Wright Mills), tomó forma la posibilidad de pensar la falta de trabajo como un problema de orden social. Para la perspectiva anarco-comunista que desplegaba El Perseguido, el trabajo era fundamentalmente una necesidad vital. Del trabajo dependía la propia supervivencia y la de la familia, y no contar con una ocupación que garantizara un ingreso implicaba la muerte social y biológica. El hombre, decían, tenía el deber de producir, y ese deber "no se impone para crear capitales y especular con ellos; lo impone el derecho para consumir" ${ }^{38}$ "[...] Proporcionarnos lo necesario para la subsistencia propia y de nuestros hijos" constituía tanto un deber como un derecho. No tener trabajo inducía al hombre a la peor de las miserias y degradaciones. Pero lo que lo hacía particularmente inaceptable era que esa miseria se producía en un marco de abundancia apropiada por la burguesía. Se planteaba entonces que "pasar miseria en medio de la abundancia, esto sería un crimen ridículo que causaría la risa de las generaciones futuras [...]". 39 Por otra parte, no estaba ausente un sentido del trabajo más vinculado a la idea de realización del hombre: "Solo en el trabajo está la felicidad", planteaban desde el periódico; pero esa realización más plena solo sería posible fuera del capitalismo, cuando cada quien pudiese producir para sí mismo y según sus necesidades y posibilidades.

Puesto que garantizarse la subsistencia era considerado un deber y tener un trabajo con qué hacerlo un derecho, no pelear por ese derecho equivalía a un "suicidio lento". Por eso, para los anarco-comunistas de El Perseguido la crisis de 1890 debía constituir un punto de inflexión en la lucha obrera por la revolución social:

Si la actual crisis no decide a los trabajadores a ejercitar sus derechos de hombres, tomando lo que necesitan para la subsistencia en donde quiera que se encuentren, como es su deber hoy que se les cierran todas las puertas de la vida, será sin duda alguna porque en sus cerebros no ha encarnado aún

\section{Ibid.}

38 El Perseguido, 6 de enero de 1891.

39 El Perseguido, 7 de diciembre de 1890. 
la idea del derecho, puesto que aceptan pasivamente el suicidio lento en vez de luchar por la conservación de su existencia. ${ }^{40}$

El derecho al trabajo se vinculaba al derecho a la vida, pero también con el lugar social de los trabajadores como los verdaderos y únicos productores. No era aceptable, decían desde las páginas del periódico, que no tuviesen "lo necesario para vivir sin privaciones de ninguna clase toda vez que siempre hemos empleado nuestra actividad en la producción a fin de tener lo necesario para la vida". ${ }^{41}$

En la concepción del trabajo por parte de los socialistas de El Obrero se encuentran fácilmente las resonancias marxianas. Para Marx, los proletarios "no viven sino a condición de encontrar trabajo [...]" (Marx y Engels, 1994: 38). Por eso, en sus Manuscritos planteaba que:

[...] tan pronto, pues, como al capital se le ocurre-ocurrencia necesaria o arbitraria- no existir más para el trabajador, este ya no existe para sí; no tiene trabajo alguno; por ende, ningún salario, y puesto que no posee un ser en cuanto hombre, sino en cuanto trabajador, puede hacerse enterrar, morir de hambre, etc. (Marx, 1999: 123).

En esa perspectiva se inscribía la argumentación de los socialistas argentinos para quienes no contar con trabajo que permitiese la subsistencia era el comienzo de un camino de degradación que llevaba a la peor de las condiciones. Pero los socialistas vernáculos enfatizaban aún más los padecimientos relativos a esa carencia en la vida de los obreros y sus familias. Como los anarquistas, también ellos sostenían, en línea con el socialismo internacional, la lucha por el derecho al trabajo, que se deducía del "derecho a la vida": "el hombre vive, y tiene el derecho y el deber de vivir. Para poder cumplir con este deber es indispensable que él halle los medios indispensables de subsistencia, y estos medios no los halla sino por el trabajo, por el trabajo productivo, propio ó ajeno" ${ }^{42}$ Constituía entonces "un deber social el de facilitar a cada individuo la parte que le corresponde en el trabajo productivo". ${ }^{43}$

De este modo, tanto para El Perseguido como para El Obrero, si bien la forma que adquiría el trabajo en las relaciones de producción capitalista no permitía la realización humana en un sentido pleno, como sucedería una vez

40 Ibid.

41 El Perseguido, 7 de diciembre de 1890.

42 El Obrero, 16 de enero de 1892.

43 Ibid. 
alcanzada la revolución, encontrarse sin trabajo era, en los términos de los primeros, "no poder cumplir con el deber que tenemos de proporcionarnos lo necesario para la subsistencia propia y de nuestros hijos", ${ }^{44}$ y para los segundos, no "ganar tanto como para poder dar de comer a sus hijos". ${ }^{45}$ Era, ni más ni menos, la reproducción de la vida la que peligraba, lo que llevaba a plantear la necesidad de hacer algo al respecto. Ahora bien, si, como vemos, las argumentaciones podían tener considerables puntos de contacto cuando se trataba de demostrar la importancia de atender el problema de la falta de ocupación, las respuestas que se postulaban en un caso y en el otro eran marcadamente diferentes.

Desde el socialismo, como ya vimos, la opción reformista era una alternativa válida y correspondía al Estado jugar un papel en la resolución del problema. En la perspectiva anarco-comunista, en cambio, la falta de oportunidades de trabajo era presentada como una "guerra a muerte que se ha declarado a los trabajadores cuando no los necesitan", 46 y esa guerra solo podía ser resuelta con la revolución social y el paso de la propiedad privada a la propiedad común. Pero, sobre todo, importa señalar que eran los propios trabajadores los que debían reaccionar y "ejercitar sus derechos de hombres, tomando lo que necesitan para la subsistencia en donde quiera que se encuentren". ${ }^{47}$ La crisis debía servir, planteaban desde El Perseguido, como puntapié inicial para fundar la sociedad comunista-anárquica en la que prevaleciera "el derecho de consumir según sus necesidades y deber de producir según sus facultades". ${ }^{48}$

En pocas palabras, tanto en la narrativa socialista como en la anarquista, el derecho a la subsistencia daba lugar al derecho al trabajo, y este se convertía en el principal argumento de justificación del no-trabajo como una situación involuntaria: nadie podía no querer trabajar cuando lo que estaba en juego era la propia vida y la de la familia. El trabajo como deber social no estaba puesto en duda, aunque en el marco del capitalismo era visto como una actividad alienante y objeto de explotación. Tampoco entraba en cuestión el carácter ocasional del trabajo, tan propio de la época, y que llevaba a que los periodos sin trabajo fuesen una posibilidad siempre latente. Lo que se reclamaba era tener un trabajo que permitiera obtener

44 El Perseguido, 7 de diciembre de 1890.

45 El Obrero, 9 de enero de 1891.

46 El Perseguido, 7 de diciembre de 1890.

47 Ibid.

48 El Perseguido, 6 de enero de 1891. 
los medios indispensables para la subsistencia. El texto de la convocatoria al "mitin de los sin trabajo" lo planteaba con ironía: "Pedimos que nos dejen trabajar al servicio del capital. Queremos ser como siempre esclavos de los medios de producción y producir el capital que pertenecerá en seguida a ellos nuestros patrones". ${ }^{49}$

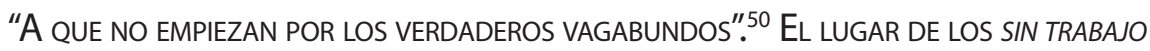 EN EL MUNDO OBRERO}

Cuando en El Obrero hablaban del problema de la falta de ocupación, utilizaban diversas formas para nombrar a quienes se veían afectados por esas circunstancias: "obreros sin ocupación", "trabajadores sin trabajo", "trabajadores baldíos", "hombres sin trabajo", "proletarios sin ocupación”, entre otras. En el caso de El Perseguido, no debemos perder de vista que el tema estaba mucho menos presente. En este periódico se los mencionaba como "obreros sin trabajo", y en una oportunidad se alude a ellos como "trabajadores, por falta de ocupación, ociosos". Pero lo que nos interesa señalar es que en todos los casos se estaban refiriendo a personas que querían y necesitaban trabajar, pero no contaban con una ocupación que les proporcionara un ingreso económico. El término "desocupados", que será el utilizado por socialistas y anarquistas poco después (en la crisis de 1897) para nombrar estas situaciones, no fue utilizado ni una sola vez.

Un elemento central en la construcción de esa figura de no-trabajo involuntario o forzado, para contraponerla a las representaciones dominantes en la época, era la distinción respecto a la figura del vago. Como vimos, la asimilación entre toda forma de no-trabajo y la idea de la vagancia estuvo en el eje de la disputa conceptual con la visión burguesa. Nos detendremos ahora en el modo en que pensaban esa relación no-trabajo/vagancia desde las corrientes socialista y anarquista.

Hemos encontrado tres formas diferentes de interpretación de esa asociación en estos periódicos. La primera de ellas, que se hallaba tanto entre los socialistas como entre los anarquistas, postulaba un desmentido contundente de esa asimilación: los "sin trabajo" no eran vagos, ni personas con tendencia al ocio. La encontramos, por ejemplo, en los esfuerzos antes analizados por demostrar que se movían activamente en busca de ocupación, que estaban dispuestos a hacer "cualquier trabajo" con tal de ganar un salario y que "sufrían" por la situación en que se encontraban. Desde esa perspectiva,

49 El Obrero, 9 de enero de 1891.

50 El Perseguido, 14 de junio de 1891. 
la idea de la vagancia era una imagen creada por los medios e instituciones burguesas para estigmatizar y perseguir a los obreros que no conseguían trabajo. Esta idea aparecía en algunas notas aisladas de El Perseguido y con particular fuerza en las páginas de El Obrero. ${ }^{51}$ Un ejemplo muy interesante es una nota en la que se burlaban del sistema de trabajo forzoso como castigo a la vagancia; allí planteaban lo paradójico que resultaba que para castigar a quienes se tildaba de vagos se les diera el trabajo de aquellos que, al quedarse sin esa ocupación, pasarían entonces a ser, a su vez, nuevos "vagos". En pocas palabras, la vagancia era la forma en que -para los socialistas- los burgueses condenaban a quienes habían perdido su ocupación.

En una línea similar, desde El Perseguido se mencionaba con sarcasmo que en los medios se informara que se aplicaría con todo vigor la ley de vagancia y, al mismo tiempo, desestimaran la relevancia del problema de falta de trabajo: "Como son ridículas nuestras autoridades: siguen diciendo que no falta trabajo y se ven hasta obligados á fabricar una ley por el miedo que les dá el continuo aumento de hombres sin trabajo!!! A que no empiezan con los verdaderos vagabundos". Desde esta perspectiva, "vagos" o "atorrantes" no era más que el nombre peyorativo que los burgueses daban a los obreros sin trabajo.

La última parte de la frase recién citada, "a que no empiezan con los verdaderos vagabundos", nos lleva a la segunda variante de la articulación entre no-trabajo y vagancia que hemos encontrado en nuestro corpus y que está presente fundamentalmente en los discursos anarquistas. En este caso, la forma en que se interpreta esa relación consiste en revertir el estigma asociado a la segunda categoría. Los "vagos", los que no trabajan, los que no producen nada útil para la sociedad eran, desde la perspectiva ácrata, los burgueses; los trabajadores, en cambio, inclusive aquellos sin trabajo, eran presentados como los miembros productivos de la sociedad. En una carta publicada en 1890 afirmaban:

Si pretenden tratarnos de vagos y fanfarrones, mas nosotros, con sobradísima razón sabremos deciros: vosotros burgueses sois la escoria que corrompe el orden de los pueblos, sois la inmoralidad, la basura. [...]. Nos echan en cara los harapos y la miseria a que ellos mismos nos han condenado. ${ }^{52}$

Otro elemento que podríamos vincular con esta estrategia de reversión del estigma, y que también es propio del discurso ácrata, es la apropiación del término 'vago' o 'atorrante' en un sentido positivo y su asimilación con el

51 Sobre el tratamiento de este tema en El Obrero hemos trabajado en Dimarco, 2016a.

52 El Perseguido, 25 de noviembre de 1890. 
ideal anarquista. Un ejemplo claro es la primera frase de la nota de apertura del periódico. “¿Qué somos y qué haremos?”, llevaba por título, y comenzaba diciendo: "Nosotros somos los vagabundos, los malhechores, la canalla, la escoria de la sociedad, el sublimado corrosivo de la organización social actual". ${ }^{53}$ De este modo, los vagabundos no solo no serían una categoría aparte, ni serían únicamente los obreros sin trabajo, sino que se producía desde el anarquismo una identificación con esa figura estigmatizada.

Finalmente, la tercera variante que encontramos y que se encuentra en ambas corrientes retomaba, aunque con diferencias interesantes, ciertos elementos de la teoría de la degeneración, muy extendida en estas tierras. ${ }^{54}$ En esta línea interpretativa, la vagancia o el "atorrantismo" se presentaba como el resultado de un proceso de degradación. Última posta en un descenso paulatino que incluía el alcoholismo, el crimen y la prostitución en el caso de las mujeres. En esta variante, no había una revalorización en un sentido positivo de la figura del vago o atorrante, como vimos en la variante anterior, pero, a diferencia de la utilización generalizada de la teoría de la degeneración que estaba muy presente en la imagen burguesa del no-trabajo, desde el anarquismo se lo explicaba como una consecuencia no deseada de un proceso que excedía ampliamente los comportamientos individuales. Y este punto resulta central porque, si bien es posible encontrar en ciertos pasajes del periódico atisbos de una condena moral de quien había "caído en el atorrantismo", se lo justificaba en tanto eran considerados víctimas de un sistema. Desde El Perseguido, por ejemplo, se preguntaban:

Es vos general: la miseria aumenta. Nunca en medio de la abundancia se ha presentado semejante espectáculo: millares y millares de obreros sin trabajo, reducidos á la más espantosa pobreza. ¿Y por qué tanta miseria? ¿Por qué es negada y contrastada la existencia á tantos obreros que no tienen otro deseo que [el] de vivir trabajando y produciendo, en bien del cuerpo social, es decir á ventaja suya y de la de todos? ¿Por qué están entonces abandonados al ocio asesino y desmoralizante? ¿Por qué una cantidad grandísima de hombres están reducidos en un ejército de atorrantes, de criminales y de mugeres $[s i c]$ del pueblo en una caterva de prostitutas?

53 El Perseguido, 18 de mayo de 1890.

54 Campos Marín, Martínez Pérez y Huertas García-Alejo (2000) plantean que los discursos socialistas y anarquistas sobre la degeneración resultan de gran interés porque ponen de manifiesto cómo dicha teoría podía ser susceptible de interpretaciones contrapuestas, al punto de poder convertirse en denuncia del sistema capitalista en el marco de estas corrientes ideológicas. 
Como vemos en la cita, consideraban que la falta de trabajo tenía consecuencias morales, y daba lugar a ese "ejército" de figuras que en la época eran catalogadas como "mala vida". También en El Obrero encontramos este tipo de explicación cuando planteaban, por ejemplo, al perder el trabajo "muchas veces [se ven] impelidos al robo y al atorrantismo" o que "en estas familias el padre á menudo se vuelve ebrio, ladrón ó atorrante, la madre, pordiosera o prostituta [...]”. Pero, como en el caso del anarquismo, la diferencia sustancial con las representaciones burguesas que ellos criticaban se encontraba en la adjudicación de las causas. Desde el anarquismo lo atribuían a "la mala organización de la sociedad", que generaba y permitía la desigualdad y aumentaba sin cesar el "número de los desheredados", 55 mientras que los socialistas planteaban que "el Socialismo ha buscado la causa principal de la criminalidad, de la prostitución y del atorrantismo en los cambios económicos [...]". ${ }^{56}$

Estas son entonces las diferentes formas en que aparece tratada la cuestión de los "sin trabajo" y la vagancia en ambas publicaciones, aunque claramente la primera de ellas prevalece en el periódico socialista, la segunda en el anarquista (y está directamente ausente en el El Obrero) y la tercera ocupa un lugar menor en ambas (y se enlaza de forma algo contradictoria con las otras dos). A pesar de las diferencias que hay entre estas tres variantes, todas tienen algo en común, que constituye el elemento central de la interpretación socialista y anarquista sobre la falta de ocupación: no se responsabiliza a los "sin trabajo" por su falta de ocupación, sino que son considerados víctimas de un sistema.

El otro elemento en común en ambos periódicos, y que se distancia de las representaciones hegemónicas, es que los "sin trabajo" eran considerados como formando parte del mundo obrero: "trabajadores" u "obreros" que no conseguían colocarse. Esto, que quizás hoy entra fácilmente en nuestro esquema de pensamiento, rompía con el esquema dicotómico propio de la época entre trabajadores (donde se incluía a todo aquel con trabajo demostrable) y vagos (categoría que involucraba al no-trabajo en sus diversas formas), dando lugar a una posición nueva: la de "trabajadores sin trabajo". Y esta interpretación tenía (o podía tener) consecuencias prácticas en lo que respecta a un movimiento obrero que se estaba organizando y en el que ambas corrientes pugnaban por hacerse un lugar. Si los "sin trabajo" podían ser pensados como obreros transitoriamente sin colocación, cobraba sentido avanzar en su organización y movilización política, como vimos con la convocatoria al "meeting de trabajadores sin ocupación" por parte del socialismo. Las personas que entraban dentro de esa categoría, según podemos ver

55 El Perseguido, 1 de enero de 1892.

56 El Obrero, 24 de octubre de 1891. 
en la convocatoria, incluían a una población heterogénea que no se reducía al proletariado industrial (muy poco desarrollado en la Argentina de entonces) ni a determinados oficios o formas de contratación. Se convocaba a "los trabajadores de todas condiciones, artesanos obreros, jornaleros simples y todos los que están sin ocupación”, mientras que otra nota describía a las víctimas de las agencias de colocación como "pobres dependientes de comercio, escribientes de escuela, maestros de escuela, aún ingenieros, doctores hambrientos, etc. etc., sin destino y sin ocupación, sin pan y sin esperanza" ${ }^{57}$ Todos entraban sin distinción: sectores de servicio, obreros, trabajadores del campo, en dependencia o independientes,

El anarco-comunismo, a diferencia del socialismo, no creía en la acción a través de la organización de los trabajadores; por eso no resulta llamativo que no hubiese en las páginas de El Perseguido intentos por generar una organización política de los "sin trabajo" o que no hubiese ni una sola referencia al mitin organizado por la Federación Obrera. Como ya mencionamos, no se postulaba tampoco la necesidad de canalizar demandas de trabajo; por el contrario, se instaba a los obreros sin ocupación a que tomasen por mano propia lo que les "correspondía". En otros términos, consideraban que la salida al problema no debía venir de la movilización política a través de mítines o huelgas, sino que apelaban a que "todos los que se queden sin trabajo y carezcan de algo se agrupen si no lo están para proporcionarse lo que necesiten sin escrúpulo de ninguna especie y no dejarse avasallar en manera alguna por la miseria". ${ }^{58}$ ¿En quiénes estaban pensando en este caso? En todos aquellos "identificados por la desgracia común", tanto de las "poblaciones" como de la campaña. Los trabajadores de la administración pública, a quienes se ubicaba más cerca de la burguesía que de los trabajadores, ocupaban un lugar ambivalente. Una nota titulada “3000 cesantes" abordaba justamente el reciente despido de tres mil empleados públicos. La posición de la nota es ambigua: el tipo de trabajo que habían tenido los ubicaba por fuera de la clase obrera, pero su situación de pérdida del empleo los acercaba a esta. Así, en un primer momento de la nota se describía a los cesantes como "tres mil atorrantes de esos que pueblan las oficinas y que no hacen otra cosa que insultar a todo el que la desgracia le lleva a tratar con ellos". Se observa aquí la estrategia de reversión del estigma que mencionamos: estos atorrantes estaban muy alejados de la imagen burguesa de esa figura. Pero enseguida aclaraban que seguramente aquellos cesantes formarían parte de ese conjunto heterogéneo que compartía la común desgracia de la falta de colocación,

57 El Obrero, 6 de agosto de 1892.

58 El Perseguido, 7 de diciembre de 1890. 
y "vienen a compartir con nosotros la miseria" dado que, suponían, quienes sufrirían las cesantías serían "en su totalidad trabajadores de los correos y telégrafos y los más desgraciados de los demás ramos de la administración”. Es decir, lo más bajo de esos sectores medios que, por su cercanía con la clase trabajadora, aunque sin formar parte de ella, se encontraban en una situación de vulnerabilidad.

\section{Palabras finales}

El artículo analiza el proceso a través del cual las organizaciones socialistas y anarquistas, sobre el telón de fondo de la crisis de 1890, fueron dando forma al "problema" de la falta de trabajo como un asunto que no remitía a la esfera individual de quien la padecía, sino, retomando las palabras de Wright Mills citadas al comienzo, a la estructura más amplia de la vida social (1986: 28). En ese camino entablaron una abierta disputa de sentido con la visión dominante en su época histórica. A partir del análisis de sus principales órganos de difusión en esos años de crisis, El Obrero (socialista) y El Perseguido (anarquista) -muy poco trabajados hasta el momento por la historiografía argentina-, nos preguntamos, entonces, por la manera en que no solo se buscó visibilizar la existencia de un problema de falta de ocupación, sino también brindar una definición particular del mismo que contrariaba las argumentaciones morales en circulación y se focalizaba, en cambio, en las dimensiones socioeconómicas como causas.

En otros términos, tratamos de mostrar cómo estas organizaciones de izquierda, con considerable influencia en el mundo obrero, fueron dando forma, a través de sus escritos y acciones, a una interpretación novedosa de esas situaciones en las que la pobreza se asociaba a la ausencia de un salario y que hasta el momento habían sido tratadas únicamente por la vía represiva, en tanto se responsabilizaba a las personas sin trabajo por su condición. Nos interesó indagar no solo en las convergencias entre sus perspectivas, sino también en las divergencias que podían encontrarse entre ellas, tanto en lo referido a la interpretación acerca de la naturaleza y las causas del fenómeno, así como también en las propuestas de resolución. Es allí, en la forma de entender las respuestas posibles, en donde las diferencias se amplían. En fin, este análisis nos permitió mostrar que, a pesar de la existencia de matices y divergencias, ambas corrientes contribuyeron con sus escritos a desprender el problema de la falta de trabajo de la interpretación en términos de vagancia y a ubicarla en el marco del problema obrero. Desde sus respectivas publicaciones pusieron en discusión cuestiones tales como la idea de la falta de esfuerzo al señalar, en cambio, una actitud activa por parte de los "sin trabajo" en la búsqueda de empleo, al mismo tiempo que hacían hincapié en 
el sufrimiento que esa falta conllevaba. Encontramos también argumentos que ponían en cuestión el tema de la disponibilidad y la voluntad de trabajo: ¿era de esperarse -decían en particular los anarquistas- que se aceptasen colocaciones en condiciones miserables y con pagas más miserables aún? ¿Podía ser considerado "vago" quien no aceptara trabajos degradantes? Pero, fundamentalmente, vimos que el hecho de ubicar la falta de trabajo como un problema social que debía ser atendido se articulaba con la posibilidad de pensar que había un valor colectivo amenazado. Ese valor era, por supuesto, el trabajo. Postular el derecho al trabajo, o el trabajo como un derecho al que no se podía acceder, era la condición de posibilidad para plantear la urgencia del problema de la falta de trabajo, incluso si este -coincidían- era inexorablemente degradante en el marco del capitalismo.

Con todas estas reflexiones, a pesar de las diferencias que hemos intentado mostrar como existentes entre ambas corrientes, socialistas y anarquistas apuntaban al corazón de la idea de la vagancia y a las prácticas represivas que se le asociaban. En ese acto, iban dando forma a la posibilidad de pensar un no-trabajo legítimo, incluso en personas consideradas válidas para el trabajo. 
82 | Trabajos y trabajadores en América Latina (siglos XVI-XXI)

\section{FueNTES}

El Obrero. Defensor de los intereses de la clase proletaria (Buenos Aires). Primera época (1890-1892) y segunda época (1893). Archivo CEDINCI.

El Perseguido. Voz de los oprimidos (Buenos Aires): 1890-1897. Archivo CEDINCI.

BIBLIOGRAFÍA

Albornoz, Martín

2015 "Los encuentros de controversia entre anarquistas y socialistas en Buenos Aires”. En: Prismas, número 16. Argentina. 187-190.

Bertolo, Marciel

2008 "Estado y trabajadores en Argentina. El Departamento Nacional del Trabajo ante el fenómeno de la desocupación, 1907-1934”. Tesis doctoral. Buenos Aires, Facultad de Filosofía y Letras, Universidad de Buenos Aires.

Blumer, Herbert

2004 "Les problèmes sociaux comme comportements collectifs". En: Politix, volumen 17, número 67. París. 185-199. [1971]

Burnett, John

1994 Idle hands: the experience of unemployment, 1770-1990. Londres: Routledge.

Campos Marín, R.; José Martínez Pérez y Rafael Huertas García-Alejo

2000 Los ilegales de la naturaleza. Medicina y degeneracionismo en la España de la Restauración (1876-1923). Madrid: CSIC.

Castel, Robert

1997 Las metamorfosis de la cuestión social. Una crónica del salariado. Buenos Aires: Paidós.

Croucher, Richard

2008 "The history of unemployed movement". En: Labour History Review, volumen 73, número 1 . Liverpool, Inglaterra. 1-7.

Daniel, Claudia

2013 "De crisis a crisis: la invención de la desocupación en la Argentina". En: Revista de Indias, volumen LXXIII, número 257. Madrid. 193-218. 
Dimarco, Sabina

2016a "Los socialistas y el problema de la falta de ocupación en la crisis de 1890”. En: Estudios sociales del Estado, volumen 2, número 4. Buenos Aires. 151-180.

2016b "Marx y el problema de la falta de ocupación". En: Astrolabio, número 17. Córdoba, Argentina. 240-264.

Falcón, Ricardo

1984 Los orígenes del movimiento obrero (1857-1899). Buenos Aires: CEAL.

Grondona, Ana

2012 'Tradición'y 'traducción': un estudio de las formas contemporáneas del gobierno de las poblaciones desempleadas en la Argentina. Buenos Aires: Ediciones Centro Cultural de la Cooperación.

Gusfield, Joseph

2014 La cultura de los problemas públicos. Buenos Aires: Siglo XXI.

Keyssar, Alexander

1986 Out of work: The First Century of Unemployment in Massachussetts. Cambridge, Inglaterra: Cambridge University Press.

Lobato, Mirta

2000 "Los trabajadores en la era del 'progreso"'. En: Mirta Lobato (dir.), El progreso, la modernización y sus límites (1880-1916), volumen 5. Buenos Aires: Sudamericana.

2009 La prensa obrera. Buenos Aires: Edhasa.

Martínez Mazzola, Ricardo

2004 "Campeones del proletariado. El periódico El Obrero y los comienzos del socialismo en la Argentina". En: Políticas de la memoria, número 4. Buenos Aires. 91-110.

Marx, Karl y Friedrich Engels

1994 Manifiesto del Partido Comunista. Santiago de Chile: Catari.

Marx, Karl

2004 El Capital. Tomo 1, volumen 3. Buenos Aires: Siglo XXI.

1999 Manuscritos: economía y filosofía. Madrid: Alianza.

Mayo, Carlos

1987 "Sobre peones, vagos y malentretenidos: el dilema de la economía rural rioplatense durante la época colonial”. En: Anuario IEHS, número 2. Tandil, Buenos Aires. 25-52. 
84 Trabajos y trabajadores en América Latina (siglos XVI-XXI)

Perry, Matt

2000 Bread and Work. Social Policy and the Experience of Unemployment, 1918-1939. Londres: Pluto Press.

2007 Prisoners of Want: The Experience and Protest of the Unemployed in France, 1921-45. Gran Bretaña: Ashgate.

Pianetto, Ofelia

1984 "Mercado de trabajo y acción sindical. 1890-1922". En: Desarrollo Económico, volumen 24, número 94. Buenos Aires: Instituto de Desarrollo Económico y Social. 297-307.

Poy, Lucas

2014 Los origenes de la clase obrera argentina. Huelgas, sociedades de resistencia y militancia politica en Buenos Aires, 1880-1896. Buenos Aires: Imago Mundi.

Pugliese, Enrico

2000 "Qué es el desempleo". En: Política y Sociedad, número 34. Argentina. 59-67.

Salais, R.; Nicolas Baverez y Bénédicte Reynaud

1986 L'invention du chômage: Histoire et transformations d'une catégorie en France des années 1890 aux années 1980. París: PUF.

Suriano, Juan

2001 Anarquistas: cultura y politica libertaria en Buenos Aires, 1890-1910. Buenos Aires: Manantial.

Tarcus, Horacio

2007 Marx en la Argentina. Buenos Aires: Siglo XXI.

Topalov, Christian

1994 Naissance du chômeur, 1880-1910. París: Albin Michel.

Walters, William

2000 Unemployment and Government. Genealogies of the Social. Cambridge, Inglaterra: Cambridge University Press.

Wadauer, Sigrid

2011 "Establishing distinctions: Unemployment versus vagrancy in Austria from the Late Nineteenth Century to 1938”. En: International Review of Social History, número 56. Cambridge, Inglaterra. 31-70. 
Wright Mills, Charles

1986 La imaginación sociológica. México: FCE.

Zimmermann, Bénédicte

2001 La constitution du chômage en Allemagne. Entre professions et territoires. París: Maison des Sciences de l'Homme. 



\title{
Una historia verosímil de la Princesa de Borbón: trabajo, género y sexualidad en América del Sur, 1905-1919
}

\author{
Cristiana Schettini (Brasil/Argentina)* \\ Diego Galeano (Argentina/Brasil)**
}

RESUMEN: ${ }^{1}$ Este texto explora algunos momentos de la trayectoria laboral y migratoria de la persona conocida como Princesa de Borbón, Luis Fernández, Pedro Pérez o Armando Ariatti. Sus recorridos por Río de Janeiro y Buenos Aires contribuyen a delinear un abanico de posibles cruces entre trabajo, género e inmigración. La Princesa de Borbón participaba, junto a una inmensa masa de migrantes, en la búsqueda de formas de supervivencia que incluía una diversidad de estrategias y salidas laborales, cruzadas por el género. Cada una de esas formas suele ser abordada por historiografías distintas (historia del delito, historia del trabajo, historia de las migraciones internacionales), pero para sus protagonistas se trataba de un mismo repertorio de caminos para sobrevivir. Al abordarlas en conjunto, este artículo busca reflexionar sobre las posibilidades de sobrevivencia y de trabajo en los circuitos migratorios sudamericanos en los ańos previos a la Primera Guerra Mundial, en el cruce de múltiples fronteras: de género, de identidades sexuales, de actividades remuneradas y no remuneradas, de la legalidad y la ilegalidad. Notas periodísticas producidas en Argentina, Brasil y Uruguay, registros de expulsión de extranjeros y correspondencia entre autoridades policiales constituyen la principal documentación consultada. El género representado por la Princesa de Borbón y los llamados "hombres vestidos de mujer" hace visible, al mismo tiempo que lo desnaturaliza, un conjunto de actividades laborales femeninas de comienzos del siglo XX: el trabajo doméstico, la prostitución y

Doctora en Historia Social por la Universidad Estadual de Campinas. Consejo Nacional de Investigaciones Científicas y Técnicas (CONICET), Universidad Nacional de San Martín (UNSAM). Contacto: crischettini@gmail.com

** Doctor en Historia Social por la Universidad Federal de Río de Janeiro. Departamento de Historia, Pontifícia Universidade Católica do Rio de Janeiro (PUC-Rio). Contacto: dgaleano@puc-rio.br

1 Agradecemos a la organización del Congreso Trabajo y Trabajadores, así como los comentarios de los evaluadores anónimos. Versiones previas de este texto fueron discutidas en el grupo Crimen y Sociedad (Buenos Aires, 2017) y en la mesa coordinada por William Acree en el simposio de la sección Cono Sur de LASA (Montevideo, 2017). Agradecemos las cuidadosas lecturas y los comentarios recibidos en ambas oportunidades. 
el trabajo artístico. El artículo se organiza en dos partes: en primer lugar, se analizan algunas percepciones contemporáneas sobre las identidades de género con relación a la movilidad geográfica de sujetos insertos en contextos migratorios. Luego, los itinerarios de la Princesa de Borbón iluminan algunos sentidos construidos y disputados en ese campo de posibilidades para mujeres registradas como ladronas, sirvientas, prostitutas y viajeras.

PalABRAS CLAVE: género; sexualidad; migración; trabajo; delito.

\section{INTRODUCCIÓN}

Personaje de las crónicas policiales y de las revistas de entretenimiento, la Princesa de Borbón alcanzó cierta fama en la costa atlántica sudamericana a comienzos del siglo XX. Su vida estuvo atravesada por múltiples tránsitos: entre diversas identidades de género, entre la experiencia artística y las constantes imputaciones delictivas, y entre ciudades de Brasil, Argentina y Uruguay, por las que circulaba frecuentemente. La trayectoria de la Princesa de Borbón, Luis Fernández, Pedro Pérez o Armando Ariatti, según el momento de su vida, la red de relaciones en que se insertaba y las maneras en que terceros registran su existencia aclaran una serie de cuestiones relevantes para una historiografía atenta a la perspectiva de género. Este texto toma como punto de partida los escasos registros de su vida como una manera de examinar las fronteras entre el mundo del trabajo y las complejas estrategias de supervivencia como "mujer-hombre". Su identidad de género, además de ser un foco de interés en sí mismo, constituye una ventana para analizar las formas y los sentidos del trabajo femenino en aquel mundo laboral marcado por el fenómeno de la inmigración masiva. A comienzos del siglo XX, sus itinerarios por ciudades sudamericanas echan luz sobre un abanico de posibles entrecruzamientos entre trabajo, género e inmigración, poniendo en tela de juicio algunos axiomas arraigados en la historiografía.

Entre el incesante movimiento de hombres y mujeres desembarcados en los puertos sudamericanos asomaban inmigrantes que, en los márgenes del mercado laboral y el mercado de entretenimiento, eran asociados a la práctica de robos, al arte del engaño y la simulación. Sus vidas entraban en la órbita de temores sociales sobre las consecuencias de la inmigración europea masiva y los cambios en las relaciones de género a partir de la expansión de circuitos de consumo cultural. En aquellos casos en que, además, transitaban entre identidades de género, la confusión se extendía, transformando sus cuerpos y acciones en un campo de batalla. El desconcierto se expresaba en la multiplicidad de denominaciones que se iban alternando: "hombre-mujer", "travestis", "transformistas", "invertidos", "imitadores de estrellas", "ladrones vestidos de mujer". 
Hace ya algunas décadas que la atención de la historiografía del trabajo se ha volcado hacia formas laborales no asalariadas en el marco de complejas relaciones de dependencia. Uno de los efectos de este foco ha sido la intensificación de un debate en torno a las ventajas y los riesgos de una eventual ampliación del propio concepto de trabajador. Por ese camino, muchas experiencias sociales relegadas a otros campos analíticos pasaron a ser temas de interés: formas de trabajo doméstico, sexual, artístico y esclavo comenzaron a ser consideradas como muy importantes para la comprensión de tramas en las que trabajadores masculinos, blancos, industriales y sindicalizados eran minoritarios o, inclusive, inexistentes. Al convocar a otros sujetos a las historias sobre la formación de la clase trabajadora se hace visible una miríada de relaciones sociales, distintivas por ser íntimas, afectivas, cercanas, silenciosas, en las que también se conformaron antagonismos y, acaso, identidades de clase. ${ }^{2}$

Partimos de un conjunto de registros repletos de confusión, sarcasmo y violencia, así como de numerosas leyendas en torno a las hazañas de la Princesa de Borbón en Buenos Aires, Montevideo y Río de Janeiro en las primeras dos décadas del siglo XX. Al tratarse de sujetos socialmente percibidos como hombres que asumían identidades femeninas, ya sea en un escenario teatral (como canzonetistas) o fuera de él (como sirvientas, prostitutas o ladronas), suscitaban reflexiones sobre las relaciones entre género y trabajo en las ciudades sudamericanas. En efecto, sus cuerpos, sus gestos, sus miradas y sus acciones se llenaban de sentidos específicos, al poner de relieve intersecciones entre jerarquías de género y relaciones sociales más amplias, incluidos los vínculos laborales, desnaturalizándolas. En este sentido, como señala Anne McClintock a propósito de ciertas prácticas de travestismo en la Inglaterra victoriana, es posible leer esas identidades a la luz de disputas más amplias sobre el trabajo femenino (y su invisibilización en el marco del llamado "culto de la domesticidad") y sobre la racialización de las jerarquías de género en un contexto imperial (2010: 201-170). Sin embargo, por más sugerentes que resulten estas ideas, nos alejamos de las inspiraciones teóricas y psicoanalíticas de la autora para replantear, desde la perspectiva de la historia social, una pregunta sobre los significados contextuales y relacionales de la experiencia. En otras palabras, la actuación de género de la Princesa de Borbón

2 Un ejemplo de esta producción es la historiadora inglesa Carolyn Steedman, quien destaca la importancia de estudiar al servicio doméstico como una manera de comprender la formación de vínculos laborales y antagonismos de clase (1994: 117). Para una defensa de la utilidad de pensar al trabajo sexual -con sus fronteras con actividades ilegales, nomadismo y formas de trabajo autónomo- en los términos de la historia del trabajo, véase Van Voss, 2012. 
y de los llamados "hombres vestidos de mujer" torna visible, al mismo tiempo que desnaturaliza, un conjunto de actividades laborales femeninas de comienzos del siglo XX: el trabajo doméstico, la prostitución y el trabajo artístico.

Para historizar la noción de homosexualidad, especialmente entre comunidades migratorias europeas, particularmente italianas, a comienzos del siglo XX, el estudio de George Chauncey (1995) resulta ineludible. Muchos hombres "convencionalmente masculinos" se relacionaban sexualmente con otros varones considerados afeminados, sin abandonar la categoría de "normales". La obra de Chauncey ha estimulado investigaciones que buscan contextualizar la primacía de los discursos médicos sobre la sexualidad a la luz de una pregunta más amplia sobre los sentidos de la sexualidad masculina en otras culturas obreras y urbanas marcadas por fenómenos migratorios. ${ }^{3}$

Tomando estos aportes como punto de partida, procuramos, en primer lugar, analizar percepciones contemporáneas sobre las identidades de género con relación a la movilidad geográfica de sujetos insertos en contextos migratorios. En segundo lugar, nos interesa destacar que la Princesa de Borbón participaba, junto a una inmensa masa de mujeres, en la búsqueda de formas de supervivencia que involucraban una diversidad de estrategias y salidas laborales. Cada una suele ser abordada por historiografías distintas (historia del delito, historia del trabajo, historia de las migraciones internacionales), pero para sus protagonistas se trataba de un mismo repertorio -bastante limitadode caminos para sobrevivir. Los pasos de la Princesa de Borbón iluminan algunos sentidos construidos y disputados en ese campo de posibilidades para mujeres registradas como ladronas, sirvientas, prostitutas y viajeras.

"LADRONES VESTIDOS DE MUJeR"

Un caballero pide un diario de la tarde y, apenas lo abre, sorprendido, exclama a su compañero de mesa:

— ¡Mira! ¡Que se murió la Princesa de Borbón!

- ¿El ladrón ese que hace poco estuvo acá en Montevideo?

-Sí, lo mató un viejo en Chile... ${ }^{4}$

3 Ese mismo enfoque fue adoptado en trabajos como los de Pablo Ben $(2007,2009)$, en los que la figura de los maricas surge de una "sociabilidad plebeya", construida en el marco de características demográficas y laborales específicas. En eso polemiza con el estudio clásico de Jorge Salessi (1995), más centrado en las dimensiones represivas. Para el caso de Río de Janeiro, el trabajo de referencia es James Green (2000).

4 "Especial para A Noite. O fim trágico de uma vida de ousadas aventuras". En: $A$ Noite, 7 de mayo de 1916: 1. 
Cuando el 7 de mayo de 1916 un diario de Río de Janeiro anunció el "final trágico" de la Princesa de Borbón, no necesitó aclarar a sus lectores que no se trataba de la muerte de un integrante de la familia real española. Raúl Gómez, corresponsal de $A$ Noite en el Uruguay, al contar cómo se había enterado de su muerte, nos presenta algunos trazos biográficos: la Princesa de Borbón, que en el prontuario policial figuraba con el nombre de Luis Fernández, era un "ladrón conocido de todas las policías sudamericanas, especialmente de [las de] Buenos Aires, Montevideo y Río". Según esta versión, apareció muerta dentro de un coche abandonado en la ciudad chilena de Quillota. La historia sugería que había sido apuñalada por un amante senil y celoso. Tenía entonces 26 años y hacía algo más de diez que había abandonado su Coruña natal, más por aventura que por necesidad, ya que sus padres eran dos acaudalados comerciantes y, sin hermanos, se perfilaba como el único heredero de esa fortuna. Aunque Luis Fernández es un nombre de lo más común en el universo hispanoamericano, según los datos que brinda este relato, embarcó hacia Argentina en 1905. Y, en efecto, en los registros de ingresos de inmigrantes al puerto de Buenos Aires aparece un Luis Fernández, soltero y de 16 años, arribado el 27 de marzo de 1905 en el barco Oruba, procedente del puerto de La Coruña. ${ }^{5}$ A cinco ańos de su llegada al país, debe haber presenciado las celebraciones del Centenario de la República Argentina, que contaron con la presencia de la Infanta Isabel de Borbón, Princesa de Asturias, en representación de la Corona española. Puesto que los primeros registros de su apodo, Princesa de Borbón, datan de 1912, es probable que se tratara de una parodia de aquella visita tan sonada.

El relato de su trágica muerte, aunque posteriormente fuera cuestionado, insistía en una referencia a la decadencia moral atribuida a una vida difícil de clasificar para la mirada de sus contemporáneos. Fue como delincuente que la Princesa de Borbón apareció, a mediados de 1912, en una crónica del reconocido periodista argentino Juan José de Soiza Reilly, publicada en la revista ilustrada Fray Mocho con el título "Ladrones vestidos de mujer". ${ }^{6}$ De acuerdo con este relato, el periodista se había encontrado en Buenos Aires con un viejo amigo de Montevideo, devenido delincuente, quien le contó de la existencia de una "cofradía de ladrones que para robar se visten de mujer". Como en otras crónicas, Soiza Reilly utilizó sus contactos con la Comisaría de Investigaciones para verificar los datos de su informante, y obtuvo un profuso dossier con nombres, apodos y fotografías reproducidas después en las páginas de la revista. Todo procedía de los prontuarios de la sección Robos y Hurtos,

5 Base de datos del Centro de Estudios Migratorios Latinoamericanos (CEMLA): Disponible en: http://cemla.com/buscador/

6 Año 1, número 6, 7 de junio de 1912, Buenos Aires. Esta crónica fue reproducida después en Soiza Reilly, 1920: 88-94. 
cuyos agentes secretos -según el cronista- conocían de memoria a estas "Evas hombrunas”. Luis Fernández no estaba sola: Juan Soya, más conocida como La Tana; Hipólito Vázquez, alias La Madrileña; José Sanguinetti, La María Luisa; Eduardo Liester, La Inglesa; Juan Pumilla, La Insipida; Jesús Campos, La Reina de la Gracia; y Julio Gimenez, La Brisa de la Primavera, eran algunos de los casos narrados. De la mano de Soiza Reilly, sus retratos pasaron de los archivos de la Policía a las páginas de una mundana revista semanal. ${ }^{7}$

La identificación de las "Evas hombrunas" con el mundo del delito le permitía a Soiza Reilly, así como a sus lectores, asociaciones más o menos inmediatas con diferentes prácticas y estilos conocidos en el periodo. Por un lado, una recurrente comparación con el "cuento del tío" atravesaba toda la crónica de Soiza Reilly. Al igual que los cuenteros (Galeano, 2016a), los "ladrones vestidos de mujer" buscaban -se decía- seducir a sus víctimas para sacarles dinero. Para el periodista, compartían con los ladrones porteños un mismo modus operandi y un mismo vocabulario, el lunfardo. Sin embargo, Soiza Reilly registraba una serie de voces que no aparecían en los diccionarios de lunfardo de la época, como plumiar (salir a buscar hombres para seducir) o chongos, para referirse a los obreros. De esta manera, entre la referencia a los "delincuentes profesionales", más bien "finos y cultos", y al uso de un lenguaje compartido por vastos grupos sociales, tomaban forma narrativa estos "ladrones vestidos de mujer".

Una segunda asociación que la nota de Soiza Reilly podía inspirar entre sus lectores era el mundo del servicio doméstico: se insistía en que uno de los blancos de esos peculiares ladrones eran las casas de familia. Para acceder a esos hogares, algunos se disfrazaban de mucamos. Culpiano Álvarez, alias La Bella Otero (como la famosa cortesana y bailarina española) solía "emplea[r]se como mucamo en casas ricas", mientras que otro conocido como Lucho era sirviente de una "reconocida familia", cuyo nombre Soiza Reilly prefería callar. De este modo, la nota periodística remitía a la percepción contemporánea de los peligros del servicio doméstico. Preocupados por formas de "contagio moral", hacía años que médicos y criminólogos venían registrando la práctica entre los "invertidos" de emplearse como "sirvientas" (Salessi, 1995; Ben, 2007). Soiza Reilly (1920), además, interpelaba una situación más inmediata: su nota fue publicada al mismo tiempo que tenía lugar un intenso debate sobre un nuevo proyecto municipal de reglamentación del servicio doméstico. En el texto resonaban temores sociales ampliamente compartidos sobre la seguridad y la moralidad de las familias, que alimentaban habitualmente el debate sobre la

7 El mismo procedimiento narrativo había utilizado en "Buenos Aires tenebroso: los apaches", una anterior crónica suya publicada en Fray Mocho, año 1, número 3, Buenos Aires, 17 de mayo de 1912: 20-24. 
regulación del trabajo de las sirvientas. Lejos del reconocimiento de derechos laborales a estas trabajadoras, se trataba de debates próximos al registro de la delincuencia y del contagio moral. En otras palabras, las inciertas fronteras entre ladrones disfrazados de mucamos y hombres vestidos de mujer remitían a temores más amplios de la contaminación moral que implicaba tener a desconocidos en el ámbito familiar y a la mercantilización de relaciones de intimidad (Allemandi, 2017; Graham, 1992).

Otra característica de estos sujetos, quizás reconocida por los lectores de Soiza Reilly, era su trashumancia. La propia vida itinerante de la Princesa de Borbón transcurrió entre Buenos Aires, Montevideo, Río de Janeiro y otras ciudades sudamericanas. Al pie de una de las fotografías que ilustraban la crónica de Soiza Reilly se leía que Fernández había sido "expulsado varias veces de Buenos Aires" y que en ese momento se encontraba en Uruguay. En otra fotografía lucía el "traje de bailarina” con el que debutó en un café cantante de Mercedes (provincia de Buenos Aires) y que también usó en el teatro Moulin Rouge de Río de Janeiro. ${ }^{8}$

Es posible rastrear parte de sus viajes por la costa atlántica sudamericana. Pocos meses después de esta crónica que mencionaba su estadía en Montevideo, la Princesa de Borbón irrumpe en las crónicas policiales de Río de Janeiro con un escandalete que la prensa tituló el "caso del hombremujer". La cobertura de la prensa brasileña permite acompañar sus pasos en una singular coyuntura: una ola de expulsiones de "apaches" y "cáftenes" por la Policía de Buenos Aires hacia fines de 1912, que obligó a las Policías de Uruguay y de Brasil a tomar recaudos por eventuales desembarques en sus puertos. ' Según las crónicas, el vapor Pampa, que llevaba varios "cáftenes, apaches y ladrones expulsados de Buenos Aires y Montevideo”, llegó a Río de Janeiro el 22 de diciembre de 1912 y quedó anclado en el puerto. La Policía dispuso que agentes del cuerpo de seguridad vigilaran a los "indeseables" para evitar que descendieran y asegurarse que siguieran viaje rumbo a Europa. Entre esos vigilados estaba la Princesa de Borbón, supuestamente expulsada de Montevideo.

8 El Moulin Rouge era uno de los varios cafés cantantes de propiedad del empresario italiano Paschoal Segreto, concentrados en la plaza Tiradentes. El nombre remitía a un intento de crear un punto de sociabilidad masculina bohemia, con un escenario para la presentación de artistas, consumo de bebida alcohólicas y la introducción del moderno cinematógrafo, entre otras atracciones. Véanse: "A empresa Paschoal Segreto" (en: Gazeta de Notícias, 25 de abril de 1910); Martins, 2007.

9 Figura central en el universo delictivo francés de comienzos del siglo XX, los apaches-caracterizados por la prensa parisina como jóvenes violentos y explotadores de mujeres- fueron estudiados por Perrot (1979) y Kalifa (2002). 
En las noticias de la prensa brasileña no se la mencionaba como Luis Fernández, sino como Pedro Pérez o Armando Ariatti, nombres que habría declarado a la Policía cuando la detuvieron tras una confusa fuga del barco. Las primeras versiones decían que había llegado a Río de Janeiro "vestido de mujer" y que logró escabullirse en una lancha que la llevó a tierra firme, pese a la vigilancia de los irónicamente llamados "sherlocks cariocas" por la prensa local. ${ }^{10}$ Pero poco después apareció una segunda versión, según la cual sobornó a un agente policial llamado Ernesto Ribeiro Lopes para que le permitiera desembarcar del Pampa. El agente tuvo que prestar declaraciones ante el 2. ${ }^{\circ}$ Delegado Auxiliar (autoridad de la Policía de Investigaciones) y terminó siendo exonerado de la fuerza. ${ }^{11}$

Poco después de desembarcar, siempre vigilada por la Policía, la Princesa de Borbón se hospedó en el Hotel Italia-Brasil, en las inmediaciones del puerto y de la estación central de trenes, donde también solían instalarse otros recién llegados. En ese hotel, anónimos inmigrantes se mezclaban con sospechosos de proxenetismo; en esos ańos, no era infrecuente que el lugar fuera el escenario de crónicas policiales de la prensa. Para moverse por la ciudad, Fernández o Ariatti salió vestida de mujer. Es significativo que haya acabado detenida por un agente de investigaciones en la zona de Lapa, en cuyas calles se multiplicaban los establecimientos de diversión nocturna. Allí, cafés cantantes y bares convivían con casas de prostitución, pensiones de artistas y las discretas casas de rendez-vous, "para entrar y salir". La región de Lapa formaba parte de un circuito de ocio nocturno que se extendía hasta las inmediaciones del "Largo do Rocío" (actual Plaza Tiradentes), que concentraba cabarets, teatros, casas de prostitución y espacios de encuentros homoeróticos (Schettini, 2006; Green, 2000).

Ariatti conocía bien ese circuito. Aquella primera vez fue apresado cuando entraba vestido como una demi-mondaine en una casa de la Travessa do Mosqueira esquina con la calle Visconde de Maranguape, en el corazón de Lapa. En 1913, la Policía local identificó seis pensiones de prostitutas en la Visconde de Maranguape, regenteadas en su mayoría por "polacas" (Schettini, 2006). Escoltada por policías y seguida de cerca por una multitud de "curiosos", la Princesa de Borbón fue conducida hasta el Departamento Central de Policía, donde la esperaba el $2 .^{\circ}$ delegado auxiliar, doctor Ferreira de Almeida. Tras el interrogatorio, se decretó sumariamente su expulsión

10 "Em travesti. Um ladrão, fugindo de bordo, é preso quando procurava fugir à polícia, vestido de mulher", Correio da Manhã, Río de Janeiro, 24 de diciembre de 1912: 5.

11 "O ladrão que desceu do bordo do Pampa subornou um agente de polícia”, Correio da Manhâ, Río de Janeiro, 25 de diciembre de 1912: 3. 
del país. Se la embarcó por la fuerza a bordo del vapor Formosa rumbo a Montevideo, poco después de Navidad, día de poco movimiento en el puerto ante la amenaza de un fuerte temporal. ${ }^{12}$

Las crónicas de los diarios añadían detalles para dar un tono cómico a la historia. Un supuesto juramento de Ariatti a las autoridades policiales (nunca más iba a "cambiar de sexo, a excepción del Carnaval") buscaba restituir la práctica del "travestismo" a uno de sus espacios aceptados, los días del Momo. Como los hombres vestidos de mujer durante dicha fiesta eran una costumbre (Cunha, 2001; Green, 2000), el registro jocoso le daba cierta comprensibilidad al episodio. De hecho, en la nota de Soiza Reilly, publicada en Argentina, las fotos de Ariatti iban acompañadas de ilustraciones con referencias literarias a bufones del siglo XVII. Sin embargo, la crónica policial carioca brindaba elementos que permitían leer de otra manera los gestos de la Princesa de Borbón: al negarse rotundamente a ser fotografiada por la Policía sin su vestimenta femenina, Ariatti daba señales de estar jugando un juego distinto al carnavalesco: mujer se percibía y como mujer quería ser reconocida socialmente. Ese gesto fue más bien desplazado a un segundo plano por los cronistas, que insistían en el lenguaje carnavalesco para relatar los sucesos de su expulsión de Brasil: la imagen de los agentes de la Policía Marítima esperando impacientes al gatuno mientras este guardaba con cuidado las piezas de su "disfraz" (vestidos, botas, pelucas, corsés, sombreros decorados con cintas, plumas y flores) se repetía en las notas de los principales diarios cariocas.

De acuerdo con $A$ Época, a uno de los agentes que la custodiaba, Julio Bailly, le habría confesado que pronto volvería a Brasil. Cuando le informaron que no la dejarían desembarcar de nuevo en Río de Janeiro, respondió que sería fácil eludir la vigilancia, que bastaba con cambiar el color del pelo, empolvarse bien el rostro y esmerarse en la toilette, "y así, tal vez, termine bajando del barco de la mano del inspector". ${ }^{13}$ La intención humorística del relato era doble: hablaba de las peligrosas dotes de seducción de Ariatti, pero también de la debilidad del inspector policial, pasible de sucumbir a sus pies. Antes de irse, la Princesa de Borbón tuvo tiempo para una segunda provocación al inspector Bailly: le entregó una tarjeta que decía "Armando Ariatti - calle Rocha n. 2F - Montevideo”. Le guiñó el ojo y se subió al barco. Otra versión de la misma anécdota aseguraba que, mientras subía la rampa, se dio vueltas y le dijo a Bailly: "Simpaticé mucho contigo, ¿̇vamos juntos hasta

12 "No mar", Jornal do Brasil, Río de Janeiro, 27 de diciembre de 1912: 6; y "Ladrão em travesti”, A Notícia, Río de Janeiro, 27 de diciembre de 1912: 2.

13 "Homem-mulher. O conhecido gatuno embarcou ontem". En: A Época, 26 de diciembre de 1912: 2. 
Santos?”. ${ }^{14}$ Bailly era en aquel entonces la máxima autoridad de la Policía Marítima, que vigilaba la circulación de navíos entre los puertos del Río de la Plata y el litoral brasileño.

Las crónicas periodísticas apelaban a recursos narrativos demostradamente exitosos y conocidos por sus lectores. En este campo, la figura del policía burlado condensaba los riesgos potenciales que corrían muchos hombres pasibles de ser engañados por performances seductoras en la gran ciudad. La ridiculización del inspector Bailly remitía a otros relatos sobre los agentes policiales derrotados por la inteligencia de los simuladores modernos. Se trataba, en efecto, de una metáfora potente del ambiente al que estaban expuestos los policías encargados de custodiar la circulación en los puertos: anarquistas expulsados de diversos países, ladrones y estafadores internacionales, cáftenes y otros "delincuentes viajeros" (Galeano, 2016b) componían un panorama desolador para los agentes de vigilancia. La historia del "ladrón vestido de mujer" que seducía y engańaba al inspector era una entre tantas noticias de policías que quedaban mal parados ante el desborde portuario. ${ }^{15}$

El guiño de ojos de la Princesa de Borbón podía tener sentidos diversos y simultáneos, interpelando el poder de seducción de las demi-mondaines y la vulnerabilidad de los potenciales seducidos. Para muchos lectores de estas noticias, el guiño expresaba el triunfo irónico de la figura del ladrón viajero, que tarde o temprano lograría cumplir su promesa de volver a Brasil, escabulléndose en los intersticios de la porosa vigilancia policial. Quizás para otros se insinuaba la atracción erótica en torno a la Princesa de Borbón en el marco del circuito nocturno que incluía las pensiones de prostitutas de Lapa y los lugares de encuentros sexuales furtivos, como la Plaza Tiradentes. Este gesto, entonces, podía aludir a las complicidades del espacio urbano frecuentado por la Princesa de Borbón, donde prostitutas de distintas nacionalidades convivían con clientes y habitués de los jardines de los teatros, cafés cantantes y casas de rendez-vous, entre ellos muchos agentes policiales (Green, 2000; Schettini, 2006).

Las noticias de los meses siguientes reforzaban estos juegos de doble sentido, a propósito de los rumores sobre un inminente desembarco de la Princesa de Borbón en Brasil, en pleno Carnaval de 1913. ${ }^{16}$ Los diarios reprodujeron una carta, en español, que Ariatti le habría mandado a un inspector de la

14 “Os casos curiosos. Partiu o homem-mulher", A Noite, 26 de diciembre de 1912: 4.

15 En efecto, la narración sobre el agente policial seducido y engañado por las falsas mujeres volvía a aparecer, de forma similar, en las notas del diario argentino Crítica del 1, 6 y 17 de agosto de 1919.

16 "Um escândalo policial”, $A$ Época, 14 de febrero de 1913: 2; y "A audácia de um ladrão. A mulher homem”, A Noite, Río de Janeiro, 17 de marzo de 1913: 2. 
Policía Marítima. La mezcla de palabras en castellano y portugués indicaban un posible juego inventivo de los periodistas brasileños. El texto decía:

Apreciado capitán Miranda. Cuanto más lejos de esa bella y buena tierra, [en la] que tan bien y carińosamente fui recibido, tengo la más profunda saudade y pienso dentro de muy breve volver para abrazarte. Estoy estudiando el modo de desembarcar sin ser conocido. Tu [sic] recibes millones de abrazos de amigo que te quiere - Armando Ariatti. ${ }^{17}$

Fuese o no resultado de la imaginación periodística, las amenazas del retorno de la Princesa de Borbón eran tomadas en serio por la Policía. Un reportero del Correio da Manhã narraba que, durante los primeros meses de 1913, varias mujeres habían sido apresadas porque "parecían hombres". Solo en la Galería Cruzeiro hubo tres casos, y en el barrio de Lapa una joven llamada Martha fue detenida por un agente secreto que la confundió con Ariatti. ${ }^{18}$ Estos casos de engaño daban lugar a una nueva ridiculización de los agentes policiales, acusados de no saber diferenciar entre una "mujer fea" y un "hombre vestido de mujer".

Aunque no se supo bien cuándo, dónde ni cómo desembarcó, a mediados de mayo de 1913 la detuvieron de nuevo en Río de Janeiro. Un agente de la Policía Marítima creyó ver a Ariatti en una mujer que, elegantemente vestida, volvía a hacer el mismo camino de antes: en tranvía, desde la Plaza Tiradentes hasta Lapa. Era la agitada zona de tránsito hacia el centro de la ciudad, en la que se formaban parejas para frecuentar las pensiones por hora, mientras que los llamados gouveias -imagen estereotipada del viejo en búsqueda de sexo con otro hombre más joven- buscaban los "meninos bonitos" que esperaban en la estatua ecuestre de Don Pedro I, ubicada en el medio de la plaza. ${ }^{19}$

17 "O homem-mulher. A polícia marítima redobra a vigilância a bordo", Correio da Manhã, Río de Janeiro, 19 de marzo de 1913: 4. Según una versión del diario $O$ Imparcial, esta carta fue mostrada por el subinspector Joaquim Miranda a un reportero que se encargó de hacerlo público entre el periodismo carioca, dando como resultado los más "jocosos comentarios". "Um ladrão audacioso", O Imparcial, Río de Janeiro, 16 de mayo de 1913: 4.

18 "Um homem-mulher. Armando Arriarte, o célebre ladrão argentino, já está nas malhas da polícia”, Correio da Manhã, Río de Janeiro, 16 de mayo 1913: 2. Otros casos posteriores de detenciones de mujeres confundidas con Ariatti aparecen en "É mulher ou homem?”, O Paiz, Río de Janeiro, 3 de junio de 1913: 3.

19 A menudo, la Policía carioca hacía razzias entre esos “jóvenes pederastas" en la Plaza Tiradentes y las áreas aledañas. Véase, por ejemplo, un texto sobre la detención de 
Al igual que los adeptos de la práctica de cherchez la femme, el agente tomó el mismo tranvía y la siguió hasta Lapa. Al percibir su mirada, Ariatti -acaso sin sospechar que se trataba de un policía- lo invitó a acercarse para conversar, siguiendo los pasos previsibles de este tipo de encuentros. Hicieron una cita para más tarde; ya de noche, el agente volvió con un guardia civil que lo ayudó a detener a la Princesa de Borbón. Ella había cambiado de vestuario: ahora lucía un largo vestido de seda azul marino con una línea de botones de madreperla y un sombrero con plumas que le tapaba toda la cabeza y la mitad del rostro. Jugando en el cenagoso terreno de la interacción entre la Policía y Ariatti, el periodista de $A$ Época recreó un diálogo: cuando la Princesa de Borbón escuchó la orden para ir a prisión preguntó indignada al agente: “ $¿ Y$ nuestro rendez-vous?". "Nuestro rendez-vous -le habría respondido- es en la Comisaría $13^{\circ "}{ }^{20}$

Entre sus pertenencias fue encontrado dinero brasileño y dos pesos en moneda argentina, lo que hace suponer que esta vez llegó desde el puerto de Buenos Aires. Recordemos que Soiza Reilly había mencionado en 1912 que la Princesa de Borbón tenía "más de 20 entradas en la policía porteña”. De hecho, en la versión que la Policía transmitió a la prensa, Ariatti habría confesado que desembarcó el día anterior en el vapor Avon, procedente de Buenos Aires. Como venían temiendo la Policía y la prensa del Brasil en los últimos meses, después de eludir la vigilancia de la Policía Marítima y de pasar una noche en un hotel, se dirigió al Largo de San Francisco, a metros de la Plaza Tiradentes, donde tomaría aquel tranvía con destino a Lapa. ${ }^{21}$ Como en su viaje anterior, pasó poco tiempo entre su llegada a Río de Janeiro y la detención policial. Queda claro que la Policía brasileña no le perdía el rastro y, además, pese a las crónicas periodísticas que seguían tratándola como "ladrón", nada indica que haya cometido ningún robo.

De nuevo fue deportada en un vapor (Oronsa) rumbo al Río de la Plata y, una vez más, juró volver. La Policía carioca, preocupada por eventuales desembarcos en las escalas del navío, mandó telegramas a San Pablo para pedir que se

diez jóvenes de entre 16 y 25 años acusados del "vicio de la pederastia pasiva” en octubre de 1907: Archivo Nacional del Brasil, Fondo GIFI - Secretaría de Policía, Caja 6C223. Sobre los “gouveias” y los “meninos bonitos”, véase Green, 2000: 51-106.

20 "Os desbriados. Armando Ariatti, o célebre larapio que operava em travesti, mais uma vez foi preso ontem”, A Época, Río de Janeiro, 16 de mayo de 1913: 2.

21 "Homem-mulher. Armando Ariatti novamente no Rio", Jornal do Brasil, Río de Janeiro, 16 de mayo de 1913: 9; y "Ladrão em travesti. Voltou ao Rio", O Paiz, Río de Janeiro, 16 de mayo de 1913: 6. 
redoblara la vigilancia en el puerto de Santos. ${ }^{22} \mathrm{~A}$ esas alturas, algunos diarios, como el Jornal do Comércio, críticos con el accionar de la Policía, ya se burlaban de la trama de esta historia, que parecía ser cíclica: "Ariatti fue conducido -narraba el cronista- del $13^{\circ}$ distrito al Departamento Central, desde donde nuevamente será enviado a bordo [de un barco], a fin de ser deportado para que más tarde la Policía [Marítima] del Sr. Julio Bailly lo deje desembarcar”, en un eventual regreso a Brasil. ${ }^{23}$ “¿Volverá?", se preguntaba un cronista de O Século. "Seguro, dentro de tres meses se reirá a carcajadas delante de la inefable policía de Belisario Távora”, en referencia al jefe de Policía. ${ }^{24}$

En los meses siguientes corrieron noticias falsas sobre supuestos viajes al Brasil de la Princesa de Borbón, movilizando siempre agentes de la Policía Marítima en búsquedas infructuosas. En agosto, la llegada del Oronsa al puerto de Río de Janeiro estuvo rodeada de un "escándalo del diablo" cuando agentes policiales confundieron a una divetti montevideana con la ya famosa Princesa de Borbón. La uruguaya se resistía a tener que "demostrar" su condición de mujer. Días después, otro rumor de la llegada de Ariatti en el vapor Principessa Mafalda fue el tema del día en la zona portuaria: al entrar al puerto, los vigilantes revisaron el barco de proa a popa, sin ningún éxito. La prensa se encargaba de difundir estas versiones sobre eventuales hallazgos de sujetos que podían ser "el verdadero Ariatti, Princesa de Borbón", circulando por las calles de Río con otros "nombres de guerra", como por ejemplo Lulú o Manón. Todo el submundo prostibulario y nocturno de la capital brasileña parecía estar bajo sospecha. ${ }^{25}$

\section{UN MUNDO ARTÍSTICO ITINERANTE}

Parte del sentido humorístico de las hazañas y rumores sobre la Princesa de Borbón derivaban de su poder de seducción y la ridiculización de la inoperancia policial. Pero es preciso tener en cuenta que los desplazamientos de

22 "O homem-mulher. A polícia marítima está seriamente preocupada com o grande pandego", Correio da Manhã, Río de Janeiro, 18 de mayo de 1913: 3.

23 "Disfarçado em mulher", Jornal do Comércio, Río de Janeiro, 16 de mayo de 1913: 5 [énfasis del original].

24 “Armando Arriarte no Rio", O Século, Río de Janeiro, 16 de mayo de 1913: 3.

25 "Manon voltou ao Rio? A polícia teve denúncia de achar-se entre nós o conhecido ladrão Armando Ariarte", Gazeta de Notícias, Río de Janeiro, 31 de marzo de 1913: 4; "Ainda Armando Arriarte. Barafunda a bordo", O Século, Río de Janeiro, 14 de agosto de 1913: 2; y "Ainda Armando Ariarte", O Século, Río de Janeiro, 9 de septiembre de 1913: 2 . 
Ariatti por la costa atlántica no siempre eran motivados por decisiones propias. Eran, más bien, una mezcla de estrategias de supervivencia entre oportunidades laborales reducidas y prácticas policiales de vigilancia. A comienzos del siglo XX, las Policías sudamericanas -en especial las de Argentina y Brasil- contaban con un conjunto de herramientas para vigilar el flujo de sospechosos e indeseables por las rutas atlánticas. Las leyes de expulsión de extranjeros sancionadas en Argentina (1902) y Brasil (1907) habían consolidado una herramienta de deportación de individuos nacidos en otros países a través de un procedimiento que le otorgaba a la Policía un amplio margen de acción y discrecionalidad. Por un lado, se encargaba de toda la etapa inicial de instrucción del proceso, que luego era elevado a un ministro (de Justicia, en el caso brasileño; del Interior, en el caso argentino), para la firma del decreto de expulsión. Además, las Policías habían logrado estructurar un canal de intercambio de informaciones entre las jefaturas de Buenos Aires, Río de Janeiro, Montevideo y otras ciudades de la región, que servía de instrumento de vigilancia de la circulación y que brindaba antecedentes en los procesos de expulsión. ${ }^{26}$

Junto a las expulsiones "formales" - es decir, aquellas que se iniciaban con un expediente policial y que terminaban con la firma de un ministro-, existían otros procedimientos más "informales" pero igualmente difundidos, y que también terminaban con la deportación forzada de un extranjero indeseable. De hecho, las expulsiones sin decreto, ejecutadas sumariamente por la jefatura policial, existían desde antes de la sanción de las leyes en el primer decenio del siglo XX. Y continuaron existiendo. Junto a este recurso, la Policía impedía desembarques de sujetos que venían expulsados de Europa y de otros países sudamericanos, o simplemente de viajeros que, según las informaciones recibidas por las jefaturas policiales, tenían "malos antecedentes”. Así parece haber sucedido con la Princesa de Borbón en sus fugaces pasos por Río de Janeiro en 1912 y 1913.

El embarque en el vapor Pampa de varios indeseables expulsados de Buenos Aires en diciembre de 1912, en el que también viajaba la Princesa de Borbón, fue objeto de un intenso intercambio de telegramas entre las Policías de Argentina y Brasil. ${ }^{27}$ Exactamente un año más tarde, la Policía brasileña la esperaba para evitar su desembarco en Santos o en Río de Janeiro, luego de ser informadas por un telegrama de Buenos Aires de la

26 Sobre la práctica de expulsión de extranjeros en Argentina y Brasil, véanse: Menezes, 1996; Schettini, 2012a; Galeano, 2016b; Albornoz y Galeano, 2017.

27 Los telegramas de la Jefatura de Policía de Buenos Aires a la Policía carioca están disponibles en el Archivo Nacional del Brasil, Fondo GIFI - Secretaría de Policía, Caja 6C392. 
expulsión de Ariatti a bordo del vapor Cap Verde. ${ }^{28}$ Las listas oficiales de extranjeros expulsados del Brasil en esos dos años muestran numerosos nombres de cáftenes embarcados rumbo a Europa y al Río de la Plata, pero no figura ningún Luis Fernández, ni Armando Ariatti ni "Ariarte", como le llamaban algunos diarios. ${ }^{29}$ Eso permite suponer que la actuación de la Policía se ciñó, por un lado, a la esfera de los impedimentos de desembarque y, por el otro, cuando la Princesa de Borbón logró eludir la vigilancia portuaria y perderse entre la ciudad, a expulsiones sumarias y expeditivas resueltas en la sede policial.

Aunque en el caso específico de Ariatti no se movilizó la legislación de expulsión de extranjeros, eso no quiere decir que en Brasil la aplicación de la ley de 1907 haya dejado fuera de su órbita de injerencia la custodia de la "moralidad y las buenas costumbres". De hecho, en el Archivo Nacional se encuentra un proceso de expulsión de dos "muchachos orientales" (uruguayos), detenidos en un bar del centro cuando estaban "vestidos de mujer". En el expediente, la Policía los acusaba de "vagabundaje", de "practicar la pederastia pasiva" y de no tener "profesión ni medio honesto de vida", solicitando su expulsión del territorio nacional, que fue decretada sin objeciones. Rafael Manso y Héctor Oliveira tenían 21 años. La policía los detuvo en abril de 1912 y, en la misma oficina del delegado auxiliar por la que pasaría la Princesa de Borbón meses después, los sometió a interrogatorio. ${ }^{30}$

Rafael contó que había llegado a Brasil el 19 de marzo de ese año, a bordo del vapor Cap Ancona, desde su Montevideo natal. Sastre de oficio, consiguió empleo en la céntrica Tintorería União, sobre la calle Sete de Setembro, pero terminó dejando el trabajo porque los cuatro mil reis que le pagaban no alcanzaban para cubrir sus gastos. Héctor también era montevideano y declaró ser empleado de comercio, como tantos otros recién llegados. Había arribado a Brasil antes que su amigo, el 20 de noviembre de 1911. Según los "testigos" -que, como solía ocurrir en los procesos de expulsión, eran empleados de la Policía-, Rafael y Héctor no tenían domicilio fijo y "pernoctaban en casas de alquiler y pensiones de ínfima categoría”. Además de la "pederastia pasiva", practicaban "hurtos de joyas y dinero, en los que eran víctimas los individuos viciosos que los acusados invitaban a tales actos inmorales". En búsqueda de dichas "víctimas", recorrían las inmediaciones de

28 "Armando Ariarte volta ao Rio? A polícia recebe um aviso", A Imprensa, Río de Janeiro, 2 de diciembre de 1913: 2.

29 Las listas oficiales de expulsados aparecen en Relatório, 1912: 59 y Relatório, 1913: 61-62.

30 Archivo Nacional del Brasil, Fondo IJJ7 - Expulsión de Extranjeros, Caja 150. 
la misma Plaza Tiradentes, tan conocida de la Princesa, "zona frecuentada por los degenerados e invertidos". ${ }^{31} \mathrm{La}$ ausencia de pruebas para sostener la acusación delictiva no impedía que la prensa -como sucedería con Ariatti y con tantos otros casos- construyera un relato en torno a la idea de los "ladrones que se vestían de mujer para robar”. Así se narró la detención y expulsión de Rafael y Héctor, embarcados en el vapor Vauban después de pasar un mes presos en la Casa de Detención. ${ }^{32}$

Si bien en un caso se trata de una expulsión formal y en el otro de una deportación aún más sumaria, los paralelos entre los muchachos uruguayos y la Princesa de Borbón son evidentes: desplazamientos por las mismas rutas atlánticas (del Río de la Plata a Brasil), el mismo territorio de acción en Río de Janeiro (la Plaza Tiradentes y la zona prostibularia y de diversiones nocturnas del centro) y la misma lógica de persecución policial -que les permitió poco tiempo de permanencia en la ciudad-. Por todo lo demás, un abismo se abría entre las ignotas vidas de Rafael y Héctor, y de la famosa Princesa de Borbón, cuyas andanzas sudamericanas la convirtieron, según la crónica de Soiza Reilly, en "el rey de los ladrones vestidos de mujer". La fama de la Princesa sobrevivió a aquel contexto inmediato. Dos años después de sus expulsiones, se transformó en un personaje de la obra teatral Los Invertidos, del dramaturgo José González Castillo, estrenada en septiembre de 1914. En el segundo acto irrumpía la Princesa de Borbón, definida como un sujeto que "viste de mujer elegantemente", que hablaba en lunfardo "con exagerada voz femenina" y bailaba con "extremados movimientos" (González Castillo, 2011: 58)..$^{33}$

El estreno de la obra fue el cenit, pero su fama ya estaba consolidada desde antes. Para Soiza Reilly, sus "picarescas aventuras" ni siquiera necesitaban ser contadas en 1912 porque eran conocidas por el público lector. Apenas mencionaba que era un "muchacho de singular belleza", alto, de grandes ojos negros, buena presencia y frecuentador de bailes; que en sus

\section{Ibid.}

32 "Os mocinhos argentinos", Gazeta de Notícias, Río de Janeiro, 5 de abril de 1912: 3; y "Deportados", Gazeta de Notícias, Río de Janeiro, 23 de mayo de 1912: 7.

33 Mucho más tarde, a comienzos de la década de 1930, los elementos característicos referidos al mundo artístico, a las relaciones de prostitución, a la expulsión y, finalmente, a la práctica del travestismo, volvían a combinarse para asociarlos con una Princesa de Borbón, esta vez una "cortesana" que frecuentaba el elegante cabaret Tabarís en la calle Corrientes de Buenos Aires (Vincelle, 1933: 110-124). Que en los años siguientes Sebreli y otros autores retomaran lo referido a la Princesa y sus historias sugiere hasta qué punto el nombre "Princesa de Borbón" estuvo asociado a este contexto social porteño del mundo de los travestis (Sebreli, 2011). 
estadías en Buenos Aires solía trabajar en "cafés cantantes" y "aprovechaba los días de Carnaval para vestirse de mujer". Si a estas alturas ya nos queda claro que la Princesa de Borbón no se vestía de mujer solo durante el Carnaval, la observación sobre la posibilidad que le daba trabajo en cafés cantantes merece ser mejor explorada. Además de los rituales carnavalescos, la práctica del transformismo era usada con frecuencia y reconocida en el circuito de los teatros de varietés que, en los primeros años del siglo XX, conectaba ciudades y pueblitos sudamericanos con grandes metrópolis europeas. Los significados y efectos de la circulación de imágenes femeninas en este ámbito ocupaban también un lugar central en trayectorias de mujeres transgénero, como la Princesa de Borbón.

El teatro de variedades, con su incesante fluir de atracciones que cambiaban cada semana en cabarets y teatros-casino, nació de una inédita organización empresarial en el mundo del espectáculo. Produjo, además, un incremento de los viajes de artistas basados en precarios acuerdos de trabajo. En términos de consumo cultural, los circuitos artísticos mercantilizaron performances de estilos de feminidad sobre escenarios, proceso que un crítico cultural denominó "espectacularización del cuerpo femenino". ${ }^{34}$

Para las mujeres, esta mercantilización se traducía en acuerdos laborales bien específicos que involucraban giras internacionales, contratos mal pagados y una permanente sospecha moral que, en muchos casos, expresaba un empalme entre el trabajo artístico y el ejercicio de la prostitución (Schettini, 2012b). Algunos apodos elegidos por Ariatti y sus amigos se referían a ese universo, caracterizado por un juego con una autenticidad inventada: estilos musicales pretendidos y formas de bailar "típicos", acompañados de denominaciones regionales, tal como La Sevillanita, La Argentinita, La Cordobesita, etc. ${ }^{35}$ En este contexto, era común que diferentes artistas se especializaran en imitar a figuras conocidas y que, de hecho, construyeran toda su carrera a partir de sus capacidades de personificar a otras artistas. Tal era el caso de la Bella Otero. Española de nacimiento, alcanzó una notoriedad inédita como una mezcla de cortesana, bailarina y cantante, presentándose en escenarios europeos y sudamericanos. Los transformistas podían ser ubicados como parte de esta cadena de personificaciones. Sus performances estaban entre las más populares y mejores pagadas a comienzos de siglo (Toll, 1976), lo que da una medida de su éxito. Bajo

34 Anastasio (2009), al referirse a la popularidad del cuplé español, subrayaba la mercantilización de las imágenes de mujeres que circulaban a través de postales y fotos en revistas, y de sus voces en discos.

35 El desafío, según un cronista nostálgico de mediados del siglo XX, era lograr inventar "algo propio y moderno" en medio de repeticiones de lo "folclórico" y de la eterna imitación de "modas extranjeras" (Onis, 1946: 180-184). 
denominaciones que iban de "transformistas" a "imitadores" o "parodistas", estos artistas llenaban las salas de los cafés-conciertos de los principales centros urbanos de Europa y del continente americano.

En la crónica de Soiza Reilly, además de la Princesa de Borbón aparecían referencias a José Rodríguez Gonzales, alias La Morosoni, quien había trabajado como actriz y corista en un teatro nacional hasta que se fugó al Brasil; Francisco Torres, con el nombre de La Venus, hacía sus números en el club La Sociedad de los Pimpollos (calle Talcahuano al 860); y Ángel Cessani, La Choricera, que tenía una casa de baile en Puente Alsina. Una década antes, en su relato autobiográfico dedicado al criminólogo Francisco de Veyga, la "Marica", que asume la identidad de la Bella Otero, lleva hasta las últimas consecuencias su identidad de artista, siguiendo un juego de imitaciones: "He estado en París, donde bailé en los cafés-conciertos, dándole mucha envidia a otra mujer que usa mi mismo nombre para hacerse pasar por mí" (De Veyga, 1903).

Los nombres artísticos como la Bella Otero, la Princesa de Borbón y otros eran mucho más que meros apodos. $\mathrm{Al}$ insertarse en este género de entretenimiento en los albores del siglo XX, participaban de un continuum de performances de identidades y personajes, en los que las copias y los originales confluían en la producción de diversas versiones de feminidad glamorosa y seductora. Recurrir a esos nombres y a la posibilidad de actuar en un escenario ponía en cuestión los postulados científicos sobre la “inversión sexual”. Además, podían reivindicar la expresión artística como una forma de ganarse la vida. Monsieur Bertin, por ejemplo, se estuvo presentando en el escenario del Casino en 1912 y el día del estreno fue anunciado como un "transformista famoso", recién llegado luego de actuar "con gran éxito por los escenarios de Londres". Bertin era un referente de los imitadores que se especializaban en personificar "a las más hermosas actrices y a las más celebradas professional beauties" ${ }^{36}$ Probando que "había Bertin para muchas noches", el transformista demostró a los porteños que "canta con precioso timbre de tiple, modula con sorprendente facilidad, acciones $[$ sic] y se caracteriza de tal modo, que por momentos sugestiona y embelleza al público".

Estas descripciones sugieren las maneras en que performances transformistas podían ser vistas en ese tiempo. El éxito no resultaba solo de la eficacia de la vestimenta, sino también de la veracidad de la actuación femenina con tonos eróticos. La Princesa de Borbón, entonces, se insertaba en este

36 "Menudencias", en: Caras y Caretas, número 517, Buenos Aires, 29 agosto de 1908: 84; y "Casino - El debut del transformista Bertin", en: Caras y Caretas, número 706, Buenos Aires, 13 de abril de 1912: 6. 
continuum de representaciones artísticas de una feminidad "picaresca", en el que participaban bailarinas y cancionistas junto con sus imitadores e imitadoras. El transformismo del teatro de variedades seguramente les abría un repertorio de performances disponibles y socialmente aceptadas, acaso delineando las versiones de feminidad que esas personas asumían también afuera del escenario. A la luz de este contexto, ganan sentido las fotografías de la Princesa de Borbón que se publicaban una y otra vez en los diarios y en las revistas de América del Sur.

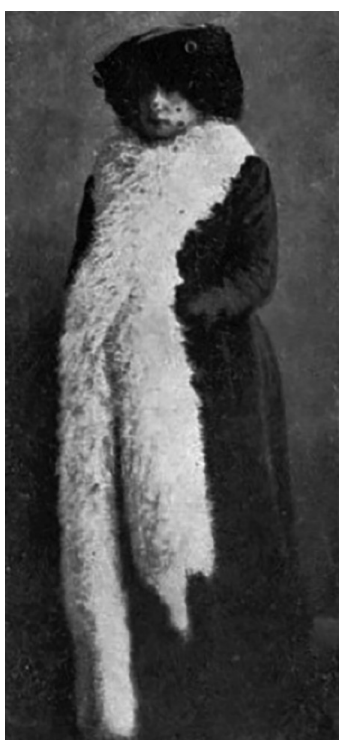

Fuente: Soiza Reilly, 1912.

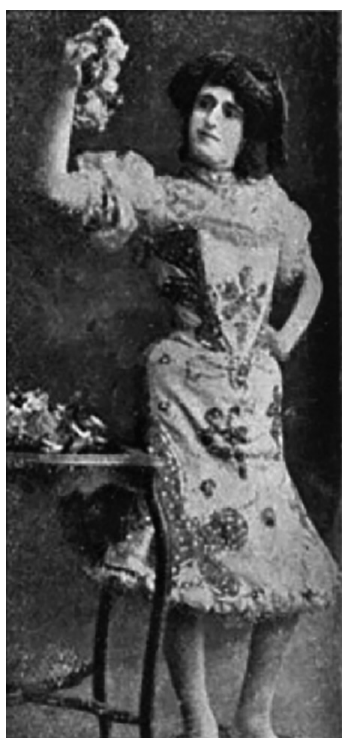

Fuente: Soiza Reilly, 1912.

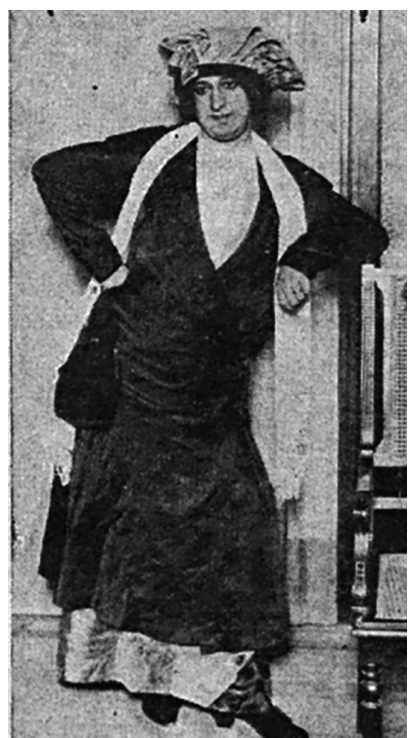

Fuente: 0 Malho, Río de Janeiro, 4 de enero de 1913.

Las fotografías sugieren que parte de la fascinación provocada por los transformistas era la posibilidad de radicalizar una escenificación del género, como menciona Sharon Ullman (1995) en un artículo sobre estos artistas en Estados Unidos de América durante el mismo periodo. En este sentido, el mundo artístico puede haber sido una salida para quienes lograron escapar de las lentes fotográficas policiales.

Estas performances de mujeres materializaban intersecciones entre nuevas tendencias de consumo cultural, estatus y nacionalidad. En ese sentido, la vida de la Princesa también es sugerente respecto a cómo esas performances e imágenes podían brindar a muchas otras personas la posibilidad de construir sus identidades de género, ofreciéndoles un "vocabulario simbólico" inteligible. 
En otras palabras, la imitación a las artistas de variedades que hacían los transformistas en los escenarios daba forma a un estilo de feminidad empleado con sentidos diversos, a veces indescifrables para sus contemporáneos.

\section{Consideraciones finales}

Por detrás de la unívoca acusación de "ladrones vestidos de mujer", esas personas ganaban múltiples identidades: sirvientas, prostitutas, artistas de varietés. El robo -sospecha insinuada por la Policía y consolidada por los relatos periodísticos- puede haber sido una estrategia para conseguir dinero en un universo social de oportunidades limitadas para la supervivencia de maricas y travestis. Pero, ciertamente, no era la actividad principal a la que se dedicaban, y mucho menos un horizonte identitario. En una época en que muchos hombres dedicados a actividades delictivas comenzaban a verse a sí mismos como "ladrones profesionales", ninguno de los personajes mencionados en este trabajo se involucraba en el mundo del delito como una forma de vida.

En rigor, con excepción de la Bella Otero, cuya voz fue captada por el criminólogo Francisco de Veyga y, a través de ese relato, recuperada por estudios históricos (Salessi, 1995; Ben, 2007), la trayectoria de otras protagonistas de dichas transformaciones de género a comienzos del siglo XX -como la Princesa de Borbón- nos llegan por medio de relatos periodísticos y policiales. Esas narrativas buscaban crear una clave de lectura de sus vidas como existencias engañosas, simuladoras y delictivas. Fue tal vez Juan José de Soiza Reilly, en la crónica de 1912, quien mejor resumió esa idea en torno al argumento de que los "ladrones que se visten de mujer" "se valen de su aspecto afeminado" para engañar a hombres ricos y diversos otarios que desconocían los secretos de la vida urbana moderna, como las víctimas del cuento del tío. El registro predominante, entonces, oscila entre "hábiles ladrones" y "enfermos psíquicos".

Una lectura detenida en esos mismos relatos, de la crónica de Soiza Reilly y de las numerosas noticias policiales sin firma, permite argumentar contra la propia hipótesis que sostienen. Tal como en el caso de los "muchachos orientales" (Rafael y Héctor) expulsados del Brasil en 1912, cuya acusación de "ladrones vestidos de mujer" no iba acompañada de una sola prueba delictiva, toda la historia de la Princesa de Borbón redunda en datos imprecisos cuando se trata de demostrar su condición de "ladrón". Ni el relato de Soiza Reilly ni las numerosas crónicas policiales en la prensa de Argentina y Brasil brindaban detalles sobre algún robo concreto. Ese vacío era ocupado por anécdotas jocosas sobre seducciones a empleados policiales y leyendas urbanas que le atribuían a la Princesa haber paseado por las calles de Montevideo abrazada a un comisario de Policía o haberse presentado en 
el Congreso argentino para pedir una pensión como viuda de un militar muerto en combate en la guerra del Paraguay, todas mencionadas en la crónica de Soiza Reilly.

Quizás algo de esas anécdotas remitan a la esfera de lo real, de lo ocurrido en la vida de la Princesa de Borbón. Pero leerlas en clave de indicios de simulación delictiva, de un personaje más en la fauna de embaucadores que circulaban por el Atlántico sudamericano en búsqueda de dinero fácil, parece más bien un gesto de legitimación de los violentos procedimientos policiales. Otra lectura es posible: mirar las formas de sobrevivencia y de trabajo disponibles para estas personas que asumían una identidad social femenina en el cruce de múltiples fronteras: de género, de identidades sexuales, de actividades remuneradas y no remuneradas, de la legalidad y la ilegalidad. La conexión entre los circuitos artísticos, laborales y delictivos merece ser abordada más allá de la nota de color o de la mera constatación de simultaneidad. Más bien, debe ser examinada como fragmentos de la experiencia de sujetos que asumían identidades de género femeninas y construían estrategias de supervivencia disponibles por las configuraciones contemporáneas del mundo del trabajo. Tomar al pie de la letra la identidad elegida por quien policías y periodistas se empeñaban en llamar Armando Ariatti o Luis Fernández, es decir, la Princesa de Borbón, es un llamado a pensar su trayectoria fuera de la jaula hermenéutica construida por sus narradores, y que conduce siempre a la idea del disfraz, de la simulación y del jolgorio carnavalesco.

Sus pasos arriba y abajo del escenario habilitan una reflexión sobre las posibilidades y los límites de un incipiente mercado del entretenimiento, en el que prácticas sociales vinculadas a la intimidad y a la sexualidad adquirían un precio. Al igual que muchas personas autoidentificadas como mujeres buscando refugio en el servicio doméstico, la adopción de un nombre artístico femenino -inteligible para sus contemporáneos- para moverse como personaje del teatro de variedades era una estrategia de supervivencia física y de construcción de dignidad. Era algo más que la "resistencia" a las inclemencias de un mundo opresor: se trataba de la invención de un espacio de existencia -frágil, es verdad, y a menudo demasiado efímero- en las fronteras del trabajo femenino. La denuncia del "ladrón vestido de mujer" buscaba clausurar ese campo de posibilidades y reponer la identidad masculina a cualquier costo.

Más compleja y ambigua es la referencia al servicio doméstico. Algunas historiadoras han mostrado que en América del Sur los debates en torno a la reglamentación de ese trabajo tradujeron diversos temores frente a la autonomía o la demanda por derechos de las mujeres en términos de un miedo al delito en los hogares (Allemandi, 2017; Fernandes de Souza, 2014; Graham, 1992). Es posible imaginar que la nota de Soiza Reilly, al asociar la figura periodística 
de los "hombres vestidos de mujer" a prácticas delictivas, pudo haber sido leída también en conexión con la polémica social sobre la reglamentación del servicio doméstico. De esa manera, se combinaban esos dos universos de significados: la asociación al refinamiento de técnicas de simulación, como la de los cuenteros del tío, y aquellos temores más específicos de "contagio moral". Nada representaba mejor estos miedos que el mundo del servicio doméstico, una relación de trabajo en la que la intimidad reforzaba los temores hacia el otro. La estrategia narrativa de apuntar al delito para caracterizar y explicar la condición travesti de estos jóvenes llevaba el clásico tópico criminológico de la "simulación" al terreno de la identidad de género: estos sujetos que amenazaban con entrar en los ámbitos más recónditos de la familia-advertían los policías, reafirmaban los periodistas- no eran lo que "aparentaban ser" y no aparentaban lo que "verdaderamente eran", ladrones vestidos de mujer.

Esa imputación disimulaba -aunque no ocultaba del todo- la inserción laboral de estas mujeres en los márgenes del teatro de variedades y del mercado del entretenimiento: desde peinadoras y maquilladoras de actrices ("peinadores de damas", decía Soiza Reilly, era el "oficio en el que todos declaran trabajar cuando se les detiene"), hasta artistas de varietés, actividad a la que solía estar vinculado su nombre femenino. Por su parte, la frontera maleable entre ese espacio teatral y el mundo de la prostitución -ambos constituidos en medio de una intensa circulación transnacional de mujeres- atravesaba la vida y las estrategias de supervivencia de sujetos como la Princesa de Borbón. Finalmente, el sentido de género de ciertos tipos de trabajo doméstico no remunerado era, con certeza, otra parte constitutiva, aunque nada glamorosa, de la experiencia de ser una mujer en aquel mundo. Esta dimensión es evidente en los recuerdos, a mediados del siglo XX, de un famoso malandro de Río de Janeiro, conocido por transformarse en Madame Satã. Barrer el piso y limpiar la comisaría, trabajo de mujer, era la actividad que la Policía daba a los travestis que arrestaba en los años de la década de 1920 (Green, 2003).

A pesar de los rumores de su muerte en 1916, el nombre de la Princesa de Borbón volvió a aparecer en las páginas del diario argentino Crítica en 1919, viviendo supuestamente en Montevideo en una casa de pensión de artistas, con el propósito de llevar "una vida tranquila". ${ }^{37}$ Es significativo que el periodista porteńo la presentara como una persona conocida por sus lectores. Recordaba que "desde nińo, gustó del ropaje femenino y de experimentar emociones propias del sexo débil" y que así se ganó un lugar "en el mundo galante". ${ }^{38}$ Unas líneas más abajo, sin embargo, retomaba el sentido ya conocido

37 "La princesa está herida", Crítica, 6 de agosto de 1919.

38 Ibid. 
al aclarar que "el robo era la finalidad de todas las pasiones que provocaba". Entre el reconocimiento de una identidad femenina y la idea de la simulación delictiva, se reiteraba el mismo repertorio de categorías que otros usaban para definir y darle verisimilitud a su vida; esa vida que transcurrió entre España, Argentina, Uruguay, Brasil y, quizás, Chile; esa vida que - de este modo-atravesó fronteras nacionales, pero también las fronteras entre diversos espacios laborales que, con toda su precariedad, le permitieron sobrevivir, viajar y, de algún modo, existir de acuerdo a la identidad que reivindicaba. 
110 | Trabajos y trabajadores en América Latina (siglos XVI-XXI)

FUENTES

PERIÓDICOS

A Noite, Río de Janeiro, 1912, 1913, 1916.

Fray Mocho, Buenos Aires, 1912.

Gazeta de Notícias, Río de Janeiro, 1910, 1912, 1913.

Correio da Manhã, Río de Janeiro, 1912, 1913.

Jornal do Brasil, Río de Janeiro, 1912, 1913.

A Notícia, Río de Janeiro, 1912.

A Época, Río de Janeiro, 1912, 1913.

Crítica, Buenos Aires, 1919.

O Imparcial, Río de Janeiro, 1913.

O Paiz, Río de Janeiro, 1913.

Jornal do Comércio, Río de Janeiro, 1913.

O Século, Río de Janeiro, 1913.

A Imprensa, Río de Janeiro, 1913.

Caras y Caretas, Buenos Aires, 1908, 1912.

MANUSCRITOS

Base de datos del Centro de Estudios Migratorios Latinoamericanos (CEMLA): http://cemla.com/buscador/

Archivo Nacional del Brasil, Fondo GIFI - Secretaría de Policía, Caja 6C223. Archivo Nacional del Brasil, Fondo GIFI - Secretaría de Policía, Caja 6C392. Archivo Nacional del Brasil, Fondo Ministerio de Justicia y Negocios Interiores Expulsión de Extranjeros, IJJ7, Caja 150.

\section{BibLIOGRAFÍA}

Albornoz, Martín y Diego Galeano

2017 "El momento Beastly: la Policía de Buenos Aires y la expulsión de extranjeros, 1896-1904”. En: Astrolabio, número 17. Córdoba, Argentina: Universidad Nacional de Córdoba. 6-41.

Allemandi, Cecilia

2017 Sirvientes, criados y nodrizas. Una historia del servicio doméstico en la ciudad de Buenos Aires (fines del siglo XIX y principios del XX). Buenos Aires: Teseo / Udesa. 
Anastasio, Pepa

2009 "Pisa con Garbo: el cuplé como performance". En: Trans. Revista Transcultural de Música, número 13. Barcelona: Sociedad de Etnomusicología. s. p.

Ben, Pablo

2009 Male sexuality, the Popular Classes and the State: Buenos Aires, 18801955. PhD. Dissertation. Chicago, Estados Unidos de América: University of Chicago.

2007 "Plebeian masculinity and sexual comedy in Buenos Aires, 1880-1930". En: Journal of the History of Sexuality, volumen 16, número 3. Texas, Estados Unidos de América: University of Texas Press. 436-458.

Chauncey, George

1995 Gay New York. Gender, Urban Culture and the Making of Gay Male World, 1890-1940. Nueva York Estados Unidos de América: Basic Books.

Cunha, María Clementina Pereira

2001 Ecos da folia: uma história social do carnaval carioca entre 1880 e 1920. San Pablo, Brasil: Companhia das Letras.

De Veyga, Francisco

1903 "La inversión sexual adquirida”. En: Archivos de psiquiatría, criminología y ciencias afines, tomo II. La Plata, Argentina: Universidad Nacional de La Plata, Facultad de Humanidades y Ciencias de la Educación / Biblioteca Orbis Tertius.

Fernandes de Souza, Flavia

2014 "A criadagem sob suspeita: as relaçóes entre o poder público e os trabalhadores domésticos na cidade do Rio de Janeiro no entre séculos XIX-XX”. En: Anais do XVI Encontro Regional de História da Anpub-Rio 1. Río de Janeiro: Anpuh-RJ. 1-16.

Galeano, Diego

2016a "Entre cuenteros y otarios: Historia transnacional de una estafa en América Latina, 1870-1930”. En: Historia, volumen 49, número 2. Santiago de Chile. 395-427.

2016 b Criminosos viajantes: circulaçóes transnacionais entre Rio de Janeiro e Buenos Aires, 1890-1930. Río de Janeiro: Arquivo Nacional.

González Castillo, José

2011 Los invertidos y otras obras. Buenos Aires: Ediciones RyR. 
112 | Trabajos y trabajadores en América Latina (siglos XVI-XXI)

Graham, Sandra

1992 Proteção e obediência. Criados e seus patrôes no Rio de Janeiro (18601910). San Pablo, Brasil: Companhia das Letras.

Green, James

2003 “O Pasquim e Madame Satã, a 'rainha' negra da boemia brasileira”. En: Topoi, volumen 4, número 7. Río de Janeiro. 201-221.

2000 Além do carnaval. A homossexualidade masculina no Brasil do século $X X$. San Pablo, Brasil: UNESP.

Kalifa, Dominique

2002 "Archéologie de l'Apachisme. Les représentations des Peaux-Rouges dans la France du XIXe siècle". En: Revue d'histoire de l'enfance "irrégulière ", número 4. 19-37.

Martins, William

2007 "Paschoal Segreto: Ministro das Diversões do Rio de Janeiro (18831920)”. En: Cidade Nova, número 1. 83-96.

McClintock, Anne

2010 Couro imperial. Raça, gênero e sexualidade no embate colonial. Campinas, Brasil: Unicamp.

Menezes, Lená Medeiros de

1996 Os Indesejáveis - desclassificados da modernidade. Protesto, crime e expulsão na Capital Federal (1890-1930). Río de Janeiro: EdUERJ.

Onis, Federico de

1946 "La Argentinita”. En: Revista Hispanica Moderna, número 12. 180-184.

Perrot, Michelle

1979 "Dans le Paris de la Belle Époque, les Apaches, premières bandes de jeunes". En: Les marginaux et les exclus dans l'histoire. París: Union générale d'éditions.

Relatório

1913 Relatório do Ministro da Justiça e Negócios Interiores. Río de Janeiro: Imprensa Nacional.

1912 Relatório do Ministro da Justiça e Negócios Interiores. Río de Janeiro: Imprensa Nacional.

Salessi, Jorge

1995 Médicos, maleantes y maricas: higiene, criminología y homosexualidad en la construcción de la nación argentina. Buenos Aires: 1871-1914. Rosario, Argentina: Beatriz Viterbo. 
Schettini, Cristiana

2013 "Los transformistas en el varieté de comienzos del siglo XX". En: Actas de las XIV Jornadas Interescuelas / Departamentos de Historia. Mendoza, Argentina: Universidad Nacional de Cuyo.

2012a "Exploração, gênero e circuitos sul-americanos nos processos de expulsão de estrangeiros (1907-1920)". En: Tempo, volumen 18, número 33. Río de Janeiro: Instituto de Historia, Universidad Federal Fluminense. 51-73.

2012b "South American Tours: work relations in the entertainment market in South America”. En: International Review of Social History, volumen 57. 129-160.

2006 Que Tenhas Teu Corpo. Uma História social da prostituição no Rio de Janeiro das primeiras décadas republicanas. Río de Janeiro: Arquivo Nacional.

Sebreli, Juan José

2011 Buenos Aires, vida cotidiana y alienación: seguido de Buenos Aires, ciudad en crisis. Buenos Aires: Sudamericana. [1964]

Soiza Reilly, Juan José de

1920 La escuela de los pillos. Buenos Aires / Montevideo: Matera / de Angelis.

Steedman, Carolyn

1994 "The Price of Experience: Women and the Making of the English Working Class". En: Radical History Review, número 59. 108-119.

Toll, Robert

1976 On with the show. The First Century of Show Business in America New York. Oxford, Inglaterra: University Press.

Ullman, Sharon

1995 "The Twentieth Century Way: Female Impersonation and Sexual Practice in Turn of the Century America”. En: Journal of the History of Sexuality, volumen 5, número 4. 573-600.

Van Voss, Lex Heerma

2012 "The Worst Class of Workers: Migration, Labour Relations and Living Strategies of Prostitutes Around 1900”. En: Marcel Van der Linden y L. Lucassen: Working on Labour. Leiden, Holanda: Brill.

Vincelle, Claudio

1933 El amor en la Argentina. Buenos Aires: El Ombú. 

2

Historiografías SOBRE TRABAJO 



\title{
Introducción
}

\author{
Larissa Rosa Corrêa (Brasil)* \\ Paulo Drinot (Perú/Reino Unido)** \\ David Mayer (Austria) ${ }^{* * *}$
}

No es posible estudiar "la historia del trabajo" sin reflexionar sobre sus trayectorias pasadas y sus rumbos recientes (tanto en los diferentes países como en líneas más generales en todo el subcontinente). Estas trayectorias se escriben enfáticamente en plural, mucho más tomando en cuenta que la historia del trabajo incluye, en los cuatro aportes a esta sección, no solo la historia de las diferentes relaciones de trabajo y de los trabajadores (mujeres y hombres), sino también los movimientos que organizan y representan a los trabajadores, otros sujetos socio-ideológicos (como "la" izquierda), entes supranacionales (como la Organización Internacional del Trabajo - OIT) o instituciones estatales, con sus diferentes grados de autoritarismo frente al mundo del trabajo.

El mapeo del campo de la historia del trabajo y sus vecinos, tanto lindantes como más lejanos, es un ejercicio que se ha practicado desde hace décadas. Tiene su propia trayectoria y ha dejado un interesante testimonio de cambiantes coyunturas, inquietudes y paradigmas. Como es buena costumbre en este ejercicio, las contribuciones de este apartado "actualizan" a sus antecesores; es decir, tanto los continúan como los cuestionan. A estas reflexiones desde los propios historiadores del trabajo en cada país habría que añadir quizás una lista de panoramas que han intentado considerar el campo en términos continentales y desde el punto de vista de una academia anglófona. ${ }^{1}$

* Pontifícia Católica do Rio de Janeiro.

** University College London.

*** Centre for Modern Indian Studies (CeMIS), Georg-August-Universität Göttingen, Instituto Internacional de Historia Social (IISG)

1 Valdría la pena analizar en un futuro metaanálisis con más detalle las convergencias y las discrepancias entre las miradas "internas" y "externas", aunque, por supuesto y afortunadamente, no existe una separación nítida entre las dos esferas. Véanse panoramas más recientes en: French, 2006: 289-333, 322-331; Brennan, 2011: $342-$ 366; Barragán y Mayer, 2018: 95-121; Fontes, Fortes y Mayer, 2017: 1-22. Vistas extensas de la literatura previa se encuentran en los ensayos bibliográficos reunidos en Bethell (1995), particularmente en los textos de Hall y Spalding Jr. (359-375), Angell (585-596) y Roxborough (617-634). 
Al leer las cuatro contribuciones de esta sección caemos en cuenta que palabras como 'expansión', 'multiplicidad' o 'diálogo' ayudan a condensar la dinámica de un campo de estudio que tiene demarcaciones borrosas. Esto se hace evidente aun con las limitaciones geográficas de este apartado, que ofrece densos exámenes de los dos países con la producción académica más extensa sobre la historia del trabajo (Brasil y Argentina), además de enfocarse en dos áreas de investigación con características más transnacionales (la OIT y el estudio comparativo de las dictaduras latinoamericanas de las décadas de 1960 y 1970). Es obvio que el cuadro se complicaría aún más incluyendo a países como Bolivia, Chile, Perú, México o Uruguay (para nombrar otros centros mayores de investigación y debate), tanto como los demás países de América Latina, el Caribe y las regiones del mundo relacionadas con ellos mediante lazos migratorios o de commodity chains.

Si bien no existe ninguna historiografía fuera de su contexto contemporáneo, la historia del trabajo, tanto en sus trayectorias históricas como en sus desarrollos recientes, tiene una relación a menudo más directa y estrecha con la sociedad y las apuestas políticas. Tomando solamente los ejemplos de Brasil y de Argentina, es claro que en los últimos 30-40 años la historiografía del trabajo ha sido profundamente influida (y a veces agilizada) por el fin de las últimas dictaduras militares, los procesos de democratización, la intensidad de las luchas obreras, el auge de otros movimientos sociales, la emblemática crisis del año 2001 en Argentina y el ascenso del Partido de los Trabajadores (PT) al poder en Brasil.

El momento actual se presenta en un ambiente mucho más sombrío: los desafíos de la escritura de la historia y, particularmente, de la historia del trabajo, se enfrentan hoy con el avance de gobiernos de extrema derecha y regímenes neoliberales sin precedentes en la historia de América Latina. En Brasil, la victoria electoral de Jair Bolsonaro, candidato de la extrema derecha, nos incita a responder por medio de la investigación académica a una ofensiva muy bien orquestada por grupos extremistas, que busca modificar la narrativa histórica. No es casualidad que ese movimiento revisionista y negacionista haga asociaciones libres o indirectas entre el nazismo y las dictaduras militares en el Cono Sur. En ese giro radical al oscurantismo, el tema de la esclavitud tampoco pasó incólume. Minimizar el legado catastrófico de la esclavitud, negando el racismo que rige las relaciones sociales hasta la historia del tiempo presente, se ha convertido en una tarea urgente en la era bolsonarista. Mientras tanto, el "nuevo populismo de derecha" en América Latina no solo representa un desafío en cuanto a las políticas de la historia, sino que afecta áreas que son fundamentales para historiadores del trabajo como consecuencia de la precarización, basada en la sustracción de los derechos laborales históricamente conquistados, asociado a las reformas en la seguridad social. 
En la era de la uberización, urge pensar en las nuevas concepciones de trabajo y de trabajadores, cuestión clave para comprender las rupturas y las continuidades del tiempo presente. Sumados a estos desafíos se encuentran los propios historiadores y demás investigadores latinoamericanos como víctimas de las políticas de austeridad. Sin embargo, a pesar de estos nuevos desafíos, nos encontramos aquí reunidos para presentar un valioso conjunto de análisis producidos por autores y autoras oriundos de Argentina y de Brasil, aunque sus trabajos no se restrinjan a las fronteras de esos dos países.

En el caso del trabajo de Fabiane Popinigis y Paulo Cruz Terra, quedan en evidencia los importantes cambios en la historiografía brasileña tanto en la historia de la esclavitud como en la historia del trabajo. Tal cual muestran los autores, la historiografía anterior a la década de 1980, así como los estudios sociológicos, solían entender estos campos como fundamentalmente distintos, dada la tendencia a pensar en la historia de Brasil a partir de categorías dicotómicas. Esto dificultaba pensar en los puntos de contacto entre estos campos de estudio o, más aún, en las experiencias compartidas entre esclavos y otros trabajadores. Es a partir de la década de 1980 cuando empieza a romperse este muro de Berlín historiográfico, para recordar la frase de los historiadores Sidney Chalhoub y Fernando Teixeira da Silva. De esta manera, como bien demuestran Popinigis y Cruz Terra, comienza a aparecer un diálogo bastante fructífero entre estos campos de estudio que se enriquecen mutuamente al echar nuevas luces sobre una serie de temáticas, entre las que se encuentran la compleja continuidad y discontinuidad entre formas de trabajo libre y coercitivo, el efecto de la inmigración sobre los regímenes de trabajo, la conflictividad laboral y la política de masas, y, finalmente, la posabolición y sus múltiples aristas y periodizaciones. En torno a cada una de estas temáticas, como bien muestran los autores, el diálogo entre las historiografías de la esclavitud y del trabajo ha llevado a los investigadores a formular nuevas preguntas, emplear nuevas fuentes y desarrollar nuevos métodos interpretativos, con resultados muy positivos.

Laura Caruso y Lucas Poy, por otra parte, ofrecen una visión panorámica de la producción historiográfica sobre el mundo del trabajo en Argentina. También apuntan a una serie de momentos de inflexión historiográfica que se corresponden en parte con giros historiográficos globales, pero que son también producto de un desarrollo historiográfico específicamente argentino. Así, en un primer momento, los autores muestran cómo la historiografía "militante" escrita a partir de la década de 1930, y que retomó una historia que reflejaba diferentes corrientes de izquierda (anarquistas, socialistas, comunistas y sindicalistas), entra en conflicto con una historiografía peronista que buscó hegemonizar el recuento del pasado trabajador. Esta historiografía inicial, en gran medida limitada a recuentos institucionales del desarrollo 
del movimiento obrero y a los grandes procesos huelguísticos, dio paso, en la década de 1980, en el contexto de la democratización del país, a una historiografía que se nutrió en particular de la obra de historiadores marxistas como Eric Hobsbawm y Edward Palmer Thompson para ampliar el estudio del mundo obrero a nuevas temáticas, como las condiciones de trabajo y de vivienda desde una perspectiva de la historia social. Un tercer momento se da a partir de la década del 2000, después de un repliegue de producción historiográfica en la década de 1990. En este contexto, marcado por la crisis de 2001, se manifiesta un auge importante en la producción historiográfica en la que destaca un retorno a la historia política de los movimientos de trabajadores (con metodologías renovadas) y aparece la perspectiva de género como campo de reflexión particularmente fructífero sobre el mundo del trabajo. Surge también un nuevo interés por el estudio de la construcción de las políticas sociales y la experiencia laboral de sectores obreros particulares, como los ferroviarios y los marítimos, entre otros.

En el siguiente estudio, Laura Caruso y Andrés Stagnaro presentan una reflexión en torno a la historiografía sobre la OIT y el papel que cumple América Latina en ella. La producción historiográfica sobre la OIT suele ignorar o minimizar el papel de América Latina en su conformación y desarrollo. Esto se debe, en parte, a la periodización que se suele favorecer y a los temas que se privilegian. Se impone, según los autores, una agenda de investigación desde Ginebra, la sede de la OIT, que convierte a la región en periférica desde el punto de vista historiográfico. Sin embargo, repensar la historia de la OIT desde y en América Latina es sumamente provechoso. Para empezar, la participación de América Latina en los primeros ańos de la OIT, cuando los países de la región proveían una parte sustancial del apoyo a la institución ginebrina, resulta ser extraordinariamente importante para entender su inicial desarrollo y sus campos de acción. Como proponen Caruso y Stagnaro, es necesario desarrollar una periodización más precisa de la interacción entre América Latina y la OIT para entender el desarrollo tanto de la OIT como de las políticas laborales en la región. Con este objetivo se ha constituido una red interdisciplinaria OIT-América Latina que reúne a investigadores de diversos países de la región, entre ellos Chile, Brasil, Argentina y Bolivia. Gracias a talleres bianuales y publicaciones colectivas, la red tiene como finalidad, precisamente, desarrollar una agenda de trabajo colaborativa que ponga en evidencia la conexión OIT-América Latina opacada en la historiografía tradicional sobre el organismo internacional.

El último texto de esta sección ofrece una revisión de la historiografía sobre la dictadura y el mundo del trabajo en cinco países latinoamericanos: Argentina, Brasil, Chile, Paraguay y Uruguay. Victoria Basualdo, la autora, se arma de una nueva y rica producción historiográfica para explorar las 
convergencias y las divergencias de las experiencias de estos cinco casos. Si bien los procesos dictatoriales en los cinco países comparten cierta orientación ideológica (en gran parte reflejo de una lógica anticomunista surgida de la Guerra Fría) e incluso, mediante el Plan Cóndor, un cierto nivel de coordinación, al mismo tiempo son evidentes las diferentes experiencias de los trabajadores en cada país. Basualdo se enfoca en tres grandes problemáticas para poner de relieve los importantes aportes de historiadores a este campo de estudio. Primero, el impacto de las dictaduras sobre el mundo obrero, tanto directo (como consecuencia de la represión) como más indirecto (producto de los giros en la política económica y sus consecuencias en el ámbito laboral). Segundo, la resistencia de los trabajadores a la dictadura, una temática que cubre un espectro muy amplio desde lo que James Scott llama "las armas de los débiles" (como el trabajo a desgano y el sabotaje) hasta estrategias de condena a las dictaduras que involucraban organismos internacionales como la OIT. Por último, el consentimiento, es decir, el hecho de que, en algunos casos, la relación entre el mundo del trabajo con los gobiernos militares no fue de simple resistencia sino que incluyó la aceptación e incluso la legitimación social de la dictadura, un campo de estudio aún en desarrollo pero que complejiza aun más la relación entre dictadura e historia del trabajo en América Latina.

La revisión historiográfica genera desafíos específicos. Se corre siempre el riesgo de dejar fuera referencias y perspectivas, y es siempre discutible en qué medida se cubre adecuadamente una u otra corriente historiográfica. Sin embargo, solemos cosechar buenos frutos de este ejercicio. Al aceptar la obra planteada inicialmente por la Red Latinoamericana y del Caribe de Trabajo y Trabajador@s (REDLATT) en el encuentro de La Paz, ocurrido en 2017, las autoras y los autores de los textos de esta sección realizaron una tarea hercúlea de sistematizar y contextualizar las contribuciones que constituyen los pilares de los debates historiográficos de la historia del trabajo latinoamericano. Estos trabajos invitan al diálogo, al mismo tiempo que contribuyen a organizar los ejes historiográficos que caracterizan este campo de estudio, señalando lagunas y nuevas perspectivas historiográficas. Esta sección, por lo tanto, no es más que un inicio (no solamente en el sentido de una tarea que todavía habrá que realizar para otros países y temáticas, sino también en un sentido más fundamental de un autocompromiso del mismo campo). La reflexión historiográfica seguirá siendo un acompañante permanente de una historia del trabajo que busca abrirse a nuevos temas, métodos y fuentes, y, al mismo tiempo, dialogar con otros campos de estudio y disciplinas. 
BibLIOGRAFíA

Angell, Alan

1995 "The Left". En: Leslie Bethell (ed.), The Cambridge History of Latin America, volumen XI: Bibliographical essays. Cambridge, Reino Unido: Cambridge University Press. 585-596.

Barragán, Rossana y David Mayer

2018: "Latin America and the Carribean". En: Karin Hofmeester y Marcel van der Linden (eds.), Handbook Global History of Work. Berlin, Alemania / Boston, Estados Unidos de América: De Gruyter Oldenbourg. 95-121.

Bethell, Leslie (ed.)

1995 The Cambridge History of Latin America, volumen XI: Bibliographical essays. Cambridge, Reino Unido: Cambridge University Press.

Brennan, James P.

2011 "Latin American Labor History". En: José C. Moya (ed.), The Oxford Handbook of Latin American History. Oxford, Inglaterra: Oxford University Press. 342-366.

Fontes, Paulo; Alexandre Fortes y David Mayer

2017 "Brazilian Labour History in Global Context: Some Introductory Notes". En: International Review of Social History, volumen 62 (Special Issue S25: Brazilian Labour History: New Perspectives in Global Context). 1-22.

French, John D

2006 "The Laboring and Middle-Class Peoples of Latin America and the Caribbean: Historical Trajectories and New Research Directions". En: Jan Lucassen (ed.), Global Labour History. A State of the Art. Berna, Suiza: Peter Lang.

Hall, Michael M. y Hobart A. Spalding Jr.

1995 "The urban working class and early labour movements". En: Bethell, Leslie (ed.), The Cambridge History of Latin America, volumen XI: Bibliographical essays. Cambridge, Reino Unido: Cambridge University Press. 359-375.

Roxborough, Ian

1995 "The urban working class and labour movements". En: Leslie Bethell (ed.), The Cambridge History of Latin America, volumen XI: Bibliographical essays. Cambridge, Reino Unido: Cambridge University Press. 617-634. 


\title{
Historiografia da escravidão e do trabalho e no Brasil: avanços e desafios
}

\author{
Fabiane Popinigis (Brasil)* \\ Paulo Cruz Terra (Brasil)**
}

RESUMEN: Neste artigo buscamos realizar uma revisão historiográfica dos debates sobre escravidão e liberdade nos mundos do trabalho no Brasil. Para isso partimos das críticas, formuladas nas décadas de 1980 e 1990, às abordagens sobre a escravidão como empecilho ao desenvolvimento capitalista, a ideia correlativa sobre o trabalho assalariado como único e fundamental produtor de valor, e a organização do movimento operário como obra de imigrantes brancos e operários assalariados. A confluência nos campos da história do trabalho e da escravidão ao longo de mais duas décadas - tendo em comum a influência de Edward P. Thompson- alimentou-se dessas críticas e diálogos para elaborar perguntas de investigação histórica que permitissem integrar as experiências de trabalhadores escravizados, livres e libertos e suas relações nas transformações sociais e políticas dos séculos XIX e XX. Assim, os historiadores passaram a pesquisar a convivência de trabalhadores de diversas condiçôes jurídicas -imigrantes que trabalhavam por contrato, africanos livres, escravizados, libertos com alforrias condicionais, entre outros- como fundamentais em obras e empreendimentos particulares e do estado. Essa convivência também foi importante organizadora de sociabilidades, das tradiçóes de luta dos escravizados e libertos na organização de movimentos, protestos, greves e sindicatos. Finalmente, estudos sobre o trabalho análogo ao escravo tem mostrado que, no lugar de um avanço constante do processo de assalariamento no século XIX, o que ocorreu foi uma diversificação das formas de exploração dos trabalhadores. Trabalhos mais recentes têm acompanhado as trajetórias de vida de homens negros após a abolição da escravidão, e suas estratégias nos debates públicos sobre cidadania e direitos. Nessa dinâmica, percebe-se não uma simples ruptura, mas o deslocamento e a reestruturação das agendas de pesquisa a partir dos trabalhos e balanços críticos que se alimentaram das investigaçóes anteriores. Assim, este artigo busca mostrar como pesquisas

* Doctora en Historia Social por la Universidad Estatal de Campinas. Universidad Federal Rural de Río de Janeiro (UFRRJ). Contacto: fpopinigis@gmail.com

** Profesor del Departamento de Historia de la Universidad Fluminense (UFF). Contacto: pauloterra@gmail.com 
de história social partiram dos questionamentos a uma rígida dicotomia entre trabalho escravo e trabalho livre e a ideia de transição, para revelar a diversidade de formas de exploraçáo do trabalho e para compreender e visibilizar a participação dos negros na luta dos trabalhadores.

PalABRAS CLAVE: historiografia; trabalho; escravidão; liberdade; Brasil.

\section{INTRODUÇão}

A história do trabalho produzida no Brasil a partir da década de 1980 passou por importantes transformaçóes em termos de temas, metodologia e recortes. Apesar de todas as ampliaçóes nessa área, no final da década seguinte foi feita a indicação que ainda perdurava a ausência dos trabalhadores negros, fosse no período da escravidão ou no pós-Abolição. Ressaltava-se também o pouco diálogo entre a historiografia dedicada à escravidáo e aquela centrada no trabalho. O presente capítulo busca justamente analisar as possíveis aproximaçóes entre os dois campos historiográficos, que tiveram desenvolvimento semelhantes a partir da década de 1980. A partir do objetivo de investigar os diálogos entre o debate historiográfico sobre a escravidão e a história do trabalho, o capítulo está dividido em duas partes. A primeira aborda brevemente as principais vertentes interpretativas sobre a história do Brasil que de alguma forma fundamentaram analises que diziam respeito à formação do Brasil contemporâneo e suas desigualdades. A segunda trata da historiografia surgida a partir da década de 1980 , e o que consideramos serem os principais eixos analíticos em torno dos quais gira a produção sobre escravidão e liberdade em diálogo com a história do trabalho. Mais do que estabelecer marcos de ruptura, buscaremos, ao contrário mostrar que esses trabalhos e balanços críticos se alimentaram de pesquisas anteriores, pioneiras, para formular perguntas de investigaçáo buscando entrelaçar questóes de classe e raça nas diversas formas de exploração dos trabalhadores (Popinigis e Terra, 2019).

\section{Vertentes interpretativas da História do Brasil}

A partir da década de 1980, os pesquisadores enfrentariam o peso de interpretaçóes canônicas sobre a história do Brasil que se construíram ao longo do século XX, tendo um momento fundamental de suas primeiras elaboraçóes a partir da década de 1930 .

Grande parte dos estudos sobre escravidão no Brasil e na América Portuguesa tiveram como questionamento inicial a permanência e a reprodução das desigualdades sociais em vários ciclos econômicos e sistemas 
políticos. Na primeira metade do século XX, as principais vertentes explicativas do Brasil procuravam nos primórdios da formação do território da América Portuguesa -fosse nas relaçóes sociais e políticas do cotidiano, ou na economia colonial-, a explicaçáo para o capitalismo incompleto do Brasil contemporâneo. ${ }^{1}$

Apesar das discordâncias na vertente marxista sobre se a América Portuguesa (o Brasil antes da Independência de Portugal, que ocorreu em 1822) já estava inserida no sistema capitalista, ou se ali se havia criado um modo de produção específico -o escravismo colonial-, essas análises convergiam no que diz respeito à violência do sistema escravista, sobre o sentido da colonização e sobre a crise do sistema colonial (Prado Junior, 2000; Gorender, 2010). Tais análises consideraram que, nas regióes em que continuava a existir, a escravidão era degradadora do trabalho e ancorava sistemas produtivos que impediam o desenvolvimento nacional e a formação de um mercado de trabalho livre. ${ }^{2}$ Por outro lado, essa mesma escravidão nas colônias era propulsora do "trabalho livre" nas metrópoles, onde se formava também um mercado de consumo para os produtos das colônias. ${ }^{3}$

No contexto de institucionalização dos estudos de ciências sociais no Brasil, nos anos 1940, buscaram-se novas formas de abordar a questáo das relaçóes entre o Estado e as classes sociais, e também o lugar das relaçóes sociais e do racismo na construção das desigualdades a partir da sociologia. Florestan Fernandes, um dos sociólogos pioneiros formados pela Universidade de São Paulo, integrou, nos anos 1950, o projeto de pesquisa da UNESCO sobre as relaçóes raciais no Brasil, que fazia parte de uma iniciativa mais ampla, de um conjunto de pesquisas internacionais sobre o racismo no pós-guerra. O Brasil era entấo visto como uma sociedade miscigenada, supostamente racialmente democrática (Freyre, 1998), em contraponto ao tipo de racismo de outros países como os Estados Unidos da América e a África do Sul. A pesquisa voltou seu eixo para São Paulo, e não para Salvador, como havia ocorrido com os primeiros estudos interessados nas relaçóes raciais e na cultura dos afrodescendentes no Brasil. Os resultados da iniciativa da UNESCO, que envolveu diversos pesquisadores além de

1 Para citar os mais conhecidos, Sérgio Buarque de Holanda (2008), publicado pela primeira vez em 1936, e Caio Prado Júnior, publicado pela primeira vez em 1942.

2 De acordo com uma certa concepção da historia econômica, "a formação do mercado de trabalho" mercantilizado e territorializado ocorreria quando homens e mulheres pudessem vender sua própria força de trabalho (Barbosa, 2005).

3 Nesse sentido Caio Prado Júnior estabelecia um claro diálogo com a obra de Eric Williams (1994), também publicada pela primeira vez na década de 1940. 
Fernandes, foi mostrar a existência de desigualdades sócio-raciais e indicar formas de combate ao racismo "à brasileira" (Maio, 2014).

Em A integração do negro na sociedade de classes, de 1961, em sua sofisticada análise Fernandes enfatizaria a desigualdade de condiçóes de moradia, ocupação, educação e renda entre brancos e negros após a Abolição e atacava o mito da "democracia racial" brasileira. No entanto, ao buscar as causas do que considerava o despreparo dos negros para competirem no mercado de trabalho livre, o sociólogo concluiu que os escravos, arrancados de suas famílias e culturas, estavam "perdidos uns para os outros" pois não teriam compartilhado laços no cativeiro no Brasil. Libertos, não estavam preparados para o mundo competitivo do "trabalho livre" e não progrediram. Ao contrário, sua situaçáo se teria agravado tendo "o estado de anomia transplantado do cativeiro" (Fernandes, 2008: 67, 120).

No contexto de discussão a respeito dos impactos do processo de industrialização sobre as relaçóes raciais e a organização dos movimentos sociais, outro sociólogo do grupo de Fernandes atribuía a suposta "atipicidade" da classe operária brasileira à experiência da escravidáo. Em artigo de 1961, Fernando Henrique Cardoso afirmava que a longa vigência do sistema escravista no Brasil havia impedido a formação de uma classe operária combativa e com forte identidade de classe. Além disso, a substituição gradativa dos trabalhadores de origem europeia nas décadas após 1930 por migrantes, em sua maioria trabalhadores de origem rural, explicaria sua suposta passividade. Assim, para Cardoso, os trabalhadores teriam sido incapazes de gestar greves e movimentos de contestação significativos que pudessem causar sérias ameaças à ordem estabelecida (Cardoso, 1962).

Tais interpretaçóes compartilhavam a ideia de incapacidade política dos atores sociais frente à exploração que lhes era imposta -fosse a falta de preparo dos negros para se inserir no mercado de trabalho no pós-aboliçáo, ou a apatia e fraqueza da classe operária para realizar uma efetiva transformação social-. Estes rápidos exemplos nos ajudam a definir os contornos de um paradigma explicativo que teve e ainda tem uma ampla aceitação entre diferentes âmbitos acadêmicos, em especial na sociologia. ${ }^{4}$

Importante e influente obra publicada pela primeira vez em 1968 foi o livro de Emília Viotti da Costa, historiadora da Universidade de São Paulo, também ligada ao grupo de estudos marxistas. Em Da Monarquia à República a autora analisou o declínio do sistema escravista de produçáo, da perspectiva da economia cafeeira, na qual predominava amplamente o trabalho escravo.

4 Para ver uma breve revisão historiográfica dessas abordagens sobre formação da classe operaria e seu papel na construção da cidadania no Brasil de uma perspectiva da história social do trabalho ver Fortes e Negro, 2012. 
Viotti da Costa pesquisou as primeiras experiências de diversificação da exploração do trabalho nas grandes plantações de café, como as de colonato e parceria, que estimulavam a imigração europeia para resolver o problema da substituição da mão de obra escrava (Costa, 1966). Em Homens livres na ordem escravocrata, trabalho de pesquisa histórica pioneiro a partir da leitura de processos criminais, Maria Sylvia de Carvalho Franco reiterou a dimensão da importância da violência na sociedade escravista como elemento fortemente constitutivo das relaçóes sociais. Para Franco, no livro de 1969, aqueles homens livres e expropriados, a "ralé", haviam permanecido apartados da produção para o mercado, ao longo de quatro séculos (Franco, 1977).

$\mathrm{Na}$ esteira desses trabalhos, na década de 1980 surgiram novos esforços de compreensão do problema pelo viés do controle e enquadramento dos trabalhadores por parte da elite política e econômica, que caracterizavam a escassa população formada por livres e libertos na sociedade escravista como vadios e imprestáveis. O pleno desenvolvimento do capitalismo e de um mercado de trabalho "livre", portanto, seria incompatível com o trabalho escravo, e se formaria apenas após a abolição, dando origem à classe operária e à luta de classes (Kovarick, 1987). Assim, a crise do escravismo no Brasil e a "substituição da mão de obra", como era tratado o tema pelos contemporâneos, foi definida como um momento de "transição" do trabalho escravo para o livre. Esse período era identificado como aquele entre a abolição do tráfico atlântico de escravos, em 1850 até alguns anos após a abolição da escravidão no Brasil, em 1888 (Lamounier, 1988).

Em influente estudo publicado pela primeira vez em 1987, Ciro Flamarion Cardoso elaborou o conceito de "brecha camponesa nas Américas": tratava-se da utilização, pelos escravos, de pedaços de terra concedidos pelos senhores, nos quais estabeleciam uma produção independente de gêneros alimentícios, tanto para subsistência, como para a venda do excedente (Cardoso, 1987). Ou seja, o que apontava para algum grau de controle de sua economia cotidiana acenava também para diversos graus de autonomia cultural que aquela pequena brecha gerava. Partindo desse pressuposto, vários estudos de história agrária levantaram evidências densamente documentadas de que no século XVIII existia um mercado interno muito diversificado que náo tinha como objetivo a produção dos produtos tropicais para exportação, de que havia camadas sim intermediárias entre senhores e escravos entre os quais livres e libertos podiam encontrar lugar (Linhares, 2000). ${ }^{5}$

5 Essa produção teria levado à acumulação interna e à formação de uma camada de comerciantes que se transformou num poderoso grupo econômico ligado aos interesses da colônia, e não da metrópole (Fragoso, 1998). Em O Arcaísmo como projeto, Manolo Florientino e João Fragoso contestam os conceitos de sentido da 


\section{A PRODUÇÃO HISTORIOGRÁFICA A PARTIR DA DÉCADA DE 1980 SOBRE TRABALHO ESCRAVO E TRABALHO LIVRE}

A história social do trabalho e aquela sobre a escravidão produzidas no Brasil passaram por importantes transformaçóes a partir da década de 1980. Com o fim da ditadura militar, a ampliação das demandas dos movimentos sociais e o crescimento dos programas de pós-graduação, as pesquisas históricas sobre o movimento operário e sobre a escravidão se multiplicaram substancialmente, uma parte delas muito influenciada pela obra de Edward P. Thompson e de outros autores da história social inglesa (Gomes, A., 2004; Chalhoub e Fontes, 2009). No campo da história social, as aproximaçóes com a antropologia e os novos interesses de pesquisa exigiram e permitiram que se fizessem novas indagaçóes a antigos objetos de estudo e abriram novas possibilidades para a investigação histórica. ${ }^{6}$

Essa produção historiográfica ficou marcada também pelo uso de uma grande diversidade de fontes. No caso da história da escravidáo, sobretudo mapas populacionais, inventários e registros paroquiais e cartoriais e açóes de liberdade; para a história do trabalho, periódicos operários e da grande imprensa, processos cíveis e processos crime, legislação e debates parlamentares. Informados pelas críticas aos enfoques estruturalistas e economicistas, historiadores submeteram os documentos à novas perguntas a partir da ênfase no contexto e na indeterminação histórica, levando em conta a ação humana para compreender aspectos diversos das experiências de vida e trabalho dos

colonização de Caio Prado, ampliado por Fernando Novais (1989) na versão do antigo sistema colonial, de que o eixo em que girava a economia colonial era dominando pelos ciclos internacionais, inserido numa dinâmica capitalista de acumulação primitiva de economia mercantilista, com um mercado interno insignificante e dependente. Para Fragoso e Florentino, o principal veiculo ultramarino não era a burguesia, mas o próprio Estado português e a expansão marítima teria servido ao fortalecimento do estado e sua burocracia, com hierarquias e privilégios. A acumulação mercantil, nessa economia colonial, serviu assim para fortalecer posições aristocráticas e valores não capitalistas: o arcaísmo não era um anacronismo, mas um projeto social (Fragoso e Florentino, 2001).

6 Nesse momento a UNICAMP (Universidade Estadual da Campinas) foi fundamental na abertura de novas perspectivas historiográficas, tanto no campo do trabalho quanto no da escravidão, no sentido aqui apontado, de reduzir o foco para levar em conta a açóes, cultura e experiência dos escravos que adquiriam sentidos políticos. Para uma boa síntese e o papel da jovem Universidade Estadual de Campinas nesse processo de renovaçáo historiográfica ver: Fontes, Fortes e Mayer, 2017. Para uma crítica recente desse campo unicampense de história da escravidão ver Marquese, 2013. 
grupos subalternos, bem como dos sistemas de dominação e controle. As pesquisas se diversificaram para abranger amplo espectro das relaçóes entre as classes e grupos sociais, que iam da negociação à resistência, considerando a formaçáo de famílias extensas, redes de solidariedade e sociabilidade no local de trabalho e de moradia e a formação de culturas de classe; pesquisas sobre os usos da lei se multiplicaram, aprofundando as discussóes sobre as lutas por direitos.

Trabalhos pioneiros deste momento de renovação na área da história da escravidão mostraram que: (i) os escravos e libertos conseguiam, apesar de toda a violência a que estavam submetidos, estabelecer laços familiares, redes de solidariedade e de identidade; (ii) havia outros mecanismos de manutenção da escravidão que não passavam pela violência física, mas sim por constantes estratégias de negociação entre senhores e subalternos; (iii) além de revoltas e fugas, brechas possibilitavam que os subalternos lutassem por liberdade e autonomia dentro do próprio sistema (Slenes, 1999; Reis e Silva, 1989; Reis, 2010; Chalhoub, 1990; Gomes, F., 1995).

Já as pesquisas do período relacionadas à história operária indicaram que: (i) a história dos trabalhadores deixou de ser unicamente a história do movimento operário organizado -partidos, sindicatos e correntes ideológicaspara ser a história da classe -abordando, assim, o cotidiano dos trabalhadores, suas formas de sociabilidade e moradia-; (ii) além das novas abordagens aos temas mais tradicionais, também ocorreu uma ampliação dos temas de interesse, antes não abordados ou secundarizados, tais como, por exemplo, o processo de trabalho, as culturas de classe e as correntes sindicais reformistas, o mutualismo e associativismo e o cotidiano fora da fábrica; (iii) houve uma ampliação da cronologia, ultrapassando o limite da década de 1930, avançando no tempo e chegando a períodos mais recentes (Sáder, Paoli e Telles, 1983; Hall e Pinheiro, 1985; Batalha, 2001).?

Apesar de todas essas transformaçóes, a história social do trabalho no Brasil continuava identificada com o trabalho assalariado, já que as pesquisas em geral não tinham um recorte temporal anterior a 1888, excluindo, portanto, os trabalhadores escravizados e suas lutas, ignorando, como apontou Silvia Hunold Lara, que "experiências acumuladas durante a escravidão por escravos e libertos foram compartilhadas por trabalhadores livres, antes e depois da Aboliçáo" (Lara, 1998: 26). A historiografia sobre escravidáo e a história do trabalho caminhavam paralelamente, e pouco se cruzavam.

Em artigo historiográfico publicado em 1999 Claudio H. M. Batalha observou que uma das razóes para a ausência de pesquisas sobre a formação da classe operária com recorte temporal anterior a 1888 devia-se ao fato de

7 Ver também: Fortes et al., 1999. 
que sua existência só era considerada a partir da expansão industrial ocorrida nos anos 1880. Tudo que viera antes era considerado, portanto, como a "pré-história" da classe. A outra razão seria a Abolição, ocorrida propriamente em 1888 (Batalha, 1999).

Trabalhos inovadores sobre a Primeira República (1889-1930) utilizaram largamente o conceito de classes populares nas pesquisas sobre o cotidiano da população urbana e suas expressóes culturais e políticas, sobretudo no Rio de Janeiro. Essas pesquisas, surgidas nas décadas de 1980 e 1990 agregaram perspectivas que levavam em conta dimensóes de raça em suas analises. Tal produção, no entanto, teria permanecido relativamente desconectada na historia do trabalho, segundo Chalhoub e Silva. Mesmo no balanço crítico produzido por eles a produçáo relevante analisada é aquela sobre escravidão no século XIX e a do trabalho no pós-1930, deixando de fora as pesquisas sobre a Primeira República (1989-1930), que corresponde ao período do imediato pós-abolição (Chalhoub, 1990; Silva, 2009). Nos textos do de Chalhoub e Silva, a produção relevante analisada é aquela sobre escravidáo no século XIX e a do trabalho no pós-1930, deixando de fora as pesquisas sobre a Primeira República (1989-1930), que corresponde ao período do imediato pós-aboliçãao (Chalhoub, 1990; Silva, 2009). Nesse momento surgiam diversos movimentos sociais de categorias de trabalhadores livres na luta por melhores condições de trabalho e vida, indicando a importância do poder municipal como esfera de regulamentaçáo do trabalho, muito antes da aprovação de leis trabalhistas em âmbito federal aprovadas a partir da década de 1910 e consolidadas, em 1943. A municipalidade foi espaço de reivindicação para homens e mulheres trabalhadoras, utilizando a experiência de negociação e organizaçáo que traziam do período da escravidão, para estabelecer parâmetros legais para noçóes do justo e de direitos (Pereira, 2006; Popinigis, 2007; Terra, 2013; Farias, 2015).

Este é o breve contexto que dá sentido aos diálogos historiográficos nos quais as pesquisas identificadas com o campo da história do trabalho se inserem. Em seguida, longe de esgotar a profícua produção historiográfica do período, elencamos abaixo alguns eixos a partir de pesquisas pioneiras que definiram os campos de debate e influenciaram outros trabalhos no sentido apontado até aqui. É importante ressaltar que essa revisão historiográfica se centrará sobretudo nos trabalhos das décadas finais da escravidão e no imediato pós-abolição (1850-1930).

Nas últimas duas décadas surgiram pesquisas que, a partir de uma perspectiva da história social, dedicaram-se a abordar temas que favorecessem o desenvolvimento dos campos de contato entre história do trabalho e história da escravidão. Vários pesquisadores têm chamado atenção para o fato de que para compreender a formação da classe trabalhadora brasileira é preciso ir 
além dos referenciais do movimento operário organizado e das grandes greves do início do século XX, e promover e integrar investigaçóes que contemplem a diversidade de experiências e movimentos de trabalhadores no século XIX e XX. Esse processo tem sido fundamental para tornar mais complexa e rever a imagem cristalizada, até entáo, de que essa classe trabalhadora era formada principalmente por homens, brancos, em sua maioria estrangeiros, e ligados ao anarquismo.

\section{LIBERDADE E ESCRAVIDÃO: A MULTIPLICIDADE DE FORMAS DE EXPLORAÇÃO DO TRABALHO}

Pesquisas extremamente densas e sofisticadas sobre as condiçóes de trabalho de escravos e libertos mostraram que os cativos podiam ter autonomia suficiente para exercer atividades remuneradas ("ao ganho") e acumular pecúlio abrindo um campo amplo e profícuo de investigaçôes. Esses trabalhos evidenciaram o papel fundamental das mulheres africanas e descendentes, escravas e libertas nas relaçóes de trabalho mercantilizadas, indo desde a produção até a circulação das mercadorias e atuando também no sistema de crédito (Mattoso, 1982; Dias, 1984; Soares, 2007; Karasch, 2000). Por outro lado, vários estudos contestaram os limites da liberdade no Brasil, mostrando que a liberdade jurídica não estava automaticamente vinculada à autonomia ou a relaçóes de trabalho assalariadas. Havia uma diversidade de arranjos de trabalho no campo e na cidade envolvendo escravos, libertos e livres.

Um importante passo a favorecer tal reflexão foram as aproximaçóes entre história e direito, que abriram uma profícua trilha para as pesquisas sobre a lei como campo de disputas nas lutas por direitos, mostrando que diversos grupos de trabalhadores, escravos e livres, utilizaram-se das brechas da lei para reivindicar a liberdade ou melhores condiçóes de trabalho, individual ou coletivamente. Esses estudos também analisaram as açóes de liberdade dos escravos contra seus senhores que se avolumaram na década de 1860 e 1870, quando e crescia o movimento abolicionista, reunindo em torno de si várias camadas da sociedade em torno dos esforços -legais ou não- de libertação dos escravos (Grinberg, 2010; Lara e Mendonça, 2006; Chalhoub, 1990; Azevedo, 1999; Mendonça, 2001; Mamigonian, 2017).

Ao mesmo tempo, os senhores articulavam seus esforços para explorar a força de trabalho dos libertos, muitas vezes condicionando as alforrias a contratos de locação de serviços. Estabelecer contratos de trabalho que podiam parecer reescravizantes eram a forma pela qual muitos patróes e antigos senhores tentaram reorganizar as relaçóes de trabalho mantendo a subordinação dos trabalhadores. Nesses contratos os trabalhadores tinham o status jurídico de livres, mas as continuidades nas suas condiçóes de trabalho e sua extensão por muitos anos em troca de alimento, morada e tratamento 
na doença assemelhavam-se às da escravidão. A escravidão era transformada num contrato para pagamento daquela dívida: se por um lado atrelava-se o recém liberto à uma relação de dependência em relação ao senhor, para o ex-escravo o acordo também podia significar a diminuiçáo das incertezas frente ao futuro no mercado de trabalho (Lima, 2005).

Escravos e livres compartilhavam ofícios e atividades idênticas realizadas, inclusive nas fábricas (Soares, 1980; Rodrigues, 1997/1998). Esses trabalhadores também partilhavam espaços de moradia, lazer, alimentação transporte e organização trazendo e transformando suas experiências de luta dos tempos da escravidão na sua vida cotidiana, nos bares, nos bailes, nas associaçóes e nos sindicatos (Cruz, 2000; Miranda, 2002; Popinigis, 2007; Castellucci, 2010; Terra, 2013). Para Marcelo Badaró Mattos, por exemplo, a experiência de convivência entre escravizados e livres, nacionais e imigrantes nas organizaçóes criadas, além das açóes coletivas, foi fundamental no processo de formação da classe trabalhadora no Rio de Janeiro (Mattos, 2008).

Se os escravos africanos estiveram durante bastante tempo ausentes das análises de história social do trabalho, o mesmo ocorreu com outros trabalhadores. O livro de John Monteiro, Negros da Terra, é pioneiro ao apresentar a exploração do trabalho indígena e o processo histórico pelo qual ele foi mesclado e depois preterido pelo dos africanos. Sua obra inspirou muitos outros trabalhos, que mostraram a utilização recorrente da mão de obra indígena de forma compulsória em várias regióes do país (Monteiro, 1994). ${ }^{8}$

Assim também a experiência dos "africanos livres" ilumina formas de trabalho compulsório utilizadas tanto por particulares como pelo Estado. Como mostra Beatriz Mamigonian, esses trabalhadores, como os indígenas e os libertos, foram sobretudo engajados em atividades "não produtivas" -em obras públicas nas fronteiras ou empregados por particulares- o que servia tanto para a necessidade de controle social como de trabalho náo pago. Esses homens e mulheres foram, segundo a autora, preteridos em relação aos imigrantes europeus nas campanhas pelo "trabalho livre". Ou seja, o status jurídico de "livres" para eles não significou nem autonomia, nem assalariamento (Mamigonian, 2005).

Essas e outras pesquisas, portanto, têm demonstrado que o século XIX não foi um período de transição do trabalho escravo para o trabalho livre, mas sim de ampliação e experimentação de uma grande diversidade de formas, arranjos e contratos de trabalho compulsório fosse dos engajados, de indígenas aldeados, dos africanos-livres, dos alforriados condicionais, dos campos de trabalho ou dos aprendizes. 
Em Proletários e escravos, texto publicado em 1988, Luiz Felipe de Alencastro propóe uma analise das transformaçóes sociais e econômicas ocorridas no mercado de trabalho do Rio de Janeiro em meados do século XIX. Como sugere o título, o autor afirma que ainda antes da efetiva proibição do tráfico atlântico de escravos, em 1850, já havia uma constante imigração de trabalhadores pobres vindos das ilhas e outras áreas de Portugal, que conviviam com os escravos de ganho e com os libertos e disputavam com eles os trabalhos urbanos.

Após 1850, os armadores passaram a usar antigos navios negreiros para transportar trabalhadores contratados em seus portos de origem em Portugal, que depois seriam distribuídos nas plantations no Brasil. Devido à viagem, o imigrante contraía uma dívida com seu patrão que o colocava em situação de dependência e prolongava a impossibilidade de mudar de trabalho. A situação dos engajados portugueses no Brasil teria sido, segundo o autor, semelhante a dos indentured servants que desembarcavam nas Antilhas e na América do Norte no século XVIII (Alencastro, 1988).

Desde 1830, com a ameaça de abolição do tráfico atlântico de escravos, houve uma crescente preocupação com marcos legais que definissem condiçôes para a contratação de trabalhadores imigrantes, brancos europeus. A inquietação com as formas de obtenção e exploração de mão de obra barata misturada à necessidade de controle foi expressa na primeira lei, em 1830. A lei de 1837, que regulamentava contratos de locação de serviços, visava a estabelecer mecanismos legais para garantir a permanência dos trabalhadores imigrantes nas fazendas e determinava que se o trabalhador demitido que não pagasse sua dívida, ou que abandonasse a fazenda poderia ser preso (Mendonça, 2012).

A expansão da produção de café em São Paulo incentivou proprietários paulistas a realizarem as primeiras experiências privadas da prática de engajamento de colonos pela prática da parceria. Os trabalhadores vinham com os custos da viagem pagos pelos proprietários, que deveriam ser ressarcidos com o trabalho na lavoura. Eles receberiam $50 \%$ dos lucros do cultivo do café e porçóes de terra para cultivar gêneros de subsistência. Mas muitos não conseguiam pagá-las e o sonho de ter seu próprio pedaço de terra desaparecia. A experiência também não foi satisfatória para os proprietários, que se ressentiam da falta de meios de coerção para extrair maior produtividade dos colonos e para fazê-los pagar suas dívidas (Hall e Stolcke, 1983).

As notícias sobre as péssimas condiçôes de trabalho e de vida que se apresentavam a partir desses contratos foram denunciadas pela imprensa da época como "escravidão branca" e chegaram a causar reaçóes nas relaçóes 
diplomáticas com Portugal (Câmara, 2013), e a comparação dos engajados com os escravos africanos era recorrente (Vitorino, 2002). A trajetória de Gladys Sabina Ribeiro como pesquisadora que publicou sua dissertação de mestrado sobre trabalhadores brancos pobres no Rio de Janeiro na primeira república (Ribeiro, 1990), exemplifica um deslocamento e reestruturação das agendas de pesquisa informada por novos questionamentos, com ênfase na diversidade dos sujeitos e sua ação política. Nesse processo a pesquisa em arquivos judiciais e o campo dos direitos em torno do qual se moviam na luta jurídica por cidadania no século XIX assumiu o ponto central de interesse (Ribeiro, 2002: 201). Na intensa convivência entre trabalhadores juridicamente livres e escravizados, o mercado de trabalho carioca era e intensamente disputado por africanos e lusos já na primeira metade do século XIX (Ribeiro, Cruz Terra e Popinigis, 2017).

Outro ponto fundamental tem sido o questionamento das próprias ideias que orientavam os debates a respeito da entrada de imigrantes no país. Assim, autores mostraram como o medo das rebelióes de escravos, por um lado, e o racismo científico, por outro, embasavam os discursos e projetos dos representantes políticos na definição do que seria o "melhor trabalhador": nos projetos imigrantistas o trabalhador nacional saía perdendo, e aqueles oriundos do norte da Europa eram vistos como os mais adequados, "trabalhadores" e "ordeiros" (Azevedo, 1987; Schwartz, 1993).

A partir da primeira década do século XX essa situaçáo começou a mudar. A massiva presença de imigrantes nos grandes centros urbanos e a escalada de greves e manifestaçóes no Rio de Janeiro e em São Paulo preocupavam os poderes públicos, que buscaram associar os imigrantes, sobretudo socialistas e anarquistas a agitadores e terroristas que atentavam contra a ordem pública (Gomes A., 2004). Em Classe e Nação, Luigi Biondi investigou a trajetória de grupos socialistas de origem italiana em São Paulo (1890-1920), tendo abordado a complexa relação entre as identidades étnicas e nacionais e a organização da classe operária (Biondi, 2011). ${ }^{9}$ O estudo de Biondi procura analisar essa relação para além da ideia de que essas identidades seriam empecilho à formação da classe trabalhadora, argumentando, ao contrário, que a presença italiana teria facilitado esse processo. Mais recentemente, Robério Souza demonstrou a complexidade das composiçóes da força de trabalho nas estradas de ferro na Bahia em meados do século XIX, quando trabalhadores migrantes labutavam lado a lado aos escravizados e nacionais livres na construção de estradas de ferro, exercendo atividades e compartilhando condiçôes de trabalho semelhantes (Souza R., 2016).

9 Sobre outro movimento influente nesse período em São Paulo ligado à imigração italiana, ver: Toledo, 2004. 
Uma das principais formas de mostrar a agência dos trabalhadores nos seus próprios termos foi partir da compreensão de que as formas de resistência escrava no Brasil nem sempre se traduziam no conflito aberto, mas nem por isso significavam passividade e aceitaçáo. Através da negociação, os escravos conseguiam certos espaços de autonomia e expandi-los. Os escravos constituíam família e lutavam para preservá-la como mostraram estudos agindo nas brechas do sistema para melhorar suas condiçóes de vida e trabalho. ${ }^{10} \mathrm{~A}$ pesquisa de Robert Slenes, que combinou estudos de demografia histórica a análises qualitativas no campo da história social da cultura muito influenciadas pela antropologia, foi fundamental para ressaltar a importância do continente africano para a análise histórica (Slenes, 1999).

As formas de negociação dos escravos poderiam incluir ainda as fugas, revoltas e formação de quilombos. Esses quilombos não ficavam isolados, mas, ao contrário mantinham uma intensa comunicação com as áreas ao redor. Seus habitantes circulavam e mantinham relaçôes comerciais de todo tipo com a população livre e liberta das cidades. Entretanto, havia a constante ameaça de que o equilíbrio do negociado nessas manifestaçóes pudesse ser rompido, colocando em perigo a propriedade escrava, a vida dos senhores ou até mesmo todo o sistema escravista (Gomes F., 2005b; Machado, 1994).

Em certas ocasióes os escravos também podiam cruzar os braços para conseguir melhores condiçóes de trabalho, tanto em áreas rurais como urbanas. Um estudo pioneiro nesse sentido foi de João José Reis sobre a greve negra em Salvador, em 1857. A Câmara Municipal aprovou uma postura que obrigava a matrícula dos ganhadores dos cantos -grupos etnicamente delimitados que se reuniam para oferecer seus serviços em determinados locais da geografia urbana- buscando controlá-los e evitar que circulassem

10 O pressuposto da brecha camponesa foi desenvolvido por outros historiadores para aprofundar a ideia de que a concessáo, pelos senhores, de um pedaço de terra para o cultivo pessoal ou familiar dos escravos. Para Robert Slenes, essa "concessáo" aos olhos dos senhores era apropriada pelos escravos como um direito essa ambiguidade de sentidos atribuídos à posse da terra era potencialmente conflitiva, pois levava à formação de laços de identidade e solidariedade nas comunidades escravas, com experiências e objetivos que se opunham aos de seus senhores (Slenes, 1999). Para Góes e Florentino, ao contrário, essa mesma possibilidade de acesso a terra e concessóes senhoriais servia para preservar o escravismo, pois apaziguaria os ânimos dos escravos ao satisfazer suas necessidades mais básicas de subsistência através do acesso à terra, o que também diminuía os custos de alimentaçáo para os proprietários. Nos dois casos, os densos estudos embasados em pesquisas empíricas minaram o argumento de que a escravidáo africana destituíra homens e mulheres de sua humanidade (Florentino e Góes, 2017). 
livremente pela cidade. Uma outra versão da postura, que já havia sido derrotada 1835 , foi novamente vencida pelos trabalhadores em 1857 , que se recusaram a usar a chapa de identificação e cruzaram os braços até que as autoridades cedessem à pressão (Reis, 1993).

Para Flávio Gomes e Antônio Negro a necessidade de superar esse hiato entre a história da escravidão e a história do trabalho, e da construção historiográfica de uma história da classe operária como branca, fabril, masculina e urbana também exige que se pense em algo que chamaram de "greve antes da greve"; ou seja, mostrar que antes que o ato de parar o trabalho para reivindicar algo tivesse esse nome os escravos já utilizavam tal estratégia, que não foi "inventada" ou "trazida" pelos imigrantes europeus, em contraste com uma suposta "passividade" dos trabalhadores nacionais (Negro, 2014; Gomes, F., 2006).

Além disso, os movimentos de trabalhadores rurais também ganharam importância na história do trabalho pois, como mostrou Paulo Pinheiro Machado, esses homens e mulheres não apenas "resistiam", mas teciam estratégias de luta e elaboravam projetos alternativos de vida comunitária e organização social. Embora não fossem escravizados, esses trabalhadores juridicamente livres viviam e morriam sob o domínio dos mesmos coronéis e suas famílias (Machado P., 2017). Sendo assim, era necessário considerar não apenas as grandes greves e o sindicalismo revolucionário do início do século XX, mas também os movimentos e greves dos trabalhadores escravizados, os agregados e dependentes, que também podiam paralisar o trabalho e organizar protestos para conseguir melhores condiçóes. As densas pesquisas de historiadores da escravidão sobre os movimentos de negociação e açóes de resistência dos escravos desde fins do século XVIII e ao longo do século XIX foram, portanto, fundamentais para compreender a organização e lutas desses grupos em seus próprios termos.

\section{Pós-ABOLIÇÃO, PÓS-EMANCIPAÇÃO E TRABALHO ESCRAVO CONTEMPORÂNEO}

Um dos grandes desafios para os historiadores era o de como encontrar os libertos e seguir suas trilhas após a emancipação ou após a Abolição. Tanto porque agregavam um sobrenome, no caso das trajetórias, quanto porque a cor tendeu a desaparecer dos documentos. Muitos trabalhos enfrentaram esse desafio e foram desenvolvidos antes mesmo de ter essa designação para sua definição como campo. No imediato pós-abolição, comunidades de escravos de médios e grandes plantéis de escravos em diferentes regiôes do Brasil buscavam conquistar o direito à terra, para produção e comercialização de alimentos, e para a manutenção de suas redes comunitárias e religiosas. ${ }^{11}$

11 Um dos mais belos exemplos é Filho, 2006. 
Temas clássicos como a inserção dos libertos no mercado de trabalho tiveram novas abordagens, levando em conta as expectativas, projetos e estratégias dessas pessoas e suas redes familiares e comunitárias, extrapolando as análises econômicas e demográficas para pensar relaçôes sociais e práticas culturais (Lugão e Mattos, 2004).

Entretanto, há também o questionamento sobre o termo "pós-abolição", reiterando um marco cronológico entre um "antes" e um "depois": afinal, quando se inicia e quando termina o pós-aboliçáo? Sobretudo considerando que a escravidão foi tornada ilegal, mas a exploração do trabalho assumiu outras formas, mais ou menos legais, como mostram os estudos sobre escravidão contemporânea e trabalho análogo ao escravo (Ferreras, 2016).

Embora haja um grande volume de pesquisas sobre o trabalho análogo ao escravo nas áreas das humanidades, apenas recentemente esse tem sido um tema mais explorado pelos historiadores. A questão da escravidão contemporânea coloca desafios em termos de abordagem conceitual que devem ser enfrentados, do ponto de vista da história social, mostrando a complexidade entre condição social e estatuto legal (Scott, 2013). Tais estudos tem buscado contribuir para o debate político sobre as ferramentas na legislação brasileira para respaldar o combate à exploração extrema de trabalhadores, que excedem as infraçóes no âmbito dos direitos trabalhistas para os da dignidade humana (Barbosa L., 2017). Numa perspectiva histórica, esses estudos têm se aprofundado em investigar os limites jurídicos das condiçóes que possibilitaram a escravizaçáo de grupos de seres humanos em diferentes locais e momentos da história, e os movimentos de criminalização dessa prática, bem como as lutas legais de uma diversidade de agentes sociais contra a sujeição, mostrando um quadro muito menos estático e conformado dessas relaçóes (Mamigonian e Grinberg, 2017). Ademais, os lugares e formas em que esse tipo de super-exploração do trabalho é encontrado -longe de ser apenas em áreas rurais longe dos centros urbanos- mais uma vez se opóe à idealização de um processo histórico de assalariamento progressivo. Finalmente, as continuidades e rupturas, além da "continuidade do Estado em apoia-la, através da falta de ação para erradica-la" (Gomes, A., 2012), no século XIX como no XXI, evidenciam as disputas em torno da questão, com as próprias vítimas e seus apoiadores se apropriando dos elementos legais disponíveis e a conceituação do termo para garantir seu direito à liberdade e à dignidade humana.

\section{CONCLUSÃO}

Procuramos apontar ao longo do presente texto algumas das aproximaçóes entre a historiografia do trabalho e a aquela dedicada à escravidão, produzida 
a partir da década de 1980. Nesse sentido, buscamos apresentar o movimento historiográfico como de construção e diálogo, mais do que como composto de rupturas. Parte dos resultados de pesquisa, ainda que se encontrassem nos marcos da ideia de transição ou de substituição do trabalho escravo para o livre, por exemplo, foi fundamental para a formulaçáo de novas abordagens e perguntas de investigação. Pesquisas nesses dois campos -a história do trabalho e a história da escravidáo- portanto, desenvolveram-se em torno do tema da diversidade das formas de exploração do trabalho, sobre a cor dos trabalhadores e as relaçóes raciais nos movimentos sociais e tradiçóes de lutas dos trabalhadores após a abolição.

Esses estudos de história social tem fornecido um quadro bem mais complexo sobre a formaçáo da classe trabalhadora no Brasil, buscando também conjugar analises micro históricas à visôes mais sistêmicas do processo histórico. Duras críticas foram feitas 'a certa leitura teleológica e mecanicista da ideia de "transiçáo do trabalho escravo para o trabalho livre", segundo a qual o avanço do capitalismo industrial e a demanda por trabalho assalariado traria no seu bojo as condiçóes para o surgimento do movimento operário, ignorando agentes, processos e suas lógicas próprias em períodos anteriores. Graças às pesquisas das últimas décadas - em perspectiva comparativa, transnacional, conectada, global - sabemos que o século XIX não foi de transição para o trabalho assalariado, mas sim de diversificação das formas de exploração desses homens e mulheres, sem remuneração ou compulsório, que conviveram durante a escravidão e se expandiram após a abolição.

Entretanto, concordamos que é necessário explorar mais as formas de organização próprias das experiências dos cativos, bem como seus impactos nas manifestaçóes dos trabalhadores livres em geral, sobretudo atentando para a cor dos indivíduos na experiência política do pós-abolição, nos partidos políticos, nos sindicatos e sobre o papel do racismo no mercado de trabalho (Gomes, 2005b; Gomes e Negro, 2006; Nascimento, 2016). Nesse sentido, estudos mais recentes têm buscado recuperar as trajetórias de homens negros para compreender suas estratégias de açáo política nos debates públicos e suas expectativas de atuação como homens livres nas lutas por cidadania e direitos (Castellucci, 2010; Albuquerque, 2015; Pinto, 2019).

É fundamental, portanto, atentar para questóes que devem ser enfrentadas pelos pesquisadores da área: (i) reconhecer os escravos como trabalhadores, assim como reconhecer suas lutas como parte do processo histórico de lutas por direitos e de formação e reformação da classe trabalhadora; (ii) apontar o racismo como elemento fundamental na produçáo e reprodução das desigualdades sociais, seja através da formulação de políticas públicas excludentes ou de hierarquias raciais entre os próprios trabalhadores; (iii) 
compreender as formas pelas quais a questão racial afetou a organização dos movimentos sociais de trabalhadores no século XX.

Outro ponto a ser destacado é que se existe uma série de estudos sobre as conexóes entre as experiências de trabalho na Europa e dos imigrantes do lado de cá do Atlântico, há ainda muito pouca produção sobre essas conexóes entre a África e o Brasil da perspectiva da história do trabalho. A historiografia da escravidão tem explorado mais amplamente, e recentemente, essas conexôes, mas a historiografia social do trabalho no Brasil também pode vir a ganhar se investigar as diversas relaçóes entre essas diferentes localidades. 
140 | Trabajos y trabajadores en América Latina (siglos XVI-XXI)

BibLIOGRAFíA

Albuquerque, Wlamyra

2015 "Teodoro Sampaio e Rui Barbosa no tabuleiro da política". En: Revista Brasileira de História, volumen 35, número 69. 83-99.

Alencastro, Luiz Felipe de

1988 "Proletários e escravos: imigrantes portugueses e cativos africanos no Rio de Janeiro, 1850-1872”. En: Novos Estudos, número 21. 30-56.

Almeida, Maria Regina Celestino de

2003 Metamorfoses indigenas: identidade e cultura nas aldeias coloniais do Rio de Janeiro. Río de Janeiro: Arquivo Nacional.

Azevedo, Celia Maria Marinho de

1987 Onda Negra, Medo Branco: O Negro no Imaginário das Elites, Brasil, século XIX. Río de Janeiro: Paz e Terra.

Azevedo, Elciene

1999 Orfeu de Carapinha: A trajetória de Luiz Gama na imperial cidade de São Paulo. Campinas, Brasil: Editora da Unicamp.

Barbosa, Alexandre

2005 A formação do mercado de trabalho no Brasil. San Pablo, Brasil: Alameda.

Barbosa, Leonardo Augusto de Andrade

2017 "Enjeux de la définition juridique de l'esclavage contemporain au Brésil: liberté, dignité et droits constitutionnels". En: Brésil(s), número 11 .

Batalha, Claudio H. M.

2001 "A Historiografia da classe operária no Brasil: trajetória e tendências". En: Marcos C. de. Freitas, Historiografia brasileira em perspectiva. San Pablo, Brasil Contexto.

1999 "Sociedades de trabalhadores no Rio de Janeiro do século XIX: algumas reflexôes em torno da formação da classe operária". En: Cadernos $A E L$, volumen 6 , números 10/11. 42-68

Biondi, Luigi

2011 Classe e nação: trabalhadores e socialistas italianos em São Paulo, 18901920. Campinas, Brasil: Editora da Unicamp. 
Câmara, Bruno Augusto Dornelas

2013 "A comunidade portuguesa do Recife e a 'escravatura branca': a imigração de trabalhadores portugueses para a Província de Pernambuco, 1840-1850". Trabalho apresentado no ST - Trabalho escravo e trabalho livre: cultura, costume e lutas, SNH XVII, Natal.

Cardoso, Fernando Henrique

1962 "Proletariado no Brasil: situação e comportamento social". En: Revista Brasiliense, número 41. 98-122.

Cardoso, Ciro Flamarion

1987 Escravo ou camponês?: o protocampesinato negro nas Américas. San Pablo, Brasil: Editora Brasiliense.

Castellucci, Aldrin

2010 "Classe e cor na formação do Centro Operário da Bahia (1890-1930)". En: Afro-Ásia, número 41. 243-290.

Chalhoub, Sidney

1990 Visóes da liberdade: uma história das últimas décadas da escravidão na corte. San Pablo, Brasil: Companhia das Letras.

Chalhoub, Sidney e Paulo Fontes

2009 "Historia social do Trabalho, Historiablica". En: Perseu: Historia, Memoria e Política, volumen 4. Disponible en: http://revistaperseu. fpabramo.org.br/index.php/revista-perseu/issue/view/22

Costa, Emilia Viotti da

1966 Da senzala à colônia. Côrpo e alma do Brasil. San Pablo, Brasil: Difusão Européia do Livro.

Cruz, Maria Cecília Velasco e

2000 "Tradiçóes negras na formação de um sindicato: Sociedade de Resistência dos trabalhadores em Trapiche e Café, Rio de Janeiro, 1905-1930". En: Afro-Ásia, número 24. 243-290.

Dias, Maria Odila Leite da Silva

1984 Quotidiano e poder em São Paulo no século XIX. San Pablo, Brasil: Brasiliense.

Farias, Juliana Barreto

2015 Mercados minas: Africanos ocidentais na Praça do Mercado do Rio de Janeiro (1830-1890). Río de Janeiro: Prefeitura do Rio de Janeiro / Arquivo Geral da Cidade. 
142 | Trabajos y trabajadores en América Latina (siglos XVI-XXI)

Ferreras, Norberto

2016 "O Brasil e o trabalho análogo à escravidão: a questão das migraçóes." En: Revista do Arquivo Geral do Rio de Janeiro, número 11. 407-422.

Filho, Walter Fraga

2006 Encruzilhadas da Liberdade: histórias de escravos e libertos na Babia (1870-1910). Campinas, Brasil: Editora da Unicamp.

Florentino, Manolo e José Roberto Góes

2017 A Paz das Senzalas - Famílias escravas e tráfico atlantico c. 1790 - c.1850. San Pablo, Brasil: Editora Unesp.

Fernandes, Florestan

2008 A integração do negro na sociedade de classes. San Pablo, Brasil: Editora Globo.

Fontes, Paulo

2009 "História Social do Trabalho, História Pública". En: Perseu: História, Memória e Politica, número 4. 219-228.

Fontes, Paulo; Alexander Fortes e David Mayer

2017 "Brazilian Labour History: New Perspectives in Global Context". En: International Review of Social History, volumen 62, número 25. 1-22.

Fortes, Alexandre; Antonio Luigi Negro, Fernando Teixeira da Silva, Hélio Costa e Paulo Fontes (orgs.)

1999 Na luta por direitos: leituras recentes em história social do trabalho.

Campinas, Brasil: Editora da Unicamp.

Fortes, Alexandre y Antônio Negro

2012 "Historiografia, trabalho e cidadania no Brasil". En: Trajetos, número 2. 1-20.

Fragoso, João Luís

1998 Homens de grossa aventura: acumulação e hierarquia na praça do Rio de Janeiro. Río de Janeiro: Civilização Brasileira.

Fragoso, João e Manolo Florentino

2001 O Arcaísmo como projeto. Río de Janeiro: Civilização Brasileira.

Franco, Maria Sylvia de Carvalho

1977 Homens Livres na ordem escravocrata. San Pablo, Brasil: Fundação Editora da UNESP. 
Freyre, Gilberto

1998 Casa-Grande y Senzala. Río de Janeiro: Editora Record.

Gomes, Ângela María de Castro

2012 "Repressáo e mudanças no trabalho análogo a de escravo no Brasil: tempo presente e usos do passado". En: Revista Brasileira de História, volumen 32, número 64. 167-184.

2005 A Invenção do Trabalhismo. Río de Janeiro: Editora FGV.

2004 "Questâo social e historiografia no Brasil pós-1980: notas para um debate”. En: Estudos Históricos, volumen 2, número 34. 157-186

Gomes, Flávio dos Santos

2006 "Além de senzalas e fábricas: uma história social do trabalho". En: Tempo Social, revista de sociologia da USP, volumen 18, número 1. 217-240.

2005a "A nitidez da invisibilidade: experiências e biografias ausentes sobre raça no Brasil Republicano". En: Maria A. Salgueiro, A República e a questão do negro no Brasil. Río de Janeiro: Museu da República.

2005b A hidra e os pântanos: mocambos, quilombos e comunidades de fugitivos no Brasil (séculos XVII-XIX). San Pablo, Brasil: UNESP.

1995 Histórias de quilombolas: mocambos e comunidades de senzalas no Rio de Janeiro - século XIX. Río de Janeiro: Arquivo Nacional.

Gomes, Flávio dos Santos y Antônio Luigi Negro

2013 "As greves antes da 'grève": as paralisaçóes do trabalho feitas por escravos no século XIX". En: Ciência e Cultura, volumen 65, número 2. 56-59.

Gorender, Jacob

2010 O Escravismo Colonial. San Pablo: Editora Fundação Perseu Abramo.

Grinberg, Keila

2010 Liberata: a lei da ambiguidade - as açóes de liberdade da Corte de Apelação do Rio de Janeiro no século XIX. Río de Janeiro: Centro Edelstein de Pesquisa Social.

Hall, Michael y Verena Stolcke

1983 "The introduction of freee labour on São Paulo Coffe Plantations". En: The Journal of Peasant Studies, volumen 10, números 2-3. 170-200.

Hall, Michael y Paulo Sérgio Pinheiro

1985 "Alargando a história da classe operária: Organização, lutas e controle." En: Revista Remate de Males, número 5. 95-119. 
144 | Trabajos y trabajadores en América Latina (siglos XVI-XXI)

Holanda, Sérgio Buarque de

2008 Raizes do Brasil. San Pablo, Brasil: Companhia das Letras.

Karasch, Mary

2000 A vida dos escravos no Brasil. San Pablo, Brasil: Companhia Das Letras.

Kovarick, Lúcio

1987 Trabalho e vadiagem - a origem do trabalho livre no Brasil. San Pablo, Brasil: Brasiliense.

Lamounier, Maria Lúcia

1988 Da escravidão ao trabalho livre: a lei de locação de serviços de 1879. Campinas, Brasil: Editora Papirus.

Lara, Silvia Hunold

1998 "Escravidão, cidadania e história do trabalho no Brasil". En: Projeto História, número 16. 25-38.

Lara, Silvia Hunold y Joseli Maria Nunes Mendonça (orgs.).

2006 Direitos e justiças no Brasil: ensaios de História Social. Campinas, Brasil: Editora da Unicamp.

Lima, Henrique Espada

2005 "Sob o domínio da precariedade: escravidão e os significados da liberdade de trabalho no século XIX". En: Topoi, volumen 6, número 11: 289-326.

Linhares, Maria Yedda (org.)

2000 História Geral do Brasil. Río de Janeiro: Editora Campus.

Lugão, Ana e Hebe Mattos

2004 "O pós-abolição como problema histórico: balanços e perspectivas". En: Topoi, volumen 5, número 8. 170-198.

Machado, Maria Helena

1994 O Plano e o Pânico: Os Movimentos Sociais na Década da Abolição. Río de Janeiro: Editora EFRJ / EDUSP.

Machado, Paulo Pinheiro

2017 Lideranças do Contestado: a atuação das chefias caboclas (1912-1916). Campinas, Brasil: Editora da Unicamp. 
Maio, Marcos Chor

2014 "Os estudos de Florestan Fernandes e Oracy Nogueira no projeto UNESCO de relaçôes raciais". En: Revista Antiteses, volumen 7, número 13. 10-39.

Mamigonian, Beatriz

2017 Africanos livres: a abolição do tráfico de escravos no Brasil. San Pablo, Brasil: Companhia das Letras.

2005 “Revisitando a 'transição para o trabalho livre': a experiência dos africanos livres. En: Manolo Florentino (org.), Tráfico, cativeiro e liberdade - Rio de Janeiro, séculos XVII-XIX. Río de Janeiro: Civilização Brasileira.

Mamigonian, Beatriz e Keila Grinberg

2017 "Le crime de réduction l'esclavage d'une personne libre (Brésil XIXe siecle)". En: Brésil(s), número 11.

Marquese, Rafael

2013 "As desventuras de um conceito: capitalismo histórico e a historiografia sobre a escravidão brasileira”. En: Revista de História, número 169. 223-253.

Mattos, Marcelo Badaró

2008 Escravizados e livres: experiências comuns na formação da classe trabalhadora carioca. Río de Janeiro: Bom Texto.

Mattoso, Katia

1982 Ser escravo no Brasil. San Pablo, Brasil: Brasiliense.

Mendonça, Joseli Maria Nunes

2012 "Livres e obrigados: experiências de trabalho no centro-sul do Brasil". En: Xavier, Regina Célia Lima (org.), Escravidão e liberdade: temas, problemas e perspectivas de análise. San Pablo, Brasil: Alameda.

2001 Cenas da Abolição: escravos e senhores no Parlamento e na Justiça. San Pablo, Brasil: Editora Fundação Perseu Abramo.

Miranda, Leonardo Affonso de

2002 As barricadas da saúde. San Pablo, Brasil: Fundação Persen Abramo.

Monteiro, John

1994 Negros da terra - índios e bandeirantes nas origens de São Paulo. San Pablo, Brasil: Companhia das Letras. 
146 | Trabajos y trabajadores en América Latina (siglos XVI-XXI)

Moreira, Vânia Maria Losada; Ingrid de Jong, Fabiane Popinigis y Cristiana Schettini

2014 "Dossiê Trabalho, política e experiências indígenas". En: Revista Mundos do Trabalho, volumen 6, número 12.

Nascimento, Álvaro Pereira do

2016 “Trabalhadores negros e o 'paradigma da ausência': contribuiçôes à história social do trabalho no Brasil”. En: Estudos Históricos, volumen 29, número 59. 607-626.

2012 "Livres e obrigados: experiências de trabalho no centro-sul do Brasil". En: Xavier, Regina Célia Lima (org.), Escravidão e liberdade: temas, problemas e perspectivas de análise. San Pablo, Brasil: Alameda.

Negro, Antônio

2014 “E.P. Thompson no Brasil: recepção e usos”. En: Critica Marxista, número 39. 151-161.

Novais, Fernando

1989 Portugal e Brasil na Crise do Antigo Sistema Colonial (1777-1808). San Pablo, Brasil: Editora HUCITEC.

Pereira, Cristiana Schettini

2006 Que tenhas teu corpo: uma história das politicas da prostituição no Rio de Janeiro das primeiras décadas republicanas. Río de Janeiro: Editora do Arquivo Nacional.

Pinto, Ana Flávia Magalhães

2019 Escritos de Liberdade Literatos negros, racismo e cidadania no Brasil oitocentista. Campinas, Brasil: Editora da Unicamp.

Popinigis, Fabiane

2015 "E.P. Thompson e a experiência da classe trabalhadora". En: Jair Batista da Silva y Henrique Amorim (orgs.), Classes e lutas de classes: novos questionamentos. San Pablo, Brasil: Annablume.

2007 Proletários de casaca: trabalhadores do comércio carioca, 1850-1922. Campinas, Brasil: Editora da Unicamp.

Popinigis Fabiane e Paulo Cruz Terra

2019 "Classe, raça e a história social do trabalho no Brasil (2001-2016)". En: Estudos Históricos, volumen 32, número 66 (dossiê Escravidão e liberdade nas Américas).

Prado Junior, Caio

2000 Formação do Brasil Contemporâneo - Colônia. San Pablo, Brasil: Brasiliense / Publifolha. 
Reis, João José

2010 Rebelião Escrava no Brasil: A História do Levante dos Malês em 1835. Edição revista. Río de Janeiro: Civilização Brasileira.

1993 "A greve negra de 1857 na Bahia”. En: Revista USP, número 18. 6-29.

Reis, João José e Eduardo Silva (eds.)

1989 Negociação e conflito: A resistência negra no Brasil escravista. San Pablo, Brasil: Companhia das Letras.

Ribeiro, Gladys Sabina

2002 A liberdade em construção: identidade nacional e conflitos antilusitanos no Primeiro Reinado. Río de Janeiro: Faperj / Relume Dumará.

1990 Mata Galegos: os portugueses e os conflitos de trabalho na Repuiblica Velha. San Pablo, Brasil: Editora Brasiliense.

Ribeiro, Gladys Sabina; Paulo Cruz Terra y Fabiene Popinigis

2017 Portugueses e cidadãos - experiências e identidades nos séculos XIX e XX. Río de Janeiro: Mauad.

Rodrigues, Jaime

1997/1998 "Ferro, trabalho e conflito: africanos livres na fábrica de Ipanema". En: Revista de História Social, números 4-5. 29-42.

Sáder, Eder; Maria Celia Paoli y Paoli Telles

1983 "Pensando a Classe Operária: Os Trabalhadores Sujeitos ao Imaginário Acadêmico". En: Revista Brasileira de História, número 6. 129-149.

Sampaio, Patrícia Melo

2012 Espelhos Partidos: etnia, legislação e desigualdade na Colônia. Manaus, Brasil: EDUA / FAPEAM.

Schwartz, Lilia Moritz

1993 O espetáculo das raças: cientistas, instituiçōes e questão racial no Brasil. San Pablo, Brasil: Companhia das Letras.

Scott, Rebecca

2013 "O Trabalho Escravo Contemporâneo e os Usos da História". En: Mundos do Trabalho, volumen 5, número 9. 129-137.

Silva, Fernando Teixeira da

2009 "Sujeitos no imaginário acadêmico: escravos e trabalhadores na historiografia brasileira desde os anos 1980". En: Cadernos AEL, volumen 14, número 26. 13-47. 
148 | Trabajos y trabajadores en América Latina (siglos XVI-XXI)

Silva, Fernando Teixeira y Alexandre Fortes (orgs.)

2004 Culturas de classe: identidade e diversidade na formação do operariado. Campinas, Brasil: Editora da Unicamp.

Slenes, Robert

1999 Na senzala uma flor: esperanças e recordaçôes na formação da família escrava. Río de Janeiro: Nova Fronteira.

Soares, Luis Carlos

1980 "A manufatura na formaçáo econômica e social escravista no Sudeste. Um estudo das atividades manufatureiras na região fluminense: 18401880". Disertación presentada a la PPGH / UFF.

Niterói, Río de Janeiro:

2007 O "Povo de Cam" na capital do Brasil: A escravidão urbana no Rio de Janeiro do século XIX. San Pablo, Brasil: Companhia das Letras.

Souza, Juliana Teixeira

2007 A autoridade municipal da Corte imperial: enfrentamentos e negociaçöes na regulação do comércio de gêneros (1884-1889). Tesis doctoral. Universidad de Campinas. Campinas, Brasil: Editora da Unicamp / IFCH.

Souza, Robério S.

2016 Trabalhadores dos trilhos: imigrantes e nacionais livres, libertos e escravos na construção da primeira ferrovia baiana (1858-1863). Campinas, Brasil: Editora da Unicamp.

Terra, Paulo Cruz

2013 Cidadania e trabalhadores: cocheiros e carroceiros no Rio de Janeiro (1870-1906). Río de Janeiro: Arquivo Geral da Cidade do Rio de Janeiro.

Toledo, Edilene

2004 Anarquismo e sindicalismo revolucionário - Trabalhadores e militantes em São Paulo na Primeira República. San Pablo, Brasil: Fundação Perseu Abramo.

Vitorino, Artur José Renda

2002 Cercamento a brasileira: conformação do mercado de trabalho livre da corte das décadas de 1850 a 1880 . Tesis doctoral. Universidad de Campinas. Campinas, Brasil: Unicamp.

Williams, Eric

1994 Capitalism and Slavery. Chapel Hill, Carolina del Norte, Estados Unidos de América: The University North Carolina Press. 


\title{
Los mundos del trabajo en la historiografía argentina: sindicatos, izquierdas y género, una mirada de conjunto
}

\author{
Laura Caruso (Argentina)* \\ Lucas Poy (Argentina)**
}

A la memoria de Juan Suriano

RESUMEN: En las últimas dos décadas, la historia del trabajo ha mostrado un crecimiento y una expansión importante en Argentina, en sintonía con el desarrollo que este campo muestra actualmente en diversos países de América Latina y del llamado "Sur Global" y, en buena medida, en contraste con lo que ocurre en Europa y Estados Unidos. Esta producción reciente está directamente vinculada con la labor profesional y académica, y se afinca en instituciones universitarias y científicas con presencia en diferentes regiones del país. Puede afirmarse que la historia académica sobre las clases trabajadoras tal vez ha atravesado por sus años de mayor productividad y consolidación. Este artículo ofrece un balance de conjunto sobre la historia del trabajo producida en Argentina sobre el periodo de fines del siglo XIX y comienzos del XX. Su objetivo es mostrar cuáles han sido las principales preocupaciones analíticas, temáticas y metodológicas -tanto en sus convergencias como en sus puntos de tensión-de este amplio recorrido. Sin pretender ofrecer un mapa exhaustivo, dado que se trata de un campo en pleno desarrollo y crecimiento, el artículo busca establecer ciertas líneas sobre las cuales reflexionar en torno a qué historias del mundo del trabajo se están construyendo, con qué interrogantes, desde qué perspectivas y ponderaciones. Como parte del objetivo central de este artículo -estimular un diálogo que vaya más allá de las fronteras nacionales y permita trazar posibles caminos y futuros desafíos-, existe un interés particular en desarrollar ese intercambio con colegas de otros países latinoamericanos. En

* Doctora en Historia por la Universidad de Buenos Aires. Consejo Nacional de Investigaciones Científicas y Técnicas (CONICET), Instituto de Altos Estudios Sociales (IDAES), Universidad Nacional de San Martín (USAM). Contacto: lauracaruso@gmail.com

** Doctor en Historia por la Universidad de Buenos Aires. Consejo Nacional de Investigaciones Científicas y Técnicas (CONICET), Instituto de Historia Argentina y Americana Dr. Emilio Ravignani, Universidad de Buenos Aires (UBA). Contacto: lucaspoy@gmail.com 
ese sentido, el trabajo apunta a visibilizar una nutrida producción historiográfica y sus trayectorias para potenciar la necesidad de la construcción de puentes entre las perspectivas históricas socioculturales, político-organizacionales y de género, que son caminos con fuerte presencia en el campo y sobre cuyos cruces y avances versa esta revisión.

Palabras Clave: historia del trabajo; Argentina; historiografía; historia social; historia de género.

\section{INTRODUCCIÓN}

Ya ha transcurrido casi medio siglo desde que la historiografía profesional comenzó a dedicar su atención a la historia de los trabajadores y las izquierdas en Argentina, desarrollando y ampliando de este modo un campo de estudios que a la sazón había estado dominado por las elaboraciones de la llamada historiografía "militante"; es decir, aquellos trabajos provenientes de autores vinculados directamente con las diferentes corrientes político-gremiales que actuaban en el movimiento obrero. Desde entonces, la historiografía del trabajo atravesó diferentes etapas, influidas por las coyunturas políticas, los ciclos de lucha de la propia clase trabajadora y las distintas tendencias académicas a nivel internacional. Es un área de estudios en el que la historia social jugó siempre un papel relevante, estableciendo diálogos con la historia cultural, la historia política y la historia intelectual de las izquierdas, así como con otras disciplinas también interesadas en examinar la agencia de los trabajadores, como la sociología o la antropología. Se ha desarrollado con fuerza, asimismo, una auspiciosa preocupación por incluir una agenda y una perspectiva de género.

A diferencia de lo ocurrido recientemente en Brasil, ${ }^{1}$ en el caso argentino estos significativos avances historiográficos no han permitido todavía una ampliación de las miradas de la historia del trabajo que integre plenamente los análisis de relaciones laborales no asalariadas y formas de acción colectiva anteriores al último tercio del siglo XIX. Es indudable que esto se debe, en parte, a los profundos cambios que tuvieron lugar en el país, en términos sociales y económicos, a partir de 1880, en el marco de la consolidación de una economía capitalista integrada al mercado mundial. Pero una perspectiva crítica no puede perder de vista que continúa existiendo un "hiato" o "muro de Berlín historiográfico" -para usar las expresiones que acuñaron Silvia Lara (1998) y Sidney Chalhoub y Fernando Teixeira da Silva (2009),

1 Véase el artículo de Fabiane Popinigis y Paulo Cruz Terra en esta misma publicación (págs. 123-148). 
respectivamente, en sus análisis del caso brasileño- entre la historia de la clase trabajadora asalariada y los estudios sobre esclavos, artesanos y sectores populares urbanos y rurales a lo largo del siglo XIX e incluso antes.

El presente trabajo, por supuesto, no es el primer ejercicio de balance historiográfico sobre el tema, sino que se inscribe en una serie más amplia $-s i$ bien no demasiado extensa- de ensayos que intentaron ofrecer un panorama sobre la historiografía obrera en Argentina, con los cuales dialoga y a cuya lectura remitimos a los lectores interesados. Juan Carlos Torre (1990), Leandro Gutiérrez y Luis Alberto Romero (1991), y Mirta Lobato (1993b) ofrecieron evaluaciones que incluyeron un temprano análisis de los desenvolvimientos historiográficos de la renovación que tuvo lugar en la década de 1980; eran, asimismo, textos que intervenían en un campo en pleno proceso de transformación. Algo más tarde, Nicolás Iñigo Carrera (2006) y Juan Suriano (2006, 2009) ofrecieron sendos balances que mostraban un cuadro de situación incierta. Ambos advertían un desplazamiento de los viejos abordajes centrados en la historia institucional de las organizaciones obreras: Iñigo Carrera tenía reparos ante los posibles derroteros de esta transición, mientras que Suriano ofrecía una mirada más optimista. En cualquier caso, ambos coincidieron en advertir que el interés por los trabajadores continuaba siendo marginal en el campo de la historia académica argentina. Retomando el camino inaugurado por previos balances realizados por Valeria Pita (1998), Dora Barrancos (2005) y Mirta Lobato (2008), con ańos muy prolíficos de producción histórica por revisar, un reciente trabajo de Andrea Andújar (2017) ofreció un valioso ensayo de reconstrucción de los aportes de las perspectivas feministas y de género en su cruce con la historia obrera, y analizó las múltiples líneas de análisis que surgieron de esas inquietudes, como la problematización del trabajo doméstico, el estudio de la feminización de diversas profesiones, los análisis del hogar, la familia y la infancia proletaria, la reflexión sobre las prácticas y relaciones desplegadas entre varones y mujeres, la reconstrucción de la participación femenina en las organizaciones gremiales y las izquierdas, etcétera.

Aun con sus limitaciones, es indudable que en los últimos 15 años el campo de la historia de los trabajadores ha mostrado, en Argentina, un crecimiento y una expansión significativos, en sintonía con el desarrollo que se observa actualmente en diversos países de América Latina, Asia y África. Esta producción reciente sobre el mundo del trabajo y sus múltiples dimensiones está vinculada directamente con la labor profesional y académica, y se afinca en instituciones universitarias y científicas con presencia en diferentes regiones del país. Como se podrá apreciar, la historia académica sobre las clases trabajadoras ha atravesado tal vez sus años de mayor productividad y consolidación, aunque, en cantidad y calidad, se ha tornado heterogénea y, de algún modo, caótica. El objetivo de este artículo es ofrecer una mirada 
renovada y de conjunto sobre los principales ejes del desarrollo historiográfico respecto al periodo de finales del siglo XIX y comienzos del XX. Busca mostrar cuáles han sido las principales preocupaciones analíticas, temáticas y metodológicas -tanto en sus convergencias como en sus puntos de tensiónde este amplio recorrido. Como mosaico de un campo en crecimiento, es necesariamente una fotografía perfectible e inacabada, pero que permite establecer ciertas líneas sobre las cuales reflexionar en torno a qué historias del mundo del trabajo se están construyendo, desde qué perspectivas y ponderaciones. A la vez, apunta a visibilizar una nutrida producción historiográfica y sus trayectorias para potenciar la necesidad de la construcción de puentes entre las perspectivas históricas socioculturales, político-organizacionales y de género, caminos con fuerte presencia en el campo y sobre cuyos cruces y avances versa esta revisión. La intención última de este trabajo es estimular un diálogo que vaya más allá de las fronteras nacionales y permita trazar posibles caminos y futuros desafíos.

\section{LAS “HISTORIAS MILITANTES”, ENTRE LAS IZQUIERDAS Y EL PERONISMO}

Tal como ocurrió en muchos otros países con un movimiento obrero fuertemente organizado -como puede ser el caso, en el propio subcontinente, de México, Brasil y Chile-, en la Argentina las primeras contribuciones a la historia de la clase trabajadora provinieron de autores vinculados en forma directa con las corrientes políticas activas en el mundo de los trabajadores. Se trató, de alguna manera, del primer episodio de una historia "global", toda vez que los trabajos que surgían del seno de las corrientes anarquista, socialista y comunista eran parte de una elaboración historiográfica más amplia que esas mismas tendencias políticas iban construyendo en diferentes partes del mundo. Su enfoque, sin embargo, era definidamente "nacional": eran trabajos que situaban un claro recorte geográfico en Argentina -y particularmente en la ciudad de Buenos Aires-, y que se concentraban en una historia política e institucional de las organizaciones obreras, así como en la reconstrucción de los principales episodios huelguísticos.

Estos trabajos de lo que dio en llamarse la "historiografía militante" comenzaron a aparecer en fechas tempranas, muchas veces en forma de artículos publicados en las propias prensas político-partidarias de las organizaciones obreras en ocasión de la celebración de aniversarios o de recordaciones de tipo necrológico. ${ }^{2}$ Su consolidación y cristalización, de todas maneras, tuvo

2 Un relevamiento exhaustivo de los periódicos obreros desde comienzos del siglo XX en búsqueda de este tipo de elaboraciones está aún por hacerse; enriquecería nuestro conocimiento acerca de la gestación de estas tradiciones historiográficas. Un trabajo 
lugar con la aparición de una serie de libros publicados a partir de la década de 1930: los trabajos del anarquista Diego Abad de Santillán (1930, 1933), del socialista Jacinto Oddone (1934, 1949), del comunista Rubens Iscaro (1958) y del sindicalista Sebastián Marotta (1960) se convirtieron en las obras canónicas de cada una de las corrientes, aunque estuvieron lejos de ser las únicas. Se fue constituyendo así una compacta biblioteca de historias del movimiento obrero y de las corrientes de izquierda, elaboradas por fuera del campo de la historiografía académica, que contaban con una importante difusión gracias a las propias redes organizativas y militantes de las organizaciones políticas y sindicales. Las vicisitudes de las reediciones y reimpresiones de todos estos trabajos, de hecho, constituyen en sí mismas un valioso tema de investigación para reconstruir los avatares de las izquierdas a lo largo de muchas décadas, a la vez que muestran el sostenido interés que estas obras han gozado durante décadas.

En muchos de estos trabajos - particularmente en aquellos publicados después de 1945- subyace, además, de forma más o menos explícita, un intento de contrastar lo que se consideraba una época heroica de lucha del movimiento obrero con un presente marcado por la influencia hegemónica del peronismo en la clase trabajadora. ${ }^{3}$ En este contexto, no debe sorprender que, desde las filas de autores vinculados al peronismo, y en lo que dio en llamarse el "revisionismo histórico", aparecieran también trabajos dedicados a reconstruir la historia del movimiento obrero en el país (Belloni, 1960; Puiggrós, 1965; López, 1971; Hernández Arregui, 1972). Escritos también con una clave militante, y por lo general desprovistos de vínculos con una historiografía académica que seguía desentendiéndose de estas temáticas, las obras del revisionismo histórico hicieron, de todos modos, un aporte sustancialmente menor a nuestro tema de estudio. Preocupados por mostrar que las corrientes de izquierda habían sido "flores exóticas" llegadas del extranjero, mal adaptadas a las tradiciones e intereses de una clase obrera argentina que solo había encontrado su auténtica representación en el peronismo, produjeron investigaciones de escaso rigor documental, incapaces de advertir el complejo proceso de estructuración de la clase trabajadora argentina como sujeto social y político desde fechas muy tempranas.

Frente a una historia académica y universitaria que parecía impermeable tanto a las preocupaciones del mundo militante como a las nuevas inquietudes

de estas características sería aún más rico si pudiera establecer comparaciones con otros países latinoamericanos.

3 El ejemplo más claro lo dio el socialista Jacinto Oddone, cuyo Gremialismo proletario argentino, de 1949, llevaba como subtítulo "Su origen, su desarrollo, sus errores, su ocaso como movimiento democrático libre". 
que surgían en la historiografía de otras latitudes, fueron sobre todo investigadores provenientes de la sociología quienes impulsaron una importante renovación, en la década de 1960 , y se orientaron a abordar con nuevas perspectivas la historia de los trabajadores. En la medida en que el peronismo continuaba ejerciendo una influencia dominante en el movimiento obrero, no sorprende que las inquietudes de los investigadores se preguntaran por las causas de esta hegemonía y, por lo tanto, los principales trabajos que aparecieron en estos ańos se centraron no tanto en el periodo temprano sino, precisamente, en los años de surgimiento y consolidación del peronismo, en la década de 1940. La contribución más importante provino del sociólogo italiano Gino Germani (1966), quien explicó el surgimiento del peronismo como una consecuencia de los cambios sociales que habían tenido lugar en el seno de la clase obrera durante la década de 1930. Las tesis de Germani -que contrastaban a una "vieja" clase obrera, de origen mayormente inmigrante y alineada con las corrientes de izquierda, con una "nueva" clase obrera surgida de la industrialización de la década de 1930 y menos consciente políticamente-fueron, por supuesto, seriamente cuestionadas (véase, por ejemplo, Murmis y Portantiero, 1971), pero resultaron enormemente influyentes y movieron hacia lo socioeconómico el eje de un debate que había estado centrado en cuestiones puramente políticas e ideológicas.

\section{LA RENOVACIÓN HISTORIOGRÁFICA DE LA DÉCADA DE 1980 Y SUS PARTICULARIDADES}

La primera mitad de la década de 1970 estuvo marcada, al igual que en muchos otros países, por un ascenso manifiesto de la conflictividad obrera y una radicalización política de amplios sectores de la juventud y la intelectualidad. En estos ańos aparecieron algunos nuevos trabajos que seguían marcados por los rasgos y las características de la vieja historiografía militante (Ratzer, 1970; Godio, 1972; Paso, 1974), e incluso de las primeras obras propiamente académicas (Panettieri, 1967). Sin embargo, en general, el periodo de los orígenes del movimiento obrero pareció atraer menos atención que otras temáticas, vinculadas a debates de la actualidad política que generaron discusiones más apasionadas, como por ejemplo la cuestión de la historia de los modos de producción en América Latina o los análisis sobre las causas del atraso económico del país y su relación con el imperialismo.

Paradójicamente, fue durante los años de la última dictadura militar (19761983) cuando comenzaron a sentarse las bases de una renovación historiográfica que tendría a la historia del trabajo y los trabajadores como protagonista destacado. En primer lugar, esto obedeció a la tarea de historiadores extranjeros, que produjeron importantes trabajos académicos sobre el periodo temprano del movimiento obrero y las izquierdas. A pesar de sus diferencias y de 
no compartir ni una tradición ni una preocupación intelectual común, fueron obras que aportaron miradas de conjunto y que todavía son material de consulta para cualquier nueva investigación (entre otros, Bourdé, 1977; Walter, 1977; Oved, 1978; Zaragoza, 1978). En segundo lugar, y más importante, las bases de la renovación historiográfica quedaron sentadas por los primeros contactos hechos por una nueva generación de jóvenes intelectuales -muchos de ellos vinculados a las organizaciones de izquierda en los años previos- que entraron en relación con diferentes perspectivas historiográficas en los años del exilio, fuera del país y, en muchos casos, fuera de las universidades. ${ }^{4}$ Allí estaría el eje de la renovación de los años posteriores.

Una de las influencias más destacadas en el tema que nos ocupa fue la de la historiografía marxista británica. Si bien algunos trabajos de Eric Hobsbawm habían sido traducidos al español a fines de la década de 1960 y circulaban en los espacios académicos locales, la versión castellana de The Making of the English Working Class, de Edward P. Thompson (1963), apareció recién en 1977, y estuvo llamada a jugar un papel fundamental en los nuevos aires historiográficos de los años siguientes. Pero este encuentro tenía sus especificidades, que marcaron fuertemente a la historiografía posterior; ocurre que este conjunto de investigadores e investigadoras que se aproximaba a nuevas lecturas e influencias historiográficas lo hacía en un contexto de transición entre los radicalizados años de la década de 1970 y las nuevas experiencias democráticas que comenzaban a aflorar en América Latina luego de la caída de las dictaduras, en la década de 1980. La recepción del marxismo británico y de otras influencias en el campo de la historia social debe ubicarse, por lo tanto, en el contexto más amplio del giro político protagonizado por un conjunto de académicos e intelectuales que se estaban alejando de sus afinidades ideológicas con las izquierdas y elaboraban una revalorización positiva de las reformas democráticas y parlamentarias en el marco de la sociedad capitalista. ${ }^{5}$

Este giro puede colocarse, por supuesto, en un contexto más amplio y en una dinámica de escala internacional. Una particularidad del caso argentino fue que tuvo lugar en los años de la llegada al poder de Unión Cívica Radical, un partido político fundado a finales del siglo XIX que fue, durante

4 Un reciente artículo sobre la recepción y usos de la obra de Eric Hobsbawm en Argentina señala su tardía recepción institucional y su impacto en los programas universitarios, debido al contexto dictatorial (Suriano, 2017). Carlos Zubillaga (1997: 518) también hace referencia a un proceso de "refugio" en instituciones privadas en el caso uruguayo.

5 Para un análisis más extenso de la renovación historiográfica de la década de 1980 y la peculiar recepción de la obra de Edward P. Thompson, véanse: Poy, 2016a; Nieto, 2013. 
décadas, el principal adversario del peronismo. La elección de Raúl Alfonsín, a fines de 1983, representó la primera ocasión en casi medio siglo en que el radicalismo venció electoralmente al peronismo en una elección limpia y sin proscripciones. El alfonsinismo atrajo, en esos años, a buena parte de esta generación intelectual, que al mismo tiempo comenzaba a ocupar espacios en los ámbitos universitarios y profesionales, que atravesaban también por un proceso de renovación luego de la dictadura.

Es importante tomar en consideración este contexto para advertir la especificidad de un periodo en el cual se produjo un importante desarrollo historiográfico en el terreno de la historia social de los trabajadores, mientras, al mismo tiempo, se procesaba un notorio alejamiento, de parte de los investigadores, del movimiento obrero y las izquierdas. El resultado fue un crecimiento y diversificación de los estudios académicos dedicados a la historia de los trabajadores -en particular, en el periodo temprano que nos ocupa en este relevamiento- $y$, al mismo tiempo, una (reivindicada) profesionalización del área, en el contexto de consolidación institucional de universidades y centros de investigación. ${ }^{6}$ Concentrada sobre todo en Buenos Aires y en Rosario, esta renovación historiográfica dedicó especial atención al periodo previo al peronismo, y movió el eje de la historia política e institucional para concentrarse en el campo de la historia social. Nuevos trabajos contribuyeron, así, a enriquecer el conocimiento sobre aspectos sociales y culturales de la vida de los trabajadores, sus condiciones de trabajo, el entorno urbano, sus condiciones de vivienda y el papel de la inmigración (Gutiérrez, 1981; Falcón, 1984, 1986, 1987; Pianetto, 1984; Armus, 1984; Sabato, 1985; Devoto y Rosoli, 1985; Romero, 1987; Sabato y Romero, 1992). En conjunto, y a pesar de su heterogeneidad, tuvieron como rasgo común su alejamiento de la anterior historia política e institucional, colocando a la historiografía argentina más cerca de los debates y las tendencias internacionales. Siguió siendo, de todas formas, una historiografía centrada en el caso argentino -y, sobre todo, de Buenos Aires-. La historiografía obrera quedaba a la espera de nuevas miradas iluminadoras de las experiencias regionales y de posibles comparaciones entre distintas regiones y con otros países del continente y el mundo.

6 Un proceso de características similares tuvo lugar en Uruguay, después del fin de la dictadura militar en 1985 (véase: Zubillaga, 1997: 532). En Brasil comenzó un proceso de renovación desde fines de la década de 1970, en la Universidad Estatal de Campinas (véase el reciente análisis exhaustivo de la historiografía del trabajo en Brasil en: Fontes et al., 2018). Para un examen de las vicisitudes de la historiografía sobre los sectores populares en Chile, que presenta una cronología algo distinta, véanse: Rojas, 2000; Grez Toso, 2005. 
Tanto el derrumbe del gobierno de Raúl Alfonsín, en el plano nacional, como la caída de la Unión de Repúblicas Socialistas Soviéticas (URSS) y otros países del llamado "socialismo real", en el ámbito global, representaron una notoria sacudida que impactó en el campo historiográfico. La década de 1990, en contraste con la anterior, mostró una marcada retracción de la historia de los trabajadores como área de interés historiográfico; según Suriano (2009), fueron años que mostraron una "fuga masiva de historiadores" hacia otras áreas temáticas, en particular hacia la historia de los regímenes políticos. No se trataba de un fenómeno puramente local y, en este punto, la crisis de la historia del trabajo y de los trabajadores mostraba similitudes con tendencias del mismo tenor en otros países.

Los años de la década de 1990 aparecen así, en una mirada retrospectiva, como un periodo durante el cual la historia de los trabajadores y de la izquierda hizo una suerte de travesía por el desierto, una cierta resistencia en los márgenes. Aun así, algunos autores que habían animado la renovación de la década de 1980, como Mirta Lobato o Juan Suriano en Buenos Aires, o Ricardo Falcón y sus discípulos en Rosario, continuaron trabajando en estas temáticas, y junto a otros dieron impulso a la revista Entrepasados, que comenzó a publicarse en 1991. Desde una perspectiva de izquierda, por otra parte, hubo distintas "trincheras" desde las cuales se defendió la continuidad y la vigencia de una historia que no dejara de mostrar su interés por la clase obrera y por la izquierda, sin ambigüedades. Pueden señalarse, en este sentido, los aportes de Pablo Pozzi, Nicolás Ińigo Carrera o Alberto Plá, que ofrecieron ámbitos de trabajo para investigadores y estudiantes más jóvenes cuya producción se daría a conocer años más tarde. Es interesante notar, en el mismo sentido, la aparición durante la propia década de 1990 de una serie de publicaciones que expresaban estas "resistencias" en papel, por supuesto que desde perspectivas diversas. La revista Taller, por ejemplo, se publicó desde 1993, mientras que PIMSA comenzó a aparecer en 1997. Cabe mencionar también El Rodaballo, editada desde 1994, Razón y Revolución, aparecida en 1995, y Herramienta, cuyo primer número salió en $1996{ }^{7}$

En cualquier caso, es a partir de la década de 2000 cuando comienza realmente a advertirse un cambio de ciclo, con un claro proceso de revitalización y reactivación de las pesquisas históricas vinculadas al trabajo, sus sujetos,

7 Las distintas fuerzas de izquierda nunca dejaron de publicar revistas de carácter teórico (Politica y Teoría, En Defensa del Marxismo y Estrategia Internacional, entre otras), en las cuales se animó también el debate y el intercambio sobre temas de historia del movimiento obrero. 
relaciones, experiencias y procesos. Con solo hacer un breve repaso de las fechas de edición de algunas de las obras destacadas, se observa que la década de 2000 fue testigo de una abundante cantidad de publicaciones sobre la historia del trabajo, los trabajadores y las izquierdas. ${ }^{8}$ Si bien son trabajos que abordaron distintos periodos y mostraron sustanciales diferencias de enfoque, se puede advertir algunas grandes líneas en las cuales se orientaron las nuevas producciones historiográficas, mostrando un contraste con lo ocurrido en las décadas previas. Una de ellas fue un renovado interés por la historia política e ideológica del movimiento obrero y las izquierdas, aspectos que en la década de 1980 habían sido cuestionados como preocupaciones propias de una ya superada y escasamente profesional "historiografía militante". Esto se expresó particularmente en el campo de los estudios sobre la segunda mitad del siglo $\mathrm{XX}$, con trabajos que revelaron la importancia de las corrientes de izquierda en el seno de la clase trabajadora a pesar de la influencia del peronismo, pero también se produjeron avances importantes en la historia del periodo anterior. En efecto, distintos trabajos ilustraron la vitalidad y el dinamismo de las izquierdas desde comienzos de siglo, así como su fuerte competencia, en un terreno común de debate y vinculación en los diversos espacios laborales y gremiales (Camarero, 2007a; Poy, 2014; Ceruso, 2015).

Un campo que muestra especial vitalidad es el de los estudios sobre el anarquismo, como lo muestran el clásico trabajo de Suriano (2001) y otros más recientes, que enfatizan la complejidad de esta particular cultura política y ponen en cuestión la idea de su virtual desaparición en la década de 1920, mostrando a la vez la complejidad del devenir de dicha corriente en el mundo de entreguerras, ante la cultura de masas y frente al peronismo, así como su vitalidad en otras latitudes nacionales (Anapios, 2013a, 2013b; Nieto, 2018).

8 Solo por mencionar algunos ejemplos: en el año 2000 se publicaron La estrategia de la clase obrera, de Nicolás Ińigo Carrera, y Los setentistas. Izquierda y clase obrera (1969-1976), de Pablo Pozzi y Alejandro Schneider. El año siguiente aparecieron tanto el trabajo de Juan Suriano, sobre el anarquismo en el periodo 1890-1910, como el de Mirta Lobato, sobre la vida en las fábricas de Berisso. Algunos años más tarde, en 2005, publicaron la compilación de Hernán Camarero y Carlos Herrera sobre el Partido Socialista argentino, y Los compañeros. Trabajadores, izquierda y peronismo, de Alejandro Schneider. En 2007, por otra parte, aparecieron Historia de las trabajadoras en Argentina, también de Lobato, el libro de Camarero sobre el Partido Comunista argentino, y Marx en la Argentina, de Horacio Tarcus (Ińigo Carrera, 2000; Pozzi y Schneider, 2000; Suriano, 2001; Lobato, 2001; Camarero y Herrera, 2005; Schneider, 2005; Lobato, 2007; Camarero, 2007a; Tarcus, 2007). Se trata de una lista necesariamente sumaria e incompleta, que además estamos recortando para destacar especialmente los trabajos dedicados al periodo que nos ocupa. 
Un creciente número de estudios sobre el Partido Socialista, asimismo, revela una revitalización del interés por esta fuerza política y sus variadas dimensiones político-electorales, gremiales y culturales. Esto se manifiesta, entre otras cosas, en la conformación de una Red de Estudios sobre el Socialismo Argentino y en la publicación de numerosos trabajos de investigación (entre otros, Camarero y Herrera, 2005; Martínez Mazzola, 2008; Graciano, 2010; Poy, 2015; Buonuome, 2015; Herrera, 2016). En los últimos años se han desplegado, en el mismo sentido, diversos estudios que abordan la corriente sindicalista revolucionaria en el Río de La Plata, su militancia y política gremial en diversas ramas, sus ideas, nociones y prácticas, así como sus transformaciones, mostrando una constelación más compleja, diversa, porosa e imbricada de las izquierdas en su relación con el movimiento obrero (Belkin, 2007, 2018; Bertolo, 2011; Aquino, 2017; Caruso, 2017; Koppmann, 2017). ${ }^{9}$

Se observa menos -aunque no es inexistente- la preocupación por los estudios sobre las condiciones de vida y la problemática de la vivienda, por ejemplo. Los trabajos más sugerentes en ese sentido vinieron de estudios que cruzaron la historia social y cultural y la historia de la arquitectura con un abordaje preocupado por las formas populares de habitar la ciudad. El caso más representativo es el libro de Anahí Ballent y Jorge Francisco Liernur (2014), compilación donde se indagan las formas de la vivienda obrera en el cambio de siglo, la casa colectiva y sus trasformaciones, así como el peso de las iniciativas estatales, de la Iglesia o del Partido Socialista, para modificar esta realidad a través de diversos proyectos, y las diversas estrategias de los propios trabajadores, como la autoconstrucción, que permean todo el periodo. Otros estudios centrados en el espacio barrial repusieron un análisis del paisaje fabril, así como de las demandas y las características del habitar obrero (Silvestri, 2004; Norando y Scheinkman, 2011). Son estudios que recuperan, con otro prisma, el interés por la vivienda obrera y, con una mirada amplia, por las condiciones de vida-que, de manera general y sensible, ya habían sido desarrollados en distintos estudios realizados en las últimas décadas del siglo XX (Panettieri, 2000, 1997, 1967; Suriano, 1983)-.

En línea con esta mayor preocupación por la conflictividad obrera y la historia de las corrientes de izquierdas, característica de la historiografía más reciente, otro elemento que se destaca en claro contraste con el periodo anterior tiene que ver con la recuperación del análisis del conflicto de clase y, en

9 Esta historiografía, que dotó de singularidad y significancia a la experiencia obrera previa al peronismo, encontró canales de expresión en publicaciones como Nuevo Topo, revista de historia y pensamiento crítico, aparecida entre 2005 y 2010, Políticas de la Memoria, publicada desde 1998, o la más reciente Archivos de historia del movimiento obrero y la izquierda, que se edita desde 2012. 
relación con ello, un serio cuestionamiento a la idea de una disminución de la conflictividad en el periodo de entreguerras, que había representado uno de los ejes fundamentales de la argumentación de Luis A. Romero en los años previos (véase: Gutiérrez y Romero, 1991). Los trabajos de Camarero (2007a), sobre el Partido Comunista, y de Ińigo Carrera (2000), sobre la huelga general de 1936, jugaron en este punto un papel muy destacado, pero tampoco pueden dejar de mencionarse los diversos trabajos -fuera de nuestro objeto de análisis aquí- que examinaron la dinámica de la lucha sindical bajo los gobiernos peronistas y, por supuesto, en las décadas de 1960 y 1970 . No es casual que, en este contexto, se haya desarrollado también un cuestionamiento en el plano teórico a la tesis de los "sectores populares", desarrollada fundamentalmente por Romero y Gutiérrez en la década de 1980 (véanse, entre otros: Pozzi, Camarero y Schneider, 2001; Camarero, 2007b). Los nuevos caminos recorridos apuntaron a visibilizar las luchas y las demandas de las organizaciones obreras, sindicales o partidarias, reposicionándolas como nodo explicativo y fundante de una nueva periodización. A la vez, dotaron de especificidad a la clase trabajadora, no entendida como "pre-peronista" sino como sujeto histórico atendible en sí mismo, en su multiplicidad de experiencias.

\section{LOS ESTUDIOS DE GÉNERO Y LA HISTORIA SOCIAL DEL TRABAJO}

Posiblemente el terreno en el cual tuvo lugar el proceso de renovación más importante fue en el campo de los estudios de género. Décadas atrás habían existido algunos trabajos pioneros que buscaron visibilizar el lugar de las mujeres en el mercado de trabajo y que, por esto mismo, se centraron en la medición y la evolución cuantitativa del trabajo femenino (Recchini de Lattes y Wainerman, 1977; Wainerman y Recchini de Lattes, 1981; Jelin, 1978; Sautu, 1980; Recchini de Lattes, 1980). Mostraban así que el trabajo de las mujeres se concentró en determinados sectores, como la alimentación y la industria textil, en el sector de servicios -con ocupaciones como empleadas administrativas, dactilógrafas o telefonistas-, en el cuidado de la salud, en la educación, en el servicio doméstico y en el trabajo a domicilio. Respecto a la influencia de autores como Hobsbawm y Thompson en la historiografía local, Lobato señaló en un balance historiográfico que incluso las historias obreras que surgieron como producto de la renovación de la década de 1980 habían sido "poco receptivas al debate que plantearon las feministas, en particular las marxistas, a los historiadores varones" (2008: 31). En la misma línea, Barrancos (2005) señaló que el auténtico desarrollo de un campo de estudios propiamente interesado en la "historia de las mujeres" se había constituido recién a partir de la década de 1990, cuando comenzaron a crecer los espacios para la producción y el debate de una historia de las 
mujeres: congresos, reuniones académicas, dossiers en revistas académicas, publicaciones especializadas, etcétera.

En las últimas dos décadas, este campo de estudios ha conocido un desarrollo notable. En términos de Lobato, los trabajos "redujeron la escala y aguzaron la mirada", con el objetivo de "generizar" el lugar de trabajo y examinar así, con más detalle, no solo las desigualdades salariales y laborales, sino también las relaciones entre los géneros dentro de los lugares de trabajo y de las organizaciones obreras. La propia Lobato examinó las industrias frigoríficas y textiles de la zona de Berisso (1993b, 2001), y otras investigaciones más recientes han explorado también otras ramas o colectivos, como la industria textil (Ceva, 2010; Norando, 2016), la enfermería y la obstetricia (Martín, 2014), el trabajo administrativo (Queirolo, 2014), los servicios de criadas y nodrizas en Buenos Aires (Allemandi, 2015) o las trabajadoras del servicio doméstico en Córdoba (Remedi, 2011) y la rama alimenticia del dulce (Scheinkman, 2017).

Una mirada retrospectiva revela que si bien los primeros trabajos y aproximaciones desde los interrogantes sobre el género y la historia de las mujeres promovieron la visibilización de estas como una tarea necesaria y central, estudios posteriores profundizaron en pensar las relaciones, las prácticas y las identidades desde la dimensión de género, complejizando la perspectiva y confluyendo en una historia social con perspectiva de género de la clase trabajadora. En esta, las nuevas preguntas apuntaron a problematizar los roles, las representaciones, las relaciones y las identidades de género, las masculinidades incluidas, así como a indagar sobre la agencia de las mujeres en periodos y grupos de trabajadores diversos, generizando el estudio de la participación gremial y política de las demandas obreras y de la protesta (en este sentido, véase: Andújar et al., 2016).

La lista de estudios en este campo es, afortunadamente, mucho más extensa que 20 años atrás. Se desarrollaron investigaciones que se ocuparon de la participación femenina en huelgas y conflictos obreros (D'Antonio, 2000; Barrancos, 2008; Palermo, 2007; Bravo et al., 2007), así como de su rol en las organizaciones políticas de las izquierdas, principalmente el anarquismo (Barrancos, 1990; Bellucci, 1990; Fernández Cordero, 2000; Ansolabehere, 2000), pero también el socialismo (Barrancos, 1997; Raiter, 2004; Rey, 2011) y, en menor medida, el comunismo (Norando, 2016). Con relación a estas organizaciones y sus campañas, pero también con las iniciativas surgidas desde las propias filas de la clase dominante, diversos estudios examinaron asimismo las luchas por el logro de reformas vinculadas con la situación y los derechos de las mujeres trabajadoras. Siguiendo el camino abierto por los trabajos de Marcela Nari (2004), se ha avanzado también en poner en discusión la construcción de una determinada "naturaleza femenina" y el lugar ocupado por la dicotomía entre espacio público y espacio privado, algo particularmente importante a la hora de reflexionar críticamente sobre las desigualdades entre 
hombres y mujeres en el mercado laboral y en las propias organizaciones políticas y gremiales de la clase trabajadora (Barrancos, 1999).

\section{NUEVOS TEMAS}

La expansión que tuvo lugar en la última década en el campo de los estudios históricos sobre el trabajo, los trabajadores y las trabajadoras, provocó, a su vez, la eclosión de temas y la especificación de algunas áreas aún vacantes de preocupación investigativa. Así, se delinearon nuevos estudios sobre la construcción polifónica de las políticas sociales en general (Lvovich y Suriano, 2006), y de la política laboral en particular. En esta línea, se investigaron las instituciones estatales que tenían potestad sobre las cuestiones del trabajo, construyendo una suerte de historia social del propio Estado. Esto permitió visibilizar las demandas desde los trabajadores y su resonancia y vinculación con leyes, instituciones, funcionarios y departamentos, a la vez que se enfocó en la construcción incipiente de una burocracia profesional productora de conocimiento, de regulación y de una particular mirada sobre el mundo del trabajo en el país, en el ámbito nacional, y en cada provincia (Lobato y Suriano, 2014; Suriano, 2000). Retomando iniciativas previas (Panettieri, 1984), otras líneas de indagación se orientaron a explorar la tensionada, y a veces trunca, construcción de leyes sobre el trabajo y las organizaciones obreras. Un área relativamente novedosa e interesante resulta el estudio de la aplicación de leyes obreras en colectivos específicos (Scheinkman, 2015; D’Uva, 2017).

En este desarrollo se destaca la perdurabilidad de preguntas e inquietudes nodales sobre la experiencia laboral, gremial y política de ciertos sectores obreros en el periodo. Uno de los grupos que más ha impulsado la investigación fue, sin duda, el de los obreros ferroviarios (Palermo, 2009; Monserrat, 2011b; D’Uva y Palermo, 2015), pero también cabe mencionar a los marítimos (Caruso, 2016; Monserrat 2011a), los gráficos (Bil, 2007; Bertolo, 2011), las comunidades obreras vinculadas a los yacimientos petrolíferos (Andújar, 2014, 2015), los trabajadores del calzado (Kabat, 2005), los del mueble (Koppmann, 2015) o los de los frigoríficos (Lobato, 2001; Tarditti, 2003), por mencionar algunos de los segmentos del trabajo sobre los cuales más se ha producido en los últimos ańos.

Estas líneas se combinaron, de todas formas, con otros estudios que tensionaron las definiciones de aquello que quedaba bajo la órbita de la historia del trabajo, al investigar, por ejemplo, a las prostitutas, a las empleadas domésticas o las infancias proletarias. ${ }^{10}$ Por otro lado, la preocupación por las

10 El tópico de la infancia obrera en el mundo del trabajo urbano está subsumido en el campo de la historia de las infancias, pero los trabajos abocados a los niños y a las 
nociones del desocupado y su construcción desde múltiples voces, muchas veces disonantes y en tensión, como las izquierdas o el Estado (Dimarco, 2015, 2016; Benclowicz, 2016a, 2016b; Bertolo, 2008; Daniel, 2013), también expandieron los horizontes de los estudios del mundo del trabajo, y de lo que el campo académico había definido como tal. Una agenda presente de la historia del trabajo incluye, por lo tanto, al trabajo doméstico y a los trabajadores desempleados, y revisita sujetos clásicos (rama de actividad/colectivo de trabajadores, sindicato, partidos) desde nuevas perspectivas y preguntas vinculadas con las experiencias generizadas, las relaciones amorosas/afectivas o las jerarquías y las tensiones dentro de estos colectivos, por nombrar algunas de las más significativas.

Es necesario aclarar que uno de los tantos recortes que encierra este listado crítico y no exhaustivo de la historiografía sobre el mundo del trabajo en Argentina en las primeras décadas del siglo XX se vincula con la historiografía de las provincias u otras regiones del país. Para varias de las nuevas y múltiples líneas de investigación -desde la historia social con perspectiva de género, pasando por la historia de las izquierdas, de la política laboral y social, y de la infancia obrera, entre otras- existen diversos trabajos que abordan tales temas en otros contextos regionales y provinciales, con peculiaridades que deberían figurar en un balance completo de lo hecho en este campo. Solo se han mencionado algunos avances significativos, a modo de ejemplo o indicio.

\section{COMENTARIO FINAL (Y POSIBLES CAMINOS A RECORRER)}

El rol de la clase obrera en la historia argentina ha sido muy significativo desde finales del siglo XIX y, en este sentido, no resulta sorprendente que los estudios históricos sobre el tema hayan sido -y sigan siendo- un núcleo importante no solo en el marco de la historiografía local, sino también un punto de referencia y de diálogo en un contexto latinoamericano. Este artículo ha intentado analizar cómo distintos contextos sociales y políticos dejaron su marca en la historiografía sobre el trabajo y los trabajadores. Entendemos que revisitar sus principales rasgos y particularidades no es un mero ejercicio nostálgico, sino un análisis que puede resultar útil para promover un análisis comparativo con los recorridos historiográficos de otros países, en particular del ámbito latinoamericano, y, al mismo tiempo, para discutir en qué situación estamos y cuáles son las perspectivas a futuro.

niñas pobres y vulnerables hacen esfuerzos metodológicos y reflexivos para incluirlos y visibilizarlos, así como interpretar sus experiencias en el llamado mundo del trabajo (Scheinkman, 2016; Aversa, 2014, 2015; De Paz Trueba, 2014a, 2014b). 
Este artículo ha puesto de relieve los principales "momentos" por los que atravesó la historiografía sobre el trabajo y los trabajadores en la Argentina del periodo anterior al peronismo, a lo largo de las últimas décadas. Debido a la centralidad de los trabajadores, sus organizaciones y su presencia política y social desde fechas tempranas, en Argentina se desarrolló una vasta "historiografía militante", de características similares a las que surgieron en otros países, que dio los primeros pasos en el campo y nunca dejó de tener un espacio en las elaboraciones históricas sobre el tema. El peso del peronismo, a su vez, dio lugar a una serie de fenómenos en el terreno historiográfico: la consolidación de narrativas apologéticas por parte de diversas corrientes de las izquierdas, el desarrollo de una poco rigurosa - pero bien difundida- corriente revisionista ligada ideológicamente al peronismo y, en la década de 1960, el surgimiento de una serie de investigaciones sociológicas en el campo de la academia, interesadas en encontrar en los cambios sociales y económicos la explicación de la hegemonía peronista en la clase trabajadora.

Más allá de los aportes de varios investigadores extranjeros, recién en la década de 1980 la historia de los trabajadores comenzó a ocupar un lugar central en la historiografía profesional. En esos años, la reorganización de las instituciones académicas se combinó con un clima político de acercamiento de buena parte de la intelectualidad progresista al Gobierno de Raúl Alfonsín. La consecuencia, en el campo que nos ocupa, fue una importante expansión de la historiografía del mundo de los trabajadores, que realizó una peculiar apropiación de influencias extranjeras, en particular del marxismo británico y la obra de Thompson. Nuevamente, el contexto social y político, no solo en el terreno nacional, aparece como clave para analizar el derrotero historiográfico en la década de 1990. El agotamiento de la experiencia alfonsinista, coincidente en el tiempo con la caída de la entonces Unión Soviética y el colapso de los países del bloque soviético, fue el marco en el cual se procesó una crisis en el campo de la historia de los trabajadores, que se retrajo a los márgenes de la disciplina. En este punto, el caso argentino mantenía un relativo acompañamiento con tendencias en boga en otras partes del mundo: este desinterés por la historia de los trabajadores no puede desvincularse de la retracción relativa del movimiento obrero y de la crisis de diversas corrientes de las izquierdas.

La primera década de los años 2000 marcó, por el contrario, un sostenido crecimiento y expansión del campo de la historia del trabajo y de los trabajadores, que se expresó en un aumento de las publicaciones, así como también de las investigadoras e investigadores dedicados al tema, y de las perspectivas y las problemáticas abordadas. Uno de los grandes campos que contribuyó a esta revitalización fue el de los estudios de género, que continuó con el desarrollo iniciado en la década anterior y que tuvo en sus análisis de la situación de las trabajadoras un eje excepcional de desarrollo 
historiográfico. Otro de los ejes fue una renovación en el campo de la historia del movimiento obrero y las izquierdas, que volvió a tomar como preocupación central la conflictividad y las organizaciones políticas. Las causas de esta revitalización historiográfica del campo en los últimos 20 años son diversas, pero no puede dejar de mencionarse un contexto de ascenso de las luchas que tuvo como episodio destacado la crisis de los ańos 2001-2002, así como el proceso de crecimiento sostenido de la militancia y de la organización feminista en los últimos años. Tal revitalización se apoyó en líneas y espacios preexistentes, muchos de los cuales habían sentado sus bases en la década de 1990, pero es indudable que un clima de mayor movilización aportó un fuerte impulso y generó nuevas preguntas a una generación de investigadores e investigadoras que ponderaban nuevamente la experiencia obrera en sus múltiples dimensiones como una clave necesaria en la disciplina y el campo historiográfico.

Frente a este mapa historiográfico local, complejo y expansivo al punto de hacerse casi inasible en su totalidad, cabe señalar algunas particularidades del presente que pueden trazar caminos hacia futuras investigaciones. Las nuevas preguntas, sujetos y perspectivas con que se aborda la historia del trabajo, de los trabajadores y las trabajadoras no supusieron una revolución archivística. Si bien surgieron nuevos recursos o se redescubrieron otros -expedientes estatales de diversos ministerios, fuentes policiales, fuentes empresariales, estadísticas y censos, registros municipales, debates, proyectos y legislación parlamentaria, memorias obreras, intercambios epistolares-, las principales fuentes consultadas continúan siendo la prensa y las publicaciones periódicas, lo que es comprensible debido a la prolífica política editorial de diversos sectores en la época, sobre todo entre los mismos trabajadores. De todos modos, la prensa, que continúa siendo un corpus invalorable para toda investigación histórica, es diversa: desde la prensa comercial de tirada nacional, pasando por los periódicos de distintas localidades y ciudades, hasta las revistas de actualidad y política, y las publicaciones de las corrientes de izquierda, de las centrales gremiales y de cada gremio en estudio. Cada serie constituye un objeto de estudio en sí mismo, en espera de nuevos interrogantes e investigaciones. ${ }^{11}$

El importante desarrollo de los estudios sobre la historia del trabajo en los últimos años en Argentina, que apuntamos a visibilizar en el recorrido de este trabajo, confirma un patrón que ha sido señalado recientemente por Marcel van der Linden, quien destacaba que son los países del llamado "Sur Global"

11 Este amplio conjunto rara vez es objeto de reflexión en sí, aunque para el caso de la prensa sindical y de las izquierdas existen trabajos que la han tomado como objeto de estudio (véanse, por ejemplo: Lobato, 2009; Buonuome, 2015, 2017; Anapios, 2011, 2016). 
los que están mostrando un notorio ascenso y crecimiento historiográfico, mientras que en Europa y América del Norte aún se habla de una disciplina en crisis (Poy, 2016b). Estas consideraciones solo aumentan la importancia de un diálogo y de una discusión más estrechos entre los investigadores de los países del "Sur", que muchas veces carecemos -debido sobre todo a las dificultades financieras- de espacios y canales de intercambio y trabajo colectivo, más allá de los que están mediados por las instituciones europeas o norteamericanas.

Con todo, aún queda mucho camino por recorrer, fundamentalmente en lo que respecta a un mayor intercambio y debate crítico entre investigadores de diferentes áreas, perspectivas y periodos. El crecimiento del campo ha dado lugar a una notoria expansión numérica de trabajos e investigaciones, y a la especialización que podría llevar, a menudo, a una fragmentación y balcanización de los trabajos enfocados en distintos periodos o áreas temáticas, haciendo difícil el intercambio y la discusión. Un ejemplo sostenido en el tiempo, y que refleja este mismo trabajo, es la tajante separación en la historiografía argentina de los estudios sobre inmigración y comunidades étnicas y la historia del mundo del trabajo. Al mismo tiempo, áreas o temas vinculados a las experiencias cotidianas de sociabilidad y a la vida privada de las y los trabajadores en el hogar, la familia obrera como un sujeto protagónico de aquel mundo, sus ciclos, dinámicas, relaciones, son preguntas pendientes en términos generales. Si bien se han desplegado por las diversas líneas aquí planteadas trabajos que analizan tales procesos en diversos contextos regionales y provinciales, no existe aún una reflexión sobre las conexiones entre estas diversas experiencias que permita que se ponderen entre sí y descubrir sus interrelaciones. Aún quedan por pensar colectivamente la cultura político-cívica de los trabajadores, su vinculación con partidos del sistema electoral y la experiencia y construcción del ciudadano entre la clase trabajadora.

De algún modo relacionado con lo anterior, y a pesar de un valioso desarrollo de investigaciones regionales sobre distintas partes del país, es notoria la escasez de trabajos pensados a mayor escala, por ejemplo con una mirada en clave analítica latinoamericana o global, que puede ser uno de los caminos probablemente más fructíferos. Recorrerlo implicaría iluminar nuevas facetas de experiencias que tal vez pierdan la singularidad atribuida y ganen en la interpretación de redes y relaciones, o que, sin apreciar las conexiones con otras latitudes y procesos, carezcan de valor interpretativo ellas mismas. Las nuevas perspectivas historiográficas, las nuevas escalas de conexiones globales, requieren a la vez nuevos diálogos y formas participativas del conocimiento. En ese sentido, los encuentros interoceánicos, la conformación de núcleos de producción temáticos multiimplantados en diversos países o la construcción de estadísticas, registros y mapas de situación conjuntos parecen ser un camino necesario. Como agenda, más que un desafío, es una invitación. 
BibLIOGRAFÍA

Abad de Santillán, Diego

1933 La FORA: ideología y trayectoria del movimiento obrero revolucionario en la Argentina. Buenos Aires: Nervio.

1930 El movimiento anarquista en la Argentina. Desde sus comienzos hasta el año 1910. Buenos Aires: Argonauta.

Allemandi, Cecilia

2015 "Sirvientes, criados y nodrizas. Una aproximación a las condiciones de vida y de trabajo en la ciudad de Buenos Aires a partir del servicio doméstico (fines del siglo XIX-principios del XX)”. Tesis doctoral. Universidad de San Andrés, Buenos Aires.

Anapios, Luciana

2016 "Prensa y estrategias editoriales del movimiento anarquista en la Argentina de entreguerras". En: Anuario del Instituto de Historia Argentina, volumen 16, número 2. e025.

2013a "La ley de jubilaciones de 1924 y la posición del anarquismo en Argentina". En: Revista de Historia del Derecho, número 46. 27-43.

2013b "La ciudad de las bombas. El anarquismo y la 'propaganda por el hecho' en la Buenos Aires de los años veinte". En: Boletin del Instituto de Historia Argentina y Americana Dr. Emilio Ravignani, número 39. 42-75.

2011 "Una promesa de folletos. El rol de la prensa en el movimiento anarquista en la Argentina (1890-1930)". En: A Contracorriente, número 8. 1-34.

Andújar, Andrea; Laura Caruso, Florencia Gutiérrez, Silvana Palermo, Valeria Pita y Cristiana Schettini

2016 Vivir con lo justo. Estudios de historia social del trabajo en perspectiva de género. Argentina, siglos XIX y XX. Rosario, Argentina: Prohistoria.

Andújar, Andrea

2017 "Historia social del trabajo y género en la Argentina del siglo XX: balance y perspectivas". En: Revista Electrónica de Fuentes y Archivos (REFA), Centro de Estudios Históricos "Prof. Carlos S. A. Segreti", número 8. 43-59.

2015 "Comunidad obrera, género y políticas asistenciales: Comodoro Rivadavia, 1922-1932”. En: Archivos de historia del movimiento obrero y la izquierda, número 7. 59-78.

2014 "En demanda de lo justo: conflictos por derechos en la Patagonia petrolera. Comodoro Rivadavia, 1932". En: Páginas, volumen 6, número 12. 41-67. 
168 | Trabajos y trabajadores en América Latina (siglos XVI-XXI)

Ansolabehere, Pablo

2000 "La voz de la mujer anarquista". En: Mora, número 6. 109-119.

Aquino, Cristian

2017 "Las disputas del sindicalismo revolucionario por los gremios ferroviarios durante la primera posguerra". En: Archivos de historia del movimiento obrero y la izquierda, número 10. 75-94.

Armus, Diego (comp.)

1984 Sectores populares y vida urbana. Buenos Aires: CLACSO.

Aversa, María Marta

2015 "Menores trabajando: Rutinas laborales puertas adentro del asilo, Ciudad de Buenos Aires, 1870-1920". 4. ${ }^{\text {tas }}$ Jornadas de Estudios sobre la Infancia, Buenos Aires.

2014 "El circuito de colocaciones laborales de niños y niñas asilados, Ciudad de Buenos Aires (fines del siglo XIX - principios del XX)”. En: Angelusnovus, volumen V, número 8. 103-128.

Ballent, Anahí y Jorge Francisco Liernur

2014 La casa y la multitud. Vivienda, politica y cultura en la Argentina moderna. Buenos Aires: FCE.

Barrancos, Dora

2005 "Historia, historiografía y género. Notas para la memoria de sus vínculos en la Argentina". En: La Aljaba, número 9. 49-72.

1999 "Moral sexual, sexualidad y mujeres trabajadoras en el período de entreguerras". En: Fernando Devoto y Marta Madero (dirs.), Historia de la vida privada en la Argentina, volumen 2. Buenos Aires: Taurus.

1997 "Socialistas y suplementación de la educación pública: la Asociación Bibliotecas y Recreos Infantiles (1913-1930)". En: Graciela Morgade (comp.), Mujeres en la educación. Género y docencia en la Argentina (1870-1930). Buenos Aires: Miño y Dávila / IIEGE.

1990 Anarquismo, educación y costumbres en la Argentina de principios de siglo. Buenos Aires: Contrapunto.

Belkin, Alejandro

2018 Sindicalismo revolucionario y movimiento obrero en la Argentina. De la gestación en el Partido Socialista a la conquista de la FORA (1900-1915). Buenos Aires: Imago Mundi / Ediciones CEHTI.

2007 Sobre los orígenes del sindicalismo revolucionario en Argentina. Buenos Aires: Ediciones CCC. 
Belloni, Alberto

1960 Del anarquismo al peronismo. Historia del movimiento obrero argentino. Buenos Aires: Peña Lillo.

Bellucci, Mabel

1990 "Anarquismo, sexualidad y emancipación femenina. Argentina alrededor del 900”. En: Nueva Sociedad, número 109. 148-157.

Benclowicz, José

2016a "Un movimiento de desocupados para la revolución. El Partido Comunista y la organización de los trabajadores desocupados hacia la década de 1930 en Argentina”. En: Revista de Historia Americana y Argentina, volumen 51, número 2. 167-200.

$2016 b$ "¿Vencidos sin dignidad o sujetos revolucionarios? Los anarquistas ante los desocupados y la desocupación en la Argentina de la primera mitad de los ańos treinta”. En: Izquierdas, número 31. 19-45.

Bertolo, Maricel

2011 "Los primeros pasos de la negociación colectiva en la Argentina". En: Cuadernos del Ciesal, volumen 8, número 10. 71-95.

2008 "Estado y trabajadores en Argentina. El Departamento Nacional del Trabajo ante el fenómeno de la desocupación, 1907-1934”. Tesis doctoral. Facultad de Filosofía y Letras, Universidad de Buenos Aires, Buenos Aires.

Bil, Damián

2007 Descalificados. Proceso de trabajo y clase obrera en la rama gráfica (18901940). Buenos Aires: Ediciones RyR.

Bourdé, Guy

1977 Buenos Aires: urbanización e inmigración. Buenos Aires: Huemul.

Bravo, María Celia; Fernanda Gil Lozano y Valeria Silvina Pita

2007 Historia de luchas, resistencias y representaciones. Mujeres argentinas, siglos XIX y XX. Tucumán, Argentina: UNT.

Buonuome, Juan

2017 "Los socialistas argentinos ante la 'prensa burguesa'. El semanario La Vanguardia y la modernización periodística en la Buenos Aires de entresiglos". En: Boletín del Instituto de Historia Argentina y Americana Dr. Emilio Ravignani, número 46. 147-179.

2015 "Fisonomía de un semanario socialista: La Vanguardia, 1894-1905". En: Archivos de historia del movimiento obrero y la izquierda, número 6. 11-30. 
170 | Trabajos y trabajadores en América Latina (siglos XVI-XXI)

Camarero, Hernán y Carlos Herrera (comps.)

2005 El Partido Socialista en Argentina. Buenos Aires: Prometeo.

Camarero, Hernán

2007a A la conquista de la clase obrera. Los comunistas y el mundo del trabajo en la Argentina, 1920-1935. Buenos Aires: Siglo XXI.

2007b "Consideraciones sobre la historia social de la Argentina urbana en las décadas de 1920 y 1930: clase obrera y sectores populares”. En: Nuevo Topo, número 4. 35-60.

Caruso, Laura

2017 "Federados, soldados, y productores: la militancia sindicalista revolucionaria en el sector marítimo (1910-1924)". En: Archivos de historia de la izquierda y el movimiento obrero, número 10. 33-53.

2016 Embarcados. Los trabajadores maritimos y la vida a bordo: sindicato, empresas y Estado en el puerto de Buenos Aires (1889-1921). Buenos Aires: Imago Mundi.

Ceva, Mariela

2010 Empresas, trabajo e inmigración en la Argentina: los casos de la Fábrica Argentina de Alpargatas y la Algodonera Flandria (1887-1955). Buenos Aires: Biblos.

Ceruso, Diego

2015 La izquierda en la fábrica: la militancia obrera industrial en el lugar de trabajo, 1916-1943. Buenos Aires: Imago Mundi.

Chalhoub, Sidney y Fernando Teixeira da Silva

2009 "Sujeitos no imaginário acadêmico: escravos e trabalhadores na historiografia brasileira desde os anos 1980". En: Cadernos AEL, volumen 14, número 26. 11-50.

D’Antonio, Débora

2000 "Representaciones de género en la huelga de la construcción. Buenos Aires, 1935-1936”. En: Fernanda Gil Lozano, Valeria Pita y Gabriela Ini (eds.), Historia de las mujeres. Buenos Aires: Taurus.

D’Uva, Florencia y Silvana Palermo

2015 "Vida sindical y sociabilidades masculinas: los trabajadores ferroviarios en la Argentina de principios del siglo XX". En: Archivos de historia del movimiento obrero y la izquierda, número 7. 37-58.

Daniel, Claudia

2013 "De crisis a crisis: la invención de la desocupación en la Argentina". En: Revista de Indias, volumen LXXIII, número 257. 193-218. 
De Paz Trueba, Yolanda

2014a "El trabajo infantil en el centro y sur de la provincia de Buenos Aires.

Niñas y niños a fines del siglo diecinueve y principios del veinte". En: Mundos do Trabalho, volumen 6, número12. 177-195.

2014b "Familias pobres, niñas y benefactoras. Estrategias y expectativas en el centro y sureste de la provincia de Buenos Aires a principios del siglo XX”. En: Páginas, volumen 6, número 12. 27-40.

Devoto, Fernando y Gianfausto Rosoli (comp.)

1985 La inmigración italiana en la Argentina. Buenos Aires: Biblos.

Dimarco, Sabina

2016 "Los socialistas y el problema de la falta de ocupación en la crisis de 1890". En: Estudios Sociales del Estado, volumen 2, número 4. 151-180.

2015 "Percepciones del no-trabajo en personas válidas a fines del siglo XIX: reflexiones en torno a la configuración de la figura del 'desocupado'”. V Jornadas de Historia Social. Córdoba, Argentina.

D'Uva, Florencia

2017 "Los accidentes de trabajo en los ferrocarriles argentinos: denuncias, reclamos y nociones sobre el riesgo profesional". En: A Contracorriente: Revista de Historia Social y Literatura en América Latina, número 14. 62-94.

Falcón, Ricardo

1987 "Izquierdas, régimen político, cuestión étnica y cuestión social en la Argentina". En: Anuario de la Escuela de Historia, número 12. 365-389.

1986 El mundo del trabajo urbano (1890-1914). Buenos Aires: CEAL.

1984 Los orígenes del movimiento obrero (1857-1899). Buenos Aires: CEAL.

Fernández Cordero, Laura

2000 "Queremos emanciparos: anarquismo y mujer en Buenos Aires de fines del XIX". En: Izquierdas, número 6. Disponible en: http://www. izquierdas.cl/ediciones/2010/numero-6-abril

Fontes, Paulo; Alexandre Fortes y David Mayer

2018 "Brazilian Labour History in Global Context: Some Introductory Notes". En: International Review of Social History, número 62. 1-22.

Germani, Gino

1966 Politica y sociedad en una época de transición. De la sociedad tradicional a la sociedad de masas. Buenos Aires: Paidós. 
172 | Trabajos y trabajadores en América Latina (siglos XVI-XXI)

Godio, Julio

1972 El movimiento obrero y la cuestión nacional. Argentina: inmigrantes asalariados y lucha de clases 1880-1910. Buenos Aires: Erasmo.

Graciano, Osvaldo

2010 "El Partido Socialista de Argentina: su trayectoria histórica y sus desafíos políticos en las primeras décadas del siglo XX”. En: $A$ Contracorriente, volumen 7 , número 3. 1-37.

Grez Toso, Sergio

2005 "Escribir la historia de los sectores populares. ¿Con o sin la política incluida?”. En: Política, número 44. 17-31.

Gutiérrez, Leandro

1981 "Condiciones de la vida material de los sectores populares en Buenos Aires, 1880-1914”. En: Revista de Indias, volumen XLI. 163-64.

Gutiérrez, Leandro y Luis Alberto Romero

1991 "Los sectores populares y el movimiento obrero en Argentina: un estado de la cuestión". En: Boletín del Instituto de Historia Argentina y Americana Dr. Emilio Ravignani, tercera serie, número 3. 109-122.

Hernández Arregui, Juan José

1972 Peronismo y socialismo. Buenos Aires: Hachea.

Herrera, Carlos, M.

2016 ¿Adiós al proletariado? El Partido Socialista bajo el peronismo (19451955). Buenos Aires: Imago Mundi.

Iñigo Carrera, Nicolás

2006 "La historia de los trabajadores". En: Jorge Gelman (comp.), La historia económica argentina en la encrucijada. Buenos Aires: Prometeo.

2000 La estrategia de la clase obrera, 1936. Buenos Aires: La Rosa Blindada / PIMSA.

Íscaro, Rubens

1958 Origen y desarrollo del movimiento sindical argentino. Buenos Aires: Anteo.

Jelin, Elizabeth

1984 Familia y unidad doméstica: mundo público y vida privada. Buenos Aires: Estudios CEDES.

1978 La mujer y el mercado de trabajo urbano. Buenos Aires: Estudios CEDES. 
Kabat, Marina

2005 Del taller a la fábrica. Buenos Aires: Ediciones RyR.

Koppmann, Walter

2017 "Un laboratorio político-gremial: el sindicalismo revolucionario en la industria de la madera, 1915-1930”. En: Archivos de historia del movimiento obrero y la izquierda, número 10. 55-74.

2015 "Lucha de clases, formas de organización y estrategia política del sindicalismo revolucionario en la industria de la madera y el mueble, Buenos Aires, 1915-1920”. En: Izquierdas, número 26. 192- 217.

Lara, Silvia

1998 "Escravidão, cidadania e história do trabalho no Brasil". En: Projeto História, número 16. 25-38.

Lobato, Mirta

2009 La prensa obrera. Buenos Aires: Edhasa.

2008 "Trabajo, cultura y poder: dilemas historiográficos y estudios de género en Argentina”. En: Estudios de filosofía práctica e historia de las ideas, volumen 10, número 2. 29-45.

2007 Historia de las trabajadoras en la Argentina (1869-1960). Buenos Aires: Edhasa.

2001 La vida en las fábricas. Trabajo, protesta y politica en una comunidad obrera, Berisso, 1904-1970. Buenos Aires: Prometeo.

1993a "Mujeres obreras, protesta y acción gremial en Argentina: los casos de la industria frigorífica y textil en Berisso". En: Dora Barrancos (ed.), Historia y género. Buenos Aires: CEAL.

1993 b "Trabajadores y movimiento obrero: entre la crisis y la profesionalización del historiador". En: Entrepasados, números 4-5. 41-64.

1990 "Mujeres en la fábrica. El caso de las obreras del frigorífico Armour, 1915-69”. En: Anuario IEHS, número 5. 171-204.

Lobato, Mirta y Juan Suriano

2014 La sociedad del trabajo. Las instituciones laborales en la Argentina, 19001955. Buenos Aires: Edhasa.

López, Alfredo

1971 Historia del movimiento social y la clase obrera argentina. Buenos Aires: Peńa Lillo.

Lvovich, Daniel y Juan Suriano (eds.)

2006 Las politicas sociales en perspectiva histórica. Argentina, 1870-1952. Buenos Aires: UNGS. 
174 | Trabajos y trabajadores en América Latina (siglos XVI-XXI)

Marotta, Sebastián

1960 El movimiento sindical argentino. Su génesis y desarrollo, 1857-1907. Buenos Aires: Lacio.

Martín, Ana Laura

2014 "Parir, cuidar y asistir. El trabajo de las parteras y enfermeras en Buenos Aires (1877-1955)". Tesis doctoral. Facultad de Filosofía y Letras, Universidad de Buenos Aires, Buenos Aires.

Martínez Mazzola, Ricardo

2008 "El partido socialista y sus interpretaciones del radicalismo argentino (1890-1930)". Tesis doctoral. Facultad de Filosofía y Letras, Universidad de Buenos Aires, Buenos Aires.

Monserrat, Alejandra

2011a "La conflictividad obrera y el partido radical. Los trabajadores marítimos entre 1916 y 1930”. En: Victoria Cañete, Florencia Rispoli, Laura Ruocco y Gonzalo Yurkievich (comps.), Los puertos y su gente, pasado, presente y porvenir. La problemática portuaria desde las ciencias sociales. Mar del Plata, Argentina: Gesmar / UNMdP.

2011 b "Los trabajadores ferroviarios: sus luchas y organizaciones sindicales en el contexto de la Argentina gobernada por el radicalismo (1916-1930)". En: Cuadernos del Ciesal, número10. 97-118.

Murmis, Miguel y Juan Carlos Portantiero

1971 Estudios sobre los orígenes del peronismo. Buenos Aires: Siglo XXI.

Nari, Marcela

2004 Politicas de maternidad y maternalismo politico. Buenos Aires: Biblos.

Nieto, Agustín

2018 Entre anarquistas y peronistas. Historias obreras al ras del suelo. Buenos Aires: Imago Mundi.

2013 "Los usos de E. P. Thompson en la historiografía 'argentina': Un itinerario posible”. En: Rey Desnudo, volumen 3, número 2. 370-391.

Norando, Verónica y Ludmila Scheinkman

2011 "La huelga de los conventillos. Buenos Aires, Nueva Pompeya, 1936. Un aporte a los estudios sobre género y clase”. En: A Contracorriente, número 9. 1-37.

Norando, Verónica

2016 "Relaciones de género y militancia política: el comunismo en la Unión Obrera Textil y las trabajadoras. Buenos Aires, 1936-1946”. Tesis 
doctoral. Facultad de Filosofía y Letras, Universidad de Buenos Aires, Buenos Aires.

Oddone, Jacinto

1949 Gremialismo proletario argentino. Buenos Aires: La Vanguardia.

1934 Historia del socialismo argentino. Buenos Aires: La Vanguardia.

Oved, Iaacov

1978 El anarquismo y el movimiento obrero en Argentina. Buenos Aires: Siglo XXI.

Palermo, Silvana

2009 "Masculinidad, conflictos y solidaridades en el mundo del trabajo ferroviario en Argentina (1912-1917)”. En: Mundos do trabalho, número 1. 94-123.

2007 “'Trabajo masculino, protesta femenina? La participación de las mujeres en la gran huelga ferroviaria de 1917”. En: María Celia Bravo, Valeria Pita y Fernanda Gil Lozano, Historia de luchas, resistencias y representaciones. Mujeres Argentinas, Siglos XIX y XX. Tucumán, Argentina: UNT.

Panettieri, José

2000 Argentina: trabajadores entre dos guerras. Buenos Aires: Eudeba.

1997 Ayer y hoy: desocupación y subocupación en la Argentina. Buenos Aires: Grupo Editor Universitario.

1984 Las primeras leyes obreras: Buenos Aires: CEAL.

1967 Los trabajadores. Buenos Aires: Editorial Jorge Álvarez.

Paso, Leonardo (ed.)

1974 La clase obrera y el nacimiento del marxismo en la Argentina. Buenos Aires: Testimonios.

Pianetto, Ofelia

1984 "Mercado de trabajo y acción sindical en la Argentina, 1890-1922". En: Desarrollo Económico, volumen 24, número 94. 297-307.

Pita, Valeria

1998 "Estudios de género e historia: situación y perspectivas". En: Mora, revista del Instituto Interdisciplinario de Estudios de Género, número 4. $72-82$.

Poy, Lucas

2016a "Remaking The Making: E.P. Thompson's Reception in Argentina and the Shaping of Labor Historiography". En: International Review of Social History, número 61. 75-93. 
176 | Trabajos y trabajadores en América Latina (siglos XVI-XXI)

2016 b "Hay un fuerte ascenso de la historia de los trabajadores en los países del sur del mundo. Diálogo con Marcel van der Linden sobre historiografía y política”. En: Archivos de historia del movimiento obrero y la izquierda, número 8. 161-172.

2015 "El Partido Socialista y las huelgas: una relación incómoda". En: Archivos de historia del movimiento obrero y la izquierda, número 6. 31-51.

2014 Los origenes de la clase obrera argentina. Buenos Aires: Imago

Pozzi, Pablo; Hernán Camarero y Alejandro Schneider

2001 "Eppur si muove. De la realidad a la conceptualización en el estudio de la clase obrera argentina”. En: Taller, revista de cultura, sociedad y política, número 16. 190-215.

Pozzi, Pablo y Alejandro Schneider

2000 Los setentistas, izquierda y clase obrera (1969-1976). Buenos Aires: Eudeba.

Puiggrós, Rodolfo

1965 Historia critica de los partidos politicos argentinos, volumen 1. Buenos Aires: Editorial Jorge Álvarez.

Queirolo, Graciela

2014 "Saberes profesionales, movilidad ocupacional e inequidad laboral: el trabajo femenino en el sector administrativo (Buenos Aires, 19101950)". Tesis doctoral. Facultad de Filosofía y Letras, Universidad de Buenos Aires, Buenos Aires.

Raiter, Bárbara

2004 Historia de una militancia de izquierda: las socialistas argentinas a comienzos de siglo XX. Buenos Aires: CCC.

Ratzer, José

1970 Los marxistas argentinos del 90. Córdoba, Argentina: Pasado y Presente.

Recchini de Lattes, Zulma

1980 La participación económica femenina en la Argentina desde la Segunda Posguerra hasta 1970. Buenos Aires: Centro de Estudios de Población.

Recchini de Lattes, Zulma y Catalina Wainerman

1977 "Empleo femenino y desarrollo económico: algunas evidencias". En: Desarrollo Económico, volumen 17, número 66. 301-317.

Remedi, Fernando

2011 "Las trabajadoras del servicio doméstico en la modernización argentina de entre siglos. Córdoba (Argentina), 1870-1910”. En: Los grupos 
sociales en la modernización latinoamericana de entre siglos. Córdoba, Argentina: CEH "Prof. Carlos S. A. Segreti" / Centro de Estudios Culturales Latinoamericanos.

Rey, Ana Lía

2011 "Palabras y proyectos de mujeres socialistas a través de sus revistas (1900-1956)". En: Mora, número 17. Disponible en: https:// www.academia.edu/34080947/Palabras_y_proyectos_de_mujeres_ socialistas_a_trav\%C3\%A9s_de_sus_revistas_1900-1956

Rojas Flores, Jorge

2000 "Los trabajadores en la historiografía chilena: balance y proyecciones". En: Revista de Economía y Trabajo, número 10. 47-56.

Romero, Luis Alberto

1987 "Los sectores populares en las ciudades latinoamericanas del siglo XIX: la cuestión de la identidad". En: Desarrollo Económico, volumen 27, número 106. 201-222.

Sabato, Hilda

1985 "La formación del mercado de trabajo en Buenos Aires". En: Desarrollo Económico, volumen 24, número 96. 561-592.

Sabato, Hilda y Luis Alberto Romero

1992 Los trabajadores de Buenos Aires. La experiencia del mercado (18501880). Buenos Aires: Sudamericana.

Sautu, Ruth

1980 El mercado de trabajo: mano de obra femenina. Buenos Aires: CEAL.

Scheinkman, Ludmila

2017 "Trabajo femenino, masculino e infantil en la industria del dulce porteña en la primera mitad del siglo XX: experiencias laborales, protesta y vida cotidiana". Tesis doctoral. Facultad de Filosofía y Letras, Universidad de Buenos Aires, Buenos Aires.

2016 "Pequeños huelguistas: participación de menores en los conflictos de la industria del dulce en Buenos Aires en la primera década del siglo XX". En: Trashumante, número 8. 108-130.

2015 "Sujetos, instituciones y derechos en la implementación de la Ley de Accidentes del Trabajo en la Ciudad de Buenos Aires (1915-1922)". En: Estudios sociales, número 49. 125-154.

Schneider, Alejandro

2005 Los compañeros: trabajadores, izquierda y peronismo, 1955-1973. Buenos Aires: Imago Mundi. 
178 | Trabajos y trabajadores en América Latina (siglos XVI-XXI)

Silvestri, Graciela

2004 El color del río. Historia cultural del paisaje del Riachuelo. Bernal, Argentina: Universidad Nacional de Quilmes.

Stagnaro, Andrés y Laura Caruso (comp.)

2017 Regular y legislar el mundo del trabajo latinoamericano. Aportes para una historia regional de la OIT. La Plata, Argentina: Ediciones UNLP.

Suriano, Juan

2017 "Algunos aspectos de la recepción de la obra de Hobsbawm en la Argentina”. En: César Mónaco (comp.), Historia y política. Seis ensayos sobre Eric Hobsbawm. Buenos Aires: Prometeo / UNGS.

2009 “Cuál es hoy la historia de los trabajadores en la Argentina?”. En: Mundos do Trabalho, número 1. 27-50.

2006 "Los dilemas actuales de la historia de los trabajadores". En: Jorge Gelman (comp.), La historia económica argentina en la encrucijada. Buenos Aires: Prometeo.

2001 Anarquistas: cultura y politica libertaria en Buenos Aires, 1890-1910. Buenos Aires: Manantial.

1983 La huelga de inquilinos de 1907. Buenos Aires: CEAL.

Suriano, Juan (comp.)

2000 La cuestión social en Argentina 1870-1943. Buenos Aires: La Colmena.

Tarcus, Horacio

2007 Marx en la Argentina: sus primeros lectores obreros, intelectuales y cientificos. Buenos Aires: Siglo XXI Editores.

Tarditi, Roberto

2003 La huelga de 1917 en los frigorificos de Berisso. Buenos Aires: Pimsa.

Thompson, Edward P.

1963 The Making of the English Working Class. Londres: Gollancz.

Torre, Juan Carlos

1990 "Acerca de los estudios sobre la historia de los trabajadores en Argentina". En: Anuario del IEHS, número V. 111-130.

Wainerman, Catalina y Zulma Recchini de Lattes

1981 El trabajo femenino en el banquillo de los acusados. La medición censal en América Latina. México: Terranova. 
Walter, Richard J.

1977 The Socialist Party of Argentina, 1890-1930. Austin, Texas, Estados Unidos de América: Universidad de Texas.

Zaragoza, Gonzalo

1978 "Anarchisme et mouvement ouvrier en Argentine à la fin du XIXe siècle". En: Le Mouvement social, número 103. 7-30.

Zubillaga, Carlos

1997 "Renovación historiográfica en el Uruguay de la dictadura y la reinstitucionalización democrática (1973-1995)”. En: Revista de Indias, volumen LVII, número 210. 511-537. 



\title{
Para una historia de la Organización Internacional del Trabajo y América Latina: perspectivas, problemas y trabajo colaborativo
}

\author{
Laura Caruso (Argentina)* \\ Andrés Stagnaro (Argentina) $)^{* *}$
}

RESUMEN: Este trabajo reflexiona sobre el vínculo entre un organismo laboral clave en la primera posguerra, la Organización Internacional del Trabajo (OIT), y las experiencias y políticas de trabajo en América Latina. Esta relación ha sido, sino ignorada, descuidada por la historiografía institucional de la OIT, que se ha centrado en otros espacios. El intento de algunos años atrás de ciertas investigaciones provenientes de ámbitos académicos latinoamericanos es, precisamente, reponer el sentido y el lugar de América Latina en el despliegue de la OIT, y, al mismo tiempo, permitir repensar las redes, los actores y las tensiones en los espacios regionales y nacionales del continente que vieron en la OIT una nueva arena de disputa y legitimidad. Ese vínculo complejo entre la OIT y América Latina es objeto de trabajo de una red interdisciplinaria que impulsamos hace unos años, y que forma parte de estas reflexiones. El trabajo allí realizado admite trazar cierta cronología tentativa de esta relación y sus etapas. Por último, planteamos algunos desafíos para desarrollar una agenda que recupere la conexión OIT-América Latina en las configuraciones del mundo del trabajo y su definición y regulación, y que pueda nutrir la propia historia del organismo internacional.

Palabras Clave: OIT América Latina; redes; cronología; historiografía.

\section{INTRODUCCIÓN}

En 2019, la Organización Internacional del Trabajo (OIT) cumplirá cien años de existencia. En esta coyuntura conmemorativa, dicha institución plantea

* Doctora en Historia por la Universidad de Buenos Aires. Consejo Nacional de Investigaciones Científicas y Técnicas (CONICET), Instituto de Altos Estudios Sociales (IDAES), Universidad Nacional de San Martín (USAM). Contacto: lauracaruso@gmail.com

** Doctor en Historia por la Universidad Nacional de La Plata. Consejo Nacional de Investigaciones Científicas y Técnicas (CONICET). Contacto: andres.stagnaro81@ gmail.com 
ciertas iniciativas para potenciar su identidad, su impronta y su historia, y también celebrarse. Según afirma en su página oficial, son siete las iniciativas en tal sentido: la justicia social, la configuración de un futuro que sirva para toda la humanidad -esto es, una globalidad equitativa-, el futuro del trabajo, poner fin a la pobreza, revisar el lugar de la mujer en el mundo laboral, la iniciativa verde o el desarrollo de herramientas para gestionar una transición justa a un futuro sustentable y, por último, el fortalecimiento del consenso tripartito fundante del organismo, junto a una autorreflexión sobre sus normas y su pertinencia. Así enumerados, salvo ciertas cuestiones vinculadas al daño ambiental y, parcialmente, a la participación femenina, ${ }^{1}$ tales enunciados fueron listados de manera similar ya en su momento inicial un siglo atrás. La vigencia de los problemas laborales que enmarcaron el surgimiento de la OIT da cuenta de la persistencia de tales dificultades y desigualdades a escala mundial, al mismo tiempo que nos alerta sobre la necesidad de historizar la existencia, las políticas, los procesos y las dinámicas del ente ginebrino, a fin de repensar tales persistencias y los conflictos en torno a estas.

Asimismo, para quienes - desde diversas disciplinas dentro de las ciencias sociales- estamos interesados en las configuraciones históricas y actuales de los mundos del trabajo, la OIT ha jugado un rol significativo a la hora de pensarlos y reinterpretarlos. Este organismo es una voz legitimada y legitimante de actores, políticas y denuncias, permitiendo visibilizar tensiones constructivas de sentidos y prácticas políticas en torno a los "problemas del trabajo", o auspiciando la reflexión de su escasa presencia, mostrando incluso la necesidad de periodizar en el siglo XX los modos y las intensidades de su vinculación, en este caso, con la región latinoamericana.

A la hora de pensar y revisar las iniciativas y las limitaciones del organismo internacional, cobra especial relevancia el lugar que ha tenido América Latina en la configuración propiciada por la OIT, en particular al reflexionar sobre las situaciones sociales diversas de nuestro continente, los procesos, las personas y los desarrollos con los que se vincularon y su mosaico de realidades nacionales y locales. La propuesta de este trabajo es repensar la historicidad de la OIT desde nuestra región, revisando la producción reciente y el desarrollo de espacios académicos que dieron cabida e impulso a esta mirada.

1 A pesar de no formar parte explícita de la agenda de 1919, las actividades realizadas, la vinculación con otras redes transnacionales y la propia presencia de las mujeres en las distintas esferas administrativas de la OIT permiten, sin embargo, enlazar este eje con las políticas de la OIT desde sus orígenes. Con relación a las redes transnacionales, el trabajo femenino y la gobernanza global con perspectiva de género, véase: Boris et al., 2018, especialmente los trabajos de Dorothy Sue Cobble, Susan Zimmermann y Paula Lucía Aguilar. 
El artículo apunta, precisamente, a situar y centralizar esta perspectiva latinoamericana en su contraste y novedad ante la narrativa oficial de la propia OIT y la producción dominante en el campo académico, ambas centradas en el espacio europeo y, para ciertos periodos, específicamente en las redes del reformismo social europeo (Van Daele, 2008). A la hora de mirar otras geografías, redes, temporalidades y sujetos que entramaron la historia de la OIT, América Latina se muestra como un espacio necesario. Una presentación general e informada de esta perspectiva es desarrollada en la primera parte del texto con el título "La OIT bajo el prisma latinoamericano".

La propuesta de una historia de la OIT desde y en América Latina plantea nuevas preguntas y problemas: ¿Quiénes representaron a los países del continente latinoamericano ante la OIT? ¿Cómo se construyeron estas representaciones, en qué trama de tensiones y acuerdos nacionales y regionales? ¿Qué representaciones construyeron las naciones de la región ante el mundo representado en la OIT? ¿Cómo se vinculó la participación en el ente ginebrino con los conflictos y los procesos en los espacios nacionales? ¿Permearon los problemas del trabajo latinoamericano la agenda de la OIT, cómo y en qué coyuntura? ¿Cuáles fueron los usos y las apropiaciones de los debates, los conceptos y las normativas producidos en la OIT por los diversos actores estatales, patronales y obreros latinoamericanos? ¿Qué lugar y rol tuvieron las experiencias latinoamericanas en la definición del campo y de los problemas de trabajo, como el trabajo infantil, el trabajo femenino, el trabajo indígena y el trabajo esclavo, entre muchos otros posibles? ¿Qué lugar tuvo la interacción de los actores latinoamericanos con la OIT en la defensa de los derechos laborales en contextos dictatoriales en la región? Sin ser exhaustivo ni completo, este listado muestra el tipo de preocupaciones y problemas que abre la perspectiva latinoamericana a los estudios históricos de la OIT, y que son revisados en la segunda parte de este escrito, "Un trabajo colaborativo: la Red interdisciplinaria OIT-América Latina, trabajos, formas e interrogantes". Allí se revisa la producción realizada en los últimos años, impulsada en el marco de un trabajo colectivo, regional e interdisciplinario, nucleado en torno a una nueva red constituida por investigadores e investigadoras de universidades de diversos países: Chile, Brasil, Argentina y Bolivia, entre otros. Finalmente, en el tercer y último apartado, titulado "Recuperar la conexión OIT-América Latina en las configuraciones del mundo del trabajo, su definición y regulación: una nueva agenda”, nos permitimos plantear brevemente, y a partir de la experiencia de la red y su reciente producción, las preguntas y los desafíos de una agenda futura en esta línea de investigación.

En otro sentido, la consideración de la OIT como actor en las realidades laborales del continente que proponemos como perspectiva, destacando su vinculación mutua y agenciando a diversos sujetos dentro de cada uno 
de estos espacios, busca poner en tensión las escalas de análisis que entran en juego a la hora de indagar el vínculo OIT-América Latina y su carácter local/nacional/regional/global. De esta manera, los debates actuales sobre el significado y la definición de aquello que consideramos trabajo y sobre quiénes son los trabajadores, entendidos como sujetos con ciertos derechos y condiciones, puede y debe ser indagado en la relación entre la OIT y los distintos actores latinoamericanos del mundo del trabajo, en la forma histórica en la que se construyeron esas definiciones y cómo fueron cambiando y transformándose a la luz de intereses, demandas, coyunturas y relaciones de fuerza en los diversos espacios involucrados. Así, desde los contactos iniciales entre el organismo y representantes gubernamentales, obreros y patronales, intelectuales y juristas, la cruzada normativa de la OIT con relación a la definición del trabajo - producto de su propio mito de origen y su vinculación con la Asociación Internacional para la Protección Legal de los Trabajadores (AIPLT) (Kott, 2015)- buscó definir los parámetros según los estándares de los países centrales. Esta política de la OIT tuvo un giro decisivo en la segunda posguerra, cuando el foco de atención se volcó al problema de la descolonización (Maul, 2017) y a los que después se llamarían los países del Tercer Mundo (Jensen y Lichtenstein, 2016), conformándose así una brecha Norte-Sur que se sumaba a la brecha Oriente-Occidente. Sin embargo, la multiplicidad de realidades del trabajo en América Latina fue un primer desafío para los funcionarios ginebrinos desde sus primeros contactos en el decenio de 1920, y tensionó algunos postulados eurocéntricos de la institución que produjeron, incluso, algunos cambios en la institución en el decenio de 1930, a fin de atender la problemática de países no europeos en 1934 (PlataStenger, 2016). Al mismo tiempo, los latinoamericanos buscaron en la OIT un faro que permitiera medir su propio grado de desarrollo civilizatorio con referencia a las relaciones laborales, aun a costa de ignorar en sus esfuerzos legislativos realidades propias de las condiciones de trabajo en cada uno de los países. Así lo muestran diversos trabajos con relación a los debates y las significaciones del trabajo indígena en la región andina, su estatus, definición y tratamiento por parte de la OIT (Barragán, 2017), como también en el caso de las consideraciones y las redefiniciones del trabajo esclavo y del trabajo forzado en Brasil (Ferreras, 2017).

Por otra parte, apostamos a recuperar la dimensión conflictiva de esa arena de disputa que, a distintos niveles, espacios y sujetos, constituyó la OIT tanto para Gobiernos y empresarios como para organizaciones obreras. Disputas locales fueron resignificadas por sus propios contendientes al vincular espacios locales con reglas pretendidamente internacionales, y muchas de las respuestas internacionales encontraron oposición en razón de disputas domésticas en distintos momentos y países (Caruso, 2017; Basualdo, 2017; Zorzoli, 2016; 
Yáñez, 2017; Nunes, 2017), no solo en América Latina (Cobble, 2016). Así, el trasvasamiento de las fronteras volvió a estas disputas en una lucha de alianzas que incluía no solo a los funcionarios de la propia OIT, sino, fundamentalmente, a otros actores con los que se tejían alianzas y lazos superpuestos. Por último, pero encabezando esta reflexión, queremos dar visibilidad a la participación activa -mas no lineal ni uniforme- que desplegaron los actores de la región en la constitución de dicho vínculo y en la propia historia de la OIT; es decir, a si la OIT fungió en ocasiones como fuente de definición y de límites de un campo laboral específico -por ejemplo, respecto al trabajo de los niños o el desempleo-, y si esta función no fue impuesta desde o adoptada por, sino construida con los actores latinoamericanos. Rescatar el propósito, muchas veces manifiesto, de los actores latinoamericanos en su relación con la OIT es también remarcar la impronta de ese aporte a la propia historia de dicha organización que, frecuentemente, queda subsumida en la bibliografía por la imposición de una agenda desde Ginebra.

En las últimas décadas, la historiografía vinculada a organizaciones internacionales como la OIT ha presentado un creciente interés cualitativo y cuantitativo (Iriye, 2002; Maul, 2012, 2017; Kott y Droux, 2013; McPherson y Wehrli, 2015; Jensen y Lichtenstein, 2016), en el marco del impacto de la historiografía de carácter global. Esto se debe, en primer lugar -y como sostiene Jasmine Van Daele (2008)-, al fin de la Guerra Fría y a una nueva oleada del proceso de globalización, cuando los Estados-nación retomaron el interés por la coordinación de políticas internacionales en estructuras multilaterales; $y$, en segundo lugar, porque este contexto revitalizó el rol de las organizaciones internacionales, como la OIT. Este reciente impulso se traduce en congresos, ponencias, simposios y artículos que muestran, de manera fragmentaria, la necesidad de desentrańar la dimensión transnacional de regulación, definición y concepción del trabajo y su anclaje en América Latina. Descentrando la mirada de los Estados-nación, esta nueva línea de análisis viene a redimensionar la relevancia de otros actores y procesos que surgen de la intersección de la dimensión internacional y local, de la mirada atenta a las delegaciones obreras y empresariales, así como a las delegaciones de países coloniales o en diversas situaciones de sujeción. Desde distintos puntos, estas investigaciones convergen en postular la centralidad de la vinculación y del impacto de las instituciones internacionales y los procesos locales, sus actores y sus dinámicas.

Ahora bien, en este nuevo repertorio investigativo, la ausencia relativa de América Latina y un análisis crítico de su vinculación con la OIT es tal vez uno de los rasgos cuya atención queda pendiente. Hasta hace poco, la OIT, pensada e historizada desde la región latinoamericana, no había sido objeto privilegiado del interés de los historiadores o cientistas sociales, a pesar de ser la institución que materializaba la búsqueda de conocimiento de las 
múltiples realidades y experiencias del trabajo alrededor del mundo, para autoconstruirse como una realidad supranacional que las abarcara, conociera y regulara. Esta ausencia relativa es todavía más llamativa si se considera que fue en esta región donde se organizó por primera vez una Conferencia Regional de la OIT (Santiago de Chile, 1936), iniciando una forma institucional que fue homologada por la institución en Asia recién en 1947, en Europa en 1954 y en África en 1960. Hoy en día, contamos con diversos aportes y un camino abierto por el libro que hace ya cinco años compilaron Fabián Herrera León y Patricio Herrera González (2013), en cuya inspiración se basa la convicción de que la única posibilidad real de generar este tipo de conocimiento es a través de diálogos e intercambios entre investigadores e instituciones, de manera fraterna, colectiva y colaborativa.

\section{La Organización Internacional del Trabajo bajo el prisma latinoamericano}

Si el fin de la Primera Guerra Mundial dio lugar a la conformación de este organismo de carácter internacional, dedicado a la promoción de la legislación laboral en el marco de los tratados de paz europeos, el transcurso del siglo XX vio su desarrollo exponencial hacia áreas geográficas y hacia diversas problemáticas vinculadas al trabajo alrededor del mundo. Generalmente, el proceso expansivo de las actividades de la OIT está asociado con el fin de la Segunda Guerra Mundial y su integración a la naciente Organización de las Naciones Unidas (ONU), bajo la dirección del estadounidense David Morse desde 1948. Este periodo del organismo se considera como el de mayor expansión, debido a la multiplicación de sus miembros y funcionarios, a la apertura de oficinas locales y regionales, y al inicio de la ejecución de programas regionales referidos al empleo de forma integral. Estos años de febril actividad -que le valió al organismo el premio Nobel de la Paz-son considerados como los de efectiva internacionalización, fundamentalmente por la actuación en los procesos de descolonización y por el vínculo de los derechos sociales con los derechos humanos (Maul, 2017). Sin embargo, la centralidad de estas problemáticas -y no de algunos aspectos ligados a los debates sobre el desarrollo- desplazan a América Latina a un lugar secundario en esta cronología establecida desde el espacio europeo.

Desde este espacio adquiere mayor relevancia el proceso de las décadas previas. En esta expansión -primordial para la supervivencia del propio organismo durante sus primeros años-, América Latina adquiere una centralidad fundamental. Como demuestra Norberto Ferreras (2011), Albert Thomas, primer director de la OIT, buscó en los países latinoamericanos el apoyo que no encontraba entre los europeos en el periodo de entreguerras; recordemos el abandono de la OIT de Alemania e Italia, así como Japón, 
entre los años 1934 y 1935. La vinculación privilegiada de América Latina durante este periodo inicial, entonces, ayuda a repensar la propia cronología de la OIT en la medida en que, en esa década, el rasgo más relevante en la historiografía de la organización fue el ingreso de Estados Unidos en 1934, bajo la presidencia de Franklin Roosevelt. ${ }^{2}$

La OIT sobrepasó así el espacio europeo con su propuesta y sus iniciativas regulatorias, que apuntaron a configurar una respuesta a la movilización obrera a través de la internacionalización de los principios de legislación laboral y de otras formas de intervención, en aras de delimitar un campo legal, legítimo y compartido de acción, disputas y demandas. Desde su creación en 1919, la OIT se constituyó en un actor relevante, y cada vez más a lo largo del siglo XX, para pensar tanto la construcción de la intervención de los Estados nacionales en el mundo del trabajo como, sobre todo, la definición de ciertos campos laborales constituidos en torno a aquello que se definió como trabajo en su seno, en función de un conjunto de sentidos y supuestos que merecen ser analizados. Precisamente, la definición de estos campos laborales estuvo configurada por las tensiones y los intereses diversos de los Estados miembros, los empresarios de numerosos sectores y magnitudes, y los trabajadores de diversos países. La peculiar característica que aún hoy distingue al organismo entre las demás entidades del ámbito mundial es la inclusión de la representación de los tres sectores socioeconómicos y políticos considerados clave -Estado, capital y trabajo-, configurando una estructura tripartita que la dotaba de legitimidad, singularidad y potencialidad en aquellos primeros años, y que aún hoy se reconoce como un elemento fundamental en la construcción política global ginebrina. La participación tripartita, además, permitió que los debates que se daban en el seno de la organización continuaran en los países miembros, garantizando así el papel de la propia Oficina Internacional del Trabajo -el órgano ejecutivo de la OIT- como una usina de pensamiento con capacidad de incidir en las políticas laborales a nivel global.

En la construcción histórica y negociada de los diversos campos del trabajo a ser intervenidos por políticas laborales -como ser el trabajo marítimo, el trabajo infantil, el trabajo femenino, el trabajo en áreas no metropolitanas, el trabajo indígena y el trabajo forzado, por mencionar algunos-,

2 El vínculo entre Estados Unidos y la OIT ha ocupado gran parte de la bibliografía sobre esta entidad, en especial a partir del retiro de este país de la organización en 1977 y su reingreso en 1980 -que produjo un fuerte impacto en el campo historiográfico-, y en lo referido a los procesos de descolonización, respecto a lo que Estados Unidos asumió una posición diametralmente opuesta a los intereses de países europeos como Francia y Gran Bretaña. 
se expresaron las demandas y disputas de intereses y posiciones entre estos tres sujetos -empleadores, Estados y organizaciones de trabajadores-, sus expectativas y estrategias. Pero también aquellas tensiones entre los diversos países del concierto mundial y sus jerarquías -esto último fue primordial en lo relativo al trabajo en los territorios no metropolitanos y al trabajo marítimo-. Un consenso fundamental configuró el conjunto de los campos laborales a ser regulados: concebirlos como trabajo implicaba dotarlos de derechos. De esta manera, en la primera posguerra, y ante la presencia activa de la clase trabajadora en el mundo, la noción de trabajo que definía un campo estaba directamente ligada, o así era concebida, a un conjunto de derechos laborales, reconocidos en ese nuevo orden que la OIT impulsaba frente a la guerra y la revolución: la justicia social como proyecto y política integradora y homogénea, al menos en la voluntad del propósito ginebrino (Kott y Droux, 2013). Cuestiones como el trabajo indígena desde la década de 1960 o el trabajo forzado aun en la actualidad constituyen mojones en ese camino proyectado.

Nuevas reflexiones sobre este tema construyen conceptualizaciones desde nuestro continente, como es el caso del trabajo de Rossana Barragán (2017), que invita a pensar el vínculo de la OIT con América Latina en torno a una geografía diferencial de derechos. El aporte de esta autora, en sintonía con una extendida tradición latinoamericanista, llama a reflexionar sobre las tensiones inherentes a los procesos integradores, como el que supone la OIT en términos globales y sus implicancias locales, nacionales y supranacionales. En el caso de América Latina, esto implicó reconocer que su condición especial se derivaba tanto de la distancia frente a los países centrales -que contaban con un mayor peso en las decisiones sobre el rumbo del organismo, fundamentalmente en el seno de la Oficina-, como de la distancia que la separaba de los países periféricos, verdaderas situaciones "especiales" en la consideración de varios de los actores latinoamericanos (Stagnaro y Caruso, 2017). Pero, al mismo tiempo, en tanto la OIT constituía discursos en la "opinión pública" global (Maul, 2017), fijaba a su vez ciertos estándares de lo que se consideraba como desarrollo y configuraba una escala sobre la cual los países latinoamericanos se medían, comparaban y construían sus aspiraciones.

En la actualidad, algunas perspectivas, entre ellas la provincialización de Europa, permiten abordar procesos complejos, como la extensión de una institución como la OIT, sin caer en una antinomia entre países centrales y periféricos. Al pensar la realidad europea como un caso más -determinante en muchos casos, claro está- y no como la normalidad o la vara, los nuevos marcos analíticos permiten reinstalar la conectividad en la que se configuran y despliegan las definiciones del trabajo, sin caer en 
las particularidades nacionales como excepcionalidad explicativa. Si bien este proceso historiográfico aún está en desarrollo, presenta potencialidades para los estudios desde América Latina, en la medida en que -y a contramano, por lo general, de las autoridades estatales que participaban en la organización- habilita a pensar estas situaciones ya no como divergencias o excepcionalidades, sino en el marco de la propia configuración de lo que se puede catalogar como trabajo.

Con este recorrido, cabe arriesgar, o al menos esbozar, una cronología inicial e inacabada de la relación entre la OIT y América Latina, que intenta ser reflexiva incluso en sus generalizaciones. Sin descuidar la cronología que la historiografía ha establecido para la propia OIT -cronología también en disputa-, lo que se pretende aquí es trazar a grandes rasgos aquello que comprendemos como características de la relación entra la OIT y América Latina. Esto no implica que no haya divergencias o excepciones con algunas naciones -como Venezuela, que atravesó diferentes momentos de extrema tirantez con el organismo, incluido su retiro en 1955-. Tampoco supone que esta cronología deba adoptarse en forma autónoma e independiente de las establecidas para otras regiones. Pero, sin duda alguna, ciertas problemáticas que tuvieron gran importancia en la OIT no despertaron el interés de los países latinoamericanos -como la descolonización en las décadas de 1950 y 1960-, mientras que debates sobre el desarrollo o los derechos humanos, así como las misiones de asistencia técnica, sí tuvieron un fuerte impacto en las agendas latinoamericanas. Así, se presentan aquí seis etapas que no buscan dar una interpretación acabada, sino proponer un ordenamiento general.

Un primer momento, entre 1919 y 1925, se caracterizó por un vínculo entre ambas partes signado por grandes expectativas, a partir de una distancia expectante, producto en gran parte de cierta desconfianza sobre el carácter universal de la OIT. No era la primera vez que se intentaba constituir un organismo dedicado a promover la legislación del trabajo a escala planetaria, y sus antecedentes no habían logrado trascender de forma permanente las fronteras impuestas por el propio desarrollo industrial europeo o norteamericano. ${ }^{3}$ Con excepción de Cuba y México, ningún país latinoamericano participó de forma oficial en estos intentos, aunque en algunos casos se establecieron contactos extraoficiales con organismos y funcionarios de segundo y de tercer orden relacionados al mundo laboral. Estos lazos previos, aunque débiles, fueron fundamentales a la hora de construir las expectativas. Los vínculos con figuras prominentes del reformismo social latinoamericano garantizaron

3 Sobre la importancia del núcleo europeo en los antecedentes de la OIT, véase: Kott, 2015. 
una fuerte difusión de las actividades de la OIT en los escenarios locales, e incluso favorecieron la incorporación de algunas organizaciones obreras en el debate.

Los ańos que van desde 1925 a 1936 presenciaron ciertos intentos de institucionalización como clave de la nueva etapa. Superadas las suspicacias iniciales, los países latinoamericanos comenzaron a tejer lazos de carácter permanente con la OIT, materializados en una red cada vez más cuantiosa de corresponsales, publicaciones, fluida comunicación y consolidación de vínculos académicos-profesionales. América Latina se tornó para la OIT en un espacio fecundo para su prédica de paz y justicia social, lo cual se tradujo en los viajes del director del organismo, el francés Albert Thomas, a distintos países de la región en 1925. En sus viajes, Thomas recibió con satisfacción el avance de las ratificaciones de las convenciones de la OIT por los países de la región y una cada vez mayor legislación laboral. La positiva respuesta encontrada en América Latina permitió sostener la prédica internacionalista de la OIT en momentos en que el aislacionismo norteamericano y una escasa ratificación de sus convenciones por parte de sus miembros habían llevado al organismo a una crisis.

A partir de 1936, y hasta mediados de la década de 1950, se abrió un nuevo periodo caracterizado por cierta relevancia y autonomía de los países latinoamericanos en la OIT, desplegando una agenda propia dentro del organismo y, por momentos, pareciera que por fuera del mismo. La Primera Conferencia del Trabajo de los Estados Americanos Miembros de la OIT -la primera de este tipo y que, como dijimos, marcaría una innovación organizativa hoy consolidada: las conferencias regionales- se desarrolló en Santiago de Chile en 1936. A partir de entonces, se realizaron con periodicidad hasta el día de hoy, incluso en momentos en que la misma OIT debió suspender sus conferencias generales en plena Segunda Guerra Mundial entre 1939 y 1944. ${ }^{4}$ La Conferencia de Santiago de Chile inició la construcción de una agenda constituida por y desde los países latinoamericanos participantes, mostrando, al mismo tiempo, la madurez de las relaciones entre la región y la OIT, y la autonomía latinoamericana frente a la sede ginebrina.

Desde mediados de 1950 y hasta finales de la década de 1960 puede apreciarse una pérdida de la importancia relativa de América Latina ante la OIT, coincidiendo con un proceso de descentralización propuesto desde el

4 Si bien la OIT sobrevivió al colapso de la Sociedad de Naciones, el traslado de su sede durante la Segunda Guerra Mundial y su virtual refundación mediante la declaración de Filadelfia, en 1944, constituyen un parteaguas fundamental para el organismo; sin embargo, el impacto de esta medida en la región fue posterior. 
organismo, enfocado en los procesos de descolonización de África y parte de Asia (Maul, 2017). Este periodo está signado por las relaciones bilaterales entre los Estados miembros y el organismo. Se observa que los vínculos establecidos previamente sostuvieron cierta continuidad en la agenda propia, al mismo tiempo que se constituían nuevos mecanismos en las relaciones que unen esta cronología con la propia cronología de la OIT. Estos mecanismos fueron las misiones de asistencia técnica y, en el caso particular de América Latina, el Programa Andino, proyecto que desde 1953 estableció un vínculo privilegiado entre estas naciones -Perú, Ecuador, Bolivia, Colombia, Argentina y Chile, aunque estos dos últimos en menor mediday la OIT. Además, inauguró en la región una función nueva para la OIT: la de organismo técnico de la ONU, un papel que cumpliría de ahí en adelante. Este programa estuvo, además, vinculado a toda una serie de discursos sobre el desarrollo, a tono con los postulados de la ONU y de la propia OIT en ese periodo. El bilateralismo en las relaciones también es apreciado en las disputas entre Venezuela y la OIT, que desembocaron en el retiro del organismo de la dictadura de Marcos Pérez Jiménez en 1955, después de varios años de denuncias sobre la libertad sindical (Yáńez Andrade, 2017). El desarrollo de las misiones técnicas fue configurando un nuevo mapa de las relaciones entre Ginebra y América Latina. Así, si en sus primeros años estos vínculos tuvieron como eje a Buenos Aires, y desde mediados de la década de 1920 a Santiago, la importancia del Programa Andino trasladó en 1968 ese eje a la ciudad de Lima, donde la sede regional de la OIT funciona hasta la actualidad.

En plena Guerra Fría, este periodo estuvo marcado también por las enemistades que en algunos actores despertaba una institución percibida como imperialista. Esta acusación, que tiene una historia propia para América Latina, marcada por una constitución cultural en el campo del antiimperialismo por lo menos desde la década de 1920, encontraba sostén en la vinculación de la OIT con expresiones sindicales bajo la égida de la Federación Estadounidense del Trabajo y Congreso de Organizaciones Industriales (AFL-CIO). Las pujas sindicales a nivel global encontraron a la OIT más cercana a las construcciones institucionales del sindicalismo libre, y el organismo incluso ofreció sus espacios de formación sindical a estas expresiones ideológicas (Scodeller, 2017; Corrêa, 2017).

La década de 1970 inauguró el ascenso de regímenes autoritarios, dictaduras militares que volvieron a tensionar la relación del organismo ginebrino con América Latina, tensión que se manifestó en puntos centrales como la libertad sindical o la persecución a líderes sindicales, hasta por lo menos mediados de la década de 1980. Las críticas esbozadas a Venezuela desde fines de la década de 1940 recrudecieron a nivel regional y las vinculaciones 
cada vez mayores entre el discurso del desarrollo y el discurso de los derechos humanos -a tono con la agenda de la ONU- marcaron la relación entre América Latina y la OIT. La agenda de dicha etapa indica el comienzo de un vínculo cada vez mayor entre los derechos laborales y los derechos humanos, relación orientada por el organismo hacia el campo laboral, generando una intensa dinámica entre derechos laborales y derechos humanos. Así, la agenda laboral se coloca en una nueva perspectiva en la relación de la OIT con América Latina y se convierte en una arena importante para las denuncias del carácter autoritario de las dictaduras latinoamericanas.

En la década de 1980, en nuestra periodización aún hipotética, se dio inicio a una nueva etapa, signada por la búsqueda de consolidación de las democracias emergentes en el continente, junto a la preocupación sobre las dificultades del organismo de lograr sus objetivos, en una situación laboral atravesada por las recurrentes y extremas crisis económicas. La aplicación generalizada de reformas de tipo neoliberal dio paso a una última etapa, en la cual la preocupación del organismo se plasmó en la consigna/objetivo "trabajo decente", en el preciso momento en que la precarización y terciarización del trabajo -conocida como flexibilización laboral-inició una escalada aún en ascenso en el continente (Basualdo y Morales, 2014).

La cronología aquí presentada busca reflexionar someramente acerca de las relaciones entre América Latina y la OIT, pero, fundamentalmente, expresa la preocupación por la centralidad de los eventos europeos en la constitución de la historiografía sobre este organismo en el que la periodización se resuelve a través de los cambios en su interior -y básicamente en su organismo ejecutivo y su burocracia, la Oficina Internacional del Trabajo- o mediante los intereses europeos y norteamericanos en su relación con la organización. Sin desechar esas cronologías, lo aquí expuesto busca reafirmar una agenda propia de los Estados latinoamericanos, agenda muchas veces secundaria en el seno del organismo, pero de una importancia cardinal para los actores latinoamericanos involucrados.

\section{Un TRABAJO COLABORATIVO: LA RED INTERDISCIPLINARIA OIT-AmÉRICA LATINA, TRABAJOS,} FORMAS E INTERROGANTES

El desarrollo de la perspectiva latinoamericana con relación a la OIT y el mundo del trabajo supone un diálogo y un intercambio por sobre las fronteras nacionales, lo que se materializa en una producción fundada en la colaboración. Para pensar la regulación de los mundos del trabajo latinoamericano y su vínculo con la OIT, así como la propia historia de la OIT en el continente y la reconfiguración de la política local, los usos y las agencias de los diversos actores -sindicatos, Gobiernos, entidades profesionales y expertos, entre 
otros- ante esta nueva institucionalidad presente en el campo laboral, y constitutiva a su vez del mismo, fue necesario crear un nuevo espacio académico, regional e interdisciplinario. Así nació la Red Interdisciplinaria OIT-América Latina, la que se materializó en talleres interdisciplinarios realizados en forma bianual en la Universidad Nacional de La Plata, Argentina (2015), y en la Universidad Federal Fluminense, en la ciudad de Niterói, Brasil (2017), con la perspectiva de un nuevo encuentro en Santiago de Chile (2019), y con un trabajo común plasmado en un dossier temático (Stagnaro y Caruso, 2017) y en un libro (Caruso y Stagnaro, 2017), publicaciones emanadas de las discusiones y los ejes trabajados. Hoy en día, la Red reúne a investigadores de diversos países de la región, como Chile, Brasil, Argentina y Bolivia, y tiene vínculos con interlocutores en Paraguay, Uruguay y Ecuador.

Un recorrido por su producción posibilita identificar los aportes en torno a algunas de las preguntas planteadas en la introducción en el contexto de la primera mitad del siglo XX. Por ejemplo, las formas, las categorías y los derechos que definieron al trabajo y a los trabajadores indígenas en los debates dentro de la OIT, en diálogo con las experiencias andinas, y, en sentido más amplio, con los países coloniales (Barragán, 2017); las concepciones y los actores puestos en juego en la discusión sobre el trabajo forzado y el trabajo esclavo, su debate en la OIT y sus derivaciones en Brasil y Argentina (Ferreras, 2017); la delimitación y la problematización del trabajo femenino en las Conferencias Internacionales del Trabajo -preocupación que se centró en torno a la brecha de desigual retribución salarial entre mujeres y varones ante tareas similares-; y el impacto de estos debates en los Estados y los actores participantes en el caso argentino (Queirolo, 2017) muestran temporalidades, sujetos y categorías laborales que, desde y en América Latina, participaron y accionaron en la configuración histórica de estos tres campos laborales. La existencia de estos estudios pone de manifiesto, de manera evidente, las contradicciones y los límites del propio discurso construido por la OIT en torno a la universalidad de los derechos y las normativas, en plena tensión con los particularismos enunciados y articulados a diversas relaciones de poder y desigualdad. Un caso similar lo ofrece la regulación y la configuración del tiempo libre y las vacaciones como derechos, en particular en Brasil, en la primera mitad del siglo XX, donde a partir de la década de 1920 se originaron las primeras leyes, plasmándose en una ley más integral en 1934. Ambos casos con diverso grado de vinculación y recepción de los planteos ginebrinos sobre ese tema (Nunes, 2017).

El trabajo infantil como campo de intervención conllevó también sendos debates y nociones en las Conferencias Regionales del Trabajo de América Latina, realizadas en Chile (1936) y en Cuba (1939), donde se pudo visualizar a la región con una voz propia y no como mera apropiación de los convenios y debates ginebrinos. En esa voz se ha rastreado la construcción 
performativa de infancias y juventudes modélicas -en tanto agentes del futuro o trabajadores del mañana-, y el rol de la familia como contexto laboral legítimo, junto a las formas que adoptó la construcción de una regulación internacional sobre niños, niñas y jóvenes y su trabajo, plasmada en convenios como instrumentos de clasificación, debate y disputa en torno a su ratificación por los diversos países de América Latina.

Otros campos, como espacios de intervención estatal multidimensional en la región, se constituyeron en diálogo con la OIT, y en el espacio ginebrino tuvieron especial presencia: el derecho laboral (Stagnaro, 2017) y la regulación del trabajo marítimo (Caruso, 2017). En ambos casos, se evidencia el protagonismo de expertos e intelectuales latinoamericanos que actuaron en la OIT y sus instancias, entramando una red cada vez más amplia y densa basada en un interés y una necesidad mutuos de la OIT y de tales expertos en su construcción y legitimación. Es posible ubicar aquí también a los líderes sindicales latinoamericanos representantes ante la OIT, cuya delegación y elección ha sido motivo de tensiones, negociaciones y conflictos (Stagnaro y Caruso, 2017). El caso particular del líder obrero mexicano Vicente Lombardo Toledano y su vínculo con Moisés Poblete como miembro de la OIT son un ejemplo de mutua configuración y de cómo esa relación construyó institucionalidad laboral en América Latina. En la relación entre los actores locales y la OIT, en la circulación de expertos e ideas, tuvieron un lugar central las publicaciones especializadas. Es el caso de El Boletin Informativo de Leyes de Trabajo, hacia mediados del siglo XX, en el cual los temas y los actores de las políticas sociales de países vecinos y de la OIT eran referencias locales e insumos fundamentales y legitimadores de la discusión sobre tales políticas (Ramacchiotti, 2017).

Un conjunto de los trabajos producidos en el marco de la Red ha reflexionado en torno a las dinámicas particulares y los desafíos que América Latina presentó a la OIT, considerando que nuestro continente estuvo marcado por el constante recambio de regímenes de excepción, autoritarios, liderados por fuerzas militares en su mayoría y por gobiernos democráticos débiles, que en mucho afectaron y condicionaron las formas del trabajo y el ejercicio de sus derechos reconocidos por la misma OIT. Para el caso de Venezuela, hacia mediados del siglo XX se interpretó la forma en que se intensificaron las relaciones del movimiento sindical latinoamericano, en particular ante las denuncias por violación a la libertad sindical durante la dictadura militar de Carlos Delgado, iniciada en 1948 (Yánez Andrade, 2017). Por otra parte, y contra el sentido común que piensa a estos regímenes como monolíticos y cerrados al diálogo con la OIT, o que supondría la total negación frente al organismo internacional, otros trabajos han mostrado el lugar significativo que la última dictadura argentina le dio a la OIT en momentos críticos, como espacio de 
legitimidad ante el mundo y ante los actores nacionales, y en particular, cómo este espacio internacional permitió una reconfiguración de las relaciones con el movimiento sindical local. A su vez, la OIT fue espacio de denuncias al gobierno militar argentino por violaciones a la libertad sindical (Basualdo, 2017; Zorzoli, 2017). En el periodo álgido de golpes militares en la región, desde la segunda posguerra hasta la década de 1970, la OIT implementó una particular estrategia educativa en torno al sector obrero. Así lo muestra un estudio sobre los programas de formación sindical para los países en vías de desarrollo, como estrategia educativa desplegada por la OIT en materia de promoción de derechos laborales en América Latina a partir del Programa de Educación Obrera, dependiente de la División de Educación Obrera. Por sobre las formas institucionales del programa, la autora se pregunta allí en torno a contenidos, buscando sentidos y concepciones sobre trabajo, trabajador y derechos, y la consolidación de tales sentidos en la vinculación entre actores locales y el ente ginebrino, a través del cual se reforzaban ciertas nociones de trabajo, trabajador y derechos (Scodeller, 2017).

En conjunto, el sentido último de estos trabajos que componen una parte nutrida de la producción de la Red OIT-América Latina es reposicionar a la región en la historia de la OIT y del trabajo, al mirar de forma renovada la participación de América Latina en la constitución de políticas de intervención en el campo del trabajo a lo largo de todo el siglo pasado y en lo que va del actual. A su vez, apuntan a construir un nuevo y novedoso conocimiento en torno a las complejas y múltiples formas de vinculación entre la OIT -como organismo de alcance virtualmente mundial para la regulación de las relaciones de trabajo- y las acciones, los debates y los proyectos estatales y políticos en materia de trabajo en la región. Tal conocimiento de las diversas dimensiones que vincularon a la OIT con América Latina, y sus realidades polifónicas, nacionales y locales, permitirá a su vez, como mencionamos, dotar de visibilidad al propio lugar de América Latina, en el concierto internacional regulatorio.

Esa perspectiva, ausente en la producción y el debate historiográfico actual sobre dichos temas, podría aportar incluso a la revisión de la propia historia institucional de la OIT, a partir de diversas investigaciones contemporáneas que marcan un camino próspero a seguir.

Tales trabajos e investigaciones - muy diversos en sus geografías, temas y abordajes- componen una trama común de intereses, itinerarios científicos, colaboraciones e interrogantes. Enfatizan tanto en las políticas y las agencias laborales como en los debates y los proyectos de legislación, la interacción entre instituciones locales e internacionales del trabajo, y el desarrollo del derecho del trabajo, así como en los actores participantes de y en la OIT -delegados tripartitos y expertos, entre otros-. En conjunto, permiten articular un diálogo necesario y conformar la Red Interdisciplinaria OIT-América Latina, una 
instancia de colaboración e intercambios de ideas, temas y recursos que da lugar a plantear una agenda común de problemas e interrogantes, la cual, sin disminuir la importancia de los estudios de caso y las especificidades, apunte sus esfuerzos a la construcción de una historia regional de la regulación del trabajo, en general, y del vínculo de nuestra región con la OIT, en particular.

El objetivo inmediato de la Red fue poner en diálogo producciones individuales que, en concierto, produjeran un salto cualitativo en los interrogantes, las escalas, los recursos y los documentos, y las perspectivas con que se aborda la historia de la OIT de manera conectada con la regulación del trabajo y las políticas y los actores de los países latinoamericanos.

Al enfatizar tanto en las políticas y las agencias laborales como en los debates y los proyectos de legislación, la interacción entre instituciones locales e internacionales del trabajo y el desarrollo del derecho del trabajo, incluidos los actores participantes de y en la OIT -delegados tripartitos y expertos, entre otros-, las investigaciones que forman parte de la Red, muy diversas en sus geografías, temas y abordajes, componen una trama común de intereses, itinerarios científicos, colaboraciones e interrogantes. Creemos que el trabajo y el diálogo colaborativo y constructivo entre disciplinas, instituciones, proyectos y colegas permitirá materializar de manera creciente la producción de conocimiento vinculado a estos temas, desplegando su complejidad y sus desafíos metodológicos, y planteando, asimismo, nuevas interrogantes.

\section{RECUPERAR LA CONEXIÓN OIT-AMÉRICA LATINA EN LAS CONFIGURACIONES DEL MUNDO DEL TRABAJO, SU DEFINICIÓN Y REGULACIÓN: UNA NUEVA AGENDA}

La experiencia desarrollada en los encuentros de la Red Interdisciplinaria OIT-América Latina y las diversas líneas e indagaciones que confluyen en ella plantean preguntas sobre un amplio espectro de temas y procesos en torno a la relación del organismo internacional con América Latina. Al mismo tiempo, potencia la necesidad de colaboración e intercambios con investigadores e investigadoras de otros continentes, a fin de comparar y vincular procesos, tiempos y formas de dicho vínculo. Lo hecho y los recursos establecidos permiten plantear con cierto optimismo una agenda común que conecte la región con la OIT y que, a la vez, esté fuertemente situada en los mundos del trabajo de los diversos países latinoamericanos. Las realidades históricas y presentes de tales sociedades, y sus especificidades, son el prisma para pensar y mirar la OIT, haciendo un esfuerzo por construir una historia regional de la regulación del trabajo y del vínculo con la OIT.

En principio, se hace patente la necesidad de una mirada más amplia, global pero no globalizante, que supere el nacionalismo historiográfico, sin por ello anular especificidades y procesos locales. El impulso de investigaciones 
ancladas en lo local permitiría iluminar las múltiples vinculaciones, las redes, los actores y los procesos recíprocos entre las diversas dimensiones y escalas.

Cabe, por un lado, una breve y positiva reflexión respecto al archivo. A partir de nuestro propio trabajo, sus limitaciones y sus dificultades, se destaca la diversidad y la originalidad de fuentes y repositorios de documentación con los que es posible abordar la OIT desde la región: informes, delegaciones, escritos y libros de delegados y políticos latinoamericanos; informes de corresponsales y expertos nacionales o internacionales; publicaciones especializadas en temas del trabajo, tanto estatales como de expertos y profesionales; periódicos diversos de carácter comercial, sindical, partidario; cartas y correspondencia variada entre delegados sectoriales; leyes y debates parlamentarios; actas de las conferencias -muchas de ellas digitalizadas-; y la lista es aún más extensa. La amplitud y la variedad de este corpus puede y debe ser profundizado con el archivo de la misma OIT, en la cual las vías de búsqueda son múltiples: por temas debatidos, por corresponsales o funcionarios, por conferencias y por secciones. Así, el archivo de la institución radicada en Ginebra, visto a partir de preguntas ancladas en el espacio latinoamericano, tiene un enorme potencial para desarrollar estas y futuras investigaciones.

Avanzando en este sentido, estamos conscientes de la enorme necesidad que existe en nuestras historiografías nacionales por conocer, para cada periodo y en profundidad, los mecanismos, las lógicas institucionales y las transformaciones estructurales (organigrama) de la OIT, las dependencias vinculadas a América Latina y las formas de su presencia en nuestra región (oficinas, corresponsalías, conferencias). Más conocidos que el resto, los delegados gubernamentales a las Conferencias Internacionales del Trabajo, incluidos los expertos o técnicos, aún ameritan análisis extensos en diversas latitudes respecto a sus procesos de selección, su grado de autonomía, sus iniciativas, posiciones y vínculos con la OIT y con sus respectivos Gobiernos, con los delegados de los gremios y los centros patronales. Precisamente, estos últimos dos actores son, tal vez, los menos analizados hasta hoy en los trabajos desarrollados sobre la temática.

Este mapa de interrogantes y temas, inconcluso e incipiente, busca organizar, a modo de diagnóstico, el estado del campo de conocimiento y visibilizar aquello que aún está por explorarse, si bien existen algunos trabajos bien encaminados sobre el tema, como los espacios regulatorios paralelos -en competencia o colaboración-a las directivas de la OIT: las Conferencias Interamericanas y Panamericanas, la construcción de una agenda propia latinoamericana, sus sentidos y políticas, y los actores locales que las construyeron. Los desafíos de tal programa de investigación, así esbozado, solo pueden ser encarados y superados por un extenso trabajo colaborativo, más allá de fronteras políticas, geográficas y disciplinares, y la promoción de un diálogo fecundo al cual este escrito es una invitación. 
198 | Trabajos y trabajadores en América Latina (siglos XVI-XXI)

BibLIOGRAFÍA

Barragán, Rossana

2017 "La geografía diferencial de los derechos: entre la regulación del trabajo forzado en los países coloniales y la disociación entre trabajadores e indígenas en los Andes (1920-1954)". En: Laura Caruso y Andrés Stagnaro (coords.), Una historia regional de la OIT. Aportes sobre regulación y legislación del trabajo latinoamericano. La Plata, Argentina: Facultad de Humanidades y Ciencias de la Educación, Universidad Nacional de La Plata.

Basualdo, Victoria y Diego Morales (coords.)

2014 La tercerización laboral. Origenes, impacto y claves para su análisis en América Latina. Buenos Aires: Siglo Veintiuno Editores.

Basualdo, Victoria

2017 "La OIT entre la dictadura y la democracia en la Argentina: aportes sobre el papel de organizaciones internacionales en la reconfiguración de las relaciones laborales en la primera mitad de los años 80 ". En: Anuario del Instituto de Historia Argentina, volumen 17, número 1. e038.

Boris, Eileen; Dorothea Hoecker y Susan Zimmermann (eds.)

2018 Women's ILO. Transnational Networks, Global labour Standards and Gender Equity, 1919 to present. Leiden, Países Bajos / Boston, Estados Unidos de América: Brill / ILO.

Caruso, Laura

2017 "Legislando en aguas profundas. La OIT, nuevas reglas para el trabajo marítimo y su desarrollo en la Argentina de la primera posguerra". En: Laura Caruso y Andrés Stagnaro (coords.), Una historia regional de la OIT. Aportes sobre regulación y legislación del trabajo latinoamericano. La Plata, Argentina: Facultad de Humanidades y Ciencias de la Educación, Universidad Nacional de La Plata.

Caruso, Laura y Andrés Stagnaro (coords.)

2017 Una historia regional de la OIT: Aportes sobre regulación y legislación del trabajo latinoamericano. Serie Estudios/Investigaciones, número 62. La Plata, Argentina: Facultad de Humanidades y Ciencias de la Educación, Universidad Nacional de La Plata. Disponible en: http:// www.libros.fahce.unlp.edu.ar/index.php/libros/catalog/book/93

Cobble, Dorothy Sue

2016 "Japan and the 1919 ILO Debates Over Rights, Representation and Global Labour Standars”. En: Jill M. Jensen y Nelson Lichtenstein 
(eds.), The ILO from Geneva to de Pacific Rim. West meets East. Londres: Palgrave Macmillan / International Labour Organization.

Corrêa, Larissa Rosa

2017 Disseram que voltei Americanizado. Relaçôes sindicais Brasil-Estados

Unidos na ditadura militar. Campinas, Brasil: Editora de Unicamp.

Ferreras, Norberto

2017 "Trabajo esclavo contemporáneo y trabajo forzado. Las políticas de la OIT y el Brasil en diálogo y conflicto, 1930-1990”. En: Laura Caruso y Andrés Stagnaro (coords.), Una historia regional de la OIT. Aportes sobre regulación y legislación del trabajo latinoamericano. La Plata, Argentina: Facultad de Humanidades y Ciencias de la Educación, Universidad Nacional de La Plata.

2011 "Entre a expansáo e a sobrevivencia: a viagem de Albert Thomas ao Cone Sul da América”. En: Antiteses, número 4. 127-150.

Herrera León, Fabián y Patricio Herrera González (eds.)

2013 América Latina y la Organización Internacional del Trabajo: redes, cooperación técnica e institucionalidad social, 1919-1950. México: $\mathrm{UMSNH} / \mathrm{UM} / \mathrm{UFF}$.

Iriye, Akira

2002 Global Community: The Role of International Organizations in the Making of the Contemporary World. Berkeley, California, Estados Unidos de América: University of California Press.

Jensen, Jill M. y Nelson Lichtenstein (eds.)

2016 The ILO from Geneva to de Pacific Rim. West meets East. Londres: Palgrave Macmillan / International Labour Organization.

Kott, Sandrine

2015 "From Transnational Reformist Networt to an International Organization: the International Association for Labour Legislation and the International Labour Organization, 1900-1930's”. En: Davide Rodogno, Bernhard Struck y Jacob Vogel (eds.), Shaping the Transnational Sphere. Experts, networks and Issues from the 1840's to the 1930's. Oxford, Nueva York, Estados Unidos de América: Berghan Books.

Kott Sandrine y Jo Droux (eds.)

2013 Globalizing Social Right. The International Labour Organization and beyond. Londres: Palgrave Macmillan. 
200 | Trabajos y trabajadores en América Latina (siglos XVI-XXI)

Maul, Daniel

2017 Derechos humanos, desarrollo y colonización. La Organización Internacional del Trabajo entre 1940 y 1970. Madrid: Plaza y Valdés Editores / OIT.

2012 Human Rights, Development and Decolonization. The International Labour Organization (ILO)1940-1970. Londres: Palgrave Macmillan.

McPherson, Alan y Yannik Wehrli (eds.)

2015 Beyond Geopolitics: New Histories of Latin America at the League of Nations. Albuquerque, Nuevo México, Estados Unidos de América: University of New Mexico Press.

Nunes, Guillherme

2017 "Ócio e lazer na regulamentação das férias operárias: a OIT e o caso brasileiro na primeira metade do século XX”. En: Anuario del Instituto de Historia Argentina, volumen 17, número 1. Disponible en: https:// doi.org/10.24215/2314257Xe033

Pacheco dos Santos, José

2017 "Pelos pequenos trabalhadores do Novo Mundo: OIT e trabalho infantojuvenil nas Américas (1936-1939).” En: Anuario del Instituto de Historia Argentina, volumen 17, número 1. 1-20. e035. Disponible en: https://doi.org/10.24215/2314257Xe

Plata-Stenger, Véronique

2016 "Europe, the ILO and the Wider World (1919-1954)". En: EGO, European History Online. Disponible en: http://ieg-ego.eu/en/ threads/transnational-movements-and-organisations/internationalorganisations-and-congresses/veronique-plata-stenger-europe-the-iloand-the-wider-world-1919-1954

Queirololo, Graciela

2017 “Igual salario por igual trabajo’. La Organización Internacional del Trabajo y el Estado argentino frente al trabajo femenino (1919-1951)”. En: Laura Caruso y Andrés Staganaro (coords.), Una historia regional de la OIT. Aportes sobre regulación y legislación del trabajo latinoamericano. La Plata, Argentina: Facultad de Humanidades y Ciencias de la Educación, Universidad Nacional de La Plata.

Ramachiotti, Karina

2017 "El Boletín informativo de Leyes de Trabajo: circulación de ideas y actores latinoamericanos sobre políticas sociales (1942-1951)”. En: Laura Caruso y Andrés Staganaro (coords.), Una historia regional de la OIT. Aportes sobre regulación y legislación del trabajo latinoamericano. 
La Plata, Argentina: Facultad de Humanidades y Ciencias de la Educación, Universidad Nacional de La Plata.

Scodeller, Gabriela

2017 "Educar en derechos laborales: políticas y acciones desplegadas por la OIT en América Latina durante los años 1950-1970”. En: Laura Caruso y Andrés Staganaro (coords.), Una historia regional de la OIT. Aportes sobre regulación y legislación del trabajo latinoamericano. La Plata, Argentina: Facultad de Humanidades y Ciencias de la Educación, Universidad Nacional de La Plata.

Stagnaro, Andrés

2017 "La delegación argentina en Washington (1919): entre el prestigio internacional y la acción local”. En: Laura Caruso y Andrés Staganaro (coords.), Una historia regional de la OIT. Aportes sobre regulación y legislación del trabajo latinoamericano. La Plata, Argentina: Facultad de Humanidades y Ciencias de la Educación, Universidad Nacional de La Plata.

Stagnaro, Andrés y Laura Caruso

2017 "Representantes y representaciones de Argentina en la Organización Internacional del Trabajo en la década de 1920”. En: Anuario del Instituto de Historia Argentina, volumen 17, número 1. 1-17.

Van Daele, Jasmiene

2008 "The International Labour Organization (ILO) in Past and Present Research”. En: International Review of Social History, número 53. 485-511.

Yáñez, Juan Carlos

2017 "La Organización Internacional del Trabajo y la libertad sindical en América Latina: el caso de Venezuela en 1949”. En: Anuario del Instituto de Historia Argentina, volumen 17, número 1. 1-14.

Zorzoli, María Luciana

2017 "La OIT y las dictaduras latinoamericanas: una aproximación al Caso 842 contra Argentina”. En: Anuario del Instituto de Historia Argentina, volumen 17, número 1. 1-21.

2016 "Operativo Ginebra. La dirigencia sindical ante la instalación internacional de la dictadura militar (1976)". En: Archivos de historia del movimiento obrero y la izquierda, número 8. 13-32. 



\title{
Dictaduras, trabajadores y sindicatos en la segunda mitad del siglo XX: propuestas para un diálogo entre los casos de Argentina, Brasil, Chile, Paraguay y Uruguay
}

\author{
Victoria Basualdo (Argentina)*
}

RESUMEN: Este artículo tiene como objetivo proponer vías de avance posible en los estudios sobre dictadura, trabajadores ${ }^{1}$ y sindicatos en cinco países de América del Sur. Partiendo de un foco central en la última dictadura argentina (1976-1983), intenta abrir líneas de diálogo con parte de la producción reciente sobre los casos de las dictaduras de Brasil, Chile, Paraguay y Uruguay en la segunda mitad del siglo XX. Estos países fueron seleccionados por su proximidad histórica y geográfica, por las vinculaciones entre sus procesos históricos y, también, por la existencia de un creciente contacto establecido entre investigadores e instituciones académicas que permitieron estos cruces. Señalando el análisis del lugar relativamente marginal que ha tenido hasta muy recientemente la producción sobre dictaduras, trabajadores y sindicatos en las miradas generales sobre las etapas dictatoriales, se abordan aquí tres ejes principales. En primer término, se retoman algunas de las investigaciones sobre el impacto de las políticas dictatoriales sobre trabajadores y sindicatos, atendiendo a la represión, pero no únicamente. En segundo término, se retoman los análisis de la comúnmente denominada "resistencia" obrera y sindical, concepto desde el que frecuentemente se abordó el amplio arco de líneas de acción y organización de los distintos sectores de la clase trabajadora y del movimiento sindical durante las dictaduras. En tercer y último término, se revisan perspectivas recientes que proponen abordar los "consensos sociales" o "consentimientos" respecto a la dictadura. En el apartado final se plantean algunas propuestas de trabajo sobre cada uno de estos campos, con el objetivo de consolidar una agenda de investigación posible sobre el tema en América del Sur.

* Doctora en Historia por la Universidad de Columbia, Nueva York, Estados Unidos de América. Investigadora del Consejo Nacional de Investigaciones Científicas y Técnicas (CONICET) y del Área de Economía y Tecnología de la Facultad Latinoamericana de Ciencias Sociales (FLACSO), Argentina. Contacto: basuvic@ yahoo.com.ar

1 Considera a mujeres y a hombres. 
PalabRas Clave: dictaduras; trabajadores; sindicatos; América del Sur; políticas dictatoriales; resistencia obrera y sindical.

\section{INTRODUCCIÓN}

La producción académica sobre trabajadores y dictaduras en los diversos países se ha diversificado en los últimos años, aunque la visión de conjunto del ciclo de dictaduras en América del Sur durante la segunda mitad del siglo XX es una asignatura pendiente. Los estudios sobre sus impactos en la estructura económica y social, en las relaciones laborales y en las condiciones de vida y de trabajo de las y los trabajadores requieren abordajes más profundos y sistemáticos. Este trabajo, a partir de determinados ejes y líneas de análisis que establecimos, busca contribuir a la construcción de miradas transnacionales desde perspectivas centradas en los casos nacionales, promoviendo miradas interdisciplinarias que vinculen los campos de la historia económica, política, social y cultural.

La superación de análisis centrados en los marcos nacionales para hallar puntos de contacto y dinámicas transnacionales y/o regionales resultan imprescindibles si se busca dar cuenta de las transformaciones productivas, las estructuras socioeconómicas y las relaciones laborales, porque son procesos que trascienden las experiencias específicas. Con este objetivo, se ofrece una lectura de parte de la producción académica sobre dictadura y trabajadores en Argentina, poniéndola en diálogo con aproximaciones sobre Brasil, Chile, Paraguay y Uruguay. Estos países han sido seleccionados por su proximidad histórica y geográfica, por las vinculaciones entre sus procesos históricos y por la existencia de un creciente diálogo académico entre sus investigadores. No apuntamos aquí a una revisión historiográfica exhaustiva para estos casos nacionales, como tampoco a una comparación entre ellos en sentido estricto. El modesto propósito de este texto es únicamente señalar puntos de contacto y de diálogo entre algunas de las investigaciones recientes en diferentes casos nacionales, como base posible y tentativa para emprender líneas de trabajo e investigación más comprensivas que permitan iluminar dimensiones regionales que han resultado hasta el momento de muy complejo abordaje.

El artículo analiza, en primer término, cuestiones relativas al impacto de las políticas dictatoriales sobre trabajadores y sindicatos, con particular énfasis en las políticas represivas. La revisión preliminar muestra que, más allá de las grandes diferencias y particularidades entre los casos nacionales, parece haber puntos de contacto significativos en el diagnóstico sobre la importancia de mirar las dictaduras desde el punto de vista de la historia de la clase trabajadora, teniendo en cuenta las transformaciones estructurales 
y los impactos distributivos, así como los cambios en las relaciones y los derechos laborales, aunque hay aún grandes dificultades para incorporar este eje en las miradas globales. En segundo término, se retoman análisis de las 'resistencias', concepto desde el que frecuentemente se abordó el amplio arco de líneas de acción y organización de los distintos sectores de la clase trabajadora y del movimiento sindical durante las dictaduras. En tercer y último término, se abordan perspectivas recientes que exploran y reflexionan respecto a las actitudes de "consentimiento" o los "consensos sociales" en las dictaduras. Finalmente, se plantean algunas propuestas de trabajo con el objetivo de consolidar una agenda de investigación sobre el tema en América del Sur.

\section{LAS DICTADURAS Y LA DINÁMICA REGIONAL EN CIFRAS}

Poner en diálogo los procesos dictatoriales de los cinco países entraña una serie de desafíos y de dificultades, entre los que figura el marco cronológico. Mientras que la dictadura del autodenominado "Proceso de Reorganización Nacional" argentino se extendió entre 1976 y 1983 (y debería combinar procesos dictatoriales previos entre 1955-1958 y 1966-1973, al menos), la dictadura chilena estuvo en el poder entre 1973 y 1990, la dictadura uruguaya se extendió entre 1973 y 1985 (según la cronología más aceptada), la brasileña se sitúa entre 1964 y 1985 (con debates sobre si el periodo debería extenderse hasta 1988) y la paraguaya va desde 1954 hasta 1989. Con las excepciones de las dictaduras de Augusto Pinochet en Chile y de Alfredo Stroessner en Paraguay (con subperiodos), los otros tres países muestran cambios en la máxima dirigencia de las dictaduras. Aunque no es posible desarrollar el tema en toda su complejidad, consideramos que estos procesos deben enmarcarse en el periodo de la Guerra Fría (desde la década de 1950 hasta finales de la década de 1980). Existen, además, precedentes históricos y judiciales de reconstrucción de dinámicas regionales de articulación represiva, particularmente las referidas al denominado "Plan Cóndor", que resultan de gran relevancia para el análisis (Slatman, 2012).

En lo que concierne al impacto de las políticas represivas de las dictaduras, hay enormes dificultades de medición y conceptualización, no solo por la dificultad de acceder a fuentes clave (debido a las características mismas de la represión), sino porque en cada uno de estos países el universo de víctimas se define y analiza de forma muy distinta. La Comisión Nacional de la Verdad de Brasil estableció recientemente un número de 434 víctimas mortales o desaparecidos, pero no se dispone de cifras confirmadas para otro tipo de víctimas, como las presas, torturadas, secuestradas y liberadas, y exiliadas, entre otras formas posibles de represión. Estas dificultades tienen que ver con lo que sucedió en el ámbito rural, que afectó, por las evidencias 
preliminares, a miles de víctimas. Argentina ha dado particular atención al número de desaparecidos, estimado en 30.000, contemplando no solo lo establecido por la Comisión Nacional sobre la Desaparición de Personas (CONADEP), sino también por datos de las propias Fuerzas Armadas, que estimaron 22.000 desaparecidos en 1978 (con altos niveles de subdenuncia y/o subregistro). No se ha puesto, sin embargo, el mismo peso en la contabilización de asesinados, presos y torturados, o en la cuantificación del proceso de exilio, sobre los cuales existe una amplia variedad de cifras y mediciones.

En el caso de Chile, de acuerdo con los informes de la Comisión de Verdad y Reconciliación (Informe Rettig) y de la Comisión Nacional sobre Prisión Política y Tortura (Informe Valech), la cifra de víctimas directas de violaciones de los derechos humanos ascendería, al menos, a unas 35.000 personas, de las cuales unas 28.000 fueron torturadas y 3.197 muertas (2.095 ejecutadas extrajudicialmente y 1.102 habrían desaparecido). Además, unas 200.000 personas habrían sufrido el exilio y un número no determinado (estimado en cientos de miles por algunas fuentes) habría pasado por centros clandestinos e ilegales de detención. En Paraguay, durante los 35 años de dictadura se cometieron graves y extensas violaciones de los derechos humanos, que incluyeron al menos la detención en forma arbitraria o ilegal de 19.862 personas, la tortura de 18.772, la ejecución extrajudicial de 58, la desaparición forzada de 337 y el exilio de 3.470 (Comisión Verdad y Justicia, 2008). Finalmente, en el caso de Uruguay, un informe gubernamental de 2011 reconoce 465 víctimas de la última dictadura (1973-1985), considerando únicamente asesinados y/o desaparecidos, y estimaciones académicas recientes estiman que la dictadura uruguaya forzó al exilio a cerca de 380.000 personas, casi el $14 \%$ de la población.

Si por diversas razones, incluyendo criterios y metodologías diferentes, es difícil comparar cifras sobre las violaciones a los derechos humanos (todas ellas todavía en proceso de elaboración y confirmación, a pesar del tiempo transcurrido), los números de víctimas obreras y/o sindicales resultan aún más inaccesibles y difíciles de establecer. Se han realizado varios intentos en el caso argentino, con resultados aún insuficientes para dar cuenta cabal del conjunto. La comprensión de las políticas represivas, sus formas e impactos en cada uno de los países, resulta un gran desafío. Son igualmente fundamentales las formas de vida, organización, niveles salariales e inserción de trabajadores y trabajadoras en los distintos países, así como las estructuras sindicales, su dinámica institucional, el alcance de afiliación y de presencia en los lugares de trabajo. Este conjunto de aspectos debería insertarse, además, en el análisis de la estructura económica y social y en las transformaciones de política económica operadas por las dictaduras en sus diversas etapas y subetapas. Lo que nos proponemos aquí es iniciar un diálogo entre los análisis disponibles 
sobre los casos nacionales, y ver posibles puntos de convergencia o contrapunto para avanzar hacia tendencias regionales. Tomaremos como vía de entrada una reconsideración de la producción historiográfica para los cinco países, sus marcos analíticos y conceptuales, y sus aportes y limitaciones, con el objetivo de consolidar hacia adelante una posible agenda de trabajo común.

\section{DICTADURAS, SINDICATOS Y TRABAJADORES}

Existe un creciente reconocimiento de la fertilidad de analizar la historia reciente a la luz de la relevancia del activismo sindical y obrero, colocando el carácter disciplinador de las dictaduras como un rasgo central de estos regímenes dictatoriales. Se han hecho aportes muy significativos hacia posibles análisis comparativos, como el trabajo de Paul Drake (1996), centrado principalmente en el Cono Sur (Argentina, Chile y Uruguay), aunque incluyó, de manera complementaria, los casos de Brasil y Europa del sur (Portugal, Espańa y Grecia). Este trabajo, realizado desde el campo de la ciencia política, intentó una primera comparación sistemática, llegando a la conclusión de que las dictaduras tenían un carácter antisindical y antiobrero, aunque presentaban variaciones significativas. El autor sostuvo que era necesario reconocer el papel central de trabajadores y sindicatos, y que la posición de confrontación contra estos sectores fue clave para estas dictaduras (ibid).

En los últimos años, un conjunto de investigadores de estos cinco países, especialmente de Brasil y Argentina, a los que se sumaron especialistas de Chile, Uruguay y Paraguay, han realizado intentos para promover una mayor articulación de la producción académica sobre el tema en América del Sur. Este proceso, que se plasmó en encuentros y publicaciones, y en la conformación en 2018 de una red de estudios sobre "Procesos represivos, empresas, trabajadores y sindicatos en América Latina", fue central para posibilitar la reflexión que aquí se propone (Winn, 2018; Basualdo, 2018; Corrêa y Fontes, 2018; Vergara, 2018; Estevez, Sales, Corrêa y Fontes, 2018). Gran parte de ellos constató que los estudios centrados en trabajadores, sindicatos y dictaduras quedaron durante mucho tiempo en un lugar marginal, frente a la predominancia de los abordajes desde la historia política, con un fuerte énfasis en el papel de las Fuerzas Armadas y de las organizaciones políticas y político-militares.

El caso argentino es revelador en este sentido. Aunque existen contribuciones muy relevantes sobre el carácter antisindical y antiobrero de la dictadura (incluso en forma contemporánea a los hechos), con evidencias sobre la persecución a trabajadores y sindicalistas existentes en las instancias de investigación estatal, como la CONADEP, y en el proceso de judicialización de la década de 1980, las visiones predominantes durante los decenios de 
1980 y 1990 privilegiaron las dimensiones políticas de análisis. Para ilustrar la dificultad de incorporar la rica historiografía sobre dictadura, trabajadores y sindicatos, puede ser útil revisar un artículo de síntesis historiográfica a 40 años del golpe de Estado (Canelo, 2016b), en el que prácticamente no hay referencias a esta línea de trabajo, a pesar de su historia y desarrollo durante varias décadas. Resulta sorprendente, en otro texto del mismo año, que se definan las visiones que buscan recuperar las transformaciones económicas y sociales como necesariamente "economicistas", llamando entonces a "recuperar como clave interpretativa fundamental la autonomía de la política con respecto a la economía" o, dicho de forma todavía más contundente, a "proponer una interpretación política de la dictadura” (Canelo, 2016a: 11-12).

En lo que se refiere al caso de Brasil, las recientes síntesis historiográficas destacan la dificultad de incluir a los trabajadores y sus organizaciones en la historia de la dictadura. En un artículo de sistematización muy útil, Larissa Rosa Corrêa y Paulo Fontes (2016) afirman que a pesar de que los trabajadores fueron "uno de los sectores sociales más notorios y expresivos en la coyuntura política previa al golpe", fueron marginados de los análisis más recientes sobre el periodo. Los autores sostienen que en los eventos de conmemoración del 50 aniversario del golpe esta ausencia ha sido "notable". Destacan también el foco en las memorias durante el régimen militar, centradas, sobre todo, en los testimonios de militantes de izquierda provenientes del movimiento estudiantil, de las camadas intelectuales y artísticas, así como de los estudios sobre la lucha armada, la prensa, la política económica y el aparato represivo, en un contexto de invisibilidad de los trabajadores y dirigentes sindicales en todos los sentidos, incluyendo el registro de las víctimas (ibid.: 130-131). Este diagnóstico es compartido por otros autores que destacan también la importancia de iniciativas como la Comisión Nacional de la Verdad, aun con sus limitaciones, para impulsar investigaciones movilizando políticas de memoria (Estevez y Assumpçao, 2013).

En el caso de Chile, no solo predominan miradas políticas, sino que los estudios sobre las transformaciones económicas destacan frecuentemente los logros del "milagro económico" atribuido a la dictadura de Augusto Pinochet. Desde la perspectiva de Ángela Vergara (2018). Sin embargo, a pesar del impacto innegable de la dictadura en la producción intelectual, puede rastrearse una historiografía rica e interesante sobre trabajo y trabajadores que tendió a combinar, a lo largo de las décadas, aportes de la sociología del trabajo, estudios de comunidades obreras urbanas y estudios de género que aportaron una mirada feminista. En este marco, un conjunto de contribuciones destacó el costo social y el profundo cambio en las políticas y las regulaciones laborales que tuvieron un impacto extremadamente regresivo sobre los trabajadores y sus organizaciones. Un libro importante en este sentido, que combinó estudios 
de caso (abordando firmas de las industrias textil, metalmecánica y del cobre, como también de la agricultura, la pesca y la industria forestal, entre otras) con miradas generales, cumplió un papel importante al cuestionar las perspectivas centradas en el supuesto milagro económico chileno, enfatizando la pérdida de derechos laborales y sociales que implicó la dictadura, desde aproximaciones que combinaron una mirada de clase con dimensiones étnicas y de género muy interesantes y que abrieron camino en el campo historiográfico (Winn, 2004).

En el caso de Uruguay, aportes recientes que han contribuido a dar un panorama del impacto de la dictadura sobre los trabajadores y sus organizaciones sindicales señalan algo parecido. Un trabajo reciente de Rodolfo Porrini (2018) es central para brindar un panorama historiográfico, señalando que los estudios se han centrado en la actuación sindical y social clandestina y en la recomposición de la década de 1980, con un carácter exploratorio inicial. Porrini indica, asimismo, que los estudios sociales e historiográficos sobre las modificaciones del trabajo, las condiciones de vida y los procesos culturales de "hegemonía y consenso" en las clases populares tienen también escaso desarrollo, y que aún falta densidad al conocimiento sobre las clases trabajadoras y sus formas de expresión durante la dictadura, entre ellas los grupos actuantes en las organizaciones clandestinas, en las cooperativas, en las entidades deportivas, sociales y culturales, y su ubicación geográfica en ciudades, barrios y localidades del interior del país, así como en el medio rural (ibid).

En el caso de Paraguay, aportes recientes contribuyeron a analizar no ya únicamente los rasgos políticos de la dictadura de Alfredo Stroessner, sino también las transformaciones de la estructura económico-social y, particularmente, el papel de las organizaciones sindicales en el periodo dictatorial extendido entre 1954 y 1989, como también el estudio de sus relaciones con el Estado (González Bozzolasco, 2014). Desde estos estudios se sostiene que para caracterizar las políticas aplicadas por la dictadura hacia el movimiento sindical resulta útil el concepto de corporativismo, que implica "que el Estado cree alguna forma de organización obrera, habitualmente con financiamiento oficial, afiliación obligatoria y fijación de límites estrictos en cuanto a los sectores que puede agrupar" (ibid.: 68-69). De acuerdo con estas perspectivas, esta forma de control sindical "lleva a los sectores opositores al régimen autoritario dentro del sindicalismo a tomar uno de dos caminos: usar los espacios oficiales y dar la disputa interna a los sectores afines al régimen, o articularse completamente por fuera" (ibid.: 69).

A pesar de su lugar secundario en las grandes miradas e interpretaciones, existe en todos estos casos una rica historiografía (más o menos diversa, según los países), que aquí examinaremos en función de las tres cuestiones ya mencionadas: las políticas estatales frente a trabajadores y sindicatos, con un fuerte acento en las políticas represivas; las contribuciones sobre la 
"resistencia" de trabajadores y sus organizaciones frente a las políticas dictatoriales; $y$, en tercer lugar, nos referimos a algunas aproximaciones más recientes a lo que se llama el "consenso social" respecto a la dictadura.

\section{PolítICAS DICTATORIALES DIRIGIDAS A TRABAJADORES Y SINDICATOS}

Los trabajos recientes iluminan no solo los diversos impactos de las políticas represivas de las dictaduras sobre la organización obrera y sindical, y sus condiciones de vida, trabajo y organización, sino también cuestiones importantes como la heterogeneidad y las corrientes del movimiento sindical y los impactos diferenciales en los distintos casos de las políticas económicas y laborales sobre distintos colectivos, y la existencia de distintas relaciones de líderes sindicales con las Fuerzas Armadas en cada uno de los casos nacionales.

En el caso argentino, diversas contribuciones abordaron el análisis de las políticas dictatoriales que afectaron a trabajadores y sindicatos, coincidiendo en señalar un nivel inédito de represión, una transformación significativa de las relaciones laborales y la estructura de derechos, así como un retroceso de gran magnitud en cuanto a las condiciones de vida y de trabajo de los trabajadores, acompañada de una transformación importante del movimiento sindical (entre otros, Abós, 1984; Fernández, 1985; Pozzi, 1988a, 1988b; Gallitelli y Thompson, 1990; Basualdo, V., 2010a). Varias de las aproximaciones recuperaron una serie de contribuciones del campo de la economía y la historia económica, aunque con diferentes metodologías, marcos teóricos, conceptuales-analíticos y fuentes. Una parte importante de los trabajos, no sin diferencias y variantes, coincidió en identificar la instauración de la dictadura con transformaciones decisivas de la industrialización debido a la sustitución de importaciones que se había desarrollado en las décadas previas. Muchas de estas interpretaciones coincidieron en destacar un viraje económico de gran importancia, a mediados de la década de 1970, consolidado con cambios en la política económica bajo el liderazgo de José Alfredo Martínez de Hoz a partir de la implementación de políticas como la Reforma Financiera de 1977 que, en conjunción con la arancelaria y el endeudamiento externo, derivados de la apertura de 1979, promovieron una reestructuración regresiva del sector industrial. Esta implicó una desindustrialización en términos agregados (es decir, un descenso en la participación del sector industrial en el PIB), con un impacto heterogéneo sobre las distintas ramas, en combinación con un proceso de concentración económica, en el marco de un incremento exponencial del endeudamiento externo, vinculado en forma creciente al proceso de financiarización (Basualdo E., 2006). Este cambio del patrón de acumulación de capital fue considerado, por una parte significativa de la producción académica, como un contexto 
clave para analizar las transformaciones experimentadas por los trabajadores y sus organizaciones durante la dictadura militar, los cambios de las relaciones laborales y los efectos de la represión, sobre cuyo carácter regresivo, tanto en términos distributivos como organizacionales, tuvo amplia coincidencia, aunque con énfasis y matices diversos.

Muchos de estos trabajos demostraron que los efectos de la represión se extendieron a los afectados de manera más directa, entre ellos fueron importantes dirigentes sindicales, delegados de base y activistas obreros, que vieron coartada su libertad e incluso su vida, así como al conjunto de los trabajadores y trabajadoras que permanecieron en las fábricas y los establecimientos laborales. Existen numerosos testimonios, documentos e investigaciones que reflejan, en el contexto de una cada vez mayor concentración económica y de poder político de las élites patronales, la creciente aplicación de violencia física y psicológica en los lugares de trabajo, junto con el severo recorte de las instancias de comunicación e interacción social que afectaron dramáticamente los lazos sociales básicos, al mismo tiempo que se incrementaba la vigilancia y el control (Basualdo, 2010, entre otros). A esto se sumó lo que algunos autores han llamado "un sistema complejo de prevención": el reclutamiento obrero comenzó a hacerse de modo provisional y solo después de recibir el informe de inteligencia de las Fuerzas Armadas se otorgaba a los obreros una relativa estabilidad en el trabajo (Delich, 1982: 140). La represión tenía como objetivo eliminar a los representantes más activos y "descabezar" a las bases, con el propósito de dejar sentadas (clara y brutalmente) las consecuencias que podía tener la militancia política y sindical en el lugar de trabajo, así como el compromiso y la solidaridad internacional de sectores relevantes (Basualdo, 2010a, 2010c; AEyT-FLACSO, PVJ, SDH y CELS, 2015; Basualdo y Jasinski, 2016).

A estas formas de represión se sumó la intervención a una gran cantidad de sindicatos y federaciones, comenzando por la Confederación General del Trabajo, mediante la designación de funcionarios militares. Asimismo, la dictadura militar promovió un conjunto de normas tendientes a legalizar la actividad represiva y la intervención en los lugares de trabajo. Desde el inicio de la dictadura se estableció el congelamiento de todo tipo de actividad gremial, así como la prohibición de toda forma de organización y protesta en el lugar de trabajo. La legislación estaba en estrecha relación con estas medidas, por lo cual, a medida que los trabajadores encontraban o creaban formas no prohibidas de organización o manifestación, estas iban siendo incorporadas a normas posteriores que las prohibían (Pozzi, 1988a, 1988b; Basualdo, 2010b).

En el caso de Brasil, aportes como los de Marco Aurelio Santana (2008 y 2014) son útiles para sintetizar algunas de las evidencias acumuladas respecto 
al impacto dictatorial sobre trabajadores y sindicatos en Brasil. Santana destaca que el decenio de 1950 marca un periodo de extrema importancia para los trabajadores brasileńos, en tanto el movimiento sindical, liderado por la alianza de las militancias comunista y trabajadora, consiguió grandes avances en la movilización y la organización que resultó en una gran participación de los trabajadores en el seno de la vida política nacional. Al mismo tiempo, destaca que "después de más de una década de este intenso crecimiento y actividad, toda la estructura organizacional fue duramente afectada por el golpe civil-militar de 1964, el cual tenía como una de sus justificaciones centrales exactamente impedir la instalación de una 'república sindicalista' en el país” (Santana, 2008: 279-280). La prisión de los líderes y la persecución de los militantes, así como la desestructuración del trabajo de los sindicatos en las fábricas, desarmaron actividades que llevaría bastante tiempo recomponer. En términos del movimiento obrero, lo que quedó, como suele suceder en periodos como estos, fue el trabajo pequeño y silencioso en el lugar de trabajo. Era preciso recomponer fuerzas para enfrentar la dictadura (ibid).

En lo que se refiere a los impactos específicos de las políticas dictatoriales sobre trabajadores, sindicatos y relaciones laborales, Santana destaca que después del golpe militar las intervenciones perpetradas por Castelo Branco (1964-1967) tuvieron un alcance significativo sobre diversas esferas de la vida sindical, afectando más fuertemente a los sectores sindicales más progresistas. Sostiene que, además de trabajar en un ataque directo a las organizaciones sindicales, con el objetivo de disciplinarlas en forma inmediata, la dictadura intentó implementar cambios en términos del largo plazo, actuando sobre la legislación (Santana, 2008: 281). Analiza, asimismo, la sanción por parte de la dictadura de una serie de medidas para reforzar el control sobre el movimiento sindical. Retomando elementos ya presentes en la Consolidación de la Ley del Trabajo, se establecieron además reglas estrictas para la ocupación del espacio sindical, con candidatos sujetos a la aprobación del Ministerio de Trabajo y de la Policía Política. Por otra parte, el uso y el acceso a los recursos de los institutos de previsión social fueron drásticamente limitados a partir de su centralización en el Instituto Nacional de Previsión Social, cuya dirección no se realizaría más con una participación de los trabajadores, como en los antiguos institutos de pensión, sino con una indicación directa del Gobierno. En lo que se refiere a las movilizaciones, Santana destaca que, a pesar de una supuesta reglamentación del derecho de huelga, lo que se dio de hecho fue una prohibición de las huelgas políticas y de solidaridad, limitando su realización para únicamente la demanda del cobro de salarios atrasados. En esta primera etapa, la dictadura militar implantó el Fondo de Garantía por Tiempo de Servicio, que ponía fin a la estabilidad del empleo, incentivaba una alta rotación de la mano de obra por 
parte de los patrones y correlativamente dificultaba una acción sindical más combativa desde los lugares de trabajo (Santana, 2008).

En el caso de Chile, la dictadura de Pinochet suspendió la vigencia de la Constitución y, en consecuencia, de todas las libertades civiles y los derechos políticos (Winn, 2004). Los partidos que apoyaron a Salvador Allende fueron prohibidos, medida que luego se extendió incluso a los partidos que antes habían sido opositores. Subrayan que los procesos eleccionarios fueron suspendidos, incluso en organizaciones sociales como clubes juveniles y muy especialmente en los sindicatos, y que se puso a personal militar al frente de escuelas y universidades, cuyos planteles de profesores y bibliotecas fueron purgados ferozmente. La quema pública de libros "subversivos" se convirtió en un símbolo visible de la nueva falta de libertad en Chile, invitando a comparaciones con la Alemania nazi (ibid.).

Estos aportes destacan que las primeras semanas fueron suficientes para visibilizar la dictadura de Pinochet como violadora serial de derechos humanos. Muchas de las víctimas eran sindicalistas, activistas y/o trabajadores, a los que Pinochet consideró objetivos primordiales de su "guerra interna" entre 1973 y 1978, en función del alto grado de poder y organización, como también de su importante papel político como base social central de la izquierda, que los volvía enemigos peligrosos que debían ser neutralizados durante el golpe, convirtiéndose en blancos muy importantes de la represión. El mismo día del golpe, la sede central de la Central Única de Trabajadores (CUT) fue uno de los primeros edificios tomados por las Fuerzas Armadas. Durante los tres días y noches de estado de sitio que siguió al golpe, se desarrollaron operativos militares con tanques, helicópteros y ametralladoras sobre los principales cordones industriales del país. La CUT fue prohibida, sus propiedades confiscadas y sus representantes marcados públicamente como "subversivos" a los que era necesario capturar (ibid.).

Al mismo tiempo, Santana subraya que se extendió la presencia de las Fuerzas Armadas en los lugares de trabajo y en muchas fábricas, y que la inteligencia militar interrogó a los trabajadores uno por uno, presionándolos para que informaran sobre militantes y activistas, particularmente sobre los dirigentes sindicales. Muchos de ellos fueron secuestrados y desaparecidos, otros torturados, forzados al exilio o al desplazamiento dentro del país, desde donde muchos participaron en la resistencia subterránea en distintos lugares. La represión continuó hasta 1978, basándose en el Decreto Ley 198, lo que le permitió al Gobierno remover a dirigentes sindicales según su voluntad y, en lugar de democracia sindical, el régimen de Pinochet promovió el ascenso de los sectores más conservadores. En un contexto de prohibición de la negociación colectiva, de las huelgas y de las elecciones sindicales, decretos militares prohibieron una gran cantidad de sindicatos, diezmando a la CUT 
y a las filas obreras que podían movilizarse. En vinculación con estas políticas represivas y laborales, la dictadura restableció la primacía de políticas de libre mercado, libertad que no se aplicaba de ningún modo a los derechos laborales y las demandas salariales. Bajo los controles gubernamentales, los salarios reales descendieron abruptamente entre 1973 y 1975 , y en general los trabajadores y sus organizaciones perdieron poder muy significativamente a lo largo de todo el periodo (ibid.).

En el caso de Paraguay, las investigaciones analizan las políticas dictatoriales respecto al movimiento sindical, de acuerdo con su predominancia relativa en cada etapa. Consideraron que durante los primeros años de la dictadura, entre 1954 y 1958, predominaron las políticas represivas, con un despliegue de todo tipo de estrategias de limitación y contención de la actividad sindical. A esto le siguió una larga etapa en que predominaron políticas de cooptación, entre 1958 y 1985, en la que una parte significativa de "los vestigios del sindicalismo sobreviviente a la gran represión rearticula su relación con el Gobierno, el Partido Colorado y los aparatos estatales" (González Bozzolasco, 2014: 68). Finalmente, destaca una etapa en la que prevaleció una "resistencia" contra estas políticas en los últimos años de Stroessner, entre 1985 y 1989, durante la cual "el modelo de cooptación impulsado y consolidado por el régimen comienza a agrietarse, conjuntamente con el aparato que lo impulsó y lo sostuvo" (ibid.: 68).

Finalmente, en el caso de Uruguay, Rodolfo Porrini realiza un aporte muy valioso a esa síntesis aún faltante, al afirmar que desde el golpe de Estado de 1973 se produjo un ambicioso intento de dominar y destruir el movimiento sindical, intentando, al mismo tiempo, cooptar a sus bases sociales: las amplias, movilizadas y mayoritariamente urbanas clases trabajadoras y populares. Se afirma también que, en distintos momentos, el régimen dictatorial buscó impulsar o construir un sindicalismo afín a sus ideas y propósitos, al mismo tiempo que la búsqueda del control de la sociedad implicó diversas formas de represión de las oposiciones políticas y sociales. Esto se combinó con políticas específicas hacia el mundo laboral y las asociaciones gremiales que fueron expresiones de la nueva forma de dominación de la dictadura, y del nuevo marco de relaciones sociales que se estaba imponiendo (Porrini, 2018).

Al igual que en el caso argentino, Porrini sostiene que durante la dictadura ocurrió una significativa concentración del ingreso. Si los salarios y los pasivos representaron el 45,8\% del ingreso nacional en el periodo 1968 1971, para 1978 significaron un 33,1\%, al mismo tiempo que los asalariados de todo el país tuvieron una caída de su ingreso real entre el $8 \%$ y el $20 \%$ (Notaro, 1984, citado en Porrini, 2018). Otra expresión de este fenómeno fue la evolución del salario real global, el cual, tomando como base 100, el salario real de 1957, representaba en 1974 el 68,4\%, y en 1984 un 35,2\% 
(Nahum et al., 2011, citado en Porrini, 2018). Otro aspecto a considerar, de acuerdo con los aportes de Porrini, fueron las prácticas de represión a los opositores políticos y sociales, y el intento de control general de diversas áreas de la sociedad uruguaya. A los partidos Colorado y Nacional, "tradicionales", se los suspendió, así como al Partido Demócrata Cristiano, mientras que los demás partidos y organizaciones políticas fueron ilegalizados, y en octubre de 1973 el Poder Ejecutivo intervino la Universidad de la República y sacó de la legalidad también a la Convención Nacional de Trabajadores.

De acuerdo con Porrini, durante los primeros tiempos de la dictadura, se aplicaron tres ejes principales de política sobre el mundo del trabajo y la vida sindical. En primer lugar, se intentó acallar la conflictividad, y para ello se desarrolló una política represiva intensa, con despidos, prisión, traslados y destituciones de los funcionarios públicos. En agosto de 1973, la Convención Nacional de Trabajadores denunció casi 1.500 despedidos; y el sindicato bancario AEBU, el cese de 42 trabajadores de su sector y unos 1.400 sancionados del total de los trabajadores. En segundo lugar, se intentó una reformulación de las relaciones laborales a partir de una serie de decretos que procuraban abarcar al conjunto de los trabajadores, delimitando y restringiendo las tareas sindicales. En tercer lugar, la dictadura se propuso crear una "nueva organización", acorde con su visión de la vida gremial. Las interpretaciones sostienen, entonces, que la dictadura implementó una combinación de "prohibir y permitir", alternando sus líneas según los momentos y también las respuestas provenientes tanto desde el medio sindical como desde los empresarios (Porrini, 2018).

\section{LAS "RESISTENCIAS" OBRERAS Y SINDICALES A LAS DICTADURAS}

En los cinco casos aparece el concepto de "resistencia" obrera para referirse a las formas de acción y organización de los trabajadores durante la dictadura. En el caso argentino, el debate explícito o implícito sobre la "resistencia” marcó el desarrollo del campo de producción desde tiempos muy tempranos. La evaluación y el análisis de la reacción de la clase trabajadora frente a las políticas dictatoriales y al proceso de cambio estructural planteó un debate entre los historiadores que enfatizaron dimensiones distintas del proceso. Francisco Delich fue uno de los primeros autores en referirse a una inmovilidad de la clase trabajadora, cuestión luego muy discutida por la historiografía. El historiador Pablo Pozzi cuestionó esa mirada en un libro y en un artículo publicados a fines de la década de 1980 (1988a y 1988b), en los cuales sostuvo que, por el contrario, existió una amplia gama de actividades de resistencia y oposición. Pozzi no solamente cuestionó las apreciaciones de Delich respecto a la ausencia de conflictos sindicales frontales y de tipo 
"clásico" (en términos de las formas históricas de lucha de los trabajadores argentinos), en especial la huelga general de 1979, sino que además enfatizó la importancia de las acciones "subterráneas" de resistencia, a las que nos referiremos más extensamente luego. El trabajo de Pozzi tiene el mérito de llamar la atención sobre la existencia de prácticas "subterráneas" a nivel de planta, y que habían sido subestimadas o directamente omitidas por la mayoría de las contribuciones previas. Estas medidas de protesta encubiertas, llevadas adelante por grupos de trabajadores con reducida coordinación e impacto, incluían el "trabajo a tristeza", el "trabajo a desgano" (reducciones del ritmo de trabajo), interrupciones parciales de tareas, sabotajes y una multiplicidad de iniciativas tendientes a organizar a los trabajadores y a perjudicar a la patronal. Se considera que estas medidas surgen de un aprendizaje previo, desarrollado en el contexto de las "resistencias" contra las dictaduras desde 1955 en adelante (Pozzi, 1988a). En suma, Pozzi demostró que fueron numerosas las instancias de protesta de los trabajadores desde los primeros días de la dictadura, y que estas aumentaron en las coyunturas que posibilitaban mayor éxito. Aunque las políticas económicas, laborales y represivas tuvieron un impacto profundamente negativo sobre la clase trabajadora, importantes sectores desarrollaron formas de organización y protesta que fueron variando y cambiando a lo largo del periodo, de acuerdo a los márgenes de acción, por lo cual contribuciones recientes enfatizaron en la importancia de llevar adelante un análisis complejo de estas distintas líneas, tanto en los establecimientos laborales como en el espacio público, con diversos métodos y medidas, y en una diversidad de regiones del país. Se analizaron también formas de resistencia internacional, tanto en instancias supranacionales (por ejemplo, la Organización Internacional del Trabajo - OIT) como a partir de campañas internacionales de denuncia en la que tuvieron participación confederaciones sindicales de otros países y también organizaciones sindicales mundiales (Basualdo, 2006b, 2010c, 2013).

En el caso de Brasil, es necesario, desde la perspectiva de Larissa Rosa Corrêa y Paulo Fontes (2016), distinguir etapas distintas en las que predominaron perspectivas muy diferentes respecto a los trabajadores, los sindicatos y la dictadura. Subrayan que, en una primera etapa, "la idea de no reacción, de parálisis y/o de pasividad de los trabajadores durante el golpe limitó sobremanera los estudios sobre los trabajadores". Mientras que el presidente Joao Goulart había buscado asociar su imagen a los trabajadores hasta 1964, luego del golpe "la decisión de Jango de no resistir el avance de las tropas militares y su fuga silenciosa para Uruguay se tomó como una imagen de lo sucedido con los trabajadores. Estos quedaron aprisionados en interpretaciones dedicadas a escudriñar sus supuestas ausencias (de organización de clase, de conciencia política, de espíritu colectivo, etcétera)" (ibid:: 134, traducción 
propia). Señalan, entonces, que gran parte de las energías de la producción académica se dedicaron, en esta etapa, a intentar responder a la pregunta de por qué los trabajadores no habían reaccionado frente a la dictadura. En términos generales, una primera línea de respuesta buscó las causas de esta supuesta "falta de resistencia" en la historia del sindicalismo anterior al golpe y en el supuesto papel subalterno de las izquierdas, en particular del Partido Comunista, en la derrota de 1964. En este marco, las teorías del populismo ganaron terreno, sosteniendo que fue el corporativismo el que actuó como una red populista que capturó a los trabajadores en las redes de dominación estatal. Desde una perspectiva teórica diferente, pero también focalizada en el periodo varguista como clave, se acuñó el concepto de "ciudadanía regulada", que proponía una mirada sobre la cima del Estado, reforzando en general una imagen de ausencia, inacción y subordinación de los trabajadores y sus organizaciones a una lógica ajena a la suya (Corrêa y Fontes, 2016).

Estos autores destacan que la literatura memorialística que emergió con fuerza en la década de 1970, durante la apertura política, reforzó un cierto ocultamiento de la presencia de los trabajadores en la resistencia a la dictadura militar, en particular entre 1964 y 1978. Las huelgas de los metalúrgicos de 1968 fueron presentadas, desde este esquema interpretativo, como excepciones que confirmaban la regla. El impacto de las memorias de activistas de la lucha armada ayudó a consolidar una visión de los trabajadores como portadores de desinterés político, aquiescencia y, a veces, apoyo al régimen. Algunas líneas de interpretación apuntaron a una creciente heterogeneidad de los trabajadores como dato clave para comprender el supuesto papel tímido de los trabajadores en el combate contra la dictadura (ibid.). En este marco, se fue concretando un cambio de visión desde un énfasis en la inacción a un creciente reconocimiento de la agencia de los trabajadores y sus organizaciones. Las grandes huelgas iniciadas en el ABC paulista en 1978, movimiento que luego se esparciría a distintas regiones del país, se convirtieron en un símbolo también de los cambios de percepción sobre el papel de la clase trabajadora y su relación con el régimen autoritario. Los actos masivos y contestatarios y el evidente protagonismo de los trabajadores fueron interpretados, por algunos, como parteaguas, un punto de inflexión que implicaba una ruptura simultánea con el pasado "populista" de 1964 y con el reciente pasado de subordinación e inmovilismo de los trabajadores durante la dictadura (ibid.).

Se impuso, entonces, en esta etapa, una idea de "novedad" que prevaleció en la lectura académica y política, y que se aplicó a la creación de un "nuevo sindicalismo" y de "nuevos" movimientos sociales que habrían superado la tradición populista de subordinación al Estado, movilizándose masivamente en los lugares de trabajo y en los barrios, y actuando en 
forma independiente y autónoma. Corrêa y Fontes subrayan que, con el entusiasmo y la efervescencia del clima de redemocratización y de activismo, se tendió a marcar el cambio como abrupto y absoluto, cuestión que luego fue relativizada por contribuciones que buscaron sus orígenes en etapas anteriores y en transformaciones progresivas que discutieron las tesis de la inmovilidad. Se fue constituyendo un campo cada vez más rico de estudios, no solo sobre un amplio arco de actividades industriales y centros urbanos como la Baixada Fluminense, Niterói, el ABC Paulista y Río de Janeiro, sino también sobre los trabajadores rurales de distintos territorios del país, sobre las relaciones internacionales del sindicalismo brasileño y también sobre distintos campos vinculados al derecho de trabajo (entre muchos otros, Pessanha, 2014; Welch, 2014; Corrêa, 2014, 2017; Gouveia de Oliveira Rovai, 2014; Montenegro, 2014; Nagasava, 2015; Pessanha y Medeiros, 2015). A pesar de estas y de muchas otras valiosas contribuciones, es necesaria una mayor diversidad geográfica de los estudios, de profundización del análisis sobre las formas de represión policial-militar a los trabajadores dentro y fuera de las fábricas, así como un análisis sobre las transformaciones de las condiciones de vida y de trabajo en cada uno de los subperiodos de la dictadura. Se requiere también recopilar datos objetivos de alteración de condiciones y derechos, así como analizar las miradas de los trabajadores sobre la dictadura, incluyendo las que la consideraron con simpatía, apreciando el "milagro económico" y algunas de las consecuencias que tuvo sobre parte de ellos (Corrêa y Fontes, 2016). El cruce entre los ricos aportes recientes desde el mundo del trabajo y desde el campo de la historia de empresas, empresarios y las transformaciones económicas (Campos, 2014, entre otros) parece entonces una tarea de enorme relevancia.

En el caso de Uruguay, también se ha enfatizado que, ante las iniciativas de la dictadura, se desarrollaron "diversas formas de respuestas y de resistencia”. Porrini destaca, en particular, los intentos de la dictadura de organizar reuniones con sindicalistas, tomando como ejemplo la convocatoria (después de una huelga el 25 de julio de 1973), que terminó en fracaso cuando fue denunciada por los trabajadores como una "pantomima" que buscaba ocultar despidos y persecuciones (Porrini, 2018). Otro de los caminos fue avanzar hacia una reglamentación de la actividad sindical. En agosto de 1973, el Gobierno emitió un decreto que proponía la "reafiliación sindical", que implicaba una reglamentación de la vida gremial, trabas y limitación del derecho de huelga. El comando clandestino de la Convención Nacional de Trabajadores realizó un plenario sindical promoviendo la reafiliación de los trabajadores a sus sindicatos y logrando, en muy poco tiempo, una masiva respuesta de los asalariados en apoyo a los sindicatos de la disuelta Convención, lo que implicó, en los hechos, un fracaso de la iniciativa 
(Porrini, 2018). Destacan también otros intentos, como la creación en 1974 de un organismo encargado de controlar las actividades laborales en las empresas: la Oficina de Asuntos Laborales del Estado Mayor Conjunto, dirigida por militares, que actuó fundamentalmente como organismo represor de los trabajadores, coordinando sus tareas con los organismos de inteligencia del Estado y cuyos archivos no se han podido encontrar, aunque se conocen algunas de sus actuaciones a partir de los registros de la Dirección Nacional de Investigación e Inteligencia Policial (Rico, 2009, citado por Porrini, 2018).

Finalmente, Porrini destaca que luego de un periodo muy difícil (en un contexto de apertura política muy limitado, después del derrotado Plebiscito de 1980) se logró abrir un espacio de reorganización y reactivación social y sindical. En un contexto de revitalización de la sociedad, de aumento de las acciones colectivas y de surgimiento de nuevas asociaciones, culturales y de tipo gremial, se fundó, en mayo de 1983, el Plenario Intersindical de Trabajadores. La intensa participación y las movilizaciones de 1983 hacia adelante se plasmaron en demostraciones antidictatoriales, con trabajadores, estudiantes universitarios y de enseñanza media, cooperativistas, activistas por los derechos humanos y de los partidos opositores, en especial de izquierda y de las fracciones más opositoras de los partidos "tradicionales", todo lo cual marcó la transición a la democracia (Porrini, 2018).

En el caso de Chile, contribuciones recientes de Rodrigo Araya Gómez (2015) consideran que el movimiento sindical vivió una primera etapa de supervivencia, marcada por la fuerte represión ejecutada por la dictadura, la prohibición de la CUT y la persecución a los dirigentes sindicales de la izquierda, lo que favoreció un debilitamiento y el fraccionamiento del movimiento sindical en grupos sindicales que tuvieron distintas estrategias para enfrentarse a la dictadura. Destaca que, en julio de 1974, se logró la formación del Comité Exterior CUT, más conocido como CEXCUT, que informó de la difícil situación de la actividad sindical en el país, sometido al poder de una "junta militar fascista", de manera que se requería de la solidaridad internacional para sostener la lucha de los trabajadores chilenos y el movimiento sindical en los tiempos más complejos de la dictadura. La tarea realizada por el CEXCUT fue importante porque pudo mantener una activa presencia internacional en coordinación con las grandes centrales internacionales, que apoyaron con financiamiento a los grupos sindicales, además que algunos dirigentes internacionales viajaron a Chile, donde constataron las desfavorables condiciones para la acción sindical, lo que sirvió para que la OIT observara, de forma crítica, la política laboral del Gobierno chileno (ibid.).

Desde estas visiones, puede considerarse que, a la etapa más crítica de los años 1973-1974 (en la que la supervivencia era el objetivo), siguió una época de mayor reactivación del movimiento sindical, con algunas acciones 
de protesta, como huelgas y "viandazos", que recibieron la dura respuesta del régimen expresada en despidos masivos, detenciones y relegaciones. El "Plan Laboral" de 1979 es visto como un punto de quiebre en la trayectoria del sindicalismo chileno, pues consolida la privatización de las relaciones laborales por el tipo de regulación de la negociación colectiva, la eliminación de los Tribunales de Trabajo y sus disposiciones en materia de despidos, horarios de trabajo, indemnización por años de servicio y financiamiento de sindicatos (ibid.). Sin embargo, la propia normativa, en principio contraria a los intereses de los sindicatos, fue desbordada en ocasiones por la acción de los propios trabajadores (un caso específico fue la huelga en la compañía minera El Teniente), lo que podría reflejar la potencialidad de la acción unitaria para enfrentar a la dictadura y sus aliados empresariales (ibid.).

En un escenario de institucionalización de la dictadura a partir de un plebiscito de la Constitución de 1980 y de la consolidación del modelo neoliberal expresado en el ámbito del trabajo con la puesta en vigencia del Plan Laboral, los grupos sindicales optaron por intentar una consolidación institucional que les permitiera asumir posiciones críticas. Plantearon la unidad de acción y la elaboración de una plataforma común de lucha para enfrentar los problemas urgentes de los trabajadores, sobre todo los de tipo económico, que se habían incrementado con el estallido de la crisis económica de comienzos de la década de 1980 y el fin del llamado "milagro económico" (ibid.). El movimiento sindical convocó a la primera protesta nacional, transformándose en un agente articulador de diversos sectores sociales, logrando también incentivar a los partidos políticos a desafiar la dictadura. Los diversos grupos sindicales se unieron en una instancia de coordinación, el Comando Nacional de Trabajadores (CNT), y se inició una nueva etapa para el sindicalismo y los movimientos sociales en general, el denominado ciclo de protestas, que se extendió desde el 11 de mayo de 1983 (fecha de convocatoria de la primera protesta) hasta el atentado contra el general Pinochet en septiembre de 1986, cuyo fracaso determinó el fin de la estrategia de la movilización social para terminar con la dictadura (ibid.).

Luego de un periodo de repliegue provocado por la imposición del estado de sitio a raíz del mencionado atentado, en el contexto de la campańa por la reelección del dictador en el plebiscito sucesorio de 1988, se dieron pasos hacia la unidad. El llamado para reconstituir la CUT de la Coordinadora Nacional Sindical fue bien recibido por la gran mayoría de las organizaciones sindicales $y$, como resultado, la nueva central empezó a funcionar en mayo de 1988. La CUT fijó un verdadero programa político que aspiraba a la transformación del modelo neoliberal, con la sustitución del régimen autoritario por un sistema democrático "justo, solidario, participativo y 
profundamente humanista", recogiendo las propuestas planteadas anteriormente por la Confederación Nacional de Sindicatos (CNS) y el CNT (ibid.).

En el caso de Paraguay, como ya se anticipó, se abordó también el tema de las "resistencias", con un fuerte énfasis en la etapa final de la dictadura. Se considera que un punto de inflexión en este sentido fue la fundación del Movimiento Intersindical de Trabajadores del Paraguay (MIT-P) el 1 de mayo de 1985. Se destaca que una de las primeras y principales tareas de esta organización fue obtener apoyo internacional que garantizara cierto apoyo frente a la dictadura; es el caso de la Organización Regional Interamericana de Trabajadores (ORIT) y la Central Latinoamericana de Trabajadores (CLAT). Sin embargo, incluso en un contexto de creciente apertura democrática a nivel regional y con estos apoyos y fiscalizaciones internacionales, la política represiva persistió, y en ocasión del acto del primer aniversario del Movimiento se desató una brutal represión que tuvo repercusión y visibilidad nacional e internacional (González Bozzolasco, 2014). Aun en un contexto de muy fuerte represión, el Movimiento Intersindical de Trabajadores del Paraguay (MIT-P) se propuso avanzar en el impulso de una nueva central, fortalecer el accionar gremial a partir de instancias de base y, desde todas estas posiciones, impulsar el regreso a un sistema democrático como base indispensable para el accionar sindical. El derrocamiento de Stroessner y el inicio de la apertura democrática, en febrero de 1989 (que tienen lugar en un contexto internacional crecientemente adverso a la dictadura, y en el que incluso hubo acciones económicas en contra de esta a partir de 1987), fueron centrales para la constitución de una nueva central obrera independiente en Paraguay (ibid.).

\section{Del análisis de la "resistencia" al foco en el "Consentimiento" y los "COnSensos"}

En los últimos años, y en diálogo crítico con las perspectivas que subrayaban las "resistencias", se fue delineando otra línea de análisis que, por un lado, cuestionaba que fuera correcto asumir que toda iniciativa de acción y organización por parte de los trabajadores hubiera constituido una acción de resistencia consciente a la dictadura y, por otro, destacaba la importancia de analizar lo que se consideraba un amplio arco de apoyos sociales a las dictaduras, enmarcándolos en el concepto de 'consenso social' o formas de "consentimiento". Un ejemplo es la investigación de Daniel Dicósimo (2007) sobre la historia de los trabajadores de dos empresas en Tandil (la empresa Metalúrgica Tandil y la empresa de cemento Loma Negra Villa Cacique, ambas en la Provincia de Buenos Aires) durante la última dictadura militar. Su investigación, al enfocarse en dos casos específicos, difiere de otras aproximaciones previas que habían intentado dar cuenta de grandes tendencias y conflictos a nivel nacional. Esta investigación le permite al autor afirmar que, en los casos en los que se llevaron 
a cabo distintas medidas de protesta y reivindicativas durante la dictadura, no es posible detectar una posición antidictatorial unánime y clara, sino que, por el contrario, el eje de los conflictos fue predominantemente económico y carente de un contenido político de magnitud. Desde su perspectiva, "el comportamiento de los trabajadores sustenta más la interpretación de una defensa de los intereses económicos de clase que la de una oposición política al proyecto del 'Proceso de Reorganización Nacional'” (ibid.). Dicósimo tiende a escindir el plano de la reivindicación económica de la política, aun en el marco de políticas represivas extremas que incluyen la prohibición y la penalización del conflicto, así como y la agitación política con la desaparición, la tortura y la muerte. Aunque reconoce la presencia de una política represiva por parte del Estado y de una política disciplinaria por parte de la patronal, cuya intersección y/o vinculaciones no son cabalmente exploradas en su trabajo, estas aparecen en un segundo plano:

Si bien hubo señales claras de cuál sería el costo de oponerse como la detención en días previos de seis delegados sindicales de la empresa, amenazas e incluso breves secuestros [...] el consenso hacia el golpe de Estado parece haber tenido mucho de voluntario: los testigos recuerdan que la planta funcionaba a pleno esa mańana [...] y que el comentario era "ahora vamos a estar mejor, se va [a] acabar el despelote, vamos a poder trabajar" (ibid.: 98).

La referencia a un "consenso voluntario" parece sugerir la existencia de una libertad de elección y de expresión que, en principio, son contrarias a la dinámica social que trae aparejada un Estado terrorista con su correlato de intervención militar en todos los ámbitos, y la existencia de desaparecidos, presos, torturados y campos de concentración. Esta perspectiva está enraizada en una corriente más amplia de la historiografía, dentro de la cual resultó muy influyente un libro que llamó a la revisión de la historia de la dictadura (Vezzetti, 2002), sosteniendo que la última dictadura militar argentina "puso a prueba a las dirigencias, al Estado y las instituciones y, en general, sacó a la luz lo peor de la sociedad." Desde esta perspectiva, este "episodio agudo de barbarización política y degradación del Estado no hubiera sido posible sin el compromiso, la adhesión, la conformidad de muchos", y propone, entonces, que la tarea central de los estudios sobre este periodo debería ser el análisis de "las responsabilidades de la sociedad" (ibid.: 12-13). En todo caso, los estudios de caso realizados por Dicósimo proveen elementos para alertar sobre los peligros de la asociación automática entre la existencia de conflictos y una posición de oposición política consciente a la dictadura, pero, al mismo tiempo, llaman la atención a lecturas simplificadoras sobre la existencia de un "consenso social" respecto de la dictadura. 
Discutiendo explícitamente con estas visiones, centradas en un supuesto "consenso social" y la asignación de responsabilidades en términos amplios, recientes investigaciones proponen documentar el papel de sujetos específicos, los cuales son analizados, además, en el marco de relaciones de poder fuertemente asimétricas. Estos trabajos se detuvieron a analizar en particular el papel de empresas y empresarios, denunciado desde la década de 1980, habiendo sido objeto también de campañas desde el campo de los derechos humanos y sindicales, así como de investigaciones académicas (Basualdo, 2006, 2010a, 2010b, 2010c; Verbitsky y Bohoslavsky, 2013).

En una investigación reciente, realizada entre 2014 y 2015, se abordó un aspecto fundamental que permite complejizar las miradas centradas central o exclusivamente en el papel de las Fuerzas Armadas y el Estado en la política represiva durante la última dictadura argentina, a partir de analizar la responsabilidad que tuvo un sector del empresariado nacional y extranjero en las violaciones a los derechos humanos cometidas en ese periodo (AEyT-FLACSO, PVJ, SDH y CELS, 2015). La investigación se centró en estudios de casos de 25 empresas de todo el país, considerando que esta escala permitía hacer foco, de forma privilegiada, en el proceso represivo desatado sobre los trabajadores en los establecimientos laborales, analizando las distintas formas de participación de funcionarios jerárquicos o de propietarios de empresas. ${ }^{2} \mathrm{Al}$ analizar el repertorio de prácticas empresariales represivas, se identificó una serie de variables que tenían como protagonistas a distintas figuras empresariales de distinta jerarquía: algunos capataces, jefes de áreas clave (entre ellas, Seguridad y Vigilancia, Relaciones Industriales o Laborales y Personal) o personal jerárquico en cargos ejecutivos de gran relevancia, como jefes de producción o superintendentes de fábrica, e incluso, en algunos casos, miembros de directorio, accionistas o dueños de empresas. Fueron estas figuras las que se relacionaron

2 Las empresas analizadas son: Ledesma, Minera El Aguilar, La Veloz del Norte, Grafanor y los ingenios La Fronterita y Concepción en la región del Noroeste Argentino (NOA); Alpargatas, Molinos Río de la Plata, Swift, Propulsora Siderúrgica, Astilleros Río Santiago y Petroquímica Sudamericana, vinculados con el cordón industrial de la zona sur bonaerense, que comprende el sur de la ciudad de Buenos Aires, la región austral del conurbano bonaerense, La Plata, Berisso y Ensenada; Grafa, Ford, Mercedes Benz, Lozadur y Cattaneo, Astilleros Astarsa y Mestrina, Dálmine-Siderca y Acindar permiten una aproximación al cordón industrial de la zona norte y oeste de la provincia de Buenos Aires, y el sur de Santa Fe; la empresa transnacional de origen italiano FIAT es un acercamiento a un territorio clave en la historia obrera del país, la provincia de Córdoba, al mismo tiempo que el análisis de la empresa Las Marías provee evidencias preliminares vinculadas a la región del Noreste Argentino (NEA). Los casos de Loma Negra y La Nueva Provincia posibilitan un acercamiento a zonas del interior de la provincia de Buenos Aires. 
con los distintos actores militares, en terrenos diferentes, y se involucraron, en interés de la empresa, en las distintas prácticas represivas.

Esta necesidad de abordar, en forma amplia, las actitudes respecto a la dictadura, así como la de examinar distintas formas de apoyo, aparece en formas diversas en contribuciones recientes sobre el resto de los casos nacionales. Para el caso de Brasil, Fontes y Corrêa recuerdan la importancia de no olvidar a quienes "miraban al régimen dictatorial con simpatía", afirmando que muchos trabajadores obtuvieron beneficios del llamado "milagro económico", que creó puestos de trabajo en un contexto de desarrollo económico. Consideran que aun cuando la política económica se basó en la explotación aguda de una parte de la mano de obra, con rebajas salariales y pérdida de derechos, existieron otros sectores, particularmente migrantes de ámbitos rurales, que aprovecharon el desarrollo de actividades de construcción civil y de servicios, por lo que algunos sectores obreros compartieron la visión de sectores de clases medias en esta etapa sobre el "Brasil del futuro" (Corrêa y Fontes, 2015). Al mismo tiempo, otros trabajos enfatizan la importancia de analizar las interacciones y los vínculos no solo entre fuerzas armadas y empresarios, sino también la de ambos con sectores de la dirigencia sindical a la que denominan "pelegos", que apoyaron y desarrollaron políticas contra sectores de trabajadores (Conselho Projeto Memória da CPM-SP, 2014).

En el caso de Chile, se toma como punto de partida el triunfo del neoliberalismo y su hegemonía, y se considera que pudo impulsarse no solo debido a las fuertes políticas represivas ya analizadas, sino también a partir del descrédito de las políticas "estatistas" y "proteccionistas", y que el núcleo de estos "consensos" se mantuvo durante la transición democrática y más allá, y de allí justamente proviene el objetivo de iluminar el costo pagado por los trabajadores y sus organizaciones (Winn, 2004). En el caso de Paraguay, algunos trabajos recientes han considerado que deben ser explicados por mecanismos de "cooptación" que ejercieron la dictadura y el Partido Colorado en el Gobierno sobre los sectores sindicales sobrevivientes a la represión de los primeros años (González Bozzolasco, 2014). En el caso de Uruguay, también se marca la necesidad de explorar comportamientos sociales "en un amplio arco que iba desde la oposición neta al consenso y la aceptación del régimen" (Porrini, 2018), haciendo referencia además a estudios más amplios sobre el "consenso social" (Marchesi, 2009). Puede considerarse, entonces, que la preocupación por iluminar posiciones diversas y niveles de legitimación social de las dictaduras está presente en todos los casos nacionales, y puede resultar muy valiosa, aunque la revisión del caso argentino puede resultar útil para recomendar cautela en la utilización de marcos conceptuales centrados en una dinámica "consensual." 
Propuestas PARA UNA AGENDA DE INVESTIGACIÓN Y TRABAJO DESDE UNA PERSPECTIVA REGIONAL

Este breve recorrido permitió una sintética aproximación al tema de las dictaduras, los trabajadores y los sindicatos en cinco países de América Latina, y mostrar que aun en la etapa actual, y luego de décadas de desarrollo de la producción científica, la integración de dimensiones económicas, sociales, políticas y culturales constituye un enorme desafío que, sin embargo, reviste enormes potencialidades. Resulta difícil, dado el foco predominantemente centrado en dimensiones políticas, tener en cuenta de manera adecuada el papel de los trabajadores y los sindicatos en esta historia, y reconocer e integrar esta dimensión en las historias nacionales. Sin embargo, en todos los casos se detectan y localizan contribuciones relevantes recientes para el campo, que permiten disponer de un punto de partida para una mirada regional más amplia.

El análisis de las evidencias sobre los cinco procesos dictatoriales seleccionados, aún en forma preliminar y sintética, muestra la existencia de puntos de contacto muy significativos en los dos grandes campos estudiados. En primer lugar, en lo que se refiere al análisis de las políticas de las dictaduras dirigidas a los trabajadores y sus organizaciones porque, en todos los casos, se analizan tres grandes áreas: política económica, política laboral y política represiva, y se concluye que la combinación de las tres tuvo como resultado un retroceso global de la clase trabajadora y del movimiento sindical, aunque con fuertes diferencias, no solo en términos de los casos nacionales, sino dentro de los mismos, con corrientes y sectores diferenciados que tuvieron distintas evoluciones estructurales, de organización y de estrategias, y también diversas visiones de los procesos. Al mismo tiempo, varias de estas contribuciones enfatizan que las políticas represivas fueron centrales durante las etapas dictatoriales, y requieren aún un análisis mucho más profundo que permita complejizar la mirada de los sujetos represores y reprimidos. Destacan también que la represión estuvo lejos de ser la única línea de política de las dictaduras respecto de los trabajadores y sus organizaciones. Por el contrario, resta saber mucho más sobre el funcionamiento de diversas instituciones que tuvieron como objetivo la reconfiguración de un conjunto de factores que afectaron las relaciones laborales, como el Ministerio de Trabajo, y una gran cantidad de dependencias adicionales, hasta el momento poco analizadas.

En segundo lugar, en cuanto a las formas de organización y acción de los trabajadores y los sindicatos, también existen fuertes puntos en común. El concepto de 'resistencia', frecuentemente aplicado en todos los casos nacionales, tiene el mérito de haber iluminado el campo de la acción de los trabajadores, con frecuencia invisibilizado y subestimado en las historias del 
periodo. Este concepto, que puede definirse como "acción y efecto de resistir o resistirse", "capacidad para resistir", "conjunto de las personas que, generalmente de forma clandestina, se oponen con distintos métodos a los invasores de un territorio o a una dictadura" o "fuerza que se opone a la acción de otra fuerza”, aunque muy útil para aludir a la existencia de sujetos en movimiento frente a imágenes de inmovilidad, ausencia o silencio, puede correr el riesgo de homogeneizar y unificar el amplio conjunto de las acciones y líneas de acción de trabajadores y sindicatos, así como de sus diversas lógicas subyacentes. De la revisión bibliográfica surge la necesidad no solo de distinguir las líneas de acción de la clase trabajadora y el movimiento sindical como sujetos diferenciados, sino de poder analizar con la suficiente apertura y complejidad los distintos sectores dentro de ellos, inclusive aquellos que pudieron haber apoyado a la dictadura por conveniencia, convicción o presión. En este sentido, el análisis de los cinco casos muestra la necesidad de analizar las distintas respuestas (incluida la posible falta de ella) con la mayor amplitud y diversidad posible, y sin rótulos ni denominaciones que, más que caracterizarlos ajustadamente, tiendan a introducirlos en clasificaciones previamente concebidas, lo cual implicaría, además, profundizar la exploración de otras dimensiones clave, como las de género, etnicidad o abordaje generacional, entre otras. Esta perspectiva no solo resultaría fundamental para comprender los periodos dictatoriales en su complejidad, sino que permitiría dar cuenta de las transformaciones en las relaciones laborales y la evolución de los indicadores de la clase trabajadora y de la dispar evolución de diferentes sectores de la clase trabajadora y de distintas corrientes del movimiento sindical, algunas de las cuales consolidaron sus posiciones a partir de las transformaciones de este periodo, justamente por ser funcionales a los proyectos de refundación del movimiento sindical.

En tercer lugar, a partir de la breve revisión de algunos de los trabajos emergentes, que parecen mostrar un viraje desde un paradigma enfatizando la "resistencia" a otro subrayando los "consensos" o "consentimientos", se destaca la necesidad de reconsiderar su aplicación. Este concepto, que puede definirse como "acuerdo producido por consentimiento entre todos los miembros de un grupo o entre varios grupos", parece de muy difícil aplicación no solo por la asimetría característica de las relaciones entre capital y trabajo, sino por la profundización de las restricciones a la posibilidad de elección libre ante la implementación de esquemas represivos de intensidad extrema. En este contexto, también parece resultar mucho más productivo abrir una línea de análisis tendiente a examinar las formas de legitimación de la dictadura y sus distintos componentes y sujetos, y de los puntos en los que puede lograr un apoyo o una falta de reacción adversa por parte de sectores sociales. Es preciso definir los comportamientos fundamentando 
empíricamente la caracterización de estas actitudes sociales. Al mismo tiempo, aun cuando se pudiera probar apoyos explícitos o implícitos, la presentación de los mismos en un marco de subestimación o desplazamiento de las asimetrías sociales y las diferencias de poder que los condicionan parece metodológicamente cuestionable.

En suma, el presente recorrido parece indicar que el tema de dictadura, trabajadores y sindicatos no solo debe ser profundizado en clave local y nacional, sino también teniendo en cuenta una perspectiva regional latinoamericana y una mirada internacional que permita dar cuenta de transformaciones cruciales a nivel internacional, dimensiones que posibilitarían iluminar cuestiones centrales de esta historia. Para lograrlo, resultaría útil una extensión del marco cronológico, a fin de fomentar una perspectiva más anclada en grandes tendencias internacionales, historizando adecuadamente las dictaduras en el marco de estos ciclos. La dictadura argentina (19761983) debería ser, desde esta perspectiva, analizada en serie y vinculación con las dictaduras en ese país desde 1955 en adelante, lo que permitiría un mucho mejor diálogo con casos como el de Paraguay (1954-1989), pero también con el de Brasil, con el que usualmente se establece un contraste forzado, desconociendo temporalidades diferentes. Evitar una mirada fragmentada dejaría ver, por ejemplo, que la contraposición clásica entre la dictadura "industrialista" y del "milagro económico" en Brasil versus la dictadura desindustrializadora de la Argentina 1976-1983 (proceso que implicó una profunda reconfiguración del sector industrial y procesos de concentración económica) debería ser enriquecida y matizada a partir del hecho de que la dictadura 1966-1973 en Argentina coexistió también con un proceso de profundización de la industrialización y el desarrollo de industrias dinámicas como la automotriz, la metalúrgica y la siderúrgica, incluida la química, durante la segunda industrialización por sustitución de importación (ISI), y que a la posible distinción, en el marco de la dictadura brasileña, produciría desaceleraciones y cambios en la última etapa dictatorial. Este es un claro ejemplo, entonces, de cómo la mirada abarcativa de un periodo mayor permitiría evitar comparaciones o diálogos entre procesos de hecho marcados por etapas y grandes tendencias distintas, promoviendo una mayor contextualización y sutileza en los análisis. 
228 | Trabajos y trabajadores en América Latina (siglos XVI-XXI)

BiBLIOGRAFÍA

Abós, Álvaro

1984 Las organizaciones sindicales y el poder militar. Buenos Aires: CEAL.

[AEyT-FLACSO, PVJ, SDH y CELS] Área de Economía y Tecnología-Facultad Latinoamericana de Ciencias Sociales, Argentina (AEyT-FLACSO Argentina), Programa Verdad y Justicia (PVJ), Secretaría de Derechos Humanos (SDH) (Ministerio de Justicia y Derechos Humanos de la Nación) y Centro de Estudios Legales y Sociales (CELS)

2015 Responsabilidad empresarial en delitos de lesa humanidad: represión a trabajadores en el Terrorismo de Estado. Buenos Aires: Infojus. Disponible en: http://www.infojus.gob.ar/responsabilidad-empresarialdelitos-lesa-humanidad-tomo-represion-trabajadores-duranteterrorismo-estado-ministerio-justicia-derechos-humanos-nacionlb000183-2015-11/123456789-0abc-defg-g38-1000blsorbil

Araya Gómez, Rodrigo

2015 Movimiento sindical en dictadura militar. Fuentes para la historia sindical en Chile (1973-1990). Santiago de Chile: Ediciones Universidad Alberto Hurtado.

Azpiazu, Daniel; Eduardo Basualdo y Miguel Khavisse

1986 El nuevo poder económico en la Argentina de los ochenta. Buenos Aires: Legasa.

Basualdo, Eduardo

2006 Estudios de historia económica Argentina. Desde mediados del siglo XX a la actualidad. Buenos Aires: Siglo XXI Editores.

Basualdo, Victoria

2018 "The Argentine Dictatorship and Labor (1976-1983): A Historiographical Essay". En: International Labor and Working-Class History, número 93. 8-26.

2013 "El movimiento sindical argentino y sus relaciones internacionales: una contribución sobre la presencia de la CIOSL y la ORIT en la Argentina desde fines de los '40 hasta comienzos de los '80". En: Revista Mundos do Trabalho, volumen 5, número 10. 199-219.

2010a "Labor and structural change: shop-floor organization and militancy in Argentine industrial factories (1943-1983)”. Tesis doctoral. Columbia University, Nueva York, Estados Unidos de América.

2010 b "La clase trabajadora durante la última dictadura militar argentina (1976-1983). Apuntes para una discusión de la 'resistencia' obrera”. Dossier La Plata, Argentina: Comisión Provincial por la Memoria. 
2010c "The ILO and the Argentine dictatorship, 1976-1983". En: Jasmien Van Daele, Magaly Rodríguez García, Geert Van Goethem y Marcel van der Linden (eds.), ILO Histories. Essays on the International Labour Organization and Its Impact on the World During the Twentieth Century. Berlín, Alemania / Nueva York, Estados Unidos de América: Peter Lang.

2006a "Complicidad patronal-militar en la última dictadura argentina. Los casos de Acindar, Astarsa, Dálmine Siderca, Ford, Ledesma y Mercedes Benz". En: Engranajes, suplemento especial a 30 años del golpe militar. Buenos Aires: Federación de Trabajadores de la Industria y Afines / Central de Trabajadores Argentinos.

2006b "La participación de trabajadores y sindicalistas en la campaña internacional contra la última dictadura militar argentina". En: Revista Sociedad, número 25. Buenos Aires: Facultad de Ciencias Sociales, Universidad de Buenos Aires.

Basualdo, Victoria y Alejandro Jasinski

2016 "La represión a los trabajadores y el movimiento sindical." En: Gabriela Águila, Santiago Garaño y Pablo Scatizza (eds.), Represión estatal y violencia paraestatal en la historia reciente argentina: nuevos abordajes a 40 años del golpe de Estado. La Plata, Argentina: Facultad de Humanidades y Ciencias de la Educación, Universidad Nacional de La Plata.

2011 La clase trabajadora argentina en el siglo XX: experiencias de lucha $y$ organización. Buenos Aires: Cara o Ceca.

Bohoslavsky, Juan Pablo (coord.)

2016 El negocio del terrorismo de Estado. Los cómplices económicos de la dictadura uruguaya. Montevideo: Penguin Random House.

Canelo, Paula

2016a La política secreta de la última dictadura argentina (1976-1983). Buenos Aires: Edhasa.

$2016 b$ “Qué estudiamos sobre la última dictadura argentina? Tres ciclos de investigaciones entre 1983 y 2015”. En: Guillermo Levy (coord.), De militares y empresarios a politicos y CEOS. Reflexiones a 40 años del golpe. Buenos Aires: Editorial Gorla / Facultad de Ciencias Sociales, Universidad de Buenos Aires.

Calveiro, Pilar

1998 Poder y desaparición. Los campos de concentración en la Argentina. Buenos Aires: Colihue. 
230 | Trabajos y trabajadores en América Latina (siglos XVI-XXI)

Campos, Pedro Henrique

2014 Estranhas catedrais: as empreiteiras brasileiras e a ditadura civil-militar, 1964-1988. Río de Janeiro: Editora de la Universidad Federal Fluminense.

Canitrot, Adolfo

1980 "La disciplina como objetivo de la política económica. Un ensayo sobre el programa del gobierno argentino desde 1976”. En: Desarrollo Económico, volumen 19, número 76. 453-475.

Castellani, Ana

2009 Estado, empresas y empresarios. La construcción de ámbitos privilegiados de acumulación 1966-1989. Buenos Aires: Prometeo Libros.

Centro de Estudios Legales y Sociales (CELS)

2011 Hacer justicia. Nuevos debates sobre el juzgamiento de crimenes de lesa humanidad en la Argentina. Buenos Aires: Siglo XXI Editores.

Comisión Verdad y Justicia (Paraguay)

2008 Tierras mal habidas. Informe final, Anive haguâ oiko. Asunción, Paraguay: Comisión Verdad y Justicia.

Conselho Projeto Memória da Oposição Sindical Metalúrgica (Brasil)

2014 Investigação operária: empresários, militares e pelegos contra os trabalhadores. San Pablo, Brasil: Intercâmbio, Informaçóes, Estudos e Pesquisas / Oposição Sindical Metalúrgica-São Paulo / Projeto Memória.

Corrêa, Larissa Rosa

2017 Disseram que voltei americanizado: relaçôes sindicais Brasil-Estados Unidos na ditadura militar. Campinas, Brasil: Editora de Unicamp.

2014 “Os 'inimigos da pátria': repressão e luta dos trabalhadores do Sindicato dos Químicos de São Paulo (1964-1979)". En: Revista Brasileira de Historia, volumen 34, número 67. 13-37.

Corrêa, Larissa Rosa y Paulo Fontes

2018 "Labor and dictatorship in Brazil: A Historiographical Review". En: International Labor and Working Class History, número 93. 27-51.

2016 “'As falas de Jerônimo': Trabalhadores, sindicatos e a historiografia da ditadura militar brasileira en Anos Noventa". En: Revista do Programa de Pós-Graduação em História da Universidade Federal do Rio Grande do Sul, volumen 23, número 43. 129-151. 
Damill, Mario

2005 "La economía y la política económica: del viejo al nuevo endeudamiento". En: Juan Suriano (ed.), Nueva historia argentina. Dictadura y democracia (1976-2001). Buenos Aires: Sudamericana.

Delich, Francisco

1983 "Desmovilización social, reestructuración obrera y cambio sindical". En: Peter Waldmann y Ernesto Garzón Valdés (eds.), El poder militar en la Argentina, 1976-1981. Buenos Aires: Galerna.

1982 "Después del diluvio, la clase obrera". En: Alain Rouquié (comp.), Argentina, hoy. México: Siglo XIX Editores.

Drake, Paul W.

1996 Labor movements and dictatorships. The Southern Cone in comparative perspective. Baltimore, Maryland, Estados Unidos de América: Johns Hopkins University Press.

Duhalde, Eduardo Luis

1983 El Estado terrorista argentino. Buenos Aires: El Caballito.

Dicósimo, Daniel

2016 Los trabajadores argentinos y la última dictadura. Oposición, desobediencia y consentimiento. Tandil, Argentina: Universidad Nacional del Centro de la Provincia de Buenos Aires.

2007 "Disciplina y conflicto en la historia durante el Proceso de Reorganización Nacional (1976-1983)”. Tesis doctoral. Universidad Nacional del Centro de la Provincia de Buenos Aires, Tandil, Argentina.

2006 "Dirigentes sindicales, racionalización y conflictos durante la última dictadura militar." En: Entrepasados, número 29. Buenos Aires: Facultad de Filosofía y Letras, Universidad de Buenos Aires.

Estevez, Alejandra; Jean Sales, Larissa Rosa Corrêa y Paulo Fontes

2018 Mundos do Trabalho e Ditaduras no Cone Sul (1964-1990). Río de Janeiro: Multifoco.

Estevez, Alejandra y Assumpçao San Romanelli

2013 "Ditadura e Repressao Contra a Classe Trabalhadora". En: Anistia, Política e Justiça de Transiçao, número 10. 432-471.

Fernández, Arturo

1985 Las prácticas sociales del sindicalismo argentino, 1976-1982. Buenos Aires: CEAL. 
Gallitelli, Bernardo y Andrés Thompson

1990 "La política laboral en la Argentina del 'Proceso'”. En: Manuel Barrera y Gonzalo Fallabella (eds.), Sindicatos bajo regimenes militares. Argentina, Brasil, Chile. Santiago de Chile: Consejo Económico y Social de las Naciones Unidas.

González Bozzolasco, Ignacio

2014 "Represión, cooptación y resistencia. El movimiento sindical paraguayo". En: Rocco Carbone y Lorena Soler (eds.), Stronismo asediado: 2014-1954. Asunción, Paraguay: Germinal / Centro de Estudios y Educación Popular. Disponible en: http://conteudo.pucrs. br/wp-content/uploads/sites/30/2016/03/Represion-cooptacion-yresistencia-2013.pdf

2013 El Nuevo Despertar. Breve historia del Movimiento Intersindical de Trabajadores del Paraguay (1985-1989). Asunción, Paraguay: Arandura y Germinal.

Gouveia de Oliveira Rovai, Marta

2014 "A memória na luta contra o trauma: significados sobre a Greve de Osasco em 1968 nas narrativas de trabalhadores". En: Revista Mundos do Trabalho, volumen 6, número 11. 41-56.

Ladosky, Mario Henrique y Roberto Véras de Oliveira

2014 "O 'novo sindicalismo' pela ótica dos estudos do trabalho". En: Mundos do Trabalho, volumen 6, número 11. 147-170.

Marchesi, Aldo

2009 "Una parte del pueblo uruguayo, feliz, contento, alegre. Los caminos culturales del consenso autoritario durante la dictadura". En: Carlos Demasi et al., La dictadura cívico-militar 1973-1985. Montevideo: CEIU / EBO.

Montenegro, Antonio Torres

2014 "Direitos trabalhistas e assassinato em tempos de regime civil-militar (1972-1973): o indiciamento dos irmãos Barreto". En: Mundos do Trabalho, volumen 6, número 11.91-106.

Munck, Gerardo L.

1998 Authoritarianism and Democratization: Soldiers and Workers in Argentina, 1976-1983. Pennsylvania, Estados Unidos de América: Pennsylvania State University Press.

Nagasava, Heliene

2015 "O sindicato que a ditadura queria': o Ministério do Trabalho no governo Castelo Branco (1964-1967)”. Disertación. Centro de 
Pesquisa e Documentação de História Contemporânea do Brasil, Programa de Pós-Graduação em História, Política e Bens Culturais da FGV, Río de Janeiro.

Novaro, Marcos y Vicente Palermo

2003 La dictadura militar, 1976-1983. Del golpe de Estado a la restauración democrática. Buenos Aires: Paidós.

Pessanha, Elina Gonçalves da Fonte

2014 "Os operários navais do Rio de Janeiro sob a ditadura do pós-1964: repressão e resistência”. En: Mundos do Trabalho, volumen 6, número 11. 11-23.

Pessanha, Elina Gonçalves da Fonte y Leonilde Servolo de Medeiros (orgs.)

2015 Resistência dos Trabalhadores na Cidade e no Campo. Colección Comunicaçóes do $3^{\circ}$ Seminário Internacional o Mundo dos Trabalhadores e seus Arquivos. San Pablo y Río de Janeiro: Arquivo Nacional / Central Única dos Trabalhadores.

Porrini, Rodolfo

2018 "Trabajadores y sindicatos uruguayos durante la dictadura (19731985). Consensos y resistencias". En: Alejandra Esteves, Jean Sales, Larissa Rosa Corrêa y Paulo Fontes (eds.), Mundos do Trabalho e Ditaduras no Cone Sul (1964-1990). Río de Janeiro: Multifoco.

Pozzi, Pablo

1988a Oposición obrera a la dictadura, 1976-1982. Buenos Aires: Contrapunto.

1988b "Argentina 1976-1982: Labour Leadership and Military Government". En: Journal of Latin American Studies, volumen 20, número 1. 111-138.

Santana, Marco Aurelio

2014 "Um Sujeito Ocultado: trabalhadores e regime militar no Brasil". En: Em Pauta, número 12. 85-98.

2008 "Ditadura militar e resistencia operaria: O movimiento sindical brasileiro do golpe a trasicao democrática”. En: Política y Sociedade, número 13. 279-309.

Schvarzer, Jorge

1987 La politica económica de Martínez de Hoz. Buenos Aires: Hyspamérica.

Verbitsky, Horacio y Juan Pablo Bohoslavsky (eds.)

2013 Cuentas pendientes: los cómplices económicos de la dictadura. Buenos Aires: Siglo XXI Editores. 
234 | Trabajos y trabajadores en América Latina (siglos XVI-XXI)

Slatman, Marisa

2012 "Archivos de la represión y ciclos de producción de conocimiento social sobre las coordinaciones represivas en el Cono Sur". En: Revista de Sociedad, Cultura y Política en América Latina, volumen 1, número 1. 47-66.

Vergara, Ángela

2018 "Writing about Workers, Reflecting on Dictatorship and Neoliberalism: Chilean Labor History and the Pinochet Dictatorship". En: International Labor and Working Class History, número 93. 52-73.

Vezzetti, Hugo

2002 Pasado y presente. Guerra, dictadura y sociedad en la Argentina. Buenos Aires: Siglo XXI Editores.

Welch, Clifford Andrew

2014 "Camponeses, a Verdade e a História da Ditadura em São Paulo". En: Mundos do Trabalho, volumen 6, número 11.57-78.

Winn, Peter

2018 "Dictatorships and the Worlds of Work in the Southern Cone: Argentina, Brazil and Chile". En: International Labor and Working Class History, número 93. 1-4.

2004 Victims of the Chilean Miracle. Workers and Neoliberalism in the Pinochet Era, 1973-2002. Durham, Reino Unido: Duke University Press.

Yaffé, Jaime

2012 "La dictadura uruguaya, 1973-1985: nuevas perspectivas de investigación e interpretación historiográfica". En: Estudios Ibero-americanos, volumen 38, número 1. 13-26. 
3

Trabajo y COACción 



\title{
Introducción \\ Diversidad y complejidad de regímenes y relaciones laborales
}

\author{
Paola Revilla (Bolivia)* \\ Christian G. De Vito (Italia/Alemania)**
}

La dicotomía libre/esclavo se ha mostrado insuficiente para explicar la diversidad y multiplicidad de relaciones y de experiencias laborales en el mundo. De esta certeza surge la necesidad de poner en evidencia y estudiar en perspectiva histórica la coexistencia de sistemas laborales que, por su diferente grado de coerción, la historiografía ha tradicionalmente calificado de "libres" y "no libres". ${ }^{1}$ Además de las posibles similitudes y diferencias, se pueden constatar ciertas conexiones y relaciones entre estos regímenes. De hecho, esto demanda superar la distinción misma entre relaciones "libres" y "no libres", para enfocarse en el continuum de coacción en el cual se sitúan todas relaciones laborales. Un acercamiento de este tipo debe ir de la mano de la reflexión renovada sobre los significados de coerción y libertad asociados a las formas laborales estudiadas en diferentes contextos y periodos.

Este gesto de renovación de la mirada de la historiografía laboral ha sido impulsado como área de interés creciente dentro de la historia con perspectiva global, lo que, a su vez, ha contribuido a la expansión cronológica, temática y geográfica de la historia de los mundos del trabajo y de los trabajadores. El enfoque ha tenido resonancia particularmente en América Latina, donde las problemáticas generadas en torno al estudio de las relaciones laborales han gozado de gran relevancia los últimos años. Esto muestra no solo el eco que ha generado la historiografía de mirada global en Latinoamérica, sino los aportes que de ella han surgido para enriquecer y avanzar en la reflexión comparativa dentro de un espectro comparativo de escala mucho más amplia.

Los ensayos aquí recogidos son un buen ejemplo de la dinámica historiográfica descrita. La reflexión de los autores se despliega entre los siglos XVI y XVIII, atiende el escenario de varias regiones latinoamericanas, concretamente de los actuales México, Perú, Brasil, Argentina y Bolivia, y se centra en el estudio de una variedad de aspectos de la historia del trabajo libre y no libre.

\footnotetext{
* Universidad Católica Boliviana (UCB).

** Universidad de Bonn. Agradecemos a Felipe Castro y Beatriz Mamigonian, cordinadores de mesa y lectores de este texto.

1 El largo debate sobre las formas laborales libres y no libres ha sido muy bien presentado por Tom Brass y Marcel van der Linden, 1997: 218-220.
} 
En "Un mundo diverso: una panorámica sobre los trabajadores mineros coloniales a partir del análisis de casos en los virreinatos de Nueva España y del Perú", las historiadoras Paula Zagalsky e Isabel Povea Moreno reflexionan sobre el contexto laboral de los siglos XVI-XVIII en el distrito de Guanajuato, dentro del virreinato de Nueva España, y el del Cerro Rico en Potosí, dentro de la Real Audiencia de Charcas, entonces bajo dependencia del virreinato del Perú. En el proceso revelan la coexistencia de varios regímenes laborales y sistemas de reclutamiento de mano de obra en las minas de plata de ambas ciudades, así como los cambios que fueron sufriendo a lo largo del tiempo. Más importante aún, el texto ofrece interpretaciones consistentes y acertadas sobre los factores económicos, culturales y políticos que influyeron en la organización y transformación de las relaciones laborales a lo largo del tiempo.

Francisco Quiroz, por su parte, se detiene en el estudio del artesanado en el contexto urbano peruano. Su texto, "Aprendiendo juntos: indios, negros libres y esclavos en talleres de Lima colonial”, estudia la composición social, étnica y legal de los trabajadores integrantes de los gremios. Una vez claro este intrincado panorama, hace un análisis detallado de la distribución del trabajo en talleres artesanales y manufactureros, midiendo el impacto que pudieron tener sobre ella los criterios coloniales de jerarquización étnicocultural y económica de la población.

"Yanaconas, colonos y arrenderos: contradicciones entre la ley y la práctica en el trabajo rural durante los siglos XIX y XX en Bolivia" es una invitación de María Luisa Soux a indagar en la normativa y la práctica del trabajo en haciendas rurales en la Bolivia de principios de la República hasta el contexto de la Revolución de 1952. En una introducción muy pertinente, la autora señala la necesidad de estudiar en profundidad la coexistencia de una variedad de relaciones laborales, antes de suponer que cada régimen de propiedad y gestión de tierras implicó un tipo específico de relacionamiento. Soux busca, además, señalar la importancia de trascender una dicotomía de uso historiográfico habitual: escenario colonial/escenario posindependencia, proponiendo una mirada más transversal, atenta a posibles cambios y continuidades en los mundos del trabajo rural. Propone que así se puede vislumbrar con mayor precisión las particularidades del cambio de estatus de los yanaconas en su devenir en colonos y arrenderos.

Finalmente, en "La discusión sobre el trabajo forzado en Brasil y Argentina en diálogo con la Organización Internacional del Trabajo", Norberto Ferreras reflexiona sobre el significado de la categoría 'trabajo forzado' y su recepción en la primera mitad del siglo XX en Latinoamérica, concretamente en Argentina y Brasil. Dos aspectos interesan particularmente al autor: el análisis de la importancia de la coerción laboral de tipo extraeconómico, y el estudio del impacto de la normativa de organizaciones supranacionales, 
en especial de la Organización Internacional del Trabajo (OIT), en las definiciones de las relaciones laborales libres y no libres.

De la lectura de todas estas contribuciones surgen varios temas transversales de potencial importancia para el debate. En primer lugar, aquel que concierne a los espacios de coerción. En sus textos, Zagalsky y Povea Moreno, y también Quiroz, permiten entrever cómo y por qué ciertos regímenes y formas de coerción laboral, pero además la combinación de los mismos, se "desplegaron" en trayectorias complejas (como diría Jairus Banaji) en determinados contextos socioeconómicos de Hispanoamérica colonial. ${ }^{2}$ Esto queda especialmente claro en el enfoque del escrito de Zagalsky y Povea Moreno sobre el trabajo minero. Los historiadores en América Latina han profundizado más que sus colegas en otras partes del mundo sobre la importancia de las interacciones entre trabajadores en concreto, no conformándose con el estudio de relaciones laborales dentro de enfoques más abstractos. El trabajo de Quiroz, en el que vemos españoles, indios, mestizos, negros libres y esclavizados interactuando en el trabajo cotidiano en los talleres de Lima, es prueba de este esfuerzo.

Otro aspecto relevante que resalta en la exposición de ideas de estos artículos es la necesidad de profundizar en la aproximación a la ambigüedad implícita del trabajo contractual remunerado en los escenarios estudiados. Buena parte del debate historiográfico tradicional sobre la coerción laboral se concentra en las relaciones laborales claramente percibidas como no libres (la esclavitud legal y el trabajo en presidios, entre otras). Sin embargo, Zagalsky, Povea Moreno, Soux y Quiroz enfocan la mirada en la pluralidad de situaciones que generan relaciones laborales en las que media un contrato y un salario. En el proceso, se detienen a reflexionar sobre el grado y el carácter que adquiere (o podría implicar) la coerción bajo estas circunstancias. Zagalsky y Povea Moreno se acercan, por ejemplo, al sistema de trabajo en minas a "raya y partido" (es decir, el del pago de un salario más un porcentaje de la producción a modo de incentivo) y al de "peonaje por deudas" en Guanajuato. Todo esto, sin dejar de reconocer en paralelo la importancia de formas menos coercitivas que conoce el trabajo remunerado.

El análisis de alrededor de 3.500 contratos laborales permite afirmar a Quiroz que la categoría de trabajador "a contrato" involucra situaciones tanto o más disímiles que las que viven los trabajadores "a jornal” o "jornaleros" o los "muchachos" que se encuentran trabajando como aprendices en talleres a modo de cumplir con algún castigo o deuda de sus apoderados. El autor atrae además nuestra atención sobre la complejidad de la remuneración, ya sea en especie, en dinero o en servicio. Puntualiza, por ejemplo, que aunque según norma los propietarios de los jornales generados por los 
esclavos eran los amos, algunos les concedían una parte de la remuneración, con la que aquellos iban acumulando un pequeño peculium. No menos importante es la demostración que hace de la importancia que va ganando el contrato verbal en el siglo XVIII con relación al del siglo XVI.

En lo que se refiere a los escenarios rurales, Soux señala como punto de partida que un elemento clave de la propiedad de la tierra en la Bolivia del siglo XIX y hasta al menos mediados del XX era que esta se transfería junto con las costumbres vinculadas a ella, incluidas las diversas formas de servidumbre que regían la vida de sus trabajadores. Comprueba la coexistencia de elementos de servicio personal conjugados con relaciones de tipo más impersonal entre empleador y empleado en un mismo espacio. La normativa sobre tierras y la "ficción legal" del contrato habrían validado tal coexistencia. Contribuyendo a esta interpretación, Ferreras recuerda la ambigüedad que caracterizó a los acuerdos que mediaban con los yanaconas y con la servidumbre a contrato. Para este autor, todo el debate sobre el trabajo forzoso en América Latina, en particular en Argentina y en Brasil, reposaría sobre el truck system, forma de explotación individual de trabajadores en la que se incluyen el 'pago en especie' y el 'trabajo por deuda' o 'peonaje por deuda', según la terminología más propiamente latinoamericana.

La etnicidad en los mundos del trabajo y de los trabajadores libres y no libres es otro tema que comparten los textos aquí presentados. Zagalsky y Povea Moreno estudian en detalle la composición étnica de la fuerza laboral que atienden y, especialmente, el papel del tributo en el reclutamiento de mano de obra indígena en Guanajuato y en Potosí. Quiroz, cuyo texto está centrado en esta problemática, pone de relieve el papel cambiante de las categorizaciones en la coacción laboral en Lima. Estudia, por ejemplo, algunos mecanismos mediante los cuales los "gremios de españoles" buscaron discriminar a los integrantes de "castas" de la jerarquía de "maestros" artesanos. Soux, por su parte, subraya que el tema de la propiedad de la tierra de los pueblos indígenas bolivianos fue clave en el contexto legislativo posindependencia, y que la etnicidad fue punto neurálgico en la divergencia entre la normativa escrita y las prácticas laborales. Refiere, entre otros ejemplos, que el proyecto para la abolición del pongueaje fue rechazado por un diputado a principios de la década de 1940: "bajo un argumento relacionado con la civilidad del indio" ${ }^{3}$ (p. 325). Así, deja entrever que la permanencia de las relaciones de dependencia personal y de servidumbre en las prácticas laborales estuvo estrechamente vinculada al origen indígena.

El influjo de la administración central y de la legislación impuesta es también debatido por nuestros autores. Para Zagalsky y Povea Moreno hay diferencias

Énfasis própio. 
concretas entre el papel jugado por los virreinatos coloniales novohispano y peruano (puntualmente el de la Audiencia charqueña), según su mayor o menor intervención en la economía y en la regulación del mercado laboral, en las relaciones tejidas entre empleados y empleadores, y en la normativa específica que validaba y buscaba hacer respetar. Esta dinámica reflejaría también la relación política establecida entre los representantes políticos y las élites económicas para el control del trabajo coercitivo, que condujo a la intervención directa o, según el caso, a la abstención de pronunciamiento sobre ciertos aspectos. Quiroz destaca con claridad las normas que se establecen en el virreinato peruano para controlar la movilidad de los esclavos en el contexto urbano, bajo el argumento de garantizar la seguridad y el orden público. Paralelamente, revela al empleador privado beneficiándose de esa movilidad "ilegal" para hacer contrataciones individuales. En el caso de la población indígena, la administración colonial habría intervenido regulando una remuneración a cambio del trabajo prestado, como debían indicar sus contratos, pero, paradójicamente, no sin resistencia de los empleadores. A su vez, habría apoyado la formación de "gremios de espańoles" diferenciados, para proteger su estatus y sus negocios en el escenario colonial. En su cuidadosa aproximación a la normativa, Soux señala la flagrante falta de implementación en la misma en la Bolivia del siglo XIX y hasta mediados del siglo XX, dentro del proceso de construcción de un discurso sobre el "trabajo libre" y la "libertad" encaminado por los mandatarios liberales de la joven República, con fines más políticos que prácticos.

La reflexión en dimensión comparativa resalta en todos los ensayos. El de Ferreras muestra las diferentes reacciones de los Gobiernos de Brasil y de Argentina ante las inspecciones, las campañas y los debates que llevaban adelante organizaciones supranacionales de la época, como la OIT y la Liga de Naciones. Zagalsky y Povea Moreno realizan, a su vez, comparaciones muy pertinentes entre las dos ciudades que escogieron para el estudio, Guanajuato y Potosí, que tienen en común la notable producción de plata, de la que hacen prueba sus vetas mineras. Comparan, además, su dinámica laboral puntual en periodos distintos, aunque presentando sus análisis más como un diálogo sobre este fenómeno en ambos espacios que como un ejercicio de comparación sistemática. Quiroz y Soux concentran el lente comparativo en los cambios y en las continuidades en ciertos fenómenos laborales, y en la situación de los trabajadores a través de los siglos. El primero se enfoca en los contratos elaborados en la Lima del siglo XVI frente a los del siglo XVIII en el mismo contexto. Soux, por su parte, mira, como hemos referido, los matices, los cambios y las permanencias en la normativa y en la vida práctica del yanacona/colono/arrendero de las haciendas rurales bolivianas de los siglos XIX y XX.

Yace sumergido en el debate el discurso de y sobre la "modernidad", así como el cuestionamiento de una aproximación lineal (o no) a los cambios 
históricos. Esta última postura metodológica permite a los autores reflejar la innegable complejidad subyacente a los procesos estudiados, problematizando las dinámicas generadas en diferentes regímenes de trabajo coercitivo, más allá de la mirada historiográfica tradicional a la cronología. Sobresale el tratamiento de dos interrogantes. La primera, la voluntad de saber cómo construyen y deconstruyen, definen y redefinen los actores sus relaciones laborales dentro y más allá de las categorías 'libre' y 'no libre'. La segunda, cómo van tomando cuerpo o cayendo en desuso ciertas relaciones laborales y sus definiciones dentro de un marco social más amplio. El trabajo de Soux es particularmente importante en este sentido, en su abordaje del yanaconazgo y del pongueaje en la Bolivia republicana y liberal de la primera mitad del siglo XX. Ferreras, por su parte, en su análisis de la construcción de relaciones laborales y de producción en Argentina enfatiza que fueron presentadas como "modernas", dentro de "una relación libre entre capital y trabajo" (p. 354). Esta idea de libertad, como subraya el autor, remitiría al discurso del liberalismo clásico al que el Estado buscaba adscribirse. No habría sido posible admitir la existencia de trabajo forzado en una sociedad que preconizaba la libertad como base de su organización política y social "moderna".

Ahora bien, ¿qué lecturas presentan los académicos sobre este asunto puntual? Sus enfoques y perspectivas son diversos. Quiroz observa la pluralidad de relaciones y situaciones laborales en el contexto limeño que analiza, pero tiende a verlas como correlato de una tendencia a la universalización homogeneizadora hacia la modernidad. En sus palabras: "Incluso en el siglo XVIII, existió el jornal, pero no las relaciones asalariadas modernas. Se trataba de elementos de libre contratación, más que la libre contratación misma" (p. 306). Soux, por su parte, encuadra su argumento dentro de cierto parámetro de modernidad que le hace afirmar por ejemplo que, en el contexto que estudia "persistían aún con mucha fuerza los principios de antiguo régimen" (p. 327); pocas secciones antes asume de hecho que las relaciones laborales no asalariadas eran señal de que imperaban condiciones laborales de sociedad precapitalista (p. 300). Académicos de diferentes partes del mundo tienen opiniones divididas sobre este punto; no obstante, algunos de ellos han destacado con solidez la compatibilidad del capitalismo con la coerción de tipo extraeconómico. ${ }^{5}$ A la vez, en su estudio, Soux deconstruye el discurso de la "modernidad" y la linealidad en el cambio histórico, mostrando el uso político de ciertos conceptos y temas. Es lo que sucede cuando alude al tildado de "carácter feudal de las haciendas" (p. 314) en el debate boliviano,

\footnotetext{
4 Énfasis própio.

5 Véase: Brass y Van der Linden (eds.), 2000.
} 
que movería los engranajes léxicos de la Reforma Agraria de 1953. Esta retórica no es de uso exclusivamente boliviano, sino que nos remite, para citar ejemplos, a las discusiones en torno a la reforma agraria en Italia, hacia 1950, y al debate político e historiográfico sobre el uso de conceptos como 'feudal' y 'semifeudal' en la India del siglo XX. ${ }^{6}$

En lo que atañe a Ferreras, en su estudio problematiza el tema de la "proletarización" después de la abolición de la esclavitud; lo hace mostrando en particular las limitaciones de la movilidad de los trabajadores y otras formas coercitivas puestas en marcha. El autor es de sobra consciente de la necesidad de evitar los análisis teleológicos sobre los cambios en las relaciones laborales, e invita a ver los conceptos 'dependencia' y 'libertad' como dos polos en tensión "que no se resuelve en determinado momento" (p. 333), en el sentido de que no hay entre ellos un momento de quiebre sin retorno. Este argumento bebe de la propuesta de Tom Brass sobre la "desproletarización". 7 Del mismo modo, Ferreras conecta explícitamente su reflexión con Marcel van der Linden (2013), en su crítica al concepto de 'esclavitud moderna y contemporánea'.

El debate sobre los mundos y las relaciones de trabajo libre y no libre tienen aún una apretada agenda reflexiva por encaminar. Las contribuciones de esta sesión ( $y$, de hecho, las de todo el volumen) presentan una reflexión articulada únicamente dentro del escenario latinoamericano. No cabe duda de que la tendencia académica, reflejada en estos textos, es tomar a los Estados-nacionales que emergieron en el siglo XIX como arquetipos de unidades espaciales de investigación. Incluso Ferreras, que invita a avanzar en dirección regional y global, y estudia la perspectiva de las organizaciones transnacionales, termina con un análisis enmarcado en dos Estados-nación. Las comparaciones han sido elaboradas dentro de estas unidades de análisis o difícilmente se abstraen de ellas en la reflexión. Si bien esto es totalmente legítimo y relevante, ¿qué más se puede decir y aprender si se adopta una mirada más sistemáticamente conectada a nivel translocal y transnacional dentro del proceso histórico de investigación? ¿En qué medida podemos decir que las interacciones de trabajo libre y no libre en América Latina pueden ser cabalmente explicadas haciendo referencia exclusiva a las experiencias de sus espacios jurisdiccionales actuales? Más aún si consideramos las conexiones transregionales a través de los siglos, así como las migraciones y el movimiento de población que han caracterizado su historia compartida con el resto del mundo. Sin duda, esta es una apertura necesaria y un reto historiográfico que valdría la pena asumir.

6 Véase: Brass, 2011.

7 Ibid. 
244 | Trabajos y trabajadores en América Latina (siglos XVI-XXI)

BiBLIOGRAFÍA

Banaji, Jairus

2010 Theory as History. Essays on Modes of Production and Exploitation. Historical Materialism Book Series, volumen 25. Leiden, Holanda / Boston, Estados Unidos de América: Brill.

Brass, Tom

2011 Labour Regime Change in the Twenty-First Century: Unfreedom, Capitalism and Primitive Accumulation. Studies in Critical Social Sciences. Leiden, Holanda / Boston, Estados Unidos de América: Brill.

Brass, Tom y Marcel van der Linden (eds.)

1997 Free and Unfree Labour: The Debate Continues. Nueva York, Estados Unidos de América: Lang.

Van der Linden, Marcel

2013 Trabalhadores do Mundo. Ensaios para uma História Global do trabalho. Campinas, Brasil: Unicamp. 


\title{
Un mundo diverso: una panorámica sobre los trabajadores mineros coloniales a partir del análisis de casos en los virreinatos de Nueva España y del Perú
}

\author{
Paula C. Zagalsky (Argentina)* \\ Isabel M. Povea Moreno (México)**
}

RESUMEN: El presente estudio propone una mirada panorámica sobre el mundo del trabajo minero durante el periodo colonial en América, a partir del análisis de dos casos paradigmáticos de la producción de plata a gran escala en sus respectivos momentos de auge: el Cerro Rico de Potosí, durante los siglos XVI y XVII, en el espacio peruano, y el distrito de Guanajuato, en el siglo XVIII, en el espacio novohispano. Considerando los contextos temporales distintos, más que una comparación se propone un diálogo que permita indagar en la diversidad de formas que adquirió el mundo del trabajo minero en la América colonial. Esto implica, por una parte, dar cuenta de las diferentes formas de trabajo que, en muchos casos, se sucedieron y convivieron en el marco de un mismo centro minero. Por otra parte, y desde una perspectiva más amplia, se aspira a subrayar los puntos de similitud y contraste entre uno y otro espacio. Al mismo tiempo, se indaga en algunas formas concretas que adoptó el trabajo minero para profundizar en sus significados históricos y anudarlos a una interpretación articulada a las categorías de trabajo "libre" y "no libre". Se aspira a desmontar de forma dialogada una serie de presupuestos extendidos, como el predominio del trabajo minero forzado en Potosí y el de relaciones asalariadas y libres en el caso novohispano. ${ }^{1}$

PalabRAS CLAVE: mundo del trabajo; minería de plata; virreinato de Nueva España; virreinato del Perú.

* Doctora en Historia por la Universidad de Buenos Aires. Consejo Nacional de Investigaciones Científicas y Técnicas (CONICET). Contacto: pzagalsky@gmail.com

** Doctora en Historia por la Universidad de Granada. Instituto de Investigaciones Históricas, Universidad Autónoma de Baja California (IIH-UABC). Contacto: isabelpovea@gmail.com

1 Quisiéramos agradecer especialmente los comentarios elaborados por Felipe Castro Gutiérrez a una versión preliminar de este artículo presentado en el marco del Congreso que dio origen a este libro, aunque la responsabilidad por el contenido en esta versión final descansa en las autoras. Por último, señalemos que algunos fragmentos centrados en la Villa Imperial de Potosí fueron previamente publicados por Zagalsky (2014b). 


\section{INTRODUCCIÓN}

El proceso de conquista y dominación europea del continente americano estuvo signado por la búsqueda y la extracción de metales preciosos, especialmente del oro y la plata. Entre 1550 y 1800, los dominios de Portugal y España en América contribuyeron al desarrollo de la economía global con más del $80 \%$ de la plata y más del 70\% del oro producido en el mundo (Cross, 1983: 403). ${ }^{2}$ Las cifras que ofrece el texto clásico de Cross son más que elocuentes respecto del rol de la producción americana de plata en el contexto mundial, y permiten, además, observar los aportes realizados por los grandes espacios americanos.

Tabla 1: Porcentaje de plata y oro americanos dentro de la producción mundial, 1500-1800

\begin{tabular}{|l|c|c|c|c|c|c|}
\cline { 2 - 7 } \multicolumn{1}{c|}{} & \multicolumn{3}{c|}{ Plata } & \multicolumn{3}{c|}{ Oro } \\
\cline { 2 - 7 } \multicolumn{1}{c|}{} & Siglo XVI & Siglo XVII & Siglo XVIII & Siglo XVI & Siglo XVII & Siglo XVIII \\
\hline Virreinato del Perú & $57,1 \%$ & $61,0 \%$ & $32,5 \%$ & $35,7 \%$ & $60,1 \%$ & $36,0 \%$ \\
\hline Brasil & - & - & - & - & $1,7 \%$ & $44,1 \%$ \\
\hline Virreinato de Nueva España & $11,4 \%$ & $23,4 \%$ & $57,0 \%$ & $3,4 \%$ & $4,3 \%$ & $4,8 \%$ \\
\hline $\begin{array}{l}\text { Porcentaje americano de la } \\
\text { producción mundial }\end{array}$ & $68,5 \%$ & $84,4 \%$ & $89,5 \%$ & $39,1 \%$ & $66,1 \%$ & $84,9 \%$ \\
\hline
\end{tabular}

Fuente: Cross, 1983: 403.

En los dominios de Portugal y España se destacaron diferentes centros mineros, cuya importancia varió a lo largo del periodo colonial. En el caso del Brasil, la producción colonial de plata ocupó un rol ínfimo en relación con la extracción aurífera, constituyéndose en la región latinoamericana con mayor producción de oro, especialmente durante el siglo XVIII. En el territorio de Nueva España, los casos más sobresalientes son los de Zacatecas, Guanajuato, Real del Monte y San Luis Potosí, todos ellos centros de producción argentífera en actividad desde el siglo XVI, pero que, en su mayoría, descollaron en el siglo XVIII. ${ }^{3}$ En el territorio del virreinato

2 La información de este apartado procede de un conjunto de textos nodales que permiten situar y ponderar los casos analizados en el contexto latinoamericano colonial, imperial español y de la economía global: Cross, 1983; Garner, 1988; Bakewell, 1990; TePaske, 2010; Hausberger e Ibarra, 2014.

3 Las minas de San Pedro, en la jurisdicción de San Luis Potosí, tuvieron además una producción muy destacada de oro, siendo por ello únicas en Nueva España: tras su beneficio, la plata salía mezclada con oro (Serrano, 2008: 40). 
del Perú también ocupó un lugar destacado la extracción de plata, con el Cerro Rico de Potosí como el centro minero que jugó un rol central durante los siglos XVI y XVII. Situado en el actual territorio del Estado Plurinacional de Bolivia, durante su apogeo (1590-1620), sus Cajas Reales habrían registrado más del $90 \%$ de la producción total de plata peruana. ${ }^{4}$ A partir de la década de 1630 y durante la centuria siguiente, importantes centros mineros argentíferos se destacaron en el contexto peruano (Oruro, Carangas, San Antonio del Nuevo Mundo, Hualgayoc, Cerro de Pasco, Chachapoyas, Cailloma y Huantajaya, entre otros), aunque sin alcanzar los niveles de Potosí ni los que mostrarían los de Nueva España (TePaske, 2010: 141-212).

Tomando todo el periodo colonial, en América se produjo más plata que oro, con el virreinato de Nueva España como el mayor productor. Sin embargo, cabe señalar que existieron dos ciclos de auge: el primero, entre 1570 y 1630, liderado por el virreinato del Perú, y el segundo, entre 1770-1800, dominado por las minas novohispanas. Potosí, uno de nuestros casos de análisis, se erigió no solo como el mayor productor de plata del espacio peruano sino también de toda América Latina durante los siglos XVI y XVII, encabezando el primer ciclo de auge. Durante la segunda mitad del siglo XVIII, las cifras de la producción de plata del virreinato del Perú alcanzarían su pico máximo, aunque ya sin el rol protagónico de Potosí, que no llegaría a producir ni la mitad de las cifras del auge de fines del siglo XVI. Pese a ese aumento de fines del siglo XVIII, para entonces el volumen de la producción peruana era superado ampliamente por el novohispano. Durante todo el siglo XVIII, el valor de la producción de plata de Nueva España fue en aumento, registrando un crecimiento espectacular entre las décadas de 1770 y 1810 . Por entonces, Guanajuato era el mayor productor de plata de Nueva España y del mundo, con una producción anual de más de cinco millones de pesos (Brading, 2012: 349), al punto que, atendiendo a datos de Humboldt, Pierre Vilar (1974: 415) apunta que Guanajuato en el siglo XVIII fue más productiva de lo que Potosí había sido en el XVI.

4 Se debe advertir que, durante ese periodo de auge potosino, la producción de plata de otros centros mineros, relativamente cercanos y situados en la misma región de Charcas, fue registrada en las Cajas Reales de Potosí, lo que llevó a que fuera considerada como producida en la Villa Imperial de Potosí. Se admite habitualmente que es imposible estimar de forma exacta esta plata no potosina. El caso más conocido es el de Oruro, pero se puede incluir a otros centros mineros pequeños, como por ejemplo Aullagas, Berenguela, Salinas de Garci Mendoza, Sicasica y, tal vez, Chocaya, hacia la década de 1630 (Gavira Márquez, 2010: 215244; comunicación personal con Raquel Gil Montero). 
Sobre la producción argentífera colonial de Potosí y Guanajuato (los mayores productores de plata de cada virreinato) se han escrito trabajos ya clásicos que constituyen referencias obligadas tanto para analizar los casos como para la historia de la minería latinoamericana en general. ${ }^{5} \mathrm{La}$ historiografía hace referencia a una serie de temas y problemas: la construcción de estimaciones de la producción total y debates derivados, las relaciones entre la minería prehispánica y la colonial, los diferentes tipos y etapas de la organización de la producción minera, las regulaciones, las prácticas y los debates sobre la organización de la mano de obra y, especialmente para el caso novohispano, el análisis de la élite minera. Además, existen contados pero valiosos análisis comparativos enfocados particularmente en la cuantificación de la producción de plata (Klein, 1991: 154-217; Bakewell, 1991: 58-72; Brading y Cross, 1972: 545-579; Garner, 1988: 898-935).

Este trabajo propone una mirada panorámica sobre el mundo del trabajo minero durante el periodo colonial americano. Para ello se han seleccionado dos casos paradigmáticos de centros productores de plata en gran escala: el del Cerro Rico de Potosí durante los siglos XVI y XVII en el espacio peruano, y el de Guanajuato durante el siglo XVIII en el espacio novohispano. Como se ha señalado en párrafos anteriores, ambos centros mineros fueron, aunque en momentos distintos, los mayores productores de plata de América y del mundo. Por eso, el análisis de estos dos marcos laborales, tomando sus respectivos periodos de auge y relacionándolos entre sí, nos brinda la posibilidad de observar un conjunto de variables presentes en escenarios de apogeo productivo y, asimismo, visualizar los sistemas de trabajo y las formas de remuneración establecidos a partir de esos condicionantes. La perspectiva amplia que nos ofrece ese análisis permite traspasar los márgenes regionales y poner sobre la mesa de debate nuevas ideas e interrogantes que, en último término, podrán matizar algunos lugares comunes.

Considerando que se trata de casos que aluden a contextos temporales muy distintos, más que una comparación, se propone un diálogo que permita indagar en la enorme diversidad de formas que adquirió el mundo

5 Dentro de un universo muy amplio de análisis vinculado a la producción minera potosina, imposible de citar extensamente, destacamos algunos de los trabajos ejemplares: Cobb, 1977; Sánchez Albornoz, 1978; Assadourian, 1979 y 1982; Saignes, 1984 y 1985; Cole, 1985; Bakewell, 1989; Arduz Eguía, 1985; Tandeter, 1992; González Casasnovas, 2000; Robins, 2011; Brown, 2012. Sobre Guanajuato, dentro de una bibliografía también extensa, destacamos algunos trabajos que han dejado huella: Brading, 2012; Castro, 2002; Villalba Bustamante, 2013; Blanco, Parra y Ruiz Medrano, 2011; Caño Ortigosa, 2006: 187-209; Pérez Luque y Tovar Rangel, 2006; Caño Ortigosa y Lacueva Muñoz, 2009: 605- 624. 
del trabajo minero en la América colonial. Esto implica, por una parte, dar cuenta de cada una de esas diferentes formas de trabajo que, generalmente, convivieron en el marco de un mismo centro minero. Al abordar el mundo del trabajo y su diversidad, se aludirá a los sujetos trabajadores y sus etnicidades, géneros, procedencias y condiciones fiscales; a los tipos de trabajos desarrollados; a la existencia de salarios y jornales, y los pagos efectivamente realizados; a las formas coactivas que operaron sobre los trabajadores; a las conexiones entre los sistemas de trabajo "libre" con los sistemas "no libres"; y a los desplazamientos posibles desde unos hacia otros. En ese sentido, se profundiza en algunas formas concretas que adoptó el trabajo minero para indagar en sus significados históricos y anudarlos a una interpretación articulada a las categorías de trabajo "libre" y "no libre".

Por otra parte, y desde una perspectiva más amplia, se aspira a subrayar los puntos de similitud y contraste entre uno y otro espacio. Entre los presupuestos más comunes, se tiende a pensar que el trabajo minero en Potosí estuvo dominado por el trabajo forzado, mientras que en Nueva España el trabajo forzado habría sido casi inexistente, con un predominio de relaciones asalariadas y libres. Esperamos desmontar de forma dialogada estos postulados generalizantes y estereotipados. Con la finalidad de preservar la complejidad del mundo laboral minero colonial, se analizan los dos grandes centros mineros en sus respectivos contextos virreinales y en relación con otros centros mineros argentíferos regionales.

\section{La Villa Imperial de Potosí y su Cerro Rico}

$\mathrm{Al}$ igual que otros centros mineros peruanos y novohispanos, Potosí dependió predominantemente de la fuerza de trabajo indígena. Los afrodescendientes (esclavos o libertos) constituían una fracción muy pequeña de la fuerza de trabajo en la minería de la plata (a diferencia de la del oro), y trabajaban siempre en la superficie y nunca en labores subterráneas. ${ }^{6}$ Mestizos y españoles constituían una minoría, jugando su rol de dueños de minas, arrendatarios, mayordomos y funcionarios encargados de la supervisión y justicia en las minas. ${ }^{7}$ Con respecto a la mano de obra indígena, durante el

6 Entre las labores vinculadas al mundo minero, trabajaban en los ingenios o refinerías como artesanos (carpinteros, elaboración de herramientas) y, en contados casos, servían a los dueños de minas como mayordomos o administradores.

7 Existen indicios fechados en el siglo XVIII que indican que el universo de los operarios mineros fue más variado de lo que se suele presuponer; tal el panorama sobre los k'ajchas, que además de indígenas incluía a mulatos, a mestizos e, incluso, a españoles (Tandeter, 1981; Abercrombie, 1996; Barragán, 2015). Sería 
periodo colonial se apeló a diversos sistemas para organizarla, y la relevancia de cada uno de ellos fue variando, coexistiendo en algunos casos: indios de encomienda, indígenas en condición de esclavitud (especialmente en las primeras décadas coloniales las llamadas "piezas"), indígenas trabajando bajo sistemas de reclutamiento forzado (mita) y trabajadores asalariados "libres", los llamados "mingas" (Bakewell, 1990). ${ }^{8}$

En los inicios de la explotación colonial del Cerro Rico de Potosí (1545), la organización de la producción y el control de los medios de producción estuvieron bajo supervisión indígena, en lo que se conoció como la etapa de la huayra, un periodo de unos 30 ańos durante los cuales el procesamiento del mineral extraído de las profundidades de las minas (de muy alta ley) se realizó en hornos de fundición (huayrachinas) instalados en las laderas del cerro, que se alimentaban de leña y viento. ${ }^{9}$ Desde finales de la década de 1540, los encomenderos de la región de Charcas, e incluso de otras más distantes, enviaban contingentes de sus indios tributarios a Potosí, de forma particular, con plazos y tareas variables. También se produjo la instalación de una población creciente de yanaconas que durante toda la etapa de la huayra controló en buena medida tanto los medios de producción como las distintas fases productivas mineras. ${ }^{10}$ Los yanaconas mineros de Potosí extraían plata

pertinente, en trabajos futuros sobre el caso potosino, revisitar la composición de la mano de obra minera en una perspectiva de larga duración, remontando el problema hasta el siglo XVI.

8 La condición "libre" de los trabajadores asalariados se entrecomilla para diferenciarla de las características contemporáneas del trabajo libre. Como se verá, la mayor diferencia entre los libres (mingas) y los trabajadores forzados (mitayos) radicaba en los mayores salarios de los primeros y, en algunos casos, el tipo de trabajo dentro de las minas, pero tendemos a pensar que las condiciones concretas de trabajo no difirieron tanto en otros aspectos centrales (duración de las jornadas, permanencia semanal dentro de las minas, etcétera).

9 Una serie de estudios remarcables en torno a las huayrachinas y la tecnología prehispánica de fundición puede verse en: Cruz y Vacher, 2008.

10 Los yanaconas tuvieron un origen prehispánico: los yanas fueron indígenas escindidos de los ayllus y los grupos étnicos y de sus vínculos de parentesco; servían como criados personales del Estado, de la élite incaica y de las autoridades políticas locales, constituyendo un grupo de ocupaciones, orígenes y estatus social muy heterogéneo (Murra, 1989). Los españoles utilizaron esa mano de obra asociándola primero a la categoría de esclavos, para, finalmente, asimilarla a la de criados o sirvientes. Existieron yanaconas del rey, pero una gran mayoría pasó a manos de particulares erigidos como sus patrones. La categoría de yanacona colonial tuvo además un carácter fiscal: excluidos inicialmente del pago de tributos, desde 1566 fueron obligados 
para sus amos, pero gozaban del derecho a explotar los desmontes como retribución por su trabajo (Matienzo, 1967). ${ }^{11}$ En la década de 1560, además de los contingentes privados de tributarios y yanaconas, la Corona obligó a los indios lupaca de Chucuito (originarios de la costa suroccidental del lago Titicaca e incluidos en una encomienda real) a enviar 500 tributarios al año para realizar tareas rotativas mineras en Potosí (Barnadas, 1973: 261-284; Assadourian, 1979: 237-249; Bakewell, 1989: 65-70).

Para la década de 1570, se consolidó un sistema nuevo de reclutamiento de trabajo forzado: la mita colonial. Durante la década previa, además de los antecedentes mencionados, una serie de factores actuaron para la configuración de este sistema. En el contexto de una Corona asediada por deudas, la obtención de metales preciosos constituía una prioridad real, mientras por aquellos años caía la calidad del mineral extraído en Potosí. Por otra parte, en el marco de la disputa con el poder encomendero y el debate sobre la perpetuidad de la encomienda, la pulseada se terminaría inclinando contra estos y en favor del poder real, materializado en el virreinato en una red de poder político fragmentado, de instancias virreinales, regionales y locales.

En ese marco, durante la década de 1570, el virrey Francisco de Toledo (1569-1581) estableció una serie de medidas con las que apuntaba a lograr varios objetivos urgentes. En primer lugar, aumentar la producción de plata del Perú, que comenzaba a declinar por la extinción de los minerales de más alta ley. Para lograrlo, introdujo el método de obtención de plata a partir de la amalgama del mineral en bruto con mercurio, ${ }^{12}$ puso en marcha el sistema de trabajo de la mita potosina y mandó a construir un sistema de lagunas

a pagar un tributo sensiblemente menor que el del resto de la población. No participaban en los trabajos por turnos ni estaban obligados a la mita potosina, todos motivos de peso para explicar el crecimiento de la categoría en tiempos coloniales. Se trató, pues, de una categoría ambigua: en teoría, cercana a condiciones no libres; en la práctica colonial, en un porcentaje no calculable, tendió a convertirse en una categoría fiscal, y sin duda operó desdibujando las etnicidades indígenas (Escobari de Querejazu, 2001, 2011; Gil Montero, Oliveto y Longhi, 2015).

11 Los desmontes eran los descartes de material que se acumulaban en montones o pilas en las entradas de los socavones. Las pilas descartadas en un principio se volvían a revisar o "repallar" en búsqueda de plata (Llanos, 1983: 40-41).

12 Durante el periodo estudiado, el mercurio utilizado en Potosí provenía de las minas peruanas de Huancavelica. Toledo determinó, además, el monopolio de la Corona en la producción de ese mercurio, cuya extracción también descansó en buena medida en el envío forzado de trabajadores de provincias cercanas a la mina real (Lohmann Villena, 1999; Cobb, 1977; Contreras, 1982; Robins, 2011; Brown, 2012; Povea Moreno, 2014). 
artificiales que alimentaron con sus aguas los ingenios donde se procesó el mineral (Bakewell, 1989; Cole, 1985). En segundo lugar, se buscó un control más estricto de la población indígena (fiscal, social, religioso, espacial y político), con grados de éxito muy variables, mediante el proceso que se conoció como la "reducción de indios a pueblos", que consistió en una política de concentración de la población indígena en pueblos, de acuerdo a parámetros europeos, trastocando el antiguo patrón de asentamiento disperso. ${ }^{13}$ Otra de las medidas nodales del virrey Toledo fue la casi total monetización del sistema de tributos, fijado per cápita sobre los hombres adultos (de 18 a 50 años), pero cuya responsabilidad de pago recayó sobre las autoridades indígenas de las jurisdicciones fiscales coloniales básicas (repartimientos de indios). El tributo monetizado fue un ingreso crecientemente controlado por la Hacienda Real, al tiempo que favoreció el aumento de la participación indígena en las relaciones mercantiles (ofreciendo su producción en el mercado, empleándose a cambio de dinero, en relaciones de carácter tanto "libre" como coactivo).

La apertura de la llamada etapa del azogue implicó, además, la casi total concentración de los medios sociales de producción en manos españolas, la ampliación excepcional de la escala de producción y un incremento de la demanda de fuerza de trabajo. Es entonces cuando se consolidó el sistema de reclutamiento forzado de mano de obra (mita), ${ }^{14}$ que en Potosí coexistía con otras formas de trabajo asalariadas, menos coactivas y más voluntarias, como la minga y la de los yanaconas. De acuerdo con algunas estimaciones, para principios del siglo XVII, aún durante el mayor auge, la proporción entre trabajo asalariado voluntario y compulsivo fue de 70 a 30 (Assadourian, 1979: 257). Si bien el sistema forzado mitayo implicaba cuantitativamente un contingente de fuerza de trabajo menor que el voluntario, subrayemos que el primero ocupó un rol determinante en la provisión de mano de obra para la minería. Por un lado, el contingente anual de mitayos se dividía teóricamente en tres grupos. Cada uno de estos tercios debía trabajar una semana y "descansar" las dos siguientes. El propio diseño del sistema preveía

13 Respecto al proceso de las reducciones toledanas, existe una bibliografía muy extensa y rica. Nos limitamos a citar aquí tan solo algunos trabajos pioneros y otros más recientes: Gade, 1991: 69-90; Málaga Medina, 1993: 263-316; Saignes, 1991: 91-135; Jurado, 2004: 123-137; Zagalsky, 2009: 57-90; Mumford, 2012; Zuloaga Rada, 2012; Saito y Rosas Lauro, 2017.

14 Con sus especificidades, como veremos, funcionaron otros sistemas similares de reclutamiento forzoso de mano de obra minera en Nueva España y en Perú, pero el sistema mitayo de Potosí resultó el de mayores dimensiones y extensión (Bakewell, 1989). 
unos jornales mitayos tan bajos que los empujaría a contratarse durante las semanas en las que no estaban teóricamente obligados a trabajar. Así, el sistema garantizaba al sector minero una fuerza de trabajo "libre" de forma permanente (Assadourian, 1979: 257). Por otro lado, a la vez que Potosí resultó ser un centro de expulsión de población que huía de su obligación de la mita y el trabajo minero, también fue un polo de atracción para numerosas porciones de población indígenas (mingas y yanaconas) que acudían de forma individual o con la anuencia de sus autoridades nativas en búsqueda de riquezas minerales y comerciales.

El sistema mitayo establecido en 1573 por el virrey Toledo contenía ciertos enlaces con los sistemas de trabajo previos (incluido el incaico), ${ }^{15}$ pero resultó uno nuevo, al tener carácter oficial, estar bajo la administración de funcionarios reales y de autoridades indígenas (capitanes de mita) y estandarizar elementos antes dispares: la composición numérica de los contingentes, la duración de la estancia en Potosí, los salarios y ciertas condiciones de trabajo en minas e ingenios.

Las características del sistema de trabajo mitayo han sido ampliamente estudiadas. Aquí solo se enuncian de forma sintética, con la adición de algunas modificaciones que, en la práctica, se fueron experimentando durante el periodo de auge (Bakewell, 1989; Cole, 1985; Zagalsky, 2014a, 2014b). La mita potosina implicó la migración forzada durante el plazo teórico de un ańo de indígenas tributarios (varones de entre 18 y 50 años) provenientes de 16 corregimientos (o provincias) de la región comprendida entre el sur del Cuzco y el sur de la actual Bolivia. Los trayectos de esta migración forzada llegaron incluso a superar los mil kilómetros de distancia en 20 días de camino. Dentro de ese conjunto de corregimientos obligados a la mita, la mayor parte de los indígenas residentes en las tierras bajas y cálidas fueron exceptuados, presuponiendo que el pasaje abrupto al clima frío y seco de las altas tierras potosinas, ubicadas a más de 4.000 metros sobre el nivel del mar, podría causarles la muerte y enfermedades. Desde 1573, sucesivos virreyes emitieron repartimientos generales de mita; esto es, listados de los indígenas obligados y de los colonos beneficiados. Los primeros repartimientos de mita, de 1573 y 1575 , establecieron contingentes anuales de 9.500 y 11.000 mitayos, aproximadamente. Desde 1578 hasta la década de 1680, el contingente mitayo anual rondó los 14.000 indios tributarios. Ese contingente anual (mita gruesa) era un porcentaje de los tributarios

15 Entre las obras que rescatan los trazos de continuidad entre este sistema colonial forzado y el trabajo estatal incaico y ciertas prácticas rituales y valores asociados a la minería no se pueden dejar de mencionar: Wachtel, 1980: 21-57; Bakewell, 1989; Bouysse-Cassagne, 2005: 443-462; Platt, Bouysse-Cassagne y Harris, 2006. 
de la macrorregión obligada, que tenía una población total aproximada de 91.000 tributarios durante el gobierno del virrey Toledo: los repartimientos de indios de la región de Charcas debían enviar el 17\% de sus tributarios a mitar anualmente; los de La Paz, el 16\%; los del Cuzco, el 15\%; y los de Canas y Canches, el 13\%. Esos porcentajes significaban que, en teoría, cada indígena tributario debía repetir su turno de mita cada seis o siete años. Cada uno de estos tributarios obligados pertenecía a un repartimiento de indios (en 1610 se contabilizaban 127 obligados). Recordemos que los repartimientos en ocasiones nuclearon una etnia, pero en otras aglutinaron a varios grupos o fragmentos de grupos. De ahí que puede pensarse en la monumental diversidad étnica indígena implicada en el sistema mitayo potosino. Estos hombres obligados a mitar habitualmente migraban a Potosí junto a sus mujeres, sus hijos y parte de sus recursos. Las asignaciones de mitayos para la producción minera en el virreinato del Perú se circunscribieron a las minas de azogue de Huancavelica y a las de plata de Potosí, contando con un caudal mucho menor las minas de Porco, que solo mostraron rendimientos eficientes de producción de plata en el periodo temprano, declinando ya para 1580 . Otros centros mineros de importancia, tales como Oruro, Aullagas o San Antonio del Nuevo Mundo, no contaron con trabajo mitayo. Eso no debe conducir a la idea de que el trabajo asalariado allí fuera completamente "voluntario" ni totalmente "libre" (Gil Montero, 2011: 297-318; Gil Montero, Oliveto y Longhi, 2015).

En 1575, se estableció el sistema que dividía el contingente anual total (mita gruesa) por tercios. Cada tercio (mita ordinaria) debía cumplir un turno semanal en minas o ingenios, quedando las dos semanas siguientes teóricamente "de huelga" (o descanso). Jeffrey Cole (1985) sostiene que para principios del siglo XVII el contingente mitayo ya no trabajaba dividido en tercios sino en mitades, frente a la declinación práctica del aporte de fuerza de trabajo. Algunos testimonios procedentes del contexto de auge (años 1610 y 1612) ponen en cuestión incluso la existencia de los turnos por mitades, sosteniendo que una parte de la fuerza mitaya trabajaba de forma permanente, sin "descansos" ni semanas para emplearse voluntariamente. Además, indican que para entonces los mitayos permanecían en Potosí por más de un año (Zagalsky, 2014b: 70-71).

El virrey Toledo estableció una serie de ordenanzas específicas sobre el trabajo mitayo minero. Subrayemos que el trabajo libre no recibió tanta consideración ni regulaciones, lo cual, tal vez, haya favorecido que se prestara mayor atención al trabajo mitayo. El turno de mita ordinaria (semanal) corría teóricamente de lunes a sábado, siendo el domingo de descanso. Los lunes, los capitanes indígenas presentaban la mita ordinaria y se distribuía a los trabajadores entre los beneficiarios del repartimiento general de mita. La 
tarea de asignación concreta de la mano de obra era conjunta entre los capitanes y los veedores, con la palabra final del corregidor de la villa. Las labores empezaban los martes a la mañana hasta el sábado por la noche. La jornada laboral estaba pautada de sol a sol, aunque en la práctica los indígenas trabajan durante el día y la noche en compañías (generalmente de dos integrantes, pero que llegaban en ocasiones a cinco); cada compañía se ubicaba en un suyu o llancana, intercalando la labor: mientras uno barreteaba, el otro descansaba, compartiendo además la pesada barreta. El testimonio de un veedor del Cerro Rico del año 1610 alerta sobre la existencia de cierta autonomía de los trabajadores dentro de las minas, señalando que los barreteros, e incluso los menos especializados cargadores, estaban solos o con poco control de los indios pongos o capitanes de la labor (Zagalsky, 2014b: 74-76).

Los jornales diarios de los mitayos que fijó el virrey Toledo variaban según el tipo de trabajo: los barreteros, que labraban las minas, recibían 3,5 reales; los repasiris, que trabajaban en los ingenios, recibían 2,75 reales; los que trajinaban dentro de las minas (apiris o cargadores), y desde ellas hacia los ingenios (chacaneadores), recibían tres reales (Capoche, 1959: 145; Zavala, 1978: 103, 118-122). Hacia principios del siglo XVII, los jornales mitayos ascendieron a cuatro, tres y 3,5 reales para los barreteros de las minas, los repasiris de los ingenios y los cargadores (apiris y chacaneadores), respectivamente. El salario semanal de un barretero mitayo ascendía en 1612 a tres pesos, mientras que el barretero minga recibía diez pesos. Por otra parte, en Oruro, en 1612 había unos 6.000 indígenas barreteros que cobraban diez pesos semanales, igual que los mingas potosinos ${ }^{16}$ (Zagalsky, 2014b: 75-77). Sobre el valor real de los jornales mitayos, fuentes de principios del siglo XVII estimaron el costo individual del viaje a Potosí y de la residencia anual allí en 100 pesos, mientras que el salario anual de un mitayo (17 semanas de seis días) rondaba los 45 pesos (Bakewell, 1989: 112; 1990). Además del ingreso salarial, los mitayos contaban con los recursos económicos bajo el control de las comunidades indígenas (ayllus), que operaron "subsidiando" la producción minera colonial (Assadourian, 1979: 257-268), ya fuera colaborando con la reproducción de los trabajadores y sus familias mientras cumplían con la mita o bien a través de su venta, garantizando los pagos conmutativos para evitar los turnos mitayos. Es igualmente importante considerar la contribución de las mujeres a partir de su trabajo en los mercados urbanos en Potosí (Mangan, 2005; Numhauser, 2005).

Por otra parte, de los salarios mitayos se descontaban varios ítems: la "imposición de los granos", de medio real diario, destinada al pago de los

16 Archivo General de Indias, Sevilla (de aquí en adelante AGI), Charcas 135, año 1612; AGI, Charcas 20, R. 8, N. 97. 
salarios del alcalde mayor de minas, el protector general, los veedores y los capitanes de mita; además, cada mitayo debía aportar anualmente medio peso ensayado para el Hospital de la Villa, aunque la mayoría de los enfermos hospitalizados no eran indígenas, a pesar de las graves consecuencias del trabajo minero sobre su salud (Platt, Bouysse-Cassagne y Harris, 2006: 832). Por lo demás, se calcula que el pago del tributo se llevaba alrededor del 90\% del ingreso salarial mitayo (Assadourian, 1979). Si a estas obligaciones se suman los gastos familiares de los mitayos residiendo en Potosí (alimentos, vestimenta y vivienda, entre otros), se comprende que los mitayos buscaran trabajo asalariado "libre" durante el periodo de "descanso" (Bakewell, 1989).

En teoría, las cuotas de productividad (tareas) estaban prohibidas por diferentes ordenanzas (emitidas sucesivamente por los virreyes Toledo, el Marqués de Cañete y Luis de Velasco), en especial por tratarse de un trabajo cuya productividad estaba signada no solo por la cantidad de horas sino, básicamente, por las condiciones y la "disposición" de las minas. En la práctica, y más allá de la legislación que prohibía la imposición de cupos, los caciques denunciaban que los pagos semanales quedaban sujetos a la cantidad de metal "que ha labrado y sacado a montones y tareas" y no a la cantidad de días y noches trabajados. En función de imponer cuotas de productividad sobre los trabajadores, los dueños y los empresarios mineros no solo eran proclives a azotar, maltratar o incluso matar indígenas para lograr disciplinar al resto, sino que calculaban las penas pecuniarias que imponía la justicia por incurrir en estas prácticas como un costo más de producción (Zagalsky, 2014b: 77).

Una cuestión fundamental para la dinámica del sistema de trabajo y la combinación entre trabajo mitayo y trabajo libre giró en torno a la conmutación de la mita. La sustitución de los mitayos por mingas (trabajadores voluntarios asalariados) se tornó en una práctica frecuente a pocos años de haberse establecido el sistema en Potosí (Zagalsky, 2014a). Habitualmente, la historiografía plantea que los trabajadores voluntarios desarrollaron las tareas mineras especializadas (barreteros), mientras que los mitayos percibían un jornal menor y realizaban las tareas más simples, como las de los apiris y los repasiris en los ingenios de procesamiento (Assadourian, 1979: 252-257; Tandeter, 1992). Este presupuesto se puede matizar, por una parte, porque las condiciones de mitayo y de minga, en muchos casos, involucraban a un mismo individuo que, en diferentes momentos o semanas, actuaba con un rol o con otro. Por otra parte, existen evidencias de que muchos de los mitayos tuvieron tareas especializadas a su cargo, y no siempre conmutaron esa obligación laboral por pagos en dinero (ya fuera porque no pudieron o porque no quisieron). Otra cuestión que parece irresuelta es la transmisión de saberes especializados mineros, ya fuera entre trabajadores mitayos, mingas o 
ambos. En esta combinación de formas de trabajo (que incluyó a los mismos actores) reside una de las peculiaridades específicas de este universo laboral indígena minero del sur de los Andes. Nos situamos en un mundo de trabajadores predominantemente indígenas, portadores de saberes y especializaciones laborales particulares y de identidades étnicas múltiples, atravesado por un sistema motorizado desde arriba que los empujó a convivir en el ámbito urbano y en las profundidades de las minas.

A pocos años de instaurarse la mita minera en la década de 1570, el discurso de los azogueros (propietarios de minas e ingenios) adoptó como uno de sus leitmotivs la lamentación por la quiebra del sistema mitayo. Pese a todo, durante sus primeros 40 años las regulaciones legales de la mita (repartimientos y ordenanzas) no experimentaron modificaciones sustanciales.

\section{EL DISTRITO MINERO DE GUANAJUATO}

En el virreinato de Nueva España, los colonizadores, movidos por su necesidad de metales preciosos, realizaron diversas incursiones por el territorio en busca de yacimientos de plata y de oro. De ese modo, entre 1531 y 1558 se hallaron y se comenzaron a explotar numerosas minas: Pachuca, Real del Monte, Zacatecas, Tlalpujahua, etcétera (Mentz, 2010: 117). También las vetas de Guanajuato fueron descubiertas en ese lapso. Los protagonistas del primer hallazgo fueron unos arrieros que en 1548 se dirigían a las minas de Zacatecas, recién descubiertas. Según Lucio Marmolejo, estos, al descansar en un paraje cercano al cerro del Cubilete, advirtieron que las piedras del lugar contenían plata: "Sorprendidos con tal acontecimiento, cavaron un poco el terreno donde estaban las piedras, y hallaron que por allí pasaba una veta que prometía los más pingües productos a los que se dedicaran a su laborío" (1883: 144). En los años siguientes, nuevas y ricas vetas fueron descubiertas en la región, como la próspera mina de Rayas, llamada así por el apellido de su descubridor, Juan de Raya. Estos descubrimientos de mineral atrajeron a mucha población e hicieron necesaria la construcción de caminos que unieran la región minera con las zonas de abastecimiento y con la ciudad de México.

El control del territorio y de los yacimientos mineros de esa región empujó a los españoles a una guerra contra los naturales, los teochichimecas, que se enmarcó en el proyecto de colonización del norte-centro (Jiménez, 2006: 109-114; Blanco, Parra y Ruiz Medrano, 2011: 52). Esa situación de guerra, que duró años, devino en la esclavización de chichimecas en una región donde la mano de obra no abundaba y era cada vez más necesaria para las haciendas agroganaderas y para las empresas mineras. Para la "pacificación” de la región, se reanudó la fundación de misiones y la reducción 
de poblaciones indígenas del centro del virreinato, como los tlaxcaltecas y los otomíes, para que ejemplificaran formas de vida sedentaria a los chichimecas. En 1598, se acordó una tregua con los teochichimecas en lo que luego sería San Luis de la Paz (Blanco, Parra y Ruiz Medrano, 2011: 61).

El desarrollo de la minería en la región estuvo acompańado por una gran demanda de trabajadores, que convirtió a la mano de obra en un factor fundamental. El sistema de trabajo y la situación de los trabajadores en Guanajuato experimentaron cambios a lo largo de los tres siglos de dominación hispana. Si en un principio los dueños de las minas pudieron emplear indígenas esclavizados, estos pronto escasearon. Ante la creciente necesidad de fuerza laboral, los mineros solicitaron a las autoridades la asignación de indígenas de repartimiento (esto es, trabajadores indígenas forzados). El virrey Martín Enríquez, en 1579, estableció el repartimiento minero para las minas de Guanajuato; sobre el papel, aquello afectó a 487 indígenas del Bajío michoacano (la mayoría purépechas), pero en la práctica las tandas que llegaron al centro minero fueron de menores proporciones (Castro, 2002: 231). En Nueva España, según la legislación, el porcentaje de trabajadores forzados no debía exceder el $4 \%$ de la población masculina, contrastando notablemente con el caso peruano. ${ }^{17}$ A comienzos del siglo XVII, eran 132 los indígenas de repartimiento que acudían semanalmente a Guanajuato, cifra que en 1628 aumentó a 150 (Castro, 2002: 234). Los indígenas eran llevados a Guanajuato por el juez repartidor, junto a un funcionario indígena denominado "papite"; este último los entregaba al alcalde mayor del real de minas y, una vez finalizado, el servicio los llevaba de regreso. ${ }^{18}$ Cada trabajador forzado acudía a las minas una semana cada siete o seis meses y era retribuido con un real diario, excepto el domingo, que era el día de descanso (Gavira Márquez, 2015: 85; Castro, 2002: 236, 243). Durante el siglo XVII existieron quejas de algunas comunidades afectadas por el repartimiento laboral destinado a Guanajuato. En ellas se señalaba que los indígenas eran obligados a trabajar en las peligrosas y duras tareas de desagüe (Castro, 2002: 230). Algunos pueblos se quejaron de estar obligados a enviar tandas de trabajadores no solo a la minería de Guanajuato, sino también a otras minas, como la de Inguarán (Gavira Márquez, 2015: 82-83). Por otro lado, la distancia a recorrer desde sus comunidades de origen hasta las minas de Guanajuato fue también motivo de queja por parte de algunos pueblos de

17 Recopilación de Leyes de Indias, Ley XXII, libro VI, título XII.

18 Según Felipe Castro, ese nombre proviene posiblemente del purépecha pahpeti, que significa "el que lleva o acarrea gente" (2002: 238). 
Michoacán situados a más de sesenta leguas, cuando la legislación fijaba como límite para la compulsión laboral una distancia de diez leguas entre el real minero y los pueblos de repartimiento. ${ }^{19}$

Con el paso del tiempo, el repartimiento minero fue perdiendo importancia numérica en Guanajuato, al igual que ocurrió en el resto del virreinato. Varias causas pudieron estar detrás de ese descenso: (i) la disminución efectiva de la población de los territorios sujetos a los repartimientos, debido a muertes, fugas a regiones exentas de esa prestación o por quedarse en los centros mineros; ${ }^{20}$ (ii) el estancamiento de la producción minera; y (iii) la congregación de población indígena en los contornos del asiento minero, que también facilitó mano de obra a las actividades mineras.

Junto a los trabajadores forzados, hay que mencionar la mano de obra libre, que terminó primando en las minas de este distrito. Una fuerza laboral nutrida, aunque en distintas proporciones, por indígenas, mulatos, mestizos y españoles. Posiblemente la disminución de la población indígena explique que el salario se extendiese por el territorio novohispano como recurso de provisión de trabajadores. Los propietarios de minas y haciendas de beneficio o fundición tuvieron que implementar distintas estrategias para atraer operarios. Así, echaron mano de mecanismos de retención, como el conocido peonaje por deudas, pero también llegaron a arreglos laborales que suponían una mejora en las condiciones de trabajo. En ese sentido, piénsese en el partido, también conocido como "pepena", que consistía en un porcentaje de mineral que el trabajador podía tomar para sí una vez cumplido con su "tequio"; es decir, la cantidad de mineral que un trabajador debía extraer en

19 Recopilación de Leyes de Indias, Ley III, libro VI, título XII: "Que a los indios se pague el tiempo que trabajaren, con ida, y vuelta, y vayan de diez leguas”. La legua era una medida que expresaba la distancia que una persona podía recorrer durante una hora, oscilando enormemente, según fuera a pie o no, y según las características geográficas del terreno (variando entre cuatro y 5,57 kilómetros). En el caso novohispano, los investigadores han tendido a calcular que una legua equivalía a 4,19 kilómetros, aunque la revisión documental ha permitido detectar que durante los tres siglos coloniales el valor de la legua fue variable. Para el caso peruano, véase: Hemming, 1982; para la variabilidad de la legua en Nueva España, véase: Garza Martínez, 2012. Tomando la medida estándar de 4,19 kilómetros, verificamos que las distancias señaladas en la legislación y la práctica del caso novohispano (unos 41,9 y 251,4 kilómetros, respectivamente) eran muy inferiores a las distancias máximas aludidas en el caso potosino peruano (en algunos casos, con distancias superiores a mil kilómetros).

20 Castro documenta algunos casos de huidas desde las comunidades indígenas que debían prestar servicio personal minero hacia regiones exentas de tal obligación (2002: 243-244). 
una jornada. ${ }^{21} \mathrm{El}$ partido permitía a los trabajadores contar con una mayor capacidad adquisitiva y los animaba a seguir trabajando una vez cumplida su jornada laboral. El trabajo empleado para obtener el partido o pepena era, en palabras de Florescano, "un trabajo extra, remunerado no en dinero, sino con una participación en la producción" (1996: 118).

Este sistema de pago se había instalado como una costumbre, fruto de una concesión voluntaria de los dueños de las minas (Gamboa, 1761: 461). En ese sentido, se debe tener presente que la falta de moneda, sobre todo al iniciar las labores de extracción en las minas, obligó a buscar otras formas de pago, como la remuneración en especie. Por ello, en muchas ocasiones, como explica Eduardo Flores Clair, el partido comenzó siendo la única retribución que el propietario podía ofrecer (1986: 51). Por otro lado, que el partido se concentrase esencialmente en los barreteros obedecía a la necesidad de este tipo de trabajadores especializados en la extracción del mineral. ${ }^{22}$ La escasez de estos operarios calificados ańadía un plus al valor que los propietarios mineros otorgaban a su trabajo. La participación en los beneficios de la mina funcionaba como un estímulo para los trabajadores, aunque el sistema de partido varió de un centro minero a otro. En Guanajuato, una vez completado el tequio, por el que se obtenían cuatro reales en el siglo XVIII, el trabajador se quedaba con la mitad de lo que extraía el resto de la jornada (Brading, 2012: 202-203). En la segunda mitad del siglo XVIII, algunos mineros intentaron reducir o abandonar el pago en especie. Esos intentos fueron propiciados, de un lado, por el incremento de la productividad de las minas, que permitió a algunos mineros pagar un salario monetario a sus trabajadores y abandonar por completo el pago en especie, $y$, de otro, por la posición ventajosa que los mineros adquirieron frente a sus trabajadores tras la represión de los tumultos de Guanajuato en 1767, protagonizados por los operarios. La mina de Rayas fue de las primeras en suprimir el partido; más tarde, también se suprimió en la Valenciana, a cambio de incrementar el salario de los barreteros, que se fijó en diez reales diarios en 1803 (Brading, 2012: 204).

La exención tributaria de los indígenas y los mulatos que trabajaban en la actividad minero-metalúrgica en Guanajuato ( $y$ en el conjunto de Nueva

21 La palabra 'tequio’ es náhuat; tequiotl significa “trabajo” (Moreno, 1976: 466).

22 Aunque los barreteros eran los que recibían principalmente el partido, hay que señalar que, en algunos casos, otros trabajadores también participaron de ese pago en especie. Así, por ejemplo, en Real del Monte los ademadores (trabajadores encargados de apuntalar y fortalecer con madera) también tuvieron acceso a una parte de la producción. Además, el barretero separaba de su partido unas piedras para los trabajadores vinculados a él, como sus peones, herreros, médicos y malacateros (encargados de la maquinaria de extracción) (Navarrete, 2007: 100-101; Ladd, 1992: 80). 
España) fue otro mecanismo pensado para atraer y retener mano de obra en la minería. El título V de los libros VI y VII de la Recopilación de Leyes de Indias establecía que los indígenas, los mestizos y los mulatos debían pagar tributo:

[...] los [indígenas] que asisten a las minas, por sacar mucha plata, y porque los más ganan a cuatro, y a cinco pesos al mes, y con comodidad podrán tributar por lo menos a dos pesos al año [...]. Mandamos, que se de orden como tributen con toda moderación, de forma, que ningunos desamparen las minas, y sean bien doctrinados, y tratados como conviene a su salvación, y conservación. ${ }^{23}$

A pesar de que la legislación fijaba la condición tributaria de los trabajadores indígenas, mestizos y mulatos, en los reales mineros novohispanos la práctica de la exención tributaria fue muy común. Tal fue su arraigo que los intentos de la Corona por cobrar el tributo en ellos a los trabajadores mineros fueron seguidos de descontento y protestas, que derivaron en autos e indultos de alcance local o regional que relevaron de tal obligación a esos trabajadores (Povea Moreno, 2016: 54). En el distrito minero de Guanajuato, un intento por cobrar el tributo a los indígenas que trabajaban en las minas tuvo lugar en 1729, causando gran agitación entre los afectados, de tal forma que en el real de Santa Ana un tumulto impidió el cobro del tributo; más tarde, en el real del Marfil, los operarios se alzaron en armas para reclamar su exención tributaria. ${ }^{24}$ Mientras duró la resistencia, la labor de esas minas quedó paralizada, lo que debió apremiar para que buscaran una solución al problema. Finalmente, en 1731, se dictó una Real Provisión que otorgó la exención de tributo a los operarios de las minas y las haciendas de beneficio de ese distrito. ${ }^{25}$ Así se mantuvo hasta las medidas fiscales emprendida por el visitador general José de Gálvez. El restablecimiento del cobro de tributos a los operarios mineros de Guanajuato fue una de las disposiciones punitivas que se tomaron tras las revueltas populares acaecidas en esa ciudad en 1767 (Castro, 1996: 191, 206). Tanto el ayuntamiento como el cuerpo de minería de Guanajuato solicitaron al virrey Carlos Francisco de Croix, marqués de Croix, la exención tributaria de los trabajadores mineros, al tiempo que alegaban las dificultades que presentaba la elaboración de una matrícula de

\section{Recopilación de Leyes de Indias, Ley IX, libro VI, título V.}

24 Archivo Histórico del Palacio de Minería (de aquí en adelante AHPM), 1783, caja 13 , documento 15 , f. 3 r. Brading menciona una revuelta de trabajadores mineros en Guanajuato para hacer frente al cobro de tributos en 1732 (2012: 368).

25 AHPM, 1783, caja 13, documentos 6, 13 y 15. Archivo Histórico de la Universidad de Guanajuato (de aquí en adelante AHUG), P.C.L. 1732, libro 36, ff. 77v-81r. 
la población laboral empleada en la minería guanajuatense (Povea Moreno, 2016: 58; Villalba, 2013: 40-42). La respuesta a dicha solicitud fue una negativa que causó gran malestar entre los trabajadores y los productores mineros. Estos últimos, preocupados por el posible menoscabo de la oferta de mano de obra como consecuencia del cobro del tributo, llegaron a un acuerdo con las autoridades por el que se comprometían a pagar una cantidad fija (8.127 pesos anuales), en concepto del tributo de los trabajadores mineros de la jurisdicción de Guanajuato (Povea Moreno, 2016: 58). ${ }^{26}$

Durante el siglo XVIII, el sistema de trabajo, la remuneración salarial y el número de trabajadores no fueron iguales en todas las minas del distrito de Guanajuato. Las variaciones respondieron a aspectos como las condiciones de la explotación subterránea y el capital de los propietarios (Villalba, 2013: 50). Un informe de 1773 de los oficiales reales de la Caja de Guanajuato sobre el estado de la minería en esa región nos ilustra al respecto. ${ }^{27}$ En él se localiza un abanico de posibilidades: minas trabajadas a "raya y partido", es decir, salario más el incentivo de un porcentaje de la producción; otras solo a partido; otras por buscones, gente que trabaja a cambio de metal; otras se trabajaban por temporadas breves mediante amparos, etcétera. Al mismo tiempo, el trabajo libre aparece en algunas minas combinado con trabajo coactivo. Al respecto, conviene señalar que en la segunda mitad del siglo XVIII tuvo lugar un incremento de los repartimientos mineros en Nueva España, del que participaron los mineros de Guanajuato. La salida de muchos trabajadores del centro minero a raíz de la supresión o reducción del partido, medida ya mencionada, y el auge de la minería guanajuatense, que demandaba mucha mano de obra, suscitaron nuevas peticiones de indígenas de repartimiento para mitigar la escasez de trabajadores y aminorar costos (Castro, 2002: 247). En 1779, la diputación de minería de Guanajuato solicitó tandas de 400 o 500 indígenas, pero no está claro si dicha pretensión obtuvo una respuesta positiva de parte de la Corona. ${ }^{28}$ Probablemente los

26 Otros centros mineros también contribuían en concepto de tributo con cantidades fijas, sin necesidad de realizar matrículas de tributarios. Posiblemente esas cantidades fueran fruto de convenios entre las autoridades locales y las distintas diputaciones de minería (Povea Moreno, 2016: 58-59).

27 Archivo General de la Nación, México (de aquí en adelante AGNM), Minería, volumen 11, ff. 1-47. Véase una transcripción del mismo en: López Miramontes y Urrutia, 1980: 13-39.

28 Felipe Castro menciona que los mineros abandonaron sus pretensiones de incrementar las cifras de cada tanda y se conformaron con el repartimiento tradicional (2002: 255). Por su parte, María Concepción Gavira Márquez afirma que hay indicios para pensar que dicho incremento se hizo efectivo (2015: 88). 
indígenas de tanda, que llegaron a ese centro minero desde Michoacán, se mantendrían en las cifras tradicionales: unos 150. También su jornal diario se mantenía en un real y medio, a lo que habría que sumar la ración de comida y un peso para el regreso. ${ }^{29}$ Sin embargo, esos agregados al jornal no siempre se hicieron efectivos; por ejemplo, no fue raro el incumplimiento del pago por el tiempo de viaje al centro minero y de vuelta a sus comunidades (Povea Moreno, 2015: 10).

No conocemos el número exacto y total de trabajadores empleados en las minas de Guanajuato en la segunda mitad del siglo XVIII. La documentación relativa a los tumultos de 1766 y 1767 aporta algunas cifras, pero no se debe olvidar el interés de las autoridades por exagerar las cifras de los trabajadores sublevados. De ese modo, en 1766, las autoridades hablaban de un total de 40.000 trabajadores de minas, de los cuales se habrían levantado entre 4.000 y 6.000 (Villalba, 2013: 48). En cambio, aunque no existen datos ajustados sobre el número total de operarios, sí disponemos de información que nos permite hablar de la disparidad entre unas propiedades mineras y otras. Mientras las grandes propiedades minero-metalúrgicas llegaron a emplear un gran número de trabajadores, muchas minas ocuparon solo a cuatro o a cinco operarios. Por ejemplo, si atendemos las cifras dadas por Humboldt a comienzos del siglo XIX, en la mina de La Valenciana, una de las más destacadas del distrito, se ocupaban 1.800 trabajadores en la minería subterránea y 1.300 en las actividades mineras de superficie (ibid.: 49). Una realidad que contrasta con la de muchas otras explotaciones, de menores dimensiones, es, por tomar un caso, la mina de San Bartolo, en el real de La Fragua, trabajada hacia 1773 solo por uno o dos barreteros (López Miramontes y Urrutia, 1980: 23).

SIMILITUDES Y DIFERENCIAS HISTÓRICAS E HISTORIOGRÁFICAS: ESBOZO INTERPRETATIVO Y PREGUNTAS ABIERTAS

Una vez presentado el escenario laboral de cada uno de los ámbitos mineros en los que se centra el presente trabajo, nos atañe realizar un ejercicio de puesta en diálogo de ambas realidades. Buscamos, por un lado, señalar los puntos en común y las diferencias que se vislumbran entre ambos distritos mineros y, por otro, determinar los motivos y los fundamentos que explicarían esas similitudes y/o diferencias. Esta mirada panorámica contribuye a apreciar cuestiones del mundo laboral que atraviesan a los dos espacios mineros, aunque bajo condiciones y características particulares y concretas. Se trata, pues, de un esbozo interpretativo inicial, el cual ofrece algunas

29 AGNM, Minería, volumen 148, f. 236r. 
respuestas que de ningún modo se consideran concluyentes, sino que, más bien, proponen algunas líneas de análisis por las cuales transitar.

En ambos espacios convivieron formas de trabajo libre con otras más coactivas. Es cierto que la imagen de Potosí ha quedado asociada a los trabajadores forzados que de forma rotativa iban a trabajar a sus minas, en tanto que la minería de Guanajuato, y novohispana en general, ha quedado vinculada al trabajo libre asalariado. Resaltemos aquí, por un lado, la presencia de trabajadores libres en la minería potosina, una presencia que tal vez pudo ir en aumento con el paso del tiempo, pero que estuvo presente desde los inicios del sistema mitayo y sobre quienes todavía resta mucho por decir; $y$, por otra parte, la existencia en Guanajuato del repartimiento minero, aunque nunca alcanzase la importancia que tuvo en Potosí. Al mismo tiempo, se debe prestar atención a que la realidad laboral no permaneció inmutable ni en Guanajuato ni en Potosí. En ambos centros mineros se produjeron modificaciones: la mita potosina sufrió transformaciones durante los más de dos siglos de vigencia y en Guanajuato el reclutamiento forzoso de operarios fue mermando con el paso del tiempo, hasta que sus cifras se incrementaron en el momento de máximo auge minero.

Una de las diferencias más notables entre uno y otro centro es, en el caso del Potosí del virreinato del Perú, la equiparación entre la condición de trabajador minero y la de indígena, que no existió en Nueva España. En la minería peruana, la mano de obra provenía fundamentalmente de los ayllus, y así fue durante todo el periodo de dominación española. ${ }^{30}$ Por otro lado, los centros mineros novohispanos, si se atiende a la "calidad" étnica, contaron con mano de obra diversa. Guanajuato era un mundo de trabajo étnicamente heterogéneo: indígenas, mestizos, españoles, mulatos y esclavos africanos componían, aunque en proporciones distintas, el grupo laboral; en cambio, en el mundo del trabajo potosino predominó el trabajo indígena, con presencia muy puntual de españoles y esclavos africanos como administradores o mayordomos de minas.

¿Qué razones se suelen esgrimir para explicar esas diferencias? La variable más habitual para explicar el papel de sectores no indígenas en el mundo del trabajo minero novohispano suele ser la situación geográfica de los reales de minas, esto es, centros mineros que estaban lejos de los núcleos densos de población indígena, con una baja densidad demográfica en el caso de Nueva

30 Indicios documentales procedentes del siglo XVIII complejizan el panorama usualmente asociado a Potosí que, además de indígenas, habría incluido trabajadores mulatos, mestizos e, incluso, españoles (Barragán, 2015). Sería interesante que futuros trabajos sobre el caso potosino incorporaran el problema de la composición étnica de la mano de obra minera, en una perspectiva de larga duración. 
España, frente a la centralidad de la mano de obra indígena en la minería potosina. Sin embargo, Guanajuato y otros reales de minas, como Real del Monte, estaban situados en sitios densamente poblados (a diferencia de Zacatecas y San Luis Potosí). Por su parte, sin dudas, la región de Potosí (dentro de la Audiencia de Charcas en el virreinato del Perú), constituía un espacio habitado por grupos indígenas, pero probablemente no fuera el más densamente poblado (como sí lo fue la zona situada más al norte, cercana al lago Titicaca). Adicionalmente, no se debe olvidar que el propio sistema mitayo implicó la movilización forzada y permanente de población asentada en zonas distantes a Potosí, en muchos casos superando los 500 kilómetros.

Para complejizar este esquema explicativo de las diferencias, se deben tener en cuenta los diferentes momentos de auge productivo de ambas minerías. El apogeo de Potosí se produjo durante el primer siglo de la dominación española, cuando las poblaciones indígenas experimentaban la condición colonial ordenada bajo nuevas normas y forjaban "pactos" de negociación que transcurrieron, en gran medida, a través de fórmulas laborales. Se necesitaba mucha mano de obra indígena y esta se proveyó, en buena medida, apelando a la puesta en marcha de formas que implicaron grados variables de coacción (Gil Montero y Zagalsky, 2016). Señalemos también que en el sostenimiento del sistema forzado debieron haber operado formas más consensuales, como las vinculadas a prácticas y creencias que anudaban las labores, los metales y las minas con espacios, seres y valores venerados desde tiempos prehispánicos y que pervivieron de maneras variables durante al menos el primer siglo colonial (Bouysse-Cassagne, 1998, 2005; Platt, Bouysse-Cassagne y Harris, 2006; Zagalsky, 2014a). Asimismo, proponemos una hipótesis, que requiere ser confrontada en futuras indagaciones, relativa a un posible elemento adicional que podría haber operado en la trama consensual que sostuvo la reproducción de un sistema forzado de trabajo de las dimensiones y durabilidad que tuvo el que se dio en Potosí. Se trata de la práctica del k'ajcheo, tan visible y denunciada en el siglo XVIII (Tandeter, 1992; Abercrombie, 1996; Barragán, 2015), que tal vez pudiera tener una existencia de larga duración rastreable hasta el propio siglo XVI.

En el caso de Guanajuato, al no requerirse tanta mano de obra durante el primer siglo y medio, fue suficiente la población indígena congregada en los contornos. Como hemos explicado, el salario, junto a distintos arreglos laborales, fueron los medios más comunes para atraer a la población hacia el trabajo minero. $\mathrm{Al}$ no contar con un repartimiento minero de las proporciones y el alcance del de Potosí, cuando en la segunda mitad del siglo XVIII se produjo el mayor pico de su auge productivo, con el consiguiente incremento de la demanda de mano de obra, los propietarios de minas y de haciendas de beneficio o fundición tuvieron que aplicar diferentes estrategias para atraer o 
retener trabajadores. Fundamentalmente, se apeló a mecanismos que combinaron lo coactivo y lo consensual: el peonaje por deudas y arreglos laborales como el partido. Las condiciones laborales ventajosas fueron atrayendo a población indígena, pero también no indígena: mestizos, mulatos y españoles. La presencia de estos últimos como fuerza laboral, según estimación de Margarita Villalba, experimentó un incremento a partir de la séptima década del siglo XVIII, que obedeció al estímulo que en ese momento las autoridades desplegaron para que los españoles ejercieran diversos oficios, incluidos los vinculados a la minería, como barrenadores, piqueadores y administradores (2013: 54). Ese incremento progresivo de españoles dentro del grupo laboral también estuvo favorecido por la movilidad de trabajadores mineros entre regiones (ibid.: 54-55).

Otra diferencia entre ambos mundos laborales es la relativa a la categoría fiscal de los trabajadores. En el caso novohispano, aunque la legislación determinaba que indígenas, mestizos y mulatos libres de entre 18 y 50 años debían pagar tributo, en los reales mineros novohispanos la exención tributaria fue una costumbre muy arraigada. Diversos autos y provisiones fueron relevando, en distintos momentos y de forma local, a los trabajadores mineros de esa obligación. Los trabajadores del distrito minero de Guanajuato también se vieron favorecidos por esa exención tributaria que, a finales del siglo XVIII (como ocurrió en otros centros mineros del virreinato) se vio amenazada por las nuevas medidas fiscales. Mientras tanto, en Potosí, los indígenas que trabajaban en la minería (mitayos o libres) continuaron pagando tributos durante todo el periodo colonial, esto es, durante el auge y también durante los periodos de decadencia. ${ }^{31}$ Quizás hay que buscar las razones de tal diferencia en la falta de medios coactivos de envergadura en la minería novohispana y, por tanto, en las dificultades para movilizar y retener la mano de obra necesaria. De este modo, la exención tributaria de los operarios debe verse como una combinación de una estrategia laboral de los empresarios mineros con la cesión por parte de la Corona de su derecho a percibir ese ingreso. Su mantenimiento en el tiempo pudo también responder al temor a posibles motines de los trabajadores ante un eventual restablecimiento de la carga tributaria (Pérez Rosales, 2003: 200). Tales temores no resultaban para nada infundados si se recuerdan los ya comentados sucesos del periodo 1729-1731, ocurridos en el distrito de la provincia de Guanajuato. Esa aprensión de los empresarios mineros debió estar detrás del convenio alcanzado entre la diputación de minería de Guanajuato y las autoridades, por el

31 Sobre la importancia del tributo en cuanto elemento constitutivo de derechos y de obligaciones entre la Corona y sus súbditos indígenas en el ámbito andino, véanse: Platt, 2016; Gil Montero y Zagalsky, 2016. 
cual la diputación se comprometía a hacerse cargo del pago de una cantidad acordada en concepto de tributo.

En cuanto a las condiciones de los trabajadores, vemos un amplio abanico de situaciones que iban desde el trabajo libre asalariado al no libre (asimilable a la condición de esclavo), pasando por las situaciones de trabajo forzado o con elementos coactivos (que no podrían equipararse al trabajo esclavo). Entre estos tres puntos del continuum, cada situación específica pudo moverse hacia uno u otro extremo, incluso tomando el caso de un mismo individuo. Considerando, por ejemplo, los casos de trabajadores asalariados y voluntarios, en teoría ubicados en el extremo "libre", con frecuencia se apeló a mecanismos coercitivos sobre ellos. El trabajo mitayo no se consideraba como trabajo no libre, pues en teoría implicaba el pago de un salario y la tarea forzada se realizaba solo por un periodo acotado. Se trataba de un sistema establecido como parte de las obligaciones de los súbditos indígenas, junto al pago de tributos. En la práctica, contaba con numerosos aspectos coercitivos: implicaba la migración forzosa generalmente a cientos de kilómetros, no siempre retribuida con un salario, y el tiempo teórico de trabajo mitayo (una semana cada tres durante un año, en ciclos que se reiteraban cada siete años) tampoco se cumplía. La práctica de la mita también ofreció aspectos adicionales que arrastraban esta condición hacia formas algo más libres de trabajo: la posibilidad de emplearse como mingas asalariados durante las semanas de "huelga" con jornales notoriamente superiores, la posibilidad de conmutar con pagos en dinero la obligación de la mita y las huidas. ${ }^{32}$

Por otra parte, el repartimiento novohispano, que en el caso de Guanajuato experimentó una intensificación con el auge de la segunda mitad del siglo XVIII, se encontró dentro de un universo igualmente coactivo, que lo ligaba al de la mita colonial andina. En este punto, hay que señalar que los mineros novohispanos siempre anhelaron la introducción del sistema mitayo por su mayor alcance en cifras de trabajadores forzados y en tiempo de servicio en el centro minero. A mediados del siglo XVIII, el incremento de la producción minera convirtió ese anhelo en fuertes presiones para lograr un aumento de las tandas de indígenas forzados, así como del tiempo que debían prestar servicio en las minas. Existe constancia documental de que, en Real del Monte, en 1771, se logró una extensión del periodo que debían permanecer

32 Muchos de los que conmutaban en dinero su semana mitaya, para evitarla, terminaban empleándose como mingas. De ahí que la conmutación pudiera empujar hacia formas más libres. En cuanto a las huidas, en algunos casos abrieron la posibilidad a formas más "libres" de trabajo; por ejemplo, emplearse como mingas en Potosí o en otros centros mineros. 
prestando su servicio personal, fijándose en cinco semanas en lugar de una (Castro, 2002: 246-247). Para el caso de Guanajuato, no tenemos conocimiento de una extensión de ese tipo, pero sí de una creciente presencia de mano de obra forzada.

Aunque de proporciones mucho menores, el repartimiento de Guanajuato presentó características parecidas a las de la mita potosina. Por ejemplo, implicó una migración forzosa con un radio de desplazamiento amplio que superó en la práctica lo fijado sobre el papel. Así, como indicamos, las leyes establecían una distancia de diez leguas entre las comunidades indígenas afectadas por el repartimiento y los centros mineros, pero algunos pueblos compelidos a mandar indios de tanda se encontraban a más de 60 leguas (Povea Moreno, 2015: 9-10). Asimismo, el repartimiento novohispano desarrolló prácticas muy parecidas a las registradas en la minería andina; al respecto, puede mencionarse la costumbre de sustituir la asignación obligatoria de trabajadores por dinero, una práctica que se ha documentado para el caso del repartimiento guanajuatense (Castro, 2002: 252-253; Mentz, 1999: 299).

Por último, con relación a los aspectos políticos, cabe reflexionar sobre las diferentes formas en las que el Estado colonial intervino en la organización del mundo del trabajo minero. Desde luego, esas diferencias se vincularon con realidades distintas ante las cuales el Estado colonial actuó de forma diferenciada, pero también, tal vez, a políticas diversas suyas que originaron situaciones diferentes en cada espacio colonial. En el caso potosino, en el virreinato del Perú no se apeló al trabajo de españoles pobres ni mestizos, sino al de los indígenas (aunque cabe señalar que en otros centros mineros de menor escala tal vez sí se verificó la presencia de estos otros actores como trabajadores, aunque nunca constituyeron una mayoría). En Perú, se produjo una intervención estatal muy directa, como por ejemplo en la organización del sistema de trabajo mitayo, en la intervención de los corregidores en el envío de los contingentes mitayos (junto a los capitanes de mita) y en la intervención del corregidor de Potosí y otros oficiales (veedores, alcalde mayor) en el proceso concreto del entero de la mita (el reparto de los trabajadores entre propietarios y arrendatarios de minas). En el caso novohispano, y en el de Guanajuato en particular, la regulación del trabajo forzado fue mucho menos detallada y específica, guiándose por las normas generales recogidas en la Recopilación de Leyes de Indias. Desde luego, el Estado reguló mucho menos el trabajo minero libre, que fue el que predominó; y cada centro minero adoptó las "reglas" que consideró más adecuadas. En Guanajuato primó el trabajo libre, pero durante la segunda mitad del siglo XVIII, con el auge y los intentos de abaratar los costos de la mano de obra, comenzaron las peticiones de repartimiento minero. Estos requerimientos fueron respondidos con provisiones de trabajadores indígenas forzados provenientes de 
Michoacán. Existieron numerosas quejas de esas comunidades solicitando se les exceptuara de este trabajo coactivo. Los enganchadores y otros personajes asociados al proceso de "captar" mano de obra no eran funcionarios, sino empleados de los dueños de minas e ingenios. Se puede señalar que en Real del Monte, durante la segunda mitad del siglo XVIII, los repartimientos estaban también movilizados por "recogedores" particulares.

Comprender la intensificación de los repartimientos mineros en el caso novohispano, en esa etapa del siglo XVIII, nos lleva a ponderar el papel y la capacidad de intervención de los grandes empresarios o inversionistas mineros de Nueva España sobre las decisiones de las autoridades virreinales (Povea Moreno, 2015: 6). Desde luego que esos grandes mineros (Pedro Romero de Terreros, José de la Borda, Antonio de Obregón o los Fagoaga) fueron hombres cercanos a los órganos de poder y de toma de decisiones. Piénsese, además, en los regalos y en los préstamos que realizaban a la Corona esperando obtener privilegios y honores (Couturier, 2003: 155). Por ejemplo, durante la guerra anglo-espańola (1779-1783), Antonio de Obregón, conde de Valenciana, principal accionista de la mina más productiva de Guanajuato, donó a la Corona 25.000 pesos (Valle Pavón, 2016: 74).

En la ponderación de las similitudes y de los contrastes, vislumbramos a los Andes como un mundo donde la Corona intervino de forma más directa: se trataba de un espacio más distante del centro peninsular, más convulsionado políticamente, donde la presencia estatal resultaba tal vez más necesaria para la reproducción del orden colonial. En cambio, Nueva España se mostraba con una mayor diversidad de tipos de mano de obra y de sistemas de trabajo, y con una intervención menor de la Corona, al menos con anterioridad a las reformas borbónicas, para codificar y controlar. Así, las variables políticas, junto a los restantes factores repasados, tuvieron su gravitación sobre la configuración del complejo mundo del trabajo de la minería colonial americana. 
270 | Trabajos y trabajadores en América Latina (siglos XVI-XXI)

\section{FUENTES}

Archivo General de Indias (AGI)

AGI, Charcas 135, "Memoria de la mita”, año 1612.

AGI, Charcas 20, R. 8, N. 97.

Archivo General de la Nación de México (AGNM)

AGNM, Minería, volumen 11.

AGNM, Minería, volumen 148.

Archivo Histórico del Palacio de Minería, México (AHPM)

AHPM, 1783, caja 13, documentos 6, 13 y 15.

Archivo Histórico de la Universidad de Guanajuato

AHUG, P.C.L. 1732, libro 36.

\section{BiBLIOgRAFÍA}

Abercrombie, Thomas

1996 "Q'aqchas and La Plebe in Rebellion: Carnival vs Lent in $18^{\text {th }}$-Century Potosí". En: Journal of Latin American Anthropology, volumen 2, número 1. 62-111.

Arduz Eguía, Gastón

1985 Ensayos sobre la historia de la minería altoperuana. Madrid: Paraninfo.

Assadourian, Carlos Sempat

1982 El sistema de la economía colonial. Mercado interno, regiones y espacio económico. Lima: Instituto de Estudios Peruanos.

1979 "La producción de la mercancía dinero en la formación del mercado interno colonial”. En: Enrique Florescano (ed.), Ensayos sobre el desarrollo económico de México y América Latina (1500-1975). México: Fondo de Cultura Económica.

Bakewell, Peter J.

1991 "Los determinantes de la producción minera en Charcas y en Nueva España durante el siglo XVII”. En: Heraclio Bonilla (ed.), El sistema colonial en la América española. Barcelona: Crítica.

1990 "La minería en la Hispanoamérica colonial”. En: Leslie Bethell (ed.), Historia de América Latina: América Latina colonial: economía. Barcelona: Crítica.

1989 Mineros de la montaña roja. El trabajo de los indios en Potosi 1545-1650. Madrid: Alianza Editorial. 
Barnadas, Joseph

1973 Charcas. Orígenes históricos de una sociedad colonial. La Paz: Centro de Investigación y Promoción del Campesinado.

Barragán, Rossana

2015 "¿Ladrones, pequeños empresarios o trabajadores independientes? K'ajchas, trapiches y plata en el cerro de Potosí en el siglo XVIII". En: Nuevo Mundo Mundos Nuevos (marzo). Disponible en: https:// journals.openedition.org/nuevomundo/ (fecha de consulta: $16 \mathrm{de}$ octubre de 2017).

Blanco, Mónica; Alma Parra y Ethelia Ruiz Medrano

2011 Breve historia de Guanajuato. México: Fondo de Cultura Económica / Colmex.

Bouysse-Cassagne, Thérèse

2005 "Las minas del centro-sur andino, los cultos prehispánicos y los cultos cristianos". En: Bulletin de l'Institut Français d'Etudes andines, tomo 34, número 3. 443-462.

1998 "Le palanquin d'argent de l'Inca petite enquête d'ethno-histoire à propos d'un objet absent". En: Techniques et Culture, número 29. 69-112.

Brading, David A.

2012 Mineros y comerciantes en el México borbónico (1763-1810). México: Fondo de Cultura Económica.

Brading, David A. y Harry E. Cross

1972 "Colonial silver mining: Mexico and Peru". En: The Hispanic American Historical Review, volumen 52, número 4. 545-579.

Brown, Kendall W.

2012 The History of Mining in Latin America: From the Colonial Era to The Present. Alburquerque, Nuevo México, Estados Unidos de América: University of New Mexico Press.

Caño Ortigosa, José Luis

2006 "Mineros en el Cabildo de Guanajuato: 1660-1741". En: Anuario de Estudios Americanos, volumen 63, número 1. 187-209.

Caño Ortigosa, José Luis y Jaime J. Lacueva Muñoz

2009 "Guanajuato: plata y azogue en una villa minera (1665-1733)". En: Fernando Navarro Antolín (ed.), Orbis Incognitvs. Avisos y legajos del Nuevo Mundo. Huelva, España: Universidad de Huelva. 605-624. 
272 | Trabajos y trabajadores en América Latina (siglos XVI-XXI)

Capoche, Luis

1959 Relación General de la Villa Imperial de Potosí. En: Lewis Hanke (ed.). Madrid: Atlas. [1585]

Castro, Felipe

2002 "La resistencia indígena al repartimiento minero en Guanajuato y la introducción de la mita en Nueva España". En: CLAHR: Colonial Latin American Historical Review, volumen 11, número 3. 229-258.

1996 Nueva ley y nuevo rey. Reformas borbónicas y rebelión popular en Nueva España. Michoacán / México D. F.: El Colegio de Michoacán / Instituto de Investigaciones Históricas, Universidad Nacional Autónoma de México.

Cobb, Gwendolyn Ballantine

1977 Potosi y Huancavelica: bases económicas, 1545-1640. La Paz: Banco Minero de Bolivia.

Cole, Jeffrey A.

1985 The Potosi Mita, 1573-1700: Compulsory Indian Labor in the Andes. Stanford, California, Estados Unidos de América: Stanford University Press.

Contreras, Carlos

1982 La ciudad del mercurio, Huancavelica, 1570-1700. Lima: Instituto de Estudios Peruanos.

Couturier, Edith B.

2003 The Silver King. The Remarkable Life of the Count of Regla in Colonial Mexico. Alburquerque, Nuevo México, Estados Unidos de América: University of New Mexico Press.

Cross, Harry E.

1983 "South American Bullion Production and Export, 1550-1750". En: John F. Richards (ed.), Precious Metals in the Later Medieval and Early Modern Worlds. Durham, Carolina del Norte, Estados Unidos de América: Carolina Academic Press.

Cruz, Pablo y Jean Vacher (comps.)

2008 Mina y metalurgia en los Andes del sur. Desde la época prehispánica hasta el siglo XVIII. Sucre: Institut de Recherche pour le Développement / Instituto Francés de Estudios Andinos.

Escobari de Querejazu, Laura

2011 "Mano de obra especializada en los mercados coloniales de Charcas. Bolivia, siglos XVI-XVII". En: Nuevo Mundo Mundos Nuevos. Disponible en: https://journals.openedition.org/nuevomundo/60530 (fecha de consulta: 16 de octubre de 2017). 
2001 Caciques, yanaconas y extravagantes. La sociedad colonial en Charcas. s. XVI-XVIII. La Paz: Plural editores / Embajada de España en Bolivia.

Flores Clair, Eduardo

1986 "Minas y mineros: pago en especie y conflictos, 1790-1880". En: Historias, número 13. 51-67.

Florescano, Enrique

1996 "La formación de los trabajadores en la época colonial, 1521-1750". En: Enrique Florescano y Pablo González Casanova (eds.), La clase obrera en la historia de México. Tomo I: "De la colonia al imperio". México: Siglo Veintiuno Editores / Instituto de Investigaciones Sociales, Universidad Nacional Autónoma de México.

Gade, Daniel

1991 "Reflexiones sobre el asentamiento andino de la épica toledana hasta el presente". En: Segundo Moreno Yáńez y Frank Salomon (comps.), Reproducción y transformación de las sociedades andinas, siglos XVI-XX, volumen 1. Quito: Abya-Yala.

Gamboa, Francisco Xavier de

1761 Comentarios a las Ordenanzas de Minas. Madrid: Oficina de Joaquín Ibarra, calle de las Urosas.

Garner, Richard L.

1988 "Long-term Silver Mining trends in Spanish America: A Comparative Analysis of Peru and Mexico". En: The American Historical Review, volumen 93, número 4. 898-935.

Garza Martínez, Valentina

2012 "Medidas y caminos en la época colonial: expediciones, visitas y viajes al norte de la Nueva España (siglos XVI-XVIII)". En: Fronteras de la Historia, volumen 17, número 2. 191-219.

Gavira Márquez, María Concepción

2015 "Entiendan que desobedecen: estrategias de resistencia de la población indígena michoacana ante la coacción para el trabajo en las minas". En: Carlos Rubén Ruiz Medrano (coord.), Los otros rebeldes novohispanos: imaginarios, discursos y cultura política de la subversión y la resistencia. San Luis Potosí, México: El Colegio de San Luis.

2010 "Política minera y conflictos entre Potosí y Oruro a principios del siglo XVII". En: Anuario de Estudios Bolivianos, Archivisticos y Bibliográficos, número 16. 215-244. 
Gil Montero, Raquel

2011 "Free and unfree labour in the colonial Andes in the sixteenth and seventeenth centuries". En: International Review of Social History, volumen 56, número S19. 297-318.

Gil Montero, Raquel y Paula C. Zagalsky

2016 "Colonial Organization of Mine Labour in Charcas (PresentDay Bolivia) and Its Consequences (Sixteenth to the Seventeenth Centuries)". En: International Review of Social History, volumen 61, número 24. 71-92.

Gil Montero, Raquel; Lía Guillermina Oliveto y Fernando Longhi

2015 "Mano de obra y fiscalidad a fin del siglo XVII: dispersión y variabilidad de la categoría yanacona en el sur andino". En: Boletín del Instituto de Historia Argentina y Americana "Dr. Emilio Ravignani", número 43. 59-93.

González Casasnovas, Ignacio

2000 Las dudas de la Corona: la politica de repartimientos para la minería de Potosi (1680-1732). Madrid: Consejo Superior de Investigaciones Científicas.

Hausberger, Bernd y Antonio Ibarra (comps.)

2014 Oro y plata en los inicios de la economía global: de las minas a la moneda. México: El Colegio de México.

Hemming, John

1982 La conquista de los incas. México: Fondo de Cultura Económica. [1972]

Jiménez, Alfredo

2006 El gran norte de México. Una frontera imperial en la Nueva España (1540-1820). Madrid: Editorial Tébar Flores.

Jurado, María Carolina

2004 "Las reducciones toledanas a pueblos de indios: aproximación a un conflicto. El repartimiento de Macha (Charcas), siglo XVI". En: Cahiers des Amériques Latines, volumen 47, número 3. 123-137.

Klein, Herbert

1991 "Las economías de Nueva España y Perú, 1680-1809: la visión a partir de las cajas reales". En: Heraclio Bonilla (ed.), El sistema colonial en la América española. Barcelona: Crítica. 
Ladd, Doris

1992 Génesis y desarrollo de una huelga. Las luchas de los mineros mexicanos de la plata en Real del Monte, 1766-1775. México: Alianza Editorial.

Llanos, García de

1983 Diccionario y maneras de hablar que se usan en las minas y sus labores en los ingenios y beneficios de los metales. La Paz: Instituto Francés de Estudios Andinos / Museo Nacional de Etnografía y Folklore. [1609]

Lohmann Villena, Guillermo

1999 Las minas de Huancavelica en los siglos XVI y XVII. Lima: Pontificia Universidad Católica del Perú. [1949]

López Miramontes, Álvaro y Cristina Urrutia

1980 Las minas de Nueva España en 1774. México: Instituto Nacional de Antropología e Historia.

Málaga Medina, Alejandro

1993 "Las reducciones toledanas en el Perú". En: Ramón Gutiérrez (coord.), Pueblos de indios. Otro urbanismo en la región andina. Quito: Abya-Yala.

Mangan, Jane

2005 Trading Roles. Gender, Ethnicity, and the Urban Economy in Colonial Potosí. Durham, Reino Unido: Duke University Press.

Marmolejo, Lucio

1883 Efemérides Guanajuatenses, ó datos para formar la historia de la ciudad de Guanajuato. Tomo I. Guanajuato, México: Imprenta del Colegio de Artes y Oficios, a cargo de Francisco Rodríguez.

Matienzo, Juan de

1967 Gobierno del Perú. En: Guillermo Lohmann Villena (ed.). París / Lima: Instituto Francés de Estudios Andinos. [1567]

Mentz, Brígida von

2010 "La plata y la conformación de la economía novohispana". En: Sandra Kuntz (coord.), Historia económica general de México. De la Colonia a nuestros días. México: Colmex.

1999 Trabajo, sujeción y libertad en el centro de la Nueva España. Esclavos, aprendices, campesinos y operarios manufactureros, siglos XVI a $X V I I I$. México: Centro de Investigaciones y Estudios Superiores en Antropología Social. 
Moreno, Roberto

1976 "Salario, tequio y partido en las Ordenanzas para la minería novohispana del siglo XVIII". IV Congreso del Instituto Internacional de Historia del Derecho Indiano. México: Universidad Nacional Autónoma de México. 465-484.

Mumford, Jeremy

2012 Vertical Empire. The General Resettlement of Indians in the Colonial Andes. Durham y Londres, Reino Unido: Duke University Press.

Murra, John V.

1989 La organización económica del Estado inca. México: Siglo XXI Editores.

Navarrete, David

2007 Propietarios y trabajadores en el distrito minero de Pachuca, 1750-1810. México: Servicio Geológico Mexicano.

Numhauser, Paulina

2005 Mujeres indias y señoras de la coca. Potosí y Cuzco en el siglo XVI. Madrid: Cátedra.

Pérez Luque, Rosa Alicia y Rafael Tovar Rangel

2006 La contabilidad de la Caja Real de Guanajuato. Una aproximación a su historia económica (1665-1816). Guanajuato, México: Centro de Investigaciones Humanísticas, Universidad de Guanajuato.

Pérez Rosales, Laura

2003 Familia, poder, riqueza y subversión: los Fagoaga novohispanos 17301830. México: Universidad Iberoamericana / Real Sociedad Bascongada de los Amigos del País.

Platt, Tristan

2016 Estado boliviano y ayllu andino: tierra y tributo en el Norte de Potosí. Obra número 43 de la Biblioteca del Bicentenario de Bolivia (BBB), "Letras y artes". La Paz: Centro de Investigaciones Sociales, Vicepresidencia del Estado Plurinacional de Bolivia. [1982]

Platt, Tristan; Thérèse Bouysse-Cassagne y Olivia Harris

2006 Qaraqara-Charka. Mallku, Inka y Rey en la Provincia de Charcas (Siglos XV-XVII). Historia Antropológica de una Confederación Aymara. La Paz: Instituto Francés de Estudios Andinos / Plural editores / Universidad de St. Andrews / Universidad de Londres / Inter American Foundation / Fundación Cultural del Banco Central de Bolivia. 
Povea Moreno, Isabel M.

2016 "La oposición al cobro del tributo en los reales de minas de Nueva España en la segunda mitad del siglo XVIII". En: José Alfredo Uribe Salas, Inés Herrera Canales, Alma Parra Campos, Omar Escamilla Escamilla González y Lucero Morelos Rodríguez (coords.), Sociedad y cultura en la historia de la minería latinoamericana. México:

Universidad Michoacana de San Nicolás de Hidalgo / Instituto Nacional de Antropología e Historia de Michoacán / Fundación Vueltabajo A. C. / Editorial Morevalladolid.

2015 "Coacción y disensión. Protestas frente a los repartimientos mineros en Perú y Nueva España, siglo XVIII”. En: Estudios de Historia Novohispana, número 53. 1-17.

2014 Minería y reformismo borbónico en el Perú. Estado, empresa y trabajadores en Huancavelica, 1784-1814. Lima: Instituto de Estudios Peruanos / Banco Central de Reserva del Perú.

Recopilación de Leyes de los Reynos de las Indias

1681 Recopilación de Leyes de los Reynos de las Indias. Mandadas imprimir, y publicar por la magestad católica del rey don Carlos II, nvestro señor: va dividida en quatro tomos, con el indice general, y al principio de cada Tomo el Índice especial de los titulos, que contiene. Madrid: por Iulian de Paredes.

Robins, Nicholas

2011 Mercury, Mining and Empire: The Human and Ecological Cost of Colonial Silver Mining in the Andes. Bloomington, Indiana, Estados Unidos de América: Indiana University Press.

Saignes, Thierry

1991 "Lobos y ovejas. Formación y desarrollo de los pueblos y comunidades en el sur andino (siglos XVI-XX)". En: Segundo Moreno Yáńez y Frank Salomon, Reproducción y transformación de las sociedades andinas, "Colección 500 Años", números 41 y 42. Quito: Abya-Yala / MLAL.

1985 "Notes on the Regional Contribution of the Mita in Potosí in the Early Seventeenth Century". En: Bulletin of Latin American Research, volumen 4, número 1. 65-76.

1984 "Las etnias de Charcas frente al sistema colonial (siglo XVII)". En: Jahrbuch für Geschichte von Staat, Wirtschaft und Gesellschaft Lateinamerikas, número 21. 27-75.

Saito, Akira y Claudia Rosas Lauro (eds.)

2017 La concentración forzada de las poblaciones indígenas en el Virreinato del Perú. Lima: Pontificia Universidad Católica del Perú . 
278 | Trabajos y trabajadores en América Latina (siglos XVI-XXI)

Sánchez Albornoz, Nicolás

1978 Indios y tributos en el Alto Perú. Lima: Instituto de Estudios Peruanos.

Serrano, Sergio

2008 "...jhay oro y no nos avisan a los amigos!... Contrabando y evasión fiscal en el Cerro de San Pedro Potosí durante la primera mitad del siglo XVII". En: Vetas, revista de El Colegio de San Luis, año X, número 29. 36-62.

Tandeter, Enrique

1992 Coacción y mercado: la minería de la plata en el Potosí colonial, 16921826. Buenos Aires: Sudamericana.

1981 "La producción como actividad popular: ladrones de minas en Potosi”". En: Nova Americana, número 4. 43-65.

TePaske, John J.

2010 A New World of Gold and Silver. Leiden: Kendall Brown.

Valle Pavón, Guillermina del

2016 Donativos, préstamos y privilegios. Los mercaderes y mineros de la ciudad de México durante la guerra anglo-española de 1779-1783. Ciudad de México: Instituto de Investigaciones “Dr. José María Luis Mora”.

Vilar, Pierre

1974 Oro y moneda en la historia (1450-1920). Barcelona: Ariel S. A.

Villalba Bustamante, Margarita

2013 "El trabajo en las minas de Guanajuato durante la segunda mitad del siglo XVIII”. En: Estudios de Historia Novohispana, número 48. 35-83.

Wachtel, Nathan

1980 "Los mitimas del valle de Cochabamba: la política de colonización de Wayna Capac”. En: Historia Boliviana, volumen I, número 1. 21-5.

Zagalsky, Paula

2014a "La mita de Potosí: una imposición colonial invariable en un contexto de múltiples trasformaciones (siglos XVI-XVII; Charcas, Virreinato del Perú)". En: Chungará, volumen 46, número 3. 375-395.

$2014 b$ “Trabajadores indígenas mineros en el Cerro Rico de Potosí: tras los rastros de sus prácticas laborales (siglos XVI y XVII)”. En: Mundos do Trabalho, volumen 6, número 12. Disponible en: file://C:/Users/ Patricia/Downloads/35223-132064-1-PB.pdf (fecha de consulta: 16 de octubre de 2017). 
2009 "El concepto de 'comunidad' en su dimensión espacial. Una historización de su semántica en el contexto colonial andino (siglos XVI-XVII)”. En: Revista Andina, número 48. 57-90.

\section{Zavala, Silvio}

1978 El servicio personal de los indios en el Perú (extractos del siglo XVI). Volumen 1. México: El Colegio de México.

\section{Zuloaga Rada, Marina}

2012 La conquista negociada: guarangas, autoridades locales e imperio en Huaylas, Perú. Lima: Instituto de Estudios Peruanos / Instituto Francés de Estudios Andinos. 



\title{
Aprendiendo juntos: indios, negros libres y esclavos en talleres de la Lima colonial
}

\author{
Francisco Quiroz (Perú)*
}

RESUMEN: Este trabajo busca establecer la dinámica del mundo del trabajo en los talleres artesanales y manufactureros de la ciudad de Lima entre los siglos XVI y XVIII, en función de criterios étnico-culturales y económicos a partir de los contratos de trabajo existentes en los archivos. El análisis muestra que indios, mestizos, negros libres y esclavos y españoles trabajaban juntos en talleres artesanales y manufactureros, pero en diferentes condiciones, según las castas y el patronazgo que presentaban. Amos de esclavos y parientes lograban mejores condiciones para sus pupilos que las que autoridades coloniales y municipales obtenían para sus patrocinados. El artículo analiza una amplia cantidad de casos de los siglos XVI y XVIII, descubriendo que, conforme avanzaba el periodo colonial, el trabajo en Lima se regía menos por las normas referidas a las castas de los trabajadores, sin que esto suponga la vigencia de un mercado laboral libre y moderno.

Palabras Clave: mundo del trabajo; Lima colonial; artesano; aprendizaje; trabajo libre y esclavo.

\section{INTRODUCCIÓN}

Lima es una ciudad que fue creada a propósito como centro administrativo de un extenso y rico territorio situado, en su mayor parte, en las serranías. Como capital, fue el lugar de residencia de la burocracia colonial y de los "notables" del virreinato, así como uno de los principales centros comerciales del Nuevo Mundo; por consiguiente, desde su fundación es una ciudad de dimensiones económicas y demográficas importantes. Aunque no llegaba a ser una ciudad industrial, desarrollaba una amplia gama de actividades artesanales y manufactureras (Quiroz, 2008).

* Doctor en Historia por la Universidad Nacional de San Marcos y por la City University de Nueva York. Profesor de la Universidad Nacional Mayor de San Marcos (UNMSM). Contacto: fquirozc@unmsm.edu.pe 
En efecto, Lima concentraba una población muy significativa, que la convertía en una de las ciudades más pobladas del Nuevo Mundo después de Potosí, México y Río de Janeiro, y, por ende, en un mercado muy atractivo. Sin embargo, carecía de dos condiciones esenciales para convertirse en un centro productor. De un lado, las actividades industriales debían ser desarrolladas con materia prima importada desde otras zonas del país, e inclusive del exterior, pero la presencia de personajes con influencia económica y política, y su papel en las redes comerciales del virreinato hicieron que la ciudad concentrara una producción industrial que, si bien nunca fue fomentada por la Corona, podía abastecer tanto el propio mercado urbano como el virreinal, e incluso exportar hacia otras partes de la América española. Además, la rápida deforestación de la costa dejaba sin combustible a la ciudad.

Por otro lado, se debe añadir la condición colonial, con las restricciones y hasta las prohibiciones protectoras del comercio ultramarino. La costa central no producía fibras vegetales (algodón, lino y cánamo) que pudieran ser la base de una amplia industria textil.

Adicionalmente, a pesar de su significativa población y de contar, por ende, con contingentes propios de mano de obra, la ciudad tenía que complementar sus necesidades laborales por medio de la migración interna y externa, sobre todo mediante el control de la población trabajadora.

Por esas razones, este trabajo se divide en dos partes. Después de dar una información breve pero sustancial acerca de la ciudad, la primera parte busca establecer la incidencia concreta del ordenamiento gremial como marco institucional que persigue controlar tanto la producción industrial como la población que se dedica a esta actividad siempre central en el marco del colonialismo moderno. La segunda parte analiza las condiciones laborales de la ciudad, teniendo en consideración la diversidad étnico-cultural de los trabajadores. La pregunta principal en la primera parte se refiere a la medida en que los gremios realmente restringían la actividad productiva, en tanto que la segunda parte busca establecer las condiciones diferenciadas por castas en las que trabajaba la población libre, servil y esclava.

\section{LA LIMA DEL TRABAjo}

Lima aparece como una ciudad de proporciones debido a las funciones político-administrativas que se le asignaron en el contexto de la colonización europea. Para 1600 contaba ya con más de 14.000 personas que, en los siguientes 15 años, aumentaron a 25.000. A fines del siglo XVIII tenía 52.000 habitantes y en vísperas de la Independencia, 64.000.

No es posible proporcionar aquí los detalles de esta población, pero sí es importante señalar que Lima nunca fue una ciudad estrictamente española. 
Su población distó mucho de ser homogénea y las llamadas castas constituyeron una parte muy considerable de sus habitantes. De las cifras disponibles para el periodo colonial, Lima tenía una composición étnico-cultural más o menos estable: $40 \%$ española, $40 \%$ negra, $10 \%$ mestiza y $8 \%$ indígena (Cook, 1968, 1985; Pérez Cantó, 1985).

Si el "diseño" original de la ciudad fue concebido para ser sede del Gobierno y residencia de las élites sociales, la realidad fue otra. La ciudad albergaba grandes contingentes de esclavos al servicio de esas élites y recibía personas libres de diferentes castas que llegaban en búsqueda de trabajo. Los indígenas encontraron en la ciudad refugio de las obligaciones coloniales (mitas y tributos, trabajo personal), en tanto que los mestizos, los negros y los mulatos libres eran atraídos por la disponibilidad de trabajos temporales en la industria, los servicios y el pequeño comercio. Españoles sin fortuna complementaban el cuadro y se dedicaban al comercio y a la pequeña producción industrial. Estos últimos fueron los maestros artesanos y manufactureros que encontraron en las ciudades un espacio favorable para obtener parte de las riquezas coloniales gracias a su actividad productiva que, aunque nunca bien vista en el régimen colonial, fue tolerada y a veces hasta incentivada por intereses particulares. El mercado era favorable al productor de artículos de consumo duradero (ropa, calzados, herramientas, muebles, velas, joyas, etcétera) y de alimentos elaborados (manteca, harina, pastas, carnes y derivados, tabaco, dulces).

Muy pronto, sin embargo, surgieron competidores en estos rubros. Indígenas, mestizos, negros libres y esclavos aprendieron oficios que los productores españoles consideraban de su exclusividad. La presencia de productores de diferentes castas en la ciudad provocaba reacciones adversas de parte de la población española, cuando veían que estos colegas aparecían en cantidades que sobrepasaban sus necesidades de ayuda laboral y empezaban a constituir un serio peligro para sus actividades. En gran medida, puede indicarse que agremiarse por oficios tenía como motivación más inmediata la necesidad de contrarrestar la competencia de colegas de otras castas, estableciendo un control eficaz sobre su actividad (Quiroz, 1995).

Los antiguos aprendices y oficiales iban adquiriendo experiencia y autonomía en su ejercicio, y nuevos contingentes de inmigrantes se instalaban como productores independientes. Por su parte, numerosos esclavos eran adiestrados en talleres por orden de sus propios amos, para obtener mayor provecho de sus criados, puesto que (sobre todo desde fines del siglo XVI) resultaba muy oneroso mantener una amplia servidumbre doméstica improductiva. A los esclavos especialistas se fueron sumando negros y mulatos libres, como también mestizos.

Aproximadamente la mitad de la población de origen africano era libre o liberta (horra). Su presencia en grandes cantidades en el comercio y la producción 
preocupaba a las autoridades y a los propietarios, pues se prefería que estuviesen como sirvientes en casas particulares. Fracasaron los intentos de crear pueblos especiales para los libres, así como gravarlos con un pago o tributo, como a los indígenas, para obligarlos a servir por un sueldo o paga a un amo español.

Lo mismo sucedía con los esclavos. Las prohibiciones a los esclavos de salir a ganar se repetían agravando las penas conforme se incrementaba ese sistema de semilibertad. Los pretextos fueron redundantes (incremento de hurtos, bailes, bodas, bautismos y costumbres no convenientes, agravio a los indios en las chacras y en el gato o mercado urbano, etcétera).

Los intereses encontrados de productores, propietarios y autoridades posibilitaban la actividad independiente de negros libres y esclavos. Así, mientras que a ciertas autoridades les interesaba el control social y a ciertos artesanos que no se inmiscuyeran en sus labores, otras autoridades tenían esclavos puestos a "ganar". Algunos productores, entretanto, requerían de mano de obra, al no ser beneficiados por el trabajo mitayo de los indígenas encomendados; algunos comerciantes traían ganado a ser sacrificado en la ciudad, buscando aprovechar las pieles al darlas a zurradores y curtidores de diferentes castas; otros propietarios de casas daban en alquiler espacios para talleres y vivienda a productores independientes, etcétera. No llama la atención, entonces, que las ordenanzas fuesen letra muerta.

La presencia del indígena era promovida y cuestionada, simultáneamente. Cuestionada por aquellos que lo requerían en las labores de minas, haciendas y obrajes, y en sus pueblos, recibiendo la doctrina cristiana y pagando tributos, amparada por los propietarios que veían en los indios mingados una alternativa a la mano de obra esclava (cara por su propia naturaleza). Al igual que los morenos, los indios también fueron independizándose en las labores productivas; pero la suerte del productor indio sería distinta a la de aquellos. En efecto, los productores indígenas supieron sacar provecho de las posibilidades que les brindaba el hecho de pertenecer a la "república de indios", utilizando para ello las instituciones gremiales y las cofradías. Así, lograron ser exonerados del pago de alcabalas, media anata y otras obligaciones. Pronto, los productores indígenas se vieron libres, de hecho, de otras cargas gremiales (exámenes y visitas).

Parte de la población mitaya que llegaba a Lima para servir temporalmente se asentó finalmente en la ciudad. Sumada a la población local, hizo de los indígenas un importante contingente de trabajadores disponibles para los propietarios de la urbe. Eran mucho más que el $8 \%$ que les asignaba el dato demográfico, pues se trataba mayormente de pobladores en edad laboral. Esta población se resistía a ser ubicada en el pueblo del Cercado, que es donde pretendían reducirla desde 1566, y habitaba en realidad en casas y en talleres tanto propios como ajenos ubicados en todos los rincones de la ciudad (Vergara, 2005; Cárdenas Ayaipona, 2014). 
La necesidad de mano de obra de los propietarios no encomenderos en Lima fue incrementándose a tal punto que, hacia fines del siglo XVI, la población indígena resultó la manzana de la discordia entre los sectores sociales, incluyendo a la Iglesia y a la administración de la ciudad para las obras públicas.

Los jornaleros fueron la fuerza laboral de los propietarios no encomenderos desde la fundación de la ciudad. La administración colonial fijó una escala de remuneraciones para la población indígena que, aunque muy exigua (un tomín y un cuartillo de maíz al día), provocó la queja de los propietarios españoles que no estaban dispuestos a desembolsar dinero para abonar a los indígenas por las tareas que realizaban. En 1576, el virrey Francisco de Toledo normó el jornal de indios fijándolo en un tomín y medio y en alimentación. ${ }^{1} \mathrm{Al}$ expresarlo en reales, la nueva remuneración oficial anual era de 108, dos vestidos de indios (algodón), alimentación y curación de enfermedades para los yanaconas y los jornaleros de las ciudades y del campo de la costa central peruana; es decir, un poco más de un cuartillo al día (cuarta parte de un real o una dieciseisava parte de un peso corriente). Era de esperarse que los empleadores evadieran estas condiciones. De hecho, en 1676, la provisión se promulgó nuevamente, debido a que no se cumplía. Pero, de todas maneras, la tarifa de remuneraciones servía de referencia para pagar el trabajo de la mayor parte de la población del país durante el periodo colonial. Posteriormente, en 1591, el virrey Hurtado de Mendoza liberó de la mita a los indios mitayos que llevaran residiendo en el pueblo del Cercado por más de cinco ańos, dejando expedito el camino para la utilización de esa fuerza laboral por los vecinos no beneficiarios de ese régimen compulsivo. ${ }^{2}$

En ese contexto, aparecieron los gremios en Lima, que surgieron siguiendo un criterio restrictivo tanto de parte de las autoridades municipales y coloniales como de parte de los maestros artesanos españoles, que se consideraban con derecho a restringir sus oficios. En realidad, durante dos o tres décadas, a los maestros españoles no les preocupó crear gremios en sus oficios, pero esto cambió cuando en la década de 1550 la competencia de "colegas" de raza negra se tornó más y más significativa. En 1551, los espaderos impidieron trabajar de manera independiente a los negros, en lo que fue el inicio de una lista larga de acciones de parte de los maestros para ir restringiendo cada vez más su actividad, hasta que en la década siguiente los maestros lograron el nombramiento de un alcalde de su oficio como segundo paso hacia la agremiación formal. El tercer paso se dio recién en 1605 con la promulgación de ordenanzas especiales para el oficio.

1 Archivo Histórico Municipal de Lima (AHML), Libros de cédulas y provisiones de Lima, legajo 6, ff. 466-468; Libros de cabildos de Lima, tomo IV: 592 y tomo VIII: 275-276.

2 Biblioteca Nacional del Perú, Virreinato, Indios, Trabajo, 1591, A53, f. 1. 
A los espaderos, en 1552, les siguieron los herreros cuando prohibieron a los negros y a los berberiscos tener fraguas propias o de sus amos. En 1557, los sastres españoles prohibieron a los negros cortar ropa por sí mismos, hasta que obtuvieron ordenanzas propias en 1636. Los zapateros trataron de excluir a los esclavos en 1562, y lo mismo buscaron hacer los pasamaneros y los sombrereros, los carpinteros y los plateros. En realidad, el primer motivo que tuvieron para "agremiarse" fue la competencia que significaban los negros esclavos y libres. Estas condiciones que se dieron en esos ańos se repitieron a fines del siglo XVIII, cuando las reformas borbónicas perjudicaron a los productores y a los comerciantes, y nuevamente los productores reavivaron sus gremios (siempre a partir de criterios étnicos) para evitar la competencia. Pero, sobre todo, en esa nueva coyuntura hubo nuevos oficios que se agremiaron, como los veleros en 1785, los chocolateros en 1787 y los zapateros en 1792. Que esto no era una tendencia solo de los españoles lo confirma el hecho de que en 1800 fueron los botoneros españoles e indígenas quienes excluyeron de su oficio a las "reprobadas castas de chinos, sambos y mulatos, cuya sociedad se ha reputado siempre perjudicial” (Quiroz, 1995: 63).

Oficialmente, los gremios de españoles aglutinaban también a los representantes de las castas no indígenas. Debían abarcarlos en su reglamentación y en su organización jerárquica. Los negros que llegaban a ser maestros, sin embargo, no alternaron por lo general con los españoles. Su situación era subordinada y solo excepcionalmente se los veía en calidad de maestros de tienda y miembros plenos de los gremios.

El caso de los indígenas es especialmente interesante, en la medida en que los productores crearon sus propios gremios y hermandades (cofradías), independientes de los gremios y de las cofradías de los españoles (Fernández Villanova, 2017). En 1634, los indios y los negros albañiles fueron amparados por el cabildo de la ciudad contra el gremio de españoles que los quería incorporar. Pero los oficios más activos fueron los de sastres, zapateros y sombrereros. A fines del siglo XVII, los sastres indígenas lograron separarse del gremio de los españoles; en 1721, los sombrereros hicieron lo propio; $y$, en 1735, replicaron la acción los silleros, los petateros y los botoneros.

La mayor preocupación de los gremios de españoles y de indios fue la vigilancia social. Los maestros artesanos iniciales y, con el tiempo, quienes se consideraban con derecho a restringir el ejercicio de sus oficios crearon gremios a imagen y semejanza de las instituciones análogas de España. Sin embargo, los gremios coloniales limeños diferían en sus funciones y dinámicas de los peninsulares. Antes que una existencia corporativa orgánica, el gremio colonial era muy simple en su composición, en sus funciones y en sus jerarquías. Muy rápidamente, los denominados maestros mayores reemplazaron la jerarquía dirigente gremial; es decir, personajes específicos designados por 
el cabildo y, sobre todo, por el gobierno colonial se convirtieron en los únicos dirigentes de los gremios. Sus funciones se restringieron básicamente al control de los que ejercían un oficio o un grupo de oficios, al margen de si eran o no agremiados, o maestros examinados (Quiroz, 1995).

Esto se reflejaba también en el aspecto laboral. En efecto, la normatividad gremial europea solo tenía vigencia parcial en la Lima colonial, con un importante impacto en la conformación de las relaciones laborales en la ciudad.

\section{LAS CASTAS TRABAJANDO}

Este trabajo analiza 855 contratos laborales correspondientes al siglo XVI y 2.635 contratos del siglo XVIII, encontrados en el archivo de Protocolos Notariales del Archivo General de la Nación del Perú y en la Biblioteca Nacional del Perú. Esta amplia información permite establecer las coincidencias y las diferencias en las relaciones laborales. El énfasis se pone en las condiciones de trabajo de aprendices y de oficiales de diferente origen étnico en el contexto del desarrollo de las actividades productivas, a fin de determinar las similitudes (patrones comunes) y diferencias (tendencias particulares) en el trato brindado a trabajadores según su condición social y étnico-cultural.

Hubo otros factores que intervinieron en la determinación de las condiciones laborales. Uno de ellos fue el patronazgo que presentaban los trabajadores al momento de cerrar los tratos laborales, es decir, si se trataba de trabajadores voluntarios o si alguna persona (amo, pariente, tutor, autoridad, etcétera) los protegía o los obligaba a asentarse con un empleador. Otro factor se relacionaba con el empleador y con la unidad productiva. Esto significa que la "naturaleza" del empleador (casta, raza) y las dimensiones del taller influían en la configuración de patrones de contratación y, en general, de condiciones laborales en la Lima colonial. Un tercer factor estaba referido a los mismos oficios. Ciertamente, hubo ciertos oficios más exigentes que otros respecto al aprendizaje formal y a la "calidad" de los trabajadores a contratar. Los orífices, los plateros y quienes trabajaban en otros oficios que usaban metales preciosos eran, por regla general, más celosos que los demás.

La información muestra tendencias interesantes en el tiempo. Si los casi 900 casos del siglo XVI son muy representativos de la Lima de entonces (una ciudad de menos de 20.000 habitantes), los 2.635 casos del siglo XVIII son, a todas luces, solo una muestra muy pequeña para una ciudad que bordeaba las 60.000 personas. Una explicación para ello sería la creciente informalización en las relaciones laborales y el debilitamiento de las exigencias gremiales sobre el aprendizaje formal previo al ejercicio de los oficios. 
288 | Trabajos y trabajadores en América Latina (siglos XVI-XXI)

Para el siglo XVI, existían tanto contratos de oficiales como de aprendices. Entre 1550 y 1600, unos 467 maestros contrataron a 157 muchachos oficiales y a 698 aprendices. La mayor parte eran españoles (casi la mitad de los oficiales y la tercera parte de los aprendices), seguidos por los indios (29\% y 44\%, respectivamente). Los esclavos fueron bastante menos en ambos casos.

Tabla 1: Lima, siglo XVl: contratos de oficiales y de aprendices por castas

\begin{tabular}{|l|c|c|c|c|c|c|}
\hline \multicolumn{1}{|c|}{ Castas } & 0ficiales & Porcentaje & Aprendices & Porcentaje & Total & Porcentaje \\
\hline Españoles & 74 & 47,13 & 224 & 32,09 & 298 & 34,85 \\
\hline Indios & 46 & 29,30 & 309 & 44,27 & 355 & 41,52 \\
\hline Negros & 4 & 2,55 & 23 & 3,29 & 27 & 3,16 \\
\hline Mestizos & 8 & 5,10 & 48 & 6,88 & 56 & 6,55 \\
\hline Mulatos & 3 & 1,91 & 37 & 5,30 & 40 & 4,68 \\
\hline Esclavos & 22 & 14,01 & 57 & 8,17 & 79 & 9,24 \\
\hline Total & 157 & 100,00 & 698 & 100,00 & 855 & 100,00 \\
\hline
\end{tabular}

Fuente: Elaboración propia a partir de los Protocolos Notariales, Archivo General de la Nación, ${ }^{3}$ siglo XVI.

Gráfico 1: Representación gráfica de los contratos de oficiales y de aprendices por castas: Lima, siglo XVI

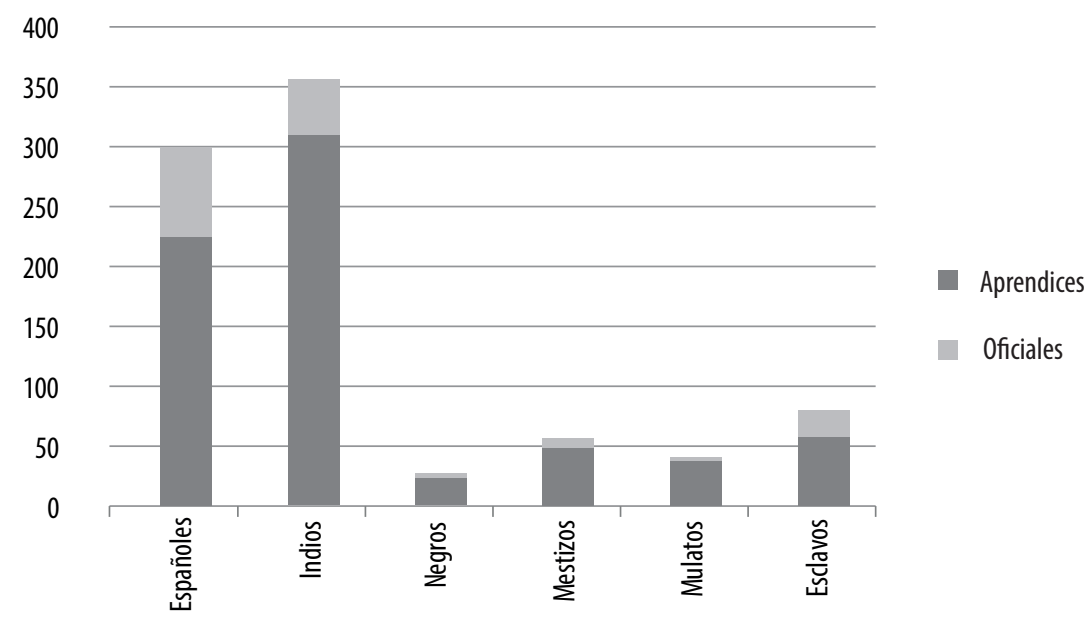

Fuente: Elaboración propia a partir de los Protocolos Notariales, AGN, siglo XVI.

3 De aquí en adelante AGN. 
Tabla 2: Lima, siglo XVI: contratos por oficios

\begin{tabular}{|c|c|c|c|c|c|c|}
\hline Oficios & Oficiales & Porcentaje & Aprendices & Porcentaje & Total & Porcentaje \\
\hline $\begin{array}{l}\text { Sastres y } \\
\text { calceteros }\end{array}$ & 50 & 31,85 & 272 & 38,97 & 322 & 37,66 \\
\hline $\begin{array}{l}\text { Sederosy } \\
\text { sombrereros }\end{array}$ & 22 & 14,01 & 96 & 13,75 & 118 & 13,80 \\
\hline Bordadores & 3 & 1,91 & 9 & 1,29 & 12 & 1,40 \\
\hline Cordoneros & 0 & 0,00 & 1 & 0,14 & 1 & 0,12 \\
\hline Tintoreros & 0 & 0,00 & 6 & 0,86 & 6 & 0,70 \\
\hline $\begin{array}{l}\text { Curtidores y } \\
\text { zurradores }\end{array}$ & 5 & 3,18 & 6 & 0,86 & 11 & 1,29 \\
\hline Zapateros & 18 & 11,46 & 128 & 18,34 & 146 & 17,08 \\
\hline Silleros & 2 & 1,27 & 17 & 2,44 & 19 & 2,22 \\
\hline $\begin{array}{l}\text { Espaderosy } \\
\text { doradores }\end{array}$ & 4 & 2,55 & 12 & 1,72 & 16 & 1,87 \\
\hline $\begin{array}{l}\text { Herreros y } \\
\text { cerrajeros }\end{array}$ & 4 & 2,55 & 18 & 2,58 & 22 & 2,57 \\
\hline $\begin{array}{l}\text { Tiradores y } \\
\text { batidores }\end{array}$ & 1 & 0,64 & 3 & 0,43 & 4 & 0,47 \\
\hline Plateros & 9 & 5,74 & 29 & 4,15 & 38 & 4,44 \\
\hline $\begin{array}{l}\text { Cereros y } \\
\text { confiteros }\end{array}$ & 7 & 4,46 & 7 & 1,00 & 14 & 1,64 \\
\hline Olleros & 3 & 1,91 & 3 & 0,43 & 6 & 0,70 \\
\hline $\begin{array}{l}\text { Pasteleros y } \\
\text { molineros }\end{array}$ & 5 & 3,18 & 3 & 0,43 & 8 & 0,94 \\
\hline Albañiles & 3 & 1,91 & 27 & 3,87 & 30 & 3,51 \\
\hline Carpinteros & 21 & 13,38 & 61 & 8,74 & 82 & 9,59 \\
\hline Total & 157 & 100,00 & 698 & 100,00 & 855 & 100,00 \\
\hline
\end{tabular}

Fuente: Elaboración propia a partir de los Protocolos Notariales, AGN, siglo XVI.

En cuanto a las actividades, es claro que el grueso de los oficiales y de los aprendices del siglo XVI se centraba en las confecciones. Los oficiales sastres constituían el 32\% y los aprendices el 39\%, lo que se ratifica con los datos de los sederos y de los sombrereros (14\% en ambos casos).

Vistos en el tiempo, los contratos se realizaron principalmente desde 1570. En esas décadas, figuran el $93 \%$ de todos los contratos de oficiales y el $83 \%$ de los de aprendizaje (la mitad de todos estos en la década de 1590). Para el siglo XVIII, las cosas cambiaron. Para empezar, los contratos 
290 | Trabajos y trabajadores en América Latina (siglos XVI-XXI)

de oficialazgo casi desaparecieron. En todo el siglo, hubo solo cuatro contratos de oficiales (tres espańoles y un esclavo), en tanto que los de aprendizaje sumaban 2.631. Los maestros, además, no eran tan numerosos (1.325), lo que hacía que existieran prácticamente dos contratos por maestro en promedio (el 94\% de los maestros era de procedencia española).

Tabla 3: Lima, siglo XVIII: contratos de oficiales y de aprendices por casta

\begin{tabular}{|l|c|c|c|c|c|c|}
\hline \multicolumn{1}{|c|}{ Casta } & Oficiales & Porcentaje & Aprendices & Porcentaje & Total & Porcentaje \\
\hline Españoles & 3 & 75,00 & 1.362 & 51,73 & 1.365 & 51,77 \\
\hline Indios & 0 & 0,00 & 724 & 27,52 & 724 & 27,48 \\
\hline Negros & 0 & 0,00 & 126 & 4,86 & 128 & 4,86 \\
\hline Mestizos & 0 & 0,00 & 150 & 5,63 & 148 & 5,62 \\
\hline Mulatos & 0 & 0,00 & 47 & 1,79 & 47 & 1,78 \\
\hline Zambos & 0 & 0,00 & 63 & 2,43 & 64 & 2,43 \\
\hline Cuarterones & 0 & 0,00 & 52 & 1,94 & 51 & 1,93 \\
\hline Quinterones & 0 & 0,00 & 4 & 0,15 & 4 & 0,15 \\
\hline Esclavos & 1 & 25,00 & 103 & 3,95 & 104 & 3,98 \\
\hline Total & 4 & 100,00 & 2.631 & 100,00 & 2.635 & 100,00 \\
\hline
\end{tabular}

Fuente: Elaboración propia a partir de los Protocolos Notariales, AGN, siglo XVIII.

Gráfico 2: Representación gráfica de los contratos de oficiales y de aprendices por casta: Lima, siglo XVIII

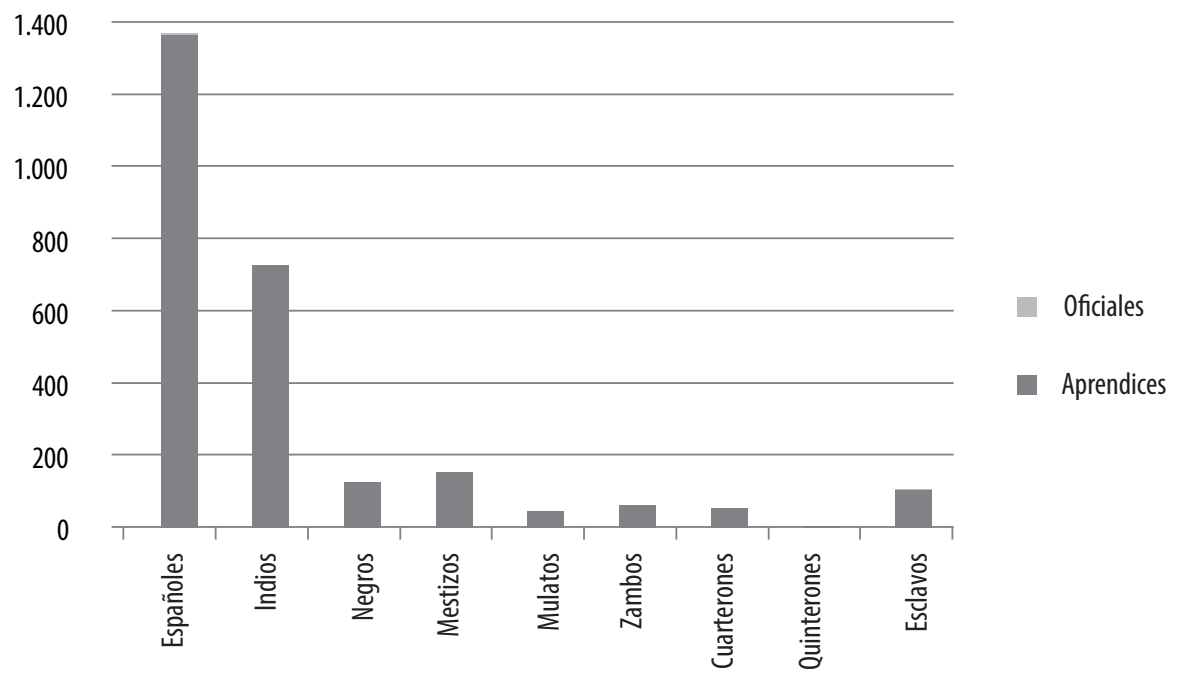

Fuente: Elaboración propia a partir de los Protocolos Notariales, AGN, siglo XVIII. 
Tabla 4: Lima, siglo XVIII: contratos por oficio

\begin{tabular}{|c|c|c|c|c|c|}
\hline Oficios & Oficiales & Porcentaje & Aprendices & Porcentaje & Total \\
\hline Sastres & 0 & 0,00 & 509 & 19,35 & 509 \\
\hline Bordadores & 0 & 0,00 & 10 & 0,38 & 10 \\
\hline Sombrereros & 0 & 0,00 & 111 & 4,22 & 111 \\
\hline Pasamaneros & 0 & 0,00 & 175 & 6,65 & 175 \\
\hline Botoneros & 0 & 0,00 & 364 & 13,83 & 364 \\
\hline Tintoreros & 0 & 0,00 & 14 & 0,53 & 14 \\
\hline Zapateros & 1 & 25,00 & 420 & 15,96 & 421 \\
\hline Zurradores & 0 & 0,00 & 14 & 0,53 & 14 \\
\hline Silleros & 0 & 0,00 & 87 & 3,31 & 87 \\
\hline Carpinteros & 0 & 0,00 & 167 & 6,35 & 167 \\
\hline Carroceros & 0 & 0,00 & 55 & 2,09 & 55 \\
\hline Ensambladores & 0 & 0,00 & 49 & 1,86 & 49 \\
\hline Toneleros & 0 & 0,00 & 16 & 0,61 & 16 \\
\hline Albañiles & 0 & 0,00 & 19 & 0,72 & 19 \\
\hline Alfareros & 1 & 25,00 & 26 & 0,99 & 27 \\
\hline Herreros & 0 & 0,00 & 125 & 4,75 & 125 \\
\hline Hojalateros & 0 & 0,00 & 13 & 0,49 & 13 \\
\hline Plateros & 0 & 0,00 & 379 & 14,41 & 379 \\
\hline Tiradores & 0 & 0,00 & 35 & 1,33 & 35 \\
\hline Doradores & 0 & 0,00 & 13 & 0,49 & 13 \\
\hline Relojeros & 0 & 0,00 & 9 & 0,34 & 9 \\
\hline Petateros & 0 & 0,00 & 4 & 0,15 & 4 \\
\hline Horneros & 0 & 0,00 & 2 & 0,08 & 2 \\
\hline Peineteros & 0 & 0,00 & 1 & 0,04 & 1 \\
\hline Coheteros & 0 & 0,00 & 2 & 0,08 & 2 \\
\hline Cuerderos & 0 & 0,00 & 1 & 0,04 & 1 \\
\hline Cigarreros & 0 & 0,00 & 1 & 0,04 & 1 \\
\hline Pasteleros & 0 & 0,00 & 1 & 0,04 & 1 \\
\hline Chocolateros & 2 & 50,00 & 1 & 0,04 & 3 \\
\hline Cereros & 0 & 0,00 & 2 & 0,08 & 2 \\
\hline Impresores & 0 & 0,00 & 6 & 0,22 & 6 \\
\hline Total & 4 & 100,00 & 2.631 & 100,00 & 2.635 \\
\hline
\end{tabular}

Fuente: Elaboración propia a partir de los Protocolos Notariales, AGN, siglo XVIII. 
292 | Trabajos y trabajadores en América Latina (siglos XVI-XXI)

Gráfico 3: Representación gráfica de los contratos por oficio: Lima, siglo XVIII

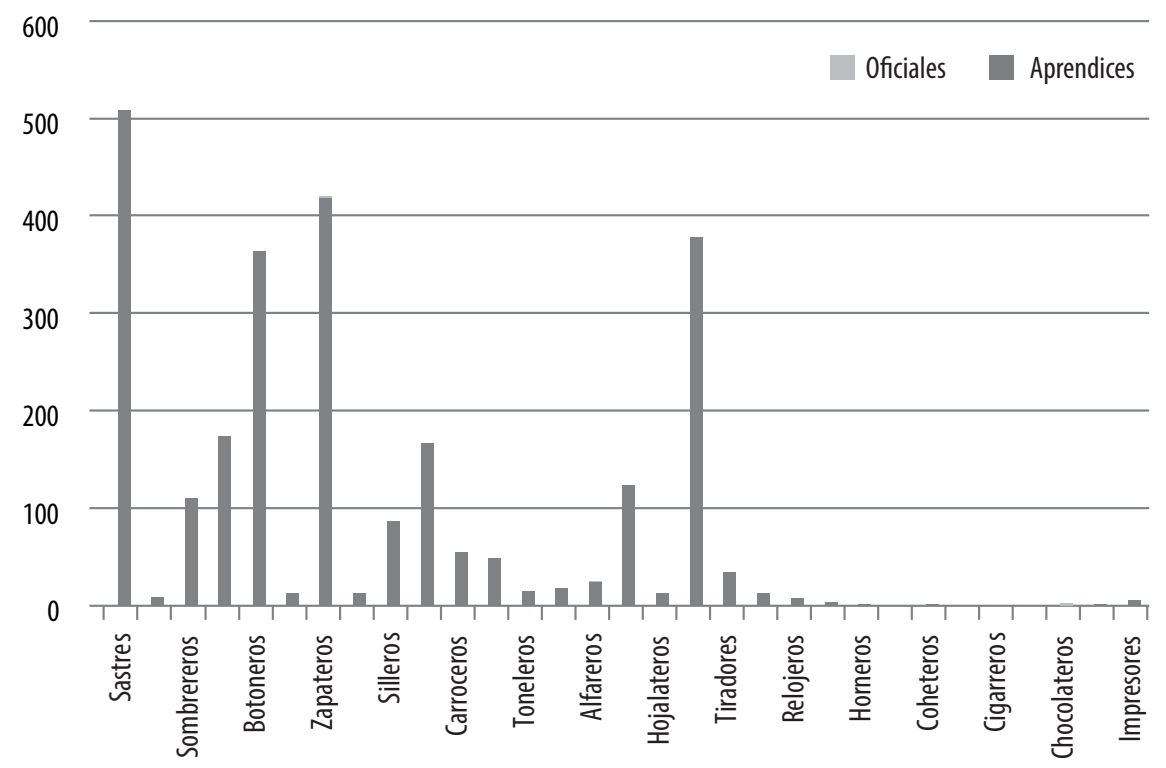

Fuente: Elaboración propia a partir de los Protocolos Notariales, AGN, siglo XVIII.

Nuevamente, los sastres, los calceteros, los sombrereros y los sederos cubrían la mayor parte de los contratos de aprendizaje con el 44\%. Les seguían los zapateros (16\%) y los plateros (14\%). El resto de oficios tenía contratos en proporciones muy pequeñas, algunos con un solo contrato en todo el siglo.

\section{TRABAJAR JUNTOS}

Los talleres artesanales y manufactureros recibían indistintamente trabajadores de las diferentes castas y condiciones. No se aprecia un patrón de discriminación en este aspecto. Es cierto que algunos oficios se identificaban con la casta, pero otros eran inclusivos. Entre los oficios "cerrados" destacaban los orífices y los plateros, cuya totalidad de maestros era de procedencia española y contrataban solo españoles como trabajadores, además de esclavos puestos a trabajar por sus amos. Los pasamaneros españoles también adujeron la "calidad" de su oficio para impedir que otros lo ejercieran. Sin embargo, la excepción fue el maestro negro Juan Gómez Morato, quien en el periodo 1704-1706 contrató a cuatro negros y a dos españoles. Los indígenas también tuvieron cierta exclusividad, pues los 
botoneros y los sederos se convirtieron con el tiempo en un oficio dominado por maestros indios.

El caso de los sederos y de los botoneros es ilustrativo, pues fueron los talleres que más contratos realizaron en el siglo XVIII. El indio Melchor Lucano contrató a 34 aprendices entre 1737 y 1789; 24 indígenas, 9 españoles y 1 mestizo. El indio Ventura Temoche tuvo 18 aprendices entre 1748 y 1799: 15 indios y 3 mestizos. El indio José Bruno Romero contrató a 16: 13 indios, 2 españoles y 1 mestizo. El indio Roque Ramos contrató a 13: 11 indios y 2 españoles. El indio Pascual Ramírez contrató a 13: 7 indios, 5 españoles y 1 mestizo. El indio Marcelo Lucano contrató a 11: 9 indios y 2 españoles. El indio Sancho Cosanchilon contrató a 11: 7 indios y 4 españoles. Y el indio Antonio Alvarado contrató a 10 indios y a 1 español.

En otros oficios los contratos también fueron variados respecto a la casta de sus ayudantes, aunque pocos casos registraron grupos numerosos. El herrero español Cosme Damián de Valdez contrató a 11 aprendices entre 1707 y 1723: 9 españoles, 1 negro y 1 mestizo. El también herrero español Juan de la Calle contrató a 8 aprendices: 3 espańoles, 3 negros (1 de ellos esclavo), 1 zambo libre y 1 mestizo. Por su parte, el herrero español Juan José del Pino contrató a 6 aprendices: 3 españoles, 2 mestizos y 1 indio.

En el caso de los carpinteros, el espańol Manuel Sánchez Blanco contrató a 10 aprendices; 5 españoles y 5 negros ( 2 de ellos esclavos). El carrocero español Alejo de Espinoza tuvo 9 ayudantes: 4 españoles, 2 negros (1 de ellos esclavo), 1 cuarterón (que tenía cuarta parte de sangre "sucia"), ${ }^{4}$ 1 mulato y 1 mestizo. Y su colega Esteban Fernández Baizán, también español, tuvo 9: 7 espańoles, 1 zambo y 1 negro. Tal vez sea oportuno resaltar que Fernández Baizán fue uno de los más grandes productores de carruajes en la Lima de la segunda mitad del siglo XVIII y, por eso, debió tener muchos más ayudantes entre oficiales y peones trabajando al mismo tiempo en su taller.

Esta convivencia trajo tanto compañerismo como discordias entre los trabajadores. Los talleres artesanales y manufactureros se manejaban de manera patriarcal. Los trabajadores debían obedecer al dueño en una relación vertical que podía llegar a la prepotencia y al maltrato físico y sicológico de los ayudantes. No parece exagerado afirmar que la relación entre el empleador y sus ayudantes era violenta, pese a que los maltratos dentro de los

4 Cuarterón es una de las denominaciones para las llamadas "castas". La pureza se medía por la sangre de los cuatro abuelos: tres de ellos eran blancos y uno indio (cuarterón de mestizo) o negro (cuarterón de mulato). 
talleres y de las casas no eran denunciados frecuentemente. ${ }^{5}$ La violencia doméstica se manifestaba en la agresión cotidiana que, por ser precisamente generalizada, se consideraba como algo normal. Así se infiere de las recomendaciones en los contratos para que los maestros trataran a sus pupilos con amor y sin excesos en los castigos. ${ }^{6}$

El propio tutor podía aprobar la corrección cuando esta era "paternal”. Si las panaderías eran cárceles privadas, los talleres en general servían de centros correccionales. El taller de un productor era un establecimiento que cumplía la función de educar e instruir, pero también de corregir, mediante el trabajo, conductas desviadas en los muchachos. Los tutores y las autoridades ponían de manera compulsiva a jóvenes y a adolescentes en talleres, como medida correctiva por fugas realizadas o por vida desarreglada (vagancia, bebida). A José Arrieta, a sus 13 años, lo pusieron con el sastre José Román, en 1785, por haber huido a Chile. El mestizo Juan de Berrocal, de 12 años, en 1709 ya había estado preso por andar vicioso cuando el alcalde del crimen de la Real Audiencia lo asentó para aprender el oficio de zapatero. El aprendiz indio José Dolores estaba preso en la Real Cárcel de Lima por vida desarreglada, al no tener sujeción ni oficio ni beneficio con qué subsistir cuando en 1789 el subdelegado del Cercado lo puso a aprender el oficio de botonero. La pena dada por robo en 1788 a Bartolomé Churruca fue quedarse de aprendiz con un zapatero, con la advertencia de que si fugaba sería enviado al presidio del Callao. El indio Juan Antonio Enríquez tenía 14 años y una deuda con el maestro Mariano Corona por la que estaba preso cuando en 1802 su tutor lo puso a aprender con otro maestro zapatero. A José Hermenegildo Palomino hubo que llevarlo en 1792 a la tienda del carrocero Domingo Huerta para que concluyera su instrucción luego de casi dos años de interrupción. ${ }^{7}$

El trato entre trabajadores pudo ser áspero. Los disgustos por motivos de trabajo entre ellos debieron ser frecuentes, aun cuando esto no se refleja en la documentación. La pelea a golpes entre dos oficiales zapateros en 1730 fue

5 Algunos ejemplos de fines del periodo colonial, en AGN, son: Cabildo, Causas criminales, 1773, legajo 5, c. [4] ff. 1-13; 1811, legajo 120, c. 1463; 1785, legajo 57, c. $665 ; 1786$, legajo 58 , c. $683 ; 1777$, legajo 39 , c. 461.

6 Algunos ejemplos de este trato paternal, en AGN, son: Protocolo Libro 44: 935v; Protocolo Libro 42: 693; Protocolo Libro 44: 1155v. El maltrato físico era motivo para cancelar una escritura ( $c f$. AGN, Protocolo Libro 533: 135; Protocolo Libro 42: 570v; Protocolo Libro 632: 362v).

7 AGN, Protocolo Libro 65: 416; Protocolo Libro 648: 503; Protocolo Libro 180: 597v y 830v; Protocolo Libro 565: 716v; Protocolo Libro 167: 435v. 
justificada por testigos (todos colegas) como algo natural y cotidiano: "Solo fue una pendencia entre amigos que suceden todos los días". ${ }^{8}$

\section{REMUNERACIÓN}

La remuneración variaba según las condiciones laborales y las castas. En este apartado, se separa a los trabajadores de talleres artesanales de aquellos que trabajaban de manera libre (a jornal) en talleres mayores (manufactureros) de la ciudad. Se hace la diferencia entre la realidad del siglo XVI y la del siglo XVIII.

Uno de los elementos importantes fue el patronazgo o respaldo que tenían los contratantes al momento de asentar el acuerdo. Muchas de las condiciones de retribución dependían de las influencias de la persona o de la institución que acompañaba a los trabajadores. En la tabla siguiente se muestra a los "padrinos" de los oficiales en el siglo XVI. En su gran mayoría, los oficiales llegaban solos a hacer contrato con los dueños de los talleres, lo que es un dato muy importante, pues involucra tanto a los espańoles como a los indígenas.

Tabla 5: Lima, siglo XVI: patronazgo de oficiales al momento del contrato

\begin{tabular}{|l|c|c|c|c|c|c|}
\hline Patronazgo & Españoles & Indios & Negros & Mestizos & Mulatos & Esclavos \\
\hline Padres & 1 & 1 & 0 & 0 & 0 & 0 \\
\hline Madres & 0 & 0 & 0 & 0 & 0 & 0 \\
\hline Familiares & 1 & 1 & 0 & 0 & 0 & 0 \\
\hline Dueños & 0 & 0 & 0 & 0 & 0 & 20 \\
\hline Dueñas & 0 & 0 & 0 & 0 & 0 & 2 \\
\hline Instituciones & 0 & 0 & 0 & 0 & 0 & 0 \\
\hline Autoridades & 1 & 1 & 0 & 0 & 0 & 0 \\
\hline $\begin{array}{l}\text { Sin } \\
\text { información }\end{array}$ & 71 & 43 & 4 & 8 & 3 & 0 \\
\hline Total & 74 & 46 & 4 & 8 & 3 & 22 \\
\hline
\end{tabular}

Fuente: Elaboración propia a partir de los Protocolos Notariales, AGN, siglo XVI.

8 AGN, Cabildo Penal, 1730, legajo 11, c. [8] f. 4; AGN, Cabildo Penal Provincias, 1805, legajo 16, paquete [4]. 
296 | Trabajos y trabajadores en América Latina (siglos XVI-XXI)

Gráfico 4: Representación gráfica del patronazgo de oficiales al momento del contrato: Lima, siglo XVI

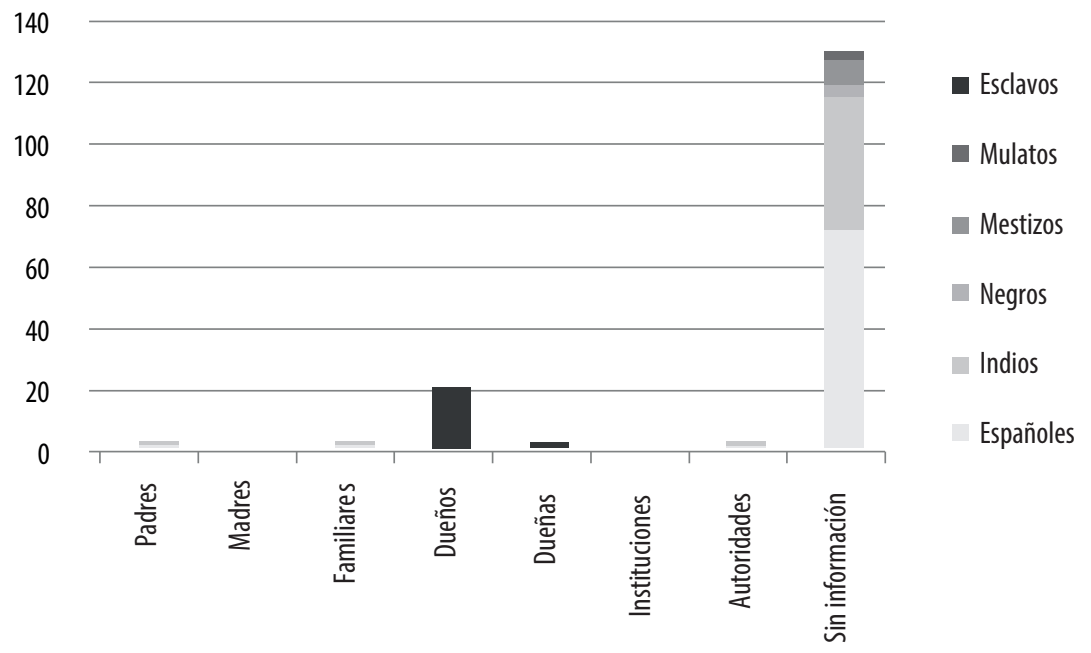

Fuente: Elaboración propia a partir de los Protocolos Notariales, AGN, siglo XVI.

En el caso de los aprendices, la información está en la siguiente tabla. Buena parte de los aprendices iban acompańados por sus padres y por otros familiares, aunque no deja de llamar la atención la alta proporción de los que iban solos, sin "padrino" la mayoría, tanto entre españoles como entre indígenas.

Tabla 6: Lima, siglo XVl: patronazgo de aprendices al momento del contrato

\begin{tabular}{|l|c|c|c|c|c|c|}
\hline Patronazgo & Españoles & Indios & Negros & Mestizos & Mulatos & Esclavos \\
\hline Padres & 31 & 4 & 4 & 3 & 5 & 0 \\
\hline Madres & 20 & 2 & 6 & 4 & 5 & 0 \\
\hline Familiares & 27 & 6 & 4 & 12 & 3 & 0 \\
\hline Dueños & 0 & 0 & 0 & 0 & 0 & 33 \\
\hline Dueñas & 0 & 0 & 0 & 0 & 0 & 24 \\
\hline Instituciones & 0 & 0 & 0 & 0 & 0 & 0 \\
\hline Autoridades & 7 & 33 & 6 & 15 & 12 & 0 \\
\hline $\begin{array}{l}\text { Sin } \\
\text { información }\end{array}$ & 139 & 264 & 3 & 14 & 12 & 0 \\
\hline Total & 224 & 309 & 23 & 48 & 37 & 57 \\
\hline
\end{tabular}

Fuente: Elaboración propia a partir de los Protocolos Notariales, AGN, siglo XVI. 
Los trabajadores artesanales limeños tenían una remuneración compleja. Esta podía ser en servicios, en especie, en dinero o en diversas combinaciones de estos tres elementos. La mayor presencia de alguno de ellos dependía de su condición de oficial o aprendiz, de su experiencia previa en el oficio, de su extracción étnico-cultural (ser blanco, indio, indio ladino, mestizo, negro o mulato), de su condición jurídica (ser libre o esclavo, indio encomendado, menor de edad), del "padrinazgo" que presentase y, finalmente, del momento del contrato.

La retribución del trabajo artesanal a aprendices incluía diez rubros entre servicios y bienes: adiestramiento, vivienda, atención médica, buen tratamiento, educación y doctrina cristiana, así como alimentación, vestido de diario, vestido de fiesta y herramientas. La de los peones u oficiales podía incluir dinero en efectivo o en reemplazo de bienes.

Los aprendices residían en casa de sus maestros y, por ende, estaban en servicio todo el día (y todos los días), desempeñando también, en la mayoría de los casos, diversas tareas domésticas (limpieza, acarreo de agua, mandados por recaudo o recados a la plaza o al mercado, a la pulpería o chingana, etcétera). El maestro debía curar sus enfermedades como parte de la remuneración (solo ocho días, por lo general) y tratarlos bien (darles buena vida, como se decía entonces), enseñarles buenas maneras y costumbres (buena policía) y los preceptos de la religión cristiana (sobre todo, pero no exclusivamente a los indios). Solo en dos oportunidades se ha hallado que en el siglo XVI se añadiese a otras formas de remuneración la alfabetización del pupilo. En el siglo XVIII, a las anteriores obligaciones se añadieron otras, como enseñar a leer y escribir, contar, cantar y tocar instrumentos musicales. ${ }^{?}$

En cuanto a la paga en especie, el primer lugar lo ocupaba la alimentación, seguida del vestido de diario y de fiesta. La vestimenta debía ser "competente a la persona" del ayudante, "lo correspondiente de modo que no sienta agravio", "darle lo de costumbre", "lo ordinario que se debe dar como aprendiz esclavo como es cada semana ropa limpia", entre otras fórmulas corrientes en los contratos. No se hablaba estrictamente de ropa especial de trabajo. Todavía se confundía la casa con el trabajo y la ropa de entrecasa con la ropa de trabajo. La vestimenta consistía en camisas, medias, calzones de jergón, chupa, capa "angarina", jubón con mangas y "balonas". La diferencia por castas estaba en el material de confección. El español y el mestizo tenían paño de Castilla ordinario o de segunda y camisas de lienzo y medias de algodón; el indio llevaba de jergueta o tocuyo, en tanto que los cuarterones, los zambos y los negros usaban paño de Quito o tocuyo. A un esclavo le correspondía el paño de obrajes locales (Cusco, Huamanga, Quito). Algunas veces, durante el primer año la ropa era de pañete y el segundo (o al final) era de paño de Quito. El calzado

9 AGN, Sección Notarial, Libro 732, f. 205; Libro 868, f. 1088. 
se entregaba con más frecuencia, pues se gastaba más rápido que la ropa; se cambiaba cada mes o cuando se requiriese, dándole un uso normal.

Contados fueron los asientos en que se establecía un pago exclusivamente en dinero. Algunos ejemplos sirven para ilustrar esta práctica, que no puede mostrarse en cuadros estadísticos por la diferencia en el valor de la moneda en el siglo XVI. Por los tres primeros años del trato, hecho en 1578 entre el carpintero Juan Cano y su aprendiz Diego Hernández, el maestro pagaba 40 pesos de a nueve reales para que su pupilo adquiriese un vestido. ${ }^{10}$ De manera similar, a partir de 1598 , el platero De la Hoz daba a Juan de Escobar 50 pesos de a nueve reales para vestido el primer año, 100 pesos de a nueve reales el segundo y 60 pesos de a nueve reales el medio ańo restante; ${ }^{11}$ y en 1593, el albañil Pedro Falcón pagaba a Gaspar Núñez 100 pesos de a nueve reales al año para su vestido, más 20 pesos de a nueve reales "para lo que quisiere". ${ }^{12}$ En 1593, el aprendiz indio Sebastián Yauraman debía recibir 28 pesos de a nueve reales al finalizar su aprendizaje, aparte de los 12 pesos de a nueve reales que debía darle cada año su maestro, el sastre Juan Cabezas. ${ }^{13}$ Los 20 pesos corrientes que recibía el oficial indio Andrés al final de los cuatro años de su contrato, de parte del herrero Francisco de Oviedo, serían para adquirir herramientas de su oficio. ${ }^{14}$

En dinero se pagaba también cuando quien realmente cobraba era otra persona, independientemente de que el trabajador fuera libre o esclavo. En numerosas ocasiones, eran familiares o tutores los que recibían el importe de los "salarios" de los oficiales y aprendices. En 1573, por ejemplo, el maestro ollero Hernán González pagaba los jornales al padre de su "obrero" Diego Pérez, con la aclaración de que si Diego quisiese podría recibir solo 40 pesos corrientes y no en dinero, sino en ropa. ${ }^{15}$

Cuando se trataba de esclavos, el amo percibía los jornales directamente del maestro. En tales casos, el trabajador solo era mantenido. Especialmente desde fines del siglo XVI, los esclavistas entregaban sus esclavos a maestros para aprovechar los jornales que generaban y no tenerlos improductivos en casa. Con ese fin, primero los ponían a aprender un oficio (principalmente albañilería, carpintería y otros oficios de la construcción), como ya lo

10 AGN, Protocolo Libro 28, f. 193.

11 AGN, Protocolo Libro 60 f. 728.

12 AGN, Protocolo Libro 53, f. 159.

13 AGN, Protocolo Libro 53, f. 299.

14 AGN, Protocolo Libro 150, f. 1v.

15 AGN, Protocolo Libro 71, f. 169. 
demostraron Emilio Harth-Terré, James Lockhart y Frederick Bowser en sus estudios (Harth-Terré y Márquez, 1962: 11-16; Lockhart, 1982; Bowser, 1977). A veces, el aprendizaje se hacía gratuitamente.

El regidor limeño Luis Rodríguez de la Serna asentó en 1598 a dos de sus esclavos oficiales torneros. A Cristóbal lo puso con el carpintero Diego Felipe por un año y medio, para dejarlo "buen oficial cumplido y acabado", a fin de que pudiese usar luego el oficio y "ganar lo que un buen oficial suele ganar"; $y$ al mulato Miguel lo colocó con el tornero Hernando Caballero, por dos ańos. En ambos casos, al término de los plazos, si no aprendían, debía Serna recibir sus jornales como si fueran ya oficiales: un peso de a ocho reales al día. ${ }^{16}$

Otros ejemplos se refieren a los sombrereros en 1598 y 1599. El esclavo Simón fue puesto con el maestro Esteban Narváez por cinco meses; en caso de que no aprendiese, Narváez debía dar a su ama cuatro sombreros al día hasta que Simón lograse dominar el oficio. ${ }^{17}$ Juan de la Riaza entregó por siete meses un negro nombrado Jacinto a su colega Diego Fuentes, para que concluyese su instrucción. Fuentes se quedaría con el producto del trabajo de Jacinto, pero si al cabo de ese tiempo no salía "oficial a vista de oficiales", pagaría a Riaza seis sombreros refinos al día hasta que lo hiciese. ${ }^{18}$

Algo similar ocurría con los aprendices libres, sobre todo si eran españoles. En 1590, el sastre Francisco de Riberos le dijo a su aprendiz Alonso García:

[...] si por my culpa e negligençia no os enseñase el dicho offiçio, os terné [sic: tendré] en my cassa y os daré y pagaré por cada un dia de los que os tardareis en acavar de deprender [sic: aprender] el dicho offiçio lo que comunmente ganase a la dicha sazon un offiçial. ${ }^{19}$

Desde el decenio de 1580 se estableció que el trabajo de los indios fuese remunerado con 12 pesos de a nueve reales y dos vestidos de indios por año. Esta disposición está acatada en 164 contratos, en tanto que en otros 59 la remuneración no alcanzó esa cantidad y en 83 la sobrepasó. Esto último obedece a que se trataba de oficiales o aprendices con alguna calificación previa.

En el siglo XVI y parte del XVII, la remuneración exclusivamente en dinero a los oficiales era más bien la excepción que la regla. Las referencias al dinero podían servir para medir la cantidad de efectos y/o de servicios a pagar efectivamente o para medir el nivel de endeudamiento entre el empleador y

16 AGN, Protocolo Libro 5, ff. 682 y 943.

17 AGN, Protocolo Libro 14, ff. 1963.

18 AGN, Protocolo Libro 57, f. 823.

19 AGN, Protocolo Libro 66, ff. 159v, 295 y 462. 
el trabajador, en una relación que no dejaba de ser precapitalista por la presencia del dinero en los tratos.

Los componentes de la remuneración de los oficiales dependían de la casta, del oficio, del momento del contrato y de su condición jurídica. Apreciemos las diferencias entre sastres, sederos, zapateros y plateros (los cuatro oficios representativos del caso) cuando los maestros eran españoles.

- Oficiales españoles. Entre los sastres hubo 26 contratos oficiales españoles, la mayor parte por un año. A excepción de uno, el resto consignó el pago en dinero con variaciones que oscilaban entre los 50 pesos corrientes y 350 pesos de a nueve reales, aparte de casa, comida y vestido diario (salvo en cinco casos). Se tienen registrados cinco contratos de sederos con salarios de entre 200 y 608 pesos de a nueve reales, más casa, comida y vestido (salvo en el último caso). En uno de los contratos se incluía el trabajo de la esposa del oficial en el servicio doméstico. Los oficiales zapateros fueron seis, incluyendo a un chapinero (el que confeccionaba sandalias de corcho para el consumo popular). Los salarios fueron relativamente más bajos en los tres casos en que figuran: uno de seis reales por día y los otros dos de 80 y 100 pesos de a nueve reales al año. Seis fueron también los plateros, y el pago en dinero fluctuó entre los 200 pesos corrientes en 1561 hasta los 30 pesos de a nueve reales en 1599.

- Oficiales indígenas. Comparando los mismos cuatro oficios, se aprecia que fueron 14 los oficiales indios con maestros sastres espańoles. El pago fue muy irregular. A unos, como Juan, quien ya tenía conocimientos de jubonería, en 1571 no se le pagaba sino casa, comida, curación y dos vestidos, en tanto que el "sueldo" nominal más elevado lo tuvo Miguel Alonso en 1583, 160 pesos de a nueve reales al año, pero sin ningún otro tipo de pago; en cambio, en 1595 Alonso recibía 12 pesos de a nueve reales al mes, además de casa, comida, curación, doctrina cristiana y dos vestidos. En el caso de los sederos, los 11 oficiales indios tuvieron una remuneración consistente en bienes y en servicios, más cantidades variables en dinero entre los ocho pesos corrientes y los 156 pesos de a nueve reales al año. Por su lado, los zapateros fueron solo cinco, casi sin pago en especie o en servicios y con bajas asignaciones en dinero. A los tres oficiales indios asentados con plateros españoles se les pagaba a uno $12 \mathrm{y}$ al otro 14 pesos de a nueve reales al mes en 1585 y en 1586 , y al tercero, solo 20 pesos de a nueve reales al año, más casa, comida y curación.

- Oficiales mestizos. El pago en dinero fue común a los cuatro oficiales mestizos asentados con sastres españoles. Los montos oscilaban entre los 100 pesos corrientes en 1557 y los 110 pesos de a nueve reales en 1582 . En 
cambio, los tres zapateros mestizos percibían 80,100 y 130 pesos de a nueve reales, además de alimentación y, en el último de los casos, un vestido al final. No hay registrados oficiales mestizos con sederos ni plateros.

- Oficiales mulatos. Tan solo se ha encontrado un contrato de oficial mulato con sastre español. Corresponde a 1593, y se le pagaba 20 pesos de a nueve reales al año, más un vestido y alimentación.

- Oficiales esclavos. Solamente dos oficiales esclavos figuran con maestros sastres. Uno en 1542 con 200 pesos de buen oro y otro en 1578 con 68 pesos corrientes. Igualmente, dos oficiales sederos esclavos: el bastidor Damián y el enfurtidor (o preparador de la lana utilizada como materia prima para los sombreros) Pedro, en 1598. Uno recibía ocho reales y el otro seis reales, por día de labores. Se encontró un solo oficial zapatero esclavo: Antón, que en 1593 no percibía más que alojamiento, comida y buen trato como toda remuneración. Probablemente su amo recibía los jornales, que no figuran en el contrato escrito o, en su defecto, la intención del amo era únicamente que su esclavo terminara de aprender el oficio.

Si la finalidad principal de la esclavitud urbana fue, en un comienzo, que los esclavos limeños sirviesen a la mano, muy pronto los amos vieron que más les convenía usarlos bajo el régimen que en la Roma antigua se denominó peculium. Es decir, la posibilidad de los esclavos de poseer bienes propios, incluyendo el disfrute de parte de los resultados de su trabajo en determinadas condiciones, lo que generó un sistema de semilibertad a cambio de un pago que el esclavo debía hacer periódicamente al amo, y que se llamó “jornal”, por referirse a una jornada y no a un salario.

Para incentivar el incremento de la productividad del trabajo, algunos maestros otorgaban un pago adicional (o aparentemente adicional) a sus dependientes. Un ejemplo es cuando en 1592 el sedero Diego Méndez daba a su aprendiz dos reales, cada domingo, aparte de casa, comida y ropa. Este pago adicional se conocería posteriormente como dinero para tabaco o para aguardiente. Con este mismo fin, en 1598, el ya mencionado platero De la Hoz permitía a su oficial Escobar trabajar "horas extras":

[...] todas las obras y trabaxo que hiziere y trabajare de noche, de lo que de ellas ganare se a de partir por mitad y la una parte a de ser para el dicho Diego de la Hoz por ser suya la casa y herramyentas y la otra mitad a de ser para el dicho Juan de Escobar por el trabaxo extraordinario que a de tener en trabaxar de noche. ${ }^{20}$ 
Así también, ese mismo año, el sedero Cristóbal de Ocaño entregó a su colega Alonso Jaramillo los dos esclavos ya mencionados: el bastidor Damián y el enfurtidor Pedro. Damián debía bastir diariamente diez sombreros comunes, mientras que Pedro debía enfurtir ocho. Por cada sombrero adicional que hiciesen se les recompensaría con un real. ${ }^{21}$

El factor edad fue determinante para establecer el trato que se daba a un aprendiz u oficial. Los maestros justificaron la ausencia de dinero en el pago a sus pupilos por ser estos muy pequeńos, como lo hiciera un carpintero en 1599:

[...] y por ser muchacho de diez o doze años no le a de dar más de tan solamente lo necesario de comer y bestir y calzar todo lo necesario y curalle de sus enfermedades y dotrinalle la dotrina cristiana y enseñalle buenas costumbres y crianza. ${ }^{22}$

Se justificaba también lo exiguo de la paga por la edad. Al indio de Surco, Felipe García, su maestro sastre le daba solo diez pesos de a nueve reales, y justificaba esta discriminación con que no tenía sino 10 u 11 años. También diez pesos de nueve reales debía recibir el indio Diego de parte de su maestro, el sastre Pedro de Arrones, "por ser pequeño y no de provecho los primeros ańos". ${ }^{23}$ Formalmente, debían recibir 12 pesos de a nueve reales.

Distinta fue la situación de quienes sí tenían ya tiempo en el oficio, aun sin "graduarse" de oficiales. El trato preferencial recibido se aprecia al comparar sus haberes con los de los demás, como se ha mostrado en varias oportunidades. Entre otros varios ejemplos, en 1595, el indio chachapoyano Domingo Viquin recibía 50 pesos de a nueve reales como aprendiz de sastre por haber tenido ya nociones del oficio. ${ }^{24}$

¿Cómo se comportaron los maestros de quienes se conoce el trato que recibieron en sus tiempos de aprendices u oficiales? Solo sabemos algo de algunos de ellos: devolvieron el trato que recibieron. Cuando en 1577 el ollero Salvador Sánchez era "obrero" de Rodrigo Hernández percibía un jornal de cuatro reales; seis años más tarde, Sánchez (ya maestro) daba a su aprendiz Bartolomé López 100 pesos de nueve reales al año, es decir, cuatro reales diarios durante 225 días. ${ }^{25}$

21 AGN, Protocolo Libro 115, f. 1427.

22 AGN, Protocolo Libro 61, f. 210v.

23 AGN, Protocolo Libro 61, ff. 34 y 237v.

24 AGN, Protocolo Libro 144, f. 196.

25 AGN, Protocolo Libro 72, f. 987; Protocolo Libro 74, f. 417. 
Juan Cano aprendió el oficio de carpintero con Francisco Jaura entre 1561 y 1564 . Los dos primeros años ganaba 25 pesos corrientes y el último, 50 pesos corrientes. En 1571, ya era maestro y, como tal, se concertó con el mulato libre Diego; en 1577 y en 1579, lo hizo con los españoles Juan Canas y Diego Hernández, por seis años los dos primeros y cuatro el tercero. A cada uno dio un juego de herramientas, como él mismo recibiera años atrás de su maestro. A Diego, que era su criado, le pagaba solo a partir del segundo año 12 pesos corrientes y los últimos tres años a razón de 20 pesos corrientes. A Canas solo le pagaba en servicios y en vestido, en tanto que a Hernández lo curaba y le daba 40 pesos de nueve reales, más un vestido al final. ${ }^{26}$

Por último, es difícil imaginar en los siglos XVI y XVII una situación en la que quienes dirigían los talleres pagasen puntual y exactamente a sus ayudantes lo que les correspondía por el tiempo que habían trabajado o por las tareas que realizaban.

\section{RemUneraciones en eL SIGLO XVIII}

Los asientos de locación de servicios del siglo XVIII difieren de aquellos celebrados en el siglo XVI. En realidad, en los protocolos notariales solo fueron inscritos los tratos que necesitaban cierta formalidad. De los 2.635 contratos, 1.810 (68\%) fueron acuerdos hechos bajo la iniciativa y/o el auspicio de familiares o de autoridades. El grupo mayor estuvo representado por mujeres (madres viudas, tías, hermanas, abuelas), otros familiares, tutores y amos, por lo que puede pensarse que se trataba tan solamente de cubrir una formalidad en casos en que se requería una seguridad para pupilos que, por diversas circunstancias, quedaban sin el amparo del padre y era necesario encaminarlos en la vida. Así lo manifestaba, por ejemplo, el mayordomo de la casa de expósitos cuando en 1774 asentó a José Bueno con el ensamblador Pedro Nolasco Rosas: "Por estar en menor edad es necesario darle algún oficio para que cuando sea mayor tenga en qué entretenerse y sustentarse y que no le suceda el trabajo que acarrea la ociosidad". También el tío del español Manuel Sangusan, al asentarlo con un platero en 1799, aseguraba: "Las ventajas que resultan a la república en que los individuos que la componen tengan los correspondientes destinos y oficios". ${ }^{27}$

El resto (32\%) resultó de la iniciativa de los propios trabajadores, o al menos no se señala lo contrario. Como ejemplos, en 1777, el zambo piurano Marcelino Zevallos, de 16 años, se asentó por su propia voluntad con un sastre,

26 AGN, Protocolo Libro 123, f. 1540; Protocolo Libro 128, f. 654v; Protocolo Libro 8, f. 65v: Protocolo Libro 28, f. 193.

27 AGN, Sección Notarial, Libro 93, f. 33v; Libro 44, f. 767. 
304 | Trabajos y trabajadores en América Latina (siglos XVI-XXI)

por hallarse en desamparo y sin abrigo. En 1779, el muchacho de 12 años José Segundo Gutiérrez se asentó por su cuenta con el maestro sastre José Rodríguez, por hallarse "vago y sin destino y deseando tener oficio con qué subsistir".

Tabla 7: Lima, siglo XVIII: patronazgo de aprendices al momento del contrato

\begin{tabular}{|l|c|c|c|c|c|c|c|c|}
\hline Patronazgo & Españoles & Indios & Negros & Mestizos & Mulatos & Zambos & Esclavos & Total \\
\hline Padres & 238 & 29 & 23 & 9 & 0 & 8 & 0 & 311 \\
\hline Madres & 363 & 7 & 61 & 11 & 15 & 24 & 0 & 501 \\
\hline Parientes & 293 & 48 & 19 & 21 & 7 & 11 & 0 & 415 \\
\hline Amos & 0 & 0 & 0 & 0 & 0 & 0 & 39 & 39 \\
\hline Amas & 0 & 0 & 0 & 0 & 0 & 0 & 61 & 61 \\
\hline Instituciones & 12 & 0 & 1 & 2 & 1 & 0 & 3 & 19 \\
\hline Autoridades & 65 & 338 & 3 & 29 & 6 & 10 & 0 & 457 \\
\hline Sin especificar & 391 & 302 & 19 & 78 & 18 & 10 & 0 & 828 \\
\hline Total & 1.362 & 724 & 126 & 150 & 47 & 63 & 103 & 2.631 \\
\hline
\end{tabular}

Fuente: Elaboración propia a partir de los Protocolos Notariales, AGN, siglo XVIII.

Gráfico 5: Representación gráfica del patronazgo de aprendices al momento del contrato: Lima, siglo XVIII

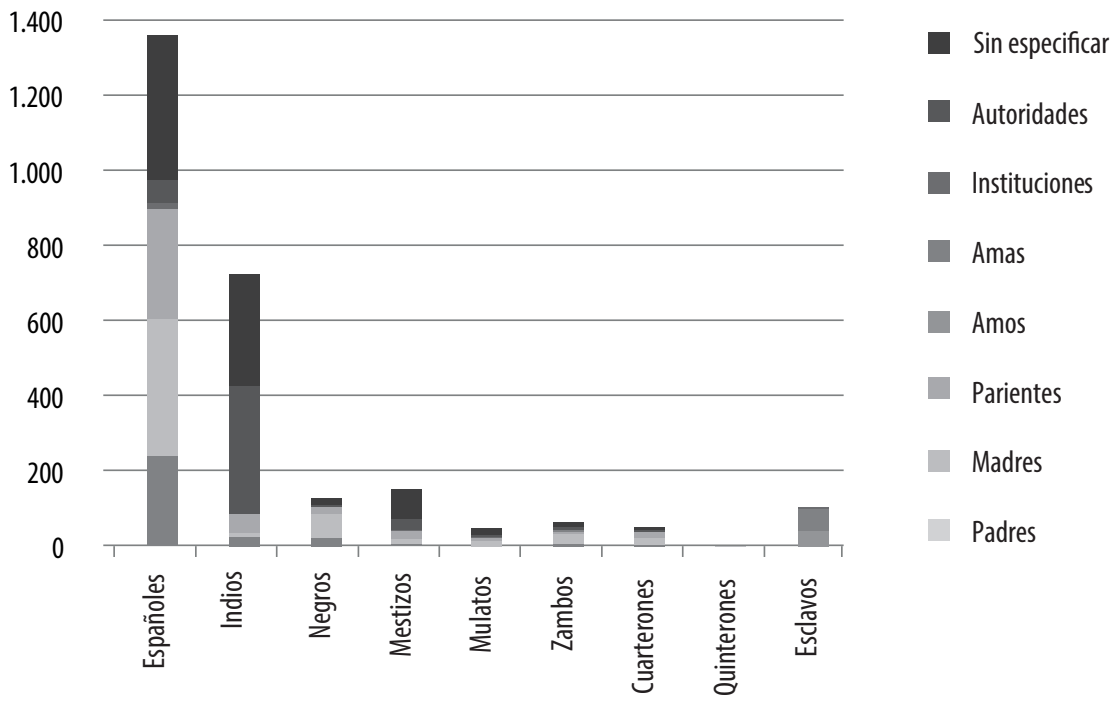

Fuente: Elaboración propia a partir de los Protocolos Notariales, AGN, siglo XVIII. 
A pesar de la gran cantidad señalada de contratos escritos, la mayoría de los tratos tuvo un carácter informal (oral). Esto quiere esto decir que la modalidad oral no era tan insegura, como podría parecer por una primera impresión. El prestigio personal del otorgante era parte considerable de su "capital fijo": la palabra era la base de un acuerdo en esa sociedad con una opinión pública que aún no era masiva.

Los contratos de oficialazgo fueron definitivamente informales, debido a que las personas mayores podían contactarse directamente con los conductores de los talleres para conseguir un trabajo. Fueron informales, además (y esto era muy importante ya en el siglo XVIII), porque el trabajo no era estable. Los vaivenes del mercado impedían cerrar contratos que obligasen a ambas partes a la continuidad de una relación laboral en condiciones de inseguridad económica. Antes bien, la relación laboral se establecía sin plazos de largo o mediano alcance. El trato se hacía casi por el día, y la estabilidad la otorgaba la frecuencia de trabajo de un oficial con un maestro y la confianza que se generaba entre ambos. La contratación fue libre en la medida en que podían ser libres las relaciones en una sociedad donde primaban la servidumbre y la esclavitud.

El trato entre uno de los mayores zurradores de la ciudad y su aprendiz puede ser ilustrativo. Matías del Solar tomó como aprendiz en 1717 al negro libre Marcos de Argandeña, quien debía estar en el taller a las seis de la mañana, todos los días laborables a lo largo de dos años. En el primer año solo le daría de comer y dos reales a la mano los fines de semana, mientras que durante el segundo año le pagaría la mitad de las tareas que trabajase. En otro caso de 1710, a Juan Esteban y Francisco de Escobar solo se los debía alimentar en el taller del pasamanero Felipe de Alcócer. ${ }^{28}$

El reclutamiento de mano de obra artesanal continuaba realizándose gracias a métodos no económicos, tales como las deudas o los compromisos de fidelidad que se generaban durante el periodo de aprendizaje. Al finalizar el plazo de aprendizaje, se estilaba que el oficial se quedase en el taller de su maestro.

Respecto a los siglos anteriores, sin embargo, es posible establecer algunas diferencias sobre las relaciones dentro del taller, tales como la prohibición de ejecutar tareas domésticas, la menor incidencia en las especificaciones de la calidad de la ropa con relación a la "calidad" de las personas en el vestido que se daba en parte de pago y, por otro lado, mayores precisiones acerca del tiempo efectivo de trabajo. Así se lo estipuló en prácticamente todos los contratos, "porque los dos años se entienden sin faltarle día, escepto [sic] los de fiesta", se decía en un contrato de 1761. "Pues los cinco años han de ser íntegros", se decía en otro. No se contaban los días de enfermedades ni de huidas, "respecto de que el término ha de ser sin interrupción”, rezaba otro contrato.

28 AGN, Protocolo Libro 776, f. 149; Protocolo Libro 1030, f. 62. 
El propio maestro estaba facultado para determinar los días que restaban servir al pupilo. Si el aprendiz se fugaba, se debían recuperar los días de ausencia al término de la escritura. El sastre Francisco Sánchez le decía a su nuevo pupilo Manuel que en cuatro años "lo ha de dar oficial hecho y derecho al fin de ellos, descontando las fallas que hiciese [...] teniendo facultad para que lo pueda sacar de la parte y lugar donde se fuere y traerlo a su poder para que aprenda dicho oficio”. La doncella tiradora de oro Margarita Tamayo de Loyola remarcaba a Juan Barrionuevo Ramírez, en 1701, que el contrato lo obligaba a estar de día y de noche en su casa. ${ }^{29}$ En ese sentido, exagerado fue el platero Ignacio de Ayala y Carrillo al especificar que si fugaba su pupilo Alejo de la Cueva lo retendría en su tienda seis meses más.

Es probable que la disciplina de trabajo haya experimentado también un cambio en este tiempo. Así lo hace pensar la separación de ayudantes por falta de aplicación o por pequeños robos o fallas (drogas, como las llamaban entonces). En todo caso, el rigor que debía aplicarse a los pupilos en el trabajo seguía ligado a la relación paternalista vigente en una sociedad tradicional entre el señor y sus dependientes.

Muy esporádicamente se menciona que al finalizar el contrato el flamante oficial recibiría un juego de herramientas de su oficio. Es importante señalar que las herramientas recibidas servían más para "oficialar" que para "maestrear" de manera independiente. Fórmulas comunes eran entregar "las herramientas necesarias" o "le ha de dar toda la herramienta". El oficio de sastres contemplaba la entrega de un juego de tijeras de diferentes tamańos. El relojero Juan de Salazar debió entregar en 1738 al indio aprendiz Rafael Colqui Puma un juego de herramientas consistente en lima, tenazas, alicates, compás y torno. ${ }^{30}$

Así, a pesar de que las relaciones laborales arcaicas descritas para los talleres artesanales del siglo XVI se reprodujeron a lo largo de todo el periodo colonial, conforme avanzaba el coloniaje, los vínculos estrictamente económicos y las relaciones monetarias se hicieron más fuertes, aunque nunca exclusivos.

Incluso en el siglo XVIII existió el jornal, pero no las relaciones asalariadas modernas. Se trataba de elementos de libre contratación, más que la libre contratación misma. La oferta y la demanda de trabajo, así como la remuneración, no dependían enteramente de condiciones netamente económicas. En efecto, el pago en dinero se presentó tanto en la producción artesanal como en la manufacturera, tanto para trabajadores libres como para esclavos, tanto para trabajadores de raza blanca como para los de las castas. Sin

29 AGN, Protocolo Libro 67, f. 199; Protocolo Libro 713, f. 915; Protocolo Libro 821, f. 651v.

30 AGN, Protocolo Libro 565, f. 712v; Protocolo Libro 37, f. 404v; Protocolo Libro 293, f. 115v; Protocolo Libro 126, f. 956. 
embargo, el pago en dinero podía ser tan solo nominal y servir como una medida de la deuda que tenían entre sí el productor y el trabajador. ${ }^{31}$

Solo en contados contratos se establecía un pago exclusivamente en dinero. Incluso cuando el pago (o parte de él) estuviese estipulado en valores monetarios, muchas veces no hacía otra cosa que reemplazar al pago en especie o en servicios y, en numerosos contratos, esto estaba señalado de manera explícita. Se justificaba el pago en dinero "para que de ello se vista". El platero José Vilela abonaba a José Antonio Seminario un real diario que debía servir para que el propio ayudante se alimentara. Este dinero aumentaba a dos reales al día al cumplirse el primer año de adiestramiento en la tienda. Su compañero de trabajo Juan Ventura González Paredes era más afortunado, pues recibía alimentos y dos reales al día para sus gastos. El sombrerero Luis Pérez, en 1718, daba a Miguel Arellano, aparte de un par de zapatos al mes, 20 pesos de a ocho reales el primer año, 30 pesos el segundo y 50 pesos el tercero, para que con ellos compre lo que hubiese menester. Con esto, el maestro se liberaba de entregar otros bienes y servicios, "sin que el dicho Miguel Arellano me pueda pedir otra cosa alguna”. Las mismas condiciones acordó en 1719 su colega Francisco Galeano. Los dos reales diarios que el herrero Domingo de Sarria entregaba al zambo Fermín Valladares eran expresamente para que comiera y se vistiera. Lo mismo y para lo mismo pagaba el zapatero Pedro Mateo a Juan de Guzmán, al igual que los tres reales diarios que el carpintero Pedro José Betanzos entregaba a Francisco de Céspedes. ${ }^{32}$

También en el siglo XVIII, se pagaba en dinero cuando quienes realmente cobraban eran los amos, los familiares o los tutores de los oficiales y de los aprendices. El carpintero Manuel Sánchez Blanco daba al amo del esclavo Francisco Javier de Sacramento dos reales diarios, que se sumaban al adiestramiento que recibía Francisco. En 1706, Manuel José de Paredes era esclavo de una orden religiosa que lo puso a aprender a tejer galones. Su maestro se comprometió a pagar a la orden solo cuatro reales los días de trabajo, "respecto de no haber siempre qué hacer continuamente en dicho oficio". Un peso diario (es decir, ocho reales) recibía el esclavo alfarero Juan Antonio de San Francisco. En la práctica ese dinero iba a dar directamente al convento de San Francisco. No solo en el caso de los esclavos el pago iba a otra persona, sino también cuando se trataba de pagar a menores de edad. José Galvis, tío de Juan de Santana, percibía los dos reales diarios que Juan

31 El pago de deudas con trabajo recuerda situaciones más conocidas para la zona rural andina. Un ejemplo es el trabajo que en 1736 realizó el carpintero negro libre Juan Bautista durante cinco meses por una deuda en favor del marqués de Torre Tagle (AGN, Cabildo Causas civiles, 1736, legajo 10 c. 135, ff. 1-6).

32 AGN, Protocolo Libro 258, f. 552; Protocolo Libro 963, f. 276. 
Manuel de Ojeda le debía por su trabajo-aprendizaje en la ollería de su propiedad en $1769 .{ }^{33}$

El orden de pago en dinero era muy variado en el siglo XVIII. En la documentación figura un pago adelantado, que pudiera interpretarse como un mecanismo de enganche del trabajador al taller o el resultado de un pedido previo del trabajador para cubrir alguna urgencia. La variante opuesta consistió en pagar el dinero solo al finalizar el contrato. El pago al final se hacía inclusive si se había pactado por dos, tres o incluso más años. Una fórmula muy común fue el pago "como los fuere sirviendo", lo cual iba acompañado de la otra fórmula aclaratoria "y pidiendo"; es decir, se pagaba por partes no especificadas, donde el propio trabajador debía recordar a su maestro el vencimiento de los plazos. Común fue también el pago "por tercias" o "por medias partes". El más frecuente fue el primero, que consistía en ir abonando al trabajador cada cuatro meses lo que le correspondía por esa tercera parte del año. Más escasos fueron los pagos por semestre. Aunque se tasase con frecuencia el pago por día, este se verificaba al finalizar la semana o el mes.

La paga en dinero estaba por debajo de los niveles mínimos de subsistencia, que era entre cuatro y ocho reales diarios por persona. Una remuneración de ocho reales o un peso al día era la soñada por un trabajador libre y soltero, pero no muchos hicieron realidad sus sueños, pues si bien la paga de un oficial podía superar los seis reales, por lo regular los montos del pago en dinero que aparecen en la documentación son realmente exiguos: entre 20 y 50 pesos al año. Divididas estas cifras entre los 220 o 240 días laborables que se tenía al año, dan sumas entre un cuarto de real y uno y medio reales diarios, lo que equivale a decir que un oficial debía vivir los 365 días del año con cifras que van desde la mitad de un cuartillo a un real al día. Cuando el pago era mensual, se tienen resultados similares, aunque algo más favorables. Por ejemplo, el hornero Nicolás de Segura pagaba cuatro pesos de a ocho reales al mes a José Zubieta y el pastelero Cipriano Fernández pagaba a Francisco Cervantes seis pesos de a ocho reales al mes. Estas sumas corresponden, en 20 días útiles, a uno y medio y dos reales diarios, respectivamente, aunque bajan a un real y a uno y medio reales al día por los 30 días del mes.

Para incentivar la productividad del trabajo en el siglo XVIII, algunos maestros artesanos otorgaban un pago adicional a sus dependientes. Era el pago llamado para tabaco o aguardiente los días domingo. Así, los cuatro reales a la semana (algo más de tres cuartillos diarios) que el albañil Luis García daba al negro libre Francisco de Paula desde el segundo año de instrucción eran solo una propina. Propina expresamente para merendar y comprar fruta era el real o medio real que numerosos maestros se comprometieron a entregar los 
días domingo a sus pupilos, al igual que las dos horas de asueto o hueco por las tardes de esos días feriados para divertirse. A veces la huelga se prolongaba hasta la oración, al caer la tarde. En la práctica, ese dinero servía para picante y aguardiente o chicha en las picanterías y chinganas. Más generoso fue el herrero Miguel Palomino, quien daba cuatro reales diarios a Antonio Cabrera, pues este ya tenía mayor experiencia en el trabajo. Gradualmente subiría el pago de Santos Chávez en la sastrería de Bernabé Iglesias, en 1777. Chávez debía culminar su instrucción durante dos ańos, percibiendo, respectivamente, tres y cuatro reales diarios a lo largo de cada año. ${ }^{34}$

Sobre todo desde la segunda mitad del siglo XVII aparece la contratación libre, en la modalidad de pago por producción (tareas o destajo). Con frecuencia, cumplida la tarea obligatoria diaria, el trabajador podía quedarse en el taller a realizar media tarea o una tarea completa adicional, por lo que percibía una mejor remuneración. Por ejemplo, Adrián de Rojas era un indio huaylino que percibía del zapatero Juan Pascual de Abregú dos reales para comer al día y cuatro reales por cada tarea adicional de zapatos que hiciese. ${ }^{35}$ No fue la remuneración en dinero, empero, el tipo de pago que prevalecía en los talleres limeños, pues solo se daba cuando el mercado tenía buenas condiciones. En realidad, la mejora en la remuneración no siempre fue usada para atraer (o retener) la mano de obra.

En la industria fue muy frecuente el trabajo de esclavos "jornaleros". Si en los contratos formales de aprendizaje del siglo XVIII aparecen tan solamente 102 esclavos, esto se debe a que los amos preferían dejarlos en libertad para que ellos mismos buscasen un trabajo con que abonar sus jornales. En efecto, si en los talleres artesanales se emplearon mayormente esclavos propios y alquilados como complemento de la mano de obra servil, en la manufactura la presencia del esclavo puesto a ganar un jornal era más frecuente. Las labores en los talleres grandes o en el propio domicilio no exigían mayor destreza de parte del trabajador y, aun cuando sí se requiriese, el aprendizaje se obtenía gracias a alguna experiencia previa en talleres artesanales o se efectuaba sobre la marcha.

En el siglo XVIII, se mantiene, aunque en menor escala, la práctica de asentar esclavos con productores para su entrenamiento y así obtener un mejor provecho de sus jornales. El contador mayor Francisco de Alarcón, por ejemplo, dio en 1756 su esclavo llamado Pedro José al maestro sastre Manuel Dávila, "en sus brazos de fierro para que lo sugete todo el tiempo referido, como si fuera su esclavo". ${ }^{36}$

34 AGN, Protocolo Libro 731, f. 423; Protocolo Libro 537, f. 864; Protocolo Libro 749, ff. 1v y 2v; Protocolo Libro 925, f. 98.

35 AGN, Protocolo Libro 928, f. 155v.

36 AGN, Protocolo Libro 484, f. 375; Protocolo Libro 507, f. 567v; Protocolo Libro 535, f. 127; Protocolo Libro 1170, f. 350; Protocolo Libro 401, f. 980; Protocolo Libro 339, f. 162. 
Un esclavo puesto a ganar debía entregar a su amo diariamente un real por cada 100 pesos de su precio de compra. Es decir, el jornal equivalía al 0,125\% de su precio de tasación. Así, si un esclavo calificado costaba 800 pesos de a ocho reales, debía entregar cada día laborable ocho reales a su amo rentista. Es evidente que el esclavo jornalero, para poder sobrevivir fuera de la casa del amo, debía percibir más, y esto puede explicar la concentración de esclavos alquilados y jornaleros en las panaderías, los molinos, las mantequerías, las velerías y las sombrererías, donde el trabajo no se distinguía precisamente por ser cualificado, pero garantizaba un pago efectivo con el cual poder cubrir las exigencias del amo. Otros trabajos que proporcionaban dinero con regularidad eran los servicios de carga de bultos y acarreo de agua (aguadores) (Quiroz, 2016).

\section{A MANERA DE CONCLUSIÓN}

La información muestra que los talleres artesanales y manufactureros en la Lima colonial fueron variados, tanto en su propiedad como en su fuerza laboral. Los maestros y los dueños pertenecieron a todas las castas existentes en la ciudad, aunque las cifras absolutas podrían estar ocultando la realidad respecto a quiénes poseían la mayor cantidad y los mejores talleres; sin embargo, no cabe duda que los españoles prevalecían en ambos criterios.

Algo similar sucede con los trabajadores. Si bien pertenecían a todas las castas, la información muestra que el trato a los aprendices y a los peones españoles fue mejor con relación a las condiciones de trabajo y a su retribución en bienes, servicios y dinero. Vivir y trabajar juntos generaba vínculos de amistad y compañerismo, pero también de discordia. La sociedad estamental limeña colonial marcaba las diferencias como algo natural. En ese sentido, la convivencia no igualaba a personas pertenecientes a las diferentes castas y condiciones sociales.

Como resulta evidente, la Lima de los tiempos coloniales estuvo muy lejos de tener un mercado libre de mano de obra. Predominaron, antes bien, diferentes formas de trabajo servil y esclavo, y ese contexto marcó de manera significativa los elementos de trabajo libre que aparecieron en la ciudad casi desde su fundación. Esto puede apreciarse en el hecho de que el jornal de los mitayos y los esclavos sirvió de base para determinar el jornal de los trabajadores urbanos formalmente libres.

Finalmente, queda claro que el sistema gremial limeño colonial estuvo enraizado en el régimen de castas y estamentos vigente. El mismo gremio surge y se desenvuelve en atención a la necesidad de controlar a una sociedad diversa en su composición social y étnica. 


\section{FUENTES}

Archivo Histórico Municipal de Lima (AHML)

Libros de cédulas y provisiones de Lima.

Archivo General de la Nación (AGN), Lima

Cabildo Penal, 1730, legajo 11, c. [8].

Cabildo Penal Provincias, 1805, legajo 16, paquete [4].

Cabildo Causas criminales, 1773, legajo 5 c. [4].

Cabildo Causas criminales, 1777, legajo 39 c. 461.

Cabildo Causas criminales, 1785, legajo 57 c. 665.

Cabildo Causas criminales, 1786, legajo 58 c. 683.

Cabildo Causas criminales, 1811, legajo 120 c. 1463.

Cabildo Causas civiles, 1736, legajo 10 c. 135.

Sección Notarial, Protocolos siglo XVI y siglo XVIII: Libro 5, Libro 8, Libro 14, Libro 28, Libro 37, Libro 42, Libro 44, Libro 53, Libro 57, Libro 60, Libro 60, Libro 61, Libro 65, Libro 66, Libro 67, Libro 71, Libro 72, Libro 74, Libro 93, Libro 115, Libro 123, Libro 126, Libro 128, Libro 144, Libro 150, Libro 167, Libro 180, Libro 258, Libro 293, Libro 525, Libro 533, Libro 537, Libro 565, Libro 632, Libro 648, Libro 713, Libro 731, Libro 732, Libro 749, Libro 749, Libro 776, Libro 821, Libro 868, Libro 925, Libro 928, Libro 963, Libro 1030.

\section{BibLIOGRAFÍA}

Bowser, Frederick

1977 El esclavo africano en el Perú colonial (1524-1650). México: Siglo XXI Editores.

Cárdenas Ayaipoma, Mario

2014 La población aborigen en Lima colonial. Lima: Fondo Editorial del Congreso del Perú.

Cabildo de Lima

1935 Libros de Cabildos de Lima (LCL). Lima: Municipalidad Provincial.

Cook, Noble David

1985 Numeración general de todas las personas de ambos sexos, edades y calidades que se ha hecho en esta ciudad de Lima, año de 1700. Lima: Corporación Financiera de Desarrollo 
312 | Trabajos y trabajadores en América Latina (siglos XVI-XXI)

1968 Padrón de los indios de Lima 1613. Lima: Seminario de Historia Rural Andina, Universidad Nacional Mayor de San Marcos.

Fernández Villanova, David

2017 "Identidad corporativa y religiosidad popular. Las cofradías del gremio de sastres españoles de Lima (siglos XVI-XVIII)". En: David Fernández Villanova, Diego Lévano Medina y Kelly Montoya Estrada (comps.), Cofradias en el Perú y otros ámbitos del mundo hispánico (siglos XVI-XIX). Lima: Conferencia Episcopal Peruana / Comisión Episcopal de Liturgia del Perú.

Harth-Terré, Emilio

1973 Negros e indios. Un estamento social ignorado del Perú colonial. Lima: Juan Mejía Baca.

1960 El indigena peruano en las bellas artes virreinales. Cuzco: Garcilaso.

Harth-Terré, Emilio y Alberto Márquez Abanto

1962 "Perspectiva social y económica del artesanado virreinal en Lima". En: Revista del Archivo Nacional del Perú, tomo XXVI, entrega II. 353-446.

Lockhart, James

1982 El mundo hispanoperuano, 1532-1560. México: Fondo de Cultura Económica.

Pérez Cantó, María Pilar

1985 Lima en el siglo XVIII. Estudio socioeconómico. Madrid: Ediciones de la Universidad Autónoma de Madrid / Instituto de Cooperación Iberoamericana.

Quiroz Chueca, Francisco

2016 "Historia de muchas ciudades: esclavitud urbana en las Américas". En: RELEA, Revista Latino-Americana de Estudos Avançados, número 1. 29-45.

2008 Artesanos y manufactureros en Lima colonial. Lima: Instituto de Estudios Peruanos / Banco Central de Reserva del Perú.

1995 Gremios, razas y libertad de industria. Lima colonial. Lima: Universidad Nacional Mayor de San Marcos.

Vergara Ormeño, Teresa

2005 “La población indígena”. En: Laura Gutiérrez Arbulú (coord.), Lima en el siglo XVI. Lima: Instituto Riva Agüero / Pontificia Universidad Católica del Perú. 175-225. 


\title{
Yanaconas, colonos y arrenderos: contradicciones entre la ley y la práctica en el trabajo rural durante los siglos XIX y XX en Bolivia
}

\author{
María Luisa Soux (Bolivia)*
}

Resumen: El artículo busca analizar las contradicciones existentes entre la normativa y la práctica en el trabajo en las haciendas bolivianas entre 1825 y 1952 . Si la norm $\neq$ ativa, mediante el Código Civil de 1832, estableció que el sistema de trabajo se basaba en formas de arrendamiento pagadas con el servicio o el trabajo del arrendero o colono, en la práctica persistió, hasta 1952, un sistema de trabajo basado en el pago en trabajo a cambio del usufructo de una parcela de la hacienda, que contemplaba no solo las labores agrícolas, sino también trabajos serviles a favor del hacendado, como el pongueaje. Esta contradicción dio lugar a varios debates en las décadas de 1940 y 1950, y, a pesar de que el Congreso Indigenal de 1945 determinó el fin del pongueaje, este solo desapareció con la Reforma Agraria de 1953.

PalabRas Clave: sistemas de trabajo; yanaconas; colonos; arrendamiento; pongueaje.

\section{INTRODUCCIÓN}

Las relaciones de trabajo en las haciendas del Altiplano y de los valles de Bolivia no han sido investigadas aún con toda la profundidad necesaria, ya que los estudios de historia rural y agraria se han centrado mayormente en el tema de la propiedad y de la posesión de la tierra, en los que de manera casi general se repiten los momentos constitutivos de la construcción de la propiedad privada y de la lucha por la tierra. De esta manera, el tema de las relaciones de trabajo ha sido subsumido en el tema de la propiedad, asumiendo que a cada sistema de tenencia y de propiedad corresponden formas dadas de relaciones laborales. Estos vacíos respecto a las formas de trabajo, así como el uso a veces político del tema agrario, ha llevado a

* Doctora en Historia por la Universidad Nacional de San Marcos (Perú). Academia Boliviana de la Historia, Carrera de Historia de la Universidad Mayor de San Andrés (UMSA). Contacto: mlsoux@yahoo.es 
establecer, inclusive en leyes y decretos, conceptos no del todo acertados, los cuales han provocado confusiones que dificultan un análisis más pertinente desde la historia. Un ejemplo de ello es el debate que, a pesar de los años, no ha concluido totalmente sobre el carácter feudal de las haciendas, y que fue una de las bases argumentativas para la dictación de la Reforma Agraria de $1953 .{ }^{1}$

En este trabajo se pretende analizar los cambios jurídicos y las permanencias fácticas de los sistemas de trabajo en las haciendas desde el inicio del sistema republicano, en 1825, hasta la Reforma Agraria, en 1953, estableciendo, por un lado, la manera en que el yanacona colonial fue cambiando su nombre y su estatus jurídico hasta el concepto de colono, mientras que, por otro lado, la relación de trabajo no sufrió los mismos cambios, dando como resultado figuras contradictorias como la del pongueaje. ${ }^{2}$ Para ello, resulta importante establecer las relaciones existentes entre tres conceptos: 'propiedad', 'arrendamiento' y 'sistemas de trabajo', dado que la contradicción se asienta, en gran medida, en la práctica del "pago con trabajo".

En este texto nos adentraremos inicialmente en el análisis de la normativa referida a los sistemas de propiedad y trabajo, y trataremos posteriormente de analizar la práctica diaria de las relaciones de trabajo, así como las contradicciones que permitieron ir modificando lentamente la misma normativa.

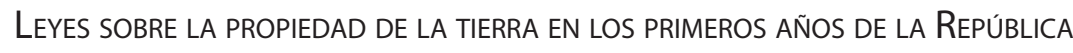

Los sistemas de propiedad y de tenencia de la tierra establecidos por el sistema republicano modificaron, en parte, las formas tradicionales coloniales, en una tensión entre el reconocimiento o no de las formas comunitarias y la introducción definitiva de la propiedad perfecta e individualizada, relacionada con los postulados liberales.

1 El debate acerca de la feudalidad del sistema de haciendas fue fundamental en los estudios de historia agraria en Bolivia y en América Latina. Las posiciones a favor de entender como feudal el sistema de haciendas se centran, precisamente, en los sistemas de trabajo esclavista y servil, que fueron mayoritarios. La posición contraria sostiene, más bien, que a pesar de que el sistema de trabajo a cambio de la posesión de la tierra fue predominante, no puede ser considerado feudal debido a que no contemplaba el dominio, central en la concepción de un sistema feudal. En el presente trabajo se busca mostrar que si bien las leyes del siglo XIX desconocían la servidumbre, en la práctica esta se mantuvo.

2 Costumbre mediante la cual los colonos debían servir en la casa urbana del propietario y/o en la casa de hacienda con labores de carácter doméstico. 
Simón Bolívar fue uno de los primeros en referirse a la distribución de tierras, buscando establecer maneras más seguras de propiedad, sobre todo para los agregados y los forasteros, tanto frente a sus autoridades como a los indios originarios. Para ello promovió la individualización de la propiedad (Antezana, 1992). A partir de entonces, la legislación bolivariana se dirigió sobre todo al tema de la propiedad en las comunidades indígenas, ya que la propiedad privada e individualizada de los hacendados sobre sus tierras nunca fue puesta en duda.

A partir de los decretos bolivarianos, los siguientes Gobiernos llevaron a cabo una política de tierras muchas veces confusa y ambivalente. Por ejemplo, durante el mandato de Antonio José de Sucre se buscó consolidar la propiedad de las tierras de las comunidades de forma individual, estableciéndose un impuesto general sobre ellas. Sin embargo, el impuesto único fue rechazado tanto por los propietarios criollos de las haciendas como por los mismos miembros originarios de las comunidades. Para los primeros, el pago de un impuesto único implicaba igualarlos con los indios, a quienes ellos habían considerado siempre como inferiores en estatus y pertenecientes a su propia república. Para los segundos, el pago del impuesto único sobre la propiedad, en lugar del tributo, implicaba un catastro previo con el cual saldrían a la luz los arreglos internos que existían dentro de las comunidades entre originarios propietarios de la tierra y agregados y forasteros usufructuarios de la misma, lo que implicaba, desde el punto de vista del originario, una intromisión del Estado en asuntos internos de la comunidad (Soux, 2012). Frente a la negativa a cumplirlos, los decretos fueron suspendidos, manteniéndose el tributo bajo el nombre de contribución indigenal (Lofstrom, 2010).

De acuerdo con Marta Irurozqui y Víctor Peralta (2000: 217), el tributo era central en el reconocimiento de la propiedad de la tierra para los indígenas, es decir que la contribución fiscal era una garantía de acceso a la tierra en el sentido de que generaba una renta; sin embargo, para ello la propiedad sobre la tierra debía ser individualizada. Desde esta perspectiva se entiende la Ley de 28 de septiembre de 1831, dictada durante el mandato de Andrés de Santa Cruz, que consolidaba la propiedad "de los terrenos de los caciques de sangre, así como de los indígenas contribuyentes que hubieran poseído estos terrenos por más de 10 ańos". La Asamblea Constituyente del mismo año confirmó el derecho de propiedad de los originarios, aunque de forma individual (Soux, 1997).

En 1838, la Resolución Suprema de 22 de noviembre, llamada de "Sucesión de indígenas", confirmaba la propiedad de la tierra en manos de los originarios, estableciendo un sistema de primogenitura para la sucesión de la tierra, "prefiriéndose el mayor al menor y el varón a la hembra”. En esta ley, la posesión era también clara: solo podía darse en herencia lo que se hallaba en propiedad, pero para evitar la división de la tierra, se establecía el sistema de primogenitura. 
Esta nueva ley especial surgió a partir del Código Civil, promulgado en 1832 también durante el gobierno de Andrés de Santa Cruz y basado en gran medida en el Código Civil Napoleónico, que se inspiraba, a su vez, en los principios de propiedad del Derecho Romano y en los principios de la modernidad de la igualdad jurídica, en contraposición a los principios de raigambre colonial, lo que muestra claramente que dicho Código no respondía totalmente a las necesidades específicas de los indígenas. Así, mientras que para la población en general era factible una división de la tierra, para los indígenas se hacía necesario establecer un principio de primogenitura para evitar la división.

Durante los primeros años de vida republicana, a partir de postulados de corte liberal, el Estado fue deslizándose hacia el reconocimiento de la propiedad de los indígenas sobre las tierras de la comunidad, aunque de forma cada vez más individualizada; también se reconoció y se confirmó la propiedad perfecta de los propietarios no indígenas de haciendas, desconociéndose únicamente los vínculos de mayorazgo sobre la propiedad de la tierra, al considerar que se trataba de privilegios que el nuevo sistema no aceptaba. En este punto es importante destacar que el principio que rigió los sistemas jurídicos republicanos estuvo basado en un aparente concepto de igualdad ciudadana, lo que implicaba necesariamente la sustitución de los privilegios y los fueros de la concepción de una sociedad jerárquica y estamental por una sociedad en la que todos eran iguales en estatus y ante la ley.

En los siguientes años, los que van desde 1842, cuando se establece mediante una circular la situación de enfiteusis de los indígenas en las tierras de comunidad, pasando por las leyes de remate de tierras que promulgó Mariano Melgarejo (1868-1869), hasta la Ley de Exvinculación de 1874, la tendencia general fue la de debilitar la propiedad comunitaria, ya sea reconociendo la propiedad del Estado, rematando las comunidades en favor de la propiedad hacendataria o, finalmente, individualizando la propiedad y declarando desaparecidas las comunidades. De una u otra forma, el resultado fue la consolidación de un sistema de haciendas caracterizado no por sistemas capitalistas de trabajo, sino por la permanencia de los antiguos propietarios indígenas en calidad de colonos. Este sistema se mantuvo oficialmente hasta 1953.

\section{FORMAS DE ADQUIRIR LA PROPIEDAD}

Si bien en los estudios sobre las haciendas consideradas capitalistas los ámbitos de la propiedad de la tierra y de los sistemas de trabajo se hallan separados, en el entendido de que la relación entre el propietario de la tierra y los trabajadores es únicamente salarial, no ocurre lo mismo cuando se aborda el análisis de las haciendas precapitalistas, en las que las relaciones laborales no asalariadas guardan relación con formas de tenencia precaria o inquilinato. 
Desde la etapa colonial subsistieron diversas formas de adquirir la propiedad de la tierra, ya sea por los grupos indígenas como por los españoles y los criollos. No desarrollaremos aquí el debate existente sobre el tema de la encomienda, debido a que su impacto ya era ínfimo durante el siglo XIX, ni tampoco el de las mercedes, que fueron la forma inicial de obtener tierras en el siglo XVI por parte de españoles y de criollos. Sin embargo, sí es importante establecer que la llamada "composición de tierras", que se dio desde fines del siglo XVI (visita del obispo de Quito), pasando por el siglo XVII (visitas de Gerónimo Luis de Cabrera y otros) (Ballivián de Romero, 1987), hasta el siglo XVIII (visita de Juan Bravo del Rivero), estableció las pautas para la consolidación de la propiedad, tanto individual en haciendas como colectiva en comunidades, en el sentido de que para ambos se garantizaba de esta manera no solo la posesión, sino también la propiedad, aunque para el caso de los indígenas de las comunidades la misma fuera colectiva (Mamani Humérez, 2012).

Con el sistema republicano, las formas de adquirir y de traspasar la propiedad de la tierra siguieron alguna de las siguientes formas jurídicas:

- Posesión "inmemorial". Aunque esta forma de adquirir derechos fue más importante durante los primeros años de la Conquista, subsistió en parte para garantizar propiedades antiguas. Este argumento fue utilizado por las poblaciones indígenas, acudiendo a normas coloniales que indicaban que la llamada posesión inmemorial se remontaba a cien años; es decir, la máxima existencia posible de algún testigo que pudiera garantizar la propiedad de esta tierra. Por lo tanto, este argumento sirvió sobre todo cuando no existía otra forma escrita de demostrar la propiedad o para transformar alguna forma no perfecta en propiedades perfectas.

- Herencia o sucesión. Era una de las formas más comunes de traspaso de la propiedad individual de la tierra a los sucesores. Los sistemas de herencia de la tierra contemplaban tanto la sucesión intervivos y la sucesión luego de la muerte del propietario. Los sistemas de herencia sobre la tierra no fueron exclusivos entre los grupos propietarios de hacendados criollos o mestizos, sino también entre la población indígena que podía transmitir sus tierras individuales (huertas, sayañas, ${ }^{3}$ etcétera), como el

3 Parcela individual o familiar donde se halla la vivienda campesina. Hasta antes de la Reforma Agraria existían sayañas tanto en las haciendas como en las comunidades. En el primer caso, el campesino cumplía un cierto número de días de trabajo a cambio del usufructo de su sayaña. 
derecho al usufructo de las tierras comunitarias (acceso a las aynoqas). ${ }^{4}$ Dependiendo del lugar, el sistema de sucesión contemplaba costumbres arraigadas con relación al género y al grupo etario, con mayor beneficio de sucesión para el grupo masculino y joven, que garantizaba tanto el trabajo comunitario como el pago del tributo (Soux, 1995).

- Compra-venta. Era una forma común de traspaso de la propiedad individual de la tierra, sobre todo entre los grupos criollos y mestizos. Se asentaba en el derecho de propiedad perfecta, que garantizaba la posibilidad de enajenar el bien en favor de otro a cambio de una cierta cantidad de dinero. Para que se pudiera dar esta posibilidad, era fundamental que el vendedor demostrara la propiedad de la tierra mediante documentos específicos, así como que la propiedad se hallara libre de cargas. El sistema de compra-venta no podía darse oficialmente en las comunidades indígenas, ya que las diversas leyes impedían que estas fueran compradas libremente; sin embargo, y a pesar de la prohibición, no faltaban casos de compra-venta de sayañas de comunidad. Esta figura jurídica fue permitida luego de la Ley de Exvinculación, que abrió el mercado de tierras de comunidad al individualizarlas (Soux, 2012).

En cada una de las formas anteriores de traspaso de la propiedad, un punto central era que la misma se traspasaba con sus usos y costumbres, lo que implicaba que se transfería con sus trabajadores, marcando la característica precapitalista de la propiedad de la tierra.

\section{ARRENDAMIENTO Y SISTEMAS DE TRABAJO}

Una de las características de la propiedad perfecta era la posibilidad de arrendarla, es decir, entregarla a otro sin hacer su traspaso, de modo que el arrendatario o arrendero pudiera trabajarla a cambio de un canon, que podía pagarse en dinero, en productos o en trabajo. Fue este último el que marcó con más fuerza las relaciones laborales en el área rural.

En las haciendas de propiedad de criollos y de mestizos, la tierra no era trabajada directamente por los propietarios, por lo que las relaciones laborales seguían modalidades de trabajo similares al sistema señorial europeo, con dos variantes: el sistema Gutsherrschaft, en el que una parte importante de la hacienda era cultivada para el propietario por campesinos-siervos adscritos a

4 Tierras de la comunidad en las cuales se sigue una misma dinámica de rotación de cultivos. Son de usufructo individual o familiar en los años de uso agrícola (liwakallpas), y se convierten en tierras de uso común cuando entran en descanso y sirven de pastizales para el ganado. 
la hacienda (yanaconas), ${ }^{5}$ que servían con un número dado de días de trabajo semanales a cambio del uso de un terreno; y el sistema Grundherrschaft, en el cual el propietario dividía y entregaba todas las tierras a los campesinos a cambio de un pago o renta en dinero o en especie (Barragán, Lema y Mendieta, 2015). Estos sistemas podían combinarse, dando como resultado las siguientes formas de arrendamiento:

- Un arrendamiento con el pago de alquiler en dinero, que se dio sobre todo entre un propietario criollo o mestizo y otro. Este tipo de contrato no establecía ninguna otra relación que el pago del canon, y no existía una relación de dependencia del uno con el otro.

- Un arrendamiento con el pago en trabajo, que se dio sobre todo entre un criollo y un indígena. Se trataba de un contrato generalmente oral y de una parte de la propiedad, lo que por lo general sí establecía una relación de dependencia.

- Un arrendamiento dentro de la misma comunidad indígena, que podía darse del originario al agregado y de este al yanapaco y al utawawa. ${ }^{6}$ Este tipo de contrato oral se podía reproducir como forma de subarrendamiento entre el arrendero o colono ${ }^{7}$ con los yanapacos y utawawas.

- Un arrendamiento de derechos sobre terrenos de uso común, como aynoqas y liwaqallpas, de uso en las comunidades.

Como se puede advertir, en la práctica existían diversas formas de arrendamiento que distinguían relaciones diversas entre grupos también diversos. Sin embargo, desde la normativa, el Código Civil promulgado en 1832 durante el gobierno de Andrés de Santa Cruz estableció el arrendamiento como un acto jurídico, tipificado como un contrato relacionado con la propiedad y donde participaban personas civiles con los mismos derechos, dejando de

5 Sistema cuyo origen se remonta a la época prehispánica y que se refería al trabajo especializado de servidumbre con las autoridades. Se mantuvo durante la etapa colonial e implicaba que el trabajador realizara determinados trabajos agrícolas y de servicio por el usufructo de un pedazo de tierra.

6 Nombres dados a los individuos que vivían en las comunidades y en las haciendas, y que, a cambio de cumplir ciertas obligaciones, recibían pequeńas parcelas para su usufructo por parte de los comunarios o yanaconas. En algunos casos recibían únicamente la vivienda y la comida a cambio del trabajo.

7 Resultado de contratos de arrendamiento, por lo general orales, en los cuales el colono o arrendero pagaba con trabajo el uso de su sayaña. Como se verá, derivó también en obligaciones de servidumbre. 
lado las diversas posiciones sociales. Así, el Código Civil establecía las siguientes formas de arrendamiento:

- De cosas. Era un contrato por el cual una de las partes se obligaba a dar a la otra una cosa, por un cierto precio y por un tiempo determinado (artículo 1129).

- De obra. Era un contrato por el cual una de las partes se obligaba a hacer algún servicio o trabajo, mediante un precio estipulado entre ellas (artículo 1130).

- El que cultivaba al partir, es decir, compartiendo los productos o frutos con el arrendador; no podía ni subarrendar ni ceder si esta facultad no se le había concedido expresamente. En caso de contravención, se rescindía el contrato, quedando obligado el "arrendero" a asumir dańos e intereses (artículo 1163).

Inquilinos y colonos eran responsables de los detrimentos y de las pérdidas que sucedían por culpa suya o por las de sus "subarrenderos y personas que vivían con él” (artículo 1145), y ambos tenían las obligaciones del usufructuario (artículo 1140).

En los artículos mencionados se puede notar que los términos 'arrendero', 'inquilino' y 'colono' se utilizaban como sinónimos, y que los mismos se equiparaban en determinados artículos con el de 'usufructuario'. Esto significa que la antigua relación entre el propietario de la tierra y el que la trabaja ha cambiado en su esencia, ya que la relación basada en la servidumbre (herencia en parte de las relaciones de vasallaje) se ha modificado y se ha convertido en contratos de arrendamiento entre personas capaces y de estatus jurídico semejante. En una sociedad que pregonaba la igualdad entre todos sus habitantes, aunque esto fuera solo en el discurso, ya no podían sustentarse formas de servidumbre.

Esta nueva forma de conceptualizar la relación entre el arrendamiento de tierras y el trabajo fue refrendada en 1851 por José María Dalence, quien en su obra Bosquejo estadístico de Bolivia aseveraba:

Los arrenderos son los colonos de las haciendas; poseen campos que los propietarios les dan por la pensión estipulada que satisfacen parte en dinero y parte en el servicio que deben prestar al dueño en las siembras, cosechas, etcétera. Este contrato es muy útil, si de él no se abusa; el propietario posee los brazos que necesita para el cultivo y el colono asegura para sí y su generación tierras en que sembrar; así es que rarísima vez sucede que el hacendado despida [a] un colono, o que este deje la hacien$\mathrm{da}$, en que él y sus abuelos han nacido. El número de arrenderos llega a 
más de 80.000 padres de familia (1975 [1851]: 211, citado por Mamani Humérez, 2012).

Este cambio jurídico, fundamental con relación al tipo de relación entre el propietario de la tierra y el trabajador, que pasa de un sistema en el cual el indígena trabaja en una forma de servidumbre (dentro de un sistema jerarquizado) a la existencia de un contrato entre iguales, implicaría necesariamente la desaparición del yanaconaje. Sin embargo, no fue eso lo que sucedió, produciéndose inclusive una confusión semántica entre el yanacona o yanakuna y el colono o peón.

Con relación a ello, Ximena Medinaceli indica que, de manera paralela, se utilizó en distintos tiempos y lugares los términos 'colono' y 'yanacona', aunque existen ciertas variaciones entre estas dos categorías: "Si el yanacona fue en principio el indio dependiente de un patrón, el colono es aquel que, sujeto a su tierra, pasa a depender de un nuevo propietario" (1986: 171). Para Medinaceli es precisamente esta sujeción a la tierra la clave para explicar el mantenimiento de la servidumbre y el yanaconaje en una etapa en la que ya no se los reconocía oficialmente, sino al arrendamiento y, por tanto, al sistema de colonato.

\section{REMATE DE TIERRAS Y NUEVOS LATIFUNDISTAS}

Entre 1866 y 1868, el Gobierno de Mariano Melgarejo buscó la forma de fortalecer el ingreso del Tesoro Nacional. Para ello decretó una serie de medidas mediante las cuales se desconocía definitivamente la propiedad colectiva de las comunidades, la cual pasaba a propiedad del Estado. Así, se decretó que en un tiempo perentorio las comunidades debían consolidar su propiedad, luego del pago de un canon; de no hacerlo, se pondrían sus tierras en remate. Pocos fueron los casos en los que las comunidades pudieron pagar lo establecido, por lo que desde 1867, y mediante procesos por demás irregulares, se procedió al remate o subasta de tierras en gran parte de las provincias del Altiplano y de los valles bolivianos. Estos remates beneficiaron sobre todo a miembros gubernamentales y a sus allegados, quienes tomaron posesión de las tierras subastadas. En contradicción con esta situación, la Constitución de 1868, promulgada durante el mismo Gobierno, aseguraba que "la igualdad es base del impuesto y de las cargas públicas. Ningún servicio personal es exigible sino en virtud de la ley" (Choque, 1997: 575).

En este contexto, ¿qué ocurría con la relación entre los nuevos latifundistas y los indios comunarios cuyas tierras habían sido rematadas? Los nuevos propietarios aprovecharon su influencia en el Gobierno y el hecho de que los antiguos propietarios indígenas no podían dejar sus tierras de forma inmediata, para convertirlos en colonos-arrendatarios obligados de sus propias tierras, 
hizo que estos pagaran no solo con trabajo agrícola sino con el cumplimiento de obligaciones, al igual que en las haciendas de origen colonial. De esta manera, los indígenas habían perdido la propiedad legal de sus tierras de comunidad y también empezaron a pagar con trabajo en labores agrarias y de servidumbre para poder usufructuar las tierras que antes les pertenecían. La única diferencia, al menos en los papeles, era que, como la antigua contribución de carácter personal se había transformado en una contribución que marcaba la propiedad, los nuevos latifundistas tenían que pagar la contribución de sus arrendatarioscolonos al Estado.

El movimiento indígena, profundamente descontento, contribuyó en el derrocamiento de Melgarejo, en enero de 1871, en medio de una sublevación general indígena que abarcó todo el Altiplano. El hecho es que todas las medidas de aquel mandatario relacionadas con los remates de tierras fueron derogadas y se retornó a la situación anterior.

En octubre de 1874, bajo el mandato de Tomás Frías, se promulgó una nueva ley relacionada con la propiedad de la tierra, la Ley de Exvinculación, que declaraba extinguidas todas las comunidades; el Estado, esta vez, de forma gratuita, entregaría la propiedad perfecta de las mismas a cada uno de los indígenas de forma individual. Si bien estas medidas implicaban el reconocimiento de la propiedad de los indígenas, el desconocimiento a las comunidades y a la propiedad común provocó una serie de tensiones y conflictos, ya que distorsionó las formas de propiedad internas y, por tanto, también los sistemas y las relaciones de trabajo en las mismas comunidades.

Es conocido el hecho de que la Ley de Exvinculación de 1874, al establecer la propiedad perfecta e individual en las tierras de comunidad, empujó a partir de 1880 (luego de una larga revisita y posterior catastro) a que muchos excomunarios vendieran sus parcelas tanto a vecinos de los pueblos como a miembros de las élites de las ciudades. Desde la perspectiva de los principios liberales, se estaba dando un paso hacia formas capitalistas de producción, donde los trabajadores, despojados de la propiedad de sus tierras, se convertirían en trabajadores asalariados. Sin embargo, la práctica tradicional y la permanencia de una sociedad jerarquizada llevaron a que las compras de sayañas, e inclusive de comunidades enteras, implicaran no solamente la adquisición de la tierra, sino de sus usos y costumbres, lo que en otros términos significaba que el indígena, al vender su tierra, aceptaba "como gracia" permanecer en la misma y pagar el usufructo con trabajo; es decir, se convertía extraoficialmente en arrenderocolono obligado de su propia sayaña. Como contrapartida, el nuevo propietario se comprometía a pagar la contribución territorial (heredera del tributo, pero que se asentaba supuestamente en la propiedad), que ya para ese 
momento se entregaba a los Tesoros Departamentales. ${ }^{8}$ Además, de forma semejante a la situación de las antiguas haciendas coloniales, el nuevo "colono" debía cumplir con otras obligaciones de servidumbre, como el pongueaje para los hombres y el mitanaje para las mujeres (Soux, 1999).

De forma paralela a estos cambios en las excomunidades, para las haciendas antiguas de origen colonial (que de forma tradicional habían trabajado con el sistema de yanaconaje), las leyes republicanas, como el Código Civil, no modificaron tampoco la práctica y los sistemas de trabajo, con la diferencia de que los indígenas eran oficialmente considerados colonos, peones o inquilinos, lo que significó únicamente un cambio semántico. El indígena trabajador dejó de llamarse yanacona, aunque en la realidad diaria las relaciones laborales no cambiaron y las haciendas mantuvieron las obligaciones y los servicios personales no agrícolas por parte de sus colonos que se acercaban más a un sistema de yanaconaje y de servidumbre.

Esta contradicción entre unas leyes que empujaban hacia una solución "moderna" de las relaciones de trabajo agrícola y unas prácticas que se mantenían en un sistema de antiguo régimen persistieron hasta mediados del siglo XX, bajo el principio de usos y costumbres.

\section{SISTEMAS DE TRABAJO Y SERVIDUMBRE EN LAS HACIENDAS}

El pago del canon de arrendamiento en las haciendas se relacionaba específicamente con el trabajo propiamente agrícola, el cual se cumplía (según el lugar y las características de cada hacienda) en tres o cuatro días por semana en las tierras del patrón o, en su defecto, durante una semana para el patrón y una para la propia sayaña. Esta obligación, sin embargo, no era exclusiva del hombre; muchas veces el trabajo era realizado por toda la familia. Así, por ejemplo, en el caso de los Yungas (departamento de La Paz), el trabajo especializado del quichi o cosecha era realizado por las mujeres, mientras que el deshierbe lo hacían los hombres, lo que duplicaba el número de jornadas trabajadas para el hacendado.

A estas obligaciones se sumaban los trabajos extra o servicios, que podían ser de distinto tipo: desde la obligación de ir a recoger quina (como lo describe Eugenia Bridikhina en su trabajo publicado en 1997 sobre los negros de Yungas) ${ }^{9}$ hasta los trabajos de mulero y apiri (cargador) para los hombres

8 Archivo Histórico de La Paz (ALP), Fondo de la Prefectura, Registro de Tierras Comunales, 1880-1899.

9 El trabajo realizado por la población negra luego de la abolición de la esclavitud, en 1851, no se diferenció del realizado por los demás trabajadores en las haciendas; 
de las haciendas del Altiplano y de los valles, o el trabajo especializado de producción de muku (base de la producción de chicha) para las mujeres de las haciendas de Cochabamba. De todos estos trabajos, los considerados más abusivos, por su carácter netamente servil, eran los de pongo y de mitani, que correspondían al servicio doméstico gratuito en la casa de hacienda o en la vivienda urbana de los propietarios.

Estas relaciones laborales, que incluían servicios personales, estaban tan naturalizadas en la sociedad boliviana que la relación contractual entre el hacendado y el colono-arrendero prácticamente era imperceptible. Esto puede ser confirmado por diversos tipos de acciones (inclusive legales) que mostraban esta relación. Así, por ejemplo, cuando un indio comunario vendía su sayaña al vecino o al nuevo hacendado, en la mayoría de los casos se anotaba en el registro correspondiente que el indígena vendedor se comprometía a quedarse en las tierras cumpliendo sus obligaciones según "usos y costumbres". Igualmente, hasta bien avanzado el siglo XX, era común encontrar letreros en las calles de La Paz y avisos en los periódicos con ofertas como: "Se alquila pongo con taquia". Es decir que los terratenientes paceños que poseían más de una hacienda y que, por lo tanto, recibían más de un pongo semanal, no tenían ningún problema en alquilar esta mano de obra en trabajos no agrícolas, con el aditamento de que el pongo debía llevar sus alimentos y su propio combustible, la taquia, que era el excremento de las llamas que servía para calentar las cocinas y preparar la comida (Barragán, Qayum y Soux, 1997).

\section{Debate sobre el pongueaje}

Este tipo de relación que muchos de los hacendados y la sociedad en su conjunto veían como normal y natural empezó a ser criticada desde inicios del siglo XX por los grupos de izquierda. La crítica empezó a crecer en la década de 1920 y se profundizó con la Guerra del Chaco (Soliz, 2012). Muchos jóvenes, incluyendo a los hijos de los mismos terratenientes, dejaron de ver como "normal" el alquiler de pongos e inclusive la misma institución del pongueaje. El tema también fue abordado en torno al problema de las propiedades municipales o eclesiásticas en Cochabamba, dando como resultado las medidas asumidas durante el mandato de David Toro (1936-1937), con la creación de los primeros sindicatos agrarios y el reconocimiento de los arrendamientos (Soliz, 2012), y fue tratado en los debates de la Convención Nacional de 1938 que, finalmente, se pronunció al respecto indicando en la Constitución de ese año que "la esclavitud

es decir, pasaron a ser considerados colonos y a trabajar algunos días a la semana a cambio del usufructo de una sayaña. 
no existe en Bolivia. No se reconocía ningún género de servidumbre y nadie podrá ser obligado a prestar trabajos personales sin la justa retribución y sin pleno consentimiento" (Gotkowitz, 2011: 183; véase también Barragán, 2006). De esta manera, se ponía en el tapete, luego de más de cien años de promulgado el Código Civil, no solo el tema de la propiedad agraria, sino también el de las relaciones de trabajo en las haciendas, al igual que las contradicciones entre las leyes y la práctica.

A pesar de que la servidumbre había sido específicamente abolida, las figuras del pongueaje y del mitanaje se mantuvieron en la práctica, y el problema fue abordado nuevamente en las legislaturas de 1940 y 1941. Bajo el empuje del Partido de la Izquierda Revolucionaria (PIR), de influencia estalinista, Eduardo Arce Loureiro impulsó que se dictaran medidas en favor de contratos de arrendamiento, "que permitirían a los campesinos librarse de su condición de colonos", como un antecedente para lograr la propiedad de la tierra (Soliz, 2012). Con estos proyectos quedaba claro que, para ese momento, sin tener en cuenta los conceptos vertidos en el Código Civil de 1832 (todavía vigente), se establecía una diferencia entre las figuras del arrendamiento (con pago de canon en dinero) y del colonato, que se fundamentaba en el pago del uso de la tierra mediante el trabajo y que implicaba además otros servicios personales.

Durante el gobierno de Enrique Peńaranda, el convencional Eguino Rodas presentó un proyecto de abolición del pongueaje, pero este fue rechazado por el diputado Hugo Salmón bajo un argumento relacionado con la civilidad del indio. Salmón indicaba:

El pongo es ahora el único vínculo que nos liga con el indio. Suprimido este, se cortará el último eslabón y el indio quedará alejado. Hay que tener en cuenta que el indio que sirve como pongo en la ciudad oye radio, recorre las calles, se interesa por las noticias y está bien alimentado (citado en Soliz, 2012: 33).

El primer Congreso Indigenal de 1945, convocado por el Gobierno de Gualberto Villarroel, asumió nuevamente el tema de la abolición del pongueaje y otras formas de servicio personal que no habían podido ser aprobados durante los anteriores periodos gubernamentales. No trataremos en este trabajo todo el debate en torno a tales temas, desarrollado ya por varios otros historiadores (Gotkowitz, 2011; Soliz, 2012). Sin embargo, es importante analizar la entrevista que cita Carmen Soliz, realizada a uno de los principales dirigentes del Congreso, y que nos permite percibir con mayor profundidad la perspectiva que se tenía sobre el tema: 
Cuando se le pregunta a Francisco Chipana Ramos, presidente del Congreso, su opinión sobre los decretos que se habían firmado durante el Congreso, su respuesta destacó los siguientes puntos: Que había desaparecido su condición de esclavos y se había logrado la libertad perdida con el hecho colonial; que se había logrado fijar en un máximo de cuatro días semanales el trabajo obligado en las haciendas; que, mediante la elaboración de un Código de Trabajo Agrario, se establecerían mejores condiciones de trabajo, impidiendo el "trabajar gratis ni en otras haciendas"; que los trabajos "extras" deberían ser pagados con jornales, es decir como trabajadores asalariados; que se controlarían los "abusos" del patrón como la entrega obligada de animales y otros productos y se implementarían escuelas para la educación de los trabajadores y sus familias. Finalmente, Chipana Ramos indicaba como el decreto más importante, la muerte del pongueaje, es decir del trabajo en la casa del patrón de forma gratuita (2012: [s. p.]).

Para el entrevistado, y al parecer para todos los que participaron en el Congreso, quedaba claro que existían dos formas totalmente diferentes de relación laboral entre hacendados y trabajadores: el trabajo agrícola y los "trabajos extras" ligados al servicio o servidumbre. Sobre la primera, el mismo Chipana Ramos indicaba: "Trabajaremos con gusto para la hacienda porque, siendo dueños de nuestras cosechas, podremos disponer de ellas" (Soliz, 2012: 37), mientras que sobre el segundo explicaba: "Desde ahora nuestros servicios serán pagados, como en cualquier otro oficio o trabajo" (ibid.).

A pesar de que el decreto de abolición del pongueaje se puso en efecto en 1945, los casos de conflictos ante el intento de hacer cumplir servicios personales por los hacendados se mantuvieron varios años más, y no será sino luego de la Reforma Agraria de 1953 que el pongueaje y otros servicios personales desaparecerían junto con la entrega de la tierra a "quienes la trabajen”, como reza el postulado de dicha Reforma.

\section{Conclusiones}

¿Qué puede explicar el hecho de que la relación laboral entre el propietario de la tierra y el trabajador hubiera sido naturalizada por más de cien años como una relación de dos tipos, por un lado la del pago de canon de arrendamiento en trabajo, ese "trabajo con gusto para la hacienda", y por el otro de una relación servil de origen colonial, a pesar de que la base jurídica republicana establecida en el Código Civil indicaba la existencia de un contrato entre iguales centrada en el arrendamiento de la tierra a cambio de trabajo? ¿Por qué el primer tipo de relación se consideraba legítimo y el segundo, un abuso por parte del hacendado? 
Para explicar esta percepción es necesario analizar los principios de la relación laboral en la etapa colonial y la forma en que el liberalismo y la modernidad trataron de modificarlos. Esto significa que si bien la normativa (fundamentalmente el Código Civil) se asentaba en principios modernos y liberales de igualdad, y en la necesidad de normar estas relaciones de iguales mediante la realización de contratos, ya sea de traspaso de la propiedad, de arrendamiento o de trabajo, persistían aún, con mucha fuerza, los principios del antiguo régimen, incluidos muchos de ellos en el de la reciprocidad, aunque el mismo principio pudiera también ser visto como perverso, es decir, como una forma de disfrazar las relaciones desiguales y la explotación.

De esta manera, ciertos principios de "pacto", esta vez entre el hacendado y sus trabajadores, de origen colonial y del antiguo régimen, se sobrepusieron a las normas modernas de contrato entre iguales. Así, las relaciones de servidumbre se entrelazaron con las formas tradicionales de garantizar el acceso a la tierra, lo que permitió que las relaciones serviles de trabajo no solo sobrevivieran en un contexto de igualdad liberal, sino que estas mismas formas serviles fueran vistas por más de cien años como naturales en la relación de trabajo en el área rural boliviana. Finalmente, las formas serviles de trabajo no desaparecieron con la transformación y la modernización de las haciendas, ni dieron lugar a un sistema de salario agrario, sino que tuvieron que esperar a una reforma agraria que entregara la propiedad de la tierra al trabajador directo. 
328 | Trabajos y trabajadores en América Latina (siglos XVI-XXI)

BiBLIOGRAFÍA

Antezana Salvatierra, Alejandro

1996 Los liberales y el problema agrario de Bolivia. La Paz: Centro de Investigaciones para el Desarrollo.

1992 Estructura agraria en el siglo XIX: legislación agraria y transformación de la realidad rural en Bolivia. La Paz: Centro de Investigaciones para el Desarrollo.

Archivo Histórico de La Paz (ALP), Fondo de la Prefectura

1880-1899 Registro de Tierras Comunales.

Ballivián de Romero, Florencia

1987 "La visita de Gerónimo Luis de Cabrera a Larecaja y Omasuyos". En: Historia y Cultura, número 12. 39-48.

Barragán, Rossana

2006 Asambleas constituyentes. Ciudadania y elecciones, convenciones y debates (1825-1971). La Paz: Muela del Diablo.

Barragán, Rossana; Ana María Lema y Pilar Mendieta (coords.)

2015 Bolivia, su Historia. Tomo IV. La Paz: Coordinadora de Historia.

Barragán, Rossana; Dora Cajías y Seemin Qayum (comps.)

1997 El siglo XIX. Bolivia y América Latina. La Paz: Instituto Francés de Estudios Andinos / Coordinadora de Historia.

Barragán, Rossana; Seemin Qayum y María Luisa Soux

1997 De terratenientes a amas de casa. La Paz: Coordinadora de Historia / Secretaría Nacional de Asuntos Étnicos, de Género y Generacionales.

Choque Canqui, Roberto

1997 "La servidumbre indígena andina de Bolivia”. En: Rossana Barragán Dora Cajías y Seemin Qayum, El siglo XIX. Bolivia y América Latina. La Paz: Instituto Francés de Estudios Andinos / Coordinadora de Historia.

Dalence, José María

1975 Bosquejo estadístico de Bolivia. La Paz: Universidad Mayor de San Andrés. [1851]

Gotkowitz, Laura

2011 La revolución antes de la Revolución: luchas indigenas por tierra y justicia en Bolivia. 1880-1952. La Paz: Plural editores. 
Irurozqui Victoriano, Marta y Víctor Peralta Ruiz

2000 Por la concordia, la fusión y el unitarismo. Estado y caudillismo en Bolivia. 1825 - 1880. Madrid: Consejo Superior de Investigaciones Científicas.

Klein, Herbert

1995 Haciendas y ayllus en Bolivia: la región de La Paz, ss. XVIII y XIX. Lima: Instituto de Estudios Peruanos.

Lofstrom, William Lee

2010 La presidencia de Sucre en Bolivia. La Paz: Instituto Internacional de Integración del Convenio Andrés Bello.

Mamani Humérez, Froilán

2012 "La práctica del arrendamiento durante el siglo XIX en la región de Santiago de Huata”. En: María Luisa Soux (coord.), El proceso histórico hacia la territorialización del poder. La Paz: Instituto de Estudios Bolivianos / Agencia Sueca de Cooperación para el Desarrollo Internacional.

Mamani Siñani, Roger

2012 "Tierra, litigio y títulos. La visita de tierras de Gerónimo Luis de Cabrera y don Juan Segura Ávalos de Ayala”. En: María Luisa Soux (coord.), El proceso histórico hacia la territorialización del poder. La Paz: Instituto de Estudios Bolivianos / Agencia Sueca de Cooperación para el Desarrollo Internacional.

Medinaceli, Ximena

1986 "Comunarios y yanaconas. Resistencia pacífica de los indios de Omasuyus. Siglo XIX”. Tesis de licenciatura en Historia. Universidad Mayor de San Andrés, La Paz.

Platt, Tristan

1982 Estado boliviano y ayllu andino. Tierra y tributo en el norte de Potosí. Lima: Instituto de Estudios Peruanos.

Rodríguez Ostria, Gustavo

1986 ¿Expansión del latifundio o supervivencia de las comunidades indigenas? Cambios en la estructura agraria boliviana del siglo XIX. Cochabamba: Instituto de Estudios Sociales y Económicos.

Rivera Cusicanqui, Silvia

1978 "La expansión del latifundio en el altiplano boliviano: elementos para la caracterización de una oligarquía regional". En: Avances, número 2. 95-118. 
330 | Trabajos y trabajadores en América Latina (siglos XVI-XXI)

Rojas, Antonio

1978 "La tierra y el trabajo en la articulación de la economía campesina con la hacienda". En: Avances, número 2. 51-71.

Soliz, Carmen

2012 "La modernidad esquiva: debates políticos e intelectuales sobre la reforma agraria en Bolivia (1935-1952)". En: Ciencia y Cultura, número 29. Disponible en: http://www.scielo.org.bo/scielo. php?script=sci_arttext\&pid=S2077-33232012000200003 (fecha de consulta: 25 de julio de 2019).

Soux, María Luisa

2012 "Territorialización y construcción del Estado-nación: el caso del Gobierno de Antonio José de Sucre”. En: María Luisa Soux (coord.), El proceso histórico hacia la territorialización del poder. La Paz: Instituto de Estudios Bolivianos / Agencia Sueca de Cooperación para el Desarrollo Internacional.

1999 "Agricultura y estructura agraria. Del latifundio a la reforma agraria". En: Historia y Cultura, número 25. 105-128.

1997 "El problema de la propiedad en las comunidades indígenas. Patrimonio y herencia (1825-1850)”. En: Rossana Barragán, Dora Cajías y Seemin Qayum, El siglo XIX. Bolivia y América Latina. La Paz: Instituto Francés de Estudios Andinos / Coordinadora de Historia

1995 "Individuo, familia y comunidad. El derecho sucesorio entre los comunarios de La Paz (1825-1850)". En: Estudios Bolivianos, número 2. $437-465$. 


\title{
La discusión sobre el trabajo forzado en Brasil y Argentina en diálogo con la Organización Internacional del Trabajo
}

\author{
Norberto O. Ferreras (Argentina/Brasil)*
}

RESUMEN: En el presente estudio analizaremos la definición de la categoría de 'trabajo forzado' en los organismos internacionales en la primera mitad del siglo XX y la forma en que la misma fue recibida en América Latina. Al mismo tiempo, indagaremos cómo se comportaron al respecto dos importantes países de América del Sur, Argentina y Brasil, para poder entender las recepciones de las normativas elaboradas en Ginebra y el relacionamiento existente entre las partes.

PaLABRAS Clave: trabajo forzado, Brasil, Argentina, Organización Internacional del Trabajo (OIT).

\section{INTRODUCCIÓN}

Una cuestión poco analizada en la historia social del trabajo en América Latina, y que al mismo tiempo atraviesa toda América, es la conformación de mercados de trabajo en cada uno de los países del continente. Estos mercados de trabajo son generalmente analizados a partir de los sectores más relevantes de cada uno de estos países. ${ }^{1}$ En algunos casos, se parte de la conformación de un mercado de trabajo urbano y, en otros, de un mercado rural. Lo interesante de estos análisis es que toman una parte como el conjunto y, al mismo tiempo, dejan de prestar atención a la evolución del conjunto, si pensamos en la nación como el conjunto principal y sus vínculos con la región. En este artículo pretendemos, justamente, avanzar en una dirección regional y global, enfatizando en los casos de Brasil y Argentina, poniéndolos en diálogo con los debates internacionales existentes a partir del vínculo que estos países tuvieron con la Organización Internacional del Trabajo (OIT). Vamos a concentrarnos en estos dos países de América del Sur porque eran

* Doctor en Historia Social por la Universidad Estadual de Campinas. Universidad Federal Fluminense (UFF). Contacto: nferreras@yahoo.com

1 El estudio de Charles Bergquist (1988) nos muestra esta forma de analizar la formación del proletariado en América Latina desde el 'leading sector' nacional. 
los que tenían mayor cantidad de trabajadores en el periodo; esto nos permitirá comprender qué ocurría y cómo se comportaban ante las denuncias de trabajo forzado que les eran presentadas.

La conformación del mercado libre de trabajo en la región se inicia en el siglo XIX y está cercana a formas de trabajo cautivo. Los trabajadores libres, generalmente individuos que dominaban una técnica específica o que controlaban el uso de determinadas herramientas, se encontraban en un contexto en que primaba la coerción extraeconómica. La constitución del mercado de trabajo en América Latina coincide con los años finales de la organización de los trabajadores por medio de la esclavitud o de otras formas coercitivas de control.

El fin de la esclavitud no implicó la adopción de la venta de la fuerza de trabajo y la libre negociación entre trabajo y capital. Por el contrario, la fuerza de trabajo tendió a ser controlada por otros medios. Al mismo tiempo que en determinados sectores el trabajador libre pasaba a negociar con el patrón $y$, posteriormente, a organizarse, en otros espacios el trabajador estaba sometido a presiones que extrapolaban la esfera de lo económico. Este fenómeno no fue una peculiaridad latinoamericana. El proceso de proletarización se dio prioritariamente en el sector primario exportador siguiendo diferentes patrones: importando mano de obra o forzando a la población existente a incorporarse en los procesos productivos trabajando para un patrón. En regiones con importante presencia indígena, desde la Colonia se crearon mecanismos que forzaron su proletarización. En las regiones de escasa población originaria y donde esta convivía con mestizos, migrantes e inmigrantes, fue preciso crear nuevas formas de retener a la mano de obra.

En los dos países analizados (Brasil y Argentina), desde el siglo XIX se implementaron restricciones a la movilidad de los trabajadores, tales como los certificados de vínculo con algún propietario rural, que ligaban a los trabajadores con él más que a una propiedad rural. Las papeletas de conchabo (contratos) argentinas y los passaportes emitidos en varios sitios del territorio brasileño a los trabajadores rurales libres tenían como objetivo el control de su circulación, con la intención de retener a los individuos que tenían grandes chances de valerse por sí mismos en una región rural abierta y con grandes dificultades de control. El terrateniente se garantizaba una cierta cantidad de mano de obra restringiendo el movimiento de sus afiliados, sus agregados, etcétera. Al mismo tiempo, a esos trabajadores se les obligaba a conformar milicias locales para la defensa de la tierra de los terratenientes contra los indios, contra otros terratenientes o contra el Estado (Secreto, 2011).

Este es un ejemplo de las dificultades para abandonar las formas coercitivas del trabajo durante el siglo XIX. En los casos de Brasil y de Argentina, las relaciones de trabajo libre comenzaron en las ciudades, a pesar de que no todos los trabajadores urbanos tuvieran relaciones contractuales con sus empleadores. 
También en el sector urbano encontramos trabajadores (principalmente mujeres) que se empleaban en el sector del servicio doméstico, los cuales implicaban relaciones paternalistas y, en el caso de las mujeres, también patriarcales, a partir del control de la libertad y del cuerpo. Trabajar en este sector implicaba la imposibilidad de contar con tiempo de descanso y estar en servicio más allá de las horas convenidas. Ni siquiera el horario de descanso era respetado en situaciones de necesidad del empleador. Este tipo de trabajo era realizado por personas incluidas en el núcleo familiar como auxiliares cotidianos. Esta categoría puede ser dividida en tres grandes grupos: los trabajadores que realizaban servicios extraordinarios y que, al concluirlos, dejaban el lar; otros que prestaban servicios diarios pero que no residían junto con la familia; y, finalmente, los que convivían junto al núcleo familiar. Estos últimos no eran vistos como trabajadores, sino como personas del servicio doméstico con capacidad de coordinar con los trabajadores ocasionales o diarios, pero también en una relación de dependencia directa del núcleo familiar. Algunos podían permanecer junto a la familia hasta el fin de sus vidas o podían ser temporales. El control de los tiempos y de las actividades dependía de las necesidades domésticas, por lo que dichos trabajadores no controlaban su tiempo, como tampoco la carga y el ritmo de trabajo. ${ }^{2}$

La presentación de condiciones de trabajo en que se naturalizaba en el núcleo familiar la explotación de la fuerza de trabajo y el control de parte de los atributos de la libertad individual nos sirven para comprender la dinámica del trabajo forzado, análogo al esclavo, en los dos principales países del Cono Sur. La historiografía del trabajo parte de la dicotomía entre dependencia y libertad, sin analizar que no son dos polos que corresponden a determinados periodos y que en un cierto momento hay un punto de ruptura del cual no se retorna. ${ }^{3}$ Debemos considerarlos, por el contrario, como dos polos en tensión que no se resuelve en determinado momento. Esta es justamente la gran trampa de los análisis teleológicos, que naturalizan la división de clases como la disputa entre dos clases organizadas en las que prima el valor de la libertad. El cautiverio es parte de la lucha de clases y de la correlación de fuerzas existentes.

En los últimos años, los medios de comunicación de masas nos han proporcionado abundante información sobre casos relacionados con el denominado "trabajo esclavo contemporáneo". El uso de esta terminología creció principalmente como una forma de denuncia antes que como una categoría analítica. Marcel Van der Linden (2013: 75-92) nos muestra que ni la

2 A pesar de ser un tema poco estudiado, es un campo en crecimiento, principalmente entre los historiadores brasileños. Para el caso de Argentina, véase: Allemandi, 2017. Para el caso de Brasil, véanse: Da Silva Telles, 2011; Roncador, 2014.

3 Como en el estudio pionero de Hobart Spalding Jr., 1977. 
libertad es un bien irreversible ni el capitalismo es su custodio. El retorno de una categoría que se pensaba desterrada evidencia que "cautiverio" y "libertad" son pares antagónicos y constantes en la organización del trabajo. En este artículo analizamos brevemente la forma en la que el trabajo forzado fue parte de los debates relacionados con las cuestiones laborales en algunos países latinoamericanos en las primeras décadas del siglo XX. Cómo el trabajo forzado ha sido abordado en la región llevó a que se establecieran consensos y tensiones entre esos países y la OIT.

Acompañando el denso y extenso debate relacionado con el tema del trabajo forzado, percibimos que este está presente en la agenda de las diversas instituciones internacionales desde que fueron creadas. A lo largo del siglo XIX, y hasta la constitución del sistema ginebrino, la presión contra el cautiverio fue creciendo. Desde la fundación de la Anti-slavery International en 1839, esa presión se relacionó con la expansión de las formas europeas de organización del trabajo, considerando que el trabajo cautivo impedía el desarrollo del trabajo libre. A fines del siglo XIX, las grandes conferencias contra la esclavitud de Berlín (1885) y de Bruselas (1890), que también implicaron la división de África entre las potencias colonizadoras, establecieron el trabajo libre como elemento central en el proceso civilizatorio (Drescher, 2009: 398; Miers, 2003: 20-21). En ese entonces, los países americanos no eran una preocupación porque podían mostrar como credenciales que habían procedido a la abolición de la esclavitud; algunas de esas credenciales eran contemporáneas a dichos tratados, como es el caso de Cuba (1886) y de Brasil (1888).

Pero el siglo XX mostró una nueva realidad que se gestaba desde fines del siglo anterior. Con la expansión de los ciclos de consumo de materias primas baratas enviadas a Europa desde los centros productores de la periferia, recrudeció la necesidad de mano de obra, principalmente en las producciones alejadas de los grandes núcleos urbanos. Los momentos iniciales del siglo XX mostraron que los grandes esfuerzos por eliminar la esclavitud parecían un espejismo. Y nos encontramos con que los mismos denunciantes del trabajo esclavo y forzado eran los que transgredían la norma. En 1904, se denunció la terrible condición de los trabajadores del caucho en el Estado Libre del Congo, propiedad personal del rey Leopoldo II de Bélgica, quien, habiendo patrocinado las conferencias internacionales de 1885 y 1890, 20 años después fue denunciado por su apetito por el trabajo barato. El diplomático británico Roger Casement reveló la esclavización de la población del territorio del Congo para la extracción de caucho, iniciando una ola de preocupaciones que se extendería a las Américas (Hochschild, 2017: 365395; Miers, 2003: 51-53).

Una serie de denuncias revelaron que en diversos países de América Latina también existían formas de trabajo cautivo, aunque no hubiese propiedad 
sobre las personas. Cuando Casement presentaba su denuncia sobre el Congo, se realizaba uno de los más importantes informes en torno a las condiciones del trabajo hasta ese momento en América Latina, el "Informe Bialet Massé" (Bialet Massé, 2010). Juan Bialet Massé, médico español radicado en Argentina, fue contratado por el Gobierno de Julio Argentino Roca para realizar un reconocimiento de la situación de los trabajadores en ese país. El resultado fue El informe sobre el estado de las clases obreras argentinas, entregado al Gobierno en 1904, y que presentaba la situación de varias categorías de trabajadores en el interior de Argentina y mostraba la utilización de trabajo forzado y la reducción a la servidumbre en determinadas áreas, principalmente en la producción de caña de azúcar, yerba mate y madera. El mismo año de la denuncia de Casement y del citado Informe, el escritor, geógrafo y militar Euclides da Cunha recorría la frontera amazónica del Brasil y mostraba la producción de caucho en el Amazonas. El texto fue publicado póstumamente en 1909 con el título de Nas margens (1999) y, si bien no tuvo un gran impacto, fue una primera llamada de atención.

Poco después, periodistas, militantes sindicales, viajeros e investigadores sociales refrendaron estos estudios con observaciones propias, mostrando las diferentes formas de servidumbre o de trabajo forzado presentes en la región. El periodista español Rafael Barret (2008) comparó la recolección de la yerba mate en Paraguay con la esclavitud en el Congo. Sus artículos periodísticos fueron publicados en 1909 con el título Lo que son los yerbales paraguayos, describiendo la situación de los mensús, como eran conocidos los jornaleros en ese país. La investigación de Barret tuvo un fuerte impacto en Buenos Aires, ya que compartía la producción de yerba con Paraguay. Las descripciones del periodista estadunidense John Kenneth Turner (2014), que fueron reunidas en México bárbaro / México insurgente, texto publicado en 1908, mostraban la utilización de prisioneros, indios yaquis y mayas, coolies chinos y trabajadores endeudados en la recolección de henequén en Yucatán y en Quintana Roo, México.

Una nueva investigación de Casement (2011), publicada en 1910, sería decisiva para la región. Casement fue enviado por el Gobierno británico a investigar las condiciones de los trabajadores de Barbados, súbditos británicos que laboraban en la producción del caucho en el Amazonas peruano. Sin embargo, lo que más impacto ocasionó en Londres fue la situación de los indígenas amazónicos. La responsable del tratamiento esclavo dado a los indígenas del Putumayo era la Casa Arana, principal productora de caucho de la región. Esta empresa tenía sede en Londres y su directorio estaba integrado por importantes miembros de la City londinense y de la realeza. Era la primera vez que las denuncias sobre esclavitud indígena tenían trascendencia internacional, y no serían olvidadas rápidamente (Taussig, 1984). Otras denuncias e investigaciones mostrarían que el fin de la esclavitud no 
desembocó en el fin de las formas extremas de explotación, sino que nuevas e intrincadas tramas aparecían superpuestas a viejas estrategias utilizadas para que los trabajadores permanecieran en los lugares de trabajo.

Estos desfases entre la preocupación europea, las denuncias americanas y la ausencia de un marco legal en América Latina están relacionados, en parte, con la historia económica regional y sus desdoblamientos institucionales y legales, como la elaboración de una legislación que contemplara estas situaciones. Hasta ese momento, la mano de obra libre no parecía suficiente para las crecientes necesidades de trabajo barato y tampoco eran suficientes los contratos para retener a los obreros por la vía del indentured service o por las vías tradicionales, como el yanaconazgo. Las formas de trabajo coercitivo denunciadas no tenían sanción legal, estaban en un limbo que no contrariaban los parcos códigos existentes y, aunque no eran totalmente aceptadas, no eran objeto de preocupación legal. Las inquietudes relacionadas con la cuestión obrera se centraban en los trabajadores urbanos o en sitios de producciones más conocidos y en locales más próximos a los grandes centros urbanos.

La terminología sobre trabajo esclavo o forzado era ignorada en América Latina. Brasil, por ejemplo, es un caso paradigmático. Después de la abolición de la esclavitud, el término fue borrado del Código Penal y del Código Civil. Legalmente no existía la esclavitud, así como no existía una figura jurídica para tratar la condición del cautiverio por deudas o alguna otra forma vinculada al trabajo. Solo en 1942 el nuevo Código Penal reincorporó el término "esclavitud". La esclavitud precisaba ser redefinida a partir del establecimiento del complejo de instituciones internacionales constituidas después del fin de la Primera Guerra Mundial, pero las respuestas eran puntuales, tardías, o no definían claramente la situación del trabajo esclavo o forzado.

Las instituciones internacionales posteriores a la Primera Guerra Mundial fueron creadas para regular las relaciones entre países y para el establecimiento de estándares para las comunicaciones, la salud, la cultura, el transporte, el trabajo, etcétera, y, como mencionamos, dieron nueva vida a la reflexión sobre la esclavitud y el trabajo forzado. Veremos ahora cómo estos debates impactaron en América Latina, especialmente en Brasil y Argentina, acompañando la existencia del truck system (pago en especie), los debates internacionales y la forma en que fueron recibidas estas categorías en Brasil y en Argentina.

\section{LA SITUACIÓN INTERNACIONAL}

Para poder comprender la forma en que se constituyó un campo de debate sobre la cuestión del trabajo forzado vamos a presentar brevemente el recorrido sobre la esclavitud y el trabajo forzado, su hermano gemelo, en las organizaciones internacionales. 
En 1919, fue firmado el Tratado de Versalles, tal como fue conocido el acuerdo de paz entre las potencias beligerantes. El tratado también pretendía resolver algunas cuestiones por la vía del diálogo entre los Gobiernos, y se creó la OIT y su institución principal, la Sociedad de Naciones. También se aprobó la Convención de Saint-Germain-en-Laye de 1919 (Gran Bretaña, 1919: 108), que en su artículo 11 trataba de la esclavitud, revisando los acuerdos alcanzados en las conferencias de Berlín (1885) y Bruselas (1890), fundacionales de la moderna lucha contra la esclavitud y el tráfico, pero que habían servido también como base para el reparto colonial de África.

Las acciones llevadas adelante por la Sociedad de Naciones representaban un cambio importante en la lucha contra la esclavitud con relación al periodo anterior, en principio porque los antiesclavistas se confrontaban con quienes eran acusados de practicar la esclavitud y también porque debería primar el consenso antes que la decisión mayoritaria. También por el Tratado de Versalles fue creada la OIT, destinada a mejorar las condiciones legales de los trabajadores. Si bien las dos instituciones tenían sus propias actividades, algunas cuestiones eran tratadas en paralelo y existían vasos comunicantes, como en la temática de la esclavitud y el trabajo forzado.

Para abordar esta temática, la Sociedad de Naciones decidió que las regiones que habían sido territorios coloniales de los países derrotados estarían gobernadas por algunas potencias mediante un sistema de mandatos. Esto implicaba que tendrían (entre otros derechos y responsabilidades) ciertas atribuciones para poder acabar con la esclavitud (Macmillan, 2002: 100). Esta política colocaba en la civilización occidental la respuesta a las costumbres de lo que consideraban como países bárbaros. Europa se daba a sí misma las responsabilidades de la gesta civilizadora. La administración de África por los países europeos garantizaría la superación de costumbres atávicas y atrasadas, como la esclavitud. En la medida en que la Sociedad de Naciones entendía que las medidas tomadas no eran suficientes, fue desarrollando otros instrumentos. Para planificar estas nuevas medidas, fueron necesarias investigaciones que permitieran llegar a un común denominador entre los países miembros.

Tanto en 1922 como en 1923, la Sociedad de Naciones realizó consultas sobre la esclavitud y el trabajo indígena en los países miembros. El trabajo indígena aparecía como la fuente de los más graves problemas laborales, vinculados a la falta de mercados de trabajo en las regiones coloniales. La falta de respuestas de los países miembros, o su ambigüedad, condujo a crear una comisión (que incluyó a un miembro de la OIT) para pensar alguna medida legal dirigida a eliminar la esclavitud. Los poderes de esta comisión, conocida como Comisión Temporal sobre la Esclavitud, fueron limitados, pues se la consideró de carácter informativo. Aun así, la Comisión consiguió colocar la temática de la esclavitud en el debate institucional, pero separada del llamado de trabajo 
forzado u obligatorio, dado que no implicaba la privación permanente de la libertad, y trataba de trabajadores fuera de África o de los centros coloniales, foco principal del esfuerzo contra el trabajo esclavo (Miers, 2003: 100-121).

En 1926, fue posible sancionar una Convención de la Sociedad de Naciones sobre el tema. Esta Convención es considerada como un marco de la legislación internacional, y hoy en día continúa vigente, con pocas alteraciones. Consta de unos pocos artículos que definen la esclavitud como la propiedad de la persona. De esta forma, la Sociedad de Naciones y su heredera, la Organización de las Naciones Unidas, que ratificó dicha Convención, definieron la pérdida de la libertad y la posesión de la persona como los principales elementos para establecer la diferencia entre libertad y esclavitud. En el artículo 5 de la Convención, se reconoció la existencia de formas de trabajo consideradas como trabajo forzado u obligatorio, pero no se las asimilaba al trabajo esclavo (Sociedad de Naciones, 1926). En la Convención, se mencionó que el trabajo forzado no debería crear "formas análogas a la esclavitud", lo que abrió camino a ciertas interpretaciones sobre la relación entre la esclavitud y el trabajo forzado (Allain, 2008).

Para la OIT, la esclavitud significaba la forma extrema de supresión de los derechos laborales, pero no era la única. En los debates para la aprobación de la Convención de la OIT sobre el trabajo forzado que se daría en 1930, la palabra 'esclavo' no fue utilizada como una categoría específica. Si la Sociedad de Naciones trataba la cuestión de la pérdida de la libertad y de la propiedad de la persona, la OIT analizaba las formas utilizadas para retener de manera compulsiva a los trabajadores. ${ }^{4}$ Pero hasta 1926 no había desarrollado una normativa debido a la cantidad de temáticas sobre las que debía legislar, todas ellas vinculadas con los mercados de trabajo ya constituidos y con las disputas dentro de las metrópolis.

El reconocimiento del tema permitió que en 1926 Albert Thomas, secretario general de la OIT, representara a la institución en la Comisión Temporal sobre la Esclavitud de la Sociedad de Naciones. Esta convocatoria y la aprobación de la Convención contra la Esclavitud dieron a la OIT la oportunidad de intensificar sus trabajos para poder alcanzar su propia legislación, contemplando aquellos aspectos que fueron dejados de lado por la Sociedad de Naciones. La Convención de 1926 trataba de la propiedad de la persona; la OIT, por su parte, debía analizar las situaciones consideradas análogas a la esclavitud, es decir, el trabajo forzado. Su rol complementario con la Sociedad de Naciones y su concentración en las cuestiones laborales impulsaron estudios que permitieron una aproximación y solución a este tema, marcado por la utilización de formas

4 En las recomendaciones, las convenciones y las resoluciones de la OIT, el término utilizado es 'trabajo forzado'. 
coercitivas de control de los trabajadores y en la apropiación de la mano de obra (OIT, 1924: 737).

Las investigaciones sociales y las informaciones recibidas por la OIT mostraban que la coerción física o económica no implicaba el cercenamiento definitivo de la libertad, y fueron consideradas como controles transitorios sobre la fuerza laboral. La preocupación estaba centrada en el trabajo colonial, principalmente en África y en Asia. Fuera de las colonias, se mencionaba el uso de la deuda como modo de control. Las formas eran variadas y asumían diversos nombres, como acasillamiento, peonaje, aviamento, habilitación o enganche. Tales formas de trabajo por deuda y de pago en especie fueron reunidas en una categoría 'truck system'. En las Américas también debían ser consideradas las formas en que se movilizaba la población indígena, basada en la utilización de la prestación de servicios comunitarios. Esta situación daría paso, posteriormente, a otra categoría: el trabajo indígena (Turner, 2014).

Es importante realizar una aclaración respecto a los usos de las diferentes denominaciones para mencionar el truck system y su relación con lo que en América se denominaba "peonaje por deudas". Algunos autores compararon el peonaje por deudas con la esclavitud por diferentes motivos, principalmente por el desconocimiento de una categoría legal que la nombrase o para generar impacto entre sus lectores. Un ejemplo de esta opción es el ya mencionado libro de Turner: México bárbaro / México insurgente. Su preocupación no es analítica o legal; es más bien periodismo de investigación y de denuncia, y por eso el primer capítulo se titula "La esclavitud en Yucatán" y el cuarto, los "Esclavos contratados en el Valle Nacional". Dos formas de cautiverio fueron asimiladas entre sí y con la esclavitud: el peonaje por deudas y la servidumbre por contrato. El peonaje por deudas se refería a los préstamos en dinero o el adelanto en especie, como alimentos y ropa, deuda que el trabajador quedaba obligado a pagar con su trabajo. La servidumbre por contrato se refería al reclutamiento de mano de obra que se empleaba de forma tal que estaba constantemente a disposición del empresario por medio de una paga que, generalmente, se daba por anticipado. Son situaciones diferentes, pero el uso del término 'esclavitud' resalta la sujeción antes que el origen y la forma de ese cautiverio.

La categoría 'truck system' corresponde a una del Derecho Internacional del Trabajo, mientras que 'peonaje por deudas' corresponde a una categoría nativa del mundo del trabajo que pretende abarcar el conjunto de modalidades en diferentes lugares del mundo, en la llamada "transición global del trabajo esclavo al trabajo libre". Esta discusión tuvo y tiene un impacto mayor en aquellas regiones donde el trabajo esclavo se mantuvo por más tiempo y coincidió con la introducción del trabajo libre legalizado. La utilización del término 'truck system' se refiere a la sujeción del trabajador en el contexto de la expansión del 
trabajo libre y tiene como intención reprimir a los particulares que restringían el acceso a la mano de obra libre (Hilton, 1960: 2)

En la Conferencia Internacional del Trabajo de 1926, la OIT propuso la realización de una investigación sobre el trabajo forzado entre los indígenas en África y en América, organizada por el Native Labour Comittee, buscando evidenciar la estrecha relación entre los dos temas. Las reacciones fueron regionalizadas y los representantes se manifestaron principalmente por su país de origen. Mientras que los delegados obreros y del Gobierno de India se enfrentaron sobre la existencia de trabajo forzado, los delegados latinoamericanos rechazaron que esta iniciativa pudiera tener utilidad en su región porque negaban la existencia de trabajo forzado o porque entendían que la cuestión no podía estar geográficamente localizada. Tanto esta investigación como una propuesta de recomendación solamente serían aprobadas cuando fuese eliminada la mención a "África y América", manteniendo la palabra "indígena". Para los delegados de Argentina, Brasil, Chile, Cuba, Uruguay y Venezuela, la esclavitud y el trabajo forzado correspondían a las sociedades coloniales y no afectaban a los países americanos, que habían abolido la esclavitud en el siglo XIX (OIT, 1926: 263-264). Estos países confundían deliberadamente "esclavitud" con "trabajo forzado" para demostrar que la abolición había sido el punto final del trabajo compulsorio, negando que continuara la apropiación forzada del trabajo por otros medios.

Después de esta tentativa, el debate sobre el trabajo forzado de la OIT fue separado de las discusiones sobre el trabajo "indígena", entendiéndose bajo este nombre a los trabajadores no europeizados o a los trabajadores nativos de las colonias europeas en África, Asia y Oceanía. Si esta preocupación estaba centrada en los países coloniales, las descripciones afectaron a los países latinoamericanos que rechazaban ser incluidos dentro de estas categorías, llevando a la OIT a afinar sus definiciones. El interés de la OIT en la esclavitud y en el trabajo forzado fue consecuencia de los estudios y de las investigaciones de la Comisión Temporal que ya mencionamos (OIT, 1922: 737).

A pesar de esta oposición, en 1929, la OIT discutió la posibilidad de llevar adelante una investigación que subsidiara una convención sobre trabajo forzado. Los miembros latinoamericanos de la OIT no participaron en el comité y desestimaron esta medida porque entendían que en sus países el trabajo nativo estaba protegido o directamente no existía como un trabajo diferenciado y obligatorio, lo que equivalía a afirmar que el único trabajo forzado que podía ser asimilado al planteado por la OIT era el trabajo indígena. Así, redujeron el trabajo forzado al trabajo indígena, intentando no tener que responder por las situaciones de explotación compulsoria por la vía de la imposición de la forma de trabajo compulsoria a las comunidades nativas. Para los países europeos, la preocupación se colocaba con relación a su responsabilidad por la civilización en África y en Asia, pero no se la consideraba una cuestión propia de su región. 
Entre los países más cuestionados estaba Japón, y también las regiones independientes de India. En esa Conferencia (como en la de 1930, en la que se aprobó la Convención 29) se mostraba que la preocupación estaba relacionada con una determinada región: las colonias europeas con mano de obra nativa (OIT, 1929: 35-62, 953-964; OIT, 1930: 267-363).

En 1930, luego de los debates que se iniciaron en la Sociedad de Naciones y continuaron en la OIT, se aprobó la Convención 29, llamada "Sobre Trabajo Forzado u Obligatorio". El artículo segundo de dicha Convención define el trabajo forzado como "todo trabajo o servicio exigido de una persona bajo la amenaza de sanción y para el cual no se haya ofrecido espontáneamente". A pesar de que esta legislación pretendía tener una perspectiva universal, aplicable a cualquier caso y situación, y que el trabajo obligatorio fuera aceptado únicamente para casos de emergencia, quedaba claro que la preocupación se centraba en los pueblos de Asia y de África no occidentales. La Convención mencionaba la existencia de jefaturas o de líderes que actuaban como mediadores de los trabajadores nativos con las autoridades exteriores, refiriéndose claramente a situaciones no contempladas por las instituciones europeas (OIT, 1929). Las primeras ratificaciones de este convenio también mostraron el interés de determinados países en controlar la esclavitud y el tráfico, más allá del nombre de la Convención. Los primeros firmantes, en 1931, fueron Gran Bretańa, Irlanda, Liberia y Suecia; un año después se adhirieron Australia, Bulgaria, Dinamarca, España, Japón y Noruega.

La negación internacional de la cuestión del trabajo forzado no implicaba que en América Latina no hubiese este tipo de casos que, como mencionamos al inicio de este texto, era una realidad conocida. Inicialmente, los Gobiernos preferían no hacerse eco de estas situaciones, considerándolas casos aislados o que habrían ocurrido en momentos específicos. El conjunto de los países latinoamericanos intentó desvincularse de esta realidad, así como del trabajo indígena. Los discursos de los representantes mostraban una América Latina europeizada y adaptada a los ritmos de trabajo de los países industrializados, con movimientos obreros activos y con derechos. Había dos grandes problemas con esta autoimagen. Por un lado, las versiones que circulaban no correspondían con la misma: ante cualquier crisis de la economía mundial, el desempleo crecía rápidamente; los Estados protegían a los emprendedores locales y esto complicaba la organización de los trabajadores; había una evidente diferencia entre los trabajadores inmigrantes y los trabajadores nativos, principalmente los indígenas; y la legislación era escasa y estaba vinculada con el cumplimiento de los contratos de trabajo por parte de los obreros antes que con la defensa de los derechos sociales, entre tantos otros problemas.

La otra cuestión era la escasa representación de los trabajadores ante la OIT. La falta de representación de este sector dejaba al grupo obrero en 
desventaja con relación a las representaciones nacionales cuando se presentaban. Si el Estado no concurría, ningún otro sector se presentaba en las conferencias internacionales del trabajo. El sector más representado después del Estado era el empresariado, que podía hacer frente a los gastos de traslado, lo que no ocurría con el sector obrero. Por tanto, la información estaba sesgada, tanto por la que mostraban los Gobiernos como por la falta de representación sectorial; todo ello perjudicaba enormemente la comprensión del fenómeno latinoamericano.

Durante la década de 1920, los países de América Latina tenían sus peculiaridades y sus problemas, pero no podían alegar que el trabajo estaba homogéneamente europeizado. En la primera Conferencia Internacional del Trabajo de 1919, Argentina enfrentó el hecho de que el delegado obrero fue cuestionado por no haber convocado al representante del sindicato más numeroso, habiendo sido designado entonces por el Gobierno argentino (OIT, 1919: 107). Esto demuestra que era necesario enviar una representación completa, pero que, al mismo tiempo, fuese permeable a los intereses del Estado. En las siguientes asambleas, Argentina optó por enviar representaciones restringidas o no enviar representantes obreros.

El caso argentino no estaba aislado de lo que ocurría con los demás países de la región. México solo se integró en 1933; Brasil enfrentó algunas crisis con Ginebra, por lo que envió únicamente a representantes estatales de embajadas geográficamente cercanas (ya sea su embajador en Suiza o en Francia); Uruguay, Chile y Cuba mantuvieron una mayor continuidad en la representación. Por lo tanto, la OIT no tuvo un gran impacto en la región en la década de 1920, aunque la situación cambió en la década siguiente.

La falta de representación obrera distorsionaba los debates en Ginebra respecto a la situación latinoamericana, dejando a la región al margen de las discusiones existentes en esa primera década de vida del asociacionismo internacional. En realidad, no hubo cuestiones propiamente latinoamericanas en este periodo.

Si bien el trabajo forzado continuó siendo construido como problema a lo largo de la década de 1920, de manera paralela a la esclavitud, no ocurría lo mismo en estos países. Esto no implica que la situación fuese ignorada. Argentina y Brasil se comportaron de forma diferente ante el trabajo forzado, y podríamos decir que conformaron dos polos sobre los que se organizaron los posicionamientos regionales al respecto.

\section{LA PERSPECTIVA LATINOAMERICANA: El CASO DE BRASIL}

Brasil tuvo una política de negación del tema. El trabajo forzado fue ignorado por los diferentes gobiernos republicanos hasta 1930. Después de la abolición de la esclavitud en 1888, Brasil anuló de su lenguaje jurídico 
cualquier referencia a la misma o a aquellas instituciones a las que podría asemejarse, como el trabajo forzado o la servidumbre. Brasil intentaba borrar de su memoria los años del cautiverio, lo que no implicaba el fin de las formas de trabajo cautivo por otras vías, como vemos en la referencia a Euclides da Cunha. La tentativa de olvidar el pasado se había extendido a la memoria de la esclavitud. En 1891, Ruy Barbosa ordenó la quema de los registros existentes relacionados con el origen, la llegada y el comercio de esclavos en Brasil. Barbosa, quien había sido uno de los más importantes abolicionistas, era entonces ministro de Economía. Durante un largo periodo nadie más quiso saber de la esclavitud: era una ignominia que debía permanecer sepultada en el pasado. ${ }^{5}$

Esa fue la opción brasileña, y dejó de lado cualquier reflexión estatal sobre el tema. La abolición de la esclavitud tuvo consecuencias muy profundas. Había dividido a los grupos que controlaban la política y la economía brasileña: abolicionistas y esclavistas comenzaron a desconfiar de la capacidad del emperador para conducir el país, y fue uno de los detonantes para deponer a Pedro II en 1889, cuando se instauró la República. El Imperio sin esclavitud había durado apenas un poco más de un año. Entre los republicanos estaban los principales abolicionistas; uno de ellos fue Barbosa.

En ese contexto, 1930 no es importante por ser el año en que Getúlio Vargas lideró la Revolución que depuso la llamada Republica Velha, sino porque era el momento en el que se produjo una segunda ola de denuncias sobre la "esclavitud" en Brasil. Esa ola estuvo vinculada con un uso liberal de la palabra 'esclavitud', con denuncias en los periódicos sobre personas en condición de cautiverio o forzadas a la prostitución. En ese marco, se presentó una denuncia relacionada al trabajo en la producción de yerba mate en el estado de Mato Grosso. La intervención del Estado que dispuso Getúlio Vargas encontró trabajadores en condiciones de esclavitud, como las definió el interventor Antonio Mena Gonçalves. ${ }^{6}$

Estas denuncias fueron publicadas en los diarios de la capital, Río de Janeiro, para que el Gobierno no pudiera alegar su desconocimiento. Sin embargo, este

5 La intención de Barbosa está sujeta a varias interpretaciones Una de ellas es que intentó impedir que los exdueños de esclavos solicitaran una compensación monetaria por los esclavos liberados (Assis Barbosa, 1988: 11).

6 En fecha 19 de enero de 1931, apareció la primera nota en el diario O Globo de Río de Janeiro, con el título "Libertos em fim do cativeiro e do martírio". En febrero, las notas sobre la situación en Mato Grosso fueron frecuentes y se refirieron directamente a la acción del interventor en ese estado: "Prosegue o combate ao escravagismo" (18 de febrero de 1931) y "A escravidão em Matto Grosso" (25 de febrero de 1931). 
prefirió no tomar medidas, excepto la acción del interventor Mena Gonçalves, que no permaneció mucho tiempo en la región y fue sustituido una vez resuelto el conflicto entre las élites locales, lo que permitió que estas volvieran a sus formas tradicionales de organizar la fuerza de trabajo. El único inconveniente que el Gobierno debió enfrentar fue que las denuncias fueron enviadas a la OIT por el Partido Trabalhista do Brasil..$^{7}$ Aunque las denuncias no ocasionaron ningún tipo de reclamo para el Brasil, sí mostraban la importancia que la situación tenía para la política brasileña. A lo largo de la década, las denuncias continuaron, sin que se tomaran medidas específicas al respecto.

De todas formas, todas las presentaciones del Brasil sobre el tema del trabajo forzado o de la esclavitud indígena se fundaban en ignorar la posibilidad de su existencia porque podrían remitir a una situación que se creía resuelta. Así, Brasil se alejó de la problemática del trabajo forzado hasta 1942, cuando fue actualizado el Código Penal elaborado un año después de proclamada la República. Si en el primer Código Penal republicano la esclavitud y el trabajo forzado como crímenes fueron ignorados, en el segundo apenas se mencionaron. De hecho, el Código Penal de 1942, 54 años después de la abolición, trataba la cuestión de la esclavitud de la siguiente forma: "Redução a condição análoga à de escravo. Art. 149. Reduzir alguém a condição análoga à de escravo: Pena - reclusão, de dois a oito anos" " Es importante hacer notar que la esclavitud fue colocada bajo el título de "De los crímenes contra la libertad individual", de modo que no se refiere al mundo del trabajo y sí a otras formas de restricción de la libertad. Vemos también que la definición es tautológica: no hace referencia ni describe ninguna otra realidad más allá de la sola mención de la esclavitud.

Cuando el Código Penal fue publicado, el ministro de Justicia, Francisco de Campos, encargado de su redacción, justificó la incorporación del artículo 149 de la siguiente forma:

En el artículo 149, está prevista una entidad criminal ignorada por el Código vigente: el hecho de reducir a alguien, por cualquier medio, a la condición análoga a la de esclavo, esto es, suprimirle, de hecho, el estatus libertatis, sujetando al agente a su completo y discrecional poder. Es el crimen que los antiguos llamaban plagium. No es desconocida su práctica entre nosotros, principalmente en ciertos puntos remotos de nuestro hinterland (Campos, 1969: 142).

7 Carta de Silva Relle a M. Staal de 26 de febrero de 1931, archivo de la OIT.

8 Brasil, Decreto-Lei N. ${ }^{\circ} 2848$, de 7 de diciembre de 1940, Código Penal. Disponible en: http://www2.camara.leg.br/legin/fed/declei/1940-1949/decreto-lei-2848-7dezembro-1940-412868-publicacaooriginal-1-pe.html (fecha de consulta: 1 de octubre de 2017). 
El plagium, según Ley Fabia, establecía "la retención contra la voluntad y la enajenación de personas libres" (Betancourt, 2007: 434), por lo que difícilmente podía ser vinculado al trabajo forzado.

En 1943, cuando se sancionó la Consolidación de las Leyes del Trabajo (CLT) (instrumento que agregaba toda la legislación previa sobre las relaciones laborales), tampoco se incorporó el trabajo forzado ni ninguna de las posibles categorías relacionadas con el mismo. Si bien la CLT determinaba que el salario debía ser pagado en moneda nacional (artículo 463), también se abría la posibilidad de que parte del salario fuese pagado en especie, según las costumbres locales (artículo 458). De esta forma, se establecía una peligrosa correlación entre formas de retener al trabajador en el lugar del trabajo por la vía de la provisión de mercaderías, situación que podía derivar en el trabajo forzado. ${ }^{9}$ Si bien la cuestión del trabajo forzado no era desconocida en Brasil, ello no implicaba que fuera incorporada a la legislación. De hecho, el Gobierno se centraba en el trabajo urbano y en las principales categorías, dejando de lado la posibilidad de la existencia del trabajo forzado. Esto fue lo más próximo que tuvo la legislación brasileña sobre el trabajo forzado o la esclavitud.

La conformación del mercado de trabajo en Brasil se dio durante el periodo esclavista, por lo que ambos tipos de trabajadores (libres y esclavos) enfrentaron condiciones similares y altos grados de explotación. Los esclavistas no querían perder el capital que habían invertido en sus esclavos y entendían que les pertenecían, así como la libre disponibilidad de la mano de obra. Al mismo tiempo, la escasez de trabajo libre, principalmente en el sector rural, condujo a que las condiciones de trabajo para los trabajadores libres fuesen similares a las del esclavo, y se crearon relaciones de trabajo que tendían a sujetar al trabajador al lugar de trabajo (Eisemberg, 1989). El hecho de retener al trabajador en el lugar de trabajo fue determinante para esta presentación de mercado libre de trabajo en Brasil, contrariando las tentativas internacionales de fiscalizar el trabajo ajeno.

\section{La PERSPECTIVA latinoamericana: el CASO de Argentina}

El caso argentino es un tanto diferente con relación a este tema. La esclavitud en Argentina había sido definitivamente abolida con la Constitución de 1853 , en cuyo artículo 15 se establecía que los pocos esclavos remanentes debían ser liberados en definitiva desde el mismo momento de la

9 Brasil, Decreto-Lei N.o 5452, de 1 de mayo de 1943, Consolidação das Leis do Trabalho. Disponible en: http://www2.camara.leg.br/legin/fed/declei/1940-1949/ decreto-lei-5452-1-maio-1943-415500-publicacaooriginal-1-pe.html (fecha de consulta: 1 de octubre de 2017). 
sanción del texto constitucional (Argentina, 2010: 33). Pero esto no implicaba que no existiesen formas de trabajo compulsorio implementadas para compensar la falta de trabajadores, principalmente en el sector rural. Las constantes informaciones sociales que se acumularon desde inicios del siglo daban cuenta de una realidad que no era comparable al periodo esclavista, pero que mostraba la tendencia a retener al trabajador por la vía de la servidumbre. La servidumbre no necesitaba ser permanente; era temporal, principalmente en aquellos lugares en que las tareas eran estacionales. Dos formas, conectadas entre sí, estaban en primer lugar: el uso de la deuda y el pago en especie. Una vez satisfechas las demandas del empleador, la deuda podía ser dejada de lado.

Si el mencionado Informe Bialet Massé había dado una muestra de lo que ocurría en algunos rincones de Argentina, otros informes mostraron su funcionamiento en detalle. El Departamento Nacional del Trabajo, creado en 1907, llevó adelante algunas investigaciones que permitieron que algunos diputados y senadores denunciaran la situación en los llamados "obrajes" $\mathrm{y}$ en las cosechas de yerba mate, en las regiones del norte argentino. Desde 1913, los informes de dicho Departamento mostraban claramente lo que ocurría en la explotación de la yerba mate y del quebracho, como también de la producción de la cańa de azúcar. En varias oportunidades sus fiscales, especialmente José Niklison, habían revelado la condición de la servidumbre por deudas en los lugares de producción.

La mayor visibilidad de la explotación de los trabajadores en estos centros de producción se produjo con la Masacre de La Forestal, momento culminante de una serie de huelgas que se sucedieron entre 1919 y 1921 . En ese periodo, los trabajadores realizaron huelgas sin efectos positivos, hasta que la última acabó con la masacre de un número indeterminado de trabajadores, que el periódico socialista La Vanguardia estimó entre 500 y 600 (Jasinski, 2013). El tamaño de la represión mostró una situación que no podía continuar ignorada, y que ganaba visibilidad con los informes del Departamento Nacional del Trabajo, en los que se afirmaba que existía un alto grado de explotación en los obrajes del norte argentino.

El tema del trabajo forzado se trató de forma indirecta. Si existía la posibilidad de que los empresarios explotaran a los trabajadores era porque estos recibían sus pagos en especie o en vales; por consiguiente, la modalidad que los legisladores argentinos encontraron para impedir esta situación fue obligar a que los pagos se realizaran en moneda corriente. Esta fue la base para combatir el trabajo forzado. El pago en especie fue encuadrado dentro de la categoría 'truck system', buscando una categoría específica y conocida en la legislación internacional que pudiera aplicarse sin crear conmoción entre los trabajadores. 
En 1925, fue aprobada la Ley N. 11728 , conocida como "Ley de pago en moneda nacional". El debate de esta normativa ocupó varios periodos legislativos, desde 1920, en el marco de las huelgas de La Forestal. Tenía como objetivo controlar y limitar la explotación de los trabajadores en algunas producciones, principalmente en las actividades extractivas, como la yerba mate o el quebracho, pero también en actividades que requerían mano de obra intensiva, como la producción de caña de azúcar. La ley tuvo enormes dificultades para ser aprobada. Por un lado, los debates se dilataron para que no fuera posible su aprobación, y cuando finalmente fue aprobada, el Poder Ejecutivo la vetó.

Los legisladores que impulsaban la ley solo consiguieron su aprobación después de una serie de negociaciones que implicaron importantes modificaciones, como por ejemplo la autorización del pago en cheques a quien recibiera salarios mayores a 300 pesos argentinos. Con el argumento de la dificultad de transportar dinero por regiones alejadas, se consagraba el hecho de que algunos trabajadores recibirían su pago mediado por el sistema financiero de las compañías. Por esta norma, las compañías o los comerciantes locales resultarían beneficiados por el hecho de que algunos trabajadores descontasen de los cheques de su salario valores menores al nominal. Así, se reinstalaba el círculo del endeudamiento en el local de trabajo. ${ }^{10}$

Este es un antecedente muy importante para que se consolidara una legislación de control al trabajo forzado. Todos los debates giraban en torno de la servidumbre por deudas, aunque la terminología utilizada era la del truck system. Pero el adoptar una forma restrictiva del trabajo forzado en una de sus vertientes, la más conocida en América Latina, es un hecho importante porque es el punto sobre el que se apoyaron los debates posteriores sobre esta cuestión.

\section{América Latina y la Organización Internacional del Trabajo: del trabajo FORZADO AL TRUCK SYSTEM}

Como podemos notar, tanto Argentina como Brasil se enfrentaron, en momentos diferentes, al trabajo forzado. La diferencia entre ambos países radicaba en sus propias historias nacionales, que hicieron que reaccionaran de distinta manera ante las denuncias presentadas. Como dijimos al inicio, durante la década de 1920, ninguno de los dos, ni los demás países de América Latina, actuaron favorablemente respecto a una discusión sobre el trabajo forzado o sobre la esclavitud. Cuando el tema fue abordado en las conferencias internacionales, la reacción fue una defensa unívoca de la región, descartando cualquier posibilidad de tratar el tema, que se restringió a Asia

10 Sobre los debates y el texto de la Ley N. ${ }^{\circ} 11728$, véase: Argentina, 1927: 808-813. 
y a África. Esto no implica que la explotación forzada de la mano de obra no existiera. Por el contrario, vimos que la situación era conocida en ambos países. La esclavitud podía ser utilizada como metáfora de explotación, pero las denuncias relacionadas con el trabajo rural mostraban que existían formas de compulsión extraeconómica contra los trabajadores.

La relación entre la OIT y los países latinoamericanos era un tanto zigzagueante. Los latinoamericanos no prestaban mucha atención a Ginebra, o esperaban un trato más próximo; en Ginebra, en cambio, esperaban que los latinoamericanos siguieran las normas, se adaptasen a sus demandas y pagasen sus cuotas de afiliación. Ninguno obtenía lo que quería (Ferreras, 2009). Para intentar resolver esa situación, Albert Thomas, secretario general de la OIT, y otros funcionarios visitaron algunos países de América del Sur, con la expectativa de superar algunos malentendidos. Pero las visitas no fueron muy efectivas (Ferreras, 2011). El segundo camino para una aproximación entre las partes fue la realización de una conferencia que permitiera a los países latinoamericanos presentar sus preocupaciones sin que los países más influyentes de la organización condicionaran los debates (Ferreras, 2015). Esta primera Conferencia de los Estados Americanos miembros de la OIT tuvo lugar recién en 1936, en Santiago de Chile, y allí se planteó con claridad la cuestión del trabajo forzado.

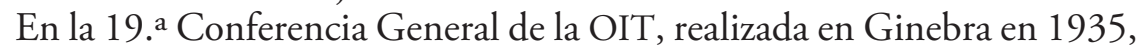
los latinoamericanos volvieron sobre el tema del trabajo forzado. Aun cuando en 1930 había sido sancionada la Convención 29, esta fue ignorada por los representantes latinoamericanos, quienes no pretendían que se aplicase porque no se adecuaba a la situación regional. Por eso, el truck system fue presentado como si se tratara de una práctica totalmente diferente.

El representante de los trabajadores brasileños, Chrisosthomo Antônio de Oliveira, fue el encargado de presentar el truck system como uno de los temas prioritarios para los representantes obreros de la región. El truck system fue descrito como una forma de obligar al trabajador agrícola a pagar los préstamos o la mercadería, y esta explotación inviabilizaba reformas laborales en los países de América Latina, ya que creaba un doble estándar laboral. También cuestionaba a los países con colonias porque, en la medida en que utilizaban esta forma de pago y de control de la mano de obra, tenían ventajas sobre los países de América Latina que debían hacer frente a ese tipo de competencia (OIT, 1935: 368-369).

El representante del Gobierno argentino, Enrique Ruiz Guiñazú, abordó el tema desde un punto de vista técnico, haciendo valer los antecedentes argentinos que remitían a la primera Conferencia Internacional del Trabajo y a la Ley N 11728, de 1925. Según Ruiz Guiñazú, ya sea por las devaluaciones de las monedas europeas o de Estados Unidos, los 
salarios rurales estaban deprimidos y el truck system contribuía a deprimirlos todavía más. La defensa del pago en moneda se vinculaba a la necesidad de que los salarios correspondieran al nivel de vida del obrero. El proyecto de resolución debía dar paso a una convención sobre el tema que acompańase la legislación de otros países de Europa y América. La Convención permitiría una remuneración más homogénea y previsible para los trabajadores sin la explotación extra en la esfera del consumo. La posición de Ruiz Guińazú fue respaldada por los representantes gubernamentales Affonso Bandeira de Mello, brasileño, y César Zumeta, venezolano. Este último entendía que el pago en especie o en bonos debía ser visto como competencia desleal en el escenario internacional. La resolución fue aprobada por unanimidad, pero debemos recordar que la aprobación no tenía consecuencias concretas; simplemente implicaba la continuidad de las investigaciones sobre el impacto del truck system en el salario de los trabajadores (OIT, 1935a: 479, 480, 484). ${ }^{11}$

Entendemos que para los representantes latinoamericanos el truck system no era visto como una forma extraordinaria de explotación. Se podría decir que era un crimen que se cometía contra el trabajo, pero no contra la humanidad del trabajador. Por eso, el discurso se enfocó en priorizar la lucha contra el truck system, ya que la utilización de una categoría que aparecía como técnica permitía verlo de forma diferente al trabajo forzado. La tentativa latinoamericana de analizar el tema no avanzó en la reunión de Ginebra, pero la temática quedó entre los puntos que serían abordados unos meses después en la Conferencia Internacional de los Países Americanos Miembros de la OIT. Varios países europeos incentivaron la realización de la cumbre americana como una forma de que los temas latinoamericanos fuesen resueltos entre los propios americanos.

\section{La Primera Conferencia Internacional de los Países Americanos Miembros de la OrganizaCIÓN INTERNACIONAL DEL TRABAJO}

$\mathrm{Al}$ aceptar que se realizara la Primera Conferencia Internacional de los Países Americanos Miembros de la OIT, también se aceptaba que se trataran algunos temas que resultaban importantes para dichos países de una manera más intensa que en las conferencias internacionales. Este encuentro, que tuvo lugar en Santiago de Chile entre diciembre de 1935 y enero de 1936, contó con la participación de todos los países americanos, incluido Canadá, que hasta entonces no había participado en ninguna conferencia panamericana. Argentina, a pesar de la proximidad y el interés manifestado en que se

11 La resolución completa está publicada en la página 744 de ese documento. 
organizara el evento, solo concurrió con la representación gubernamental, debido a una huelga que paralizó la ciudad de Buenos Aires.

La Conferencia tuvo un alto contenido político; se discutió, sutilmente, la constitución de una Organización Americana del Trabajo, por lo que los debates estuvieron marcados por dicha posibilidad. Entre los temas tratados figuraron el trabajo femenino, el trabajo indígena, la alimentación popular y el salario mínimo, entre otros, así como el truck system. Dos grupos estaban empeñados en esta cuestión, los trabajadores y los representantes del Gobierno argentino, con Enrique Forn como portavoz. El grupo de los trabajadores colocaba al truck system junto con otras cuestiones de la legislación social que merecían ser atendidas y que eran dejadas de lado por los Gobiernos.

El delegado argentino, en cambio, discutió las cuestiones técnicas vinculándolas con la explotación de trabajadores en aquellos lugares alejados de los centros urbanos. Forn aportaba los 20 años de debates en Argentina sobre la materia y vinculaba el truck system con una práctica propia del trabajo rural, principalmente de aquellos establecimientos dedicados a la extracción, refiriéndose a la yerba mate o a la obtención de madera, o que utilizaban grandes cantidades de mano de obra en forma extensiva, como los ingenios azucareros y los obrajes.

Para Forn, la segunda característica del truck system era la centralidad de las proveedurías y de los economatos en estos centros productivos. La preocupación estaba más centrada en la explotación al consumidor que en la vinculación entre empresa contratante de mano de obra y su posición privilegiada como proveedora de bienes de consumo a sus trabajadores, que era como se creaban la deuda y la sujeción extraeconómica. La propuesta de Forn era dar continuidad a los estudios de la OIT sobre el tema, lo que fue aprobado sin debate. También llamaba a realizar investigaciones sobre esta cuestión y a solicitar a Ginebra los datos disponibles que permitieran su sanción en una futura Convención (OIT, 1936: 145, 158, 291-298). ${ }^{12}$ Esta era una tentativa de involucrar a la comunidad internacional, al tiempo que se ampliaba la información sobre los casos regionales, para que las Américas no fuesen el único lugar en que se legislase sobre el tema.

\section{LOS DEBATES POSTERIORES SOBRE EL TRUCK SYSTEM}

Los debates de la Conferencia Internacional del Trabajo (CIT) de 1935 y de la Conferencia Internacional de los Países Americanos Miembros de la

12 Como insumo para el debate, Paraguay presentó la Ley N.o 1218 de ese país, de 6 de agosto de 1931, por la cual era obligatorio que las empresas que operaban en el Alto Paraná pagaran a sus obreros dentro del mismo país y en moneda corriente, para combatir el truck system. 
OIT de 1936 estuvieron basados en impresiones o datos de algunos pocos países, como las leyes de Argentina y de Paraguay, pero no eran suficientes como para pensar en una legislación universal. Por ese motivo, la OIT inició en 1936 una investigación general sobre el truck system, solicitando el envío de un cuestionario a los países miembros. Las respuestas a ese cuestionario serían la base de una futura convención. A pesar del esfuerzo realizado para avanzar en esta dirección, las respuestas fueron pocas y frustrantes. Los países que respondieron a la consulta fueron: Argentina, Bolivia, Brasil, Chile, Estados Unidos, Liberia, México, Perú y la Unión Soviética. Los países de América Latina aportaron algunos datos, junto con sus legislaciones; los demás enviaron comentarios generales sin proporcionar información concreta. Parecía un asunto restringido a América Latina (OIT, 1935b).

Los representantes de América Latina retornaron a la cuestión del truck system en la CIT de 1937. El representante de los trabajadores venezolanos, Luis Alfonso Parra, denunció la continuidad del truck system y el pago en vales a los trabajadores rurales y petroleros de su país. El representante de los trabajadores de India, Satis Sen, presentó la situación de los trabajadores de su país enmarcando el truck system en los debates del trabajo forzado y del trabajo indígena. Se entendía que los sistemas de explotación por medio de la deuda, el adelanto de bienes y/o la obligación de utilizar a los proveedores de las empresas, entre otras formas de retener y de explotar a los trabajadores, continuaban por todo el sistema colonial británico, provocando crisis alimentarias y desnutrición generalizada entre los nativos.

Ciertamente, la crítica era mucho más seria y tenía un impacto mayor que las posiciones latinoamericanas, lo que llevaba a revisar las convenciones previamente aprobadas. Por primera vez, el truck system fue claramente vinculado con el trabajo forzado, y se colocó en el centro del debate a uno de los más importantes países europeos, Gran Bretaña, el principal impulsor también de medidas contrarias a la esclavitud y al trabajo forzado. De esta forma, se relacionaba el truck system con el cuadro de hambre y pobreza con el que la India era vista en el mundo occidental. El truck system y otras formas de control de la mano de obra o de sujeción extraeconómica, como la obligación de cultivar sus propios alimentos, aparecían como otra forma de burlar los límites a la explotación colocados por las convenciones anteriores. Una vez más, la propuesta de una resolución apuntaba a ampliar los estudios sobre el truck system y sobre otras formas de explotación (OIT, 1937: 263, 460, 461-562). ${ }^{13}$

13 En 1938, el representante de los trabajadores de Suecia, Gunnar Andersson, colocaba la cuestión de forma marginal al solicitar una resolución sobre los trabajadores en las madereras y mostrando la utilización del truck system en esta industria (OIT, 1938: 482). 
En la segunda Conferencia Internacional de los Países Americanos, que tuvo lugar en Santiago de Cuba, en noviembre de 1939, el tema todavía estaba vigente. En esa reunión se presentó brevemente lo realizado, que no era mucho, haciéndose referencia a que la OIT había reunido algunos datos al respecto. La novedad fue que los debates sobre el truck system entraron en diálogo con la temática del peonaje, a pesar de que se tratara de una breve mención y sin que hubiera realmente una reflexión.

El tema no pudo avanzar puesto que las potencias mundiales se disponían a entrar en guerra y el interés era mantener la capacidad de trabajo, incluso ampliándola, por lo que todo el andamiaje legal internacional se retomó después de la Segunda Guerra Mundial; de hecho, el truck system volvió a ser tratado en la Conferencia Americana que se desarrolló en 1946. La peculiaridad fue que su abordaje estuvo claramente dirigido a tratar la cuestión como propia de las comunidades indígenas. De esta forma, ya no se refería a los trabajadores como un todo, sino a una categoría específica: los trabajadores indígenas de América Latina (OIT, 1939: 22-23; OIT, 1946: 46 y 47).

Evidentemente, el truck system fue un sistema que, con varios nombres, correspondió a una forma muy extendida de control y pago. Si bien este era un aspecto marginal para los trabajadores urbanos, medio del cual provenían los representantes obreros, la situación de los jornaleros agrarios no podía ser ignorada y mostraba el rostro más grave de la explotación del trabajo en la región. Recordemos que, excepto Argentina, los demás países americanos eran mayoritariamente rurales. E incluso en Argentina la explotación agraria era de vital importancia.

\section{CONCLUSIONES}

En este trabajo, intentamos presentar la creación de una legislación internacional sobre el trabajo forzado, en la cual la OIT tuvo una influencia decisiva, pero también mostramos que América Latina recibió estas iniciativas con desconfianza e intentó llevarlas por otro camino: por ejemplo, el del truck system (pago en especie). Así, desde América Latina se abría una nota discordante con la tentativa de imponer una visión universal del trabajo forzado. De hecho, únicamente tres países de la región adoptaron la Convención 29 en la primera mitad del siglo XX: Chile en 1933 y tanto México como Nicaragua en 1934. Los demás prefirieron discutir la existencia de la Convención y priorizaron la discusión sobre el truck system que, si bien estaba incluido en las formas de control extraeconómico de la mano de obra, al restringir la práctica a una categoría técnica centrada en la explotación de la reproducción de la mano de obra, antes que en la esfera de la producción, invertía la lógica de la explotación: el obrero trabajaba para pagar sus deudas y no a la 
inversa; la deuda se creaba para obligar al obrero a trabajar. Los representantes de los Estados de América Latina privilegiaron la deuda y no el hecho del trabajo, que debía ser mal pagado y abundante. La deuda era la excusa para la explotación y no el centro del sistema.

De cualquier forma, prevaleció el discurso del truck system, y el trabajo forzado por deuda, que fue incorporado por las representaciones de obreros, principalmente en las conferencias americanas del trabajo. Es decir, fueron los propios trabajadores los que articularon este discurso y sus luchas consecuentes, como la reivindicación de los derechos ante las autoridades. La lógica del mismo fue la de ampliar representaciones y derechos sociales, lo que conducía a una política de universalidad de los derechos y a su consolidación mediante la ley.

Es importante mencionar la existencia de una significativa literatura teórica que analizó las limitaciones del trabajo libre y la emergencia de trabajo forzado o compulsorio. Las discusiones giraron, en gran medida, sobre la relación entre esclavitud y capitalismo, y la compatibilidad de ambos en una sociedad abiertamente capitalista. Esto llevó a pensar que el capitalismo no solo podía ser compatible con la esclavitud, al crear otras formas posibles de explotación que vincularan el trabajo con el dinero de una manera diferente a la que anunciaba el liberalismo, que era la venta libre de la mercancía "trabajo" a cambio de dinero. Nos enfrentamos a que la relación establecida en el hinterland brasileño y argentino fue la inversa: el dinero ofrecido por el capitalista debía ser retribuido en trabajo por el obrero. No solamente se invertía la lógica, sino que la mercancía "trabajo" no era suficiente para satisfacer la oferta realizada en primera instancia. De esta forma, el capitalismo generaba la condición de sujeción del trabajador.

Orlando Patterson, uno de los teóricos de la esclavitud más reconocidos, entendía que había dos formas de vínculo por la deuda: la esclavitud y el peonaje. El primero sería permanente, producto de la pobreza y la desigualdad; y el segundo, transitorio, producto de malas cosechas (1982: 124). El caso latinoamericano parece ser un poco más complejo. Si bien en Yucatán parecían existir las dos variables de esclavitud y peonaje, no parecía ser el caso de Argentina y de Brasil, donde la deuda se generó después del despojo de las tierras. El peón era obligado a la deuda para poder ejercer su oficio: la compra de un hacha o de las herramientas para la cosecha del látex, a lo que debían sumarse los alimentos para poder reponer la fuerza de trabajo y la vestimenta; es decir, una alteración del ciclo productivo regional por la privatización previa de un espacio que era de uso común. Por eso, el truck system nos lleva a los aspectos legales (antes que a los sociales y económicos) del peonaje por deudas en la región, que fue lo que analizamos aquí. 
La vinculación de lo regional con lo universal de las legislaciones de Brasil y de Argentina, sus prácticas y sus reflexiones, y las salidas que cada país intentó ante el trabajo forzado nos permiten ver una realidad compleja, atravesada por la historia del trabajo local y por las formas de explotación consagradas y aceptadas en cada sociedad. La forma en que Brasil eludió la existencia del trabajo forzado, aun con las denuncias existentes, la tentativa de la sociedad civil de enmarcar esas formas de trabajo compulsorio, o a veces criminal, dentro de la esclavitud, se relaciona con la permanencia de una institución que había sido abolida en todo el resto del continente. Esto no permitía entender correctamente lo que ocurría en la región rural al ser tratada de una forma que remitía a una institución que estaba extinta, aunque no lo estaba la cultura de la explotación. La forma de procesar esta ambigüedad fue por la vía de la legislación local y del compromiso internacional en la lucha contra el truck system.

Por el lado argentino tenemos una situación diferente, a pesar de que ambos países llegasen al punto en común del truck system. Este país pretendía mostrar que tenía relaciones de producción modernas, en las que existía una relación libre entre capital y trabajo. Esta libertad, en realidad, se definía por la adscripción a un liberalismo clásico que inhibía cualquier forma de asociación entre los trabajadores, y no entre los propietarios, como lo comprueban la creación y la acción de diversas asociaciones empresariales en defensa de la libertad de trabajo. ${ }^{14}$ Por tanto, no podía existir trabajo forzado en una sociedad que preconizaba la "libertad" como base de su organización política y social. Lo que los investigadores sociales podrían haber encontrado eran formas abusivas de una posición dominante, ya que el propietario ejercía una función extraordinaria creando un monopolio y sacando provecho de esta situación privilegiada, restringiendo, en consecuencia, la libertad del obrero-consumidor de acceder a sus bienes libremente. El problema estaba centrado en la esfera del consumo y no en la producción: el truck system mostraba que la deuda se utilizaba para retener al trabajador, en una situación más próxima al peonaje por deudas y al trabajo forzado que al abuso de una posición dominante en el mercado.

En resumen, Argentina y Brasil, junto con el resto de América Latina, coincidían en que las reflexiones sobre el trabajo forzado que derivaron en la Convención 29 no se adecuaban a la región y que debían restringirse al ámbito colonial. Todos los debates se encaminaron en esta dirección, a pesar de que las evidencias encontradas apuntaban en sentido contrario.

14 La más conocida de ellas fue la Asociación del Trabajo, creada en 1918 (Rapalo, 2012). 
BibLIOGRAFÍA

Allain, Jean

2008 The Slavery Conventions: The Travaux Préparatoires of the 1926 League of Nations Convention and the 1956 United Nations Convention. Leiden, Holanda: Martinus Nijhoff.

Allemandi, Cecilia

2017 Sirvientes, criados y nodrizas: una historia del servicio doméstico en la ciudad de Buenos Aires: fines del siglo XIX y principios del XX. Buenos Aires: Teseo.

Argentina

2010 Constitución de la Nación Argentina. Publicación del Bicentenario (facsímil). Buenos Aires: Corte Suprema de Justicia de la Nación / Biblioteca del Congreso de la Nación / Biblioteca Nacional.

Argentina, Congreso Nacional

1927 Diario de Sesiones de la Cámara de Diputados de la Nación. Año 1926. Tomo IV. Sesiones ordinarias. Agosto 12-septiembre 1. Buenos Aires: Imprenta y encuadernación de la Cámara de Diputados.

Assis Barbosa, Francisco

1988 “Apresentação". En: Américo Jacobina Lacombe, Eduardo Silva y Francisco Assis Barbosa (comps.), Rui Barbosa e a Queima dos Arquivos. Brasilia / Río de Janeiro: Ministerio de Justicia / Fundação Casa de Rui Barbosa.

Barret, Rafael

2008 "Lo que son los yerbales paraguayos". En: Rafael Barret, El dolor paraguayo. Caracas: Biblioteca Ayacucho.

Bergquist, Charles

1988 Los trabajadores en la historia latinoamericana: estudios comparativos de Chile, Argentina, Venezuela y Colombia. México: Siglo XXI Editores.

Betancourt, Fernando

2007 Derecho Romano Clásico. Sevilla: Universidad de Sevilla.

Bialet Massé, Juan

2010 Informe sobre el estado de las clases obreras argentinas. La Plata, Argentina: Ministerio de Trabajo de la Provincia de Buenos Aires. 
356 | Trabajos y trabajadores en América Latina (siglos XVI-XXI)

Brasil

1943 Decreto-Lei No 5452, de $1 .^{\circ}$ de maio de 1943. Consolidaçáo das Leis do Trabalho. Disponible en: http://www2.camara.leg.br/legin/ fed/declei/1940-1949/decreto-lei-5452-1-maio-1943-415500publicacaooriginal-1-pe.html (fecha de consulta: 1 de octubre de 2017).

Brasil, Senado Federal, Subsecretaría de Informaciones

1940 Decreto-Lei 2848, de 7/12/1940. Código Penal. Disponible en: http:// www6.senado.gov.br/legislacao/ListaPublicacoes.action? id=102343 (fecha de consulta: 1 de octubre de 2017).

1890 Decreto $N .^{\circ} 847$, de 11 de outubro de 1890. Código Penal. Disponible en: http://www2.camara.leg.br/legin/fed/decret/1824-1899/decreto847-11-outubro-1890-503086-publicacaooriginal-1-pe.html (fecha de consulta: 1 de octubre de 2017).

Campos, Francisco de

1969 “Exposição de motivos do Código Penal de 1940”. En: Revista de Informação Legislativa, volumen 6, número 24. Brasilia: Senado Federal, Dirección de Información Legislativa.

Casement, Roger

2011 El Libro Azul. Informes de Roger Casement y otras cartas sobre las atrocidades en el Putumayo. Lima: Centro Amazónico de Antropología / Aplicación Práctica.

Da Cunha, Euclides

1999 À Margem Da História. San Pablo: Martins Fontes.

Da Silva Telles, Lorena Féres

2011 "Libertas entre sobrados: Contratos de trabalho Domestico em São Paulo na derrocada da Escravidão". Tesis de maestría. Facultad de Filosofía, Letras e Historia Social, Universidad de San Pablo, Brasil.

Drescher, Seymour

2009 Abolition. A History of Slavery and Antislavery. Nueva York, Estados Unidos de América: Cambridge University Press.

Eisenberg, Peter

1989 Homens esquecidos: escravos e trabalhadores no Brasil-séculos XVIII e XIX. Campinas, Brasil: Unicamp.

Ferreras, Norberto

2015 "Europa-Geneva-America: The First International Conference of American States Members of the International Labour Organization”. 
En: Alan Mcpherson y Yannick Wehrli (orgs.), Beyond Geopolitics. New Histories of Latin American at the League of Nations. Albuquerque, Nuevo México, Estados Unidos de América: University of New Mexico Press.

2012 “La modernité intégrée par les peuples indigènes. L’Organisation internationale du travail et l'Amérique latine, la question des peuples indigènes et tribaux". En: Daniel Aarão Reis y Rolland Denis, Modernités Nationales, Modernités Importées entre Ancien et Nouveau Monde XIXe-XXIe siècle. París: L’Harmattan.

2011 "Entre a expansão e a sobrevivência: a viagem de Albert Thomas ao Cone Sul da América”. En: Antiteses, volumen 4, número 7. 127-150.

2009 "O Prêmio Nobel e o burocrata: a conformação de um campo intelectual no Direito do Trabalho na Argentina da década de 1930". En: Anos 90, volumen 16, número 29. 213-236.

Ferreras, Norberto y María Verónica Secreto

2013 "Trabalho decente, trabalho escravo, trabalho degradante, trabalho análogo à escravidão e outras categorias do Mundo do Trabalho Contemporâneo". En: Norberto Ferreras y María Verónica Secreto, Os pobres e a politica. História e Movimentos Sociais na América Latina. Río de Janeiro: Mauad.

Gotkowitz, Laura.

2007 A Revolution for Our Rights: Indigenous Struggles for Land and Justice in Bolivia (1880-1952). Durham, Inglaterra: Duke University press.

Gran Bretańa, Parlamento

1919 Convention Revising the General Act of Berlin, February 26, 1885 , and the General Act and Declaration of Brussels, July 2, 1890, Signed at Saint-Germain-en-Laye, September 10, 1919. Londres: H. M. Stationery Office.

Hilton, George W.

1960 The truck system including a history of the British Truck Acts, 1465-1960. Cambridge, Inglaterra: W. Heffer.

Hochschild, Adam

2017 El fantasma del Rey Leopoldo. Una historia de codicia, terror y heroismo en el África colonial. Barcelona: Malpaso.

Jasinski, Alejandro

2013 Revuelta obrera y masacre en La Forestal: sindicalización y violencia empresaria en tiempos de Yrigoyen. Buenos Aires: Biblos. 
358 | Trabajos y trabajadores en América Latina (siglos XVI-XXI)

Macmillan, Margaret

2002 Paris 1919. Six months that changed the world. Nueva York, Estados Unidos de América: Random House.

Miers, Suzanne

2003 Slavery in the Twentieth Century. The evolution of a Global Problem. Walnut Creek, California, Estados Unidos de América: AltaMira Press.

Organización Internacional del Trabajo (OIT)

1946 Tercera Conferencia del Trabajo de los Estados de América miembros de la Organización Internacional del Trabajo. Acta de las Sesiones, México, abril de 1946. Montreal: OIT.

1939 Segunda Conferencia del Trabajo de los Estados de América Miembros de la Organización Internacional del Trabajo. Informe de la Oficina Internacional del Trabajo acerca de las medidas tomadas para dar cumplimiento a las resoluciones adoptadas por la Conferencia de Santiago de Chile. Ginebra: OIT.

1938 International Labour Conference. Twenty-fourth Session. Records of Proceedings. Ginebra: OIT.

1937 International Labour Conference. Twenty-third Session. Records of Proceedings. Ginebra: OIT.

1936 Conferencia del Trabajo de los Estados de América Miembros de la Organización Internacional del Trabajo. Actas de las Sesiones. Santiago de Chile. 2 al 14 de enero de 1936. Ginebra: OIT.

1935a International Labour Conference. Nineteenth Session. Records of Proceedings. Ginebra: OIT.

1935b 'Dossier No 102/6. Study on the 'truck system' (payment of wages). State of Resolution, $19^{\text {th }}$ Session". Archivo de la OIT.

1930a Convenção $N^{\circ} 29$. Sobre o Trabalho Forçado ou Obrigatório. Disponible en: http://www.ilo.org/ilolex/portug/docs/C29.htm (fecha de consulta: 1 de octubre de 2017).

1930b International Labour Conference. Fourteenth annual meeting. Geneva, 1930. Volumen 1. Ginebra: OIT.

1929 International Labour Conference. Twelfth annual meeting. Geneva, 1929. Volumen 1. Ginebra: OIT.

1926 International Labour Conference. Eighth annual meeting. Geneva, 1926. Volumen 1. Ginebra: OIT.

1924 International Labour Conference. Sixth annual meeting. Geneva, 1924. Ginebra: OIT.

1922 International Labour Conference. Fourth annual meeting. Geneva, 1922. Ginebra: OIT.

1919 International Labour Conference. Fourth annual meeting. Geneva, 1919. Washington, Estados Unidos de América: Government Printing Office. 
Patterson, Orlando

1982 Slavery and Social Death: A comparative Study. Cambridge, Inglaterra: Cambridge University Press.

Rapalo, María Ester

2012 Patrones y obreros. La ofensiva de la clase propietaria, 1918-1930. Buenos Aires: Siglo XXI Editores.

Roncador, Sônia

2014 Domestic Servants in Literature and Testimony in Brazil, 1889-1999. Nueva York: Palgrave McMillan.

Secreto, María Verónica

2011 Fronteiras em movimento. História comparada-Argentina e Brasil no século XIX. Niterói, Brasil: Eduff.

Sociedad de Naciones

1926 Convención sobre la Esclavitud. Disponible en: http://www.acnur. org/t3/fileadmin/scripts/doc.php?file=biblioteca/pdf/2448 (fecha de consulta: 1 de octubre de 2017).

Spalding Jr., Hobart

1977 Organized Labor in Latin America. Historical cases of Urban Workers in Dependent Societies. Nueva York, Estados Unidos de América: Harper Torchbooks.

Taussig, Michael

1984 "Culture of Terror - Space of Death. Roger Casement's Putumayo Report and the Explanation of Torture". En: Comparative Studies in Society and History, volumen 26, número 3. 473-478.

Turner, John Kenneth

2014 "México Bárbaro". En: John Reed y John Kenneth Turner, México Bárbaro / México Insurgente. México D. F.: Grupo Editorial Tomo.

Van der Linden, Marcel

2013 Trabalhadores do Mundo. Ensaios para uma História Global do trabalho. Campinas, Brasil: Unicamp. 

4

Conflictos y luchas 



\title{
Introducción
}

\author{
Gabriela Scodeller (Argentina)* \\ Lucas Poy (Argentina)** \\ Sergio Serulnikov (Argentina) $)^{* * *}$ \\ Carlos Illades (México) ${ }^{* * * *}$
}

¿Cuál es el punto de partida de la historia de las luchas de trabajadores y trabajadoras? ¿Cuándo comienza la historia de los conflictos del trabajo? ¿Cuáles son los límites geográficos de nuestras unidades de análisis? Cuando Lucas Poy y Gabriela Scodeller, los coordinadores, realizamos la convocatoria a la segunda sesión del congreso en La Paz, nos interesaba particularmente establecer un intercambio entre quienes examinamos los conflictos del trabajo en distintos periodos y espacios geográficos: un diálogo que habitualmente se ve obturado por la especialización en que nos entrampa la producción académica. ¿Qué puentes pueden trazarse entre las rebeliones de esclavos e indígenas en tiempos coloniales con las resistencias individuales a los procesos de proletarización o con los movimientos y los partidos obreros más recientes? Buscábamos promover una visión de conjunto sobre la conflictividad en la historiografía del trabajo y las/los trabajadores en América Latina, revisitando áreas, temas y problemas nodales, o al menos reflexionar en torno a la posibilidad de elaborar dicha síntesis, sus pros y sus contras.

Las propuestas de ponencias que recibimos fueron ilustrativas de estas particularidades de nuestro campo. En buena medida, se trataba de trabajos anclados en el largo siglo XX y que abordaban temas acotados espacial o temporalmente; en general, revelaban poco entusiasmo por mirar más allá del caso de estudio, por las comparaciones diacrónicas o translocales. La selección de trabajos que finalmente se presentaron en la mesa apuntó a lograr un siempre difícil equilibrio en términos de países y de género, a su vez contemplando cierta diversidad temática y temporal. Toda la región, a excepción del Caribe,

* Consejo Nacional de Investigaciones Científicas y Técnicas (CONICET), Instituto de Ciencias Humanas, Sociales y Ambientales (CCT Mendoza).

** Consejo Nacional de Investigaciones Científicas y Técnicas (CONICET), Instituto de Historia Argentina y Americana Dr. Emilio Ravignani, Universidad de Buenos Aires (UBA).

*** Consejo Nacional de Investigaciones Científicas y Técnicas (CONICET), Universidad de San Andrés (UDESA).

**** Universidad Autónoma Metropolitana (UAM-Cuajimalpa). 
estuvo representada. En términos cronológicos, la sesión abarcó desde las últimas décadas del siglo XVIII hasta el último tercio del siglo XX, desde la crisis del orden colonial hasta el proceso de dictaduras en el Cono Sur.

La exposición y el debate colectivo de los 12 textos presentados permitieron un conjunto de valiosas observaciones y reflexiones. El esfuerzo realizado por correr las fronteras temporales de lo que clásicamente suele considerarse la historia del movimiento obrero permitió que la mitad de las ponencias refiriesen a una variedad de actores (indígenas, artesanos urbanos, trabajadores forzosos o gratuitos, campesinos u otros referenciados más amplia y genéricamente como plebe urbana o clases populares) que difícilmente respiran el mismo aire que el proletariado urbano, industrial, masculino y blanco. Tanto las ponencias y las intervenciones de Carlos Illades y Sergio Serulnikov, los comentaristas, como las discusiones posteriores dejaron entrever también una preocupación por cómo conceptualizar a estos sujetos de los que se habla, cuestión fundamental si se pretende comenzar a entramarlos en términos culturales e identitarios.

$\mathrm{El}$ intercambio entre investigadores e investigadoras que usualmente circulamos por circuitos de producción distintos permitió un beneficioso cruce de interrogantes y miradas analíticas. Como se señaló en su momento, muchas de las ponencias se encontraban informadas más por el núcleo de preocupaciones propio de una historia política de los grupos subalternos que por los de una historia social del trabajo y sus conflictos; sin embargo, el problema era mirado ahora desde otro ángulo, el del cruce entre trabajo y conflictividad. Dicho de otro modo, nuevamente el esfuerzo por ensanchar las fronteras del trabajo en términos cronológicos hacía que quienes nos dedicamos al largo siglo XX nos nutriéramos de las preguntas de una tendencia ya instalada entre quienes estudiamos el periodo tardocolonial o el siglo XIX.

Como condensación de dicha jornada y algunos de los debates que se pusieron sobre la mesa, esta publicación reúne cuatro trabajos que recorren distintos puntos de América Latina a lo largo de un amplio marco temporal: desde fines del siglo XVII hasta mediados del siglo XX. Nos permiten mirar nuevos sujetos y pensar cómo nombrarlos y cómo conceptualizar sus formas de hacer política; expandir el horizonte de lo que se consideraba entonces o consideramos hoy como trabajo, y la diversidad e imbricación de tipos y situaciones laborales; atender el conflicto y repasar sus múltiples formas de expresión, más o menos solapadas, individual o colectiva.

Rossana Barragán se adentra en la complejidad de la coexistencia de situaciones laborales en el Potosí de los siglos XVII y XVIII, invitándonos a pensar cómo se fue reconfigurando la mita desde los discursos e intereses de las altas esferas coloniales, pero también, y fundamentalmente, desde las prácticas de los propios mitayos. De este modo, discute con una mirada que 
ubica al trabajador minero de la época colonial como un sujeto pasivo que sufrió las consecuencias de esa forma de explotación laboral.

El texto recorre el debate entre las autoridades coloniales en torno a la mita como servicio personal en nombre del bien público. En la escucha de estas voces "desde arriba" se advierte que, en tanto símbolo de opresión, la mita comenzaría a ser fuertemente deslegitimada. A su vez, la lectura a contrapelo de estos documentos permite a la autora resaltar la enorme dificultad que autoridades y azogueros encontraron para controlar la mano de obra. Aparecen así las respuestas que los mitayos diseñaron a fin de correrse de dicha situación laboral hacia otras más beneficiosas. Leída desde estas acciones que tenían lugar "desde abajo", la disminución numérica del trabajador mitayo posibilita visualizar una serie de estrategias individuales y colectivas, en la perspectiva de mejorar sus condiciones de existencia; pagar, ausentarse o migrar eran maniobras activas de la población indígena ante la mita. De allí que emerjan con mayor fuerza los k'ajchas y los trapicheros. Ambos sistemas coexistían y quienes producían en los trapiches también trabajaban o estaban relacionados con quienes extraían el material de la mina. Si la modalidad practicada por k'ajchas y trapicheros muestra la búsqueda de mayores beneficios y grados de autonomía, estos también fueron tolerados por la alta rentabilidad que suponían sus tareas para la Corona. Al mirar el mundo de la producción minera potosina en su complejidad, considerando todas estas categorías de trabajo como temporales, Barragán logra reponer la agencia de los trabajadores mineros del siglo XVIII.

Por otra parte, el artículo de Barragán agrega un grado de complejidad mayor a los debates sobre los modos en que históricamente se empalmaron trabajo libre y no libre, ya que la dinámica potosina no presentó continuidad ni oposición, sino coexistencia en los propios cuerpos de las y los trabajadores de la mina, quienes circulaban de una situación laboral a otra. A su vez, a las múltiples formas de lucha esbozadas por distintos autores (resistencias cotidianas, acuerdos y pactos de reciprocidad o rebeliones e insurrecciones), la autora suma la estrategia desplegada por los trabajadores mineros en la reformulación de sus propios modos de trabajo y la participación de estos en los mercados, entendida como una forma más de lucha contra las condiciones que les deparaba el sistema de la mita.

Huascar Rodríguez García presenta un estudio ubicado entre las últimas décadas del siglo XIX y el primer tercio del siglo siguiente. Explora la construcción del imaginario construido "desde tiempos inmemoriales" en torno al campesino del Valle Alto cochabambino, como pícaros y ladrones, identificación que a su vez despierta orgullo entre los vallunos al insinuar un espíritu justiciero y rebelde en una subregión no solo importante geoestratégicamente en la época sino emblemática, pues allí surgiría posteriormente el sindicalismo campesino boliviano. 
Ubicándose en una nutrida tradición de estudios que articularon, sobre todo para las áreas rurales, la relación entre delito/criminalidad y resistencia, el autor se pregunta hasta qué punto el robo en el trabajo y el robo como trabajo pueden ser pensados como una forma de protesta contra un sistema considerado injusto. En una época de recurrentes crisis agrícolas, destaca una serie de prácticas ilegales como el extendido (e institucionalizado) chajmeo (costumbre que atentaba contra la noción liberal de propiedad privada), los robos de cosechas o alimentos con fines de subsistencia y los sabotajes clandestinos realizados contra los hacendados, en las que puede observarse un trasfondo político por más que no siempre fuese deliberado o tuviese sólidas bases organizativas, aunque sí una potente utopía, la de la tierra propia. El bandolerismo también ocupó la escena del Valle Alto, práctica que es caracterizada como antisocial por la falta de simpatía popular que generaba, y en tanto no encarnaba ningún tipo de noción alternativa de justicia.

El texto de Rodríguez García deja relucir una interpretación minuciosa de cada una de estas prácticas, destacándose la multiplicidad de sentidos con que fueron impulsadas. Actualizando la vieja polémica suscitada por Eric Hobsbawm en torno a la caracterización de los movimientos sociales premodernos, el autor sostiene que el campesinado valluno se expresaba soterradamente en el mundo de la infrapolítica. Analizando este quehacer (en las condiciones en que vivían y trabajaban, como las concepciones del mundo que los atravesaban), afirmará que su accionar poseía un nítido trasfondo político o, más bien, que no había nada allí que no fuese político. Asimismo captura la densidad y los matices de esta sociedad campesina y, sobre todo, los diversos niveles en que operaban las relaciones sociales; logra con ello restituir el significado social profundo de las prácticas colectivas que describe. De un modo elocuente, muestra la articulación de los ilegalismos con dos componentes centrales de la sociedad boliviana decimonónica en general y cochabambina en particular. Por un lado, la extrema labilidad de los derechos de propiedad y la compleja coexistencia o yuxtaposición de derechos privados, corporativos o comunitarios. Por otro, la irreductible aspiración de los campesinos cochabambinos a la propiedad parcelaria de la tierra, a dejar de ser colonos de las haciendas.

Pablo Ferreira nos lleva al mundo popular urbano montevideano en los primeros años del siglo XIX. Se detalla un espacio social híbrido, conformado por esclavos empleados en el comercio o la manufactura, artesanos pobres, vendedores ambulantes, pescadores, peones, entre tantos otros, de diversa condición jurídica y origen étnico. Reconstruye sus demandas y la forma en que fueron convocados o se hicieron visibles en la esfera pública, apelando a un variado pero conocido repertorio de acciones. De igual modo, fueron múltiples los espacios de socialización y los canales por los que transcurría 
la política para quienes, en principio, la tenían vedada. Si la participación plebeya en acciones tumultuarias erosionaba barreras sociales, la milicia fue el espacio por antonomasia en que se procesó esa participación.

Como parte de un proceso de renovación historiográfica que busca reponer la participación política de un sector social que hasta no hace muchos años había ocupado un lugar marginal en los estudios de las guerras de independencia, la indagación de Ferreira nos muestra el impacto y la dinámica de la participación de la plebe urbana en distintos momentos del ciclo revolucionario (en la mayoría por circunstancias políticas y en algunos por cuestiones económicas). Su texto permite percibir en todas sus dimensiones las derivaciones sociales que tuvo el elevadísimo nivel de militarización de la población urbana durante el periodo revolucionario, la cual posee una dimensión trasformativa en sí misma, ya que tiene el potencial de alterar las relaciones sociales de manera profunda y duradera con prescindencia de los resultados de la conflagración. La incorporación de las clases populares a las fuerzas bélicas introdujo nuevos mecanismos de diferenciación social, fenómeno que puso en cuestión las pluriseculares divisiones estamentarias de la sociedad de las Indias. A su vez, el análisis destaca cómo el efecto social disruptivo de la militarización no fue menor por tratarse de fuerzas realistas. Vale decir, las derivaciones de la militarización contrarrevolucionaria fueron igualmente corrosivas que las de la militarización revolucionaria, al contribuir ambas a la expansión del ámbito legítimo de intervención de los grupos plebeyos en los asuntos públicos, en las cuestiones de Estado.

Como otros, el texto de Ferreira prueba un fenómeno inherente a la crisis de las sociedades de Antiguo Régimen, particularmente durante la era de las revoluciones atlánticas. En la medida en que en dichas sociedades las personas del común no constituían sujetos de opinión, lo nuevo, lo subversivo del surgimiento de espacios públicos de deliberación sobre asuntos de interés común, radicó menos en el contenido de las opiniones de estas personas que en la reivindicación de su legítimo derecho a opinar.

Finalmente, Renán Vega Cantor y Luz Ángela Núñez Espinel abordan la experiencia social y política de los trabajadores de una industria extractiva, y sobrevuelan el tema de los discursos e identidades nacionalistas en juego en la conciencia de los trabajadores de ese sector estratégico de la economía. Se trata de un estudio sobre los trabajadores petroleros de la Tropical Oil Company en la región colombiana del Magdalena Medio, entre las décadas de 1920 y 1950. El concepto de enclave, utilizado para caracterizar la implantación de la empresa extranjera en la región, recorre todo su texto y juega un papel explicativo importante; se analizan los distintos periodos de su implantación, cada uno con sus especificidades laborales. Vinculado a ello, la investigación ancla la radicalidad de estos obreros (quienes llegaron a una experiencia de 
poder popular local en 1948), en una diversidad de factores: las condiciones de trabajo y de vida, y la segmentación social-nacional y sexual del territorio; las características culturales y la procedencia geográfica de los trabajadores, que muchas veces llevó a divisiones y conflictos horizontales; sus afectos, hábitos culturales y recreativos; sus reclamos, los primeros pasos clandestinos de organización y el posterior crecimiento sindical, las ideologías y las formas de lucha; y también las respuestas patronales y estatales. Como resultado de la vida compartida en los campos de explotación petrolera, los obreros formaron una identidad comunitaria y otra de clase.

De todos los artículos que componen este apartado, este es el que, por periodo, sujeto y rama que analiza, se ubica sin tensiones en el campo clásicamente delimitado como propio de la historia del movimiento obrero. Haciéndose eco también aquí de un renovado análisis, se incorpora una dimensión de género que enriquece tanto la mirada sobre la organización productiva y espacial del enclave como la esfera reproductiva y de la vida cotidiana. Se señalan, por un lado, la prostitución y otros oficios femeninos no reconocidos pero vitales para el funcionamiento del enclave y, por otro, su participación en la protesta. En un contexto en el que el machismo generaba una explícita marginación de las mujeres en el potente movimiento sindical, destaca la intervención de estas en dos importantes huelgas.

Al hablar de una ideología de la protesta obrera antiimperialista y de corte nacional (potenciada por el reclamo de nacionalización del petróleo) y mostrarnos cierta tensión entre la fuerte cohesión que generaba la vida comunitaria con la fragmentación laboral y social entre las poblaciones obreras que convivían en el enclave según su origen nacional o étnico, el texto de Vega Cantor y Núnez Espinel nos permite reflexionar también sobre un tópico complejo, la relación entre nacionalismo, regionalismo e identidad.

En una mirada de conjunto, los cuatro trabajos aquí reunidos son una muestra de los debates que recorrieron nuestra mesa en el congreso de La Paz, que a su vez no eran más que una selección (arbitraria, como todas) de la profusa y valiosa historiografía sobre conflictividad del trabajo que se produce en América Latina y explora los más diversos periodos y geografías. Reunirlos en una publicación es una apuesta por mostrar que, más allá de que abordan situaciones muy distintas, tienen al mismo tiempo un hilo conductor común: el de reponer el protagonismo de las personas que vivían de su trabajo en América Latina y que ensayaron luchas colectivas para defender sus derechos, mejorar sus condiciones de vida e imaginar alternativas emancipatorias. Creemos que este cruce entre distintos periodos y geografías constituye un elemento clave para enriquecer la historiografía latinoamericana del trabajo en el futuro. 


\title{
El "bien público" del trabajo compulsivo en entredicho: contrapuntos de voces y acciones en Potosí (siglos XVII-XVIII)
}

\author{
Rossana Barragán R. (Bolivia/Holanda)*
}

RESUMEN: A partir de la importancia de los k'ajchas y los trapicheros en la minería potosina del siglo XVIII, nos preguntamos: ¿cómo conciliar ese mundo, mucho más autónomo, libre y empoderado con el servicio personal de los mitayos instaurado en nombre del bien público y descrito como "horror" a fines del siglo XVII y como "esclavitud temporal" a fines del siglo XVIII por algunas autoridades coloniales? Se busca, por tanto, contribuir a pensar en lo que hicieron los trabajadores frente a la mita y al trabajo minero desde lo que denominamos las "voces" desde arriba y las "acciones" desde abajo porque ambas se entretejen y entraman. El argumento central es que la mita fue cuestionada desde las altas esferas coloniales, lo que consideramos que la deslegitimaba, pero fue también resquebrajada desde los propios involucrados. Los mitayos no solo evadieron la mita, sino que buscaron también cómo sacarle mayor provecho a la minería siendo mingas alquilados pero también k'ajchas o trabajadores independientes. Por consiguiente, debemos pensar en diferentes situaciones laborales de trabajo más que en diferentes tipos de trabajadores. Se fueron creando entonces espacios más autónomos y propios con los que generaban recursos económicos. Esto supone que entre la resistencia como despliegue de armas cotidianas infrapolíticas (James Scott), los acuerdos y pactos de reciprocidad de derechos y obligaciones (Tristan Platt) o las abiertas rebeliones, se debe pensar en la sistemática participación y el involucramiento en la nueva economía, como lo hicieron los mitayos y como lo hicieron los k'ajchas y trapicheros.

Palabras Clave: Potosí; servicio personal; mita; minería; trabajo libre no libre e independiente; agencia indígena.

\section{INTRODUCCIÓN}

"Su nombre... es Agustín Quespi, su patria esta Villa...". Presentado así por el cronista potosino Bartolomé Arzáns de Orsúa y Vela, Quespi es un héroe

* Doctora por la Escuela de Altos Estudios en Ciencias Sociales de París. Instituto Internacional de Historia Social (IISG), Coordinadora de Historia. Contacto: rba@iisg.nl 
popular. Andaba con un par de pistolas, con sus herramientas y cuatro apiris como compañeros, y como no tenía mina propia, entraba en las desiertas, sacando metal, pero sin hacer daños. Causaba temor en indios y españoles; azotó a los guardas del cerro y resistió incluso al alcalde mayor de minas, que lo buscaba por las quejas recibidas de los mineros azogueros. Como no lograban prenderlo, se decía que tenía un pacto con el demonio. Pero muchos tenían también amistad con él, porque entregaba quintos a su majestad y era liberal con el culto divino. Su riqueza y estima de parte de muchos españoles y curas lo salvaron hasta que llegó su ruina y fue acusado de homicida, de derribar puentes en las minas, de capitanear bandidos ladrones, de azotar españoles y de haber tenido resistencia a la justicia. Agustín Quespi era capitán de los k'ajchas (Anzáns de Onsúa y Vela, 2012-1965: 201 ${ }^{1}$ ). ${ }^{2}$

Este relato nos enfrenta a la fuerza y el poder de un personaje como Quespi, y la investigación que estamos realizando corrobora esa visión. Los k'ajchas que ingresaban los fines de semana al cerro, descritos como "ladrones" de mineral, estuvieron articulados a los trapicheros, ${ }^{3} \mathrm{y}$ ambos tuvieron un empoderamiento a mediados del siglo XVIII. Constituyeron un importante contingente de trabajadores y beneficiadores de plata, hombres y mujeres (más de 500 personas) produciendo hasta el 50\% de la plata de Potosí, ${ }^{4}$ desplegando también prácticas, tecnologías y conocimientos (Barragán, 2014, 2017). La actividad de k'ajchas y trapicheros no fue por tanto colateral o marginal sino central en Potosí del siglo XVIII, constituyendo otra faceta de la minería potosina y de los trabajadores.

Pero ¿cómo conciliamos o entendemos el mundo de los k’ajchas y trapicheros con el mundo de la mita minera potosina o trabajo coactivo

1 Edición de Lewis Hanke y Gunnar Mendoza.

2 El término aparece escrito de diversas maneras. La palabra k’ajcha sería quechua y aludía al sonido de la honda utilizada para ahuyentar a las personas que se acercaban a ellos al interior de las minas (Anónimo, Descripción histórica de Potosí, 1759: 256). Gunnar Mendoza, en 1965, planteó que en quechua significaba "brioso, atrevido, atemorizador", relacionando este sentido al trabajo que realizaban clandestinamente durante dos noches (Hanke y Mendoza, 1965, tomo II: 477). Pero consideró también su significado aymara, relacionado al trueno o al rayo (Mendoza, 1983: XLI).

3 Eran los que trabajaban en los trapiches. Un trapiche consistía en una instalación en la que existía un sistema que permitía la trituración del mineral extraído gracias a una piedra solera de base sobre la que se acomodaba otra, llamada voladora, movida para lograr la molienda.

4 Se conocía que la producción de los k’ajchas podía ser del $15 \%$ al $35 \%$, pero una fuente reciente permite apreciar que entre 1751 y 1774 fue de alrededor del $50 \%$ (AGI Charcas 692, cuerpo 13). 
considerado como "horror" por el oidor de Quito y Lima, Matías Lagúnez, que abogó por su abolición a fines del siglo XVII, y como "esclavitud temporal" por el fiscal de la Audiencia de Charcas, Victorián de Villaba, a fines del siglo XVIII? ¿Qué tipo de trabajo y actividad desarrollaron los k'ajchas y los trapicheros y cómo se relacionaron con los mitayos?

Nuestro interés se sitúa desde la agencia de los trabajadores porque cuando se habla de los mineros del siglo XX emergen aguerridos luchadores sindicalizados, mientras que para la época colonial la visión aún predominante es la de sujetos pasivos que sufren las consecuencias de la mita minera. ${ }^{5}$ Esta perspectiva es el resultado, al menos en parte, de la convergencia de tres factores. En primer lugar, de las visiones críticas pero compasivas de las autoridades coloniales que describieron y cuestionaron la mita por diversas razones, incluyendo su oposición a la minería como sector que recibía políticas que se consideraban privilegiadas. En segundo lugar, de la existencia de la mita durante más de dos siglos y medio. En tercer lugar, de la ausencia de mayores fuentes que muestren el cuestionamiento explícito desde los mitayos. ${ }^{6}$

En este artículo buscamos contribuir a pensar lo que hicieron los trabajadores frente a la mita y al trabajo minero desde lo que denominamos las "voces" desde arriba y las "acciones" desde abajo, porque ambas se entretejen y entraman. ${ }^{7}$ Nuestro argumento central es que la mita fue cuestionada

5 Es fundamental recordar que el trabajo minero en Bolivia es, hasta hoy, uno de los más duros y realizado en condiciones muy precarias.

6 La pregunta es por qué la mita no figura de manera mucho más visible en los archivos cuando tenemos cientos de expedientes sobre tierras, repartos o cuestionamiento a los caciques. No siempre figura como demanda en las revueltas y rebeliones del siglo XVIII. En el caso de Túpac Amaru, sí se dio una explícita demanda contra la mita. Se trata de una carta escrita por él en 1777 que hacía referencia a la distancia, los viajes, el cambio de temperamentos y también a la "granjería" que hacían con los indios. Señalaba que los trataban como a esclavos. Pidió también que la provincia de Canas y Canchis no esté obligada a la mita de Potosí. Se refirió, igualmente, a la dolorosa despedida que hacían y a la disminución poblacional (véase: Lewin, 1967: 320-323). Entre las posibles explicaciones aludidas se encuentra la de considerar el pacto de reciprocidad de derechos y obligaciones. Tristan Platt, Thérèse Bouysse-Cassagne y Olivia Harris señalaron que las protestas de los caciques charka y qaraqara contra el trabajo minero eran muy pocas y solo pedían que no se aumentara el número de mitayos (2006: 368). El caso de la mita "nueva" en 1795 sí suscitó amplias protestas.

7 Dada esta aproximación, proporcionamos perspectivas más generales sin todo el detalle de cada aspecto que estamos abordando en la investigación para el libro que estamos realizando. 
desde las altas esferas coloniales, lo que consideramos la deslegitimaba, pero fue también resquebrajada desde los propios involucrados. Planteamos que la disminución de los mitayos debe ser vista también como deserción de un trabajo mal pagado a través del ausentismo y las migraciones, pero también a través del pago de montos en dinero que les permitía exonerarse para no ir a Potosí o para trabajar allí con salarios más altos, con mejores condiciones pero, sobre todo, con mayor autonomía y recursos. Esto supone que los mitayos desarrollaron estrategias que les permitieron ocupar otras situaciones laborales. El trabajo de los mitayos no puede por tanto entenderse si no se toma en cuenta la dinámica del mundo laboral minero en Potosí. Desde esta perspectiva es importante recordar que los mingas podían ser los propios mitayos y aunque algunos estudiosos lo señalaron antes, lo hicieron siempre de manera tangencial y no central, como lo planteamos desde el año 2014 y lo volvemos a hacer aquí. Pero, además, en la actividad económica de los k’ajchas y los trapicheros convergían distintos trabajadores. Al igual que en el caso de los mingas, si bien la historiografía se ha ocupado de los k'ajchas (Barragán, 2014), no se los ha relacionado con los trapicheros ni se ha visto las consecuencias de que ambos produjeran del $30 \%$ al $50 \%$ de la plata potosina. Finalmente, no se ha considerado cómo estas características implican una particular situación del centro minero potosino, en el que ser "mitayo", "minga" o " $k$ 'ajcha" podía constituir actividades y categorías de trabajo temporales como lo era también ser agricultor/ganadero. Planteamos, por consiguiente, que debemos pensar en diferentes situaciones laborales, más que en diferentes tipos de trabajadores, y el reconocer esta situación resulta vital a la hora de analizar las estrategias de respuesta y agencia de los trabajadores.

El circuito económico comenzaba, sin embargo, con la obligación del servicio personal de la mita instaurado en nombre del bien público y fue precisamente esa situación la que fue debatida y cuestionada desde arriba y desde abajo.

EN NOMBRE DEL BIEN PÚBLICO: EL SERVICIO PERSONAL Y EL TRABAJO COMPULSIVO “LIBRE, VOLUNTARIO Y OBLIGATORIO"

Aunque no podemos referirnos con detalle a la cuestión de los servicios personales instaurados desde los primeros años de la colonización, es preciso partir de una síntesis muy apretada recordando algunos puntos, autores y funcionarios coloniales clave. En primer lugar, la revisión de las fuentes tempranas muestra que la prestación de trabajo sin retribución era lo que se consideraba servicio personal como parte del privilegio que suponía la otorgación de encomiendas al inicio del proceso de la colonización. Después de los debates en los que estuvo involucrado Bartolomé de las Casas y la 
legislación que se fue desarrollando, ${ }^{8}$ se habló categóricamente de los indios como vasallos libres, lo que suponía que no estaban sujetos a la esclavitud. Sin embargo, la compulsión y la obligación para que trabajaran se hizo en nombre del bien público, invocándose también la ociosidad y la holgazanería de los indios, y en muchos casos su naturaleza servil. Esta visión se encuentra en el oidor de la Audiencia de Charcas, Juan de Matienzo, en su Gobierno del Perú. Como eran "enemigos del trabaxo" había que empujarlos a trabajar. ${ }^{10}$ El virrey Toledo expresó en su momento la misma perspectiva porque si se esperaba "su voluntad" no habría ningún trabajador disponible, aunque reconoció también que los españoles buscaban para cualquier cosa "un repartimiento" o adjudicación del trabajo de los indios. Tanto por esta razón como por el caos en la "distribución" de ese trabajo y el reducido jornal que se les daba, Toledo informó, al final de su gestión, que se ocupó de estos aspectos particularmente. ${ }^{11}$ Ordenó que solo el virrey pudiera asignar indígenas y dictó una serie de ordenanzas para el repartimiento y "servicio de las ciudades", para las minas y para el servicio de los tambos. ${ }^{12}$ En otras palabras, gran parte de la población indígena estaba sujeta a diversas mitas bajo el sistema de repartimiento. Los mitayos fueron precisamente definidos por Matienzo como "indios de repartimiento que sirven

8 Los servicios personales se debatieron ampliamente, lo que dio lugar a las Leyes Nuevas de 1542-1543 que trataron de abolir las encomiendas y cuya aplicación en el Perú implicó hasta una guerra civil. Estas leyes declararon a los indios como vasallos prohibiendo que se hiciera de ellos esclavos. "Y porque nuestro principal intento y voluntad siempre ha sido y es de la conservación y aumento de los indios, y que sean instruidos y enseñados en las cosas de nuestra santa fe católica, y bien tratados, como personas libres y vasallos nuestros"; "teniendo como tenemos a los naturales de las dichas nuestras Indias, Islas y Tierra-Firme del Mar Océano por nuestros vasallos libres"; "no se pueda hacer esclavo indio alguno". Para una breve síntesis de este periodo en Charcas, véase: Bridikhina y Arze, 2016.

9 Planteó en 1567 que eran "pusilánimes e tímidos, que les viene de ser melancólicos naturalmente, que abundan de cólera adusta fría”. Sus humores o temperamentos explicaban su contextura peculiar y particular. La melancolía o bilis negra, era seca y fría, y hacía referencia a la tierra que se relacionaba con el otoño, el atardecer y la vejez. Matienzo, 1967/1910: 14.

10 Ibid.: 16-19.

11 "Memorial que D. Francisco de Toledo dio al Rey nuestro Señor del estado en que dejó las cosas del Perú en el Virrey y Capitán General trece ańos que comenzaron en 1569". En: Relación de los Virreyes y Audiencias que han gobernado el Perú. Lima, 1867: 21 .

12 Ordenanzas “De los Mesones y ventas", ibid. 
por sus tandas que llaman mitas" (1910 [1567]: 25). Es claro, por tanto, que mitayo no era sinónimo de trabajador de las minas de Potosí. Además, a fines del siglo XVI, y según el propio virrey Toledo, el servicio personal se entendía como obligación laboral "sin jornal" (en Zavala, 1978, I: 99), en contraste con el trabajo por el bien común, "voluntario" pero obligatorio y pagado, lo que hoy nos parece una contradicción. De ahí que las disposiciones y regulaciones laborales de Toledo enfatizaran el jornal y el salario. ${ }^{13}$

En las primeras décadas del siglo XVII, se legisló sobre el servicio personal. La Cédula Real de 1601 buscó proteger la libertad de los indios como vasallos "sin nota de esclavitud ni de otra sujeción y servidumbre", pero al mismo tiempo reguló el trabajo. De manera muy clara se estableció una situación de tensión entre voluntad, compulsión y fuerza. ${ }^{14}$ De ahí que se empezó a plantear la noción de bien público, es decir el trabajo pagado "para la república", lo que justificaba la compulsión, reconociéndose, al mismo tiempo, la división orgánica del trabajo. ${ }^{15}$ A mediados del siglo XVII, el gran jurista Solórzano definió el servicio personal como el exigido a los indios, contra su voluntad, de parte de los encomenderos para cualquier fin (labores, trabajos domésticos, minas, etc.) (1703: 27). Planteó en 1647, en su Politica Indiana, que los reyes y príncipes tenían la potestad coercitiva sobre sus vasallos "siempre que entendieren que así conviene al bien universal" (ibid.: 49) y, citando las sagradas escrituras, a Matienzo y a varios autores, subrayó la obligación que existía para la guerra, pero también la interdependencia necesaria de diferentes tareas por parte de los miembros de la República, como sucedía en el cuerpo humano (ibid.: 47 y ss.).

13 El rey había solicitado a Toledo en 1575 que "los dichos indios no sean llevados contra su voluntad sino como hombres libres..." (en Zavala, 1978, I: 99 [énfasis propio]). Matienzo ya había planteado que no era quitarles la libertad compelerlos a trabajar pagándoles (ibid.: 56).

14 Se reconocía que las minas no podían atenderse sin indios, "obligándolos o compeliéndolos a que trabajen y se alquilen y no estén ociosos". El "concierto" (acuerdo, contrato, alquiler) debía ser voluntario, pero sin abandonar la obligatoriedad (Zavala, 1978, I: 4). Se habla también de "indios repartidos".

15 "Tratado que contiene tres pareceres que ha compuesto el padre Fray Miguel de Agia, de San Francisco" (Turín, 1603-1604). Agia distinguía el servicio personal para el encomendero sin pago, perpetuo, servidumbre, y sin interés público, de los tributos y el repartimiento que se hace para el servicio de la república, con libertad pública, con pago, sin violencia sino libertad natural y cristiana (en Zavala, 1979, II: 18. "Les quita la ociosidad sin privarlos de su libertad"). Decía también que era necesario que "haya pies que anden, y manos que trabajen, y cabezas que gobiernen", y que unos manden y otros sirvan y obedezcan"; "todos son miembros del cuerpo místico desta república indiana" (ibid.: 20). 
El trabajo en las minas de Potosí impuesto por el virrey Toledo a fines del siglo XVI se inscribió en este contexto. ${ }^{16} \mathrm{La}$ mita minera potosina, que supuso el reclutamiento de trabajadores de 16 provincias, implicó la movilización anual hacia Potosí de alrededor de 12.000 hombres de entre 18 y 50 años de edad, que debían trabajar por turnos semanales de 4.000 individuos. Debían permanecer en Potosí durante un año entero porque trabajaban una semana y estaban "de huelga" o descanso otras dos. Como iban con sus familias, cada año se movilizaban hacia Potosí alrededor de por lo menos 40.000 personas.

El peso que esto implicaba para las comunidades indígenas llevó a grandes transformaciones, las que nos interesa precisamente analizar, resultado de su seria impugnación desde arriba, a fines del siglo XVII, aunque a través de ellas es posible vislumbrar la acción de los mitayos desde abajo.

LAS ESTRATEGIAS DE LOS MITAYOS Y DE LOS TRABAJADORES MINEROS: DESERCIÓN, PAGOS EN DINERO E IRRUPCIÓN DE LOS K'AJCHAS Y TRAPICHEROS

Las investigaciones han mostrado que el número de trabajadores mitayos descendió particularmente a partir de 1630-1640. Paralelamente, la producción de plata potosina decayó junto al continuo declive de la población indígena mitaya, como se puede apreciar en el gráfico 1.

Gráfico 1: Producción de plata de Potosí y número de mitayos (1545-1817)

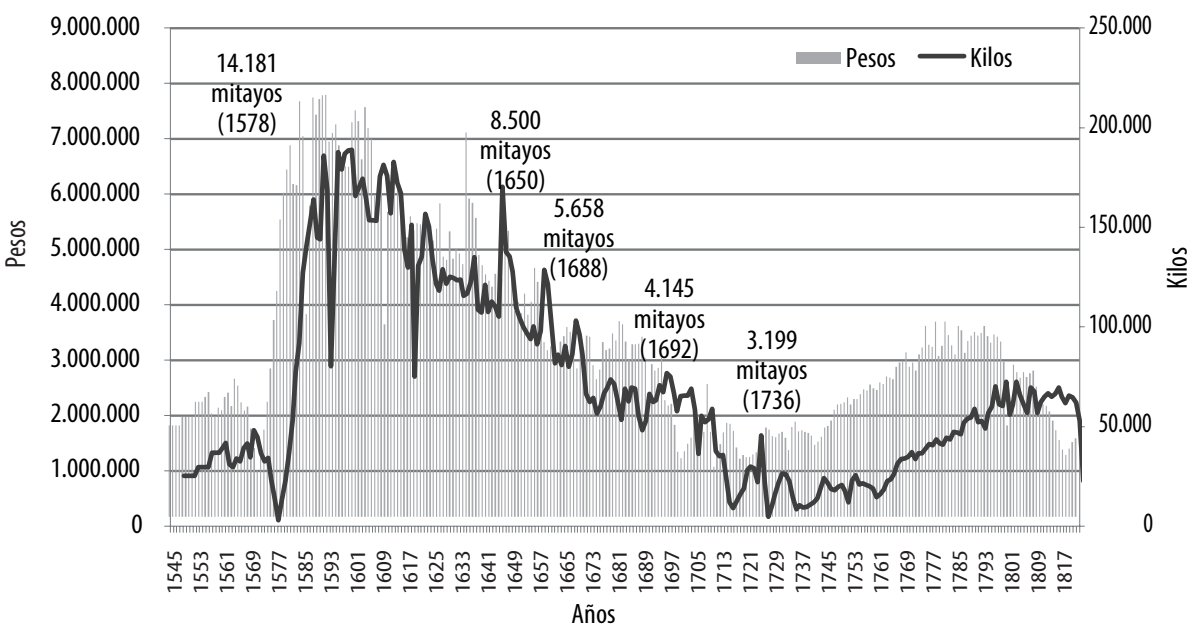

Fuente: Richard Garner, www.insidemydesk.com

16 Para una visión general sobre fines del siglo XVI, véanse: Bakewell, 1989; Zagalsky, 2014; Bridikhina, 2015. 
El número decreciente de mitayos que se observa en el gráfico 1 encubre además la prestación de la mita no ya en trabajadores sino en dinero. Así, desde 1606-1608, de $20 \%$ a $25 \%$ (e incluso hasta el $50 \%$ ) de la mita era pagada en dinero efectivo por los mitayos (Cole, 1985: 37-38; Zagalsky, 2014: 385). Se empezó a hablar entonces de indios en dinero (Bakewell, 1989: 123-124, 197; Cole, 1985: 57). ${ }^{17}$ Interesa subrayar aquí que las sumas entregadas eran bastante elevadas. El monto de solo dos pueblos de la provincia Pacajes ascendía a 16.408 pesos, y el de toda la provincia a 50.000 pesos alrededor de $1660-1665$ (Cole, 1985: 37). La cantidad de dinero del conjunto de los mitayos podía llegar a 587.000 pesos, es decir, el doble de los ingresos por impuestos de la minería de plata potosina (alrededor de 300.000. Informe de Cruz, $c f$. Cole, 1985: 92).

¿Cómo conseguían este dinero las comunidades? Existieron diversas estrategias individuales y colectivas que han sido exploradas en las investigaciones. La venta temporal de mano de obra en las haciendas o en las ciudades y la venta tanto de los productos de sus propias tierras como de las tierras del común de los llamados bienes de comunidad constituyeron una estrategia común. Otra de las modalidades que permitía conseguir efectivo fue el nombramiento de indios colquehaques, literalmente "indios de plata", en las comunidades (Sánchez Albornoz, 1978: 103). Ellos pagaban montos importantes que permitían su propia exoneración, así como la de otros miembros de su comunidad. Adicionalmente, otros ingresos podían lograrse a través del arrendamiento de tierras y, sobre todo, mediante la participación activa en todos los trajines y comercios de las comunidades cuyos ganados eran utilizados en el acarreo y el transporte de productos.

Otra importante opción para lograr numerario era el propio trabajo en las minas, incluyendo Potosí, pero como trabajadores mingas, dado que el salario era mayor. Esta situación supone una articulación entre dos estatus y situaciones laborales: implica que los mitayos podían ser mingas en las semanas de huelga o descanso. Algunas fuentes apuntalan esta práctica desde muy temprano. Jeffrey Cole señaló para 1603 que alrededor de 600 mingas podían ser mitayos en huelga (1985: 30). Pero una fuente poco utilizada de 1692 revela que esta situación pudo estar presente incluso en el diseño planificado por el virrey Toledo que había instituido la mita. Así, el fiscal de la Audiencia de Lima explicó que Toledo ordenó que los mitayos:

17 Hay una diferenciación con los indios de faltriquera, aunque ambos están articulados. El monto entregado en dinero por los que no iban a la mita se destinaba, en principio, a alquilar a otros trabajadores o indios voluntarios o mingas. Cuando ese monto iba directamente a los bolsillos del empresario minero, se denominaban "indios de faltriquera", situación que era considerada como una descarada exacción y total corrupción porque no era empleada para la producción. 
[...] descansen dos [semanas] así porque tuviesen este alivio, como para que las semanas de descanso se pudieran mingar (que es alquilarse) y aplicarse al rescate de metales, sus guairas ofundiciones en hornillos y otras grangerias que les fueren de mas conveniencia que el jornal de la mita. ${ }^{18}$

Explicó también que La Palata planteó disminuir el número de semanas, ${ }^{19}$ suscitando gran queja de los indios, tanto "por el corto descanso" así como "por no poderse mingar" y ganar siete pesos en lugar de solo 29 reales. ${ }^{20}$ Por consiguiente, hay que pensar que la fuga de la situación de mitayo para poder trabajar como minga fue otra poderosa razón para explicar la disminución del contingente de mitayos.

Estos datos corroboran un planteamiento que hizo Mattew Smith (2004) hace algunos años: que la fuga de la mita no era una fuga de la minería o de la ciudad de Potosí porque este centro minero constituyó un polo económico y poblacional de gran atracción. ${ }^{21}$

El constante ausentismo de mitayos debe ser considerado entonces como deserción, una deserción que oculta múltiples estrategias. Ausentismo, movilidad geográfica y deserción constituyen algunas de las expresiones más conocidas de las estrategias individuales y colectivas de los trabajadores en diferentes partes del mundo. Eran también una manera de negociar las condiciones laborales y escapar de ellas temporal o definitivamente. "Caminar y huir con los pies" fue uno de los actos más importantes en muchas de las sociedades donde imperaban trabajos no libres. ${ }^{22} \mathrm{La}$ particularidad en Potosí es que uno de los objetivos de estar ausente era pagar para estar exento de la mita para aprovechar mejores oportunidades de venta de su fuerza de trabajo.

La disminución de mitayos en Potosí, junto a la disminución de la producción, llevó a que los mineros azogueros reclamaran una serie de medidas a su favor. Ya en 1645 presentaron un documento titulado "Pretensiones de la

18 AGI Charcas 272, ff. 11v-12 [énfasis propio]; véase también: Cole, 1985: 32 y 43.

19 Quiso que saliesen menos indios de las comunidades (repartió 2.829) para el trabajo continuo y por tanto solo tenía que tener un total de 5.658, porque teniendo solo una semana de descanso no era necesario más que duplicarlos (AGI Charcas 272, ff. 12v-13).

20 AGI Charcas 272, f. 48.

21 Esto mismo estaría encontrando Gil Montero en su reciente investigación sobre la Visita de La Palata, donde observa que la mayor parte de los indígenas de una comunidad estaban viviendo en Potosí.

22 Véase, por ejemplo: Van Rossum y Kamp, 2016 
Villa Imperial de Potosí”, en el que planteaban un plan de reactivación consistente en una disminución del impuesto a la Corona (del quinto o $20 \%$ al diezmo o 10\%), mayores facilidades en el aprovisionamiento de mercurio y la realización de una nueva numeración de la población indígena (Cole, 1985: 52-53; González Casasnovas, 2000: 93), base para una reorganización del trabajo mitayo dirigido a Potosí. En este contexto se sitúa la numeración de la población indígena realizada por el virrey Duque de La Palata en 1689, que mostró una importante disminución y una distinta distribución de la población indígena con relación a la que existía en 1570-1575. Para acercarse y volver a las cifras iniciales de la mita de fines del siglo XVI, había que incluir ahora a la población indígena forastera que había aparecido en las provincias sujetas a la mita, pero también extender la mita a algunas provincias antes exentas.

Las reformas que La Palata quiso introducir, así como la oposición generalizada que suscitó, dieron lugar a un análisis serio y a una gran discusión sobre la mita entre las autoridades coloniales. En 1691, el nuevo virrey Monclova convocó a una Junta integrada por oidores de la Audiencia de Lima, el Protector General de Indios, el excorregidor de Potosí y el representante de los mineros para analizar la política planteada por La Palata. Uno de los involucrados fue el fiscal Matías Lagúnez, que ha dejado un impresionante y voluminoso alegato en el que sugiere la abolición de la mita. Fue Lagúnez quien transmitió tres interpretaciones que han sido retomadas por los historiadores. En primer lugar, que existían dos mitas: la que se permitía y la que se practicaba, posición planteada por González Casasnovas (ibid.: 274 y 29); en segundo lugar, que el trabajo minero de los mitayos subsidiaba a la minería a través del corto salario que les era pagado (ibid.: 303 y 311), perspectiva sustentada también por Enrique Tandeter, que planteó que el centro minero potosino no podría subsistir en condiciones de un mercado libre; finalmente, que el "horror de la mita" consistió en la gran mortandad y disminución de la población nativa en las provincias precisamente sujetas a este trabajo.

Lagúnez buscó desbaratar otra interpretación existente entonces: que el descenso poblacional no debía atribuirse al movimiento de la población de las provincias sujetas a la mita hacia las provincias libres de la mita, sino a la mortandad causada por ese trabajo. Para esa autoridad, se "consumieron" ("aniquilaron") 58.075 indios que eran las dos terceras partes de la población numerada por el virrey Toledo. ${ }^{23}$ Con este argumento buscó que la Corona decidiera la abolición de la mita. El rol del trabajo mitayo en el declive poblacional es hasta hoy un tema pendiente que ni la historiografía

23 Toledo había encontrado 91.498 indios tributarios originarios y en la Visita de La Palata no se habrían encontrado más que 33.423 (AGI Charcas 272, 1261 ff.). Véanse particularmente: ff. 99-200. Estamos haciendo un análisis de este documento. 
ni los análisis demográficos y poblacionales han encarado. En todo caso, los antiguos aportes de Nicolás Sánchez Albornoz, Carlos Sempat Assadourian y Thierry Saignes mostraron que importantes migraciones fueron parte de las estrategias indígenas para escapar a la mita, acogiéndose en otros pueblos y comunidades como forasteros o en haciendas como yanaconas, o, finalmente, en las ciudades (Saignes, 1985: 8), como mencionamos antes.

Por el momento es fundamental reconocer que la interpretación de Lagúnez es parte de un importante conflicto de la época. El tema es complejo pero de manera muy sintética podemos decir que la mirada cristiana, piadosa y humanitaria encubre el enfrentamiento y la pugna entre diferentes intereses económicos sobre el mayor o el menor control que podían tener sobre la mano de obra. ${ }^{24}$ Para muchos sectores en el virreinato del Perú, la asignación de mitayos trabajadores de 16 extensas provincias en provecho de un escaso número de mineros azogueros era una política de absoluto privilegio y subsidio en desmedro de otras regiones y sectores.

En las últimas décadas del siglo XVII, se vivieron, por tanto, las discusiones que se desencadenaron como consecuencia de las tres modalidades que se habían desplegado para enfrentar y eludir la mita. Recordémoslas de manera sintética. En primer lugar, el pago en dinero realizado por las comunidades y los mitayos para no trabajar como tales, permitiendo que en su reemplazo se contratara a otros trabajadores gracias a la suma erogada; "pagar" para no ser mitayo supone una incursión continua en los circuitos mercantiles (el espacio de los trajines y el rol de las caravanas de llamas son fundamentales, cf. Glave, 1989; Medinaceli, 2010). En segundo lugar, el figurar como trabajador ausente, ausencia que fue bajando incesantemente las cuotas de la mano de obra que debía ser entregada en Potosí. En tercer lugar, el migrar hacia las provincias no sujetas a la mita. Estos tres procesos, analizados por la historiografía como impacto y consecuencias de la mita, deben considerarse, simultáneamente, como las principales acciones, intervenciones y respuestas activas de la población indígena. Desde el punto de vista del trabajo en la mita de Potosí, señalamos ya que el ausentismo y las migraciones deben ser considerados como deserciones laborales. Es claro, en consecuencia, que, tanto por las acciones de los mitayos como por las discusiones y las determinaciones de las autoridades, la mita continuó, pero bien disminuida. La dinámica laboral se volvió mucho más movida y compleja.

24 Las altas autoridades religiosas consideraban que alterar la geografía de las estructuras y los acuerdos (implícitos), buscando un mayor drenaje hacia la minería, podía significar, como ha mostrado González Casasnovas (2000: 256 y 277), poner en peligro las unidades productivas agrícolas que podían quedar sin trabajadores, amenazando los propios ingresos de la Iglesia católica a través de los diezmos (Cole, 1985: 125). 
En el siglo XVIII emergieron, o se visibilizaron, otros actores como los k'ajchas y los trapicheros, un mundo que expresa la constitución de un circuito económico (paralelo al de los azogueros) de extracción de los minerales del cerro, su procesamiento en los trapiches hasta la obtención de plata y su posterior venta.

La extracción estaba a cargo de los k'ajchas que ingresaban al cerro los fines de semana. Aunque esta práctica pudo existir antes, los k'ajchas parecen haber tenido un empoderamiento a mediados de $1700 .{ }^{25}$ Así, el jueves 4 de febrero de 1751, en pleno Carnaval, se celebraba ya la fiesta de la Caccha Cruz, auspiciada por "los trapicheros", llevándose la cruz de la capilla de los k'ajchas a una de las parroquias indígenas de la Villa para celebrar allí una misa. ${ }^{26} \mathrm{La}$ fiesta de 1751 , que seguramente estaba ya instituida, se dio en un contexto de fuertes tensiones con las autoridades, algunas de las cuales buscaban erradicar a los k'ajchas y demoler los trapiches. El alcalde de minas dijo que cuando subió al cerro "lo quisieron matar [...] porque dichos cacchas estauan alsados [...] para matar a quantos se les opusiesen". Recordó también la muerte de un guarda y lamentó que cuando fueron a capturar a cuatro k'ajchas sus compañeros "en crezida multitud y atropellando a la Real Justicia les quitaron los presos [...]". Finalmente, la autoridad, "con el celo y experiencia y conocimiento de más de 20 años" logró apresar a uno de los principales capitanes Patapata", ${ }^{27}$ en junio de 1752. El reo habría sido finalmente ejecutado por orden del corregidor Santelices por considerársele el capitán mayor de los k'ajchas y, en 1752, el alcalde Urquizu informó que prendió “al pie del cerro rico" y en su propia morada "a Vicente Santiesteban nombrado y conocido por el equeqho uno de los principales cagchas. ${ }^{28}$ El Ekeko es hasta hoy el dios de la abundancia y el apodo que Vicente recibió puede remitir a la representación que tiene este personaje. Es un hombre que carga todos sus implementos, pero también todo lo que necesita para subsistir en la vida. Representa la aspiración de que no falten los bienes necesarios para vivir. Vicente, el ekeko minero, iba seguramente muy abarrotado de todos sus instrumentos para trabajar en la mina, como suben en general los mineros al cerro. Pero posiblemente también se asociaba a la riqueza y

25 AGI Charcas 481, AGI Charcas 435; ABNB ALP Minas 25/13, ABNB ALP Minas 28/1.

26 La capilla de los cacchas ya existía, según Arzáns Orsúa y Vela (tomo III : 201), en 1725 , así como el festejo a la santa cruz.

27 ABNB ALP Minas 25/13, ff. 420-421v.

28 ABNB ALP Minas 25/13, f. 402, 18 de julio de 1752. Véase también: Tandeter, 1992: 140-142. 
a la abundancia que tenía y logró Agustín Qhespi del relato de Arzáns, así como Vicente Santiesteban, alias el Ekeko.

Los k'ajchas llevaban sus minerales a los trapiches. En 1761-1762, una visita detalló la existencia de 220 trapiches, de los que 58 estaban en manos de los españoles y $160(73 \%)$ en manos de la población indígena en los diez curatos o parroquias indígenas ( La Ranchería) de la ciudad, donde llegaban también los mitayos. Algunos de estos trapiches eran también propiedad de mestizos y mulatos.

Algunos documentos señalan que los "yndios trapicheros" eran "empleados" como k'ajchas, como pongos (que trabajaban en el interior de las minas), palliris (trabajadores que seleccionaban el material) y barreteros. ${ }^{29}$ El nuevo gobernador de Potosí señaló también que curacas y capitanes de mita, mitayos, pongos y apiris eran k'ajchas. Aseguraba que llegaban a 4.000 , un número similar al de los mitayos, ascendiendo los trapiches a 235, los que habrían sido levantados por "Curacas y Capitanes enteradores de mita”. Aunque los testimonios podrían estar exagerando la mezcla que podía darse entre diferentes tipos de trabajadores y diferentes situaciones laborales, es fundamental subrayar que la gente que producía en los trapiches estaba relacionada o podía ser incluso la misma que trabajaba en las minas extrayendo mineral. Si las autoridades indígenas como los curacas de las parroquias estaban involucradas activamente en los trapiches, esto significaría que tanto la población local como los mitayos que llegaban a esas parroquias fueron los que dinamizaron este circuito de producción y obtención de la plata, aprendiendo a coexistir con la producción de los azogueros, cuyo trabajo estaba sustentado en la mita. Ser k'ajcha y trapichero constituía una estrategia y modalidad de intervenir en la actividad económica minera buscando ciertamente mayores grados de autonomia y mayores beneficios.

Otro de los datos importantes de la visita a los trapiches de 1761-1762 es que los que aparecían como dueños de estos trapiches no solo eran hombres sino también mujeres. Algunos nombres son claramente indígenas (como Bartholomé Canchi, Blas Condori y María Sissa) aunque hay otros como Juan Morales, Joseph Montoya y Luisa Guevara. Estos patronímicos no significan, sin embargo, que estamos tratando fundamentalmente con población no indígena. Mientras algunos nombres de los trapicheros hacen pensar que estamos frente a mestizos o a españoles, otra documentación revela que son indígenas. En 1777, por ejemplo, Blaz de Subieta hizo una solicitud a nombre de su esposa, Antonia Ybarra, por un trapiche que había heredado de su primer esposo, don Melchor

29 AGI Charcas 481, número 19. 
Gutiérrez. A medida que leíamos el documento nos dimos cuenta de que ellos no solo eran indígenas, sino indígenas mitayos del ayllu Orurillo, y que Blaz de Subieta era un zambo. ${ }^{30}$

La plata obtenida en estos trapiches era vendida al $\mathrm{Banco}^{31} \mathrm{o}$ a otros rescatiris. Los libros del Banco en 1762 muestran a más de 500 k'ajchas y trapicheros, incluyendo mujeres, que vendieron, en más de 1.500 transacciones, un monto total de casi 200.000 pesos, representando el 16\% respecto a la plata vendida por los azogueros el mismo año. Gran parte de los trapicheros realizaba una sola transacción (327 personas o 63\%), por lo que suponemos que se trataba fundamentalmente de trabajadores, tal vez mitayos, que de manera muy puntual lograban incrementar sus salarios o generar un ingreso económico adicional. En el otro extremo estaban los que vendían bastante plata, que significaba altos montos de dinero. Los trapicheros constituían entonces un mundo con grandes diferenciaciones internas (Barragán, 2014, 2017). ${ }^{32}$

Lo que interesa subrayar entonces es que el conjunto k'ajchas/trapicheros significó la emergencia de un circuito cuasi paralelo al del gremio de mineros azogueros que dio lugar a intensos debates y pugnas entre las autoridades. Mientras algunos empresarios mineros azogueros y algunas autoridades locales abogaron en general por políticas radicales para la destrucción de los trapiches, prohibiendo la práctica de los k'ajchas, las autoridades jerárquicamente superiores, como los gobernadores-corregidores, las autoridades de la Real Hacienda, el virrey y el Consejo de Indias, tuvieron una posición firme, pero al mismo tiempo de tolerancia, porque recibían beneficios de la compra de la plata (Barragán, 2014). La demolición de trapiches que había sido sugerida por algunos no tuvo lugar porque la plata que generaban "acrecentaba los reales quintos" y las arcas de la Real Corona, pero también porque la cantidad de gente involucrada era muy grande.

30 AHP Cabildo Intendencia CGI 288701777.

31 El Banco de San Carlos, bajo el total control de la Corona, fue establecido en 1779, aunque existía ya un "Banco" que compraba plata desde 1752 (Banco de Rescates, 1752-1754). Para la historia de este tipo de bancos, véanse: Méndez, 1992; Mira, 1997. Véase sobre su constitución: AGI Buenos Aires 440, Real Cédula de Incorporación del Banco de Potosí a la Real Hacienda y ordenanzas para su régimen y gobierno (Madrid, 1795).

32 AHP BSC 313, Libro donde se sientan los marcos que se traen al rescate de los trapicheros de esta rivera, 1761-1764. Para los azogueros: AHP BSC 360, Libro donde se asientan los marcos de plata que los señores Azogueros de esta Villa traen a rescatar a este Banco y mercadería que corre a cargo del Maestre de Campo, 1759-1762. 
Se ha propuesto en otro trabajo (Barragán, 2017) que en lugar de "actividad popular de fin de semana", como lo planteó Tandeter, se hable de la existencia de una "economía popular". Popular en el sentido de ser una actividad que no estuvo en manos de los azogueros tradicionales; popular por su magnitud, sobre todo por la cantidad de gente involucrada, por los montos que obtenían y por la variedad de personas, incluyendo mitayos, mulatos, mestizos y pobres españoles. Fue popular también porque fue el resultado de un campo de fuerzas. Pero tampoco se debe exagerar. Es claro que su unidad se ha construido y se construyó en relación y oposición a los azogueros, apoyados por la Corona española porque detrás de su unidad emerge también un grupo sumamente heterogéneo y desigual.

Esta situación de activo involucramiento de mitayos que podrían convertirse en k'ajchas y trabajar en los trapiches, alimentados también de otros trabajadores, contrasta notoriamente con el discurso sobre la mita del fiscal Protector de Indios Victorián de Villaba, que la impugnó dando lugar a un gran debate a fines del siglo XVIII.

\section{LoS INDIOS ESCLAVOS DE VILLABA Y EL GRAN DEBATE}

El Discurso en contra de la mita, de 1793, de Victorián de Villaba, ${ }^{33}$ debe situarse en el contexto local de un incremento de mitayos y en el contexto global de la economía política de la época (Genovesi, Filangieri y los napolitanos). ${ }^{34} \mathrm{Su}$ escrito fue profundamente interpelador porque caracterizó la mita como "esclavitud temporal de los Yndios". ${ }^{35}$ Aunque no era la primera

33 El discurso se encuentra publicado por Ricardo Levene (1946). Villaba fue autor también de Apuntes para una Reforma de España sin trastorno del gobierno monárquico ni la religión (1797). Nació en Aragón y murió en Charcas, en 1802. En 1783 pidió una plaza en la Audiencia de Buenos Aires y en 1789 se le dio su nombramiento como Fiscal de la Audiencia de Charcas, donde llegó en 1791 después de haber estado todo un año en Buenos Aires (Buechler, 1989, tomo I: 223-224). Fue fundamentalmente Levene (1946) el que lo sacó del olvido y para él fue un precursor de la emancipación. Sobre Villaba, véanse, más recientemente: Portillo, 2007; Morelli, 2006, 2010.

34 Villaba fue profesor de Derecho de la Universidad de Huesca y tradujo fragmentos del voluminoso trabajo de Filangieri, Ciencia de la Legislación (1780, 5 volúmenes), y el libro Lecciones de Comercio, de Genovesi. Véase sobre los napolitanos: Morelli y Portillo, 2007.

35 Afirmar que eran esclavos era profundamente interpelador, puesto que Vitoria, ya en el siglo XVI, había defendido la racionalidad de los indios atacando la teoría de su esclavitud (Brading, 1993: 108), mientras que Las Casas desarrolló el argumento 
vez que se calificaba así a la mita, su alegato tuvo mucha repercusión, tanto en su momento como muchas décadas después, como veremos más adelante.

Villaba explicó que, como habían prevalecido "las voces del interés, sofocando las de la humanidad", buscaba hacer "dudosas" las que se tenían por verdades. ${ }^{36}$ Estuvo en lo cierto: logró sacudir las políticas existentes dando lugar a un gran debate y los documentos publicados por Ricardo Levene en 1946 son solo algunas de las piezas de un conjunto importante y voluminoso de escritos entre 1793 y $1801 .^{37}$

Fue un gran debate porque involucró (en olas cada vez más expansivas e intensas) a funcionarios de distintas instancias y ciudades, a las autoridades políticas de la Audiencia, a los mineros azogueros, pero también a las autoridades religiosas e indígenas, poniendo en el centro de la discusión la plata o la "sangre del cuerpo político". Pero igualmente importante es que Villaba generó una serie de averiguaciones sobre la mita en diferentes regiones y comunidades. Finalmente, puso en discusión la similitud o no de los vasallos indios con relación a los vasallos de la península. Se convirtió, así, en una discusión que sobrepasó el trabajo minero de los mitayos porque lo que estaba en cuestionamiento era el derecho a que se obligara o no a trabajar a una parte de la población, rememorando las célebres disputas de fines del siglo XVI y XVII.

El debate inicial se dio entre Villaba, Fiscal de Charcas y Protector de los indios, y el Gobernador Intendente de Potosí, Francisco de Paula Sanz, apoyado por su asesor, Pedro Vicente Cañete, ${ }^{38}$ y por el gremio de los azogueros. Aquí queremos retomar dos de los más importantes aspectos discutidos y

de que todos los hombres, incluso bárbaros, tenían los derechos de propiedad, autogobierno y libertad (ibid.: 114).

36 Villaba, en Levene, 1946: XXX.

37 La contestación al escrito de Villaba de parte de Francisco de Paula Sanz tiene más de 150 fojas. (AGI Charcas 69, Contextacion al discurso sobre la mita de Potosi, escrito en La Plata a 9 de marzo de 1795).

38 El fiscal era el defensor de los intereses de la Real Hacienda y tenía también a su cargo la defensa y el amparo de los indios porque, según el jurista Juan de Solórzano Pereira, las causas de los indios, "abatidos y miserables", eran propias del rey ( $c f$. Jurado, 2004: 21). Pedro Vicente Cañete nació en Asunción (Paraguay) y estudió en Santiago de Chile. Fue asesor y auditor de guerra del virrey Pedro de Cevallos en Buenos Aires. En 1793, fue nombrado asesor de la Intendencia de Potosí. En 1787, escribió la Guía histórica, geográfica, física, politica civil y legal del Gobierno e Intendencia de la Provincia de Potosí y, más tarde, el Código Carolino de Ordenanzas Reales de las Minas de Potosíy demás provincias del Río de la Plata. En 1803, fue trasladado a La Plata, donde estuvo como asesor del presidente de la Audiencia. Véase: Mendoza, 2005. 
articulados. Primero, la importancia de la plata como el nervio del Estado y la sangre del cuerpo político, y si su explotación se justificaba por el bien público que había sido enarbolado desde la institución de la mita. Segundo, si la naturaleza y la indolencia de los indígenas constituían razones suficientes para obligarlos a trabajar.

Para Villaba, el dinero no hacía la felicidad de una nación y el propio Potosí era ejemplo de que "en los países de minas no se ve sino la opulencia de unos pocos con la miseria de infinitos". Afirmó, por un lado, que el dinero no era riqueza, sino una simple mercadería universal, y, por otro lado, que las minas no eran públicas. ${ }^{39}$ Sanz sostuvo, en cambio, que Villaba cometía un error al llamar como bien público solo los productos "inmediatos" de la "Nación o del Soberano". ${ }^{40}$ A su entender, había dominios que el rey no podía transferir a sus vasallos, por lo que tenía el derecho de regalía, pero que se hallaban destinados al bien público, como sucedía con las minas en toda Europa. ${ }^{41}$ Por el derecho del soberano, este obtenía una parte de los productos de explotación ${ }^{42}$ bajo el nombre de los quintos (impuesto del quinto a la producción). Sanz consideró, además, que "en estas colonias" no había otro ramo de industria tan importante como el de la minería y que la mita era necesaria en "bien del estado". ${ }^{3}$

Otro de los argumentos fundamentales de Villaba fue el relacionado al trabajo coactivo en nombre de la indolencia que se atribuía a los indígenas. ${ }^{44}$ Introduciendo la comparación con España, consideraba que la "holgazanería" no era un argumento para "esclavisarlos en las minas", que no había ninguna razón que pudiera dar lugar a "la esclavitud de los hombres" y menos todavía cuando se sacrificaba la humanidad por el interés. ${ }^{45}$ Pero, asimismo, la indolencia para Villaba era resultado del despotismo. Sostuvo, finalmente, que los que planteaban que los indios no querían trabajar debían explicarse, porque ellos estaban trabajando "para otro(s) y no para sí".

Para Sanz, en cambio, el trabajo de la mita existió en tiempos de los Incas, precisando que Toledo no hizo más que retomar las medidas del inca

\section{En Levene, 1946: XXXII-XXXIII.}

40 AGN Colonia Gobierno 148 8, cuaderno número 1. Sobre la Mita de Potosí. Contiene la representación del Gremio de Azogueros de aquella villa con varios documentos, año de 1795 , f. $27 \mathrm{v}$.

41 Ibid.: ff. 29-30.

42 Ibid.: f. 37v.

43 Ibid.: f. 177.

44 Villaba, 1793 (en Levene, 1946: XXXI).

45 Ibid.: XXXVI-XXXVIII. 
Guayna Capac. Fue Sanz el que planteó que hubo "un contrato" con los caciques, resucitándose ese servicio forzado pero "mudándolo en un contrato voluntario bien que obligatorio", bajo ciertas condiciones, mucho más humanizado y pagado. ${ }^{46}$ Afirmó, de manera categórica, que no podía considerarse esclavitud. Sin embargo, se refirió también a la holgazanería y a la rusticidad de los indígenas, al igual que a su rechazo a trabajar, por lo que justificaba la obligación que debían tener. Decía que si hubiera "yndios laboriosos y voluntarios", sería el primero en oponerse a la mita. ${ }^{47}$

A raíz de la discusión y el debate, se llevaron a cabo una serie de averiguaciones. Villaba pidió informes sobre los perjuicios que ocasionaba la mita al Protector de Naturales de la ciudad Potosí, ${ }^{48}$ a los curas de las doctrinas de Chaquí, en el partido de Porco, y en la doctrina de Moscarí, en el partido de Chayanta (ambos en la Intendencia de Potosí) a la Intendencia de Cochabamba y Puno.

Uno de los primeros reportes o informes fue el de Francisco de Viedma, gobernador de Cochabamba. ${ }^{49}$ Describió el viaje de "estos miserables" con sus mujeres, incluso embarazadas, y con sus hijos; los malos alojamientos en los que debían quedarse en Potosí; y las tareas asignadas. Enfatizó la distribución de "tareas" o cuotas fijas (al igual que lo había hecho, un siglo antes, Matías Lagúnez), que no podían humanamente ser entregadas, de tal manera que recurrían a pagar a otra persona, por lo que por dos semanas de trabajo recibían solo seis días de jornal y si había algún problema podían incluso recibir menos sueldo. ${ }^{50}$ Se refirió también a la situación existente en Santiago del Paso, en Cochabamba, que tenía solo 34 originarios y debía enviar 17 cada año para la mita. Comparó entonces la mita con la guerra que mermaba ejércitos, llevándolos hasta el "exterminio de la humanidad" ${ }^{51}$ La conclusión de Viedma era importante: sostuvo que "Su Majestad” probablemente perdió más en tributo que lo que ganó en quintos de minerales y que el provecho iba en completo "beneficio de los particulares azogueros". ${ }^{52}$ Aquí, el intendente Viedma estaba poniendo en la balanza lo que podía proporcionar la población indígena en tributos, que consideraba podía ser mayor al propio ingreso que recibía el erario

46 AGN Colonia Gobierno 148 8, cuaderno número 1, ff. 84-85.

47 Ibid.: f. 177.

48 ABNB ALP Minas 129/7.

49 ABNB ALP Minas 129/8.

50 Ibid.: ff. 2 y 49.

51 Ibid.

52 Ibid.: ff. 52-55. 
de la Corona en impuestos provenientes de la plata. En otras palabras, si las arcas reales debían dar preferencia a la agricultura, basada en las comunidades indígenas y en las haciendas privadas, o a la minería.

El contrapunto a esta situación fue esgrimido por Francisco de Paula Sanz. Lo que me interesa destacar es que en los intersticios de su escrito se vislumbra también, de manera clara, la enorme dificultad que tenían los empresarios y la propia red de autoridades para controlar la mano de obra. Esta situación muestra nítidamente la limitada autoridad de los propios mineros azogueros, que justificaba la propia coacción. Decía que no había sitio de producción que no "suspirara" constantemente por mano de obra y que ni el pago en efectivo, adelantado y "alto", lograba atraer el trabajo de los indígenas. ${ }^{53} \mathrm{La}$ autoridad pidió también una serie de averiguaciones de las que emergía un cuadro donde se mostraba que la mita era un total "caos y desorden": la del partido de Porco era considerada "irregentable" porque no cumplían con su cupo y porque los que iban desertaban en las noches, llevándose hasta las herramientas. Pero más importante aún, informaron que pagaban para no ir, la antigua costumbre que ya estaba presente en el siglo XVII. Esta situación era la regla en las comunidades del partido de Paria, consideradas como muy acomodadas (o en buena situación). Se decía también que las comunidades de Chayanta dejaban sin indios a los ingenios del cerro, mientras que las de la provincia de Cochabamba fugaban. Finalmente, las comunidades del partido de Sicasica se dedicaban, junto con enteradores y curacas, al comercio en la ciudad de Potosí y sus alrededores, y cuando terminaban se volvían a sus pueblos, entregando en dinero la mayor parte del "servicio personal de su gente". ${ }^{54}$

En este contexto de discusión, se conoció que Marcelino Lupa, cacique de Moscarí, anunció, en marzo de 1795, una rebelión indígena en contra de la llamada "nueva mita", lo que complicaba aún más el panorama (Buechler, 1989, tomo I: 248, 250; 259-263). Sanz aseguró "la falsedad de las voces que se habían corrido con referencia a la rebelión” y culpó al arzobispo, al clero y, sobre todo, al fiscal Villaba, por los papeles, las conversaciones y los movimientos contra el buen gobierno y contra las leyes del reino (ibid.: 252). Sanz se dedicó a investigar la conducta de los sacerdotes, concluyendo que el número de indios que servían en las iglesias cada año llegaba a más de 1.000, excediendo incluso a los que servían en Potosí. La máxima autoridad colonial de Potosí procedió a nombrar nuevos caciques mestizos y empezó a regular la conducta del clero. Al poco tiempo, en mayo de 1795, se desautorizó y se acusó a Sanz

53 Ibid: :ff. $54 \mathrm{v}-56$.

54 ABNB ALP Minas 129/5. 
de haber vulnerado la jurisdicción eclesiástica. Sanz contraargumentó señalando que el despacho de los propios mitayos regulares había estado en peligro porque corría la voz de que "la mita había sido abolida por completo". ${ }^{5}$

Las diferentes corporaciones de Potosí hicieron entonces una "Representación Apologética de la muy noble Imperial Villa de Potosí”, expresándose, al unísono, contra el fiscal Villaba porque:

[...] dio al publico con anticipación un papel en que confutándolo abiertamente lo calificaba de tiránico, sin respeto alguno a las leyes que lo autorizan ni consideración la mas mínima a los Magistrados [...] mucho menos a las impresiones que $[\ldots]$ en perjuicio público y del erario había de causar forzosamente en nuestras provincias contribuyentes un contexto tan decidido por la libertad de los indios y tan contrario al pretendido despotismo que supone en los azogueros. ${ }^{56}$

Culparon a Villaba de apoyarse en los curas, mientras que ellos, las altas autoridades políticas de Potosí, se oponían al "Gobierno theocrático" de los eclesiásticos que gozaban de los "servicios personales" y las "escandolosas contribuciones exigidas por los curas". ${ }^{57}$ Dijeron era esa la verdadera razón de su oposición a la mita y que nunca antes se habían oído quejas tan importantes "contra la pretendida tiranía de los azogueros" ${ }^{58}$ Incriminaron también a la Audiencia de inmiscuirse en asuntos de "gobierno", dominio exclusivo del gobernador de Potosí. ${ }^{59}$ Acusaron abiertamente al fiscal de convertirse en abogado de los tiranos y los opresores de los indígenas.

En la "Representación Apologética" de los azogueros se encuentran otra vez importantes indicios sobre las actuaciones de la población indígena. Nos enteramos de que se "agavillaron" entre más de 500 personas para asaltar al subdelegado de una de las provincias de Potosí, obligándolo a deponer de su empleo a uno de los caciques indígenas que había sido

55 La Cédula Real de 3 de agosto de 1796 suspendió la mita nueva (Buechler, 1989, tomo I: $265-267$ y 273 ).

56 ABNB ALP Minas 129/13, ff. 2/10v.

57 ABNB ALP Minas 129/13, f. 10 128; 16134 y 16v-134v.

58 Véase: ABNB ALP Minas 129/13, f. 3/121. “[...] validos de la barbarie, de la rusticidad e ignorancia de los indios avivaron con mas calor las especies sediciosas de que el servicio de la mita era injusto y tiránico en su totalidad como proclamaba de palabra y por escrito su Protector" (ibid.: ff. 4v-122v).

59 ABNB ALP Minas 129/13, ff. 6v-124v. Sobre los sacerdotes y la mita, veáse también: ABNB ALP Minas 129/6. 
nombrado por Sanz, acusado de "pretendidas ventas de mitayos". La máxima autoridad provincial, el subdelegado, fue forzado a aceptar a las autoridades indígenas. ${ }^{60}$ Finalmente, se quejaron, en alusión a Villaba y a sus colaboradores, de que "hombres poderosos" eran escuchados y obedecidos por los naturales, ocasionando la ruina de la soberanía y la jurisdicción real, lo que debía considerarse como verdadero delito de Estado y crimen de lesa patria y lesa majestad. ${ }^{61}$

La deslegitimidad que tuvo la mita fue por tanto enorme. Las autoridades de Potosí acusaron a los caciques de aliarse con Villaba (personaje que los estaba conduciendo también a la insurrección al calificar de tiranos a los ministros y a las autoridades coloniales), de inhumana y bárbara a la mita y de avaros e insaciables del "sudor y la sangre del indio" a los mineros de Potosí. ${ }^{2}$

El debate en el que se involucró Villaba fue entonces una discusión sobre el trabajo obligatorio, sobre la coacción y sobre el derecho a exigir el trabajo forzado indígena. Los argumentos de Villaba muestran continuidades, pero también trastornos radicales. Entre estos últimos es preciso señalar que al considerarse la "indolencia" como resultado, y no causa, de la obligación de trabajar, invirtió la percepción sobre el indio. De ahí que la mita pudo concebirse como injusta y opresora, y concebirse al indígena como víctima de ella. Fundamental también fue comparar la situación de los indios con los vasallos en Espańa, porque permitió afirmar la "uniformidad" e igualdad de los hombres ("todo hombre es lo mismo en general"), así como explicar algunas de sus acciones como resultado de la desconfianza "natural del oprimido". ${ }^{63}$ Es posible pensar, también, que en el propio desarrollo del debate Villaba adquirió, por lo menos, en algunos momentos, un discurso mucho más radical, como este:

60 "[...] y evitó este buen magistrado [...] el riesgo de su vida y que el canzer cundiese a los demás repartimientos” (ABNB ALP Minas 129/13, ff. 4v-122v/5-123).

61 ABNB ALP Minas 129/13, f. 137-19.

62 “[...] no pudieran haver empleado medios más eficaces para promoverla, quales son argüir de inhumano y barbaro el servicio de la mita, caracterizar de tiranos e insensibles a los Ministros que la sostiene: a los Mineros de Potosí de avaros e insaciables del sudor y sangre del Yndio, a cuia costa acopian sus riquezas; al Subdelegado de déspota que quita los caciques desafectos a este servicio y pone los addictos a sus ideas de aumentarlo; y no perdonar al Governador de la Provincia, atreviéndose a representar al Virrey que no hay que esperar de el justicia a favor del yndio contra un cobrador de tributos que contribuía al despacho de la mita [...]" (Villaba, en Levene, 1946: LXVIII).

63 Villaba, "Contraréplica" (en Levene, 1946: XLIV). 
Desgraciados y miserables Yndios vosotros [...] sois indolentes, embrutecidos, borrachos, ladrones, ya sin religión, ya supersticiosos, y no se cuenta con vosotros quando se trata de la Plata que se difunde por el Estado! Afortunados Azogueros pues [...] Sois Caballeros, sois Ylustres, sois humanos, sois benéficos, sois desinteresados y todo el bien del estado se atribuye a vuestras fatigas ${ }^{164}$

Aunque no parece existir ningún escrito de Villaba después de 1797, sus argumentos fueron reutilizados muy pronto en diversos expedientes locales, pero también en otros escritos.

\section{Conclusiones}

La mita instaurada a fines del siglo XVI permaneció durante más de dos siglos y medio. La mita pudo permanecer invariable durante un tiempo, como señaló Paula Zagalsky. Pero la mita tuvo también cambios y metamorfosis, como sugirió Jeffrey Cole. La mita fue también muy distinta entre la que se había planificado y la que se practicaba, como planteó Ignacio González Casasnovas, pero habría que señalar que fue como resultado de la correlación de fuerzas en acción. Lo que interesa subrayar aquí son los cambios que deben atribuirse tanto a la agencia y a las acciones de los mitayos trabajadores, y a la de sus comunidades, como a las discusiones y a los debates de las autoridades coloniales.

Hemos visto que el contingente mitayo mermó muy rápidamente como resultado de la disminución poblacional, aunque también de las estrategias desplegadas por los involucrados. Pero fue también profundamente deslegitimada por las autoridades coloniales. Los involucrados en la mita parecen haber buscado, en todos los casos, mayores salarios y mayor grado de autonomía e independencia, dando lugar a una diversidad de situaciones laborales que podían articularse. No podemos pensar, por tanto, que había grupos de mitayos o trabajadores coactivos y forzados, por un lado, de trabajadores libres y mingas, por otro, y, finalmente, de k'ajchas y trapicheros o trabajadores independientes o por cuenta propia. Debemos recordar también que gran parte de ellos eran los mismos agricultores/pastores de las comunidades sujetas a la mita que podían circular, además, de una situación laboral a otra, pero la mita fue el punto de partida. El caso de la minería potosina nos permite, de manera muy concreta, pensar en la articulación de distintas relaciones laborales, pero también en las consecuencias que tiene sobre esas relaciones (De Vito, 2017). Estamos, por 
tanto, frente a una vinculación particular, porque no nos enfrentamos con una mano de obra no libre y, en el otro extremo, con una mano de obra libre; pero tampoco con un continuum entre uno y otro, que se ha enfatizado en la historiografía sobre trabajo libre y no libre (Van der Linden y Rodríguez, 2014; Brass y Van der Linden, 1997). Aqui estamos, al menos en parte, frente a casos en que los mismos trabajadores se desplazan por distintas situaciones laborales.

Pero la mita implicó, aun para escapar de ella, montos en dinero que suponen un drenaje de recursos económicos de gran magnitud. Esta estrategia, que implica una continua y sistemática incursión en los circuitos mercantiles, nos vuelve a hacer pensar en la importancia crucial que tuvieron los trajines y la participación indígena en los mercados (Harris, Larson y Tandeter, 1987; Glave, 1989). Esto indica que, entre la resistencia como despliegue de armas cotidianas infrapolíticas de las que habla James Scott (2000), la existencia de acuerdos y pactos de reciprocidad de derechos y obligaciones de Tristan Platt (1982) o las abiertas rebeliones analizadas por varios autores, se debe pensar en la sistemática participación en la nueva economía como lo hicieron los mitayos y como lo hicieron los k'ajchas y los trapicheros.

Todo lo anterior cambia de cierta manera nuestra aproximación a la mita porque revela la increíble variedad de estrategias que se tuvo para enfrentarla. Pero es indudable también que la mita se convirtió, desde ciertas autoridades coloniales hasta personajes que tuvieron un accionar más crítico a fines del periodo colonial, en un símbolo y en un paradigma de opresión. En 1802, uno de los más radicales personajes de Buenos Aires, Mariano Moreno, ${ }^{65}$ presentó su disertación en Charcas sobre el trabajo de los mitayos preguntando hasta qué punto había aún que apoyar unas minas que no lograban sufragar sus gastos (Moreno, 1943: 33). Solo unos años después, en 1809, en medio de la formación de los primeros gobiernos autónomos en defensa del rey y en medio del abierto enfrentamiento (otra vez) de la Audiencia de Charcas con Potosí, circuló un anónimo: el famoso

65 Moreno estudió leyes en la Universidad de Chuquisaca, donde estuvo desde 1799 hasta 1805. Fue secretario de la Primera Junta de Gobierno de Buenos Aires. Tradujo en 1802 El contrato social de Rousseau y escribió en 1809 La representación de los hacendados, en 1810 el Plan de operaciones y la redacción de La Gaceta de Buenos Aires. Moreno y Villaba estuvieron ligados a través de Matías Terrazas, amigo de ambos, en cuya biblioteca el primero pudo leer a Raynal, Bossuet y Filangieri (Portillo, 2007: 446). Moreno, siendo estudiante en Charcas, había leído también a Viscardo y su Carta a los Americanos (Brading, 1993: 594). 
392 | Trabajos y trabajadores en América Latina (siglos XVI-XXI)

Diálogo entre el Inca Atahuallpa y Fernando VII, ${ }^{66}$ donde la mita constituye uno de los argumentos más fuertes para cuestionar y deslegitimar el poder del rey, calificándolo de tirano y usurpador. El autor estaba claramente retomando el tema abordado siete años antes por Mariano Moreno en su Disertación en la Academia Carolina ${ }^{67}$ en 1802, y 15 años antes en el Discurso sobre la Mita, de Villaba. ${ }^{68}$ Las imágenes sobre las "cadenas de la esclavitud" estarían también presentes después de la independencia en el propio himno nacional de Bolivia.

66 La autoría de este texto está en disputa.

67 En Thibauld, 1997.

68 En Levene, 1946: XXX. Uno de los virreyes, el conde Alba, sostuvo en el siglo XVII que las "piedras de Potosí y sus minerales están bañados con sangre de indios y que si se exprimiera el dinero que de ellos se saca había de brotar más sangre que plata" (ibid.: Apéndice XLI). 


\section{Fuentes}

Archivo y Biblioteca Nacionales de Bolivia (ABNB), Sucre

ABNB ALP Minas 25/13. 1752. Competencia de jurisdicción suscitada entre don Ventura de Santelices y Venero, corregidor de Potosí y don Cristóbal de Urquizu, alcalde ordinario de Primer Voto de dicha Villa, respecto al conocimiento de la causa contra los ladrones vulgarmente llamados K'ajchas. Fs. 106.

ABNB ALP Minas 28/1. 1751-1753. Expediente seguido por don Gerónimo Gómez Trigoso y don José Roque de Arismendi, sobre la culpa que les imputó el Corregidor de Potosí en el destrozo y derribamiento de los estribos, puentes y pilares de las vetas de plata, San Miguel y San José, en la labor de Alkjo-barreno, cerro de dicha Villa, cuando esos desperfectos fueron causados por ladrones denominados K'ajchas. Fs. 457.

ABNB ALP Minas 129/5. 1794-1795. Expediente instruido por don Francisco de Paula Sanz, gobernador intendente de Potosí, sobre los defectos con que hoy corre la mita del Cerro y la Ribera de dicha Villa en los distintos partidos que la contribuyen. Fs. 6.

ABNB ALP Minas 129/6. 1795. Reflexiones sobre las diligencias obradas en la Intendencia de Potosí, acerca de la conducta de los curas de Chayanta con motivo del aumento de mita decretado en dicho partido, y auto en su razón proveído con remisión a los subdelegados de los partidos de dicha Intendencia para que se publique en forma de bando.

ABNB ALP Minas 129/7. 1795. Informe dirigido por don Juan José de la Rúa, protector de naturales en Potosí, al doctor don Victorián de Villava, fiscal de la Audiencia, sobre los abusos introducidos en el servicio de los indios mitayos del Cerro y la Ribera de dicha Villa. Fs. 4.

ABNB ALP Minas 129/8. 1795. Informes que a instancia del doctor don Victorián de Villava, fiscal de la Audiencia de la Plata, expidieron don Francisco de Viedma, gobernador intendente de Cochabamba, el Marqués de Casa Hermosa, gobernador intendente de Puno, el doctor Felipe Antonio Martínez de Iriarte, cura propio de la doctrina de Chaqui, partido de Porco, y vicario pedáneo de Potosí; y el doctor don José de Osa y Palacios, cura propio que fue de la doctrina de Moscari, partido de Chayanta, sobre los perjuicios que a los pueblos de indios de dicha circunscripción se siguen de la mita de Potosí. Fs. 13.

ABNB ALP Minas 129/13. 1796. Representación apologética de la muy noble Imperial Villa de Potosí, sus tribunales, oficinas y gremios, al excelentísimo señor Virrey del Perú, sobre los acontecimientos de la provincia de Chayanta con motivo de la nueva mita consignada a los caballeros don Juan Bautista Jáuregui y don Luis Orueta, en que incidentemente se trata de las injurias inferidas al señor gobernador intendente, don Francisco de Paula Sanz y 
394 | Trabajos y trabajadores en América Latina (siglos XVI-XXI)

demás magistrados y ministros encargados de proveerla en los repartimientos de la misma provincia. Fs. 20.

Archivo Histórico de Potosí (AHP)

Banco de San Carlos (BSC) 313, Libro donde se sientan los marcos que se traen al rescate de los trapicheros de esta rivera, 1761-1764.

BSC 325, Libro donde se asientan los marcos que se rescatan de los trapicheros de esta Villa y minerales de las provincias de afuera, 1754-1755.

BSC 360, Libro donde se asientan los marcos de plata que los señores Azogueros de esta Villa traen a rescatar a este Banco y mercadería que corre a cargo del Maestre de Campo, 1759-1762.

AHP Cabildo Intendencia CGI 288701777.

Archivo General de la Nación (AGN), Buenos Aires

AGN Colonia Gobierno 148 8. Cuaderno número 1. Sobre la Mita de Potosí. Contiene la representación del Gremio de Azogueros de aquella villa con varios documentos. Año de 1795.

Archivo General de Indias (AGI), Sevilla

AGI Charcas 272. Expediente sobre la mita de Potosí. Año 1692. Fs. 1261.

AGI Charcas 435. [Documentos sobre los capchas, 1751-1752].

AGI Charcas 481, número 19, 1763-1769. [Varios documentos sobre los capchas].

AGI Charcas 700. Testimonio de la Visita de Cerro Yngenios y Trapiches del Cerro Rico y Ribera de la Imperial Villa de Potosi con expresion de los nombres de las Minas, sus varas, rumbos y frontes. 1789. 22 de febrero de 1790.

AGI Buenos Aires 440. Real Cédula de Incorporación del Banco de Potosí a la Real Hacienda y ordenanzas para su régimen y gobierno. Madrid, 1795.

AGI Charcas 697. Contextacion al discurso sobre la mita de Potosi escrito en La Plata a de Marzo de 1795.

\section{BiBLIOGRAFÍA}

Abercrombie, Thomas

1996 "Q'aqchas and La Plebe in rebellion: Carnival vs. Lent in 18th century Potosi”. En: Journal of Latin American Anthropology, número 2, volumen 1. 62-111. 
Arzáns de Orsúa y Vela, Bartolomé

2012 Historia de la Villa Imperial de Potosí. Edición de Lewis Hanke y Gunnar Mendoza. Tres tomos. Providence: Brown University Press. La Paz: Edición facsimilar de Plural editores / Casa Nacional de Moneda / Fundación Cultural del Banco Central de Bolivia. [1965]

Assadourian, Carlos Sempat

1982 El sistema de la economía colonial. Mercado interno, regiones y espacio económico. Lima: IEP.

Bakewell, Peter

2006 Mineros de la Montaña Roja: el trabajo de los indios en Potosi, 15451650. Madrid: Alianza. [1989]

Barragán, Rossana

2017 "Working Silver for the World: Mining Labor and Popular Economy in Colonial Potosí". En: Hispanic American Historical Review, número 97. 193-222.

2014 "K'ajchas, trapiches y plata en el cerro de Potosí en el periodo colonial" En: Anuario de Estudios Bolivianos, número 20. 273-320.

2013 “'Indios Esclavos': en torno a la mita minera y los servicios personales, 1790-1812”. En: Clément Thibaud, Federica Morelli, Alejandro Gómez y Gabriel Entin (comps.), Les révolutions des empires atlantiques. Une perspective transnationale. París: Pérseides.

Brass, Tom y Marcel van der Linden (eds.)

1997 Free and Unfree Labour: The Debate continues. Berna, Alemania: Peter Lang.

Brading, David

1993 Orbe andino. De la monarquía católica a la república criolla, 1492-1867. México D. F: Fondo de Cultura Económica. [1991]

Bridikhina, Eugenia (coord.)

2015 Bolivia: su historia. Tomo II. La experiencia colonial en Charcas, siglos XVI-XVII. La Paz: Coordinadora de Historia.

Bridikhina, Eugenia y Silvia Arze

2016 "En busca de un nuevo orden. La primera fase del Estado colonial 1542-1570”. En: Eugenia Bridikhina, Ximena Medinacelli, Silvia Arze y Pablo Quisbert, Bolivia: su historia. Tomo II. La Paz: Coordinadora de Historia. 
396 | Trabajos y trabajadores en América Latina (siglos XVI-XXI)

Buechler, Rose Marie

1989 Gobierno, minería y sociedad. Potosí y el "renacimiento" borbónico, 17761810. Dos volúmenes. La Paz: Biblioteca Minera.

Cañete y Domínguez, Pedro Vicente

1952 Guía histórica, geográfica, física, politica, civil, y legal del gobierno e intendencia de la provincia de Potosi 1787. Potosí: Editorial Potosí.

Cole, Jeffrey

1985 The Potosi Mita, 1573-1700: Compulsory Indian Labor in the Andes. Stanford, California, Estados Unidos de América: Stanford University Press.

González Casasnovas, Ignacio

2000 Las dudas de la Corona. La politica de repartimientos para la minería de Potosí. Madrid: CSIC.

Gil Montero, Raquel

2013 "Migración y tributación en los Andes. Chichas y Lípez a fines del siglo XVII". En: Anuario de Estudios Americanos, número 70, volumen 1. 39-65.

Glave, Luis Miguel

1989 Trajinantes, caminos indigenas en la sociedad colonial, siglos XVI-XVII. Lima: Instituto de Apoyo Agrario.

Hanke, Lewis y Gunnar Mendoza

2012-1965 "Bartolomé Arzáns de Orsúa y Vela: su vida y su obra. El Autor y el manuscrito de la historia”. En: Bartolomé Arzáns Orsúa y Vela, Historia de la Villa Imperial de Potosí. Edición de Hanke y Mendoza.

Harris, Olivia; Brooke Larson y Enrique Tandeter

1989 La participación indigena en los mercados surandinos. Estrategias y Reproducción social, siglos XVI a XX. Cochabamba: CERES.

Levene, Ricardo

1956 Vida y Escritos de Victorián de Villava. Buenos Aires: Peuser.

Lewin, Boleslao

1967 La rebelión de Túpac Amaru y los orígenes de la Independencia en Hispanoamérica. Buenos Aires: Sociedad Editora Latino Americana.

Linden, Marcel van der

2016 “Mass exits: Who, Why, How?”. En: Matthias Van Rossum y Jeanette Kamp (comps.), Desertion in the Early Modern World. A comparative 
History. Londres, Inglaterra / Nueva York, Estados Unidos de América: Bloomsbury.

2011a Workers of the World. Leiden, Países Bajos: Brill.

2011 b "Introduction". En: Marcel van der Linden (ed.), Humanitarian Intervention and Changing Labor Relations. The Long-term Consequences of the Abolition of the Slave Trade. Leiden, Países Bajos: Brill.

Linden, Marcel van der y Magaly Rodríguez García

2016 On Coerced Labor. Work and Compulsion after Chattel Slavery. Leiden, Países Bajos / Boston, Estados Unidos de América: Brill.

Lucassen, Jan

1997 "Free and Unfree Labour before the $20^{\text {th }}$. Century. A brief overview". En: Tom Brass y Marcel van der Linden (eds.), Free and Unfree Labour: The Debate Continues. Bern, Alemania: Peter Lang.

Matienzo, Juan de

1967 Gobierno del Perú. Lima: IFEA. [1567]

1910 Gobierno del Perú. Buenos Aires: Cia. Sud-Americana. [1567]

Méndez, Luz María

1992 "Los bancos de rescate en Hispanoamérica (1747-1832). El proceso histórico y sus fundamentos ideológicos. Estudio comparado para México, Perú y Chile”. En: D. Ávila, I. Herrera y R. Ortiz (comps.), Minería colonial Latinoamericana: Primera Reunión de Historiadores de la Minería Latinoamericana (1). México D. F.: INAH.

Mendoza, Gunnar

2005 "El Doctor Don Pedro Vicente Cañete y su Historia física y política de Potosî". En: Obras Completas. Volumen II. Sucre: Fundación Cultural del Banco Central de Bolivia / Archivo y Biblioteca Nacionales de Bolivia.

Mira, Guillermo

1997 "El Real Banco de San Carlos y la minería altoperuana colonial, 17791825”. En: Julio Sánchez Gómez, Guillermo Mira Delli-Zotti, y Rafael Dobado (eds.), La savia del Imperio. Tres estudios de economía colonial. Salamanca: Universidad de Salamanca.

Medinaceli, Ximena

2010 Sariri. Los llameros y la construcción de la sociedad colonial. Lima: IFEA.

Morelli, Francisca

2010 "De la «ciencia del comercio» a la «ciencia de la legislación»: la ruta napolitana a la reforma de la monarquía (siglo XVIII)". En: Anne 
Dubet y José Javier Ruiz Ibáñez (eds.), Las monarquías española y francesa (siglos XVI-XVIII). ¿Dos modelos politicos? Madrid: Casa de Velázquez.

2006 "Tras las huellas perdidas de Filangieri: nuevas perspectivas sobre la cultura política constitucional en el Atlántico hispánico”. En: Historia Contemporánea, número 33. 431-461.

Moreno, Mariano

1943 "Disertación Jurídica sobre el servicio personal de los indios". En: Ricardo Levene, Escritos I. Prólogo y edición crítica. Buenos Aires: Estrada. [1802]

Platt, Tristan

1982 Estado boliviano y ayllu andino. Tierra y tributo en el norte de Potosi. Lima: IEP.

Platt, Tristan; Thérèse Bouysse-Cassagne y Olivia Harris

2006 Qaraqara-Charka: Mallku, Inka y Rey en la Provincia de Charcas (siglos XV-XVII): Historia antropológica de una confederación aymara. La Paz: Plural editores.

Portillo, José M.

2007 "Victorian de Villava, fiscal de Charcas: Reforma de España y nueva moral imperial". En: Anuario de Estudios Bolivianos, Archivisticos y Bibliográficos, número 13. Sucre: Archivo y Biblioteca Nacionales de Bolivia.

Recopilación de Leyes

1741 Recopilación de Leyes de los Reynos de las Indias. Tomo segundo. Madrid: s. e.

Saignes, Thierry

1985 "Caciques, Tribute and Migration in the Southern Andes Indian Society and the 17th Century Colonial Order (Audiencia de Charcas)". Occasional Papers. Londres, Inglaterra: University of London / Institute of Latin American Studies.

1984 "Las etnias de Charcas frente al Sistema colonial (siglo XVII). Ausentismo y fugas en el debate sobre la mano de obra indígena". En: Jahrbuch, número 21. 27-76.

Sánchez Albornoz, Nicolás

1978 Indios y tributos en el Alto Perú. Lima: IEP.

Scott, James

2000 Los dominados y el arte de la resistencia. México: Era. [1990] 
Serulnikov, Sergio

2007 "La imaginación política andina en el siglo XVIII". En: Aljovin de Losada y Nils Jacobsen (comps.), Cultura politica en los Andes (1750-1950). Lima: IFEA.

2006 Conflictos sociales e insurrección en el mundo colonial andino. El norte de Potosi en el siglo XVIII. Buenos Aires: Fondo de Cultura Económica.

Smith, Mattew

2004 "Coertion and Choice in the Potosi Mita". En: Past Imperfect, volumen 10. 21- 44 .

Solorzano y Pereyra, Juan de

1703 Política Indiana compuesta por Don Juan Solórzano y Pereira. Amberes, Bélgica: Henrico y Cornelio Vendussen.

Stanziani, Alessandro

2016 "Runaways: A Global History". En: Matthias van Rossum y Jeannette Kamp (eds.), Desertion in the Early Modern World. A comparative History. Londres, Inglaterra / Nueva York, Estados Unidos de América: Bloomsbury.

Tandeter, Enrique

1992 Coacción y Mercado. La minería de la plata en el Potosí colonial 16921826. Cusco: Centro de Estudios Regionales Andinos "Bartolomé de las Casas".

1981a "Forced and Free Labour in Late Colonial Potosi". En: Past and Present, número 93, volumen 1.98-136.

1981b "La producción como actividad popular: ladrones de minas en Potosí". En: Nova Americana, número 4. 43-65.

Toledo, Francisco de

1986 Disposiciones Gubernativas para el Virreinato del Perú, 1569-1574. Introducción de Guillermo Lohmann Villena. Sevilla: Escuela de Estudios Hispanoamericanos / CSIC.

Van Rossum, Matthias y Jeannette Kamp (eds.)

2106 Desertion in the Early Modern World. A comparative History. Londres, Inglaterra / Nueva York, Estados Unidos de América: Bloomsbury.

Vito, Christian G. de

2017 "Precarious Pasts. Labour flexibility and labor precariousness as conceptual tools for the historical study of the interactions among 
400 | Trabajos y trabajadores en América Latina (siglos XVI-XXI)

labour relations". En: Karl Heinz Roth (ed.), On the Road to Global Labour History. Leiden, Países Bajos / Boston, Estados Unidos de América: Brill.

Zagalsky, Paula

2014 "La mita de Potosí: una imposición colonial invariable en un contexto de múltiples transformaciones (siglos XVI-XVII; Charcas, Virreinato del Perú)”. En: Chungara, volumen 46, número 3. 375-395.

Zavala, Silvio

1979 El servicio personal de los indios en el Perú (extractos del siglo XVII). Tomo II. México D. F.: El Colegio de México.

1978 El servicio personal de los indios en el Perú (extractos del siglo XVI). Tomo I. México D. F.: El Colegio de México. 


\title{
Pícaros y ladrones. Robo campesino y bandidaje en el Valle Alto (Cochabamba, 1880-1930)
}

\author{
Huascar Rodríguez García (Bolivia)*1
}

RESUMEN: El presente artículo explora cómo y por qué se fue construyendo, a lo largo del siglo XIX y de las primeras décadas del siglo XX, una imagen tradicional del campesino cochabambino del Valle Alto en la que aparece como pícaro y ladrón. El argumento propuesto es que los campesinos de la región afrontaron el contexto de crisis característico del periodo a través de difusos e ilegales modos de subsistencia que remiten a bandidajes endémicos, pero también a dinámicas laborales agrícolas y a luchas por acceder a la propiedad de la tierra, tras las cuales es posible entrever un horizonte político. Para desarrollar este argumento se analizan diferentes prácticas y fenómenos, que incluían el robo, el bandolerismo, el abigeato (robo de animales) y la delincuencia común en una época de recurrente violencia política y convulsión social.

Palabras Clave: robo; bandolerismo; campesinado; abigeato.

INTRODUCCIÓN

Omonte, que regresó a la mina, trajo a dos cochabambinos de turbia historia, sentenciados a cárcel por un asesinato en Cliza. Fueron contratados por Centeno en Pulacayo que, con una breve apología, los recomendó diciendo: - Son guapos y no pueden curar ese escozor que tienen en el dedo del gatillo. Por lo demás, todos los dedos les escuecen... para apoderarse de lo ajeno. Augusto Céspedes, Metal del Diablo (1946)

Exceptuando ciertas obras de criminología y justicia penal, con todas sus limitaciones inherentes, el tema del robo, o más específicamente el robo en el

* Doctor en Historia por la Universidad Pablo de Olavide, Sevilla. Contacto: ayawaskar@gmail.com

1 Agradezco a Rossana Barragán, Ximena Soruco y Sergio Serulnikov por su estímulo para dar forma definitiva a estas páginas. 
trabajo y el robo como trabajo, ha ocupado durante mucho tiempo un lugar algo marginal y aislado entre cientistas sociales e historiadores, pese a la potencialidad que el análisis de las conductas consideradas delictivas ofrece para examinar determinadas épocas, hechos y fenómenos. ${ }^{2}$ Con todo, es posible constatar que durante las últimas tres décadas los estudios históricos interesados en el delito se han renovado, generando nuevas y atractivas investigaciones. ${ }^{3}$ Algunas de ellas llevaron el foco de atención a las áreas rurales, vinculando el robo y la criminalidad a la resistencia, a la esclavitud y a otras formas de dominación y explotación, lo que dio lugar a una perspectiva analítica sumamente sugestiva pero plagada de preguntas no siempre fáciles de responder. $\mathrm{Al}$ respecto, son ilustrativos los trabajos de Eric Hobsbawm y George Rudé (1978), Alex Lichtenstein (1988), Carlos Aguirre (1990), Gilbert Joseph (1990), Carmen Vivanco (1990), Christopher Birkbeck (1991), Richard Slatta (1987, 1991), Jorge Gascón (1999) y María Aparecida de S. Lopes (2005) que, en diálogo crítico con los aportes de James Scott (2000) y Janice Thompson (1984) en torno de la "economía moral" y las "formas cotidianas de resistencia", abrieron un horizonte de desafíos desplegados en el ámbito de la campesinología. Y es que, como señala Aguirre, examinar la transgresión de la ley genera el inevitable interrogante de si el delito es o no -y en qué medida- una forma de respuesta y de protesta de los oprimidos contra un sistema considerado injusto (1990: 143); aguda cuestión que abordo en esta pesquisa a partir de un caso regional.

Me gustaría aclarar que llegué al tema del robo en el marco de una investigación doctoral más amplia que indagaba los nexos entre criminalidad y violencia política a fines del siglo XIX en la ciudad boliviana de Cochabamba

2 Cabe mencionar que una obra temprana y pionera en los estudios sociales que versan sobre el robo fue Ladrones profesionales, del sociólogo Edwin Sutherland (1993 [1949]), quien al mismo tiempo que dio a conocer otras investigaciones que hasta su tiempo se habían hecho acerca del delito demostró que el robo constituye un oficio como podría serlo cualquier otro "normal". Merece también mención Bandidos, de Eric Hobsbawm (2011 [1969]), ambicioso e influyente trabajo que suscitó numerosas críticas y polémicas que tienen que ver, entre otros puntos, con la caracterización que dicha obra hace del bandolerismo y de otras formas de descontento asumidas por los movimientos sociales preindustriales, pues para Hobsbawm serían modos "primitivos" y "prepolíticos" de protesta, cuestión que retomaré más adelante.

3 A partir de la década de 1980, una nueva generación de estudiosos abordó el delito, o la denominada "cuestión criminal", desde distintos enfoques, destacando el papel de la transgresión a la ley, vía apropiación de lo ajeno, en la configuración de las sociedades y de los propios Estados nacionales en varias latitudes, por ejemplo: Charles Tilly (1984), Richard Slatta (1987), Paul Vanderwood (1986), Carlos Aguirre y Charles Walker (1990), Janice Thomson (1994) o, más recientemente, Daniel Palma (2001) y Lila Caimari (2004), entre muchos otros. 
y sus provincias circundantes. Algo que me llamó la atención en ese estudio fue la recurrencia de diversos datos folclóricos, etnográficos y de tradición oral referidos a que los habitantes rurales de una subregión cochabambina conocida como Valle Alto eran pícaros y ladrones "desde tiempos inmemoriales". Y, en efecto, pude comprobar rápidamente que existía un estereotipo del "valluno ladrón" que, curiosamente, también formaba parte de una especie de orgullo e identidad local. Pero no solo eso. Descubrí asimismo que esta subregión se caracterizó en el siglo XIX y en parte del siglo XX por bandidajes que podrían caracterizarse como endémicos, e intuí que tenía que haber en todo esto un trasfondo histórico relacionado con formas de trabajo y luchas campesinas. Además, el Valle Alto cochabambino es un lugar verdaderamente emblemático, pues fue allí donde surgió el primer sindicalismo campesino de Bolivia, en 1936, y donde se firmó el decreto de Reforma Agraria de 1953, hechos cruciales en la historia y en la imaginería nacionalista bolivianas que pusieron por un tiempo al campesinado valluno en el centro de la política del país. Con tales antecedentes, no tardé en verme irresistiblemente atraído por este conjunto de indicios y cabos sueltos que prometían develar aspectos desconocidos de la historia regional vinculados tanto con el trabajo agrícola como con las luchas contra el poder patronal.

¿Cuál es el origen de las tradiciones que pintan a los vallunos como pícaros y ladrones? ¿ ¿Tiene esto que ver con viejos repertorios de luchas campesinas por tierra y justicia contra los hacendados? ¿Cuál es el sentido de la incursión de trabajadores agrarios y sectores populares en actividades delictivas? ¿Tenían las actividades fuera de la ley un trasfondo político? ¿O eran solo manifestaciones de la desesperación ante las crisis y simples salidas individuales que no cuestionaban el orden dominante? En otros términos, ¿qué connotaciones tenía el robo campesino y por qué el Valle Alto tuvo una tradición de bandidaje? Mi argumento es que el estereotipo del campesino valluno ladrón y pícaro tiene sus orígenes en varios fenómenos decimonónicos relativamente interrelacionados: una práctica llamada chajmeo, consistente en la cosecha ilegal de maíz en tierras de hacienda, el establecimiento del pueblo de Cliza dentro de una propiedad privada y una vieja recurrencia de robos, abigeatos y sabotajes en fincas y caminos que se yuxtaponían con bandolerismos "antisociales". Estos fenómenos formaban parte

4 'Valluno' ha sido el apelativo aplicado tradicionalmente a las personas nacidas en Cochabamba, en general, y en el Valle Alto, en particular.

5 Recurro a la palabra 'antisocial' debido a la diferenciación que establezco entre el bandidaje que carece de apoyo plebeyo y el "bandidaje social" propuesto por Hobsbawm (2011), para quien hubo en distintas partes del mundo un tipo de bandolerismo que contaba con la admiración y el apoyo campesino. Utilizo el vocablo 
de un variado repertorio de acciones campesinas y populares orientadas a la subsistencia y también, según los casos, a la adquisición de recursos a fin de obtener pequeñas parcelas de tierra liberadas de las haciendas. Los fenómenos mencionados, excluyendo el bandolerismo "antisocial", eran formas de resistencia contra el monopolio de la tierra establecido por la Iglesia y por clanes familiares cuyo poder se basaba en grandes propiedades y en el abuso sobre la fuerza laboral campesina. No obstante, conviene señalar que las estrategias campesinas para acceder a la tierra y al ascenso social incluían también repertorios de acciones legales e incursiones mercantiles, como la migración, la artesanía, la fabricación de chicha y la conformación de mercados campesinos y redes de ferias, aspectos ampliamente tratados por una importante tradición historiográfica regional (Larson, 1992, 2000; Jackson, 1994; Gordillo, 2000; Rodríguez Ostria y Solares, 1990; Laserna, 1984).

Por otra parte, si bien los ilegalismos campesinos -chajmeo, pequeños robos y sabotajes menores- no tenían firmes bases organizativas o comunitarias, puede observarse en ellos un trasfondo político, aunque este no siempre era deliberado ni explícito. Planteo, por último, que estos variados repertorios fueron utilizados por campesinos y sectores populares para afrontar una época marcada por la recurrencia de crisis agrícolas que amenazaban seriamente los niveles básicos necesarios para la subsistencia, contexto que potenció, a su vez, el que se agudizaran los bandidajes "antisociales", y aquí me refiero a las acciones violentas de pequeños grupos de forajidos que operaban sin ninguna base local y motivados por el beneficio personal, aun robando a los desposeídos o trabajando como matones al servicio de partidos conservadores.

En otros términos, propongo que es preciso separar lo que aquí considero "robo campesino" -apropiación de lo ajeno por parte de trabajadores agrícolas como estrategia de subsistencia y, a la vez, como resistencia contra los hacendados- del bandolerismo -robos y pillajes violentos e indiscriminados que no conllevaban ningún cuestionamiento al orden social-. Empleo

entre comillas porque, como señala Sutherland, los ladrones, particularmente los ladrones profesionales, no consideran a la sociedad necesariamente como un enemigo. El objetivo principal para ellos es "conseguir dinero y no tienen más remedio que procurárselo en detrimento de la sociedad [...]. Más que detestar a la sociedad, el ladrón profesional se congratula con la riqueza pública. Le gustaría ver cómo la sociedad se hace cada vez más próspera, pues de este modo sus golpes resultarían cada vez más lucrativos" (Sutherland, 1993: 175). Aprovecho para señalar que la bandidología no ha concitado el interés de los historiadores bolivianistas, salvo por los trabajos específicos de Erick Langer (1990), Antonio Paredes Candia (1998), Carlos Pérez (2003), Carla Prieto y Orlando Tapia (2013), y Huascar Rodríguez García (2015a, 2016). Una reseña retrospectiva y crítica de la escasa bandidología boliviana se halla en Rodríguez García (2015b). 
esta distinción únicamente con fines analíticos -pues en los hechos pudieron existir personajes que se movían entre varios ámbitos- y sin ningún afán moralizador, en el sentido de considerar unos ilegalismos "buenos" y otros "malos". Se trata simplemente de desenmarañar prácticas y fenómenos cuya complejidad exige interpretaciones matizadas que eviten las generalizaciones.

A objeto de desarrollar el panorama descrito, el texto reconstruye, sobre la base de una pesquisa hemerográfica, bibliográfica y archivística, la historia larga del Valle Alto, para luego exponer un sumario de tradiciones folclóricas y datos etnográficos que han ido delineando la imagen de los vallunos como ladrones. Más adelante, el lente se centra en una hacienda llamada Santa Clara, y a partir de este zoom o acercamiento se examinan algunas dinámicas laborales y el fenómeno del chajmeo, así como otros robos de cosechas y alimentos. Para finalizar, el artículo ofrece un muestrario de ilegalismos cargados de gran ambigüedad, incluyendo abigeatos y bandidajes violentos, con el propósito de problematizar la faceta más oscura de los orígenes del estereotipo del valluno ladrón.

\section{El Valle Alto en perspectiva}

La historia del Valle Alto condensa, en gran medida, la historia de Cochabamba. Se trata de una subregión antiguamente designada con el nombre "valle de Cliza", que en la época republicana pasó a ser conocida simplemente como "el Valle", por antonomasia. En tiempos preincaicos estaba habitada por grupos de distintas etnias que practicaban una agricultura de pequeña escala, lo cual cambió con las colonizaciones inca y española, que introdujeron transformaciones trascendentales mediante la importación de otros grupos étnicos para el desarrollo de proyectos agropecuarios de gran envergadura. Los colonizadores -andinos primero y peninsulares después- comprendieron que grandes zonas del valle de Cliza eran apropiadas para tierras de pastoreo, y también se hizo evidente la posición geoestratégica de la subregión, que se potenció aún más debido al cultivo de coca en los yungas de Totora y Pocona, hacia el sureste. Así, el Valle Alto se convirtió rápidamente en un espacio de tránsito de caravanas de llamas cargadas de diferentes productos, al tiempo que la agricultura comercial también se desarrollaba con vigor creciente como consecuencia del auge minero de Potosí, desde mediados del siglo XVI, que demandaba vorazmente alimentos e insumos. El enorme espacio económico abierto por la minería potosina aceleró un proceso de ocupación de los colonizadores españoles, que fueron apropiándose de las tierras más fértiles, dando lugar al surgimiento de haciendas con fuerza de trabajo servil, en tanto llegaban indígenas de distintas partes huyendo de la mita minera y de las imposiciones fiscales para integrarse como yanaconas en las fincas convertidas en empresas agrícolas. A la larga, esto generó la formación de un dinámico campesinado mestizo y mercantil, 
sin una identidad étnica ni comunitaria claramente definida o reivindicada, que arrendaba tierras para su subsistencia y reproducción (Schramm, 1991: 7-29). He ahí el origen de los habitantes de esta subregión, conocidos luego como "vallunos": campesinos quechuahablantes que en el imaginario local y nacional emergieron como pícaros, negociantes, individualistas, predispuestos al clientelismo y siempre abiertos a nuevas experiencias (Albó, 1987).

Otro rasgo característico del Valle Alto a partir del siglo XVII fue su gran densidad poblacional; ya a fines del siglo XVIII era indiscutiblemente la zona más poblada y cultivada de toda la provincia de Santa Cruz, a la que pertenecía el actual departamento de Cochabamba (Larson, 1992: 222). Además, en su territorio se formaron pueblos que, con el tiempo, adquirieron tanto o más importancia que la propia ciudad capital cochabambina. Me refiero a Tarata, Arani y Punata, pequeños pero cruciales centros políticos que, desde inicios del siglo XIX, aspiraban a la urbanización merced a las élites letradas y terratenientes formadas en su seno. La relevancia política y estratégica del Valle Alto quedó claramente establecida durante la crisis de la Guerra de la Independencia, cuando fue esta subregión la que engrosó, en gran medida, las fuerzas insurgentes dirigidas por el caudillo criollo Esteban Arze, cuyo ejército popular estaba integrado por campesinos y artesanos que descollaron en batallas cruciales para la historiografía republicana. Además, la posición geográfica de la zona determinó que quien controlase el Valle Alto controlaba también un acceso vital no solo a la ciudad de Cochabamba, sino también al Sur -La Plata y Potosí-, al Este -Santa Cruz- y al Oeste y al Norte -Oruro y La Paz-, por lo cual la región fue muy apetecida por los ejércitos en contienda (Rodríguez Ostria, 2012). Esta centralidad geopolítica continuó evidenciándose a lo largo de la época del caudillismo militar republicano, e incluso después, cuando, por ejemplo, en 1875 o en 1888, diversos pueblos vallunos se vieron hondamente sacudidos por los partidarios de las distintas facciones políticas que conseguían movilizar considerables cantidades de simpatizantes para generar revueltas y alzamientos no menores, pero poco estudiados.

Aparte de su abundante población -característica que se mantuvo hasta el siglo XX-, de su posición geográfica articuladora con el Oriente y con el Sur, y de su vocación agropecuaria y comercial, el Valle Alto tenía relieve también debido a la importante presencia de la Iglesia católica, particularmente en Tarata, pero también en Arani, la primera sede episcopal de la región (Laserna, 1984: 26). De hecho, la hacienda más grande de la provincia de Santa Cruz pertenecía a la Iglesia, y estaba ubicada en lo que hoy es Cliza. Me refiero a la célebre finca de Santa Clara, escenario central en esta historia, sobre el cual volveré en los siguientes acápites. La presencia de centros eclesiásticos de poder, monasterios y grandes conventos en Arani y en Tarata, por ejemplo, provocó que algunos pueblos se convirtieran en lugares de peregrinación y de festividades 
religiosas, con el infaltable correlato de la aparición de improvisadas -pero crecientes- ferias alrededor de las procesiones y demás actos católicos que concentraban pequeñas multitudes, venidas incluso de allende el valle.

Por último, otra peculiaridad del Valle Alto fue un recurrente estado de agitación social y política, debido, en parte, a una serie de sequías y epidemias que catalizaban los seculares descontentos de campesinos y sectores populares. Cabe recordar que el carácter fundamentalmente agrícola de Cochabamba constituye una de las razones por las cuales esta región tuvo una relación casi traumática con el agua y con las alteraciones cíclicas de la producción campesina, pues recurrentes epidemias y crisis climáticas incidieron de diversas formas en los precios de los cereales y de otros productos durante distintas coyunturas históricas, provocando a la vez hambrunas, mortandad, migraciones, desempleo y convulsión social (Rodríguez Ostria, 1995: 111). Al respecto, Humberto Solares ha sido el primer investigador en demostrar elocuentemente que, a fines de la década de 1870, varias subregiones del departamento de Cochabamba, incluyendo el valle de Cliza, vivieron una gran sequía y, a la vez, una terrible epidemia de "fiebres intermitentes", como se decía en la época, enfermedades que ocasionaron la peor tragedia ocurrida jamás en la historia de la región (Solares, 1990: 114-122). Se trataba de brotes de tifus, "caquexia palúdica", cólera y fiebre tifoidea, entre otros males, que se expandieron desde las provincias hasta la ciudad, produciendo más de quince mil muertos entre 1879 y 1881 (Rodríguez Ostria, 1995: 113-114). La grave situación provocó una caída de la producción agrícola y que los precios del trigo, del maíz, de la harina y de otros productos de primera necesidad se elevaran especulativamente. La explosiva combinación de desabastecimiento, sequía, especulación y epidemias mortales derivó pronto en un cuestionamiento de orden social, expresado mediante manifestaciones populares y luego pequeñas revueltas y asaltos a la propiedad privada ocurridos en distintas provincias del departamento -particularmente en el Valle Alto-, que exigían la fijación de los precios de los alimentos (Solares, 1990: 117) y, poco más tarde, el acceso campesino a las tierras monopolizadas por los terratenientes.

Las recurrentes revueltas del campesinado y de los sectores populares provincianos arreciaron en la década de 1890 , en virtud de una nueva ola de sequías y de la crisis política desatada por la rivalidad política entre conservadores y liberales, que disputaban con armas en mano su legitimidad electoral en el Valle Alto, pues una diputación o una senaduría por Tarata o la designación de un intendente para Cliza o Arani eran asuntos no menores en el mapa político de la época; otro efecto de la densidad poblacional valluna, que concentraba nada despreciables cantidades de potenciales electores (Rodríguez García, 2016).

Esta síntesis de rasgos puede darnos una idea de la importancia del valle de Cliza y de su permanente estado de agitación, provocado cada vez más 
por grupos campesinos emergentes que no solo se levantaban contra los hacendados mediante ocasionales motines y revueltas, sino que también practicaban otro tipo de acciones de resistencia menos espectaculares, mas no por ello menos efectivas.

\section{EL “VALLUNO LADRÓN"Y LA PICARDÍA: ENTRE EL FOLCLORE Y LA TRADICIÓN ORAL}

En el anterior acápite se ha visto brevemente la recurrente aparición del Valle Alto como escenario de desórdenes sociales, a lo cual se añade una suerte de "cultura del robo" que se ha ido forjando en esta subregión desde mediados del siglo XIX, al punto que a fines de dicha centuria ya existía en diversos discursos letrados un nítido estereotipo del "habitante valluno" -especialmente del cliceñocomo ladrón. En 1894, por ejemplo, un escritor y viajero llamado Agustín de Porcel, que pasó por el Valle Alto, señaló -a propósito de esa parte de su viaje- que "el cholo cochabambino" podía robar incluso a sus propios amigos (Porcel, 1894: 18). También resulta interesante un temprano libro de folclore escrito por Víctor Varas Reyes en 1947. Dicho autor titula un capítulo de su obra como "Cliza en los cuentos de robos", donde rescata tradiciones orales que muestran a los cliceños como "hábiles timadores". Varas Reyes escribe: "tanto se ha hablado de los robos, que los mismos pobladores [de Cliza], como los de la capital, han inventado y repetido tradicionalmente casos de autoburla [sic], a la manera desenfadada del gato que, jugando, jugando, se muerde la cola" (1947: 177). De los divertidos relatos recogidos por Varas Reyes destaca el ya clásico del abigeo que, tras robar un burro, lo pintó y lo vendió a su propio dueño sin que este notara la tramoya, cuento que les valió a los cliceños el mote de burru-tiñis -es decir, los que tiñen a los burros para ocultar el robo-y que se mantiene hasta ahora, tal como refiere el escritor Jorge Guevara cuando afirma que a los cliceños les dicen así "desde sus antiguos padres" (2012: 119). La caracterización de los cliceños como burru-tiñis está esbozada asimismo en un conocido Diccionario de bolivianismos, alimentado por diversas tradiciones folclóricas, y que dice lo siguiente al respecto:

Sujeto que tiñe burros. Ladrón avispado, hábil y dueño de tretas y expedientes, capaz de transformar los objetos robados en otros que el dueño no podrá reconocer. El apodo es alusión a los cliceños, de quienes la conseja popular dice que son ladrones consumados (Gómez y Fernández, 1996: 213).

Como se ve, existe una recurrencia del latrocinio en los cuentos y tradiciones de la región, y a veces tales relatos involucran a altas autoridades en el papel de víctimas. Jorge Guevara menciona algunos cuentos populares en los que aparecen un par de presidentes de la República: se supone que en una 
ocasión el gobernante Aniceto Arce -en el poder entre 1888 y 1892- "perdió" su sombrero en Cliza -la explicación implícita es un hurto, por supuesto-, ${ }^{6}$ y que Hugo Banzer -dictador entre 1971 y 1978-, cierta vez, dada la fama de latrocinio que tenían los valle alteños, "sujetó desesperadamente sus bolsillos en Ucureña cuando fue levantado en hombros”, pero estas serían, en opinión de Guevara, "solo bromas y muestras de la picardía del cliceño" (2012: 119).

Considero que el tema de las bromas y de la picardía del valluno en general, y del cliceño en particular, no es inocente y brinda una clave interpretativa interesante. Como ha señalado James Scott, en ciertos relatos populares de distintas partes del mundo se destaca el elemento de la picardía, como también los divertidos actos y dichos de su personaje principal: "[es] difícil encontrar una sociedad de campesinos, esclavos o siervos sin una figura tradicional de pícaro" (2000: 194). El pícaro, en cierta medida equivalente al trickster de la teoría antropológica anglosajona (véase: Balandier, 1994: 48-67), es el que se burla de la autoridad, invistiéndose de todos los atributos clásicos del rebelde. Esto tiene que ver con lo que Scott llama el "discurso oculto" de la resistencia de los subordinados: una diversidad de prácticas sutiles que expresan y alimentan el descontento y la politización, eludiendo la represión. Las prácticas del discurso oculto constituyen para Scott auténticas "artes de ocultamiento político"; entre ellas están los cuentos populares, el rumor, la burla, la picardía, la inversión simbólica, etcétera, aspectos sobre los que volveré brevemente al final. Y así, las narraciones referidas a que en esta zona abundan los ladrones pueden rastrearse en distintos libros de tradiciones y folclore, ${ }^{7}$ en innumerables notas de prensa, ${ }^{8}$ en folletos, ${ }^{9}$ en relatos orales e, incluso, en un par de publicaciones muy serias de

6 He oído otra versión en la que fue al presidente Daniel Salamanca-gobernante entre 1931 y $1934-$ a quien le robaron el sombrero en Cliza.

7 Aparte de los textos ya mencionados, la "tradición" de los robos en Cliza figura igualmente en Tradiciones de Bolivia (Paredes Candia, 1976) y en Tradiciones y costumbres cochabambinas (Cossío, 2002).

8 La prensa de fines del siglo XIX y principios del siglo XX está llena de equiparaciones de ciertas zonas rurales de Cochabamba con la Calabria, al punto que el Valle Alto era conocido en reiterados discursos periodísticos como "la Calabria cochabambina" y sus habitantes eran llamados "calabreses". Las referencias al respecto son prácticamente inagotables. Conviene recordar que Calabria es una zona del sur de Italia, famosa por sus bandoleros. Llama la atención el lugar que Calabria empezó a ocupar en la imaginación de los periodistas de varios países de Europa y de Latinoamérica, asociando dicha región con un fantasioso lugar regido por el bandolerismo.

9 Entre muchos de los ejemplos de folleterías que aluden al tema, destaco dos procesos judiciales por corrupción y propiedades, impresos a principios del siglo XX, en los que se usa la expresión "playa de Cliza" como metáfora para designar un lugar 
corte etnográfico. Una de ellas pertenece al científico y explorador sueco Erland Nordenskiold, personaje que durante un extenso viaje pasó por el Valle Alto en 1913. En aquel trajín, el sabio sueco se refirió a Tarata como un pueblo famoso "por sus conventos, su chicha y sus ladrones de caballos" (Nordenskiold, 2001: 103). Otra alusión al tema se halla en una pionera etnografía realizada por el antropólogo estadounidense John Francis Goins, quien vivió en el Valle Alto a inicios del decenio de 1950. Mientras tomaba fotografías de una fiesta en la plaza de Toco, Goins se dio cuenta de un hecho curioso, el cual narra a propósito de ciertas imágenes que logró capturar con su cámara:

Esta fotografía la tomé [...] mientras me balanceaba en el parachoques de un camión, justo al lado de tres jóvenes de Toco. Toco está tan orgulloso de su fama de ladrones como lo está Cliza. Mientras tomaba las fotografías, los tres jóvenes me sacaron metódicamente todo lo que llevaba en los bolsillos, dinero, cigarrillos, los filtros de la cámara, el cuaderno de notas, el de las anotaciones de las fotografías, los cerillos, la pluma fuente y el lápiz. Cuando comencé a descender del camión, me dieron un golpecito en el hombro, y me mostraron todo lo que me habían quitado, y me lo fueron devolviendo uno por uno, sonriendo alegremente y muy satisfechos de sí mismos (Goins, 1967: 242).

Postulo que todas estas historias tienen una procedencia muy concreta y una explicación histórica que nos remite a diversas modalidades de resistencia campesina contra los hacendados durante el siglo XIX y las primeras décadas del siglo XX, mas también a una extensa serie de actividades delictivas, en ocasiones ligadas con luchas político-partidarias. Para abordar estos tópicos es necesario remitirnos a un lugar muy específico: la hacienda Santa Clara, una gigantesca propiedad de la Iglesia católica en el corazón del Valle Alto.

\section{LA HISTORIA DE UNA HACIENDA Y LA UTOPÍA DE LA TIERRA PROPIA}

La hacienda Santa Clara tiene su origen en tierras de encomienda legadas por una rica familia española a las monjas clarisas a inicios del siglo XVIII. La heredad en cuestión, de la cual tomaron posesión las clarisas y sus representantes en 1715, era un territorio de extensión descomunal que se perdía en el horizonte, pues sus confines nunca estuvieron nítida ni totalmente definidos. Gracias a hábiles gerentes contratados para la administración y a poderosos latifundistas arrendatarios que invertían en más propiedades y tierras vecinas, la hacienda Santa Clara se convirtió rápidamente en un verdadero imperio financiero mediante

o situación de mentiras, robos e infamias. Dichos procesos están resumidos en los trabajos de Emilio Mostajo (1904: 36) y Hermógenes Sejas (1905: 10). 
el arrendamiento, el subarrendamiento y la producción agrícola, de tal forma que la Iglesia quedó convertida en el mayor terrateniente de la región (Larson, 1992: 271; Dandler, 1969: 45; Mercado, 1994: 110). En suma, esta hacienda se constituyó en un auténtico poder en la zona, ejerciendo su dominio mediante la explotación de mano de obra campesina, por lo cual, desde el siglo XVIII, se convirtió en el blanco de la ira de los trabajadores agrarios en varias ocasiones. Por ejemplo, durante el Carnaval de 1781, en el marco de las grandes rebeliones anticoloniales surandinas del periodo, los colonos (labradores) de Santa Clara $\mathrm{y}$ otras fincas vecinas se rebelaron y mataron a dos altos administradores de la propiedad, intentando luego tomar los pueblos de Punata y Toco. Se estima que los movilizados eran aproximadamente mil, quienes, tras feroces combates, fueron derrotados, dejando al menos 500 muertos (Rodríguez Ostria, 2012: 25).

Nada detuvo la continuidad de la rentable hacienda y de la explotación de la fuerza de trabajo campesino: la producción agrícola de Santa Clara fue adquiriendo dimensiones cada vez mayores a lo largo del siglo XIX, al punto que, ya en la época republicana, la fertilidad de sus tierras garantizaba la existencia de maizales de hasta tres metros de alto, y se cuenta que los trabajadores se perdían allí, siendo necesario abrir callejones entre los extensísimos campos de cultivo. Además, en época de cosecha, el maíz recogido lograba llenar varias canchas con auténticas "montañas de mazorcas" (Rejas, 1948: 8, 9). La hacienda, en suma, era la más importante de todo el departamento, y su éxito se debía a su ubicación en un privilegiado lugar de tierras fértiles e irrigadas por enlames, pues no todo el Valle Alto gozaba de accesos eficientes a fuentes de agua (Larson, 1992: 271). De hecho, buena parte de esta subregión, particularmente en el norte, tiene hasta hoy habituales problemas de sequías.

Santa Clara resultaba, pues, muy apetecible, tanto para los hacendados y los arrendatarios de élite ávidos de más fortuna como para los campesinos sin tierra que intercambiaban su fuerza de trabajo, y parte de su producción, por el usufructo de una parcela de subsistencia o "colonato". Dicho sea de paso, los campesinos sujetos a esta forma de producción eran conocidos como "colonos" y estaban sometidos, además, a diversas obligaciones y prestaciones personales domésticas a los hacendados, aglutinadas bajo el término genérico de 'pongueaje'. Así, un colono generalmente era también pongo, es decir arrendatario sometido al pongueaje, y desarrollaba su trabajo en medio de diversos arreglos contractuales, no siempre muy claros, entre patrones y campesinos por un lado, y entre los propios campesinos por el otro. Por ejemplo, estaba la "aparcería": el pago del colono al hacendado exclusivamente en especie, no en trabajo. Había también la figura del "arrimante": el campesino sin capacidad de arrendar tierras directamente de los hacendados y que se veía obligado a usufructuar parte del terreno alquilado por un colono. Ofrecía pagos en especie o trabajo, ayudando también al colono a cumplir las obligaciones de este 
con la hacienda. Estaban asimismo los "sitiajeros": aquellos que tenían muy poco o ningún acceso a tierras de cultivo y prestaban cualquier servicio en las fincas de los gamonales a cambio de diminutos espacios donde construían sus chozas. Por último, estaban los "desahuciados": campesinos expulsados de las haciendas que no tenían casi ninguna opción para subsistir, viéndose generalmente obligados a incursionar en actividades fuera de la ley. En suma, este breve listado de arreglos laborales revela los efectos de una alta densidad demográfica sobre tierras fértiles limitadas, junto con una estratificación interna dentro del propio sector campesino (Dandler, 1969: 50).

Ahora bien, los miles de colonos, arrimantes y sitiajeros que empezaron a subarrendar tierras y a trabajar como pongos en la finca Santa Clara fueron construyendo sus viviendas al borde de los senderos y acequias de la propiedad, no siempre de modo legal, constituyendo pequeños caseríos que son la génesis del actual pueblo de Cliza (Guevara, 2012: 15-17). Esto determinó que en 1844 el naciente poblado adquiriese rango de cantón, con el nombre de Orihuela, y que en 1846 el Gobierno empezara a exigir a la hacienda que vendiera lotes para el ordenamiento y la expansión del pueblo, que ya se venía formando de facto (Mercado, 1994: 112; Guevara, 2012: 16). A la larga, tanto por el surgimiento de un pueblo dentro de una propiedad privada como por las rivalidades entre terratenientes, la hacienda de Santa Clara se vio involucrada en decenas de laberínticos conflictos legales, algunos publicados en folletos, aunque la mayoría yacen todavía desconocidos en los no catalogados archivos de los juzgados del Valle Alto, según he podido constatar.

Conviene señalar aquí un detalle: los trabajadores de la hacienda tenían la obligación de vender los productos cosechados como parte de sus deberes para con los administradores, y así fueron creando gradualmente sus propios espacios económicos. Este fue el inicio de un modesto mercado campesino en los límites de la finca hacia la década de 1840. Lo llamativo es que dicho mercado adquirió cada vez más relevancia, y no tardó en absorber el flujo antes en tránsito de un amplio circuito mercantil que abarcaba todas las áreas del Valle Alto, y que se convirtió en una feria de considerables dimensiones (Mercado, 1994: 112-113). De esta manera, el inicialmente pequeño mercado de Cliza pasó a ser un eje articulador entre varias ciudades, e incluso con ultramar, debido al ir y venir de arrieros, como también a la confluencia de una gran variedad de comerciantes, rescatistas, timadores, bandidos, colonos y vividores de diversa calaña que vendían casi de todo, incluyendo mucho ganado robado, finos caballos, ovejas, gallinas, etcétera. Un conocido intelectual decimonónico, Luis Felipe Guzmán, señaló que en 1888 esta feria reunía "hasta 15 mil almas" cada domingo y que el capital que movía era superior a los 170.000 pesos bolivianos en cada jornada de funcionamiento (1888: 66). 
Sin embargo, el auge comercial no beneficiaba necesaria ni igualmente a todos, considerando que el Valle Alto constituía una sociedad altamente estratificada. Por un lado, no pocos hacendados afectados por las crisis económicas de fines del siglo XIX empezaron a fragmentar sus haciendas, abriendo un interesante mercado de tierras; por otro, la agricultura intensiva y de pequeña escala resultaba cada vez más insuficiente para mantener los hogares campesinos, por lo cual los colonos dieron mayor vigor a la diversificación de su economía, combinando la migración con la artesanía, el arrieraje, la confección de chicha y diversas formas de robo, todo con el fin de subsistir y con la ilusión de emanciparse de los hacendados accediendo a la propiedad parcelaria. Y es que se había forjado una verdadera utopía: la de la tierra propia (Mercado, 1994: 207), ideal que resultaba más atractivo aún debido al surgimiento de los denominados "piqueros", ${ }^{10}$ desde mediados del siglo XIX, campesinos privilegiados liberados del poder terrateniente mediante la compra de diminutas porciones de tierra: las "piquerías". De este modo, el único horizonte que muchos campesinos veían para liberarse del yugo que les imponían los terratenientes era la pequeña propiedad, es decir convertirse en piqueros, más todavía considerando la agudización de las cíclicas crisis y la intensificación de los abusos patronales, sin mencionar en detalle las expulsiones de colonos que los administradores de la finca Santa Clara empezaron a realizar, aparte de exacciones e innumerables abusos e injusticias que fueron colmando la paciencia de los campesinos (Guevara, 2012: 18).

Por otra parte, y al mismo tiempo que el empuje mercantil del campesinado en pos de comprar tierras, surgió una crítica liberal a la hacienda de las monjas clarisas, pues a la larga había generado una situación que ponía en entredicho la noción de la propiedad privada, tanto porque el pueblo de Cliza se formó dentro de una hacienda como por una suerte de institucionalización del robo de maíz, como se verá enseguida.

\section{LA RESPUESTA: EL CHAJMEO}

La situación de la hacienda Santa Clara empezó a captar cada vez más la atención pública en la década de 1890 , en virtud de varios factores que resultan muy importantes para esta historia. Aquí, resulta ilustrativa una discusión planteada desde la prensa: un conjunto de extensos editoriales periodísticos escritos en 1898 por José Quintín Mendoza -famoso abogado tarateño, director del diario El Siglo XX y, a la sazón, senador por el Partido

10 De piqui, palabra quechua para designar insectos pequeños, particularmente piojos y pulgas, en referencia a las parcelas pequeñas llamadas precisamente piojales o piquerías. 
Liberal- estaban dedicados a comentar la situación de la finca Santa Clara con motivo de las "manifestaciones comunistas del pueblo de Cliza", en alusión a una revuelta ocurrida en mayo de ese año, cuando campesinos y artesanos que se oponían a la instalación de una fábrica de alcohol de maíz, y que aspiraban a saquear la hacienda de las monjas clarisas, se sublevaron ocasionando un muerto y graves disturbios (El Heraldo, 8 de junio de 1898). Los comentarios de Mendoza en El Siglo XX giraron en torno a discutir "la condición civil de aquel pueblo excepcional", no solo a propósito de la reciente revuelta mencionada, sino, sobre todo, por el hecho de que el propio pueblo se formó ilegalmente en una propiedad privada, además de que se había ido desarrollando y consolidando una serie de prácticas y de costumbres que incluían la cosecha de maíz ajeno. En su argumentación, Mendoza se refiere a Cliza como un "pueblo salvaje y abyecto" que practicaba "humillantes tradiciones":

Lo prueba la falta absoluta de toda idea en ese antro, y la exuberancia de apetitos carnales y bestiales de sus habitantes. Pero es preciso confesar que los gobiernos de cohecho que [...] explotan la barbarie cliceña no han creado [...] esa situación. La han encontrado hecha. Ella es resultado de causas complejas que la incuria cochabambina nunca se ha cuidado de estudiar, y mucho menos combatir. Cliza es una población anormal y extravagante, constituida fuera del Código Civil y de la civilización [...]. ¿Cómo vive entonces esa numerosa población de 14.000 personas? Robando en la finca y robando en el comercio. Tienen por ley y por vínculo social el robo [...]. Los cliceños atacan la propiedad porque no la conocen (El Siglo XX, 4 de junio de 1898).

En su puntilloso afán, Mendoza calculó que durante 1898 Cliza era "un fundo de 50 a 60 kilómetros de superficie", donde vivían "de 8 a 10.000 habitantes" -a veces señala 14.000-, todos los cuales, según el editorialista de $E l$ Siglo XX, asumían el robo como algo normal:

Tan numerosa población se ha dedicado al robo como a una profesión lícita, lucrativa y cómoda [...]. El robo crónico y consuetudinario transformado en longanimidad [...]. Una población tan numerosa transformada en nido de ladrones. ¿ No es esa una verdadera desgracia para el departamento de Cochabamba? (El Siglo XX, 27 de junio de 1898).

Mendoza se quejaba también del sólido clientelismo político establecido en Cliza por parte del Partido Conservador, y su correlato de bandidaje político-electoral, y del arriendo de la finca Santa Clara a latifundistas 
improductivos que la subarrendaban a los colonos, lo que se consideraba un absurdo, pues se estaba perdiendo mucho dinero que podía ser utilizado para el progreso del departamento:

Y en qué se emplea esa pérdida. En proteger el robo, en mantener una población anónima, casi impersonal, nocturna, absolutamente dedicada al hurto, refractaria a todos los progresos de la civilización, rebelde a todo sentimiento moral, fatalmente inclinada a hacer del hurto una religión, incapacitada para todo estímulo y puesta fuera de los alcances de esos grandes aguijones de la actividad humana, llamados trabajo y propiedad. El habitante de Cliza está fatalmente inclinado por su exótica constitución a ejercitarse en el pillaje [...].

Y ese sistema de depredación crónica [...] se ha inoculado en el gran comercio de esa plaza. Las leyes de todos los pueblos civilizados se han trastocado allí, para que no imperen sino las leyes de Licurgo. ${ }^{11}$ Cuando el ladrón ejecuta con habilidad un hurto cualquiera, se congratula y se alaba de él. Es el único honor que conocen esos adoradores de Mercurio, protegidos como están por la perpetua complicidad de las autoridades y de la Policía, y por la incurable anemia del poder judicial [...].

Por eso [los militantes del Partido Conservador] simpatizan con ese nido [...]. Les gusta el cuadrillaje, les conviene el bandolerismo. Si roban maíz de la finca, también roban votos a la República.

Expropiar un fundo a un monasterio pagándole su justo valor para desecar un pantano infecto, un nido de microbios, [...] para transformarlo en un campo risueño y bien cultivado, cubierto de flores y de mies, ¿es acaso herir el derecho? [...] El proyecto de El Siglo XX ${ }^{12}$ consiste en curar ese pueblo haciéndole entrar en el ejercicio del derecho de propiedad (El Siglo XX, 27 de junio de 1898).

En su activa campaña para que el Estado expropie legalmente la hacienda, Mendoza brinda algunos datos acerca del trabajo en la zona, e intenta explicar los motivos de esta suerte de naturalización del robo que se achacaba a los campesinos cliceños:

11 Hábil legislador espartano y, por extensión, adjetivo aplicable a quien es astuto y mañoso.

12 Se refiere a un proyecto de ley para expropiar la hacienda Santa Clara, a fin de que pase a manos del Estado. 
Esa falta de remuneración [económica a] los colonos que todo hacen para el hacendado, les da el permiso o la autorización de robar al patrón para tener por ese medio participación en las ganancias del gran afincado. Hay otra causa que influye para que no se respete lo ajeno y es que la gran finca de Cliza [...] facilita al colono para hacer cambios en especie con los del pueblo, porque solo así puede en alguna manera obtener utilidades que el patrón no las da [...].

La finca de Cliza, dividida y subdividida, distribuida entre la gente del pueblo y los labriegos, los haría a éstos laboriosos y honrados; pero hoy, en la situación actual [...] necesariamente tienen que ser ladrones (El Siglo XX, 6 de noviembre de 1898).

En efecto, todo indica que la finca era el escenario común de pequeńos pero cotidianos robos. Al respecto, David Mercado halló un contrato de arrendamiento de 1873 en el Valle Alto que incluía una cláusula en la que los mayordomos o conductores de la hacienda pagarían por los probables robos de los colonos (1994: 121): una muestra de los medios de que disponían los poderosos en su intento de impedir los frecuentes hurtos. ¿Pero qué era lo que realmente sucedía en Cliza y en su famosa hacienda para que los campesinos colonos fueran calificados de ladrones de modo tan sistemático? La respuesta pasa por una práctica, una suerte de institución extendida en todo el Valle Alto, e incluso más allá de él: el chajmeo, que consiste en el recojo de una parte de las cosechas de las fincas por los trabajadores locales y también por gentes ajenas a las propiedades -los denominados "merodeadores"-, sin ningún tipo de rendición de cuentas a los patrones o a los administradores. Usando una reflexión de Tristan Platt, acerca de los conceptos de legalidad en el trabajo minero decimonónico, deduzco que los orígenes de esta práctica pueden hallarse en la antigua reciprocidad distributiva andina entre quienes contribuyen con el trabajo y quienes ponen el objeto y los medios para trabajar (Platt, 2014: 116), algo que la instalación de la agricultura comercial, desde mediados del siglo XVI, empezó a modificar, dado el monopolio español sobre la tierra y el sistema de haciendas que introdujo además la noción "moderna" de propiedad privada. Como fuere, el caso es que para el siglo XIX el chajmeo era una práctica más o menos generalizada que, de ser considerada atentado y hurto, terminó siendo institucionalizada y aceptada resignadamente por los terratenientes y sus administradores, a fin de disminuir la incidencia de los robos, situación parecida al robo de mineral llamado juqueo, en las zonas argentíferas (Mercado, 1994: 159). ${ }^{13}$ Absolver la pregunta de cuándo los

13 Un indicio de la similitud entre juqueo y chajmeo puede rastrearse en una novela de Julio Paz publicada en 1944, pero ambientada en 1812. En ella, Paz asume la 
terratenientes habrían empezado a aceptar el chajmeo implicaría realizar una nueva pesquisa, que espero alguien asuma en el futuro. Entretanto, planteo como hipótesis que aquello quizá ocurrió en las décadas de mediados del siglo XIX, que coincide con el gradual ascenso de una economía campesina relativamente autónoma respecto al poder hacendal.

Los chajmiris, es decir aquellas personas que practicaban el chajmeo, provenían de los niveles más pobres de la sociedad valluna -probablemente sitiajeros, arrimantes y campesinos desahuciados-, según narró Damián Z Rejas, abogado de la finca Santa Clara por más de 25 años, y que fue el primero en escribir parte de su historia:

En la cosecha el producto era tan abundante que los cosechadores no podían avanzar y tenían que dejar una tercera parte del producto para los chacmiris, que así se llamaba a la gente pobre del pueblo, que en gran avalancha seguía a los cosechadores para recoger las mazorcas que habían abandonado; estos mismos chacmiris no conseguían recoger el total del producto abandonado y dejaban para otros chacmiris que acudían al día siguiente, pero ni estos podían recoger íntegramente y quedaba algo para el consumo del ganado que entraba después de ellos, de este modo los chacmiris conseguían reunir una o dos fanegadas de maíz para su sustento de todo el año (1948: 9).

Rejas, al igual que la prensa finisecular, daba a entender que el chajmeo era una costumbre, pero no por ello dejó de considerárselo una "pérdida y sustracción", mientras que otras referencias indirectas a esta práctica la caracterizaban como un "extraño método de explotación":

La mujer del labrador, los habitantes de otros caseríos y los del mismo pueblo en épocas de cosecha se proporcionan maíz y otros productos sirviendo[se] de cosechadores; ellos exigen su paga en productos [...]; modificar esa costumbre es arrebatar el pan de la boca del hambriento. Bajo esta manera de ser ha vivido el pueblo de Cliza [...]. El colono y los del pueblo a vista

palabra 'juqueo' - del quechua juqu, es decir búho, y por extensión quien hace actividades nocturnas y por tanto oscuras-como sinónimo de recolección de maíz. Los protagonistas de Paz son dos jovencitos que salen de Cochabamba hacia el sur, buscando integrarse a las fuerzas auxiliares porteñas en plena Guerra de Independencia. A su paso por el Valle Alto, el narrador cuenta: "Así nos íbamos [...] cuando nos aturdió una gritería dedicada a nosotros [...]. Era el juqueo de los pícaros vallunos, que deshojaban maíz en una gran calcha” (Paz, 1944: 30). Respecto a las discusiones en torno al robo en el trabajo minero -juqueo o kajcheo-, véanse: Rodríguez Ostria, 1989; Barragán, 2014; Platt, 2014. 
[d]el dueño acostumbraban llevarse grandes porciones de maíz (El Siglo XX, 6 de noviembre de 1898).

Sus productos [de la hacienda Santa Clara], jraro fenómeno!, se aprovechan en común y sosegado usufructo por arrendatarios y merodeadores sin que nadie se haya osado a pretender extinguir o aminorar tan extraño método de explotación. Sólo la sorprendente exuberancia de la finca de Cliza, debida a los riquísimos enlames que mejoran sus tierras, puede hacer que sus conductores se sobrepongan a quiebras inminentes (Guzmán, 1888: 66).

Ahora bien, más allá del chajmeo en la finca Santa Clara, diversos expedientes judiciales que he podido leer muestran cierta frecuencia de robos de productos ya cosechados y almacenados en diversos puntos del Valle Alto. Se trataba de hurtos de pequeña escala cuyo móvil era la necesidad básica de alimentación de sus ejecutores. En efecto, mucha gente se dedicaba ocasionalmente al robo solo para alimentarse, tal como se observa en varios procesos legales iniciados debido a hurtos de escasas cantidades de papa, maíz, trigo y cebada, almacenadas en trojes o casas de hacienda. Los modus operandi eran diversos: desde forados en muros hasta forzamiento de puertas y ventanas. En ocasiones, los forzamientos eran efectuados con instrumentos especialmente diseñados para tal fin $\mathrm{y}$, de hecho, en varios expedientes pude advertir la expresión "llavemaestrero", que aludía a los individuos expertos en abrir puertas ajenas. En otros casos, los robos se combinaban con sabotajes contra las propiedades latifundistas, ejecutados tanto por colonos vernáculos como por personas foráneas; estos actos se daban también más allá del Valle Alto. Un ejemplo digno de mención lo hallé en Tapacarí, subregión cochabambina dominada por acaudalados caciques indígenas que monopolizaron la tierra y el poder desde tiempos prehispánicos, logrando conservar sus privilegios y linajes en la época colonial, e incluso en la republicana. Allí, en julio de 1897, un terrateniente indio llamado Matías Condori, personaje autodenominado "indígena originario", enfrentaba, junto a otros latifundistas, destrozos y robos en su propiedad, siendo sus propios colonos los responsables. Esta situación queda bien ilustrada en un oficio enviado por Condori al prefecto de Cochabamba el 29 de julio de 1897:

En la comarca en donde vivo, alejada relativamente del centro de esta capital, mi propiedad y la de mis vecinos está frecuentemente sujeta a dańos que con toda audacia y por cuadrillas [cometen] mis propios colonos. Cortándome las sementeras se [las] llevan con detrimento de mis intereses $\mathrm{y}$ con desprecio del derecho de propiedad, base fundamental del progreso de los pueblos. Los anteriores atentados se verifican por fustigaciones 
[instigaciones] de un Juan Quispe, quien induce a mis colonos a que me desobedezcan y atropellen mis sementeras, sin que la autoridad local y el Corregidor [...] reprima[n] y frene[n] semejantes expoliaciones. A efecto de resguardar mis intereses acudo a su probidad para que se sirva incitar al Señor Corregidor a que con todo celo y vigilancia [...] evite en lo sucesivo la repetición de los ataques que llevo enunciados, notificando a dicho Juan Quispe y a mis colonos rebeldes a que se abstengan. ${ }^{14}$

Destaco la acción de los "colonos rebeldes" contra las sementeras: cuando no las destruían, las cosechaban para sí mismos, llevándoselas impunemente y sin autorización alguna. Inspirado en James Scott (2000), interpreto este tipo de actos como una forma de resistencia, más o menos silenciosa, contra el poder latifundista, y ello ocurría en distintas latitudes e igualmente entre comunarios de las alturas de Vacas -zona contigua al Valle Alto-, que atentaban vigorosamente contra propiedades municipales o de grandes gamonales, tal como he podido constatar en diversos expedientes judiciales. Sin embargo, el Valle Alto era un escenario donde no solo el chajmeo, los pequeños sabotajes clandestinos o los hurtos a pequeña escala daban de qué hablar, sino también los robos violentos, incluyendo asaltos directos a casas $\mathrm{y}$ atracos en los caminos. En este punto entra en escena el bandolerismo, fenómeno que tuvo su parte en la creación del estereotipo del valluno ladrón.

\section{LATROCINIOS VIOLENTOS Y ABIGEATOS}

En base a varios indicios y evidencias, es posible afirmar que el Valle Alto era una zona de bandidajes endémicos desde inicios del siglo XIX, probablemente como efecto de la Guerra de la Independencia, pero fundamentalmente por la recurrencia de crisis económicas y políticas. Se trata de prácticas que constituyen un desafío para la interpretación, pues muy pocas podrían ser calificadas como "sociales". Aquí me refiero al concepto de 'bandolerismo social' de Eric Hobsbawm, que designa cierta delictividad violenta que sería aceptada y apoyada por el campesinado u otros sectores empobrecidos, a diferencia de una criminalidad "antisocial", esto es, carente de cualquier tipo de simpatía popular. Si bien los límites entre una y otra forma de bandidaje son muy difusos, los bandolerismos que he identificado en el Valle Alto presentan en gran medida un rasgo "antisocial" por el hecho de que quienes los ejercían no contaban con una base de legitimidad o apoyo campesino y sus víctimas eran tanto ricos como pobres. Así, una difusa criminalidad rural fue creciendo en coincidencia

14 Archivo Histórico de la Gobernación de Cochabamba. Expedientes republicanos, volumen 88,1897, f. 2 . 
con ciclos de crisis agrícolas, sociales y políticas, y ello se puede constatar con especial intensidad en distintos momentos situados entre 1880 y 1902.

En 1882, por ejemplo, unos autodenominados "pasajeros" enviaron una desesperada carta a las autoridades de Punata y Tiraque, la cual fue publicada por la prensa con la intención explícita de promover la autodefensa. En la carta se habla de que personas "apostadas en los caminos ejercen el oficio de asaltar a los pacíficos transeúntes". Y es que había aparecido un temible líder bandido, de nombre desconocido, que "hacía estremecer en [...] los bosques a los desgraciados labriegos" en la ruta entre Punata y Tiraque (El 14 de Septiembre, 6 de octubre de 1882).

Así por el estilo, decenas de noticias de parecido tenor se difundieron hasta fines del siglo XIX, siendo la Guerra Federal -que duró desde diciembre de 1898 hasta abril de 1899- el contexto en el que más aparecieron, tanto durante el conflicto bélico en sí mismo como en sus vísperas y en su larga resaca. Por ejemplo, con el título de "Crímenes de Cliza", un diario local señalaba en 1899 que "la inseguridad personal es característica en ese pueblo", a propósito de dos asesinatos y de una reciente fuga de varios presos de la cárcel, algo que, por otra parte, era muy frecuente en todas las prisiones provinciales (El Heraldo, 15 de septiembre de 1899).

Otros muchos ejemplos provienen del emblemático año de 1902, cuando una nueva crisis agrícola azotó los valles cochabambinos. Una noticia titulada "La situación del valle" seńalaba, aludiendo a Punata, Arani y Cliza, que "Continúan llegando del valle rumores alarmantes acerca de las propagandas de asalto a las casas de no pocos hacendados. Aunque ellos sean muy abultados, no dejan de tener fundamento en la excitación de la clase proletaria $^{15}$ que presiente la crisis" (El Comercio, 18 de febrero de 1902). Tres meses después se puede hallar más elocuencia todavía cuando la prensa abordaba este tipo de sucesos vinculándolos con el hambre y la crisis. He aquí un ejemplo:

Personas venidas del valle nos dan cuenta de un malestar social que merece un estudio serio y la atención inmediata de las autoridades. Han aumentado de una manera asombrosa los robos, y algunos de ellos últimamente se han consumado con caracteres feroces [...]. La crisis agraria, cuyas consecuencias van desarrollándose es, sin duda, la causa principal de ese estado. El pobre labriego que no tiene con qué satisfacer el hambre, acude a tomar lo ajeno, impelido por una cruel circunstancia, y poco a poco va avanzando en esa carrera

15 Por supuesto que la expresión "clase proletaria" se emplea en sentido figurado, y aquí debe entenderse por plebe en general, ya que el único e incipiente proletariado boliviano de la época se hallaba recluido en las minas de Potosí y de Oruro. 
extrema [...]. El estado social del valle no puede ser más delicado, y tiene vicios de acarrear serias perturbaciones (El Comercio, 14 de mayo de 1902).

Si bien la nota citada no justifica los robos, pues de hecho algunos tenían "caracteres feroces", intenta explicar que ciertos campesinos pobres se iniciaban en el camino delincuencial obligados por las crueles circunstancias. No obstante, el contexto de crisis era un caldo de cultivo para el accionar de bandidos de todo tipo, la mayoría de ellos sin ningún escrúpulo. Esta coyuntura desató una verdadera paranoia entre los hacendados, dados los rumores de que en Punata y Cliza "varios grupos de individuos espían la ocasión propicia de caer sobre las sementeras en actual cosecha, para llevarse algo que honradamente no pueden adquirir" (El Comercio, 13 de junio de 1902). Y así, referencias periodísticas que vinculaban "la escasez de producción agrícola" con el miedo "de que pudieran producirse algunos ataques a la propiedad" en Tarata, Punata y Cliza fueron prácticamente cotidianas ( $E l$ Comercio, 26 de junio de 1902). Este verdadero estado de miedo estaba por demás justificado en aquellos meses: con el título "El bandalaje en pie", $E l$ Comercio informó el 24 de mayo de 1902 que en Cliza y Toco estaban ocurriendo "graves disturbios [...], especialmente en este último pueblo, donde con motivo de la fiesta de Pentecostés, una cuadrilla de treinta individuos" había "sembrado el terror" ante el pasmo de muchos vecinos que nada podían hacer "por falta de fuerza competente". Meses más tarde regresaron las noticias de este estilo, y es que en pequeñas comarcas aledańas a Cliza apareció una nueva y numerosa "cuadrilla de malhechores compuesta de hombres de mal vivir de distintas partes, que ha emprendido una verdadera campańa contra la cosa ajena, especialmente en las campiñas, donde los indígenas son sus víctimas seguras" (El Comercio, 6 de noviembre de 1902). Usaban "numerosas ganzúas, llaves maestras y otras herramientas ingeniosas del oficio" en sus incursiones a casas y fincas (ibid.), mas también asaltaban a los viajeros en los caminos. Luego, en noviembre del mismo año, cuatro indígenas de Pandoja, localidad de Cochabamba, se presentaron en la prefectura "a denunciar la existencia en aquel lugar de una gavilla de cacos a cuál más audaces" (El Comercio, 4 de noviembre de 1902). "Sus atrevidos golpes" eran "llevados al cabo de día, con la misma frecuencia que de noche" y afectaban a "los pobres labriegos que privados de sus escasos bienes adquiridos con el trabajo de toda su vida quizá [...] sufren una verdadera calamidad"(ibid.).

Otro grupo surgido en esta coyuntura operaba en los límites del Valle Alto, en las alturas de Challaje, camino de herradura que conducía a Chuquisaca, "descamisando" a "cuanto infeliz" pasaba "por esas soledades, especialmente a la gente de campo" (El Comercio, 22 de julio de 1902). Ante ello, la prensa pedía a las autoridades "limpiar" la región de quien "vive de lo ajeno y goza en 
hacer sufrir a la gente más desvalida" (ibid). Con todo, pese a que los ciclos de crisis menguaban y la situación mejoraba después de llegar a picos límite, "la paz del vecindario de Cliza" estaba "incesantemente interrumpida". Es lo que señala un diario del 8 de abril de 1905, El Heraldo, aludiendo a que "veinte vagos armados asaltaron la propiedad de la seńora Eduviges viuda de Rivero, en Toco", y a que "las sementeras en su mayor parte" se hallaban "en pésimas condiciones", siendo "gravemente perjudicadas con el robo que en ellas se efectúa a toda hora”.

Fue tal el auge delictivo en esta subregión a inicios del siglo XX que, en determinado momento, el Valle Alto empezó a exportar sus bandidos a otras zonas, como el Norte de Potosí, donde se registraron varios casos de asaltos y acciones atroces narradas con mucho detalle en la prensa, actos cometidos por bandoleros generalmente procedentes de Cliza, que reforzaban el estigma que recaía cada vez más sobre este pueblo como cuna de delincuentes. Puedo abundar en ejemplos, pero para no extenderme solo cito uno. A fines de 1902 se conoció el caso de Pablo Balderrama, un rico hacendado de Tayapaya, frontera entre Cochabamba y el Norte de Potosí que, según notas periodísticas, tenía un litigio por tierras con un agresivo terrateniente vecino. Balderrama, temiendo por su vida, decidió contratar guardaespaldas, para lo cual se dirigió a la "playa de Cliza" -el famoso mercado del Valle Alto- en busca de cuatro "malhechores", quienes se dirigieron a Tayapaya junto con su contratante. Una vez allí, aquellos se pusieron al tanto de la riqueza de Balderrama y urdieron un siniestro plan ejecutado a inicios de octubre de 1902. La prensa narró dramáticamente los sucesos en los siguientes términos:

Balderrama, su mujer y su hijo de corta edad fueron súbitamente apresados y amarrados por los cuatro sabuesos [bandoleros], que tuvieron la precaución de poner mordaza a las bocas de sus víctimas [...]. Empezó la faena criminal a garrotazos contra el desgraciado Balderrama, y después de un prolongado martirio en que se gozaban aquellas fieras [...] llegó la hora de dar fin a la existencia del que les daba el pan para que guardaran su vida amenazada. Dos de los principales bandidos vaciaron en la boca de la agonizante víctima un litro de ácido sulfúrico, dispuesto de antemano. Ese refinamiento de crueldad, de barbarie, de salvajismo, [...] se hacía en presencia de la esposa y del hijo de la víctima, que en vano pugnaban por deshacerse [...] las ligaduras. Consumada la primera parte de ese horrendo crimen, los bandidos procedieron [...] a apoderarse de los dineros, joyas y otros objetos de valor (El Comercio, 19 de septiembre de 1902).

Tras cargar el abundante y cuantioso botín en varios animales de carga, los bandoleros retornaron al Valle Alto, y para no ser descubiertos, pues era 
obvio que la noticia del asesinato y del robo iba a difundirse rápidamente, utilizaron una ingeniosa táctica:

Tres de ellos se titulaban de funcionarios públicos, para viajar tranquilamente por esas regiones, y tuvieron el raro cinismo de simular que llevaban al cuarto, convenientemente amarrado, como autor del asesinato [...]. Los aterrorizados campesinos que se encontraban con esa jauría de chacales en el camino oían de boca de esos mismos la sangrienta relación del drama (ibid.).

De este modo llegaron a Cliza sin problemas, pero allí despertaron sospechas y fueron finalmente apresados por la Policía. Entonces se supo que los bandidos eran miembros de una conocida cuadrilla integrada por 12 individuos procedentes de Huallpero-rancho, "comarca célebre en las proximidades de Cliza por la marcada afición de sus moradores a la cosa ajena" ( $E l$ Comercio, 21 de octubre de 1902). Los presos fueron conducidos a Tarata, donde se les inició un proceso penal; empero, desconozco el desenlace del mismo. Y así, entre otros casos, la exportación de bandidos vallunos -en particular cliceños-al Norte de Potosí aparece también en la literatura, tal como sucede en la novela Metal del Diablo, de Augusto Céspedes (2013 [1946]), de la que se extracta el epígrafe que encabeza este artículo.

Cabe mencionar adicionalmente que, en general, casi todos los salteadores de caminos y asaltantes de casas y haciendas operaban "disfrazados", o sea ataviados con ponchos largos, sombreros tipo lockos y con la caras cubiertas o pintadas de negro. No obstante, por varios indicios que he observado, tengo la impresión de que, más allá de la exagerada espectacularidad mediática, no eran tan comunes los casos de bandoleros a tiempo completo, ya que entre una fechoría y otra algunos bandidos podían ser campesinos, artesanos, arrieros o comerciantes.

La práctica del abigeato, por otra parte, es un tema que requeriría en sí mismo un estudio específico. ${ }^{16}$ Puedo adelantar aquí, a partir de mis propias exploraciones, que el robo de ganado formaba parte del repertorio de acciones que los sectores populares vallunos usaban tanto para subsistir como para intentar la acumulación económica. Si bien la mayor parte de los caballos, los bueyes, las mulas, los burros y las vacas se marcaba, y, según he visto en varios expedientes en los archivos judiciales de Tarata, Cliza y Punata, cada compra se efectuaba con los debidos comprobantes - una suerte de recibos que intentaban otorgar un estatus legal a las transacciones-, gran parte de las bestias robadas se vendía exitosamente al margen de la ley. Los abigeos

16 El abigeato es otro tema ausente en la historiografía boliviana, excepto por el estudio de Carla Prieto y Orlando Tapia (2013). 
crearon extensas redes constituidas por diferentes intermediarios involucrados en lo que pasó a ser un negocio próspero que, en ocasiones, contaba con la complicidad de los matarifes. Unos actores eran los ladrones propiamente; otros, los transportistas que llevaban los animales a los mercados; y, finalmente, aquellos que conducían la mercancía a lugares allende el Valle Alto, hacia La Paz, Oruro o los valles templados de Santa Cruz, en una actividad que mezclaba la arriería con la criminalidad. No obstante, no todos los abigeos se dedicaban al negocio organizado y dirigido a la venta, pues algunos robaban los animales directamente para comerlos y, solo en ciertos casos, vender algunos restos utilizables ya carneados. La frecuencia de los robos de animales era tal que las víctimas por lo general se movilizaban sin apoyo de la ley, demostrando grandes conocimientos en el seguimiento de las huellas, hasta dar, en ocasiones, con los ladrones.

Sin duda, en esta actividad pesaban también las prácticas de derechos de propiedad de los terratenientes, cuyas zonas de pastoreo no siempre estaban bien definidas, lo que a algunos ladrones les daba el argumento de que no estaban robando, sino tomando "animales perdidos" o haciendo ajustes, por encargo, de los límites entre haciendas en litigio. Empero, no solo los sectores populares estaban en el negocio del abigeato, sino también una élite emergente de nuevos propietarios que robaban a ricos y pobres por igual, tal como he constatado en dos expedientes judiciales, uno en Punata, de 1915, y otro en Totora, de 1924. ${ }^{17}$ Por tanto, también en el ámbito del abigeato existía una estratificación, pudiendo hallarse dentro de este rubro una gama en la que aparecen tanto abigeos de las clases bajas -solitarios ocasionales $\mathrm{u}$ organizados en cuadrillas- como algunos propietarios criollos y mestizos que tenían una condición social "respetable". Debido a la diversidad de los abigeos y sus motivaciones, el robo de animales podría ser interpretado como

17 El expediente hallado en Punata se refiere a una banda de abigeos liderada por una tal Valeriana Villarroel, hasta ahora el único caso de una mujer lideresa en mi pesquisa, pues generalmente las mujeres aparecen en estas historias como chajmiris, amantes o cómplices de los bandidos, o como víctimas. Respecto a la banda de abigeos aludida, esta operaba en Cañada Chica, cerca de Vacas. Era un clan familiar encabezado por Villarroel, su amante y sus hijos, y gozaba de notoria fama en 1915. Villarroel, "conocida ladrona" y jefa de la "cuadrilla de Cañada Chica", instauró un modus operandi que consistía en acusar de robo a las propias víctimas de sus atracos. Lo hacía con la complicidad y ayuda de un abogado célebre, Juan Atanacio Lara, personaje que negociaba con los obrados y montaba las chicanas a la medida de sus clientes. Varios testigos afirman que cuando se perdía ganado en la zona de Vacas se atribuía el hecho directamente a Villarroel, quien iba cada tanto "al yunga", o sea a los yungas de Vandiola, donde tenía propiedades (Archivo del Juzgado de Instrucción de Punata, Expediente Rojas-Lara, 1915). 
subsistencia y estrategia económica o como simple acto en pos del beneficio individual, según el caso que se analice.

Por último, conviene mencionar, así sea brevemente, los nexos entre bandolerismo y política, en su faceta de lucha partidista y electoral. Sucede que las provincias cochabambinas fueron el escenario principal en el que, entre 1880 y 1900, diversos "clubes políticos" se fueron convirtiendo poco a poco en cuadrillas armadas: temibles organizaciones de matones a sueldo capaces de cometer cualquier tipo de violencia, e incluso asesinatos a sangre fría. Vistas en conjunto, las cuadrillas políticas eran bandas irregulares y piramidales, casi siempre clanes familiares, cuyos miembros tenían distintas procedencias y estaban articulados por el clientelismo. Las cúpulas las ocupaban los letrados: caudillos menores, generalmente abogados y terratenientes pertenecientes a las élites provincianas, quienes en muchas ocasiones detentaban también cargos de poder. La base de los grupos estaba constituida por artesanos, pequeños comerciantes, campesinos o malhechores solitarios sin oficio conocido. Eran financiados y armados por las autoridades gubernamentales, y su función consistía en asegurar los triunfos electorales, atemorizar o castigar a los rivales y organizar grupos de propagandistas, espías y delatores. De este modo, los partidos políticos Conservador y Liberal comenzaron a ejercer un efectivo control territorial mediante sus "clubes" y cuadrillas, que fueron adquiriendo una importancia crucial debido a su polivalencia: podían ser grupos de choque, hacer proselitismo o ejecutar asesinatos selectivos.

Existieron muchas de estas cuadrillas en Cochabamba, y algunas de ellas tuvieron tanta celebridad que la prensa de fines del siglo XIX las calificaba de "legendarias", pero carecían de cualquier halo romántico, pues generalmente eran grupos de matones autoritarios y sin una base social efectiva que, además, terminaban operando por su cuenta, robando y abusando del poder que les daban las autoridades, y aquí destaco como ejemplo la afamada "cuadrilla de Punata" (Rodríguez García, 2016). Sin embargo, los liberales fueron la excepción. Es el caso de la cuadrilla de Julio Rafael Castro, joven valluno que dirigió un grupo fuera de la ley en el contexto de un levantamiento liberal contra el recientemente elegido presidente Aniceto Arce durante 1888. En octubre de ese año, Castro reunió una "montonera" de campesinos y procedió a asaltar haciendas de propietarios ricos en apoyo al Partido Liberal. Su fama se extendió debido a su audacia y valentía: un columnista anónimo de El Heraldo publicó la siguiente afirmación el 7 de noviembre de 1888: "Con las hazañas de Castro se podría escribir algo así como la historia de los bandidos de la Calabria".

Las fuerzas del audaz joven, quien ostentaba visibles cicatrices en el rostro como marcas de coraje, estaban compuestas por aproximadamente 50 personas que tomaron varios pueblos, incluyendo Totora y Punata, con la 
consigna de "no quito a los pobres sino a los ricos", mientras que otros grupos aprovechaban el caos para asaltar haciendas por su parte y sin ninguna reivindicación política (El Heraldo, 10 de octubre y 7 de noviembre de 1888). Finalmente, Castro cayó preso a fines de aquel año y no se supo más de él, salvo aisladas referencias entre los liberales durante la Guerra Federal (1898-1899), conflagración que volvió a sacudir el Valle Alto con asaltos y robos frecuentes (Rodríguez García, 2015). Con todo, pese a que los liberales habían prometido importantes transformaciones sociales y habían contado con el decisivo apoyo campesino y popular, en los hechos, el nuevo régimen emergido del conflicto bélico no introdujo mejoras para los estratos subprivilegiados de la sociedad, que tuvieron que continuar con sus propias estrategias -legales e ilegales- de subsistencia y ascenso económico.

En efecto, la "tradición" de hurtos y robos en el Valle Alto continuó durante las primeras décadas del nuevo siglo. Basado en datos de Alberto Rivera Pizarro (1992: 106) y María Lagos (1997: 56-57), afirmo que hubo una reemergencia de bandidajes y robos campesinos contra los terratenientes durante 1920 y a inicios de la década de 1930, cuando algunos colonos y artesanos armados ocasionaban gran inquietud mediante asaltos a los hacendados, en los caminos o en sus propias casas, y que es necesario indagar con más profundidad en este periodo.

\section{CONCLUSIONES}

Al igual que otras regiones del mundo, Cochabamba fue un escenario en el que varias prácticas consideradas ilegales, algunas de ellas violentas, constituyeron, según los casos, una forma desesperada de subsistencia, una estrategia económica o bien un tipo de resistencia campesina contra el poder latifundista. No obstante, esta afirmación requiere ciertas matizaciones.

Reconsideremos, en primer lugar, la práctica del chajmeo, una costumbre que atentaba contra la noción liberal de la propiedad privada. El significado del chajmeo en la hacienda Santa Clara puede variar según la óptica con que se mire. "Desde abajo", podría ser visto como una suerte de impuesto popular aplicado de facto sobre la hacienda que monopolizaba el usufructo de las mejores tierras de la zona o como un modo de aparcería informal, pero a la inversa. Recordemos que los aparceros eran un tipo especial de colonos que pagaban al patrón exclusivamente en especie, no en trabajo, por el uso de determinados terrenos de la hacienda. Entonces, es posible interpretar el chajmeo como una práctica que invertía la relación de la aparcería: si bien los campesinos no eran legalmente dueños de aquellas tierras, es lógico pensar que en el fondo sentían que les pertenecían. Por tanto, recoger la cosecha sin autorización alguna fue, quizá, una manera de recuperar en especie lo que 
consideraban que los patrones les debían por la utilización de aquellos terrenos, sin importar quién ostentara los títulos de propiedad. En suma, desde el punto de vista campesino, el chajmeo puede ser interpretado como una manera de hacer justicia y redistribuir los excedentes de la producción de la finca. O planteado en otros términos, y usando las reflexiones thompsonianas de Tristan Platt acerca del juqueo minero, diría que el chajmeo era una versión del viejo y permanente "conflicto entre la propiedad privada como base de la acumulación originaria, y los derechos de cultivo y recolección de la comunidad" (Platt, 2014: 116).

No obstante, "desde arriba", el chajmeo era considerado, simple y llanamente, como un robo. Pese a ello, al ser los terratenientes-administradores incapaces de ejercer un efectivo control sobre la enorme propiedad, resultaba inevitable la aparición de no poca gente, incluyendo "merodeadores", que aprovechaba todas las ocasiones posibles para llevarse consigo al menos una parte de la cosecha, sin trámite ni consulta con nadie. Es más, el chajmeo terminó aceptándose a regañadientes y nunca dejó de ser una práctica polémica en distintas latitudes rurales vallunas hasta mediados del siglo XX, cuando fue desapareciendo en virtud de la transformación de los campesinos colonos en pequeños propietarios. Permanece hasta la actualidad su remanente menor, el kukeo: robo ínfimo de frutas tomadas directamente de plantaciones o árboles ajenos, una práctica no exclusiva de Cochabamba.

Todo lo dicho constituye el origen del estereotipo del valluno, y del cliceño en particular, como ladrón: por una parte, el hecho de que Cliza emergió como pueblo sobre una propiedad privada y, por otra, la práctica del chajmeo y los diversos robos y bandidajes que se desarrollaban allí desde el siglo XIX. Significativamente, el estereotipo del cliceño ladrón es asumido hasta hoy con un cierto orgullo de espíritu justiciero y rebelde, en clave de picardía, y ya se sabe que la picardía forma parte del "discurso político oculto" de los subalternos (Scott, 2000: 194). Al respecto, si se piensa en el orgullo de los cliceños por sus demostradas habilidades en el hurto (Goins, 1967: 242) o en el significado de los cuentos de presidentes de la República que son recibidos con respeto, e incluso ovación, pero que a la vez son víctimas de algún latrocinio (Guevara, 2012: 119), puede considerarse que tales fenómenos y relatos constituían un mensaje de los sectores populares vallunos a la gente foránea. El mensaje podría ser: hay personas importantes - un gringo como Goins o los presidentes del país- que nos visitan y los recibimos bien, pero que no intenten robarnos ni usurparnos nada porque esta es nuestra tierra y luchamos para obtenerla, y si quisiéramos, somos nosotros quienes podemos robarles. El sentido en este posible discurso oculto radica en la reivindicación de una hospitalidad generosa, que a la vez funciona como una amenaza amable en aras de la autodefensa colectiva ante posibles agresiones externas. Una suerte 
de idiosincrasia cuyos orígenes se remontan a varios fenómenos del siglo XIX, tal como se ha observado.

Sin embargo, el tema del contenido político explícito o implícito de los ilegalismos requiere un tratamiento más amplio. Si bien las prácticas abordadas no tenían una nítida ideología nativa por detrás - de tipo milenarista, por ejemplo-, no significa que no tuvieran ideología. En primer lugar, hay que tomar en cuenta que los grupos dominados, como señala James Scott (2000), hacen infrapolítica: un plano que se materializa en diversas acciones que, desde el rumor hasta el hurto y la burla, ponen en cuestión la injusticia del orden social. Y lo sutil de la infrapolítica se explica por la necesidad de evadir la represión. En segundo lugar está el tema de la parcela, la "piquería": el sueño del pedazo de tierra propia que se fue generando gradualmente desde mediados del siglo XIX y que, con el paso del tiempo, alcanzó a tener un considerable poder ideológico y movilizador. Es más, el acceso a la pequeńa propiedad terminó convirtiéndose en un objetivo político en sí mismo, pues implicaba la lucha por los recursos, por el territorio y por su administración. Tenemos así que el campesinado parcelario valluno luchó por ser tal, y que su lucha, a la larga, lo expandió como clase (Laserna, 1984: 79-80).

Por tanto, resulta anacrónico hablar de "prepolítica" o de primitivismo -como lo hace Friedrich Engels ${ }^{18}$ y posteriormente Eric Hobsbawm (2014) - en las acciones del campesinado y de los sectores populares, por muy ambiguas, ilegales y poco organizadas que hayan sido. Parafraseando a Ranajit Guha (2002: 100-101), diría que, al igual que en la India colonial y en otras partes, no hubo nada en los movimientos de los trabajadores rurales de Cochabamba que no fuese político. No podía ser de otra manera, considerando las condiciones en que trabajaban y en que vivían, y también las concepciones del mundo que entre estos sectores surgían como resultado de un contexto de crisis, opresión y luchas constantes, y que, con el paso del tiempo, adquirieron una nueva dimensión: el sindicalismo campesino. Este surgió en Cliza en 1936 cuando los colonos, después de una sublevación ocurrida un año antes, en la que intentaron destruir -una vez más- la casa de hacienda del latifundio Santa Clara, plantearon a las clarisas que les arrendaran directamente los terrenos de la finca-dado que los campesinos, en realidad, eran subarrendatarios de arrendatarios ricos y mafiosos que gozaban de la preferencia de las monjas-. Esta demanda se transformó luego en la petición de que tales terrenos les sean vendidos. Fue un giro hacia la lucha eminentemente legal, la cual resultó apoyada desde el Estado "socialista-militar" de David Toro y asesorada por profesores, intelectuales y activistas

18 En The condition of the working classes in England, Engels afirmó que el robo es la "forma más primitiva de protesta" (citado en Taylor, 1990: 216). 
marxistas criollos representantes de partidos de izquierda. Finalmente, a fines de 1941, los colonos cliceños lograron su cometido y se transformaron en piqueros, comprando buena parte de las tierras clarisas (Dandler, 1969: 64-101). La consagración de estas luchas fue la Reforma Agraria de 1953, fruto de un proceso revolucionario acelerado desde abril de 1952, con la que los campesinos terminaron expulsando a los terratenientes del Valle Alto.

¿Cómo comprender el paso desde los ilegalismos hacia las luchas legales y sindicales? Si aplicara el enfoque hobsbawmniano a esta transformación en la acción colectiva campesina, diría que se trató de una "evolución". Pero asignar a las luchas escalas evolutivas, además de unidireccionales -del tipo bandidaje/sindicalismo/partido de vanguardia/partido de masas- puede derivar en un esquematismo con el cual sería difícil comprender la complejidad de los casos específicos. Entonces, en mi criterio, se trata sencillamente de cambios en las tácticas y en las estrategias, adaptadas por los campesinos a las exigencias y oportunidades de las distintas coyunturas. Por cierto, me pregunto si el boom del narcotráfico durante la década de 1980 en el Valle Alto (Albó, 1987: 58; Aguiló, 1986b: 51; Cruz, 2015: 127) y en la actualidad tiene que ver con las viejas adaptaciones de los vallunos para ascender socialmente, y en qué medida es una continuidad de lo narrado en este texto. ${ }^{19}$

Por otro lado, vale la pena mencionar la hipótesis de Erick Langer (1990) a propósito de su estudio de dos pueblos chuquisaqueños entre 1882 y 1930. Este investigador plantea que las diferencias en el comportamiento delictivo residen no solo en condiciones económicas sino, sobre todo, en la composición del campesinado. Para Langer, el bandolerismo se daba en zonas más mestizas donde ya no había lazos comunitarios, de modo que las respuestas a las crisis pasaban por el delito común. En zonas más indias, en cambio, y debido a las tradiciones organizativas comunitarias, las formas de protesta decantaban en rebeliones colectivas o en luchas legales, antes que en robos solitarios. Es decir que, aunque en las regiones indígenas existían casos de abigeato, allí el bandolerismo fue menor con relación a los pueblos mestizos

19 Xavier Albó afirmó explícitamente que la llegada del narcotráfico a los valles fue "una manifestación más de la ancestral experiencia qhochala [cochabambina] de que vale la pena probar lo nuevo traído desde arriba y desde afuera” (1987: 58). Por su parte, Federico Aguiló señaló en 1986 que las regiones más gravemente afectadas por el narcotráfico estaban en Beni, Santa Cruz y Cochabamba, donde el Chapare y el Valle Alto resultaban siendo la punta de lanza del negocio. Respecto al Valle Alto, Aguiló apuntó que era una zona de venta y también de fabricación: "en las cercanías de Cliza" existían "mercados nocturnos de cocaína” en los que las transacciones eran "realizadas con mayor holgura" (1986a: 285). En otro texto, Aguiló afirmó: "las fábricas [de pasta base de cocaína] se extienden como reguero de pólvora no solo por Cliza, Toco y otras poblaciones [...] sino por todo el valle alto" (1986b: 51). 
y sus alrededores. Langer sugiere, de modo ambicioso, que esta hipótesis podría ser aplicada al resto de los Andes y de América Latina, aunque su planteamiento es impugnado por otros estudios, por ejemplo el de Jorge Gascón (1999). Hago esta alusión para señalar que en un momento de mi pesquisa me vi tentado a adscribirme a esta hipótesis, pues Cochabamba es una región emblemáticamente mestiza, y pensé que ello podría explicar en parte la recurrencia de hurtos y brotes de bandolerismo que he narrado. No obstante, pronto caí en cuenta en que, si bien la hipótesis de Langer es interesante, atisba en ella un halo del viejo estereotipo del mestizo ladrón, individualista y "malo", y, frente a él, el indio comunitario "bueno" y honesto, perspectiva claramente insostenible. Como fuere, lo que queda claro es que toda generalización resulta peligrosa y que lo más apropiado es analizar casos concretos sin desligarlos de sus respectivos contextos.

Llegados a este punto, cabe preguntar: ¿y entonces cómo interpretar el bandidaje? Se ha hecho evidente que, más allá del hurto y del sabotaje al patrón, existía también un bandolerismo "antisocial" y violento que buscaba el beneficio individual e inescrupuloso, una criminalidad que, aun saliendo del seno plebeyo, no hacía distinciones entre robar a ricos o a pobres, motivo por el que carecía de base o simpatía popular. Esto significa que el bandolerismo, incluso conteniendo una implícita protesta contra la distribución inequitativa de oportunidades y bienes materiales, terminaba obstaculizando y desvirtuando las acciones campesinas de lucha contra los hacendados, dado que agudizaba la represión y otorgaba argumentos a los patrones y a las autoridades. Inspirado en Carlos Aguirre (1990), sostengo que el bandidaje, también en su faceta político-partidaria -exceptuando acciones de caudillos liberales, como Julio Rafael Castro-, reproducía valores y motivaciones de las clases opresoras -abuso, despotismo, etcétera-, de manera que no encarnaba ninguna noción alternativa de justicia ni albergaba ningún potencial emancipatorio. A lo sumo, podía alterar efímeramente el orden dominante, mas sin ocasionar consecuencias considerables.

Como demostró Paul Vanderwood (1986), para el caso mexicano decimonónico, los bandoleros comúnmente son egoístas y oportunistas que no buscan trastocar la sociedad, sino integrarse en ella de modo ventajoso y a cualquier precio, sin importarles la política en el sentido de ideología o de utopía. Es verdad que en algunos casos de bandolerismo se puede hablar de politización, pero esta fue, con pocas excepciones, casi siempre conservadora y asumida por conveniencia. Entonces, tenemos que los mitos en torno a bandoleros justicieros que redistribuían entre los necesitados el fruto de sus desafueros son solo eso, mitos, y de hecho no es casual que sean muy escasos y que con el paso del tiempo pasen al olvido, tanto en Bolivia como en otras partes del mundo, a no ser que, convertidos en símbolos, generen recursos a 
la industria del espectáculo, otra muestra de que son agentes del Gobierno -y del capital-.

Con todo, lo paradójico es que el tema del latrocinio siempre termina revelando un trasfondo de lucha de clases. Para ilustrar lo dicho, cito a don Jorge Guevara, quien cuenta que el mote de "burru tiñis", en alusión al abigeato, que no inmuta a los ancianos campesinos de Cliza, pero que estos sí pueden ofenderse si se les dice "suwa thapas", insulto quechua que literalmente significa "ladrones de nidos", y por extensión ladrones de hogares. En la visión de Guevara, fueron "los nativos" del Valle Alto quienes en algún momento lejano llamaron suwa thapas a las gentes foráneas que se asentaron en Cliza, "robándoles sus tierras y echándolos fuera de sus casas, como a pájaros de sus nidos" (2012: 119). Una verdadera metáfora alusiva al colonialismo que nos lleva a pensar quiénes son los ladrones en la historia. Pero si la propiedad es un robo, como planteó Proudhon en el siglo XIX, ¿¿dónde están los límites entre lo propio y lo ajeno? Quizá la respuesta pasa por la lucha y por la resistencia, tal como lo asumieron los campesinos de tantas partes. 
432 | Trabajos y trabajadores en América Latina (siglos XVI-XXI)

\section{FUENTES}

ARCHIVOS

Archivo Histórico de la Gobernación de Cochabamba

Expedientes Republicanos, volumen 88, 1897.

Archivo del Juzgado de Instrucción de Punata

Expediente Rojas-Lara, 1915.

PERIÓDICOS

El Siglo XX, 4 de junio de 1898.

El Siglo XX, 27 de junio de 1898.

El Siglo XX, 6 de noviembre de 1898.

El 14 de Septiembre, 6 de octubre de 1882.

El Heraldo, 15 de septiembre de 1899.

El Heraldo, 8 de abril de 1905.

El Heraldo, 10 de octubre de 1888.

El Heraldo, 7 de noviembre de 1888.

El Comercio, 14 de mayo de 1902.

El Comercio, 24 de mayo de 1902.

El Comercio, 13 de junio de 1902.

El Comercio, 26 de junio de 1902.

El Comercio, 22 de julio de 1902.

El Comercio, 19 de septiembre de 1902.

El Comercio, 21 de octubre de 1902.

El Comercio, 4 de noviembre de 1902.

El Comercio, 6 de noviembre de 1902.

BiBLIOGRAFÍA

Aguiló, Federico

1986a "El narcotráfico y su proceso desestructurador de las culturas autóctonas de Bolivia”. En: Rossana Barragán, Federicó Aguiló y René Arze, Historia y evolución del movimiento popular. Cochabamba: CERES / Centro Portales.

$1986 b$ "Los peones de la cocaína”. En: Cuarto Intermedio, número 1. 44-57. 
Aguirre, Carlos

1990 "Cimarronaje, bandolerismo y desintegración esclavista. Lima, 18211854”. En: Carlos Aguirre y Charles Walker (eds.), Bandoleros, abigeos y montoneros. Criminalidad y violencia en el Perú, siglos XVIII-XX. Lima: Instituto de Apoyo Agrario.

Aguirre, Carlos y Charles Walker (eds.)

1990 Bandoleros, abigeos y montoneros. Criminalidad y violencia en el Perú, siglos XVIII-XX. Lima: Instituto de Apoyo Agrario.

Albó, Xavier

1987 “Por qué el campesino qhochala es distinto?”. En: Cuarto Intermedio, número 2. 43-59.

Balandier, Georges

1994 El poder en escenas. De la representación del poder al poder de la representación. Barcelona: Paidós.

Barragán, Rossana

2014 "K'ajchas, trapiches y plata en el Cerro Rico de Potosí en el periodo colonial". En: Anuario de Estudios Bolivianos, Archivisticos y Bibliográficos, número 20. 273-320.

Birkbeck, Christopher

1991 "Latin American Banditry as Peasant Resistance: a Dead-end Trail?". En: Latin American Research Review, número 26, volumen 1. 156-160.

Caimari, Lila

2004 Apenas un delincuente. Crimen, castigo y cultura en la Argentina, 18801955. Buenos Aires: Siglo XXI.

Céspedes, Augusto

2013 Metal del Diablo. La Paz: Librería editorial G.U.M. [1946]

Cossío, Lizet

2002 Tradiciones y costumbres cochabambinas. Cochabamba: Prefectura del Departamento de Cochabamba.

Cruz, Juvenal

2015 El Papi. Vida y pasión de un matón. Cochabamba: Gráfica Valencia.

Dandler, Jorge

1969 El sindicalismo campesino en Bolivia. Los cambios estructurales en Ucureña. México: Instituto Indigenista Interamericano. 
434 | Trabajos y trabajadores en América Latina (siglos XVI-XXI)

Gascón, Jorge

1999 "Robo y resistencia campesina en los Andes peruanos". En: Quaderns de l'Institut Català d'Antropologia, número 13, volumen 14. 163-171.

Goins, John Francis

1967 Huayculi. Los indios quichua del valle de Cochabamba, Bolivia. México: Instituto Indigenista Interamericano.

Gómez, Dora y Nicolás Fernández

1996 Diccionario de bolivianismos. La Paz: Los Amigos del Libro.

Gordillo, José

2000 Campesinos revolucionarios en Bolivia. Identidad, territorio y sexualidad en el Valle Alto de Cochabamba, 1952-1964. La Paz: PROMEC I

CEP-UMSS / Plural editores / Universidad de la Cordillera.

Guevara, Jorge

2012100 años cliceños. Cochabamba: Kipus.

Guha, Ranajit

2002 "Aspectos elementales de la insurgencia campesina en la India colonial". En: Las voces de la historia y otros estudios subalternos. Barcelona: Crítica.

Guzmán, Luis Felipe

1888 Instrucciones para la vida campesina. Cochabamba: s. e.

Hobsbawm, Eric

2014 Rebeldes primitivos. Estudio sobre las formas arcaicas de los movimientos sociales en los siglos XIX y XX. Barcelona: Crítica. [1959]

2011 Bandidos. Barcelona: Crítica. [1969]

Hobsbawm, Eric y George Rudé

1978 Revolución industrial y revuelta agraria. El Capitán Swing. Madrid: Siglo XXI.

Jackson, Robert

1994 Regional Markets and Agrarian Transformation in Bolivia. Cochabamba, 1539-1960. Albuquerque, Estados Unidos de América: University of New Mexico Press.

Joseph, Gilbert

1990 "On a trail of Latin American Bandits: a Reexamination of Peasant Resistance". En: Latin American Research Review, número 25, volumen 3. 7-53. 
Lagos, María

1997 Autonomía y poder. Dinámica de clase y cultura en Cochabamba. La Paz: Plural editores.

Langer, Erick

1990 "Bandolerismo andino y organización comunal campesina, 18821930". En: Carlos Aguirre y Charles Walker (eds.), Bandoleros, abigeos y montoneros. Criminalidad y violencia en el Perú, siglos XVIII-XX. Lima: Instituto de Apoyo Agrario.

Larson, Brooke

2000 Cochabamba. (Re)construcción de una Historia. La Paz: AGRUCO / CESU.

1992 Colonialismo y transformación agraria en Bolivia. Cochabamba, 15501900. La Paz: CERES / HISBOL.

Laserna, Roberto

1984 Espacio y sociedad regional. Constitución y desarrollo del mercado interno de Cochabamba. Cochabamba: CERES.

Lichenstein, Alex

1988 “That Disposition to Theft, with which they Have Been Branded': Moral Economy, Slave Management and the Law". En: Journal of Social History, número 21, volumen 3. 25-41.

Mercado, David

1994 "Hacienda y mestizaje en Cochabamba: estrategias de cambio social en Vacas y Cliza". Tesis de licenciatura en Sociología. Universidad Mayor de San Simon, Cochabamba.

Mostajo, Emilio

1904 Cuestión Judicial. Defensa del Dr. Teodosio Pericón ante la Corte Superior del Departamento contra la condenatoria fulminada contra él, por el Juez y Fiscal del Partido Judicial de Tarata, complotados para perpetrar una injusticia. Cochabamba: Imprenta y Litografía El Siglo XX.

Nordenskiold, Erland

2001 Exploraciones y aventuras en Sudamérica. La Paz: APCOB / Plural editores. [1913]

Palma, Daniel

2001 Ladrones. Historia social y cultura del robo en Chile, 1870-1920. Santiago de Chile: LOM. 
436 | Trabajos y trabajadores en América Latina (siglos XVI-XXI)

Paredes Candia, Antonio

1998 Bandoleros, salteadores y raterillos. La Paz: Isla.

1976 Tradiciones de Bolivia. Cochabamba: Los Amigos del Libro.

Paz, Julio

1944 Porteños y guerrilleros (Recuerdos de un voluntario). Cochabamba:

Editorial América.

Pérez, Carlos

2003 "El bandidaje político en la frontera de la Cinchona: el caso de Juan José Pérez”. En: Josefa Salmón y Guillermo Delgado (eds.), Identidad, ciudadanía y participación popular desde la Colonia al siglo XX. La Paz: Asociación de Estudios Bolivianos / Plural editores.

Platt, Tristan

2014 "Caccheo y minería mediana en las provincias de Potosí: Lípez y Porco (1830-1850)”. En: Estudios Atacameños, número 48. 85-118.

Porcel, Agustín de

1894 Tipos y paisajes de la América Meridional. Buenos Aires: Litografía e Imprenta G. Kraft.

Prieto, Carla y Orlando Tapia

2013 "Bandolerismo en la indómita frontera (1910-1930)". En: Surgiendo. Investigaciones desde el Sur, número 2. 135-167.

Rejas, Damián Z.

1948 Tercer Centenario de la Fundación del Monasterio de Santa Clara de Asis en Cochabamba-Bolivia. Años 1648-1948. Cochabamba: Editorial Universo.

Rivera Pizarro, Alberto

1992 Los terratenientes de Cochabamba. Cochabamba: CERES / FACES.

Rodríguez García, Huascar

2016 Bandidos y policías. La cuadrilla de Punata: una organización politicocriminal en Cochabamba, 1890-1898. Santa Cruz: El País.

2015a Guerra, politica y bandolerismo. El caso de Martín Lanza: un caudillo cochabambino a fines del siglo XIX. Cochabamba: Gobierno Autónomo Municipal de Cochabamba.

2015b "Crimen y mito. La (incipiente y desconocida) historia del bandolerismo en Bolivia”. En: Decursos, número 31. 63-102. 
Rodríguez Ostria, Gustavo

2012 Morir matando. Poder, guerra e insurrección en Cochabamba, 17811812. Santa Cruz: El País.

1995 "Las razones de la multitud: hambruna, motines y subsistencia en Cochabamba (1878-1879)". En: Gustavo Rodríguez Ostria. La construcción de una región: Cochabamba y su historia, siglos XIX-XX. Cochabamba: UMSS.

1989 "Kajchas, trapicheros y ladrones de mineral en Bolivia (1824-1900)". En: Revista de Historia, número 8. 125-139.

Rodríguez Ostria, Gustavo y Humberto Solares

1990 Sociedad oligárquica, chicha y cultura popular. Cochabamba: Serrano.

S. Lopes, María Aparecida de

2005 De costumbres y leyes. Abigeato y derechos de propiedad en Chihuahua durante el porfiriato. México D. F. y Zamora: El Colegio de México / El Colegio de Michoacán.

Schramm, Raimund

1991 "Mosaicos etnohistóricos del valle de Cliza (valle alto cochabambino). Siglo XVI”. En: Historia y Cultura, número 18. 3-41.

Scott, James

2000 Los dominados y el arte de la resistencia. Discursos ocultos. México: Era.

Sejas, Hermógenes

1905 Defensa del cirujano Hermógenes Sejas y proceso de los munícipes Alejandro Ayala y Zenón Salinas. Cochabamba: El Siglo XX.

Slatta, Richard (ed.)

1991 "Bandits and Rural Social History". En: Latin American Research Review, número 26, volumen 1. 145-151.

1987 Bandidos. The varieties of Latin American Banditry. Nueva York: Greenwood Press.

Solares, Humberto

1990 Historia, espacio y sociedad. Cochabamba 1550-1950: formación, crisis $y$ desarrollo de su proceso urbano. Tomo 1. Cochabamba: Honorable Alcaldía Municipal de Cochabamba y Cidre.

Sutherland, Edwin

1993 Ladrones profesionales. Madrid: Las Ediciones de La Piqueta. [1937] 
438 | Trabajos y trabajadores en América Latina (siglos XVI-XXI)

Taylor, Lewis

1990 "Los orígenes del bandolerismo en Hualgayoc, 1870-1900". En: Carlos Aguirre y Charles Walker (eds.), Bandoleros, abigeos y montoneros. Criminalidad y violencia en el Perú, siglos XVIII-XX. Lima: Instituto de Apoyo Agrario.

Thomson, Janice

1994 Mercenaries, Pirates and Sovereigns: State-Building and Extraterritorial Violence in Early Modern Europe. Princeton, Estados Unidos de América: Princeton University Press.

Thompson, Edward P.

1984 Tradición, revuelta y consciencia de clase. Estudios sobre la crisis de la sociedad preindustrial. Barcelona: Crítica.

Tilly, Charles

1984 "War Making and State Making as Organized Crime". En: Peter Evans, Dietrich Rueschemeyer y Theda Skocpol (eds.), Bringing the state back in. Cambridge, Inglaterra: Cambridge University Press.

Vanderwood, Paul

1986 Desorden y progreso. Bandidos, policías y desarrollo mexicano. México D. F.: Siglo XXI.

Varas Reyes, Víctor

1947 Huiñaypacha (Aspectos folklóricos de Bolivia). Cochabamba: América.

Vivanco, Carmen

1990 "Bandolerismo colonial peruano, 1760-1810. Caracterización de una respuesta popular y causas económicas”. En: Carlos Aguirre y Charles Walker (eds.), Bandoleros, abigeos y montoneros. Criminalidad y violencia en el Perú, siglos XVIII-XX. Lima: Instituto de Apoyo Agrario. 


\title{
Los lugares de la política plebeya en Montevideo, 1806-1817
}

\author{
Pablo Ferreira (Uruguay)*
}

RESUMEN: El texto analiza los lugares y las formas de acción política de las clases populares en Montevideo entre 1806 y 1817. Plurales desde el punto de vista étnico y ocupacional, estas no siguieron exclusivamente una agenda diseñada por las élites, sino que fueron capaces de leer el periodo, identificar adversarios y actuar sobre la base de un repertorio de prácticas conocido y, al mismo tiempo, innovador. La guerra casi permanente, la incorporación a contingentes armados y la politización extendida al conjunto de la sociedad incrementaron la capacidad de incidencia de las clases populares en la toma de decisiones y fueron factores disruptivos del orden social, generando extendidos temores entre las élites. El texto consta de tres partes. En la primera se reconstruye la formación de un campo de estudio sobre la participación política popular anterior a la "moderna" sociedad industrial, deteniéndose en la renovación historiográfica de las últimas décadas en España e Hispanoamérica. En la segunda se analiza la participación política popular en Montevideo entre 1806 y 1817. En la parte final se reflexiona sobre los aspectos comunes de la movilización popular en el periodo, sus formas, sus motivaciones y la relación entre clases populares y élites, y los espacios en que esa participación se llevó adelante. ${ }^{1}$

PalabRas Clave: acción política; Montevideo; clases populares; plebe urbana; orden social; tumultos; contrarrevolución.

* Doctorando en Historia por la Universidad de la República (Uruguay). Departamento de Historia del Uruguay (FHCE, Udelar), becario de la Comisión Académica de Posgrados (Udelar), Sistema Nacional de Investigadores (ANII). Contacto: pablo.ferreira2311@gmail.com

1 El escrito presenta resultados de una pesquisa en curso que se realiza en el marco del grupo de investigación "Crisis revolucionaria y procesos de construcción estatal en el Río de la Plata”, financiado por la Comisión Sectorial de Investigación Científica (CSIC) en el programa Grupos de I+D 2015’2019 y dirigida por los doctores Nicolás Duffau y Ana Frega. 


\section{INTRODUCCIÓN}

Trabajadores esclavizados empleados en el servicio doméstico, el comercio o la manufactura, o autorizados por sus "amos" a vender su fuerza de trabajo, jornaleros libres que se "conchavaban"2 para realizar trabajos en la construcción, dependientes en establecimientos comerciales de diversa escala, artesanos pobres, trabajadores dedicados a la práctica de diversos oficios manuales, vendedores ambulantes, pescadores, peones en las chacras de extramuros y trabajadores itinerantes integraron el vasto universo laboral de la ciudad de Montevideo entre fines del siglo XVIII y las primeras décadas del siglo XIX. A pesar de la diversidad étnica, jurídica, ocupacional y de ingresos, el discurso de la "gente decente" los agrupó bajo denominativos como "plebe", "bajo pueblo", "populacho", "infelices" o "chusma", entre otras expresiones que tuvieron un claro sentido peyorativo y denotan la construcción ideológica en términos duales de la sociedad de Indias (Serulnikov, 2009: 244). Se trató de sectores de la sociedad que no tuvieron un lugar específico para su participación en la vida política colonial, pero que en la coyuntura de crisis, revolución y guerra encontraron espacios para expresar sus demandas, fueron convocados o se hicieron presentes sin pedir permiso en el espacio público (Rújula, 2011: 174; Di Meglio, 2013b: 53).

En la historiografía iberoamericana reciente se constata un renovado interés por las formas de participación política de las clases populares en el periodo. Nos encontramos frente a nuevos abordajes que se preguntan por sus modalidades de participación, sus objetivos, la relación con las élites y la forma en que la acción política fue moldeando sus identidades. ${ }^{3}$ Para el caso de Uruguay, existen importantes antecedentes sobre la temática, aunque han predominado los trabajos referidos a los sectores rurales, en especial aquellos que optaron por seguir al bando revolucionario. ${ }^{4}$ Los abordajes sobre las clases populares urbanas han tomado, mayoritariamente, como punto de partida, el último tercio del siglo $\mathrm{XIX}$, momento en el que surgieron las primeras organizaciones de trabajadores que "anticipan" el sindicalismo moderno. Las excepciones han sido trabajos de historia económica, estudios sobre afrodescendientes y esclavitud, así como algunos estudios recientes sobre formación de milicias y agrupamientos políticos. ${ }^{5}$

2 Conchavar refiere a un contrato efímero, un trabajo de jornalero por algunos días, sin relación laboral estable.

3 Varios de los textos más representativos de esta renovación son referidos en las páginas siguientes. Para una buena mirada de conjunto, véase: Di Meglio, $2013 \mathrm{~b}$.

4 Véanse: Beraza, 1961; Sala, De la Torre y Rodríguez 1987; Frega, 2008, 2011.

5 Desde la historia económica, véanse los trabajos del grupo de investigación "Pueblos y números", dirigido por María Inés Moraes (disponible en: http://pueblosynumeros.fcs.edu.uy). Sobre los afrodescendientes y la esclavitud, véanse: Frega, 
Poner la mira en el periodo colonial tardío y en los primeros años de las guerras de independencia conlleva enfocarse en una coyuntura en que la condición de asalariado era solo una posibilidad entre las clases populares. ${ }^{6}$ Implica reivindicar el carácter plenamente político de las acciones de un actor social plural e híbrido, analizando retazos de una cultura política de escritura endeble, que se constituyó a partir del vínculo asimétrico con los grupos dominantes (Izquierdo, 2014: 252). Las clases populares montevideanas fueron heterogéneas desde lo étnico y lo ocupacional, y desde sus vínculos de paisanaje; si bien no explicitaron una agenda de intereses propia, sus acciones no pueden ser entendidas desde una lógica que suponga únicamente su manipulación por los grupos dominantes. Estas leyeron el periodo, identificaron adversarios y actuaron sobre la base de un repertorio de prácticas conocido y, al mismo tiempo, innovador.

El artículo ha sido dividido en tres partes. En la primera se ordena un conjunto de aportes que, desde diversos enfoques teóricos y metodológicos, contribuyó a constituir la participación política de las clases populares urbanas en campo de estudio. En la segunda se aborda una serie de episodios ocurridos en el periodo, que muestran la extensa y variada participación política de estos sectores. En el último apartado proponemos una reflexión sobre su accionar, identificando protagonistas y discutiendo los factores desencadenantes, como también las formas y los espacios en que se dio esa participación.

Las fuentes consultadas van desde apuntes históricos y memorias posteriores a los hechos, diarios personales, documentación oficial y fuentes judiciales. La principal limitación heurística radica en la dificultad para acceder, sin mediaciones, a la voz de los integrantes de estas clases populares. Se trata de un problema que ha generado un amplio debate historiográfico que sería imposible resumir en este apartado. ${ }^{7}$ Reconociendo estas limitaciones, consideramos que es posible acercarnos a sus formas de entender y vivir la política a través de sus acciones, y que estas últimas pueden ser conocidas a partir de

2004; Bentancur y Aparicio, 2006; Borucki, 2011. Sobre las milicias y los agrupamientos políticos, véanse: Ferreira y Frega, 2016; Ferreira, 2016a, 2016b, 2017.

6 El uso de la categoría 'clases populares' es problemático por los múltiples sentidos atribuidos en la época al término 'pueblo'. Pese a lo anterior, coincidimos con Gabriel Di Meglio (2007: 18) en las ventajas en que esta categoría presenta frente a la de sectores populares, en la medida en que remite de forma más directa a la idea de diferenciación y al carácter subordinado de estos grupos respecto a las élites. Se utilizará también de forma indistinta los términos de época 'plebe/ plebeyos' o 'bajo pueblo'.

7 Un acercamiento a estos problemas véase en: Farge, 1991. 
la lectura crítica de su impacto en la documentación oficial y en las diversas fuentes que dejaron los sectores letrados de la sociedad.

\section{UN SUJETO HISTÓRICO EN CONSTRUCCIÓN}

Las clases populares solo pueden caracterizarse adecuadamente dentro de una coyuntura temporal y geográfica específica, en la medida en que formaron sujetos históricos que "se está[n] haciendo y rehaciendo permanentemente" (Romero, 1997: 1). En la Iberoamérica colonial tardía formaron un espacio social diverso e híbrido que hace necesarios para su comprensión abordajes que superen categorías puras y permitan dar cuenta de esa complejidad (Di Meglio, 2013b: 40).

Su participación política en la etapa previa a la sociedad industrial se ha constituido en campo de estudio tras un largo recorrido. La historiografía romántica del siglo XIX constituyó al pueblo como un sujeto homogéneo e indiferenciado, escasamente marcado por el devenir histórico. En las primeras décadas del siglo XX, a la par que subsistía esa tradición, surgieron enfoques que parcelaron el campo social e identificaron lo popular como lo opuesto a las élites. El objeto de análisis pasó a ser el de las multitudes; peligrosas cuando irrumpían en el espacio público, proclives al socialismo, a seguir y ser utilizadas por líderes cesaristas. Más allá de las connotaciones políticas de tales premisas, estos trabajos tuvieron el mérito de señalar que el accionar de la multitud no era solo la suma de las acciones de los individuos que la componían, sino que tenía una entidad propia que podía ser aprehendida. ${ }^{8}$

Otra vertiente teórica importante ha sido el materialismo histórico. En una primera etapa, las sociedades preindustriales recibieron miradas esquemáticas y su estudio fue encarado como mero preámbulo a la formación del proletariado moderno. En el periodo de entreguerras, al mismo tiempo que se hacían más rígidos los enfoques ortodoxos, surgieron propuestas como las de Antonio Gramsci (2000), que convocaba a estudiar de forma monográfica aquellos indicios del accionar autónomo de lo que denominó "grupos subalternos anteriores al proletariado industrial”, destacando su carácter "disgregado y episódico". Paralelamente, Georges Lefebvre (1986) publicó un libro de enorme influencia en el que analizó cómo se generalizaron en 1789 los "pánicos" entre campesinos y aldeanos en Francia, construyendo una línea de interpretación en la que dialogaron las tradiciones de acción colectiva con los elementos surgidos en la coyuntura de la Revolución.

En las décadas de 1950 y 1960, el campo de estudio se enriqueció con los aportes de la llamada "historia social". En ella convergieron varias líneas de trabajo. Por un lado, la historiografía marxista británica, en la que

8 A modo de ejemplo de este tipo de enfoques, véase: Le Bon, 1995. 
autores como Eric Hobsbawm (1968), Georges Rudé (1971) y, especialmente, Edward Thompson (1995) mostraron una transición mucho más matizada y larga entre feudalismo y capitalismo, y en la que subsistieron formas sociales y tradiciones de acción colectiva que no podían ser interpretadas como mero preámbulo a la nueva sociedad industrial. Otra línea de trabajo que converge en la historia social proviene de la cátedra sobre la Revolución francesa en La Sorbona, en la que se destacaron los estudios de Albert Soboul (1987) sobre los sans-culottes parisinos. Finalmente, la sociología histórica abordó de forma comparativa los grandes procesos revolucionarios de los siglos XVIII y XIX, y ha trabajado en clave de repertorios las formas de acción colectiva de las clases populares urbanas y rurales (Tilly, 2002). Todas estas corrientes coincidían en varios aspectos: la mirada estructural, la construcción de sujetos amplios (el campesino, la multitud) y la pretensión de alcanzar conclusiones que posean cierto nivel de generalización.

La historiografía de las décadas siguientes estuvo signada por una reducción en la escala de observación. La búsqueda de una mirada "a ras del suelo" permitiría cambiar las dimensiones de lo observado y hacer visibles aspectos nuevos de la realidad. Este cambio metodológico tuvo implicaciones teóricas: en la medida en que cada caso pasaba a ser único e irrepetible, las posibilidades de alcanzar conclusiones generalizables resultaban muy limitadas. $\mathrm{Al}$ mismo tiempo, los sujetos de análisis dejaron de ser categorías sociales u ocupacionales para ser individuos o pequeños grupos con móviles múltiples $y$, en ocasiones, contradictorios. ${ }^{9}$

El cuestionamiento a la historia social continuó y se amplió en los últimos años del siglo XX y los inicios del siglo XXI. Los enfoques culturalistas, las perspectivas de género y en especial los estudios subalternos dieron preeminencia a las prácticas como elemento formador de identidades, problematizaron el uso de las fuentes tradicionales y procuraron poner de manifiesto las múltiples contradicciones que minimizaba la historia social al priorizar el conflicto de clase.

En España, los estudios sobre la participación política de las clases populares desde fines del siglo XVIII hasta la primera mitad del siglo XIX han tenido un importante desarrollo. Pierre Vilar (1982) abordó los nexos entre subsistencias y politización popular en diversos episodios de acción colectiva del siglo XVIII, así como las acciones populares de resistencia ante los franceses, tanto en la Guerra de la Convención como en la Guerra de Independencia. Recientemente, Ronald Fraser (2007) actualizó

9 Especialmente, véanse las reflexiones de Jacques Revel (2005) y Michel Bertrand (2011). 
la perspectiva social sobre este último conflicto, sosteniendo que el vacío de poder que se produjo en 1808 otorgó a las clases populares un inesperado protagonismo que canalizaron a través de diversas formas de acción. Pedro Rújula (2011), por su parte, ha destacado el papel de la Guerra de Independencia para entender la emergencia de una cultura política popular en clave contrarrevolucionaria. Para el autor, durante esta etapa se produjo una "densificación" del universo político popular, proceso que definió como la inmersión de amplios sectores hasta entonces alejados de la política en el desempeño de un papel activo en ella. A su vez, Álvaro París Martin (2017) trabajó el periodo que transcurre entre el trienio liberal y la "década ominosa", analizando la participación popular en Madrid con énfasis en las milicias de voluntarios realistas. Discutió la caracterización de esa participación como "irracional y espasmódica", destacó el intenso proceso de politización que vivieron estos grupos y seńaló cómo desarrollaron estrategias que les permitieron influir en la esfera pública persiguiendo intereses propios que fueron negociados de forma pragmática con las élites. Finalmente, Jesús Izquierdo (2014) señaló la pervivencia de concepciones que veían la política como una práctica jurisdiccional basada en la controversia para la resolución de conflictos entre los grupos sociales; propuso pensar los sectores subalternos como sujetos que interpretaron el mundo y actuaron a partir de lenguajes y prácticas provenientes de esa tradición.

En Hispanoamérica, la participación popular en la revolución y en las guerras de independencia también viene generado una vasta producción. Para Nueva España, se ha debatido el rol político de las comunidades indígenas y campesinas, señalándose cómo estas actuaron en la coyuntura bajo las coordenadas de la "cultura política" en que estaban inmersas (Guarisco, 2007). Eric Van Young (2010) destacó el componente "antimoderno" de lo que denominó como "la otra rebelión". Esta última tuvo por protagonistas a los grupos populares, fue localista, portó una visión religiosa del mundo y defendió la autonomía comunitaria ante las propuestas centralizadoras de las élites criollas. Para Nueva Granada, Marcela Echeverri (2009) estudió la participación política de esclavizados e indígenas y su apoyo al bando realista durante las guerras de independencia, señalando que su accionar no fue expresión de retraso o dominación ideológica, sino una estrategia para negociar la afirmación de derechos a través de una alianza táctica con sectores de la élite dirigente. En Perú, se han analizado las formas en que se negoció la participación popular, tanto en el campo realista como en el insurgente, con el objetivo de salvaguardar ideales políticos e intereses prácticos (Morán y Aguirre, 2013). Se destacó su perspectiva localista (O'Phelan, 1987) y las diferencias que existieron dentro de las clases populares (Flores Galindo, 1984). Para la región de Charcas, Sergio Serulnikov $(2009,2013)$ abordó la etapa colonial tardía y analizó los 
profundos cambios en la cultura política popular, destacando cómo fueron cuestionadas la legitimidad y las reglas de funcionamiento del régimen español a partir de un prolongado proceso de politización de las relaciones de mando y obediencia. El autor señaló cómo la erosión de la estructura binaria de la "sociedad de las Indias" dio lugar a la emergencia de formaciones identitarias mucho más complejas que las existentes hasta el momento.

Con relación a Buenos Aires, Lyman Johnson (2013) estudió las condiciones de vida y de trabajo y las formas de participación política de los sectores plebeyos en el periodo colonial tardío, en tanto que Raúl Fradkin (2008) y Gabriel Di Meglio (2007, 2013a) trabajaron el periodo de la revolución y las guerras de independencia. Fradkin propuso pensar las formas de participación política popular en término de tradiciones, recuperando "los hilos muchas veces opacos" que unieron las formas coloniales y poscoloniales (2010: 2-3). Di Meglio, por su parte, ha señalado la continuidad de formas de acción colectiva provenientes del pasado colonial, pero en el marco de una coyuntura que expandió los horizontes políticos de los grupos plebeyos. En diversos trabajos de Di Meglio que parten desde análisis micro (2008), pasando por estudios de más larga duración $(2007,2013 a)$ y reflexiones sobre el conjunto de Iberoamérica (2013b), el autor analizó la participación política del "bajo pueblo”, su relación con las élites, sus modalidades y la construcción de liderazgos populares.

\section{CLASES POPULARES Y POLÍTICA, 1806-1817}

La ciudad de Montevideo fue fundada en 1730 con el objetivo de establecer un bastión defensivo en una zona de frontera con las posesiones portuguesas. Las reformas comerciales de la segunda mitad del siglo XVIII, las condiciones naturales del puerto y la cercanía con Buenos Aires estimularon su rápido crecimiento. Paralelamente, se expandió la frontera agrícola al consolidar los hacendados hispano-criollos el control sobre el territorio al sur del río Negro, desplazando a los grupos indígenas. El crecimiento demográfico fue importante, multiplicándose por siete la población entre 1769 y 1810 . Para 1805 , la población residente en el casco urbano rondaba los 15.000 habitantes, entre los que se contaba un alto porcentaje de esclavizados de origen africano o afrodescendientes (cercano al 40\%) y un número importante de emigrados recientes provenientes de la península Ibérica y, en menor número, de las zonas noroccidentales del virreinato. ${ }^{10}$

10 Las cifras de población y de esclavizados son tomadas de Raquel Pollero (2013: 241). Sobre la emigración peninsular en la etapa final de la Colonia, véanse: Bentancur, 1997; Harrington, 2012. 
El conocimiento sobre las condiciones materiales de existencia de estos sectores es incipiente. Desde la historia económica, Inés Moraes y Florencia Thul (2016) han avanzado en el estudio de la evolución de precios y salarios entre 1760 y 1810 . Sus trabajos han mostrado una tendencia a la estabilidad en el precio de los alimentos en el largo plazo (aunque identificando el inicio de una fase alcista a partir de 1790, muy marcada si se toman de forma aislada algunos productos como el pan) y una tendencia sostenida al crecimiento del valor nominal de los salarios, que se explicaría por la falta crónica de mano de obra. Por otra parte, tomando como base los padrones de población elaborados en la etapa luso-brasileña (uno de 1819 y otro de 1823), un equipo coordinado por la historiadora Ana Frega avanzó en la caracterización sociodemográfica de las clases populares montevideanas y en su ubicación espacial en la ciudad. ${ }^{11}$ La investigación confirmó la importancia numérica de la población esclavizada, que llegaba a superar el 50\% del total de residentes en muchas de las manzanas de Montevideo. En lo que respecta al trabajo libre, los padrones permiten aproximarnos a las actividades más comunes desarrolladas en la ciudad: el trabajo en el comercio minorista (en calidad de dependientes, mozos u otras denominaciones) y en distintos talleres artesanales, quienes declaran practicar oficios manuales y aquellos que realizan tareas vinculadas a la pesca o que obtienen su sustento diario a partir de la práctica de oficios ambulantes. ${ }^{12}$

\section{LA IRRUPCIÓN PLEBEYA, 1806-1810}

Entre 1806 y 1810, la ciudad de Montevideo vivió una serie de episodios políticos de carácter tumultuario que contaron con una importante participación de las clases populares. ${ }^{13}$ En su mayoría, estas acciones no tuvieron como horizonte un desafío a la subordinación a la Corona, pero pusieron en cuestión la legitimidad de las autoridades locales, generaron temores entre las élites criollas y contribuyeron a transformar los espacios y las formas de hacer política. Repasaremos brevemente tres coyunturas que permiten apreciar estos procesos.

11 Los resultados de esta investigación has sido publicados en Frega, 2018: 127-136. El estudio de los padrones fue realizado por las historiadoras Inés Cuadro y Sabrina Puentes.

12 Cabe consignar que en ambos censos los empadronadores registraron los oficios únicamente de los varones adultos libres y de las mujeres libres (viudas o solteras), lo que representaba un $29 \%$ de la población registrada.

13 Sobre los sentidos atribuidos al término 'tumulto' en el lenguaje de la época y su importancia como práctica política, véase: Fradkin, 2008: 28-30. 
En julio de 1806, Buenos Aires fue invadida por fuerzas inglesas. Las noticias que circularon en Montevideo destacaban los errores cometidos en la defensa de la capital y hacían eco de las críticas al virrey Rafael de Sobremonte por haber abandonado la ciudad. En los días siguientes, se produjo una intensa militarización de la población sobre la base de la conformación de cuerpos milicianos y se organizó una expedición que logró expulsar a los ingleses en agosto.

Pese al revés sufrido, los ingleses continuaron en el Río de la Plata, obtuvieron importantes refuerzos, bloquearon el puerto de Montevideo y, el 16 de enero de 1807, sitiaron la ciudad. La tensión intramuros fue en aumento y desbordó progresivamente a las élites, que no lograban contener la creciente politización de las clases populares. Esta se aprecia específicamente en su progresiva irrupción en el espacio público y en la puesta en discusión de decisiones hasta entonces reservadas a los sectores gobernantes. A fines de enero, circularon rumores de que los integrantes del cabildo y algunos comerciantes procuraban negociar una capitulación con los sitiadores. Según un oficio dirigido por los cabildantes al gobernador, "la mayor parte de la gente se excitaron contra los inocentes procedimientos del cabildo" y llegaron al extremo de tomar las armas "para matar a todos los Capitulares". Según estos, "ningún capitular ha[bía] osado salir a la calle" durante horas, y "para desvanecer el concepto que se ha[bía]n formado" tuvieron que fijar carteles anunciando el arribo de tropas de refuerzo desde Buenos Aires. El oficio de los capitulares pedía una guardia permanente, que se impidan las "juntas arriba de tres hombres" y que se averigüe quiénes eran los instigadores para aplicarles un castigo "ejemplar" que evitara "una completa sublevación del Pueblo". ${ }^{14}$ En esos días, fue colocado un pasquín que denunciaba cómo un grupo de "patriotas simulados" negociaba la capitulación. En él se nombraba a figuras políticas de la ciudad y se advertía que, de darse la capitulación, serían "reunidos y asesinados", mientras los "verdaderos patriotas" continuarían la resistencia por el honor de "morir matando". Asimismo, proponía el "secuestro y reparto" de los bienes de comerciantes que habían huido de la ciudad. ${ }^{15}$

Estos hechos ilustran la tensión imperante y muestran cómo las élites apelaron a la movilización plebeya para influir en el modo de dirimir sus diferencias. Evidencian también un efecto no previsto para las primeras; en

14 Archivo General de la Nación-Uruguay (en adelante AGNU), Fondo Ex Archivo General Administrativo (en adelante AGA), caja 314, carpeta 1, f. 15.

15 AGNU-AGA, caja 447, carpeta 1, sin foliar. 
la medida en que se había armado a las clases populares y estas se incorporaban al debate político, la obediencia a las autoridades debía ser negociada en términos más complejos que antes.

\section{"Una efervescencia popular tumultuaria", 1808}

La dominación inglesa sobre la ciudad se extendió hasta septiembre de 1807. A inicios del ańo siguiente predominaba la incertidumbre; se temía una nueva invasión inglesa o una acción expansiva de los portugueses alentada por el traslado de la familia real a Río de Janeiro. A fines de julio comenzaron a llegar noticias de los sucesos españoles (motín de Aranjuez, abdicación de Carlos IV, sucesos de Bayona, formación de juntas) y de diversos comisionados, con el objetivo de solicitar el reconocimiento a las autoridades que disputaban el poder en la Península.

La tensión política se agravó en septiembre con la llegada del capitán Juan Ángel de Michelena, designado como gobernador en sustitución de Francisco Xavier de Elío. El mes anterior había estado marcado por la circulación de papeles que se leían y comentaban en la ciudad, en los que se ponía en entredicho la fidelidad del virrey Santiago Liniers, de origen francés. El 20 de septiembre, por la noche, un complejo episodio de características tumultuarias impidió que Michelena se hiciera con el mando y generó la instalación de una Junta que gobernó la ciudad hasta mediados de 1809.

El alférez de navío Francisco de Nava relató los hechos ante la Real Audiencia de Buenos Aires, en un expediente iniciado poco después y que tenía por objetivo dictaminar responsabilidades respecto a la formación de la Junta en Montevideo. ${ }^{16}$ Según su versión, en las primeras horas de la noche, el ayudante de plaza Matías Larraya se presentó "sobresaltado" en el café de Mariño (ubicado frente al "Fuerte", sede de la Gobernación), pidió un "sombrero redondo de hule" y un "capote", y se retiró indicando que "iba de orden del Gobernador [Elío] a dar varias interesantes a los cuarteles y guardias" (Pivel, 1962: 539). Horas más tarde, se había congregado a las puertas del Fuerte un número importante de personas haciendo "bulla". Según el capitán José Obregón, el conjunto de "sediciosos" estaba integrado por oficiales y milicianos de los Regimientos de Infantería Ligera y de Voluntarios del Río de la Plata, que se hacían notar por la presencia de sus músicos, ${ }^{17}$ acompańados de algunos "vecinos blancos de la clase más ínfima [junto a]

16 El expediente, junto con un valioso cuerpo de documentos relativos a los hechos de 1808, está publicado en Pivel, 1962.

17 Milicias disciplinadas formadas luego de las invasiones inglesas. 
unos cuantos esclavos". En medio de los "alborotadores", señaló haber visto disfrazados al sargento mayor (Diego Ponce de León) y al ayudante de plaza, "con algún que otro vecino de carácter". Los músicos tocaban "paso de ataque" y muchos de los participantes llevaban antorchas (Pivel, 1962: 532 y 575). Según el oficial Juan Bermúdez, Elío salió a las puertas del Fuerte a la medianoche y fue levantado en andas por cuatro capitanes de milicia que le ofrecieron pasearlo por las calles, negándose el gobernador para no ser visto como el "motor del alboroto" (ibid.: 575).

De allí el tumulto se dirigió a la casa del administrador de aduanas José Prego de Oliver, donde había sido alojado Michelena. En un documento elaborado tiempo después, Prego señaló las gestiones de varios oficiales de milicias para proteger a Michelena. En dos oportunidades le pidieron que se retirara con ellos, señalando que les costaba "inmenso trabajo contener al Pueblo" y que "corría peligro su vida" (García, 1956b: 63-64). Según el teniente Manuel de la Iglesia, en las inmediaciones de la residencia había "mas [sic] de cincuenta hombres del bajo Pueblo", que según sus conversaciones "trataban de matar a Michelena" (Pivel, 1962: 543). Finalmente, este aceptó retirarse protegido por los oficiales.

A la mañana, aparecieron papeles en diversos puntos de la ciudad convocando a un cabildo abierto ese día. El comandante del Resguardo de las Rentas de Aduana, Miguel de Cabra, en su testimonio ante la Real Audiencia señaló que desde su casa ubicada frente al Fuerte vio salir en la madrugada "de uno en uno y dos en dos mas [sic] de cien negros", todos con un "cigarro de hoja en la boca", que "habrían sido instruidos de lo que habían de gritar" (ibid.: 564). El señalamiento repetido en las fuentes a la presencia de "negros" en estas movilizaciones (no se aclara si se trataba de esclavizados o libertos) denota la pretensión de los declarantes de establecer un juicio crítico sobre sus enemigos por "manipular" a sectores sometidos a dependencia, mientras que también podría apelar al temor que generaban experiencias previas de movilización colectiva de los esclavizados en el Río de la Plata. ${ }^{18}$

18 En 1795, en Buenos Aires hubo detenidos, interrogados y torturados a causa de rumores extendidos sobre una potencial rebelión de esclavizados inspirada en la Revolución francesa y también la haitiana (Johnson, 2013: 203). En Montevideo fue detenida por las autoridades, en 1803, una "junta de negros levantiscos" que pretendía huir de la ciudad y establecer una población en la región de Monte Grande. El Gobierno realizó averiguaciones y detenciones, y colocó un "rollo” en la Plaza Mayor con el objetivo de "contener el desmedido engreimiento q.e [sic] estos Negros de todas clases y Naciones ha tomado y sugetarlos dentro de los límites de la subordinacion a sus Amos" (RAGA, 1917: 81). 
El cabildo que sesionó de forma abierta decidió obedecer, pero no cumplir, la orden de sustituir al gobernador y conformó una Junta presidida por Elío e integrada por representantes de los distintos cuerpos de la ciudad, a ejemplo de las formadas en Espańa. ${ }^{19}$ Tanto los partidarios como los detractores de la Junta utilizaron el argumento del temor a la movilización plebeya y el desborde social (Frega, 2007: 255). Los primeros justificaron su instalación en la necesidad de contener y encauzar esa movilización. En carta del 7 de octubre de 1808, el gobernador y los vocales de la Junta expresaron a la Real Audiencia que si exigían su disolución debían proponer arbitrios "para contener a un pueblo que conspira contra los vocales hasta exterminarlos por tímidos e inconstantes". Expresaban el temor a una "guerra dentro de los muros" que enfrentaría a "padres e hijos" (Pivel, 1962: 452). A su vez, el dictamen de la Real Audiencia, firmado por el fiscal Manuel Villota el 15 de octubre de 1808, señalaba que la Junta tenía su origen en una "efervescencia popular tumultuaria", que la convertía en "subversiv[a] del orden", lo que hacía necesario disolverla (ibid.: 460 y 462).

\section{"Todo era exaltación", 1810}

En 1810, en mayo, llegaron noticias de la disolución de la Junta Central y Gubernativa del Reino y la constitución de un Consejo de Regencia, de discutida legitimidad, en la ciudad de Cádiz. Se instalaba nuevamente el problema de la legitimidad del Gobierno, las disruptivas dudas respecto a quién gobierna y a nombre de quién (Guerra, 1992: 122). En Buenos Aires, un cabildo abierto decidió desconocer la Regencia y sustituir al virrey por una Junta que tutelara los derechos de Fernando VII. El 24 de mayo se recibieron en Montevideo las primeras noticias de lo acaecido en la ciudad vecina, generándose una intensa conmoción. La participación de las clases populares fue lograda por los dos bandos que alinearon a las élites montevideanas: "españolistas" o "leales" (partidarios del reconocimiento a las autoridades metropolitanas) y "americanos" (afines a la Junta instalada en Buenos Aires). El 26 de mayo fue necesario tomar acciones para proteger al capitán Juan de Vargas, secretario interino del virrey, que había sido enviado a la ciudad con el objetivo de informar lo sucedido y, según consigna el sacerdote Bartolomé Muñoz en un diario personal, buscar apoyos para "formar una contrarrevolución”. Según Muñoz, partidario del reconocimiento a la Junta, "el Pueblo se disgustó tanto que tuvo que esconderse porque lo buscaron en su casa y en su chacra para matarlo" (CNAA, 1975: 219).

19 Sobre la Junta de 1808 en Montevideo, véanse: Pivel, 1962; Frega, 1998, 2007; Ribeiro, 2013. 
Por su parte, el cabildo abierto celebrado el 1 de junio debió ser guarnecido por 40 soldados ante la importante presencia de público y el temor a que se generaran disturbios (MD, 1965a: 215). El 10 de junio se anunció la llegada de Juan José Paso, integrante de la Junta de Buenos Aires, que procuraba buscar el reconocimiento a esta y el envío de diputados. Cuatro días después fue recibido por el cuerpo capitular y al día siguiente se convocó a un cabildo abierto. Dámaso Antonio Larrañaga y José Guerra (1914: 100), en unos apuntes históricos elaborados años después, señalaron que el diputado se retiró "ofendido de las maneras bruscas y gritos desaforados de algunos hombres ignorantes" que "atravesaban" los discursos y "hacían ruidos". Bartolomé Muñoz, a su vez, mencionó "las vivas de la chusma que se agolpó a la puerta" con el objeto de "intimidar" al diputado (CNAA, 1975: 220). Ambas fuentes denotan la disputa establecida por la legitimidad de los espacios políticos y por los límites de la participación popular. Las decisiones no podían ser tomadas únicamente por las autoridades; el cabildo debió abrirse a la participación de los "vecinos distinguidos", pero, al mismo tiempo, debió dialogar con quienes quedaban afuera. Estos últimos no estaban convocados a tomar decisiones, aunque, sin embargo, influían sobre las mismas. Finalmente, el cabildo abierto mantuvo la posición de no acatar la Junta mientras esta no reconociese a la Regencia, y Paso debió abandonar la ciudad intimado por algunos jefes militares que no le dieron seguridad de contener al pueblo que estaba "alborotado con su presencia" (MD, 1965b: 60-61).

En los días siguientes la situación política se fue tornando cada vez más tensa. Entre las élites, las posiciones no estaban definidas ni explicitadas, lo que generaba desconfianzas y temores. En la madrugada del 12 de julio, los regimientos milicianos de Infantería Ligera y de Voluntarios del Río de la Plata se amotinaron en el cuartel de dragones y en la Ciudadela, dando a conocer una proclama donde exigían el reembarco de la marina y la separación del sargento mayor Diego Ponce de León de su cargo. Para muchos de los protagonistas, los líderes del motín buscaban con su acción que la ciudad reconociera a la Junta de Buenos Aires. A las pocas horas, sin embargo, se hizo evidente que la empresa estaba condenada al fracaso; la marina, las milicias urbanas y una multitud de personas que se habían concentrado en la plaza rodearon el cuartel de dragones y avanzaron sobre la Ciudadela, estableciendo una negociación entre los capitulares y los jefes amotinados, que decidieron deponer su actitud. En las actas del cabildo se relata cómo, en el momento en que los amotinados entraron al cabildo, una reunión de "vecinos en armas" que se "agolpó" a las puertas pidió las "cabezas de los delincuentes", lo que obligó a decretar su arresto y el desarme de los regimientos (RAGA, 1919: 437). 
Tras los hechos de julio de 1810, la ciudad quedó enfrentada a los distintos gobiernos formados en Buenos Aires y fue sitiada en dos ocasiones: entre mayo y octubre de 1811, y entre octubre de 1812, y su capitulación en junio de 1814. La participación política de las clases populares tuvo diversas facetas. En este texto nos detendremos específicamente en dos de ellas. Por un lado, la experiencia del "partido empecinado", agrupamiento político que logró una creciente incidencia sobre las autoridades y fue expresión de un posicionamiento contrarrevolucionario radical y exaltado; liderado por figuras de la élite, logró una importante adhesión de sectores plebeyos que marcaron con su impronta las acciones políticas que emprendieron. Por otro, durante el segundo sitio, y con el trasfondo de un abrupto deterioro de las condiciones de vida de la población, se produjeron tumultos vinculados a la obtención de alimentos en que participaron las clases populares y parte de los soldados. Las acciones "empecinadas" y los "tumultos del hambre", fenómenos en apariencia independientes, terminaron ligados y generando una lógica disruptiva del orden que provocó extendidos temores entre las autoridades.

\section{La "terrible facción" de los empecinados}

Distintas fuentes mencionan el accionar del grupo de los "empecinados" desde los últimos meses de 1810 y les atribuyen acciones de intimidación a figuras consideradas afines al Gobierno de Buenos Aires. ${ }^{20}$ El sacerdote Bartolomé Muñoz, mencionado anteriormente, expresó en su diario una posición crítica sobre las principales figuras del Gobierno montevideano $y$, en especial, sobre el sargento mayor de la plaza, Diego Ponce de León, a quien consideraba un "intrigante". Según Muñoz, Ponce de León era el "demagogo de una terrible facción que se nominó de los Empecinados" y que estaba compuesta por "gente baja y rica, pulperos patrones, almaceneros, cafeteros", muchos de los cuales habían sido marinos. Ponce de León los "embelezaba" diciendo que contaba "con ellos para el sostén del trono del adorado desgraciado Fernando 70" y los “enloquecía” expresándoles que eran "los verdaderos espańoles". Destacaba el autor otros incentivos, como el "grano a mano de su mucho dinero, buenos vinos [y] muchos dependientes", además de "jamones, vinos y ricos pescados", que facilitaban "empresas de músicas, hachas, merendonas y alborotos" con que "llevaba[n] la voz del Pueblo para ahorcar, desterrar, o encerrar a cualquiera" (CNAA, 1975: 221).

20 Para un abordaje más extenso del accionar de los "empecinados", véase: Ferreira, 2016a. 
La fuente, parcial e interesada, permite apreciar cómo la adhesión se lograba a partir de gratificaciones simbólicas (ser los "verdaderos españoles") y materiales, y se sustentaba en un conjunto de relaciones jerárquicas preexistentes. ¿Cuáles fueron las acciones concretas de los “empecinados"? En esta primera etapa, lo principal fue la delación y la denuncia de figuras afines a la Junta bonaerense; tal el caso de un grupo de sacerdotes a los que se acusó y hostigó hasta lograr su expulsión entre julio y agosto de 1810. Otro recurso fue la colocación de pasquines y la presión sobre las autoridades.

En marzo de 1811 se iniciaron las hostilidades militares entre el Gobierno de Montevideo y el Gobierno de Buenos Aires. El avance de las fuerzas revolucionarias fue rápido y a fines de mayo la ciudad fue sitiada. En los días siguientes fue expulsado un nuevo grupo de religiosos y varias familias consideradas afines a la insurgencia. Los "empecinados" favorecieron y acompañaron la instalación y las acciones de un tribunal de seguridad pública, proporcionaron nombres de sospechosos y acompañaron con actos de hostilidad la salida de los religiosos y las familias. La expulsión violenta del enemigo y su familia representaba la exclusión física y simbólica de la comunidad, y denotaba la creciente violencia política imperante. En ese marco, la figura del "insurgente" parece haber condensado significados múltiples, algunos claramente políticos, pero también elementos culturales y sociales, en la medida en que la mayoría de los expulsados integraba la élite de la ciudad. Insultarlos, arrojarles objetos mientras eran sacados de la ciudad y tomar los bienes que dejaban eran algunas de las "revanchas" que permitía ese tiempo de incertidumbres.

Mateo Magariños, comerciante de importante actuación política en el Montevideo leal, llevó una relación diaria de los sucesos en la ciudad que envío a su hijo residente en España. Su relato es representativo de los recelos que el accionar de los "empecinados" generaba entre las élites, incluso entre los leales a la Regencia. Identificó a los "empecinados" como una "cafila de tunantes" que se habían convertido en apoyo del capitán general Gaspar de Vigodet y los describió como "una porcion de Andaluces, q.e no tienen sobre q.e caer" pero que contaban con la protección de Ponce (CNAA, 1963: 40-41). Otra referencia interesante es la que dejó el por entonces miliciano patriota José Encarnación de Zás en una memoria escrita años después, donde cuenta cómo fue atacado en su casa por un grupo "de los más empecinados", que lo "escupieron y dieron puntapiés y muchos golpes”, acusándolo de "tupamaro". Entre ellos identificó a dos "sastres gallegos pobres" y calificó a los demás como unos "calaveras", término que en la época remitía a sujetos de mal vivir (Zás, 1951: 123-124). El episodio concluyó con la intervención de su padre que, al grito de "todos somos unos Viva España paisanos”, logró disuadir a los atacantes (ibid.).

En octubre de 1811 se firmó un armisticio entre el Gobierno de Montevideo y las autoridades revolucionarias. La tregua fue efímera y un 
año después la ciudad fue nuevamente sitiada. Durante el llamado segundo sitio, los "empecinados" alcanzaron su momento de mayor influencia política, utilizando las modalidades descritas e incorporando otras nuevas, como las movilizaciones masivas para presionar a las autoridades ante la toma de decisiones. Su acción se hizo intensa en coyunturas como la discusión de armisticios o las derrotas del Ejército. En esos momentos se ubicaron como partidarios de continuar la guerra hasta las últimas consecuencias, denunciaron todo intento de capitulación e impugnaron a los mandos militares, acusándolos de debilidad o cobardía. Los "empecinados" aparecen aquí como los "ultras" de la contrarrevolución; radicales enemigos del cambio por sus posiciones políticas, pero disruptivos del orden establecido por su forma de actuar. Fueron para las élites el "temible" resultado de una sociedad militarizada y politizada en la que las distancias sociales parecían erosionarse.

\section{Los tumultos del hambre}

Para el segundo sitio, las fuentes mencionan acciones colectivas vinculadas a la obtención de alimentos, agua u otros bienes que se volvían cada vez más escasos. Se trató de episodios asimilables a los clásicos "motines de subsistencia" sobre los que ha trabajado la historiografía europea, pero que no fueron habituales en la historia colonial de Montevideo. ${ }^{21}$

En los meses finales del sitio, con la ciudad bloqueada por mar y muy desabastecida, estos episodios se generalizaron. El 27 de mayo de 1814 se produjo un tumulto en el reparto de pan, ante rumores de que se falsificaban las papeletas de racionamiento otorgadas a los enfermos. "Temiendo cada cual que el pan no alcance", se generó un "tumulto férvido a sablazos", que según el diario llevado por Francisco Acuña de Figueroa (1978: 292-293) no fueron capaces de contener "las bayonetas" de la tropa. Un escenario frecuente de estos tumultos fue la recova, ubicada en los fondos del Cabildo, punto de venta público de carne y otros alimentos. Días antes, el 22 de mayo, tras varias semanas sin que se comercializara carne, se puso a la venta lo que un lanchón había logrado ingresar el día anterior. Describe Acuña de Figueroa (1978: 286) cómo se generó "una guerrilla sangrienta" que obligó a la intervención de la partida del sargento mayor, que fue "arrollada" por una "turba del pueblo", "exaltada" por un "fatal frenesi" (ibid.).

Días después, una nueva "gresca" se generó en la recova, la cual no pudieron contener los guardias del cabildo y la Ciudadela. El cabildo dejó constancia del hecho en sus acuerdos, y elevó una nota al capitán general Gaspar de Vigodet en la que acusaba al comandante del Batallón de América

21 Véanse: Hobsbawm, 1968; Rudé, 1971; Thompson, 1995. 
de haber desamparado la guardia de la Ciudadela, de apoderarse de la recova, "y [de] solo vender carne a las personas que los soldados quisieron" (RAGA, 1934: 190-195). ${ }^{22}$ La ciudad había recibido importantes tropas de refuerzo que generaron dificultades para su alojamiento y alimentación. El recorte de las raciones, el atraso en los sueldos, las rivalidades entre los mandos militares y la falta de compromiso de los soldados con un conflicto lejano a la guerra europea fueron factores que aumentaron la indisciplina en la tropa. Para las élites, esto hacía más grave la situación, en la medida en que esperaban de los soldados ayuda para imponer el orden y no que actuaran a la par de los grupos plebeyos.

En las semanas finales del sitio confluyeron las dos formas de movilización referidas. La derrota de la escuadra naval y el bloqueo impuesto a la ciudad obligaron a las autoridades a retomar las negociaciones, propiciando nuevas acciones "empecinadas", a la par que se agravaban las condiciones de subsistencia. ${ }^{23}$ En la noche del 20 de junio, tras la firma de la capitulación, se amotinaron las milicias acuarteladas en la iglesia Matriz. Se trató de un motín disuelto por la rápida presencia de tropas veteranas y cuyos protagonistas no llegaron a formular sus aspiraciones, más allá del rechazo a la capitulación y la acusación de traición a los gobernantes. La modalidad puede asociarse con episodios reseñados: circulación de rumores y generación de estados de ánimo; exaltación de valores de valentía en oposición a la supuesta cobardía de quienes dirigían las negociaciones; dirección del movimiento por un jefe subalterno, pero con mando de tropa que se reveló contra su superior. Además de la presencia plebeya en los cuerpos milicianos, el movimiento tuvo extensiones en otros puntos de la ciudad, donde las fuentes señalan la presencia de grupos que proferían gritos contra los "traidores" (Bauzá, 1929: 197).

El frustrado motín pudo haber tenido algunos beneficios inmediatos para sectores de la plebe. Al día siguiente se sucedieron saqueos, que llevaron a que muchas tiendas cerraran sus puertas. Al mismo tiempo, Acuña señaló que, ante la amenaza "de las míseras turbas", los "pudientes" abrieron "sus amplias despensas al público" y entregaron alimentos (1978: 347).

Con estos hechos se cerró una etapa en la historia de la ciudad. En su miseria y en el marco de la militarización y la expansión de la vida política, las clases populares habían incrementado su capacidad de incidencia en la

22 El Batallón de América era uno de los contingentes llegados de la península entre 1812 y 1813 (véase: Ferreira, 2012: 26-27).

23 Las primeras negociaciones se habían realizado a fines de marzo de 1814 y también habían generado acciones "empecinadas" (véanse: Ferreira y Frega, 2016; Ferreira, 2016a). 
toma de decisiones, proceso que fue tan temido como los cambios que se generaban fuera de las murallas, en el frente revolucionario.

LOS AÑOS DE LA "PATRIA"

El 23 de junio de 1814 ingresaron a Montevideo los ejércitos del Directorio de las Provincias Unidas del Río de la Plata. El gobierno directorial fue breve, y nunca pudo consolidarse en el conjunto de la provincia Oriental, debido a su enfrentamiento con las fuerzas comandadas por José Artigas. A fines de febrero de 1815, estas tomaron el poder en Montevideo y lograron unificar bajo una misma soberanía al conjunto de la Provincia.

Desde 1811, los orientales o artiguistas se habían constituido en una de las vertientes de la revolución rioplatense y habían quedado (con efímeros intervalos) enfrentados a la conducción de Buenos Aires. El principal factor de conflicto fue la interpretación radical de la retroversión de la soberanía, que consideró a cada pueblo como su depositario y que entró en colisión con los intentos de establecer una dirección centralizada de la revolución. La etapa que se extiende entre 1815 y 1817 ha sido caracterizada como la "fase radical" del artiguismo; en ella coinciden su máxima expansión territorial en el litoral platense (y la formación del "sistema de los pueblos libres"), con la implementación de una política agraria de proyección igualitarista en la provincia Oriental. ${ }^{24}$

El artiguismo, surgido en la campaña oriental, tuvo dificultades para constituir una base de apoyo en la ciudad, siendo el ejército su principal sostén. La relación de sus jefes militares y políticos con las élites urbanas fue compleja; las actitudes de estas últimas oscilaron desde la tolerancia y el apoyo crítico hasta la conspiración para acelerar su derrota. El contingente armado más importante destinado a la ciudad fue el de los "dragones de la Patria" o "de la Libertad", un cuerpo de origen miliciano convertido en veterano durante la revolución y que era comandado por Fernando Otorgués, uno de los principales oficiales artiguistas. En las fuentes dejadas por las élites son constantes las referencias a los desórdenes producidos por los soldados, muchos de origen campesino y cuya disciplina era muy laxa. Mateo Magariños, comerciante español a quien ya hemos mencionado, escribió en un diario personal que "el mejor e[ra] un Gran demonio" y describió la indisciplina imperante seńalando que había montevideanos "que al turco se entregarían si se presentase", con tal de protegerse de ellos (Anónimo, 1957: 88). Lucas Obes, abogado e integrante de la élite política montevideana, en carta al emigrado Francisco Juanicó, de julio de 1815, escribía que los "dragones todo lo mancharon", que la ciudad "no

24 Sobre la fase radical de la "revolución artiguista”, véanse: Sala, De la Torre y Rodriguez, 1987; Frega, 2011. 
se purificará de sus crímenes con expiaciones de medio siglo" y comparaba su conducta con "los excesos del Sanculotismo" (Falcao, 1939: 166).

Estas fuentes dejan entrever los recelos que generaba el poder que tenía un ejército de base popular, convertido en actor clave de la política en la ciudad durante esta etapa. En la segunda mitad de 1815, las élites presionaron para que se tomaran acciones orientadas a contener a los soldados y a disminuir su poder. Entre ellas se destacó la división del contingente de dragones (una parte marchó a proteger la frontera norte) y, paralelamente, la conformación de un cuerpo miliciano cívico dirigido por las élites y proyectado como contrapeso de los primeros. ${ }^{25}$

Parte de la plebe urbana se integró a grupos en armas, constituidos sobre la base de factores étnicos o condición jurídica. Desde el inicio de la revolución se habían formado cuerpos de pardos y morenos libres, al tiempo que se había propiciado la fuga de esclavizados durante los sitios, bajo la promesa de obtener la libertad a cambio de su incorporación a los ejércitos revolucionarios. ${ }^{26}$ En la etapa que analizamos se formaron compañías de morenos libres integradas al regimiento de dragones y se reclutó un contingente que cumplió tareas en la maestranza de artillería. En carta dirigida al gobernador delegado, Miguel Barreiro, en julio de 1816, Artigas ordenaba fortalecer el cuerpo de artillería con más morenos libres a los que consideraba "buenos soldados y de confianza" y sugería "armarlos de fusiles" (CNAA, 1987: 244). Por esa fecha, el ejército portugués avanzaba sobre territorio oriental y las autoridades montevideanas decidieron pasar del pedido a los "amos" a acciones expropiatorias. El 25 de agosto, Barreiro escribía al regidor Joaquín Suárez informándole que, en proporción de los esclavos que tenía cada vecino, les había "sacado" un determinado número para formar un batallón de milicias. Este nuevo contingente cumplió un papel fundamental para sostener a las autoridades artiguistas cuando en septiembre se produjo una conspiración liderada por figuras de la élite criolla que contó con el apoyo de las milicias cívicas (Ferreira, 2016b: 34-35).

La incorporación de los esclavizados a estos regimientos no fue, claramente, un acto voluntario. A los propietarios se los consolaba diciéndoles que "los negros [iban] a servir en clase de milicia" y que los recuperarían en tanto acabaran las urgencias militares (CNAA, 1998: 199). Más allá de lo anterior, la idea de que la "patria" (entendida como la "revolución" o el "sistema") abría caminos de libertad a los que peleaban por ella, parece haber sido una noción muy extendida, que se reflejó en pleitos judiciales contemporáneos y posteriores

25 Véase: Ferreira, 2016b, 2017.

26 Sobre el tema, véase: Frega, 2004: 50. 
(Frega, 2004: 54-55). También existió entre las élites la percepción de un relajamiento de la obediencia y de un acortamiento de las barreras sociales.

Un ejemplo de lo anterior surge de la lectura del sumario que se le instruyó al miliciano cívico Martín Bentancour en 1816. Este se encontraba de guardia en el muelle la tarde del 30 de abril y pidió autorización para ir con tres compañeros a buscar leńa a la playa. De regreso, mientras descargaban, vieron en las cercanías al artillero negro Joaquín Estrada y le ordenaron que acarreara la leña hasta la guardia. Según varios testigos, Estrada se resistió "y lo echó al carajo por dos o tres veces", señalándole "que era tan bueno como él y paisano como él", y que no cumpliría la orden. La situación terminó en un lance violento y derivó en la muerte (accidental, según Bentancour) de Estrada. ${ }^{27}$ Lo interesante del episodio son los argumentos expresados para no acatar la orden. La obediencia y la actitud servil que se esperaba por su origen no eran tomadas en cuenta, ya que Estrada se consideraba tan libre, "bueno" y "paisano" como Bentancour.

\section{Apuntes para un balance}

Las coyunturas reseñadas hacen posible una mirada de conjunto que avance en la elaboración de un repertorio de las formas y un mapeo de los espacios de participación política de las clases populares en Montevideo durante el periodo analizado.

Un lugar fundamental donde se procesó esa participación fue la milicia. Si bien el reglamento de milicias de 1801 estableció la obligación de prestar servicio al conjunto de los vecinos, el proceso de incorporación se aceleró con las invasiones inglesas. A fines de 1807, en una estimación que puede ser generosa, el gobernador Francisco Xavier de Elío afirmaba que dos terceras partes de los montevideanos varones adultos estaban adscriptos a algún servicio militar activo. ${ }^{28}$ Para los grupos plebeyos, tanto el prest (una forma de jornal) que se pagaba en los cuerpos estables como la distinción que reportaba integrarlos hacían de la milicia una opción interesante. ${ }^{29}$ Por otra parte, los regimientos que tenían una carga más continua

27 AGN, Fondo Escribanía de Gobierno y Hacienda (EGyH), caja 112, expediente número 79 "'Sumaria contra Martín Bentancour, Cívico de la $1^{\text {a }}$ Compañía de haber herido al Negro miliciano de Artillería Joaquín Estrada de que le resultó la muerte la tarde del 30 de abril").

28 AGNU-AGA, caja 316, f. 148.

29 Un miliciano en 1807 recibía 12 pesos mensuales como prest, según cifras que maneja Ana Frega (2018: 20). Un peón que trabajaba en la construcción de la iglesia Matriz durante el mismo periodo ganaba entre 4 y 8 pesos al mes (Thul, 2015: 19). 
de servicio se convertían en un espacio importante de socialización, donde se difundían noticias y se formaban grupos de afinidad que traspasaban las barreras sociales. ${ }^{30} \mathrm{La}$ incorporación de la población a las armas, en una coyuntura de politización creciente, está íntimamente relacionada con la expansión de la violencia política, fenómeno que, según se aprecia en las fuentes, se desbordó por todo el tejido social.

Otro aspecto a analizar es la incidencia política de la participación plebeya, y si esta siguió motivaciones propias o directrices de las élites. Gabriel Di Meglio (2013b: 38) ha señalado que la historiografía actual elude la idea de manipulación (aunque muchas veces la sugiere), y tiende a converger en la hipótesis de una "agenda popular bajo dirección de la élite". Tal premisa podría ser adecuada al caso montevideano, pero abre el problema a nuevas interrogantes. Resulta necesario dar cuenta de las múltiples formas en las que se produjo la interacción entre esa "agenda" popular y los intereses de las élites. Si pensamos las clases populares como un sujeto plural, tal proceso debió haber estado signado por múltiples y paralelas negociaciones. También es necesario abordar los temores que generó esa participación entre las élites y la manera en que estas experiencias contribuyeron a configurar identidades políticas.

El periodo analizado permite apreciar la riqueza de tales interacciones y la percepción de los protagonistas. En octubre de 1808, el dictamen de la Real Audiencia sobre la formación de la Junta reconocía el protagonismo plebeyo y señalaba que el gobernador había tolerado esos "excesos" y dejado "impune los desórdenes" con el fin de usarlos políticamente (Pivel, 1962: 464). El teniente Manuel de la Iglesia, tras declarar que las "gentes imparciales" estaban contra la formación de la Junta, señalaba que eran algunos jefes militares y los grupos plebeyos los que la sostenían. Desde su perspectiva, condicionada por su ubicación en la sociedad y sus motivaciones políticas inmediatas, la "clase de artesanos y menestrales y mucho mas [sic] el ínfimo Pueblo" seguía a los jefes porque no contaban con el "discernimiento" necesario para tomar sus propias decisiones (ibid.: 49). Sin embargo, los episodios reseñados permiten otra mirada. La identificación con el "patriotismo español" agredido por los ingleses, la "conspiración francesa" o la "subversión juntista" pudieron haber constituido un poderoso factor de identidad para sectores cuyas condiciones de existencia se modificaron aceleradamente durante el periodo. La participación en acciones tumultuarias erosionaba barreras sociales, daba poder a la plebe en detrimento de la "gente decente", podía brindar compensaciones materiales inmediatas, legitimaba la expresión de una sociabilidad acostumbrada al

30 Para Buenos Aires, esta idea es planteada por Tulio Halperin (2014: 187). 
ejercicio de la violencia y permitía ciertas "revanchas" ante algunos privilegiados de la sociedad colonial. ${ }^{31}$

Los protagonistas apelaron a un repertorio conocido de formas de acción colectiva que fue utilizado de modo pragmático. La colocación de pasquines, la lectura de papeles sobre las autoridades, la congregación y manifestación en espacios públicos, las acciones de intimidación o la propagación de rumores formaban parte de tradiciones de raigambre colonial. Ligaban a los protagonistas con experiencias lejanas que, en tanto repertorios aprendidos, eran adaptados a una coyuntura novedosa. En 1810, al joven abogador Lucas Obes, que había pasado a Buenos Aires luego de instalada la Junta, le colocaron pasquines "amenazándole la vida y bienes si continuaba con sus ideas de Independencia”, lo que generó un estado de opinión en la ciudad que lo obligó a marcharse (MD, 1965b: 106-107). La colocación del pasquín apelaba a significados compartidos por emisores y destinatarios, y era parte del repertorio al que aludíamos. También la tradición estuvo presente en episodios de intimidación y acción directa. El brigadier Bernardo Lecocq, uno de los mandos de la marina que no reconoció a la Junta en 1808, fue visitado en su casa por "enmascarados armados" que lo intimaron "en nombre del pueblo" a irse de la ciudad (Pivel, 1962:525). Tales acciones contaron con la tolerancia de las autoridades, siempre y cuando contribuyeran a sus fines políticos.

Otra forma de acción política de la que participaron los grupos plebeyos fueron los rumores. No solo los recibieron, también los propagaron y los tiñeron de sus preocupaciones y valores. Como señalan Arlette Farge y Jacques Revel estos traducían y "crea[ba]n convicciones socialmente compartidas" (1998: 111). En julio de 1806 el rumor de que se suspendía la expedición de reconquista generó protestas violentas. En octubre de 1812 la circulación de informaciones falsas que indicaban que los sitiadores avanzaban sobre la plaza culminó con el asesinato del granadero Manuel Félix. Según los testigos, mientras la gente corría a las armas y gritaba "viva España", alguien contestó "Viva la Patria, carajo de mierda", apareciendo luego Félix asesinado. Entre los testigos nadie sabía quién lo mató, ni de donde surgió el aviso de un avance de los sitiadores (CNAA, 1966: 55-61). En ambos casos, los valores de honor y de masculinidad de la cultura plebeya, sumados al miedo, teñían la construcción de las noticias y las reacciones posteriores.

La política transcurría en múltiples espacios. En los lugares más institucionalizados, como el cabildo o la Gobernación, no eran novedosos los choques de atribuciones y la formación de facciones de notables. Lo nuevo fue

31 Para profundizar en las características de esta sociabilidad masculina, véase: Johnson, 2013: 32. 
la irrupción plebeya en la definición de esas disputas, lo que afectó un rasgo clave de la política colonial, como era el carácter reservado de la toma de decisiones (Serulnikov, 2013: 31). Hemos visto varios ejemplos: la presencia plebeya en 1807 ante los rumores de capitulación, los tenidos por amenazantes "paysanos y negros" que exigían cabildo abierto en 1808 o quienes presionaron a las juntas de guerra de 1814. Aun cuando el accionar de las clases populares pudo haber sido funcional a intereses elitistas, su presencia era disruptiva y limitaba los márgenes de negociación y pacto.

Los espacios de sociabilidad tradicional, como mercados y plazas públicas, fueron punto de difusión de ideas y lugar de acciones colectivas. Eran espacios de enunciación en una cultura política que se basaba en la controversia pública (Izquierdo, 2014: 263). La plaza principal de la ciudad era la Matriz, a la que daban el cabildo, la iglesia principal, la recova y donde se formaba el mercado de verduras. El tránsito de personas era importante, las conversaciones eran habituales y la presencia del cabildo hacía de la plaza una suerte de antesala donde se juntaban los interesados en lo que allí se discutía. En la ciudad había casi un centenar de pulperías registradas, si incluimos las ubicadas en extramuros; eran punto de encuentro cotidiano de los sectores plebeyos, lugar de compras y espacio de tertulias que acompañaban la ingesta de bebidas alcohólicas. ${ }^{32}$ También había más de una decena de cafés, que no parecen haber sido exclusivamente elitistas, como en otras ciudades. ${ }^{33} \mathrm{El}$ capitán Martín Cevader, en el expediente formado por la Real Audiencia en 1808, refería que las cartas que acusaban a Liniers "eran copiadas por muchas clases de personas" y que todos los integrantes del cuerpo de artilleros, tanto "grandes" como "chicos", tenían conocimiento de los papeles porque "en los cafés se sabía todo" (Pivel, 1962: 586). Las descripciones que aparecen en las fuentes sobre estos espacios de sociabilidad abonan las críticas de Robert Darnton (2014: 109) a la tesis habermasiana de la formación de la opinión a partir de la discusión racional en la esfera pública. Muestran una imagen cercana a la de una "cacofonía que se arremolinaba por las calles y bullía en sitios clave", no siempre racional ni ceñida a los hechos, pero que lograba operar como una fuerza capaz de desestabilizar Gobiernos.

Otro aspecto que surge de estos episodios es la presencia de figuras clave para promover la movilización plebeya. Se trató de una convocatoria basada en relaciones jerárquicas preexistentes y donde los mediadores o "agitadores” tuvieron un papel relevante. George Rudé (1971: 255) clasificó a estos

32 Véase: AGNU-AGA, caja 314, carpeta 1, f. 83.

33 Sobre este tema véase, para el caso de Buenos Aires: González Bernaldo, 2000: 71-73; para el caso de Madrid: Paris, 2017: 97. 
"líderes" en tres categorías: los que actúan desde fuera de la multitud, los que surgen dentro y los intermediarios. Diego Ponce de León es el más interesante de los líderes intermedios. Su figura va en ascenso en el periodo; proveniente de la Armada, en 1807 Elío lo designó sargento mayor interino y le otorgó mando de tropa. Para 1808 se había convertido en su principal articulador; lee y difunde cuantos papeles circulan en los cafés, se pasea por la plaza conversando con los que se congregan y es uno de los que encabeza la movilización del 20 de septiembre (Pivel 1962: 532 y 587). Como se ha visto, a partir de 1810 fue el líder de los "empecinados" y su poder fue en aumento hasta 1814.

Un último aspecto a referir es la importante presencia de esclavizados, negros libres y pardos en los episodios reseñados. Si bien su participación política aparece ligada al accionar de sectores de la élite, ella no dejó de generar temores. Su ingreso a espacios reservados a peninsulares y criollos era disruptiva aun cuando actuaran siguiendo sus iniciativas. En la etapa artiguista, la experiencia de incorporación masiva a contingentes armados otorgó un mayor poder dentro de la sociedad a los afrodescendientes, generando entre las élites una extendida sensación de acortamiento de las distancias sociales.

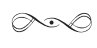

En enero de 1817, fuerzas lusitanas ingresaron a Montevideo y fueron recibidas bajo palio por las autoridades capitulares. Estas vieron en su presencia una alternativa para apagar el "incendio de las pasiones" y dar por cerrada "una revolución inevitable en su origen, pero desgraciada y terrible en sus vicisitudes" (CNAA, 2000: 175). Encuadrar y disciplinar a las clases populares y limitar la participación política a las élites fue la utopía que persiguieron los grupos dirigentes en los años subsiguientes. Sin embargo, el camino de politización de quienes no integraban la "mejor clase" (a decir del cónsul británico en Montevideo, en 1824) era difícil de desandar (Barrán, Frega y Nicoliello, 1999: 75). 


\section{FUENTES}

Archivo General de la Nación, Uruguay, Fondo Ex-Archivo General Administrativo (AGNU-AGA), cajas 314, 315 y 316, y libro 406.

Archivo General de la Nación, Uruguay, Fondo Escribanía de Gobierno y Hacienda (AGNU-EGyH), caja 112.

Comisión Nacional Archivo Artigas

1952, 1963, 1966, 1975, 1987, 2000 Archivo Artigas, tomos 3, 5, 7, 13, 21, 32. Montevideo: Imprenta Dorneleche.

\section{BiBLIOGRAFÍA}

Acuña de Figueroa, Francisco

1978 Diario Histórico del Sitio de Montevideo en los años 1812-13-14. Tomo II. Biblioteca Artigas, Colección Clásicos Uruguayos, volumen 158. Montevideo: Imprenta Nacional.

Anónimo

1957 "Diario anónimo adjudicado a Mateo Magariños Baliñas, con anotaciones de Andrés Villaba”. En: Boletín Histórico de Ejército, número 73, volumen 74. 79-91.

Barrán, José Pedro; Ana Frega y Mónica Nicoliello

1999 El Cónsul Británico en Montevideo y la Independencia del Uruguay. Montevideo: FHCE.

Bauzá, Francisco

1929 Historia de la Dominación Española en el Uruguay. Tomo 1. Montevideo: Palacio del Libro.

Beraza, Agustín

1961 La revolución oriental. Montevideo: Ediciones de la Banda Oriental.

Bentacur, Arturo

1997 El puerto colonial de Montevideo. Tomo I. Guerras y apertura comercial. Tres lustros de crecimiento económico, 1791-1806. Montevideo: FHCE.

Bentacur, Arturo y Fernando Aparicio

2006 Amos y esclavos en el Río de la Plata. Buenos Aires: Planeta. 
464 | Trabajos y trabajadores en América Latina (siglos XVI-XXI)

Bertrand, Michel

2011 "Microanálisis, historia social y acontecimiento histórico". En: Revista de Historia, número 63. 141-149.

Beverina, Juan

1935 El Virreinato de las Provincias del Río de la Plata. Su organización militar. Buenos Aires: Círculo Militar.

Borucki, Alex

2011 "From Shipmates to Soldiers: Emerging Black Identities in Montevideo, 1770-1850". Tesis de doctorado. Emory University, Atlanta, Estados Unidos de América.

Darnton, Robert

2014 El diablo en el agua bendita o el arte de la calumnia de Luis XIV a Napoleón. México: FCE.

Di Meglio, Gabriel

2013a "La participación política popular en la Provincia de Buenos Aires, 1820-1890. Un ensayo". En: Raúl Fradkin y Gabriel Di Meglio (comps.), Hacer politica. La participación popular en el siglo XIX rioplatense. Buenos Aires: Prometeo.

2013 b "La participación popular en las revoluciones hispanoamericanas, 1808-1816. Un ensayo sobre sus rasgos y causas". En: Daniel Santilli, Jorge Gelman y Raúl Fradkin (comps.), Rebeldes con causa. Conflicto y movilización popular en la Argentina del siglo XIX. Buenos Aires:

Prometeo.

2008 "Las palabras de Manul. La plebe porteña y la política en los años revolucionarios”. En: Raúl Fradkin (ed.), ¿Y el pueblo dónde está? Contribuciones para una historia popular de la revolución de independencia en el Rio de la Plata. Buenos Aires: Prometeo.

2007 iViva el bajo pueblo! La plebe urbana de Buenos Aires y la politica entre la revolución de Mayo y el rosismo (1810-1829). Buenos Aires: Prometeo.

Echeverri, Marcela

2009 "Derecho de los indios y esclavos realistas y la transformación política de Popayán, Nueva Granada (1808-1820)”. En: Revista de Indias, número LXIX, volumen 246. 45-72.

Falcao Espalter, Mario

1939 “Epistolario del Doctor Lucas José Obes”. En: Revista del Instituto Histórico y Geográfico del Uruguay, tomo XV. 143-178. 
Farge, Arlette

1991 La atracción del archivo. Valencia: Edicions Alfons el Magnanim.

Farge, Arlette y Jacques Revel

1998 Lógica de las multitudes. Secuestro infantil en París, 1750. Rosario, Argentina: Homo Sapiens Ediciones.

Ferreira, Pablo

2017 “Que se vaya la Patria al ajo.... El año XV, las milicias cívicas y los espacios de resistencia al poder artiguista en Montevideo". En: Revista Historia para Todos. 10-23. Disponible en: https://drive.google. com/file/d/0B2uxHA0anTHvdWFxQXhOLW/mTHM/view (fecha de consulta: 27 de noviembre de 2017).

2016a "La guerra de independencia española, los 'empecinados' y el Montevideo leal, 1808-1814". En: Pasado Abierto, revista del CEHIS, número 4. 41-60. Disponible en: http://h.mdp.edu.ar/revistas/index. php/pasadoabierto/article/view/1997/2101 (fecha de consulta: 27 de noviembre de 2017).

2016b "Ciudadanos en armas. La experiencia de la milicia cívica en Montevideo, 1815-1817”. En: Claves, revista de Historia, número 2. 9-45. Disponible en: http://www.revistaclaves.fhuce.edu.uy/index.php/Claves-FHCE/ article/view/86/67 (fecha de consulta: 27 de noviembre de 2017).

2012 "Los amotinados de la Matriz. Una aproximación al estudio del conflicto social y político en el ocaso del poder español en Montevideo". En: Avances de Investigación. Facultad de Humanidades y Ciencias de la Educación 2011-2012. Docentes. Montevideo: FHCE. 23-42.

Ferreira, Pablo y Ana Frega

2016 "Leales españoles, orientales y porteños en Montevideo en 1814". En: Scarlet O'Phelan Godoy (ed.), 1814: La junta de gobierno de Cuzco y el sur andino. Lima: Fondo Editorial PUCP / IFEA / Fundación M. J. Bustamante de la Fuente.

Flores Galindo, Alberto

1984 Aristocracia y plebe. Lima 1760-1830. Lima: Mosca Azul.

Fradkin, Raúl

2010 "La acción colectiva popular en los siglos XVIII y XIX: modalidades, experiencias, tradiciones". En: Nuevo Mundo, Mundos Nuevos. Disponible en: http://nuevomundo.revues.org/59749 (fecha de consulta: 27 de noviembre de 2017).

2008 "Cultura política y acción colectiva en Buenos Aires (1806 -1829): un ejercicio de exploración”. En: Raúl Fradkin (ed.), ¿Y el pueblo dónde está? Contribuciones para una historia popular de la revolución de independencia en el Rio de la Plata. Buenos Aires: Prometeo. 
466 | Trabajos y trabajadores en América Latina (siglos XVI-XXI)

Fraser, Ronald

2007 La maldita guerra de España. Historia social de la guerra de la Independencia, 1808-1814. Barcelona: Crítica.

Frega, Ana

2018 "Revolución y contra-revolución en Montevideo en 1810". En: Ana Frega (coord.), La vida politica en Montevideo: élites y sectores populares en tiempos de revolución. Montevideo: CSIC / Udelar.

2011 Pueblos y soberanía en la revolución artiguista. La región de Santo Domingo Soriano desde fines de la colonia a la ocupación portuguesa. Montevideo: Biblioteca Nacional, Ediciones de la Banda Oriental. [2007]

2008 “Los ‘infelices' y el carácter popular de la revolución artiguista”. En: Raúl Fradkin (edit.), ¿Y el pueblo dónde está? Contribuciones para una historia popular de la revolución de independencia en el Río de la Plata. Buenos Aires: Prometeo.

2007 “La Junta de Montevideo de 1808". Manuel Chust (coord.), 1808. La eclosión Juntera en el Mundo Hispánico. México: El Colegio de México / FCE.

2004 "Caminos de libertad en tiempos de revolución. Los esclavos en la Provincia Oriental Artiguista, 1815-1820”. En: Arturo Bentancur, Alex Borucki y Ana Frega (eds.), Estudios sobre la cultura afro-rioplatense. Historia y presente. Montevideo: FHCE.

1998 "Tradición y modernidad en la crisis de 1808. Una aproximación al estudio de la Junta de Montevideo". En: Luis E. Behares y Oribe Cures (org.), Sociedad y cultura en el Montevideo colonial. Montevideo: FHCE / IMM.

García, Flavio (comp.)

1956a "Espigas de la Patria Española, b) La actuación rioplatense del Comandante General Salazar (1809-1815)”. En: Boletín Histórico, número 69. 53-78.

1956b "Secuelas documentadas de la Junta Montevideana de 1808”. En: Boletín Histórico, número 70. 41-67.

González Bernaldo, Pilar

2000 Civilidad y politica en los origenes de la nación argentina. Las sociabilidades en Buenos Aires, 1829-1862. Buenos Aires: FCE.

Gramsci, Antonio

2000 Cuadernos de la cárcel. Tomo VI. Puebla, México: Era.

Guarisco, Claudia

2007 "La Constitución de Cádiz y la participación política popular en la Nueva España, 1808-1821. Balance y nuevas perspectivas". En: Revista Complutense de Historia de América, número 33. 55-70. 
Guerra, José Luis

1992 Modernidad e Independencias. Madrid: Mapfre.

Halperin, Tulio

2014 Revolución y guerra. Formación de una élite dirigente en la Argentina criolla. Buenos Aires: Siglo XXI.

Harrington, Thomas

2012 "Los catalanes: La levadura de la colonia montevideana". En: Revista Encuentros Latinoamericanos, VI, número 1. 275-296.

Hobsbawm, Eric

1968 Rebeldes primitivos. Barcelona: Ariel.

Izquierdo Marín, Jesús

2014 "La política como controversia: crisis constitucional y respuesta subalterna en los albores del liberalismo". En: Miguel Cabrera y Juan Pro (coords.), La creación de las culturas politicas modernas, 1808-1833. Historia de las culturas politicas en España y América Latina, tomo I. Zaragoza, España: Marcial Pons.

Johnson, Lyman

2013 Los talleres de la revolución. La Buenos Aires plebeya y el mundo del Atlántico, 1776-1810. Buenos Aires: Prometeo.

Larrañaga, Dámaso y José Raymundo Guerra

1914 "Apuntes históricos sobre el descubrimiento y población de la Banda Oriental del Río de la Plata y las ciudades de Montevideo, Maldonado, Colonia, etc.”. En: Revista Histórica, VII. 532-557.

Le Bon, Gustave

1995 Psicologia de las masas. Madrid: Morata.

Lefebvre, Georges

1986 El gran pánico de 1789. Barcelona: Paidós.

(MD) Mayo Documental (Universidad de Buenos Aires, Facultad de Filosofía y Letras, Instituto de Historia Argentina “Dr. Emilio Ravignani”)

1962, 1965a, 1965b Mayo documental, tomos II, XI y XII. Buenos Aires: Talleres Gráficos Guillermo Kraft Ltda.

Moraes, María Inés y Florencia Thul

2016 "Salarios reales y niveles de bienestar en Montevideo Colonial, 17601810". En: VI Jornadas Académicas Facultad de Ciencias Económicas y de Administración. Montevideo, 8, 19 y 20 de octubre de 2016. 
Universidad de la República. Disponible en: http://pueblosynumeros.fcs. edu.uy/images/stories/moraes\%20y\%20thul_versin $\% 20$ completa\%20 jfcea_\%202016v2.pdf (fecha de consulta: 4 de abril de 2018).

Morán, Daniel y María Aguirre

2013 La plebe en armas. La participación popular en las guerras de independencia. Lima: Universidad Peruana Simón Bolívar.

O'Phelan Godoy, Scarlett

1987 "'El mito de la "independencia concedida'. Los programas políticos del siglo XVIII y del temprano XIX en el Perú y el Alto Perú, 17301814”. En: Alberto Flores Galindo (comp.), Independencia y revolución, volumen II. Lima: INC.

Paris Martin, Álvaro

2017 "Los voluntarios realistas de Madrid: politización popular y violencia contrarrevolucionaria”. En: Pedro Rújula y Francisco Ramón Solans (eds.), El desafío de la revolución. Reaccionarios, antiliberales y contrarrevolucionarios (siglos XVIII y XIX). Granada, Espańa: Comares.

Pivel Devoto, Juan

1962 "La Junta Montevideana de 1808”. En: Revista Histórica, tomo XXXIII. 371-902.

Pollero, Raquel

2013 "Historia demográfica de Montevideo y su campaña (1757-1860)." Tesis doctoral. Facultad de Ciencias Sociales, Universidad de la República, Montevideo. Disponible en: pueblosynumeros.fcs.edu.uy/ images/stories/raquel-pollero-historia-demografica-de-montevideo.pdf (fecha de consulta: 27 de noviembre de 2017).

(RAGA) Revista del Archivo General Administrativo

1917, 1919, 1934 Revista del Archivo General Administrativo o Colección de documentos para servir al estudio de la Historia de la República Oriental del Uruguay. Tomos 6, 9 y 12. Montevideo: Imprenta Dornaleche.

Revel, Jacques

2005 Un momento historiográfico: Trece ensayos de historia social. Buenos Aires: Manantial.

Ribeiro, Ana

2013 Los muy fieles. Leales a la Corona en el proceso revolucionario rioplatense. Montevideo/Asunción, 1810-1820. Dos volúmenes. Montevideo: Planeta. 
Romero, Luis Alberto

1997 "Los sectores populares como sujetos históricos". En: Última Década, número $7.1-12$.

Rudé, Georges

1971 La multitud en la Historia. Los disturbios populares en Francia e Inglaterra, 1730-1848. Buenos Aires: Siglo XXI.

Rújula, Pedro

2011 "La densificación del universo político popular durante la guerra de independencia”. En: Pedro Rújula y Jordi Canal (eds.), Guerra de Ideas. Politica y cultura en la España de la Guerra de Independencia. Zaragoza, España: Marcial Pons Historia.

Sala, Lucía; Nelson de la Torre y Julio Rodríguez

1987 Artigas y su revolución agraria 1811-1820. México D. F.: Siglo XXI.

Serulnikov, Sergio

2013 "Nuevas formas de hacer política: los sectores plebeyos urbanos y la debacle de la sociedad de indias en el Alto Perú". En: Raúl Fradkin y Gabriel Di Meglio (comps.), Hacer política. La participación popular en el siglo XIX rioplatense. Buenos Aires: Prometeo.

2009 "Crisis de una sociedad colonial. Identidades colectivas y representación política en la ciudad de Charcas (siglo XVIII)". En: Desarrollo Económico, número 192. 439-469.

Soboul, Albert

1987 Los sans-culottes. Movimiento popular y gobierno revolucionario. Madrid: Alianza.

Thompson, Edward

1995 Costumbres en común. Barcelona: Grijalbo.

Thul, Florencia

2015 "Relaciones laborales en el sector de la construcción en el Montevideo tardo-colonial. La construcción de las fortificaciones y de la Iglesia Matriz, 1760-1808". Ponencia presentada en las 6. ${ }^{\text {tas }}$ Jornadas Uruguayas de Historia Económica, AUDHE, Montevideo. Disponible en: http:// www.audhe.org.uy/sextas-jornadas-de-investigacion-2015.html (fecha de consulta: 22 de febrero de 2016).

Tilly, Charles

2002 "Repertorios de acción contestataria en Gran Bretaña: 1758-1834". En: Mark Traugott (comp.), Protesta social. Repertorios y ciclos de la acción colectiva. Barcelona: Editorial Hacer. 
470 | Trabajos y trabajadores en América Latina (siglos XVI-XXI)

Van Young, Eric

2010 La otra rebelión. La lucha por la independencia de México, 1810-1821. México: Fondo de Cultura Económica.

Vilar, Pierre

1982 Hidalgos, amotinados y guerrilleros. Pueblo y poderes en la historia de España. Barcelona: Crítica.

Zás, José Encarnación de

1951 “Memoria autobiográfica de José Encarnación de Zás”. En: Revista Histórica, año XLV (segunda época), tomo XVII, números 49-50. 121-173. 


\title{
Los trabajadores petroleros en el enclave de la Tropical Oil Company: formación, cultura y resistencia (1920-1948)
}

\author{
Renán Vega Cantor (Colombia)* \\ Luz Ángela Núńez Espinel (Colombia)**
}

REsUmen: Este trabajo reconstruye la historia de los trabajadores petroleros de la Tropical Oil Company en la zona del Magdalena Medio (Colombia), durante el periodo 1920-1948. En primer lugar, se examinan las características del enclave que se proyectó en el Puerto de Barrancabermeja desde la implantación de la empresa petrolera, destacando la segmentación espacial y socioeconómica que se produjo en la región entre la urbe estadounidense y el poblado colombiano. Esas características son fundamentales a la hora de explicar las luchas y resistencias de los trabajadores. En segundo lugar, se analiza la formación histórica de los trabajadores petroleros, evidenciando sus diversos orígenes geográficos y culturales, para explicar cómo las particularidades sociales y culturales de esa primera generación de trabajadores va a moldear sus luchas durante todo el siglo XX. En tercer lugar, se estudia la configuración de comunidades obreras cosmopolitas, el telón de fondo de la radicalidad social de los petroleros, y las formas particulares que asumió la ideología de la protesta obrera. Finalmente, se relacionan estos tres aspectos con las luchas de los petroleros en el periodo propuesto, destacando los procesos de resistencia a la proletarización, así como las huelgas, y culminando con la experiencia de la Comuna Popular de 1948 en el puerto de Barrancabermeja.

PalABRAS CLAVE: enclaves; movimiento obrero; trabajadores petroleros; sindicatos; Colombia.

* Doctor por la Universidad de París 8. Universidad Pedagógica Nacional (UPN), Colombia. Contacto: colombia_carajo@hotmail.com

** Doctora en Historia por la Universidad de los Andes, Colombia. Pontificia Universidad Javeriana (PUJ), Colombia. Contacto: luanesp@yahoo.es 
INTRODUCCIÓN

\begin{abstract}
El Obrerismo colombiano asesinado y robado por los amos de Wall Street conoce ya de sobra lo que son las leyes, pues ya principia el cortejo de nuestros compañeros siendo reducidos a prisión y enviados a las cárceles por haberse salvado milagrosamente de la bala de los pretorianos a sueldo de la Tropical Oil Company.

Declaración de La Unión Obrera de Barrancabermeja, con motivo de represión de la huelga petrolera de enero de 1927, 24 de enero de 1927.
\end{abstract}

Los trabajadores petroleros conformaron la columna vertebral del movimiento obrero colombiano durante el siglo XX por su nivel de organización, radicalidad y liderazgo. Por su importancia, este tema ha dado lugar a un significativo volumen de bibliografía; no obstante, muchos estudios se limitan a aspectos particulares y se carece de análisis integradores que permitan comprender tanto la complejidad de los procesos, como su dinámica de cambio temporal. Con el propósito de aportar en dicho sentido, este texto reconstruye la historia de los trabajadores petroleros de la Tropical Oil Company (Troco) en la zona del Magdalena Medio, en Colombia, en el periodo comprendido entre 1920 y 1948. Para ello, el artículo está estructurado en cuatro partes. En primer lugar, se presentan las características del enclave, fundamentales a la hora de explicar el tipo de luchas y de resistencias de los trabajadores. En segundo lugar, se hace referencia a, la formación de esos trabajadores, mostrando sus diversos orígenes geográficos y culturales. En tercer lugar, se describe la configuración de comunidades obreras cosmopolitas, el telón de fondo de la radicalidad social de los petroleros, y las formas particulares que asumió la ideología de la protesta obrera. Finalmente, se relacionan estos tres aspectos con las luchas de los petroleros, culminando con la experiencia de la Comuna Popular de 1948 en el puerto de Barrancabermeja.

\title{
LOS ENCLAVES Y LA EXPLOTACIÓN PETROLERA
}

Desde finales del siglo XIX, la expansión mundial del capitalismo industrial asumió la forma de imperialismo, consistente en dominar y controlar territorios extranjeros a partir de criterios claramente económicos: contar con reservas de materias primas para el desarrollo de los principales renglones de la actividad capitalista (caucho, minerales, maderas, petróleo, entre otras); establecer zonas de influencia geopolítica y geoeconómica para la exportación de capitales en forma de inversiones directas o de préstamos financieros; 
disponer de reservas de fuerza de trabajo abundante y barata para reducir costos en la producción de mercancías estratégicas en la competencia capitalista mundial; imponer en las zonas periféricas el consumo de mercancías producidas en los centros capitalistas, para contribuir a obtener las ganancias de la producción industrial en condiciones favorables para las potencias.

Estas características de la dominación imperialista se materializan en un tipo particular de relación entre grandes empresas de los países dominantes a nivel mundial (Estados Unidos, Francia e Inglaterra, entre los principales) y los países dependientes y periféricos, relación que queda plasmada en la imposición de los enclaves. Esa relación se caracteriza porque una determinada compañía extranjera vinculada a las potencias mundiales se implanta en una franja territorial de un país periférico, con la finalidad de apropiarse de un recurso natural, explotarlo y trasladarlo a su país de origen, sin que esa actividad tenga un impacto real y duradero, de naturaleza positiva, sobre el país donde se ha establecido el enclave.

Los enclaves suelen definirse con la apropiada metáfora de que son "estados dentro del Estado", para referirse a que una compañía extranjera controla un vasto territorio en otro país, mediante la figura jurídica de las concesiones. El Estado local le cede tanto territorialidad como soberanía, para que la empresa desarrolle su actividad sin que eso redunde en el desarrollo del mercado nacional. Para ello, el enclave dispone de una "infraestructura de fuga"; es decir, comunica la zona donde está el recurso con los ríos, los mares y los puertos que permiten transportar el producto hacia el mercado mundial. Para los países dependientes, los enclaves tienen consecuencias negativas por el deterioro ambiental, la destrucción de ecosistemas, la contaminación y la explotación intensiva de los trabajadores locales, así como por la represión y la discriminación por parte de las compañías extranjeras. Algunos de los enclaves más tristemente célebres en la historia de América Latina entre 1870 y 1945 se desarrollaron alrededor del banano, el petróleo, el estaño, el cobre y el salitre.

La explotación petrolera en Colombia comenzó hace un siglo, y desde un principio fue evidente el control del capital transnacional sobre los hidrocarburos, aunque se recurrió a testaferros nacidos en Colombia para facilitar el proceso legal. Eso sucedió con las dos concesiones más importantes del país en la primera mitad del siglo XX: la Concesión de Mares, situada en la región del Magdalena Medio, y la Concesión Barco, ubicada en la zona de El Catatumbo, en el límite con Venezuela. En el primer caso, la beneficiaria fue la Standard Oil Company, de Rockefeller, aunque se presentó con el nombre de Tropical Oil Company, mientras que la Concesión Barco fue controlada por las compañías South American Gulf Oil (Sagot) y Colombian Petroleum Company (Colpet), donde tenía intereses el multimillonario Andrew Mellon. 
A la hora de iniciar la explotación de petróleo, las empresas mencionadas establecieron sendos enclaves, cuyas características determinaron la configuración de la industria petrolera en el país. Por su importancia espacial y social, nos centramos en el caso de Barrancabermeja, ejemplo de una economía de enclave.

\section{Aspectos demográficos y espaciales}

Antes de la implantación del enclave, Barrancabermeja era un pequeño caserío ubicado a orillas del río Magdalena, habitado por pescadores, campesinos y hacheros. Era un sitio de paso por el que circulaban, en pequeñas embarcaciones, cantidades exiguas de madera, tagua, caucho y quina. Se accedía por vía terrestre, utilizando caminos de herradura diseñados según el ritmo lento, pero seguro, de las recuas de mulas.

El pequeño puerto tenía 415 habitantes en 1907, en 1919 registraba 1.450 y en 1927, en el centro, vivían unos 5.000 trabajadores y 200 estadounidenses, de un total de 12.000 habitantes (Galvis, 1997: 69, 93; Galán, 1945: 560-561). A fines de la década de 1920, Barrancabermeja tenía la mayor concentración obrera de Colombia. Por haber surgido y crecido como municipio en torno al enclave petrolero, presentaba desbalances demográficos, como lo registró el Censo de 1938: habitaban allí 15.400 personas, 9.300 de ellas en el casco municipal; la mayor parte de la población eran hombres (61\%); había muy pocos niños y personas mayores de 60 años; un $45 \%$ del total de la población estaba formada por jóvenes hombres mayores de 15 años, y había muy pocas mujeres casadas (Galvis, 1997; Galán, 1945).

Este extraño panorama demográfico era resultado de las características del enclave, puesto que la empresa ocupaba a hombres solteros y jóvenes en edad de trabajar. La explotación del petróleo escindió en términos espaciales el trabajo entre la fase de extracción y la de procesamiento, lo que originó una segmentación social y una división sexual de tipo territorial. En el centro, en Infantas, y en los campamentos de los pozos, la población era masculina y soltera, y en Barrancabermeja habitaban las mujeres.

El eje de la vida social, económica y cultural de la zona de enclave era la extracción, el procesamiento y el transporte de petróleo. En torno a estas actividades se diseñó su estructura espacial: la mayor pieza urbana era Barrancabermeja. que se complementaba con los sitios de extracción de crudo (los pozos) y de acopio y transformación de petróleo (la refinería). Los empleados de la Troco trabajaban en ambos lugares, separados por unos 30 kilómetros. Esta organización espacial originó "un movimiento humano laboral, pendular y diario", entre los lugares de extracción de Infantas-El Centro y los sitios de procesamiento en el puerto de Barrancabermeja (Aprile-Gniset, 1997: 147-148). 


\section{Prostitución y sociedad de enclave}

Desde finales de la década de 1910, en el enclave se generó una política familiar de tipo discriminatorio: a los obreros se los aislaba en campamentos, donde estaba "prohibida la asistencia de mujeres y el uso de alcohol" (AGN, MME, TOC, CM, 1919: 240-241), mientras que los estadounidenses llegaban con sus familias y podían viajar a su país cuando quisieran. Esta situación llegaba al punto de que las mujeres de los funcionarios de la compañía eran llevadas a su país de origen cuando iban a tener un hijo, para que allí ocurriera el parto, y unos meses más tarde retornaban a sus lujosas casas californianas, construidas al lado de la Barrancabermeja pobre y miserable (Álvarez, 1983: 181).

Al puerto llegaron mujeres de varias regiones del país, e incluso de otros lugares del mundo, atraídas por la leyenda del "oro negro", y desempeñaron diferentes oficios fundamentales para el funcionamiento del enclave: lavanderas, cocineras o fritangueras, aunque su trabajo no fuera reconocido y desde el principio debieran cargar con el estigma de "prostitutas". En efecto, la prostitución era una actividad económica importante en Barrancabermeja, sobre la cual recaía la doble moral de la sociedad, que seńalaba a las mujeres solas (sin importar su oficio), pero no cuestionaba los réditos económicos que producía. Basta señalar que el funcionamiento de hoteles, bares y prostíbulos proporcionaba ingresos fiscales al municipio que eran tan significativos como los de las regalías del petróleo. Por ejemplo, en 1926, las rentas producidas por la prostitución equivalían al 50\% de las regalías (Álvarez, 1983: 220-221; Valbuena, 1947: 289).

La prostitución tenía implicaciones sociales y culturales. Era un espacio de distensión para los trabajadores, que llegaban los sábados al comenzar la noche, luego de haber permanecido durante seis días de la semana en los campamentos sin disfrutar de la compañía de sus familias. Mientras las veladas amatorias de los trabajadores no generaron problemas sanitarios, ni laborales, la Troco no se preocupó del asunto. Si la juerga ayudaba a mantener a los obreros alejados de la lucha sindical y política, mucho mejor. Pero cuando aparecieron la sífilis y las enfermedades venéreas, la compañía se alarmó por los gastos sanitarios en que incurría y por las consecuencias laborales que eso podría originar.

La prostitución generó costumbres muy particulares entre los trabajadores que, con el tiempo, se convirtieron en mecanismos de identificación del puerto petrolero. Los sábados por la noche Barrancabermeja se transformaba tras la llegada de los "peludos", con lo cual aumentaba la circulación monetaria y se reactivaba la vida nocturna de la localidad.

Se había instalado un engranaje de diversión para que los trabajadores gastaran la mayor parte de sus salarios en las 24 horas que permanecían en el 
pueblo, entre el sábado y el domingo. Los obreros eran clientes del negocio de la prostitución, lo que generó una apreciación paradójica acerca de la misma: era, a la vez, la expresión de la degradación moral, el pecado y las malas costumbres, pero era la fuente esencial de la vida económica del municipio. De ahí que se esperara a los trabajadores los sábados con un sentimiento contradictorio de ansiedad y temor. Alguien afirmó que Barrancabermeja era "un burdel con alcalde y cura", lo que espacialmente era cierto, pues la iglesia estaba en medio de los prostíbulos (Aprile-Gniset, 1997: 216).

\section{Segmentación socioespacial}

Al ritmo vertiginoso del capital, con su aceleración del tiempo y su contracción del espacio, se transformaron la vida de hombres y mujeres, como también los paisajes naturales. Se desmontó selva, se abrieron trochas, se talaron árboles para construir campamentos y viviendas, se perforaron pozos, se construyeron carreteras y tramos férreos, se empalmaron líneas telegráficas y telefónicas, se erigieron cercas y mallas metálicas, y se construyeron oleoductos. Eso era inusitado para el tiempo y el espacio agrícola y precapitalista predominante hasta entonces. Lo que no fuera funcional a ese ruidoso capitalismo, tanto desde el punto de vista humano como espacial, tenía que desaparecer.

La represión ocupaba un puesto central y singular en ese dispositivo espacial. En la década de 1920 se articularon tres cuarteles policiales (nacional, departamental y local) y, a continuación, un cuartel militar. Esos espacios estaban subordinados a la actividad central del enclave, para que la fuerza policial velara por su adecuado funcionamiento y mediante el control militar se mantuviera a la población a raya y sometida a las nuevas imposiciones sociales y económicas. Era tan importante la Policía para la empresa que esta le proporcionó las habitaciones para que se albergaran los primeros contingentes y le adecuó un local como sede del telégrafo. ${ }^{1}$

En términos espaciales, se configuraron dos hábitats urbanos antagónicos. Por un lado, la ciudad de la Troco, donde se erigieron viviendas típicas de algunos lugares de Estados Unidos, con construcciones amplias y aireadas, con hospital y servicios públicos adecuados. Este era el llamado barrio Staff, donde vivían los técnicos y administradores extranjeros. Por otro lado, los barrios y campamentos donde habitaban los trabajadores, caracterizados por condiciones arquitectónicas, higiénicas y sanitarias deficientes.

La segregación espacial entre la "Barranca estadounidense" y la "Barranca colombiana" se mantenía mediante un elemento material y simbólico contundente: una alambrada que impedía el paso de los colombianos hacia 
donde estaba la Troco. Las dos ciudades no solo eran distintas, sino que entre ambas, a manera de protección y de segregación, se instaló un colchón de seguridad, conformado por celadores de la compañía y por la Policía Nacional, que tenía la misión de proteger a la compañía y de controlar la vía de acceso a las instalaciones de la Troco. Por ello, para los lugareños la malla metálica era la "frontera" que separaba a Colombia de Gringolandia (Buenahora, 1997: 30), brindando seguridad a los residentes extranjeros y sirviendo como mecanismo de control y de confinamiento para los colombianos.

La separación espacial entre los estadounidenses y los colombianos evidenciaba la segregación social que caracterizaba el enclave. Por tal razón, no se la puede considerar como una situación particular, sino como una lógica que permeaba todas las actividades. Uno de los ejemplos más representativos al respecto era el ferrocarril de la Troco, que tenía dispuesto un vagón especial -con todas las comodidades- para los estadounidenses; otro para los oficinistas, los capataces y sus familias; un tercero para los obreros casados; y, el último, para los obreros solteros que viajaban en "cuarta categoría", en vagones destartalados y sin asientos, en los que se amontonaban al lado de los materiales de construcción.

\section{FORMACIÓN DE LOS TRABAJADORES PETROLEROS}

Los primeros trabajadores eran de origen campesino; habían sido pequeños colonos, minifundistas o pescadores antes de engancharse en la compañía. En términos étnicos, sobresalieron las influencias afrocampesinas de las sabanas de Bolívar, Sucre y Córdoba, aunque también llegaron trabajadores provenientes de las empobrecidas montañas antioqueñas, de las zonas circundantes de Santander y de otros lugares del interior del país. En términos de sus trayectorias familiares, conformaron la primera generación de obreros, pero esta situación también se podía aplicar a todo el país, puesto que el trabajo asalariado en actividades industriales apenas empezaba a despegar en Colombia.

Del exterior llegaron trabajadores calificados de origen caribeño, conocidos como "yumecas", que habían demostrado su capacidad laboral en otros enclaves agroindustriales del Caribe y en el Canal de Panamá. Esta mano de obra tenía la ventaja adicional de hablar inglés, por lo que ocupaba un lugar privilegiado en el ámbito laboral. Los yumecas fueron considerados por los trabajadores colombianos como parte de la élite de la empresa, la que los incorporó como personal fijo y los "alojó" en instalaciones muy superiores a los campamentos miserables y desvencijados en los que aquellos residían. En consecuencia, no hubo integración laboral ni social entre ambas poblaciones obreras; por el contrario, su convivencia conflictiva tendió a reforzar la segregación y el conflicto. 
El naciente proletariado petrolero se desempeñaba en disímiles actividades, empezando por las relativas a la extracción y al procesamiento del crudo (perforación y sondeo de los pozos), que en un comienzo eran realizadas por trabajadores calificados de Estados Unidos o por algunos yumecas, y más adelante por obreros nacionales. El desmonte de selva, la construcción de carreteras, tramos férreos, instalaciones de la compañía y campamentos, y el tendido de un oleoducto de más de 500 kilómetros hasta la costa atlántica fueron algunas de las actividades desempeñadas por los primeros trabajadores. Junto a estas se desarrollaron labores complementarias (cocinar, lavar, limpiar los campamentos y las habitaciones de la compañía), que configuraron un heterogéneo grupo de trabajadores asalariados formado por hombres vinculados a la empresa. Paralelamente, en la cabecera municipal, las mujeres, por su cuenta y riesgo, cocinaban, atendían los sitios de fritanga y limpiaban los hoteles.

\section{Fundación de la Sociedad Unión Obrera}

En vista de las condiciones laborales y de vida imperantes en el enclave, las protestas de los trabajadores no se hicieron esperar. En un principio fueron espontáneas, individuales y desorganizadas. Las quejas se referían al pésimo estado de los campamentos, a las continuas enfermedades, a la inexistencia de un hospital, a la mala calidad de la alimentación y al maltrato al que eran sometidos los trabajadores colombianos por los capataces, en su gran mayoría coterráneos. En ese contexto, en 1923 se organizó en la clandestinidad La Unión Obrera, el nombre originario de la Unión Sindical Obrera, principal sindicato de la industria petrolera que subsiste hasta la actualidad.

Su fundación se explica por razones objetivas y subjetivas que confluyeron en ese momento. Entre las primeras estaban las pésimas condiciones materiales de vida y de trabajo que soportaban los obreros. Al mismo tiempo, emergieron los factores subjetivos, que hicieron posible la constitución de una embrionaria conciencia de clase, consolidada mediante la lucha contra la explotación y la opresión, como se explica en los siguientes párrafos.

En 1918 se vivió en Colombia un momento de auge de movilización y luchas laborales, algo inédito en la historia del país. Estas expresiones de protesta tomaron un cariz más político con la fundación del Partido Socialista en Bogotá, ese mismo año. Esta organización, si bien no tenía un peso político electoral que pusiera en peligro el histórico dominio bipartidista, adquirió fuerza en las riberas del río Magdalena, donde se empezó a escuchar una prédica social que hablaba de terminar con la hegemonía conservadora.

Durante los primeros años, la Troco y las autoridades locales optaron por la represión y la persecución de cualquier intento de protesta adelantado 
en la región. Se recurría a las fuerzas policiales para expulsar a las personas que protestaban, catalogándolas como sujetos malsanos e indeseables. Así, en agosto de 1922, Martiniano Valbuena, comisario de Policía, procedió a desterrar a José Calixto Mesa por haber intentado organizar una huelga contra la Troco, "determinando la pena de expulsión por el término de seis meses del territorio santandereano adyacente a las laderas del Magdalena y sobre el cual tiene jurisdicción esta Comisaría”. ${ }^{2}$

En 1922 se presentó un cambio significativo en las condiciones de organización y de lucha de los trabajadores petroleros con la llegada a la región del líder obrero Raúl Eduardo Mahecha, con experiencia organizativa en diversos lugares del país, en especial en los puertos del río Magdalena. En septiembre de ese año, Mahecha se instaló como un inquilino más en una de las atiborradas casas de la población, ofreciendo sus servicios como abogado. Inmediatamente empezó a organizar a los campesinos y a los obreros, para lo cual fundó una tienda (similar a una cooperativa de consumo) donde se vendían a bajo costo los artículos de primera necesidad. Estos campesinos fueron afiliados a una organización que Mahecha denominó Sociedad Unión Obrera. Aunque todas estas actividades eran clandestinas, la Troco las descubrió y, valiéndose del recién llegado comisario de Policía Valbuena, decomisó los alimentos de la tienda (Valbuena, 1947: 176).

El 10 de febrero de 1923 se reunió en la clandestinidad la primera junta directiva de la Unión Obrera, a orillas de la quebrada La Putana. Para posibilitar su funcionamiento, se aprobó una cuota de diez centavos por afiliado, que empezó a ser cancelada por una importante cantidad de trabajadores, a pesar de que representaba un gran porcentaje de su salario. En 1923, el sindicato ya contaba con más de 400 colonos y 1.500 afiliados, y un año más tarde tenía 3.000 afiliados (El Espectador, 1924). Esta organización dirigió las luchas obreras del periodo, entre las que se destacan las huelgas de 1924, 1927, 1935 y 1938, y, lo que es más significativo, tuvo un lugar destacado en la configuración de una cultura obrera radical en el valle medio del Magdalena.

\section{COMUNIDADES OBRERAS COSMOPOLITAS}

Los enclaves se mantenían aislados de los centros de la economía nacional, donde también se ubicaban las instituciones tradicionales de control social, lo cual tendría efectos importantes en la construcción de lazos de solidaridad entre los trabajadores petroleros, pues al compartir rutinas laborales y de ocio, en territorios apartados, conformarían comunidades obreras con fuertes niveles de cohesión social. Las comunidades obreras son grupos estructurados

2 AGN, FMG, S. 4, T. 156: 493. 
a partir del compañerismo generado por actividades laborales y cotidianas compartidas: similares condiciones de trabajo, vivienda, alimentación, hábitos de vida, diversiones, privaciones materiales, aspiraciones sociales, comportamientos sexuales... En términos generales, se trataba de comunidades "en el sentido objetivo de que estaban compuestas por personas que compartían la experiencia común de vender su fuerza de trabajo a capitalistas que no pertenecían a la comunidad" (Rule, 1990: 227-244).

Además de la venta de su fuerza de trabajo, de la opresión política y de la miseria, los obreros petroleros compartían otros elementos que reforzaban su identidad comunitaria. Esta identidad era producto de una conciencia adquirida sobre las situaciones de subordinación y de explotación experimentadas colectivamente, y de prácticas culturales generadas a partir de tales circunstancias materiales. Esto fomentaba aspiraciones sociales compartidas que, al estar en contra de los intereses de otras clases sociales, contribuían a reforzar la cohesión comunitaria y la conciencia de pertenecer a una clase social distinta.

El aislamiento en el que vivieron estos trabajadores en las zonas selváticas era relativo. Pese a que debían internarse por tiempos prolongados en los campos de explotación, allí mismo y en los alrededores confluían personas de diversas procedencias. En esas condiciones, se conformaron comunidades obreras cosmopolitas en los campos de explotación petrolera. Concebimos el cosmopolitismo como una situación de apertura mental, generada por la interacción de múltiples agentes y actores sociales con identidades culturales diversas en un mismo lugar, donde la heterogeneidad social posibilita el enriquecimiento cultural y la recepción de nuevas ideas y la recreación de variadas pautas de comportamiento.

Este cosmopolitismo facilitaría al obrero una comprensión más profunda y ampliada del mundo, que se vería reflejada en el quiebre de mentalidades que antes se hallaban confinadas en el localismo aldeano o parroquial. Desde una perspectiva política, el cosmopolitismo influyó en que los obreros tuvieran una visión más compleja de las relaciones sociales, ya que les permitía una mejor compresión del poder y los ayudaba a diseñar formas novedosas para confrontarlo.

Por su antigüedad y su mayor cantidad, los trabajadores de la Concesión de Mares tenían más experiencia social y política acumulada a mediados de la década de 1940. Su comunidad obrera era la más cohesionada, la mejor organizada y la que ofrecía ejemplos a seguir para sus similares de otras empresas. Esto ayuda a explicar el liderazgo político que ejercía la Unión Sindical Obrera entre las demás organizaciones de base de las compañías petroleras, pero también el papel de la Troco como modelo de acción para las otras empresas en su trato con el Estado y con los trabajadores. 
Los trabajadores petroleros, al emigrar de sus pueblos de origen y encontrarse con gentes de otras partes, tenían oportunidades de adquirir una imagen más global sobre el significado de ser colombiano; es decir, sobre la idea de nación. Esto no excluía que la coincidencia de grupos con identidades regionales distintas se prestara a choques culturales. Lo ocurrido en la huelga de 1938, cuando se agitaron supuestas diferencias entre costeńos y santandereanos para debilitar el movimiento, muestra que el regionalismo podía ser utilizado para dividir al obrerismo.

La existencia de expresiones regionalistas implicaba que los obreros reconocían personas con identidades culturales distintas a las de sus lugares de origen. Esto en sí mismo se prestaba para adquirir una visión más amplia del país, pues solo viendo las partes que componían el conjunto nacional se podía tener una mejor idea del mismo. Para personas que en su mayoría no habían ido a la escuela o no tenían facilidades para moverse de un lugar a otro del país, tal convivencia sería decisiva en el proceso de adquirir una noción ampliada sobre la colombianidad, porque las características de la industria petrolera propiciaban que entre los trabajadores primara la identidad nacional por sobre la regional.

Que las empresas fueran de capital extranjero, y sus directivas también, tenía consecuencias en el reforzamiento de la identidad nacional. Tal situación hacía que la distancia que separa a un obrero de su patrón adquiriera rasgos políticos en estas zonas de enclave, puesto que era fácil para cualquier trabajador identificar el imperialismo con aquel patrón rubio que, además de tener costumbres distintas, hablaba en otro idioma.

\section{Comunidades obreras y patriarcado}

Antes de finalizar la década de 1940, los obreros petroleros habían logrado formar una identidad comunitaria y otra de clase, como resultado de la vida que compartían en los campos de explotación petrolera. La mayor concentración de trabajadores estaba en el valle medio del río Magdalena, en las tres grandes concesiones de explotación, plenamente activas. Por orden de tamaño y antigüedad eran: la Concesión de Mares, administrada por la Troco desde 1916; la Concesión Barco, manejada por Colpet desde 1931; y la Concesión Yondó, controlada por el Grupo Shell a partir de 1938. Lo que distingue a los enclaves petroleros y a la población barranqueña ha sido el aporte de los lazos comunitarios tejidos por los obreros en los campos de explotación. Allí surgió la solidaridad obrera, generada en el ámbito del trabajo, y luego se trasladó a la ciudad, configurando comunidades obreras radicales muy cohesionadas.

A mediados del decenio de 1940 el número de obreros era alrededor de 8.000 y el personal total se acercaba a 15.000. En 1947 se registró la 
mayor cantidad de personal, con 17.857, de los cuales 8.442 eran obreros. Ese mismo año se realizó el Primer Censo Sindical, que registró 7.878 obreros sindicalizados en el área de la industria del petróleo, con una tasa de sindicalización superior al 90\%. Este era un porcentaje sorprendente, pues para 1947 la tasa general de sindicalización en el país apenas alcanzaba el 5\% (Archila, 1991: 359). Es decir que los obreros de la industria petrolera evidenciaban un nivel de organización que contrastaba con el promedio general del país. Esa situación se debía al tipo de conciencia de clase que expresaban estos trabajadores y a la cohesión comunitaria que habían logrado para entonces, lo cual se evidenciaba, por ejemplo, en el uso del lenguaje, porque el trabajador que no se afiliara al sindicato "o estaba desindicalizado se le llamaba esquirol” (entrevista a Aranda, 1982).

La alta tasa de sindicalización de los trabajadores petroleros se debía, probablemente, a la madurez política que habían alcanzado. Era tan difundida la idea de sindicalizarse que se daban casos de pequeños gremios, como el Sindicato de Trabajadoras del Servicio Doméstico de El Centro, con 61 afiliadas, todas del sexo femenino (Contraloría General de la República, 1947: 66).

Se podría pensar que no visibilizar el trabajo femenino en este sector industrial era consecuencia del reducido número de mujeres, pero esto no parece tener tanto peso como el machismo de los obreros petroleros. Aparte de las características propias de la cultura colombiana, el machismo de los petroleros se reforzó por las rudas condiciones a los que estaban sometidos en los campos de explotación, donde todos eran hombres que vivían hacinados y aislados del resto de la sociedad. Esto originó unas pautas de comportamiento regidas por normas donde no bastaba ser hombre, sino que había que demostrar la hombría constantemente. Una consecuencia del machismo de los petroleros ha sido la marginación política femenina del movimiento sindical, lo que se suma al escaso número de trabajadoras contratadas por las compañías.

\section{LA CIRCULACIÓN CULTURAL EN LAS COMUNIDADES OBRERAS}

Aparte de las diversas experiencias colectivas que tuvieron los trabajadores petroleros en su vida cotidiana y laboral para ir formando sus identidades comunitarias y de clase, también contaron, en lo ideológico, con la experiencia política adquirida en los conflictos que sostuvieron contra sus patrones y contra el Gobierno. Un tercer elemento contribuyó a definir la identidad política de estos trabajadores: el contacto cultural con intelectuales que, por su activismo político, se vinculaban con ellos.

No es que a los trabajadores petroleros les hay venido la conciencia de clase desde afuera, sino que, en virtud de las relaciones que trabaron con intelectuales 
identificados a nivel ideológico con sus luchas, aquellos ampliaron sus perspectivas políticas y culturales. Esto se aprecia en el interés que los trabajadores demostraron en que el líder sindical mexicano Vicente Lombardo Toledano fuera a visitarlos a Barrancabermeja, en 1943, o al recibimiento que brindaron al poeta cubano Nicolás Guillén en su visita a la ciudad y en los recitales que ofreció en la Shell y en El Centro (Guillén, 1997: 282).

Durante la primera parte del siglo XX entraron en contacto con los trabajadores petroleros líderes sindicales, políticos e intelectuales de izquierda, algunos de los cuales estuvieron de paso, ofreciendo conferencias o charlas, otros acompañaron a los obreros de una manera más prolongada, participando en huelgas y eventos que generaban intercambios culturales y políticos (como editar periódicos o dar arengas en plazas públicas).

Los intelectuales cercanos a los trabajadores petroleros tuvieron oportunidad de aprender de ellos. Una prueba es la trayectoria ideológica de Gonzalo Buenahora. Si no se hubiera vinculado a las luchas de los trabajadores de la Unión Sindical Obrera, le hubiera resultado muy difícil escribir sobre los obreros de Barrancabermeja y, mucho menos, asumir la perspectiva radical que contenían sus interpretaciones sociales. Estos obreros enfrentados a las empresas petroleras ejercían una especial atracción sobre los intelectuales, quienes se vieron estimulados para desplegar sus ideas entre los pobladores de Barrancabermeja porque "esta articulación entre el mundo del saber 'científico' encarnada por los intelectuales, y el mundo del saber 'empírico' popular, constituye un excelente ejemplo de la circulación cultural” (Archila, 1991: 156).

'Circulación cultural' es una noción que permite comprender el intercambio de ideas entre obreros e intelectuales, o entre la cultura de las clases subalternas y la cultura de las clases dominantes. En la dicotomía entre cultura popular y cultura de élite no hay una adaptación pasiva por parte de los sectores populares en el sentido en que se entiende la aculturación. Tienden a presentarse influencias recíprocas, de convergencias de ideas, a lo que se llamaría circulación cultural (Ginzburg, 1986: 20-21). En lo concerniente a la relación entre obreros e intelectuales, portadores de una cultura de élite, la circulación cultural se presentaba con mayor fluidez, dadas las identificaciones políticas de estos intelectuales con las luchas de los obreros.

\section{Entre la risa y la tragedia}

Las iniquidades vividas en las zonas de concesión generaban malestar entre los trabajadores, y ayudaron a afianzar sus lazos comunitarios y su conciencia de clase, identidades que no se excluían, sino que se reforzaban 
de manera recíproca. Las cuadrillas de trabajo generaban grupos informales de amigos que tenían su expresión cotidiana en la camaradería, en la tomadura de pelo o en la "mamadera de gallo", así como en colocar el remoquete adecuado a un compañero desprevenido. Así, la integración producida por los grupos de amigos constituidos en los campos de trabajo era tan importante para madurar la comunidad obrera y la conciencia proletaria, como los conflictos surgidos con las empresas por las condiciones de trabajo.

Es difícil imaginar la felicidad que estos obreros sentían al salir del encierro de seis días que implicaban las duras jornadas de trabajo en los campos de explotación. Para los que estaban casados, era la posibilidad de ver a la familia; para los solteros, la ocasión de encontrarse con la amiga del bar o de sentarse a tomar un trago con compañeros que laboraban en pozos distantes a los suyos. El trabajo en campamentos aislados, a pleno sol y con $37^{\circ} \mathrm{C}$ de temperatura, era recompensado el sábado con la desinhibición y el jolgorio.

El sábado por la noche, cuando todo el país dormía, Barrancabermeja despertaba de su modorra semanal porque llegaban los obreros, que le daban vida al puerto tropical. Barrancabermeja se agitaba, se mostraba lujuriosa. Cualquier pescador que saliera en la noche del sábado podía escuchar desde el río los gritos desaforados de coquetas prostitutas que bailaban con velas encendidas. Con envidia en los ojos, los policías salían a patrullar y los comerciantes y proxenetas buscaban la forma de quitarles el sueldo a los obreros. Hasta los que tenían esposa buscaban la manera de escaparse para compartir en los bares con el resto de compañeros. Todos reían, se embriagaban, peleaban, escuchaban música, cantaban y bailaban.

Sin embargo, aunque en Barrancabermeja la fiesta que comenzaba el sábado en la noche se la podía considerar un simple derroche de alegría: la parranda escondía una profunda tragedia. Las primeras generaciones de obreros tuvieron que experimentar la descomposición de la familia tradicional campesina, porque se había roto el vínculo con el pueblo o la aldea de origen. A la esposa y a los hijos, de tenerlos cerca, solo era posible verlos los fines de semana. Con todo, la situación de los obreros sin familia era peor: al salir de los campos de explotación se estrellaban con el vacío, pues aparte de las muchachas del bar no tenían a nadie que los esperara.

Esa situación originó la nueva familia obrera. Pero antes de que surgiera plenamente, los trabajadores petroleros debieron padecer un deterioro en sus relaciones afectivas, porque en la medida en que las condiciones de trabajo limitaban las posibilidades de expresar el amor filial, el trato cotidiano tendía a tornarse más brusco, machista y soez en el lenguaje. Así, el noviazgo pueblerino había sido reemplazado por una sexualidad brutalizada, en la que el amor a primera vista no tenía cabida, pues cada momento de afecto había 
que pagarlo a una mujer que, por su miseria, comerciaba con el cuerpo (entrevista a Morón, 1982).

Este romanticismo obrero, que parece trágico y cursi a la vez, era una expresión dramática del dolor exacerbado, producto del quiebre de los afectos familiares y de la desaparición de las relaciones sentimentales de tipo tradicional. Pelear a muerte por sacar a bailar a una mujer no solo debía ser entendido como una competencia por la virilidad ( $\tan$ posible en un mundo compuesto en su mayoría por hombres sometidos a bruscas formas de vida y de trabajo), sino que expresaba una búsqueda de afecto, tan desesperada que no medía consecuencias, ni lo fugaz de un cariño que, en todo caso, debía pagarse en dinero.

Estos trabajadores estaban sumergiéndose en una vida mercantilizada, rutinaria, donde el tiempo se había vuelto oro. La racionalidad del lucro y los valores utilitaristas presionaban por imponer sus normas de conducta, acentuando el individualismo y la competencia por obtener más dinero. Aunque el trabajo no era bien remunerado y existía malestar por la vida perdida, el incentivo era ganar más dinero que antes o, por lo menos, tener la seguridad de que en determinada fecha se recibiría un sueldo. Mientras muchos regresaban a sus pueblos al no soportar las duras condiciones del trabajo, la mayoría aguardaba esperando ahorrar lo suficiente para largarse un buen día y comprar una parcela en la tierra de sus padres. Con un sueldo insuficiente y con escasa mentalidad para el ahorro (pues gran parte se gastaba en las fiestas del fin de semana), la mayoría de los trabajadores se estableció en los municipios cercanos a los campos petroleros. Algunos formaron sus familias con prostitutas, otros fueron trayendo a la novia o a la esposa y a los hijos que habían dejado en sus pueblos de origen.

\section{Experiencias de lucha}

La experiencia es un componente mediador entre el ser social y la conciencia de clase, porque las experiencias vividas por los trabajadores ejercen presiones sobre la conciencia que antes tenían, trazan nuevos problemas y proporcionan "gran parte del material de base para los ejercicios intelectuales más elaborados" (Thompson, 1981: 20). Las experiencias vividas no se dan sin pensamiento o, lo que es lo mismo, todo individuo, por el solo hecho de ser racional, piensa y llega a tener una interpretación sobre lo que le sucede desde su posición en la sociedad. En breve, las experiencias producen conocimiento, lo que implica que, por más limitada que sea la educación intelectual de un obrero, las experiencias que ha tenido en el mundo material le posibilitan un discernimiento de la realidad social. Esta forma directa de acceder a un entendimiento de la realidad le permite tener una idea básica sobre el hecho de pertenecer a 
una comunidad y a una clase social. Por ello, la experiencia cumple un papel mediador entre el ser social y la conciencia de clase.

En el proceso de maduración de la conciencia de clase, son cruciales las experiencias que proporcionan los conflictos con otros grupos sociales o, mejor dicho, las experiencias que brinda la práctica política durante las luchas con otras clases sociales.

La identidad comunitaria que se generó fue estimulada y, a la vez, ayudó a fomentar la conciencia de clase, cuya formación estaba en proceso de maduración. Las mismas experiencias que llevaron a crear lazos comunitarios propiciaron una identidad de clase entre los obreros. Las experiencias vividas cotidianamente en los ámbitos de trabajo y de recreación favorecían la rápida aparición de la cohesión comunitaria. Podría incluso hablarse de una hermandad obrera, mas no era tan inmediato el proceso en lo que respecta a la conciencia de clase. Esta, para su maduración, necesitaba de las experiencias que traían las prácticas políticas generadas durante los conflictos sociales. La ideología derivada del obrero petrolero común y corriente contenía una mezcla de ideas que, a pesar de no indicar una conciencia política definida, sí revelaban rasgos anticapitalistas que podían favorecer la formación de una radical conciencia de clase.

\section{Ideología y cultura en la protesta obrera}

Por la forma espontánea en que surgió y creció el casco urbano de Barrancabermeja, la migración que se desencadenó, la mezcla cultural de diversas regiones del país y la llegada de extranjeros, se gestaron elementos culturales que entraron en pugna con los parámetros dominantes en el resto de la sociedad colombiana. Eso se manifestó en la crítica implícita a los valores religiosos, dominantes durante la Hegemonía Conservadora (periodo entre 1886 y 1930 en el que el Partido Conservador se mantuvo en el poder), que generaban sumisión, resignación, conformismo, hipocresía y mojigatería. Aunque los conservadores, a través de curas y policías, intentaron defender los elementos católicos convencionales, su esfuerzo fue fallido. Las críticas más acerbas dirigidas a Barrancabermeja y a su población la mostraban como la encarnación de las cuatro 'p': plata, puerto, petróleo y prostitutas (Barreto y Giraldo, 1998: 136).

Esos elementos culturales se constituyeron desde finales de la década de 1910 y se manifestaron en la ideología de la protesta obrera, cuyos rasgos más significativos fueron la postura antiimperialista, el nacionalismo y la dignificación del obrero.

La postura antiimperialista y el nacionalismo estaban íntimamente ligados, y se convirtieron en un eje central del horizonte mental de la protesta obrera y popular, y no solo por las cuestiones inmediatas originadas por la llegada de la 
Troco. Estaba ligado al sentimiento antiestadounidense que, en distintos sectores de la población colombiana, se configuró desde comienzos del siglo XX a raíz de los sucesos que determinaron la pérdida de Panamá en 1903.

Las luchas de los obreros adquirieron un sentido antiimperialista y nacionalista, porque en el puerto era visible la alianza entre la Troco y las autoridades colombianas. Y aunque no siempre los trabajadores pudieron captar el sentido estratégico de dicha alianza, sí entendieron que era el soporte de la explotación y la injusticia que ellos experimentaban en carne propia. En Barrancabermeja, ser obrero no era solo una cuestión laboral, sino que adquiría dimensiones políticas, dado que asumía la defensa de la nacionalidad (o de lo mejor de ella).

Sobre la dignificación del obrero y de su trabajo, se destacaba la permanente denuncia contra la humillación de la que eran víctimas los trabajadores por parte de la Troco, sus capataces nacionales y extranjeros, y la Policía. A partir de la lucha contra la discriminación, los obreros reivindicaban la dignidad del trabajo, el cual suponía el derecho a rebelarse. Por ello, se sostenía que la huelga no solo era una forma de lucha, sino una acción encaminada a reivindicar al obrero colombiano, confiriéndole dignidad ante la compañía extranjera.

Algunas de los lemas de los trabajadores de la década de 1920 expresaban ese proceso de dignificación del trabajo como generador de riqueza (Vanguardia Obrera, 1926; Germinal, 1926, [énfasis del original]):

\section{NO ME DIGAS QUE PADECES HAMBRE Y ESCLAVITUD, DIME QUÉ HACES PARA EMANCIPARTE.}

OBREROS: el que no protesta de su verdugo no merece vivir en una República libre como la nuestra.

Las libertades no se piden, se toman.

La justicia no se compra ni se pide de limosna: si no existe, se hace.

TODAS las libertades que hoy disfrutamos han sido conquistadas por hombres que amaban más la libertad universal que su bienestar.

Como parte de la dignificación del obrero, sobresalió su reclamo al derecho a la lectura y al estudio. En los pliegos de peticiones de 1924 y 1938 se solicitaba a la Troco que permitiera la lectura de la prensa nacional en sus instalaciones. En medio del estricto orden del enclave, regido por la lógica capitalista de controlar el tiempo y de extraer la máxima plusvalía posible, era significativo que los trabajadores defendieran su derecho a leer la prensa, máxime cuando el analfabetismo era dominante entre la población colombiana. La lectura de la prensa se entendía como una actividad colectiva, ya que una hoja, un volante, un manifiesto, un pequeño periódico, podían circular 
profusamente de mano en mano y ser conocidos por muchos trabajadores mediante la lectura en voz alta. Tener acceso a la prensa significaba apropiarse del conocimiento para poder entender las razones por las cuales se vivía así, y esbozar formas de resistencia basadas en la comprensión de esos problemas.

\section{LUCHAS DE LOS TRABAJADORES PETROLEROS}

Desde su formación, los petroleros recurrieron a diversos mecanismos de lucha, "pasivos" y activos. Entre los primeros sobresalió la resistencia a la proletarización, con la huida del trabajo y la disminución del ritmo laboral. Entre los segundos estuvieron las huelgas y un hecho político especial: la Comuna Popular de 1948. En este último parágrafo analizamos cada uno de esos aspectos.

\section{Resistencia a la proletarización}

La matriz principal de identificación de los petroleros provenía de la alteración cultural que experimentaron al tener que asumir nuevas disciplinas laborales. Por su procedencia campesina, los trabajadores que ingresaron a las compañías petroleras debieron soportar el quiebre de sus tradiciones rurales. No fue una ruptura absoluta, sino un proceso de transición desigual en el que estuvieron involucradas las primeras generaciones de obreros, desde la década de 1920, y se evidenció, entre otros aspectos, en la resistencia a la proletarización.

La forma más visible de esa resistencia fue la colonización de tierras que algunos de ellos efectuaron en los predios de las compañías petroleras. Dados los bajos salarios y la inestabilidad laboral que padecieron hasta que lograron la firma de convenciones de trabajo, a mediados de la década de 1940, ciertos trabajadores colonizaron predios para sembrar cultivos de pan coger. En estas ocupaciones participaban obreros y campesinos sin tierra que llegaban a los territorios de concesión huyendo de la miseria de sus lugares de origen. Una de las motivaciones principales de los obreros para cultivar sus parcelas era la ilusión de obtener ingresos adicionales, aunque también tenían expectativas provenientes de su pasado campesino: la intención de controlar su propio tiempo y mantener una independencia que permitiera determinar los ritmos de trabajo y de ocio, ritmos irregulares en el mundo agrario.

La búsqueda de un vínculo con la tierra era un arma de doble filo para la cultura política del obrero petrolero. Por un lado, mantenía el sueño campesino de tener una parcela propia, lo que podía generar cierta mentalidad individualista, similar a la del campesino de minifundio, y que, en determinadas circunstancias, no favorecía el desarrollo de lazos de solidaridad obrera. Irónicamente, por otro lado, el vínculo con la tierra podía favorecer 
la nostalgia por costumbres tradicionales campesinas, de marcado tono anticapitalista, más abiertas a la recepción de utopías políticas colectivistas. Estas costumbres mantenían viva la resistencia contra la proletarización, lo que no implica que el campesinado gozara de una existencia idílica. Después de todo, los que llegaron a trabajar en las empresas petroleras venían con la esperanza de mejorar su calidad de vida.

La cultura campesina de quienes luego se hicieron obreros permitía ritmos irregulares en las labranzas del campo, más sujetos a los ciclos climáticos que al cronómetro. Los tiempos para la labranza y la recreación podían acomodarse a las necesidades del trabajador. En el momento en que quisiera, podía ver a su familia, fumarse un tabaco tirado en la hamaca, sin tener que diferenciar el sitio de trabajo y el de esparcimiento, pues ambos quedaban en la parcela. Podía dejar de asistir al culto católico y dedicar ese valioso tiempo a la próxima fiesta del pueblo, en la que, alrededor de una botella de ron, hablaría durante horas y horas con sus compadres de banca. En no pocos casos, el contacto con el patrón era directo, cara a cara, disfrazado del tramposo paternalismo que permitía a los ricos del campo bautizar al hijo de uno de sus labriegos. Pero ni siquiera ese trato directo, no horizontal, era posible en las compañías petroleras, donde el patrón era invisible, pero omnipresente para controlar la intensidad del trabajo y las horas de entrada y salida de la empresa.

En las labores del enclave, los supervisores y la sirena estridente de la compañía señalaban los momentos de entrada y de salida del trabajo, ordenando la hora de comer o cuándo y durante cuánto tiempo se podía descansar. Era un tiempo estricto, medido en dinero. Refriéndose a la nueva disciplina que experimentaban los obreros de El Catatumbo, un observador relataba: "cuando llega el momento exacto, 'norteamericano', de iniciar trabajos, quienes no se hayan desayunado tienen que trabajar sin desayuno, inapelablemente" (Bautista, 1939: 12). Evidentemente, el cambio en las pautas de trabajo y recreación supondría una alteración cultural significativa en las costumbres de estos trabajadores.

Comparar esas situaciones con la existencia anterior podía hacer odiar los ritmos de trabajo del capitalismo. La resistencia a la proletarización fue derrotada y en la década de 1940 la mayoría se asumía como obreros. Sin embargo, la nostalgia que algunos sentían por la vida antigua podía llevarlos a crear una mentalidad de desprecio al capitalismo, que era un puente fácil para acceder a ideas revolucionarias. Esa nostalgia la expresaba un trabajador que afirmaba: "La época de pescador la llevo en el alma, duerme en mi corazón” (Vinculo, 1950: 11).

El temperamento de la cultura popular costeña está relacionado con las actitudes antiseñoriales y las tendencias anticapitalistas, propias del mestizaje 
triétnico y anfibio que tuvo lugar en el caribe colombiano. Las actitudes culturales de estas poblaciones triétnicas se expresan en el comportamiento informal y descuidado de las gentes, con un predominio de las relaciones horizontales, en las que el sentido del humor es importante y el incumplimiento no es un crimen.

Aparte de ese temperamento cultural, la nostalgia por los elementos positivos de la economía familiar campesina condujo a las primeras generaciones obreras a percibir la explotación capitalista como una alteración en sus costumbres. La conciencia de saber que se estaba cediendo la independencia personal y todas las cosas que antes hacían agradable la vida llevaba a percibir la condición de explotado. Al ser esta una condición compartida, generaba el sentido de pertenecer a una comunidad. Este sentimiento comunitario era nutrido por situaciones cotidianas que se vivían de manera colectiva, pues en gran medida estaban condicionadas por las formas de explotación a las que todos estaban sometidos. Así, el inconformismo y los hábitos de vida ocasionados por la explotación, aunque propiciaban la rápida aparición de una identidad comunitaria, no necesariamente suponían el surgimiento de una identidad de clase. El común malestar por la explotación podía expresarse en muchas formas de rechazo al capitalismo que no tenían una coherencia política definida, como embriagarse hasta quedar sin un centavo, llegar borracho al trabajo, demorarse en desempeñar las tareas asignadas, armar una parcela en los terrenos de la compañía, enfrentarse "a trompadas" con uno de los supervisores de la empresa... Si bien eran actitudes sin objetivo político explicito, expresaban cierta indocilidad que podía abrir las puertas para adquirir una conciencia de clase.

\section{Huelgas}

Hasta 1948, se efectuaron seis huelgas de petroleros: en 1924, 1927, 1935, 1938, 1946 y 1948. Las dos primeras se dieron en el marco de la Hegemonía Conservadora, cuando la naciente Unión Sindical Obrera no estaba reconocida legalmente y los conflictos laborales se consideraban un asunto de orden público. En esas dos primeras huelgas, las peticiones apuntaban a solucionar los problemas más acuciantes de los trabajadores: comida adecuada, construcción de hospitales, aumento de salarios, pago doble en días feriados y reconocimiento de horas extras por trabajo nocturno, arreglo de los campamentos, retiro de funcionarios que maltrataban a los obreros y permiso para leer la prensa.

Como la labor de los petroleros era el epicentro de la vida de Barrancabermeja, desde las primeras huelgas se presentó una confluencia de intereses entre los trabajadores de la Troco y el resto de los habitantes del puerto (campesinos y colonos, comerciantes, tenderos, dueños de viviendas, 
prostitutas, etcétera), lo que le daba un carácter cívico a las protestas obreras, y era un respaldo material a los huelguistas.

Estas dos primeras huelgas fueron brutalmente reprimidas. En la de 1924, unos 1.500 obreros fueron expulsados de la región y sus principales dirigentes fueron encarcelados. En 1927, la huelga se saldó con la muerte de varios obreros. Como parte de la represión, los dirigentes del movimiento fueron apresados y torturados. Uno de ellos, que estuvo confinado en la ciudad de Tunja, afirmaría que la ley de la Troco, secundada por el Gobierno colombiano y sus Fuerzas Armadas, se resumía en un lema lacónico: "matar colombianos era igual que matar micos en la selva" (Almario, 1984: 82).

Las dos siguientes huelgas se presentaron durante la República Liberal (1930-1946), cuando se reconoció la existencia de la Unión Sindical Obrera como representante de los trabajadores petroleros y se implementaron algunas medidas legales que propiciaban la organización sindical, aunque continuaban las restricciones a las huelgas en los "servicios públicos", una noción elástica en la que cabían muchas actividades, entre ellas la extracción de crudo.

La Unión Obrera, que había sido destruida en 1927 luego de la segunda huelga, se reconstruyó en la clandestinidad para evadir los controles de la Troco. Obtuvo su reconocimiento legal en 1934 y en 1935 contaba con 1.500 afiliados. Ese año se organizó la tercera huelga, con reivindicaciones similares a las de la década de 1920, que fue declarada ilegal y que contó con una masiva participación de los habitantes del puerto. Las "muchachas del barrio" sostuvieron la huelga con sus aportes económicos y su campaña de recolección de dinero para los trabajadores (Rivera, 1984; Morón, 1982; Foronda, 1984). El Comité de Huelga expedía pasaportes, daba licencias y permisos, y en la práctica actuó como ente legislativo al expedir decretos, como los de prohibición de alcohol, control de precios para el expendio de víveres, mantenimiento del orden y la vigilancia o almacenamiento y distribución de abastos por el sistema de racionamiento. Al respecto, el corresponsal de Vanguardia Liberal comentaba en forma contundente: "Existe en este puerto un gobierno dentro de otro Gobierno" (1935). Al final, la huelga concluyó con un sabor agridulce, puesto que no se alcanzaron las reivindicaciones propuestas y la Troco expulsó a los principales dirigentes.

En 1938 se efectuó la cuarta huelga, que exigía mejoras salariales, buen trato a los obreros, establecimiento de contrato colectivo de trabajo, permiso para leer la prensa y, como algo novedoso, se incluían las demandas de las trabajadoras del servicio doméstico de El Centro y de Barrancabermeja. Esta huelga terminó sangrientamente, en medio de una represión que dejó un número indeterminado de muertos y heridos. La Unión Sindical Obrera quedó seriamente debilitada; nuevamente, tendría que reconstruirse en la clandestinidad en los años siguientes. 
En 1946, en un contexto político nuevo por el triunfo del Partido Conservador en las elecciones presidenciales, estalló otra huelga, con la particularidad de que no fue exclusivamente contra la Troco, sino que fue una huelga general contra las empresas petroleras en el país. Su principal demanda era que se fijara un nuevo estatuto laboral que regulara las relaciones entre las compañías extranjeras y los trabajadores colombianos. Para ello, se creó la Federación de Trabajadores del Petróleo (Fedepetrol), donde la Unión Sindical Obrera desempeñaba un papel importante. Esta huelga, que se cerró con una victoria para el movimiento sindical petrolero, puso sobre el tapete de la discusión la nacionalización de los hidrocarburos y mostró que los trabajadores eran los portavoces más preclaros de dicho nacionalismo, el cual se había ido construyendo durante varias décadas. Un editorial de 1946 de El Tiempo manifestó:

Tenemos la impresión de que la huelga petrolera se está desviando, de manera peligrosa e inocultable, hacia el interés político, con grave menoscabo del interés económico-social que debiera primar en sus finalidades. [...] Entre las nuevas exigencias presentadas por los trabajadores, figura la de la nacionalización de la industria petrolera, que es un tema específicamente político. Claro está, que el país debe prepararse para asumir, cuando la ocasión llegue, la explotación de sus riquezas naturales. Pero esa política no puede adoptarse de la noche a la mañana, ni improvisarse por la presión revolucionaria de una huelga.

En 1948 se produjo una de las huelgas más transcendentales no solo de la historia de la Unión Sindical Obrera, sino de la historia colombiana del siglo XX. Fue la huelga que derrotó a la Troco y que sentó las bases para la reversión de la Concesión de Mares, así como para la creación de la estatal Empresa Colombiana de Petróleos (Ecopetrol), en 1951. El revuelo público generado por esta última huelga impactó a amplios sectores de la sociedad, que empezaron a manifestarse a favor de la reversión de la concesión y de la pronta nacionalización del petróleo. Como resultado, el Gobierno se vio forzado a promulgar la Ley 165, de 27 diciembre de 1948, con la que se autorizaba a fundar una empresa colombiana de petróleos. Aunque esta no recogía en su totalidad la propuesta de nacionalización de los obreros, tenía el valor de sujetar cualquier medida posterior al concurso del Estado en la futura empresa. Esto fue lo que a la larga sucedió, pese a que, en los años siguientes, la persecución y la violencia oficial limitaron la participación de los trabajadores con su proyecto alternativo de una completa nacionalización de dicha concesión. 
En la entrada del Batallón Antiaéreo Nueva Granada de Barrancabermeja reposó durante décadas un rústico cañón de artillería fabricado en acero. Este cañón, junto a otros ocho, fue elaborado por los trabajadores de la Troco y de la Shell con el fin de defender el gobierno alternativo que surgió en Barrancabermeja tras el asesinato del líder liberal Jorge Eliécer Gaitán, el 9 de abril de 1948. Con brigadas y milicias obreras, los trabajadores petroleros sostuvieron una Junta Revolucionaria de Gobierno, que condujo durante diez días la Comuna de Barrancabermeja, experiencia de poder popular única en el país, solo comprensible si se tiene en cuenta la identidad radical que habían forjado los obreros petroleros durante la primera parte del siglo XX en sus luchas contra las compañías petroleras y las clases dominantes del país (Ortiz, 1978: 192-195; Alape, 1981, Díaz Callejas, 1989). Como en otras ciudades y pueblos, tras el asesinato de Gaitán, en Barrancabermeja la gente salió a la calle con la consigna de hacer justicia por su propia cuenta, atacó a los conservadores y exigió la caída del régimen.

Las milicias obreras fueron uno de los soportes de la Junta Revolucionaria. Por su mayoría numérica y por sus experiencias organizativas en torno a la Unión Sindical Obrera, los obreros de la Troco sobresalieron entre la multitud, pero también estuvieron presentes los que trabajaban en la Shell, en Casabe, al otro lado del río, y los que laboraban en las estaciones cercanas del oleoducto de la Andian. Esas milicias controlaron los medios de transporte y de comunicación con los que contaban las compañías. Lanchas con motor fuera de borda, vehículos automotores, el ferrocarril, buques y planchones fueron incautados y puestos a disposición del nuevo gobierno, junto con los servicios radiotelefónicos, telegráficos, de correos y de telefonía. La gasolina y otros combustibles fueron decomisados para asegurar el abastecimiento del gobierno revolucionario y de la población de Barrancabermeja. Los comisariatos de las compañías fueron vigilados y controlados para asegurar el aprovisionamiento de los rebeldes.

El gobierno revolucionario se sustentaba en tres pilares: la alcaldía, bajo la conducción de Rafael Rangel; una Junta Revolucionaria, que cumplía funciones similares a las de una asamblea municipal; y las milicias obreras. Estas tres instituciones alcanzaron tal coordinación de fuerzas que, a escala municipal, lograron desplazar las tradicionales formas de gobierno del sistema bipartidista colombiano. Ese gobierno encarnaba las aspiraciones de poder contrahegemónico, tanto de los sectores radicales de Barrancabermeja como del obrerismo petrolero. Creó de facto una democracia directa, autogestionaria y participativa. En ello influyeron las experiencias políticas de los 
obreros petroleros que, en sus prácticas sindicales, realizaban asambleas y organizaban comités de trabajo. Así como la Junta Revolucionaria fue elegida por voto popular, se administraba justicia con la participación de los propios pobladores, a través de la mediación que hacían los vecinos de la comunidad o las organizaciones sindicales existentes. Los conflictos menores, que no podían ser tratados por la Junta Revolucionaria, iban siendo resueltos por los propios habitantes, que discutían los problemas y actuaban de manera concertada. Los delitos, el robo y el hurto fueron sancionados, e incluso se creó una "oficina de objetos robados", con el fin de devolver los artículos sustraídos de los almacenes antes de que el nuevo poder empezara a actuar.

Las asambleas populares y obreras administraban los servicios públicos, como acueducto, energía y comunicaciones; los servicios de salud eran gratuitos; y la radio se puso a disposición del gobierno revolucionario. Las ollas comunitarias, de vieja usanza durante las huelgas petroleras, funcionaban para todos los habitantes, incluyendo a los conservadores y a altos empleados de las compañías. Los insumos utilizados en la cocina provenían de decomisos hechos por los trabajadores a los almacenes de víveres y a los comisariatos de sus respectivas empresas, aunque también se compraron productos agrícolas a los campesinos de la región, mediante un comité de abastecimiento creado para tal fin. El dinero con el que se compraban esos productos provenía del sistema de recaudo de impuestos que se implementó, y que gravaba a las personas con mayores ingresos: dueños de tierras, de almacenes y de otros establecimientos.

El nuevo gobierno estimulaba la participación activa del pueblo, logrando, por primera vez en la historia del país, una forma de Estado local capaz de regular las necesidades de la gente común, por medio de la autogestión, la ayuda mutua y del cobro de impuestos a los ciudadanos más pudientes. Se trataba de un régimen municipal redistributivo que buscaba que las companías petroleras se pusieran al servicio de los colombianos. Como las empresas eran controladas por los obreros, la exportación del crudo quedó suspendida, mientras se utilizaban los combustibles almacenados en la defensa y abastecimiento del gobierno local y de la población en general. Con el decomiso de cargas de explosivos en los talleres de las compañías y con las armas incautadas a las fuerzas represivas oficiales, el poder militar pasó a manos del pueblo.

Luego de una semana, el poder del Gobierno central fue restableciéndose en Bogotá y en otras ciudades y pueblos donde se dieron levantamientos populares. Pero en Barrancabermeja, gracias a la organización interna, el poder revolucionario continuaba, constituyéndose en el último bastión de resistencia en todo el país. Debido al aislamiento político de los barranqueños, las fuerzas militares amenazaron con invadir a sangre y fuego al puerto petrolero si el gobierno revolucionario no se entregaba. Para doblegar la resistencia, los 
militares lanzaron, desde avionetas, hojas volantes anunciando que tomarían por la fuerza el puerto. Pero "el ejército no pudo entrar, porque los trabajadores amenazaron con colocar dinamita, no sé cómo se supo que venía un avión con soldados, y le colocaron gasolina y dinamita al aeropuerto" (Bolaño, 1984).

Ocho días después de que la Junta Revolucionaria se rindiera entró el Ejército y encarceló a los miembros más reconocidos del levantamiento popular. Los que tuvieron mejor suerte fueron procesados en un Consejo Verbal de Guerra, muchos otros fueron encarcelados sin juicio previo y no pocos fueron asesinados por la Policía que llegó a la región, matando rojos (comunistas) y cachiporros (liberales). Ante este panorama, algunos se refugiaron en el monte y formaron una guerrilla, conducida por Rafael Rangel, que enfrentó al régimen conservador durante varios años en las tierras de Santander.

Que el cañón nueveabrileño haya ido a parar a un batallón se explica por el peligro, para las clases dominantes, de una memoria popular de resistencia, puesto que, con base en recuerdos de experiencias de lucha, los sectores populares pueden elaborar una contracultura que deslegitime el consenso impuesto por las clases dominantes para sostener su hegemonía.

Es difícil imaginar otro objeto que simbolice mejor la identidad de clase que habían alcanzado los obreros petroleros que aquel inquietante cañón de acero: un cañón utilizado para defender el poder popular que desplazó por unos días al de las clases dominantes, pero que reposa hoy en un batallón del Estado como una pieza hurtada a la memoria obrera y popular.

\section{PALABRAS FINALES}

En este ensayo se rastrearon las acciones de hombres anónimos que, con la fuerza de sus brazos, transformaron el paisaje de zonas selváticas y boscosas para que allí se instalaran los campamentos que posibilitaron la extracción de crudo y su posterior envío al mercado mundial. Las primeras generaciones de obreros petroleros soportaron duras condiciones de vida y de trabajo, y cientos de ellos dieron la vida sin que supiéramos ni sus nombres, porque para la Tropical Oil Company los seres humanos de origen nacional no tenían ningún valor, salvo como productores de riqueza material.

Desde la implantación del enclave en la zona del Magdalena Medio, se erigió un sistema despótico con los obreros colombianos, que habían acudido a ese lugar con la perspectiva de mejorar sus condiciones de vida. Estos se encontraron con una dura realidad, soportando regímenes oprobiosos de trabajo, insalubridad, enfermedades, carencias y represión. Esas mismas situaciones se repitieron durante el siglo XX en todos los lugares donde se instalaron empresas petroleras. 
Estas condiciones materiales fueron el soporte sobre el cual se erigió la lucha de los trabajadores, que fueron aprendiendo y asimilando ideas en la medida en que recibieron diversas influencias ideológicas de corte socialista y radical. En su resistencia y lucha contra las empresas extranjeras forjaron una identidad y una conciencia social, y emergió el sentimiento nacionalista que llevó a alentar luchas por la reversión de las diversas concesiones. Ese sentir nacionalista se alimentaba con la experiencia de la explotación imperialista y el saqueo de recursos naturales.

En Colombia se ha regresado a la época de las concesiones y de los enclaves, porque zonas enteras, como la de El Centro en Barrancabermeja o Tibú en El Catatumbo, han sido cedidas nuevamente a multinacionales estadounidenses y se han vendido a muy bajo costo instalaciones completas (entre ellas las refinerías) a otras empresas.

Como las empresas petroleras cuentan con la protección del Estado y/o de sus ejércitos privados de tipo paraestatal, se diseña una política de terror dentro de las zonas de explotación y en las áreas circundantes, con el fin de evitar cualquier obstáculo para la libre extracción del crudo. Eso implica, como en tiempos de los enclaves, que la inconformidad y la protesta social sean contenidas a sangre y fuego con tal de asegurar que el petróleo fluya sin interrupción hacia los centros de consumo mundial.

Los sindicatos son vistos como un obstáculo que no tiene razón de existir, salvo que sean una fachada burocrática para avalar el dominio de las multinacionales. Como consecuencia, se han perdido algunas conquistas de los trabajadores, empezando por la estabilidad laboral (ante la generalización de los contratistas) y el derecho a la organización y la protesta, y se han eliminado ciertos logros que habían obtenido los trabajadores en materia de educación, salud, recreación y cultura.

Todo esto constituye (dicho de forma lacónica) el retorno a las condiciones de lucha de la década de 1920, cuando no se permitía la organización de sindicatos, cuando había que reunirse en forma clandestina en las selvas y en las montañas de los campos petroleros, enfrentándose a poderosas compañías extranjeras que, además, contaban con el respaldo del Estado colombiano, mientras que los obreros eran sometidos a las peores formas de explotación laboral. Eso se daba, asimismo, en un ambiente de fuerte identidad nacional (que hoy se ha perdido o desdibujado), gestada durante varias décadas, porque era claro que se enfrentaba a un poder extranjero. Este hecho no ha cambiado; simplemente se camufla (lo cual hace más difícil identificar al adversario) bajo la fachada de empresas, en apariencia manejadas por funcionarios nacionales, y cuya acción beneficia al país, como lo proclaman aquellos que regalan el petróleo, la tierra, los minerales y la biodiversidad al imperialismo. 
Para concluir, la historia de los trabajadores petroleros y su organización principal, la Unión Sindical Obrera, nos enseña que, en el proyecto de vincular presente, pasado y futuro, "Fueron buenos tiempos, esos que perdimos, en que vimos lo bello del ser humano, cuando reafirma su dignidad y defiende sus derechos. Ha sido una larga vida, pero quizás lo mejor está todavía por venir, incluso ahora, en el peor de los tiempos" (Petras, 2000: 13). 
498 | Trabajos y trabajadores en América Latina (siglos XVI-XXI)

\section{FueNTES}

\section{DOCUMENTOS DE ARCHIVO}

Archivo General de la Nación, Ministerio de Minas y Energía. Tropical Oil Company, Concesión de Mares, Tomo 211 (AGN, MME, TOC, CM), 1919, Informe de Rafael Antonio Ariza, Prefecto Provincial de Zapatota al Secretario de Gobierno, al Secretario de Gobierno de Santander.

Archivo General de la Nación, Fondo Ministerio de Gobierno, Sección 1, (AGN, FMG, S. 1). Tomos 932 y 989.

Archivo General de la Nación, Fondo Ministerio de Gobierno, Sección 4, Tomo 156 (AGN, FMG, S. 4, tomo 156).

\section{PERIÓDICOS}

Vanguardia Obrera, Barrancabermeja, 1926.

Germinal, Barrancabermeja, 1926.

El Espectador, Bogotá, 1924.

Vanguardia Liberal, 1935.

El Tiempo, 1946.

\section{ENTREVISTAS}

Aranda, Marco Lino, enero de 1982.

Bolaño, Ángel, marzo de 1984.

Foronda, Antonio, mayo de 1984.

Morón, Julio, junio de 1982.

Rivera, Félix, marzo de 1984.

\section{BiBLIOGRAFÍA}

Alape, Arturo

1981 "Los días de abril del 48 en Barranca". En: Magazin Dominical, 5 de junio.

Almario, Gustavo

1984 Historia de los trabajadores petroleros. Bogotá: Cedetrabajo. 
Álvarez Gutiérrez, Jaime

1983 Las putas también van al cielo. México: Costa-Amic.

Aprile-Gniset, Jacques

1997 Génesis de Barrancabermeja. Barrancabermeja: Instituto Universitario de La Paz.

Archila, Mauricio

1991 Cultura e identidad obrera. Colombia 1910-194. Bogotá: Cinep.

Barreto, Juanita y Luz Giraldo

1998 "Yo digo que ellos son un león de papel y que hay un tigre dormido. Barrancabermeja: palabras, imágenes y relaciones de género". En: Ana Inés Robledo, Juanita Arango, Yolanda Puyana y Cristina Orduz, Mujeres, hombres y cambio social. Bogotá: Universidad Nacional.

Bautista, Ramón

1939 "Petróleo. Grandezas y miserias de una explotación minera en la selva del Catatumbo". En: El Liberal, 21 de mayo.

Buenahora, Gonzalo

1997 Sangre y petróleo. Barrancabermeja: Alcaldía.

Contraloría General de la República

1997 Primer Censo Sindical de Colombia. Bogotá: Publicaciones Contraloría.

Díaz Callejas, Apolinar

1989 Diez días de poder popular. Bogotá: El labrador.

1946 "El sindicalismo revolucionario, estimulo de la reacción" En: $E l$ Tiempo, 12 de noviembre.

Galán Gómez, Mario

1945 Geografia Económica de Colombia. Tomo VIII, Santander. Bogotá: Contraloría General de la Nación.

Galvis, Simón

1997 Monografía de Barrancabermeja. Barrancabermeja: Alcaldía.

Ginzburg, Carlo

1986 El queso y los gusanos. Barcelona: Muchnik.

Guillén, Nicolás

1997 "Nicolás Guillén en Colombia”. En: José Luis Díaz Granados (comp.), Viajeros extranjeros por Colombia. Bogotá: Presidencia de la República. 
500 | Trabajos y trabajadores en América Latina (siglos XVI-XXI)

1935 "Los huelguistas piden apoyo monetario o en víveres a los comerciantes de Barranca” En: Vanguardia Liberal, 12 de enero.

Ortiz Márquez, Julio

1978 El hombre que fue un pueblo. Bogotá: Carlos Valencia.

1950 “Personal Shell: Cosme Ortiz Escobar". En: Vinculo, números 23-24 (abril-mayo). 11.

Petras, James

2000 Escribiendo historias. Tafalla, España: Txalaparta.

Rule, John

1990 Clase obrera e industrialización. Historia social de la revolución industrial británica, 1750-1850. Barcelona: Crítica.

Thompson, Edward

1981 Miseria de la teoría. Barcelona: Crítica.

Valbuena, Martiniano

1947 Memorias de Barrancabermeja. Bucaramanga, Colombia: El Frente. 
5

Informalidad y precariedad 



\section{Introducción \\ De la estructura al proceso}

Gioconda Herrera (Ecuador)*

La precariedad, entendida como aquella condición laboral de inestabilidad, inseguridad, escasez y falta de proyección temporal para los trabajadores, ha acompañado el devenir histórico de las relaciones laborales en América Latina. Los despojos coloniales y las subsecuentes formas de dominación que se instalaron en el trabajo y en la sociedad naturalizaron formas de explotación que luego (en los siglos XIX y XX) siguieron incrustadas en muchas relaciones de trabajo. Si bien las luchas sociales de las décadas de 1920 y 1930 permitieron caminar hacia el reconocimiento de ciertos derechos frente al trabajo, estos fueron restringidos a finales del siglo XX en la mayoría de nuestros países, con la instauración de ensayos neoliberales que buscaron individualizar la responsabilidad y los riesgos sociales, negando con ello a los trabajadores la realización plena de la reproducción social y de la vida.

Este proceso tuvo sus variantes de país en país en el continente americano. Al final del siglo XX, encontramos situaciones de precarización del trabajo; es decir de regreso a una precariedad anterior y pasada, que los proyectos nacionales pensaron haber suprimido. En efecto, los ensayos neoliberales desregularon los mercados de trabajo y flexibilizaron los códigos laborales, cultivando con ello la aparición de relaciones precarias.

En otros casos, las relaciones laborales basadas en el día a día, inestables y con ingresos personalistas y por debajo de lo reglamentado nunca desaparecieron, sino que, más bien, convivieron y se articularon fácilmente con el sustrato formal de la economía. En estos contextos, no se produjeron procesos de precarización; por el contrario, la precariedad continuó siendo parte constitutiva de las formas de sobrevivencia, y lo es hasta ahora. La pobreza, como manifestación de una desigualdad estructural, se mantuvo, y con ella las formas precarias de trabajo. Así, las experiencias de precariedad laboral mantuvieron una vida paralela a aquellas relaciones de trabajo formales, estables y con reconocimiento de derechos básicos o también se entretejieron y se articularon con las relaciones formales, alimentando y permitiendo su existencia. Por ejemplo, desde la década de 1970, las feministas marxistas insistieron mucho en la idea de que las relaciones laborales formales se

* Facultad Latinoamericana de Ciencias Sociales (FLACSO), Ecuador. 
fundaban en relaciones precarias de subsistencia y de reproducción social, que predominantemente involucraban a las mujeres, como el trabajo doméstico no remunerado.

En la década de 1980, a la precariedad se sumará el concepto de informalidad en el mundo del trabajo, en contraste con lo que se concibe como trabajo formal o decente. La informalidad adoptará varios sentidos en el debate, y sigue siendo un terreno bastante heterogéneo que puede abarcar muchas formas de trabajo. Un primer sentido es la ausencia de contribuciones al fisco. Una segunda característica (que se fue desvaneciendo con el pasar de los años) es su condición de excepcionalidad. Se pensaba que, a medida que se consolidaba el crecimiento económico, la informalidad sería absorbida por el sector formal de la economía. Esto fue contrarrestado, en primer lugar, por varios trabajos que comprobaron que el sector formal tendría poco interés en absorber el trabajo informal, pues este último más bien permitía su existencia y el abaratamiento de costos. Luego, con la llegada tanto de las políticas neoliberales como de las medidas de flexibilización laboral, el trabajo informal se generalizó, y si bien formaba parte sustancial de las economías de los países pobres y en desarrollo, también estaba presente y era cada vez más visible en los países con ingresos altos, como Estados Unidos o España (Benería y Floro, 2006).

Por otra parte, la globalización y la desnacionalización de la producción bajo formas de trabajo como la maquila, la subcontratación o el trabajo a domicilio, vinculados a empresas transnacionales, implicaron repensar la artificial división y separación entre trabajo formal e informal, y más bien analizar sus vínculos (ibid.).

Para la primera década del 2000, interesa más bien entender las distintas dinámicas de la informalidad y su relación con la precarización de las condiciones de trabajo. Asimismo, surgen investigaciones que miran las diferencias de género dentro del trabajo informal, constatando, por un lado, una mayor participación de las mujeres en este sector y, por otro, múltiples formas en las que el trabajo precario se constituye en la única forma de supervivencia para las mujeres, y que si bien no permite su reproducción social plena y la de sus familias, sí posibilita para ellas ciertas posiciones de resguardo y también de liderazgo. Finalmente, el trabajo informal será un espacio para el análisis de los vínculos entre trabajo remunerado y no remunerado de las mujeres, muchas veces superpuestos, en el que se entrecruzan las actividades productivas y reproductivas tanto en el espacio (en el trabajo a domicilio, por ejemplo) como en el tiempo (como cuando una vendedora de la calle se sienta junto a sus hijos a vender, al mismo tiempo que los está cuidando). Esta discusión es radicalmente distinta de aquella que mira las tensiones en la conciliación entre trabajo y hogar para las mujeres, y que 
asume que las actividades reproductivas están separadas en tiempo y espacio de las actividades productivas que estas realizan. El sector informal se ha convertido entonces en un lugar para el análisis no solo económico sino, sobre todo, social, que demanda expandir nuestra concepción misma del trabajo.

Los dos textos de esta sección aportan precisamente en este sentido. El de Cristina Vega, Magali Marega y Lucrecia Saltzmann parte del reconocimiento del amplio debate en América Latina sobre informalidad histórico-estructural e informalización con las políticas neoliberales, y se sitúa más allá de las condiciones precarias de trabajo y de subordinación, para mirar las formas de agencialidad de las mujeres a partir de su experiencia de trabajo como comerciantes minoristas en un barrio popular de la ciudad de Quito. Las autoras examinan la manera en que las actividades de comercio informal están articuladas a formas de apropiación y de ocupación del espacio que empoderan o desempoderan a las mujeres. La venta en la calle, nos dicen las autoras, permite disputar ciertas regulaciones sobre el espacio, dispuestas por las autoridades municipales, y afirmar cierta autonomía en un contexto adverso, de precariedad. En otras palabras, las autoras miran cómo, mediante el trabajo, las mujeres comerciantes minoristas construyen acciones sociales de resistencia (por ejemplo, transgredir las normas del municipio) y también acciones de afirmación individual que las empoderan. La reflexión de Vega, Marega y Saltzmann se diferencia de la abundante literatura de corte más estructural, centrada en las conexiones entre los espacios más formales e informales, o que pone énfasis en las desigualdades estructurales de las mujeres, y se interesa por recuperar su agencialidad. De ahí que el análisis se asienta sobre conceptos como la experiencia o el "modo de ser" y busca pensar los procesos desde el punto de vista de las y los actores involucrados, y sus estrategias.

Las tres autoras analizan lo que sería un sector informal tradicional, que se remonta inclusive a la época de la Colonia y que ha sido una forma de ocupación del espacio urbano de las mujeres indígenas a lo largo del siglo XX, como lo han mostrado varios trabajos historiográficos (Kingman, 2006). Ellas nos muestran que, en el marco de la precariedad que ha marcado la vida de estas mujeres comerciantes minoristas, la autonomía que han construido a través de su trabajo y de su accionar organizativo debe entenderse con relación a las historias personales y sociales de dominación que ha vivido cada una de ellas en su infancia y en su juventud; por ejemplo, sus experiencias muy tempranas en el trabajo doméstico. Además, a diferencia de las percepciones dominantes sobre el trabajo en la calle como espacio de caos y/o de desorden, las autoras lo analizan como un espacio de cooperación (sobre todo en tiempos de crisis), de conflictos y de negociación para las mujeres.

En contraste, el texto de Dasten Julián examina un proceso de informalización y de precarización de un sector laboral producto de las políticas 
neoliberales de desregularización y extractivismo, entre otras, como es la minería en Chile. Su interés es, más bien, mostrar aquello que el autor llama "el funcionamiento de una sociedad precaria”, y al neoliberalismo como un ordenamiento social más allá de las relaciones laborales. El autor nos muestra, en primer lugar, cómo en la minería, sector emblemático en la historia de las relaciones laborales y la economía chilena, priman lógicas laborales construidas en torno al riesgo y a la inseguridad como un problema individual, y, en segundo lugar, de qué manera la tragedia de los 33 mineros que quedaron atrapados en 2010 (y que tuvo una cobertura mediática mundial) representaron la imagen de la indefensión y de la vulnerabilidad que obligaron a los trabajadores a asumir riesgos y estrategias precarias de vida para atender la reproducción social de sus familias. Pone el ejemplo de un trabajador que vuelve a la mina a sus 63 años para sostener la reproducción de sus hijas y de sus nietas. La precariedad, nos dice el autor, se vuelve un consentimiento del riesgo cuando el orden social y las concepciones dominantes del entorno han borrado la protección social como parte central de sus acciones, y cuando ya no es posible ningún tipo de cuestionamiento al contexto social más amplio de generación de la precariedad, más allá de las condiciones de trabajo. Pero, además, desde el análisis de la espectacularización del drama de los 33 mineros, aquello que Julián denomina la "sociedad precaria” construyó una imagen del minero con un rol "sacrificial", de héroe individual, como símbolo patrio, ocultando los múltiples riesgos sociales y la desprotección de estos trabajadores.

Los dos textos que siguen examinan dos situaciones y procesos de precarización que, si bien parten de una matriz histórica parecida, de despojo colonial, han asumido recorridos de acuerdo a los contextos sociales y políticos donde se han desarrollado. Así, mientras que en la ciudad de Quito las mujeres vendedoras son analizadas desde sus formas de resistencia (a los ordenamientos del municipio y la construcción de subjetividades precarizadas pero autónomas a la vez), lo que las autoras llaman la autonomía subsumida, en el caso de la tragedia de los mineros en Chile el análisis subraya la expresión de una dominación sistémica en la cual las subjetividades de los trabajadores son construidas a partir de un ordenamiento social que sitúa en el individuo la responsabilidad frente al riesgo y la suerte de su futuro. 
BiBLIOGRAFÍA

Benería, Lourdes y María Floro

2006 "Informalización del mercado laboral, género y protección social: reflexiones a partir de un estudio de hogares pobres urbanos en Bolivia y Ecuador”. En: Gioconda Herrera, La persistencia de la desigualdad. Género, trabajo y pobreza en América Latina. Quito: FLACSO Ecuador / CONAMY / Secretaría Técnica Frente Social.

Kingman, Eduardo

2006 La ciudad y los otros. Quito 1860-1940: higienismo, ornato y policía. Quito: FLACSO Ecuador/ Universitat Rovira i Virgili. 



\section{Sociedad precaria en Chile: la "tragedia" de los 33 mineros}

Dasten Julián Vejar (Chile)*

RESUMEN: La discusión respecto a la precariedad del trabajo se ha instalado a nivel global. En América Latina, este debate se cruza con una estructura del mercado del trabajo altamente segmentada, donde predominan el racismo, un legado colonial y de estructuras patriarcales. La acompaña una significativa diferenciación a partir del campo y la ciudad, con una ciudad altamente diferenciada en función de los procesos de expulsión, informalidad y asalarización flexible, y un campo en franca desagrarización, con presencia de población indígena y la profundización de los modelos extractivos. En este artículo tratamos de analizar la realidad de las sociedades precarias desde el caso particular de los 33 mineros que fueron atrapados por un derrumbe en el mes de agosto de 2010, en Chile, analizando las diversas condiciones, implicancias y consecuencias que se develan en el ejercicio de la precariedad en el trabajo. ${ }^{1}$

PalABRAS Clave: precariedad; trabajo; extractivismo; minería, Chile.

\section{INTRODUCCIÓN}

La neoliberalización de la sociedad ha llegado a un punto de madurez en Chile (Gaudichaud, 2015). Ello involucra considerar la profundidad que ha alcanzado el neoliberalismo, a modo de ordenamiento social, en las diferentes dimensiones de la vida. Su rizomática forma de extenderse en la mercantilización de los bienes sociales, la monetarización del bienestar social, la

* Doctor en Sociología por la Friedrich Schiller Universität de Jena. Universidad Católica de Temuco (UCT). Contacto: dasten@gmail.com

1 Este texto ha sido posible gracias al financiamiento de la Comisión Nacional de Investigación Científica y Tecnológica (CONICYT) y su línea de financiamiento Fondecyt Regular, a través del proyecto número 1161347, titulado "Cartografía de la(s) precariedad(es) laboral(es) y las relaciones laborales de la Zona Centro Sur de Chile. Tipología del Trabajo Precario y su incidencia en la práctica sindical en las regiones del Maule, Biobío y La Araucanía”. 
prolongación del mercado a la salud, la educación, las pensiones, etcétera, han configurado diversos espacios de rentabilidad y de competitividad que no tan solo han "racionalizado" las relaciones sociales, sino que también han configurado sujetos y subjetividades a partir de esta situación de dependencia y vulnerabilidad.

Este espacio de "lo público" es el que ha entrado en disputa en la actualidad de manera más abierta en el escenario político. La denuncia pública de la reproducción de modelos de aseguramiento y bienestar diferenciados y segregadores, fundados en el dinero como mecanismo de integración, o del ejercicio del dinero como rol determinante del acceso, etcétera, ha movilizado la presencia pública de diversos actores e intereses relacionados con la reproducción y la reforma del mismo sistema selectivo de protección. Y es que el neoliberalismo no deja de ser una expresión histórico-espacial del capitalismo. El capital se apoya en la colonización de estos espacios para extender las fronteras de la acumulación, movilizando dinámicamente sus intereses, desactivando y redefiniendo los límites y los consensos políticos, las estructuras de sentido (común), y aumentando la inversión y la concentración económica de forma de acabar con "la competencia irracional por los precios".

La maduración de este sistema y su expansión geográfica hacia otros países de la región exhiben las marcas históricas del neoliberalismo en la producción de la sociedad y su especial relación con los bloques históricamente dominantes. Bastante literatura hay respecto a las consecuencias y a los impactos de las políticas neoliberales y su particular modelo de dominación/poder, especialmente en materia de desigualdad del ingreso, la pobreza, la desregulación laboral, la delincuencia, la privatización, etcétera (Harvey, 2007; Therborn, 2008). Es más, considerando todos los antecedentes mencionados, creemos que la maduración de estas políticas y su enraizamiento en las bases de la organización social pueden haber modelado un tipo particular de sociedad, una sociedad precaria. En este trabajo nos centramos en el caso de los 33 mineros que resultaron atrapados el año 2010 en medio de una jornada de trabajo en la mina San José, en Chile. Nos preguntamos por las causas de este hecho, revisando las condiciones precarias de trabajo en que se desempeñaban, así como los marcos institucionales y agenciales que incidieron en lo que fue reconocido como "tragedia".

Creemos que este ejemplo puede mostrarnos la extensión de la "precariedad" como una dimensión social generalizada, en tanto estrategia subjetiva de gestionar el riesgo como condición inducida y coercitiva hacia los trabajadores (mujeres y hombres) desde el capital. Por último, generamos algunas conclusiones y preguntas para el estudio de relaciones sociales precarias a partir de nuestra experiencia en los estudios del trabajo en Chile. 


\section{"NeOliberalismo ChILENO": PARADIGMA DE LA PERIFERIA CAPITALISTA}

El neoliberalismo puede ser entendido como una actualización de las estrategias de las clases dominantes, en nueva forma y expresión, por implantar un régimen de expoliación con carácter global (Silver, 2005; Harvey, 2007; Mezzadra y Neilson, 2013), pero integrando las dinámicas y las marcas históricas de precarización, racismo, vulnerabilidad y violencia normalizadas en los regímenes de poder anteriores (Harvey, 2014). El objetivo central es la expansión de los "límites del capital" (Harvey, 2007; Altvater, 2011), como también la generación de sociedades, relaciones sociales y subjetividades de acuerdo a la reproducción de las estrategias de monetarización y realización del capital.

En este proceso, la emergencia de la precariedad y de la precarización del trabajo es entendida como una estrategia global de transformación y de readecuación de las condiciones de producción de vida y de sociedad. La precariedad del trabajo (Julián, 2017) involucra una serie de debates respecto a las formas en que se ha ido modelando e instituyendo un régimen de condiciones, procesos, relaciones y sujetos del trabajo.

A modo de síntesis podríamos advertir la existencia de tres enfoques principales en el análisis del fenómeno de la precariedad laboral y del trabajo:

- Institucionalista y regulacionista, que se centra en los mecanismos y en las instituciones de protección y de seguridad social, junto con una definición de la precariedad como producto de un proceso de descomposición del Estado, la erosión de las condiciones del empleo y el retroceso de las políticas de aseguramiento social (Castel, 2010).

- Neomarxista, que problematiza la relación y la reproducción de la precariedad con los procesos y los cambios globales en los patrones de acumulación de capital, especialmente mediante la financiarización, el despojo y la sobreexplotación del trabajo (Dörre, 2009).

- Posestructuralista, que concibe la precariedad por parte de una estrategia y régimen de gobierno por medio de la inducción de una posición de control en las relaciones sociales de dominación y de subordinación para poblaciones específicas (Butler, 2004; Lorey, 2015).

La condición de precariedad está intrínsecamente asociada a los conceptos de 'incertidumbre', 'inseguridad' y 'vulnerabilidad' en los estudios del trabajo; es decir, a distintas vertientes y dimensiones de la precariedad del trabajo, las cuales parecen haberse convertido en una tendencia a nivel internacional en el reordenamiento de los espacios de trabajo y de restructuración productiva desde la década de 1980 (Castel, 1997; Auer y Cazes, 2000; Antunes, 2003; Castel y Dörre, 2009; Marín, 2013). 
Por otra parte, la incorporación de la precariedad como parte de la nueva realidad del empleo exhibe: (i) una aparente permeabilidad e internalización de los debates de las ciencias y de los estudios del trabajo sobre los cambios en la matriz socioproductiva (Kalleberg, 2013; Paugam y Zhou, 2007; Van der Linden, 2014); (ii) un nuevo escenario de flexibilización de las relaciones de empleo (Esping-Andersen y Regini, 2000; Thompson y Van der Broek, 2010); como también (iii) una connotación especial a los procesos constitutivos de resistencias, colectividades y movilización social (Frege y Kelly, 2004; Ross, 2008; Barattini, 2009; De la Garza, 2011).

En este sentido, la precariedad se ha vuelto un fenómeno extensivo en las relaciones sociales que se encuentran más allá del trabajo (De la Garza, 2005). De ahí que entendamos que la precariedad del trabajo, desde la centralidad del trabajo en la reproducción de las relaciones sociales, ha dado forma a sociedades precarias, las cuales resultan ser causa y efecto de un complejo entramado de relaciones de poder a nivel global y local.

Entendemos por "sociedad precaria" una sociedad donde la reproducción social se ve afectada por deficiencias estructurales en la satisfacción de las necesidades básicas, así como en la insuficiente/inexistente consagración y ejercicio de derechos sociales, y la colonización de los mecanismos de regulación social por el dinero. La sociedad precaria incorpora una lógica de inducción a la vulnerabilidad social como un mecanismo de normalización y poder que pretende asegurar su propio gobierno. Para ello, intercepta la explotación, el racismo, el patriarcado, etcétera, como prácticas de reproducción social.

Como sociedad precaria, el caso del neoliberalismo chileno es presentado a nivel internacional como un "icono exitoso" de la aplicación de las políticas del consenso de Washington y de la desregulación total del mercado (Salazar, 2015). Su modelación fue sustentada en el marco totalitario del despliegue de una dictadura militar (1973-1990) y del terrorismo de Estado, con la colaboración de un grupo de economistas chilenos formados en la ciudad de Chicago, en la escuela de Milton Friedman, y de la promoción de una política imperialista de parte de Estados Unidos para el control de América Latina. Su consolidación, en tanto, fue y ha sido fruto del trabajo de un régimen posdictatorial democrático que buscó el perfeccionamiento, la legitimación y la extensión de las políticas de mercantilización social (Garretón, 2012; Gaudichaud, 2015).

Este montaje de medios de depredación social significa una fuerte desregulación de los ejes centrales de aseguramiento y de protección. Constituye la modelación de relaciones individualizadas, centradas en la privatización de una serie de esferas de la vida. Para ello, la dictadura militar tuvo un carácter instituyente, por medio de la extensión del miedo, del horror, de la violencia y del pauperismo como formas disciplinarias (Salazar, 2015). 
En ese contexto, el neoliberalismo se impone mediante una serie de medidas "modernizadoras" (Hoehn, 2005: 10-14), entre ellas: (i) el Código del Trabajo de 1981, que destaca el Plan Laboral de José Piñera Echeńique (una reforma trascendental del Código Laboral vigente desde 1924 y producto de cinco décadas de lucha sindical), que eliminó progresivamente todas las conquistas del movimiento obrero respecto al derecho laboral y sindical, flexibilizando y desregulando el mercado laboral, acompañado de políticas represivas hacia el movimiento sindical; (ii) el Sistema Previsional, que produjo la creación de un sistema de administradoras privadas de los fondos de pensiones (AFP); (iii) la Reforma de Salud, con dos objetivos principales: primero, reducir los aportes estatales al mantenimiento del sistema (principalmente por medio de la municipalización de establecimientos de salud) y, segundo, abrir una nueva fuente de acumulación para los empresarios con la creación de las Instituciones de Salud Previsional (ISAPRE); (iv) la Reforma Educacional, política que se expresó en la municipalización de las escuelas y en la desmembración de la Universidad de Chile, así como en la privatización de la enseñanza técnico-profesional y de la educación superior; (v) la Contrarreforma Agrícola, que consistió básicamente en la liberalización del sector y su apertura al exterior, incorporando las políticas neoliberales a un rubro caracterizado hasta entonces por el proteccionismo; (vi) la Reforma Politica-Justicia, con una serie de restricciones constitucionales contenidas en la Constitución de 1980 que buscan impedir el ejercicio de la soberanía popular, tales como las Leyes de Quórum Calificado (aprobación por dos tercios del Parlamento), los senadores designados y vitalicios, la inamovilidad de los comandantes en jefe y de las Fuerzas Armadas como garantes de la institucionalidad, el sistema electoral binominal, la conformación del Tribunal Constitucional y el Consejo de Seguridad Nacional (COSENA); y (vii) la Reforma en la distribución regional: la dictadura militar hizo suyo un discurso muy descentralizador (ciertamente una contradicción en sí misma) que, en consonancia con su estrategia económica, logró que los nuevos empresarios ligados a los negocios de exportación de recursos naturales asumieran como suyo el discurso descentralista.

Estos pilares del régimen gubernamental neoliberal chileno se mantienen hasta el día de hoy ${ }^{3}$ como mecanismos que inducen la precariedad en

2 La Reforma Previsional, otra iniciativa del ministro Piñera, se propuso entregar los fondos previsionales de los trabajadores a los grandes conglomerados de empresas para su uso especulativo y la financiarización, con resultados que a la fecha han puesto a "los cotizantes" en estado de alerta, frente a la incertidumbre y a la insuficiencia de las pensiones.

3 Se podrían excluir de esta lista a los senadores designados y vitalicios (suprimidos en 2004), la inamovilidad de los comandantes en jefe (suprimidos en 2005 con una reforma constitucional) y el sistema electoral binominal (suprimido en 2015). 
las relaciones sociales y proyectan una lógica de desaseguramiento y de vulnerabilidad, consolidando la indefensión como forma de disciplinamiento social (Hoehn, 2005). Este ejercicio del poder involucra traspasar el aseguramiento social público al espacio privado de la inversión y de la monetarización, lo cual a la vez involucra una subvención al capital en la acumulación (Gaudichaud, 2015), poniendo al Estado como un actor activo en la gestación y el "perfeccionamiento" de la gubernamentalidad neoliberal.

De esta forma se consolida un modelo de desregulación social promovido por el capitalismo neoliberal, entendiendo por ello el retiro del rol del Estado como actor garante de posibilidades de protección y de vigilancia del abuso de la asimetría del poder entre los actores (Garretón, 2012: 21-38). En este "retiro" se gestan y se fortalecen áreas desreguladas al poder autónomo de intereses privados en ejercicio. El Estado finalmente no se retira, sino que avala implícita y tácitamente los repertorios del capital, por medio del uso de sus influencias y de sus capitales agenciados y transferidos a privados para la obtención de sus intereses. Los espacios de negociación de la acción quedan sujetos al dinero, como mecanismo de coordinación y de intercambio, y a la proscripción normativa ética individual, antes que a organismos y a normativas institucionales forjadas en la protección de la indefensión.

Ante esta dependencia del mecanismo dinero, y de la lógica depredadora e irracional de la acumulación del capital, es como las reflexiones en torno al "riesgo" (Rosanvallon, 2006; Beck, 2006) se vuelven clave para entender los dispositivos disuasivos, coactivos y disciplinares de la precariedad y de la vulnerabilidad social. La modelación de las situaciones de riesgo son las que introducen la idea de un estado de inseguridad (Kessler, 2015; Lorey, 2015) y de dependencia, donde los sujetos son coaccionados a transitar en puestos y formas de trabajo que carecen de adecuaciones a la protección de su integridad física, su salud o su bienestar psicosocial.

El neoliberalismo se encarga de desmontar instrumentos de aseguramiento social, transfiriéndolos al área de "los seguros privados" (de vida, de enfermedad, de incendio, etcétera), conducidos a la esfera privada e individual (Castel, 2010). Este ejercicio induce la proyección de autorresponsabilidad del sujeto, gestionándose a sí mismo en situaciones y en circunstancias de trabajo que incluso pueden amenazar su propia existencia y en las cuales, contradictoriamente, la transferencia de este riesgo parece ser la única posibilidad de reproducir su vida y las de sus familias.

En esta identificación de situaciones de riesgos hay un elemento que ingresa al análisis: la historicidad del riesgo como posibilidad y realidad inducida en América Latina. La jerarquización establecida en la dinámica de los actores que dan forma al sistema-mundo sujeta hoy la configuración de poblaciones "aptas" o "precarizables" en el riesgo, lo cual tiene un carácter 
histórico, racial y global que se requiere introducir en las sociedades precarias para entender la data de las relaciones de poder que prefiguran la realidad del trabajo en la actualidad.

En este caso, consideraremos la minería como un sector que históricamente ha exhibido situaciones de sobreexplotación del trabajo, donde los accidentes, la muerte y las consecuencias psicológicas se entremezclan con poblaciones precarizadas, pauperizadas y despojadas de su territorio y de su vida (Sassen, 2010). La minería, además, se encuentra en la columna vertebral de la economía dependiente en América Latina, y sigue exhibiendo su importancia estratégica para la inversión transnacional, el modelo de despojo y depredación ecológico a nivel global (Harvey, 2004).

MINERÍA, EXTRACTIVISMO Y PRECARIEDAD: UN PATRÓN HISTÓRICO

Es posible rastrear la extensión y la convergencia de la precariedad en hechos sintomáticos de la articulación y de la reproducción de las sociedades precarias, y particularmente en situaciones de trabajo en las que el riesgo de vida es un elemento constitutivo. Estos hechos cobran socialmente el carácter de aberraciones y "tragedias", que responden a la síntesis de relaciones y de equipamientos sociales de precarización social y de situaciones de riesgo de la vida. En ellas se desnudan la confluencia sistémica de los mecanismos de pauperización, su normalización y sus consecuencias en el plano de la indefensión y la vulnerabilidad estructural de sujetos marcados por la precariedad (Butler, 2004). Este será el caso de los emblemáticos 33 mineros que quedaron atrapados en la mina San José durante casi 70 días, a más de 700 metros de profundidad. Analizaremos este caso en el siguiente punto para ejemplificar nuestra tesis.

A modo de contextualización podemos decir que la minería es una rama de la producción en Chile con una larga data histórica (Julián, 2013). Solo pudo ser desarrollada como "empresa" por medio de una lógica eurocéntrica (Amin, 1989), colonial, imperialista y clasista, que devino en la normalización de la precariedad, la sobreexplotación, la esclavitud, el trabajo forzado, etcétera (Bengoa, 2015), la aniquilación y el despojo, y la justificación de la depredación de la naturaleza. ${ }^{4}$ Estos elementos se convertirían en una condición histórica de la reproducción de las sociedades precarias en la periferia del sistema-mundo, las cuales se mueven entre la colonialidad del poder y la dependencia económico-política (Wallerstein, 1988; Escobar, 2014).

4 Utilizando la fuerza de trabajo indígena, por medio de la sobreexplotación y de la esclavitud, los españoles acabaron pronto con los metales y la población indígena mapuche e inca del centro de lo que hoy se conocer por Chile (Bengoa, 2015). 
La situación periférica de Chile (su espacialidad e historia) introduce una nueva cuestión a la conformación de las sociedades precarias: una condición histórica que delimita su génesis, reproducción y ampliación en la dialéctica de los límites del capital (Harvey, 2007). En este marco, la minería se consolida como parte estratégica del "modelo de desarrollo" exportador (Salazar y Pinto, 2002), y como expresión del modelo de acumulación periférico dependiente en América Latina. Este modelo también configura una forma específica de Estado (Salazar, 2015: 244), una demarcación racializada y jerarquizada de la población para el poder y una relación con la naturaleza.

Por su parte, en el ciclo neoliberal, la promoción de un modelo extractivista minero se refuerza, y cobra una nueva expresión en las democracias latinoamericanas en la década de 1990, teniendo su caso pionero en Chile:

[...] donde a la salida de la dictadura militar, los sucesivos gobiernos de la Concertación por la Democracia mantuvieron la arquitectura básica del sector minero, alentaron su ampliación a partir de emprendimientos privados, y los intentos de diversificación productiva no han tenido mucho éxito (Gudynas, 2011: 79).

La principal localización geográfica de la actividad minera chilena se encuentra en el norte del país. Se trata de una zona marcada por una "alta vulnerabilidad territorial” (Fuenzalida y Quiroz, 2012: 9-10), la cual se caracteriza por:

[...] un evidente escenario de injusticia ambiental, en donde se observa una desigual o desproporcionada participación de grupos de población más desaventajados y, por tanto, más vulnerables, en los impactos negativos resultantes de las actividades mineras, industriales y proyectos de infraestructuras (ibid.).

Los planes de restructuración y de modernización productiva, como nueva lógica de la competencia a nivel internacional, no han dejado exenta a la gran minería en Chile. Por ello es que los modelos de flexibilización y de precarización laboral han abierto una brecha dentro del histórico "núcleo aristocrático" de la clase trabajadora en el sector del cobre (Leiva, 2009). La permanente erosión de sus condiciones de reproducción (beneficios sociales, remuneraciones, contratos y seguridad laboral, etcétera) ha quedado sujeta a la introducción de la subcontratación laboral (Leiva, 2009 y 2013) y a un recrudecimiento de las condiciones de degradación de la salud (psíquica y física) de los trabajadores (Carrasco y Vega, 2011).

Por su parte, las características del trabajo en las minas varían de acuerdo con el tamaño de las empresas. Es claro que en las grandes empresas del 
cobre, donde hay mayor presencia de capitales extranjeros, encontramos un sector de trabajadores que obtiene beneficios salariales sobre la media salarial en Chile (Rivera y Aroca, 2014). A la vez, existe un alto riesgo a la accidentabilidad $^{5}$ y a la exposición a materiales tóxicos y a altas temperaturas, un alto sacrificio en los turnos y las jornadas laborales (Organización Internacional del Trabajo, 2015: 21), la exposición a condiciones de altura y la vida en campamentos (Carrasco y Vega, 2011), así como la migración laboral, sujeta a un constante aislamiento intensivo y a la homosociabilidad (Pávez y Hernández, 2014).

El subcontratado en la minería aparece como la síntesis final de un mecanismo de disciplinamiento, pauperización y reingeniería tecnológica empresarial del trabajo (Muñoz, 2011; Pérez, 2016). El subcontrato crea su propio síntoma de debilitamiento de las bases de bienestar, seguridad y cooperación corporativa en el núcleo de la división del trabajo (Leiva, 2009). Los trabajadores subcontratados son profundamente precarizados y se construyen como una alteridad con menores condiciones de protección y seguridad (Muñoz, 2011; Leiva, 2013). La subcontratación se instala en todos los niveles de la minería (grande, mediana y pequeña), de manera acelerada (Leiva, 2009), acrecentando la segmentación y la indefensión de los trabajadores respecto a las condiciones del trabajo, instalando un régimen de competencia entre proveedores de servicios que pujan por la precarización del empleo.

Es en este régimen en el que se da la confluencia de las relaciones sociales de precarización y la indefensión generada e instituida mediante la institucionalización neoliberal de lo precario como forma de vida. Las consecuencias de esta dinámica se pueden graficar en la relación simbiótica que se produce entre extractivismo y precarización del trabajo (Alister y Julián, 2018), lo cual cobra expresión en cuerpos, subjetividades y prácticas en las que se sintetiza un conjunto de relaciones de poder.

A continuación, queremos analizar el caso de 33 los mineros de la mina San José que se hicieron famosos a nivel global como parte de un espectáculo mundial de rescate, luego de que quedaran atrapados en el derrumbe de una mina de cobre en el norte de Chile. En este hecho veremos cómo la precariedad del trabajo y la vida se vuelve un elemento central para descomponer el concepto de tragedia, al igual que para entender la vitalidad de las relaciones sociales precarias como formas instituyentes de riesgo, sufrimiento y explotación en las sociedades periféricas.

5 Como señala el informe de la Organización Internacional del Trabajo (2015: $20)$, la mayoría de los encuestados $(86,4 \%)$ consideraba que los trabajos que desempeñaban eran "riesgosos", ya sea porque podían producir accidentes laborales $(86,4 \%)$ y enfermedades físicas $(57,6 \%)$ y de salud mental $(34,5 \%)$. 


\section{Los 33 Y LA TRAGEDIA dE LA MINA SAN José}

El día 5 de agosto de 2010, la mina San José, ubicada a unos 810 kilómetros al norte de Santiago de Chile, sufrió un derrumbe en el que 33 mineros quedaron atrapados durante 69 días a 700 metros de profundidad. El hecho atrajo la atención internacional, desde los medios de comunicación, las redes sociales, las embajadas y las agencias internacionales de noticias. La cobertura mediática dio al hecho el carácter de "accidente", un hecho fortuito en el cual las causas no cobraban relevancia; más bien se resaltaba la capacidad de los mineros de soportar las condiciones del encierro, lo arbitrario de la situación y los "perfiles de personalidad" de cada uno de ellos.

Más allá del sensacionalismo y del espectáculo de la noticia, de lo cual abusó el Gobierno de Sebastián Piñera (2010-2014), la mina San José representa un icono histórico de la indefensión y de la precariedad en Chile. La mina, que tiene alrededor de 170 años de explotación, es parte de la Compañía de Minería San Esteban, fundada en 1957 por Jorge Kemeny Letay, un adinerado emigrante húngaro que llegó a Chile luego de que el Partido Comunista llegara al poder en su país. La mina fue estatizada por el Gobierno de Unidad Popular en 1971 (con la nacionalización del cobre), para luego ser reprivatizada por la dictadura militar, junto con una serie de empresas estatales en la década de 1980. Le siguió un proceso de modernización en la década de 1990, con una profunda desregulación laboral y un modelo de sobreexplotación minera, cuando pasó a ser propiedad de Marcelo Kemeny Füller ${ }^{6}$ y Alejandro Bohn Berenguer, y transitó de ser una "pequeña empresa" a una "mediana empresa minera".

La mina es parte del modelo extractivo exportador dependiente del Chile neoliberal, fundado en la depredación de la naturaleza, la sobreexplotación del trabajo en condiciones de precariedad y la generación de commodities para el mercado global (Gago y Mezzadra, 2015). Para el año 2009 la minería representaba el 15,5\% del producto interno bruto (PIB) nacional, mientras que para el primer semestre de 2010 las empresas del sector registraron ganancias por cerca de 4.656 millones de dólares estadounidenses. Ese año (2010), la minería finalizaría representando el 20\% del PIB, lo que acrecentaría la dependencia del sector y fortalecería el ciclo de altos precios del cobre

6 Kemeny Füller era miembro del Consejo General de la Sociedad Nacional de Minería. Su empresa cargaba a la fecha del derrumbe con una lista de 28 documentos impagos, de hasta más de dos años, que sumaban 85,5 millones de pesos chilenos, mientras que él, como individuo, registraba 17 impagos, por un total de 45,5 millones de pesos. Entre estas deudas se encontraba una de 1.300 millones de pesos a casi 300 trabajadores de la Minera San Esteban (El Mostrador, 18 de octubre de 2010). 
(Muñoz, 2011), donde la mediana minería pasaba de representar un 4,5\% de la producción total de cobre en 2009 a un $5,1 \%$ en 2010 y un $5,8 \%$ en 2011 (Sociedad Nacional de Minería, 2014).

En este contexto de rentabilidad en el sector, de expansión y de crecimiento de la producción, el derrumbe aparece como un fenómeno sintomático. La base material del derrumbe se produciría a partir de la combinación de estos elementos: infraestructura de seguridad insuficiente y mina sobreexplotada; sujetos precarizados y dispuestos al riesgo por medio de "altos salarios"; 7 bonanza en la demanda de commodities a nivel global; inmaterialidad de los organismos reguladores (del trabajo, de las minas, etcétera); y una clase capitalista insaciable a la hora de ser clase (al acumular capital). ${ }^{8}$

Los trabajadores de la mina San José trabajaban en condiciones de riesgo permanente. Contaban con altos sueldos con relación a aquellos de los demás sectores productivos de la región, desempeñándose bajo un régimen de subcontratación. Este régimen involucraba seria inestabilidad, así como jornadas de larga extensión (por encima de las 45 horas legales), con un cumplimiento de normativas laborales deficiente (The Clinic, 29 de octubre de 2010).

Este hecho visibiliza la lógica depredadora de explotación económica de la clase capitalista chilena, la cultura empresarial de objetualización del ser humano y la serie de dispositivos que ofrece la indefensión para soportar y/o asumir el riesgo (vital) como una práctica cotidiana. ¿Por qué asumir el riesgo? La indefensión y la vulnerabilidad incitan a asumir estrategias precarias de vida. La venta de su fuerza de trabajo está subordinada a la marca de precarización, ya que las faltas de aseguramiento obligan a los sujetos a buscar formas de integración/subordinación en la esfera privada, mediadas por el salario y/o ingresos del trabajo, ${ }^{9}$ sin importar muchas veces las condiciones

7 Como señalaba el diario El Mercurio (9 de agosto de 2010), el hecho de ser una mina peligrosa solo podía "seducir" a los trabajadores a partir de "altos sueldos". Así es como algunos trabajadores recibían 700 mil pesos chilenos (aproximadamente mil dólares estadounidenses), siendo la media de 550 mil pesos (790 dólares).

8 Para Vincenot Tobar, exsuperintendente de seguridad de la mina San José, el problema fue que no se respetó el método de explotación presentado por la misma compañía y visado por el Servicio Nacional de Geología y Minería (Sernageomin). Esto se debería a "la ambición de llevar más mineral a la planta", por lo que se "cometieron errores garrafales" (The Clinic, 29 de agosto de 2010).

9 El informe de la Comisión Investigadora del Senado señala que "los mineros atrapados reconocieron saber de la inseguridad del yacimiento, pero trabajaban de todas formas en él, pues los pagos eran mayores al mercado y las exigencias de experiencia previa, nulas. Por hacerlo, eran llamados 'kamikaze' por mineros de otras empresas" (2011: 11). 
en que se desarrolla esta venta: son los riesgos de muerte frente a los riesgos de seguir con vida.

El caso de Mario Gómez resulta icónico para graficar esta tensión cotidiana constitutiva de la precariedad. Diagnosticado con silicosis a sus 63 años, derivado a un establecimiento de salud local donde no encontraría cura y trabajando de chofer en un taxi colectivo de manera mal remunerada y sujeto a la inestabilidad, "asumió el riesgo" de volver a trabajar en la mina luego de conocer el embarazo de dos de sus hijas.

Como señala Robert Castel, el riesgo social puede ser definido como un "acontecimiento que compromete la capacidad de los individuos para asegurar por sí mismos su independencia social. Si no se está protegido contra estas contingencias, se vive en la inseguridad" (2003: 35). En el caso de Gómez, el riesgo marcó y definió los límites de la reproducción social de su vida y la de su familia. Cercado por diferentes necesidades de aseguramiento (salud, comida y bienestar), se vio sujeto a la esfera del trabajo minero por la "crisis del espacio del cuidado" (Lorey, 2015), y por la insuficiencia y la flexibilidad salarial, que no permitían subsanar dicha crisis. A su regreso al trabajo minero no se le realizaron exámenes médicos, sino que, pese a los dos dedos amputados de su mano derecha, se le asignó la labor de conducir el camión que bajaba a recoger a los trabajadores a las profundidades de la mina.

Su inserción en el trabajo era precaria, e involucraba un consentimiento de normalización de esta precariedad y discrecionalidad de precarizar el empleo: es el riesgo social que se expresa en la lucha de seguir con vida. Pero esta tesis, la de la precariedad como un consentimiento en el riesgo, conlleva en su seno el otro polo de interpretación, que proviene de parte de la racionalización del capital: el riesgo es responsabilidad del individuo que se precariza. Esta sentencia, propia de la concepción de la subjetividad del liberalismo clásico, no problematiza ni tematiza el contexto social de generación de la condición de precariedad, y en la cotidianidad tampoco considera las relaciones de asimetría existentes entre capital/trabajo y subordinación, ya que se entienden como relaciones entre iguales, y no fundadas en el riesgo social (Castel, 2003).

Este hecho se manifiesta en la apelación de Luis Larraín (Cooperativa, 25 de octubre de 2010) a la responsabilidad en la seguridad laboral de los empleadores en la mina San José. Larraín, director de la Fundación Libertad y Desarrollo, think tank ligado al partido Unión Demócrata Independiente (UDI) y de confesada tradición neoliberal en Chile, afirmó que "la responsabilidad frente a la vida de cada uno, y frente al trabajo, es primero del trabajador, y allí hay una falla" (ibid.).

Para el neoliberalismo y su ideología el derrumbe no era el tema central en discusión. El hecho concreto fue negado, por otorgar centralidad a las 
"decisiones individuales" de quienes, con menor poder en la relación de trabajo, se expusieron libremente al momento trágico. Según Larraín, "hay una falla de un trabajador que acepta ir a trabajar en condiciones de trabajo que no son las que cautelan su vida" (ibid.). La transferencia del problema y el delito se moviliza así a la cuestión de "aceptar la precariedad", la cual, en su "riesgo" y "aumento del peligro", como vendría a decir Ulrich Beck (1998), tiene un carácter catastrófico y ajeno a la voluntad del sujeto.

Larraín sabe que la sociedad precaria ha impulsado un reparto desigual de los riesgos de muerte y que estos están presentes en las decisiones de vida, y apela a que debería existir de parte de los individuos una responsabilidad sobre si mismos. Este es el incumplimiento que permite ser atrapado bajo el derrumbe: no cuidar de sí mismo, pese a las opciones de seguridad que ofrece el mercado (de trabajo en este caso). Por ello, la discrecionalidad respecto al "trabajo" y "la explotación" son responsabilidad de los trabajadores, de su propia soberania cognitiva del riesgo (ibid.). La relación de subordinación puede asumir las formas que estimen el capital y el trabajador, vaciando a la institucionalidad (al Estado) de su ejercicio regulador. Al realizar la operación argumentativa de vaciamiento de contenido político público y práctico de protección de "las regulaciones", la relación capital y trabajo quedaría sujeta a las influencias de actores privados con mayor poder e información en el campo social.

El vaciamiento de contenido no es solo ideológico, sino también material. Como lo señalara la Comisión investigadora de la Cámara (2011), los organismos fiscalizadores no contaban con financiamiento y personal para realizar una fiscalización real, ya que no tenían como contrapeso un marco legal y político de aseguramiento de derechos sociales a ejercerse. Por su parte, Alejandro Vio, quien fue despedido por el presidente Sebastián Piñera de su cargo de director del Servicio Nacional de Geología y Minería (Sernageomin), dijo al DiarioUChile (11 de agosto de 2010) que el servicio contaba con tan solo 16 fiscalizadores a nivel nacional y solo dos en toda la región de Atacama.

A la anterior zona de discrecionalidad empresarial se pueden agregar las características del sistema de multas a las empresas que incumplían las normas, ya que estas alcanzaban las $30 \mathrm{UTM}^{10}$ (2.118 dólares), lo cual hacía que las empresas prefirieran el pago de las multas a la inversión en infraestructura para procesos productivos seguros y adecuados. Todos estos elementos apuntan a legitimar activamente la precariedad como relación constitutiva

10 Nota de edición: unidad tributaria mensual; índice expresado en pesos y determinado por ley, el cual se actualiza en forma permanente por el índice de precios al consumidor (IPC) y se utiliza como medida tributaria. 
de las relaciones sociales y a inducir (en el riesgo) la tragedia como síntoma de la gubernamentalidad de las sociedades precarias.

El modelo de las "sociedades precarias" se replica en: (i) la desidia de la (des)regulación institucional sobre las condiciones de trabajo en que se desempeñaban los mineros de la mina San José; (ii) el prontuario de la empresa en materia de incumplimientos normativos y de accidentabilidad laboral; ${ }^{11}$ (iii) la dinámica precaria en que se inscribía la reproducción del ciclo productivo ante el abusivo espacio microfísico de las relaciones de poder en el mismo lugar de trabajo; ${ }^{12}$ y (iv) la permisividad de la institucionalidad y sus irregularidades para reabrir la mina en 2008, sin existir los antecedentes suficientes para dicha acción.

Luego del derrumbe se inició una investigación de parte de distintos organismos públicos, liderada principalmente por la Fiscalía de Atacama. La Fiscalía intentó reunir los antecedentes necesarios para dar paso a la formalización de Alejandro Bohn y Marcelo Kemeny. Luego de dos años de investigación, el Ministerio Público dio por cerrada la indagatoria, tras determinar que "no había antecedentes que permitieran presentar una acusación y no se pudiera establecer la existencia de un delito", ${ }^{13}$ mientras que la Comisión de Minería y Energía de la Cámara de Diputados del Congreso de Chile había determinado en enero de 2011 la responsabilidad

11 El informe de la Comisión Investigadora del Senado señalaba que "el 5 de enero de 2007 falleció don Manuel Villagrán Díaz (28 años), técnico geólogo, por un desprendimiento de material de la caja, debido a un estallido de roca, en la intersección de la rampa con el acceso del nivel 135 de esta mina”. En marzo del mismo año, la empresa fue obligada a paralizar sus faenas hasta que se encontraran las causas del hecho.

12 Tal como sostiene Héctor Tobar en el primer capítulo de su libro (2015, 3141), la discrecionalidad de los directores de la obra jugaba un rol disuasivo entre quienes habían notado las fallas y los avisos de derrumbe de la mina. Se apelaba a la "masculinidad", al "despido", al estatus, etcétera, todas reacciones asociadas a la homosociabilidad en el sector (Pávez y Hernández, 2014). En la misma dirección está la declaración de Estanislao Morales, quien afirmó: "yo mismo había sido testigo y objeto de burlas cuando uno iba con quejas. Inmediatamente te menoscababan dando a entender que no eras muy hombre. En otras palabras, te tildaban de maricón. Y claro, a la segunda que te dan ganas de quejarte, te quedas callado y te convences de que no va a pasar nada” (Centro de Investigación Periodística, 16 de julio de 2011).

13 Como señalaba el diario La Tercera (1 de agosto de 2015), Alejandro Bohn inició "querella por injurias y calumnias contra Vicenot Tobar, exsuperintendente de seguridad de la mina San José, y el exjefe regional del Sernageomin Anton Hraste, quienes hicieron declaraciones en que deslizaban responsabilidad de los empresarios en el accidente minero". Ambos tuvieron que desdecirse y señalar ante los tribunales que sus palabras no tenían sustento $\neq$. 
principal de los dueños de la empresa y una responsabilidad de incumplimiento de labores de los organismos reguladores en el derrumbe (Cámara del Congreso, 2011: 195-199).

Este hecho exhibe la indefensión de los mineros en el proceso de "obtención de justicia”, reproduciendo la misma lógica que los indujo y situó a padecer la actividad minera. Su posición social no cambió con el derrumbe, sino que más bien se reafirmó, conservó y se trasladó a otra esfera de la sociedad precaria (la ley y el derecho). En esta instancia, los trabajadores se enfrentaron a la misma vulnerabilidad y desprotección social que exculpó a los dueños de la mina, interpretando el derrumbe como un hecho imprevisible.

Así, el conflicto entre la significación del derrumbe como "accidente" o como "acción humana" problematizaba el enfrentamiento de los abogados y de los fiscales en el caso. Mientras Luis Urzúa, uno de los mineros, decía en CNN Chile (1 de agosto de 2013) que "esto no fue un accidente, ni obra de la naturaleza, sino una acción humana", los abogados defensores de la empresa señalaban en otra entrevista para el mismo medio que nos encontrábamos frente a "un lamentable accidente" (ibid.).

La tensión entre ambas interpretaciones del derrumbe involucra dos equidistantes posiciones respecto al riesgo, al conocimiento experto y a la subordinación cognitiva del riesgo (Beck, 1998). Por un lado, una condición fatalista de lo contingente del derrumbe, que normaliza y naturaliza la precariedad de las condiciones de explotación en la mina por medio de lo imprevisible y de la imposibilidad de "detectar el riesgo". Por otro lado, hay una visión focalizada en la capacidad tecnológica de "prever el riesgo" a partir del conocimiento de las condiciones morfológicas de la mina, de las medidas de seguridad permanente en la explotación y de las fiscalizaciones con que debía contar esta.

Para no suponer esta cuestión como un debate "teórico", habría que considerar el sistemático prontuario de incumplimiento de medidas solicitadas por la Asociación Chilena de Seguridad (ACHS), el Sernageomin y la Dirección del Trabajo a los administradores de la mina San José. Por ejemplo, la ACHS solicitó en octubre de 2006 la habilitación de salidas de emergencia, la ejecución de proyectos de ventilación y un estudio geomecánico. A la fecha del derrumbe nada de esto se había implementado. Días antes del hecho, la ACHS había insistido en desarrollar procesos de fortalecimiento (minero) para evitar el desprendimiento de rocas en la mina. Esta solicitud provino del "accidente" que había sufrido Gino Cortés el 3 de julio de 2010, a raíz del cual el trabajador perdió una pierna.

Pese a todos los antecedentes existentes, el sistema judicial, por medio del Juzgado de Garantía de la ciudad de Caldera (región de Atacama, Chile), aprobó el sobreseimiento de la causa por los delitos de "lesiones leves, prevaricación, cohecho y homicidio en contra de los expropietarios de la mina San 
José, Marcelo Kemeny Fuller y Alejandro Bohn Berenguer” (El Mercurio, 21 de noviembre de 2015). Esto se produjo debido a que fue acogida "la solicitud presentada por la defensa de los imputados, por encontrarse cumplido el plazo de prescripción de la acción penal de la causa iniciada en 2010, con la presentación de querellas de familiares" (ibid.).

Este hecho exhibe el carácter recurrente de la precariedad. Los argumentos referentes al gobierno precario de la mina, los cuales habían sido ratificados por diversos organismos públicos de fiscalización, fueron atribuidos a una contingencia indeterminable en sus causas, un suceso imprevisto, un "accidente", y no una situación inducida, autoconfigurada, a partir del incumplimiento de regulaciones en la explotación de la mina y en el (des)conocimiento técnico necesario de la morfología geológica del lugar.

El último reducto de la indefensión de los mineros fue la narración de "lo épico" de su "accidente". La idea del accidente como interpretación y relato del hecho puso la individualidad heroica frente a la tragedia como el factor que se debía documentar visualmente. En este sentido, la precariedad aparece nuevamente con un trasfondo centrado en valores como el esfuerzo, la lucha por la supervivencia y la idea de superación, los cuales invisibilizan la situación de dominación, explotación y de responsabilidad del empresariado.

Esta propuesta de visualización de "la tragedia" se materializó en el proyecto cinematográfico dirigido por la directora mexicana Patricia Riggen, quien realizó la película Los 33 (con la participación de Antonio Banderas y de Martin Sheen, entre otros), con un presupuesto de 26 millones de dólares (mayormente financiados por Carlos Eugenio Lavín). ${ }^{14}$ Este film exhibió tres dimensiones de la ampliación de la precariedad de la tragedia hacia "lo intangible": (i) la fagocitación discursiva de la interpretación y la narración de la tragedia, mediante un ejercicio metonímico que acallaba "la denuncia" y la sustituía por el heroísmo individual; (ii) la apropiación política y narrativa para el ejercicio de la propaganda política; y (iii) la continuidad de la indefensión de los mineros "fuera de la mina", al quedar desprovistos de la posibilidad de interceder en la representación ("que hicieron otros") de sí mismos.

14 Con su socio Carlos Alberto Délano, fundaron el holding Empresas Penta, a partir de negocios realizados en la década de 1980 en el campo de los seguros de vida. En 1991 adquirieron la AFP Cuprum y también Isapre Vida Tres S. A., y en 1999 compraron el Banco de Chile (vendido en 2000 al Grupo Luksic). Actualmente las inversiones del grupo se concentran en las empresas Penta Vida, Penta Security, Banco Penta y Banmédica, entre otras. En 2014 fue denunciado por el Servicio de Impuestos Internos de Chile, denuncia formalizada en 2015 por fraude al Fisco. Lavín utilizaba un sistema de financiamiento irregular de campañas políticas que lo eximía ante el fisco de carga tributaria. 
Esto fue acompañado, además, de una industria cultural y de un aparato de abogados que se apropió del "heroísmo individual" como la narrativa hegemónica en "enfrentar la precariedad", y de la apropiación de los derechos de autor y de la imagen de los mineros. Esto, finalmente, terminó en la presentación de una demanda de nueve de los mineros en 2015 a sus exabogados por el hecho de "estafa, apropiación indebida y contrato simulado" 15 (CNN Chile, 2 de noviembre de 2015); el Cuarto Juzgado de Garantía de Santiago de Chile rechazó tramitarla, alegando incompetencia.

Las citaciones fueron realizadas por el Tribunal de Caldera en mayo de 2016, en tanto que las primeras declaraciones se realizaron en agosto del mismo ańo, mientras que los mineros debieron volver a contar con la "asesoría" y la mediación de un nuevo abogado, Alejandro Peña, quien había sido fiscal del Gobierno en la persecución de "grupos terroristas".

El proceso legal por los recursos económicos comprometidos por las ganancias de la película fue la culminación de la indefensión. Con la operación de distintos equipamientos de la gubernamentalidad de las sociedades precarias, exhibiendo lo tortuoso, engorroso, lento y desigual del proceso de "búsqueda de justicia", se escribió un nuevo caso de institucionalización y de normalización de la precariedad.

La "profundidad histórica" de esta normalización es que, frente a la indefensión, los mineros habían logrado articular una figura de "protección" y amparo colectivo, una fundación (sin fines de lucro) que, de la mano de mecanismos compensatorios y solidarios, había canalizado aportes y ayudas económicas a los mineros. Pese a ser un organismo generado por los propios trabajadores, las relaciones entre los desprotegidos, entre las víctimas, amenazados por la permanente ansiedad (de justicia) en la desprotección y la precariedad, fue trastocada por la "barbarización de las relaciones sociales" (Fernández, 2013), lo cual repercutió en sus frágiles lazos de solidaridad, con el ejercicio del individualismo y el dinero como motor que aceleró la descomposición de las identidades y de las identificaciones colectivas producidas en el compartir la precariedad, especialmente en la experiencia de estar atrapados bajo tierra.

15 Los trabajadores acusaron a los abogados Remberto Rodrigo Valdés Hueche y Fernando Darío García O’Nell (este último vinculado al estudio Carey) de "haber incurrido en una serie de maniobras fraudulentas y engañosas para inducir a error a los '33', haciéndoles creer que tendrían una sociedad administrada por ellos, para, en definitiva, perjudicarlos y apropiarse de partidas de dinero que les corresponden" (El Mercurio, 4 de noviembre de 2015). Los abogados desmintieron esto y señalaron que ellos representaban a 24 de los 33 mineros en el momento de la demanda. 
Con las negativas de responsabilización del empresariado y la institucionalidad fiscalizadora, sumadas a la expoliación narrativa y material de la película, las acusaciones cruzadas entre mineros (respecto a la apropiación de dineros), la pérdida de credibilidad entre ellos, una solicitud a la Subsecretaría de Justicia presentada por dos mineros para investigar el destino de los montos percibidos por la Fundación Los 33, la destitución de la directiva de la Fundación y una demanda del Consejo de Defensa del Estado para la disolución de la entidad convierten el epílogo del derrumbe en una tragedia de mayor profundidad histórica.

\section{Conclusiones}

En 2010 la cifra de muertos en el sector de la minería chilena fue de 45 trabajadores. No hubo jamás responsables frente a la justicia por lo sucedido en la mina San José. De la mina San Esteban, 300 trabajadores quedaron sin empleo, y en 2011 seguían esperando el pago de sus finiquitos. La mina fue vendida y los mineros comenzaron un tortuoso camino de retorno desde el espectáculo de la escena pública hacia la precariedad de la cotidianidad.

Luego de la "tragedia", las estructuras de poder de las sociedades precarias persisten en su constante "creación 'automática' de individuos desechables y excluidos” (Žižek, 2013: 25). El resultado final de este largo proceso ha sido una estigmatización social de los mineros, una "marca precaria" (Butler), que se manifiesta en la actitud de los potenciales empleadores de la minería, quienes no los contratan y no los consideran para algún trabajo en minas.

Como señalara José Ojeda en 2014, "Éramos personajes públicos, ninguna empresa se arriesgaba a contratarnos" (La Nación, 2 de noviembre de 2014). Los 33 mineros habían pasado a conformar una suerte de lista negra, donde eran clasificados como "locos", "anormales" (por las consecuencias del encierro y las consecuencias del trauma) y "conflictivos" (por sus declaraciones de denunciar las prácticas de inseguridad en la minería y por haber demandado a los dueños de la mina San José).

Es interesante el hecho de que la santificación pública y popular de los mineros, del milagro de su resurrección (luego ser dados por muertos) y su salvación (al ser rescatados), sea solo contrastable con su satanización por parte de la cultura empresarial de la minería en el norte de Chile, en su expulsión. Porque si la violencia ejercida sistémicamente por la precariedad en el trabajo fue contenida en la conversión de los mineros en víctimas del fortuito y "lamentable accidente", para luego volverlos héroes, esta violencia regresó al año del derrumbe para orientarse hacia la expulsión social, hacia una zona de imposibilidad de integración, con el consecuente acrecentamiento de la indefensión. 
Es en este mismo regreso a la condición de indefensión que la mina, pese a toda la carga simbólica y a los traumas psicológicos que podría implicar este trabajo para cada uno de los 33 mineros, se vuelve nuevamente "una opción". Para el año 2014, muchos ya estaban insertos en empleos en el transporte y la minería, otros con emprendimientos independientes (en la construcción y el transporte) y otros aún permanecían en el desempleo, con problemas psicológicos y de alcoholismo.

La gubernamentalidad precaria desplegó los medios necesarios para invisibilizar la exposición de su síntoma en la escena pública. Luego de ser expuestos e idolatrados como objetos de la política y de la manipulación emocional, los mineros pasaron a ser una molestia, un estorbo. Es "el estorbo" el que persistentemente recuerda a la opinión pública que "si hubiese habido mayor seguridad, esto nunca hubiese pasado" (Jimmy Sánchez, en Canal 13, 24 de agosto de 2011), y que "no hay pena carcelaria, porque ninguno de nosotros salió muerto" (Mario Sepúlveda, ibid.).

Queremos destacar aquí cómo la sociedad precaria organizó, modeló y zanjó la tragedia que desnudaba su propio síntoma. Involucró un proceso narrativo, una apropiación simbólica y la construcción de un "imaginario del minero". Se trata del mismo imaginario evocado en otras circunstancias de la historia por las clases dominantes para referirse a la clase laboral y proletaria (Salazar, 2015: 452-474), a esa clase que cumple un rol sacrificial ("por la patria"), experimentando la redención a través de vivir en la exclusión, la barbarie y la precariedad.

Pero no todo ha sido "imaginario". Las instituciones fiscalizadoras de las actividades mineras, los tribunales de justicia, los poderes económicos del sector, el capital político y la industria cultural se unieron de forma sincrónica para sepultar a los mineros. La sociedad precaria modelada por el neoliberalismo vio constantemente su síntoma de constitución en casos como: (i) el incendio de la cárcel de San Miguel, con 81 muertos (Tijoux, 2011), y que fue un hecho modelado a partir de las leyes de encarcelamiento y prisionización (Salinero, 2012), que tiene las cárceles chilenas en expansión y licitación privada, con una población carcelaria que vive en el hacinamiento y la vulneración a los derechos humanos (Instituto Nacional de Derechos Humanos, 2014: 2); (ii) la huelga de hambre de los 34 comuneros mapuches el mismo 2010; (iii) los 1.383 niños y niñas muertos en el Servicio Nacional de Menores con el fracaso de la lógica de gestión neoliberal del organismo para, en este caso, dar respuesta a la crisis del cuidado privado a la infancia en Chile (Cappella y Gutiérrez, 2014); y (iv) las tragedias asociadas a los desastres naturales, como terremotos, tsunamis, inundaciones, erupciones, etcétera, que sacuden constantemente la geografía social chilena. 
La experiencia del Sur Global logra visibilizar estas contradicciones del trabajo, el cual no puede reducirse a un "estudio disciplinar", sino que requiere potenciar el carácter emergente de proyectos de investigación y de transformación orientados a clarificar los alcances de la lógica de mercantilización institucionalizada por parte del Estado neocolonial y neoliberal, así como de la fragilidad que asume la vida y el tejido social en contextos de racismo, discriminación, pobreza, sexismo, clasismo y vulnerabilidad social, como es el caso de América Latina. En este contexto, las sociedades precarias nos introducen en una "sociología de la tragedia", ya que allí aparecen los riesgos sociales asumidos por el desaseguramiento, la desprotección y la vulnerabilidad social como síntomas de la (re)producción del capitalismo y de la perdurabilidad de las estructuras coloniales de dominación. 


\section{FUENTES-PRENSA}

ABC Internacional

2015 "Cinco años después solo algunos de los 33 mineros han podido ver la luz", 6 de agosto de 2015. Disponible en: https://www.abc.es/ internacional/20150805/abci-rescate-mineros-chile-201508051103. html (fecha de consulta: 13 de agosto de 2017).

Canal 13, "Contacto"

2011 "Los 33: con los pies en la tierra. La vida después del rescate”, 24 de agosto de 2011. Disponible en: http://www.t13.cl/videos/contacto/ contacto-los-33-con-los-pies-en-la-tierra-parte-1 (fecha de consulta: 23 de agosto de 2017).

Centro de Investigación Periodística

2011 "Se salvan 33, mueren 45: siniestro balance de los accidentes de la minería chilena en 2010”, 17 de Julio de 2011. Disponible en: http:// ciperchile.cl/2011/07/16/se-salvan-33-mueren-41-el-siniestro-balancede-los-accidentes-de-la-mineria-chilena-en-2010/ (fecha de consulta: 16 de julio de 2011).

CNN Chile

2015 "Quedan muchos de los 33 que no entienden lo que está pasando", 2 de noviembre de 2011. Disponible en: https://www.cnnchile.com/pais/ luis-urzua-quedan-muchos-de-los-33-que-no-entienden-lo-que-estapasando_20151102/ (fecha de consulta: 11 de agosto de 2018).

2013a "Esta decisión no es antojadiza". En: www.cnnchile.com (fecha de consulta: 9 de agosto de 2017).

2013b "Mineros tildaron de 'rara' la investigación tras el derrumbe en la mina San José”, 1 de agosto de 2013. Disponible en: https:/www.cnnchile. $\mathrm{com} /$ pais/mineros-tildaron-de-rara-la-investigacion-tras-el-derrumbe-enla-mina-san-jose_20130801/ (fecha de consulta: 11 de agosto de 2017).

\section{Cooperativa}

2010 "Director LyD y seguridad laboral: La responsabilidad es primero del trabajador”, 25 de octubre de 2010. Disponible en: https://www. cooperativa.cl/noticias/pais/trabajo/director-lyd-y-seguridad-laboralla-responsabilidad-es-primero-del/2010-10-25/121647.html (fecha de consulta: 9 de agosto de 2017).

\section{DiarioUChile}

2010 "Mineros: Inseguridad bajo tierra". Columna de Sohad Houssein y Loreto Soto, 11 de agosto de 2010. Disponible en: https://radio.uchile. cl/2010/08/11/mineros- inseguridad-bajo-tierra/ (fecha de consulta: 25 de agosto de 2017). 
El Mostrador

2010a "Qué aprendimos de la mina San José”. Columna de María Ester Feres, 3 de septiembre de 2010. Disponible en: https:/www.elmostrador.cl/ noticias/opinion/2010/09/03/que-aprendimos-de-la-tragedia-de-lamina-san-jose/ (fecha de consulta: 15 de agosto de 2017).

2010 b "El drama de los mineros que quedaron fuera: Bohn y Kemeny les deben $\$ 1.300$ millones”, 18 de octubre de 2010. Disponible en: https://www.elmostrador.cl/noticias/pais/2010/10/18/el-drama-delos-mineros-que-quedaron-fuera-bohn-y-kemeny-les-deben-1-300millones/ (fecha de consulta: 20 de agosto de 2017).

El Mercurio (on line)

2010 "Minera ofrecía altos sueldos para atraer a trabajadores a un yacimiento complejo", 9 de agosto de 2010. Disponible en: http://buscador.emol. com/vermas/El\%20Mercurio/Nacional/2010-08-09/5332f379-6e404 bcc-bc5e-bd34fb76291e/Minera_ofrec\%C3\%ADa_altos_sueldos_ para_atraer_a_trabajadores_a_un_yacimiento_complejo/ (fecha de consulta: 12 de agosto de 2017).

\section{La Nación}

2014 "La vida luego del rescate: los 33 de Atacama, entre las divisiones, el éxito y el olvido", 2 de noviembre de 2014. Disponible en: https:// www.lanacion.com.ar/el-mundo/la-vida-luego-del-rescate-los-33-deatacama-entre-las-divisiones-el-exito-y-el-olvido-nid1740673 (fecha de consulta: 20 de agosto de 2017).

\section{La Tercera}

2015a "Mina San José: dueños encargan últimos informes para vender yacimiento", 1 de agosto de 2015. Disponible en: https://www.latercera. com/noticia/mina-san-jose-duenos-encargan-ultimos-informes-paravender-yacimiento/ (fecha de consulta: 9 de agosto de 2017).

2015 b "Sobreseen causa en contra de los dueños de la mina San José", 20 de noviembre de 2015. Disponible en: https://www.latercera.com/noticia/ sobreseen-de-manera-definitiva-a-duenos-de-mina-san-jose/ (fecha de consulta: 12 de agosto de 2017).

\section{The Clinic}

2010a "Wall Street Journal: El capitalismo salvó a los mineros". Disponible en: www.theclinic.cl, 14 de octubre de 2010 (fecha de consulta: 31 de agosto de 2017).

2010b “El prontuario laboral de la San José. La mina maldita”, 29 de octubre de 2010. Disponible en: https://www.theclinic.cl/2010/08/29/elprontuario-laboral-de-la-san-jose-la-mina-maldita/ (fecha de consulta: 29 de agosto de 2017). 
Biblografía

Alister, Cristian y Dasten Julián

2018 "Precariedad(es) laboral(es) en territorios extractivos de la Araucanía". En: Martín Ramírez y Stefan Schmalz (eds.), ¿Fin de la bonanza?: Entradas, salidas y encrucijadas del extractivismo. Ciudad Autónoma de Buenos Aires: Biblos.

Altvater, Elmar

2011 Los limites del capitalismo. Acumulación, crecimiento y huella ecológica. Buenos Aires: Mardulce.

Amin, Samir

1989 El eurocentrismo. Crítica de una ideología. México D. F.: Siglo XXI.

Antunes, Ricardo

2003 ¿Adiós al trabajo? Ensayo sobre metamorfosis del trabajo y el rol central del trabajo. Buenos Aires: Herramienta.

Auer, Peter y Sandrine Cazes

2000 "The Resilence of Long-Term Employment Relationship: Evidence in the Industrialized Countries”. En: International Labour Review, volumen 139, número 4. 379-407.

Barattini, Mariana

2009 "El trabajo precario en la era de la globalización ¿Es posible la organización?”. En: Polis, volumen 8, número 24. 17-37.

Beck, Ulrich

2006 La sociedad del riesgo global. Madrid: Siglo XXI.

1998 La sociedad del riesgo: hacia una nueva modernidad. Barcelona: Paidós.

Bengoa, José

2015 Historia rural de Chile central. Tomos I y II. Santiago de Chile: LOM ediciones.

Butler, Judith

2010 Frames of War. Londres / Nueva York: Verso.

2004 Precarious life: the powers of mourning and violence. Londres / Nueva York: Verso.

Capella, Claudia y Carolina Gutiérrez

2014 "Psicoterapia con niños/as y adolescentes que han sido víctimas de agresiones sexuales: Sobre la reparación, la resignificación y la superación”. En: Psicoperspectivas, volumen 13, número 3. 93-105. 
532 | Trabajos y trabajadores en América Latina (siglos XVI-XXI)

Carrasco, Celina y Patricia Vega

2011 Una aproximación a las condiciones de trabajo en la gran minería de altura. Cuaderno de Investigación número 40. Santiago de Chile: Dirección del Trabajo.

Castel, Robert

2010 El ascenso de las incertidumbres: trabajo, protecciones, estatuto del individuo. Buenos Aires: Fondo de Cultura Económica.

2003 La inseguridad social. ¿Qué es estar protegido? Buenos Aires: Ediciones Manantial.

1997 La metamorfosis de la cuestión social. Una crónica del salariado. Barcelona: Paidós Ibérica.

De la Garza, Enrique

2011 Trabajo no clásico, organización y acción colectiva. Tomos 1 y 2. México D. F.: Universidad Autónoma Metropolitana, Unidad Iztapalapa / Plaza y Valdés Editores.

2005 "Del concepto ampliado de trabajo al de sujeto laboral ampliado". En: Enrique De la Garza (comp.), Sindicatos y nuevos movimientos sociales en América Latina. Buenos Aires: Consejo Latinoamericano de Ciencias Sociales.

Donovan, Patrick; Ximena Oñate, Gonzalo Bravo y María Teresa Rivera 2008 "Niñez y juventud en situación de riesgo: la gestión social del riesgo. Una revisión bibliográfica”. En: Última Década, volumen 16, número 28. 51-78.

Dörre, Klaus

2009 “La precariedad: ¿centro de la cuestión social del siglo XXI?”. En: Actuel Marx Intervenciones, número 8. Santiago de Chile: LOM Ediciones. 79-108.

Escobar, Antonio

2014 "Instituciones y trabajo indígena en la América española". En: Mundos do Trabalho, volumen 6, número 12. 27-53.

Esping-Andersen, Gosta y Marino Regini

2000 Why Desregulate Labour Markets? Oxford, Reino Unido: Oxford University Press.

Fernández, Ana María

2013 La diferencia desquiciada. Géneros y diversidades sexuales. Buenos Aires: Biblos. 
Fevre, Ralph

2007 "Employment Insecurity and Social Theory: The Power of Nightmares". En: Work, Employment \& Society, volumen 21, número 3. 517-535.

Frege, Carola y John Kelly (eds.)

2004 Varieties of Unionism: Strategies for Union Revitalization in a Globalizing Economy. Oxford, Reino Unido / Nueva York: Oxford University Press.

Fuenzalida, Manuel y Rodolfo Quiroz

2012 "La dimensión espacial de los conflictos ambientales en Chile". En: Polis, volumen 11, número 31. 157-168.

Gago, Verónica y Sandro Mezzadra

2015 "Para una crítica de las operaciones extractivas del capital. Patrón de acumulación y luchas sociales en el tiempo de la financiarización”. En: Nueva Sociedad, número 255. 38-52.

Garretón, Manuel Antonio

2012 Neoliberalismo corregido y progresismo limitado: los gobiernos de la Concertación en Chile 1990-2010. Santiago de Chile: Universidad de Arte y Ciencias Sociales / Consejo Latinoamericano de Ciencias Sociales.

Gaudichaud, Franck

2015 Las fisuras del neoliberalismo chileno. Trabajo, crisis de la "democracia tutelada" y conflicto de clases. Santiago de Chile: Quimantú / Tiempo Robado Editoras.

Gudynas, Eduardo

2011 "El nuevo extractivismo progresista en América del Sur: Tesis sobre un viejo problema bajo nuevas expresiones”. En: Alberto Acosta et al., Colonialismos del Siglo XXI. Negocios extractivos y defensas del territorio en América Latina. Barcelona: Icaria. 75-92.

Harvey, David

2014 Diecisiete contradicciones y el fin del capitalismo. Madrid: Traficantes de Sueños.

2007 Espacios del capital. Hacia una geografía critica. Madrid: Akal.

2004 “The 'New' Imperialism: Accumulation by Dispossession”. En: Actuel Marx Intervenciones, número 35. 71-90.

Hoehn, Marek

2005 "Neoliberalismo, vulnerabilidad y disciplinamiento". En: Castalia, Revista de Psicología de la Academia, número 9. 32-42. 
534 | Trabajos y trabajadores en América Latina (siglos XVI-XXI)

Instituto Nacional de Derechos Humanos

2014 Estudio de las condiciones carcelarias en Chile: diagnóstico del cumplimiento de los estándares internacionales de derechos humanos. Santiago de Chile: Instituto Nacional de Derechos Humanos.

Julián, Dasten

2013 "Precariedad laboral y neocolonialismo en Chile. Un acercamiento a la minería del cobre”. En: CEScontexto, número 5. 28-43.

Kalleberg, Arne

2013 Good Jobs, Bad Jobs: the Rise of Polarized and Precarious Employment systems in the United States, 1970s to 2000s. Nueva York: Russell Sage Foundation.

Kessler, Gabriel

2015 Sentimiento de inseguridad. Sociología del delito. Buenos Aires: Siglo XXI.

Leiva, Sandra

2013 "Movimiento social de trabajadores subcontratados en la minería privada del cobre en Chile". En: Psicoperspectivas, volumen 12, número 2. 51-61.

2009 "La subcontratación en la minería en Chile: elementos teóricos para su análisis". En: Polis, número 24. 111-131.

Lorey, Isabel

2015 State of Insecurity. Londres: Verso.

Marín, Enrique

2013 "Precarious Work: An International Problem". En: International Journal of Labour Research, volumen 5, número 1. 153-168.

Muñoz, Mauricio

2011 La minería del cobre en Chile. Santiago de Chile: Instituto de Ciencias Alejandro Lipzchurt.

Organización Internacional del Trabajo

2015 Informe y análisis de la encuesta "Vida de mineros: Condiciones de trabajo y salud sexual de mineros chilenos en la región de Tarapacá". Santiago de Chile: Organización Internacional del Trabajo.

Paugam, Serge y Ying Zhou

2007 "Job Insecurity". En: Duncan Gallie (ed.), Employment Regimes and the Quality of Work. Oxford, Reino Unido: Orford University Press. 
Pávez, Jorge y Gerardo Hernández

2014 "Regímenes de trabajo, relaciones laborales y masculinidades en la gran minería del cobre (norte de Chile)". En: Trabajos y familias en el neoliberalismo. Hombres y mujeres en faenas de la uva, el salmón y el cobre. Santiago de Chile: LOM Ediciones.

Pérez, Sebastián

2016 "Trabajo y política en el Chile contemporáneo. Contribución a una lectura crítica del régimen de subcontratación”. En: Actuel Marx Intervenciones, número 20. 231-256.

Rivera, Nathaly y Patricio Aroca

2014 "Escalas de producción en economías mineras: El caso de Chile en su dimensión regional”. En: EURE, volumen 40, número 121. 247-270.

Rosanvallon, Pierre

2006 El capitalismo utópico. Buenos Aires: Nueva Visión.

Ross, Andrew

2008 "The new Geography of Work: Power to the Precarious?". En: Theory,

Culture \& Society, volumen 25, números 7-8. 31-49.

Salazar, Gabriel y Julio Pinto

2002 Historia contemporánea de Chile. Tomo III. Santiago de Chile: LOM Ediciones.

Salazar, Gabriel

2015 La enervante levedad de la clase política civil (Chile 1900-1973). Santiago de Chile: Debate.

Salinero, Sebastián

2012 “Por qué aumenta la población penal en Chile?: un estudio criminológico longitudinal”. En: Ius et Praxis, año 18, número 1. 113-150.

Santos, Boaventura de Sousa

2009 Epistemologías del Sur. México D. F.: Siglo XXI / Consejo Latinoamericano de Ciencias Sociales.

Sassen, Saskia

2010 Territorio, autoridad y derechos. De los ensamblajes medievales a los ensamblajes globales. Buenos Aires: Katz Editores.

Silver, Beverly

2005 Fuerzas de trabajo. Los movimientos obreros y la globalización desde 1870.

Madrid: Akal. 
536 | Trabajos y trabajadores en América Latina (siglos XVI-XXI)

Sociedad Nacional de Minería, Gerencia de Investigación y Desarrollo

2014 "Caracterización de la pequeña y mediana minería en Chile". Disponible en: http://www.sonami.cl/site/wp-content/uploads/2016/03/01.Importancia-de-la-pequena-y-mediana-mineria-Chile-VP11.pdf (fecha de consulta: 22 de agosto de 2017).

Therborn, Göran

2008 What does the ruling class do when it rules? State apparatuses and state power under feudalism, capitalism and socialism. Londres / Nueva York: Verso.

Thompson, Paul y Diane van den Broek

2010 "Managerial control and workplace regimes: an introduction". En: Work, Employment \& Society, volumen 24, número 3. 1-12.

Tijoux, María Emilia

2011 "El infierno en la torre 5. Reflexiones sobre la cárcel en Chile". En: Revista Latinoamericana sobre Cuerpos, Emociones y Sociedad, volumen 3, número 5 (abril-julio). 39-49.

Tobar, Héctor

2015 En la oscuridad. La historia jamás contada de los 33 mineros chilenos. Barcelona: Paidós.

Van der Linden, Marcel

2014 "Santo Precario: A new inspiration for Labor Historians". En: Labor. Studies in Working-Class History of the Americas, volumen 11, número 1. 9-21.

Wallerstein, Immanuel

1988 El capitalismo histórico. México D. F.: Siglo XXI.

Žižek, Slavoj

2013 Sobre la violencia. Madrid: Austral. 


\title{
Protagonismo femenino y construcción de la ocupación. La apropiación del espacio urbano por parte de las vendedoras minoristas en la Martha Bucaram (Quito, Ecuador)
}

\author{
Cristina Vega (España/Ecuador)* \\ Magali Marega (Argentina/Ecuador)** \\ Lucrecia Saltzmann (Argentina) ${ }^{* * *}$
}

RESUMEN: El texto aborda las experiencias laborales y vitales de un grupo de mujeres comerciantes minoristas de la Asociación Martha Bucaram, ubicada en el sur de Quito (Ecuador). Partiendo de las trayectorias de estas mujeres, de su relación con el municipio y con el barrio, se analizan los procesos de identificación en la venta minorista en la calle, en un contexto marcado por una reorientación en la regulación y un repunte de la informalización. Desde un enfoque que advierte la intersección entre el género, la etnicidad y la experiencia migratoria, y conectándose con investigaciones precedentes en sociología y antropología del trabajo acerca del protagonismo comercial femenino en la América Latina, el estudio revela los modos de ser y de estar en la calle, así como el papel de las redes familiares, asociativas y de vecindario para modular las restricciones económicas e institucionales que enfrentan estas mujeres en la gestión de "su negocio". Con una metodología cualitativa basada en la observación y en entrevistas en profundidad a minoristas y a otros actores barriales y municipales, se concluye que la venta confiere a estas mujeres un sentido

* Doctora por la Universidad de Cambridge. Investigadora y profesora del Departamento de Sociología y Estudios de Género de la Facultad Latinoamericana de Ciencias Sociales (FLACSO), Ecuador. Contacto: cregas@flacso.edu.ec

** Magister en Sociología por la Facultad Latinoamericana de Ciencias Sociales (FLACSO), Ecuador. Universidad Nacional de Rosario, Argentina, Grupo de Estudios sobre el Trabajo (GET) de la FLACSO, Ecuador. Contacto: magamarega@gmail.com

*** Doctorante en Humanidades con mención en Antropología, Universidad Nacional de Rosario, Argentina. Becaria doctoral del Consejo Nacional de Investigaciones Científicas y Técnicas (CONICET). Miembro del Núcleo de Estudios del Trabajo y la Conflictividad Social (NET), Universidad Nacional de Rosario, Argentina. Contacto: lucreciasaltzmann@hotmail.com 
de sí basado en la autonomía en el trabajo y en la capacidad para cooperar, negociar y disputar el espacio. ${ }^{1}$

PalabRas Clave: trabajo; género; informalización; venta minorista; espacio urbano.

\section{INTRODUCCIÓN}

En América Latina, la actividad comercial informal en el contexto urbano, con una acusada presencia femenina, ha marcado una tendencia histórica en la región que hoy, tras un periodo de retroceso, experimenta un repunte en el contexto de desaceleración y de contracción económica desde $2011 .^{2} \mathrm{La}$ tasa de informalidad (no agrícola) era del $50,1 \%$ en 2009, que se redujo al $46,8 \%$ en 2013 , tendencia a la baja que continuó para volver al $46,8 \%$ en 2015 (Organización Internacional del Trabajo, 2016: 38).

En Ecuador, el subempleo, definido por la insuficiencia de ingresos y/o de tiempo de trabajo, aumentó desde 2012, superando los niveles de 2007 (20,4\% para los varones y 19,1\% para las mujeres) (Instituto Nacional de Estadística y Censos, 2016). Si miramos datos comparativos de cinco ciudades ecuatorianas, en todas se advierte esta alza; en Quito, por ejemplo, pasó del 5,5\% en diciembre de 2015 al 13,1\% en 2016. La tasa de informalidad, que actualmente se estima con relación al Registro Único de Contribuyentes, oscilaba entre el 43,1\% en diciembre de 2007, el 39,3\% en junio de 2015 (el dato más bajo) y el 43,7\% en diciembre de 2016. En el ámbito urbano, los sectores formal e informal estaban prácticamente a la par.

Un reciente estudio proporciona una visión de conjunto que vincula a las mujeres a empleos y a condiciones más inestables y precarias, hecho que

1 Este texto está basado en la investigación "Mujeres, mercado laboral informal y empoderamiento. Venta directa y comercio minorista femenino en la Martha Bucaram", realizada por el GET de la FLACSO, Ecuador. Fue financiada por el Centro Internacional de Investigaciones para el Desarrollo (IDRC) y forma parte del proyecto Promoviendo el Empoderamiento Económico de las Mujeres a través de Mejores Políticas, coordinado por el Centro Interdisciplinario de Estudios sobre el Desarrollo-Uruguay (CIEDUR); involucra a Argentina, Bolivia, Chile, Ecuador, México y Uruguay.

2 Según la Organización Internacional del Trabajo (2016), desde 2011 el desempleo se ha incrementado en 1,5 puntos porcentuales (6,6\% en 2015 y 8,1\% en 2016), destacando el caso de Brasil (+2,9 puntos porcentuales) y de Ecuador (+1,2 puntos porcentuales). Afecta en mayor medida a jóvenes $(18,3 \%)$ y a mujeres $(9,8 \%)$, a pesar de que estas aumentaron su participación en el mercado laboral ( 0,3 puntos porcentuales en 2015). Los salarios medios también han descendido, al mismo tiempo que la informalidad comenzó nuevamente a crecer. 
se acentúa en momentos de crisis como el actual (Vásconez, 2016). Según la información, la "inactividad" femenina, concentrada en los primeros quintiles, se eleva al 50\%, mientras que su desempleo duplica el de los varones (entre el $10 \%$ y el $20 \%$ en la década de 1990 , el $4 \%$ en 2007 y el $8 \%$ en 2016). La participación en el sector informal en condiciones precarias, con bajos ingresos y desprotección social, es patente y corresponde al $51 \%$ de las mujeres y al 45\% de los hombres en 2014. En los últimos ańos de la denominada "década ganada", ${ }^{3}$ el crecimiento más moderado del empleo respecto a años anteriores va acompañado para las mujeres de un cuentapropismo precario que se acentúa paulatinamente. Para estas mujeres, desplazarse hacia trabajos formales resulta complicado. El pequeño comercio se perfila como una opción flexible ante la emergencia de crisis familiares, y es en él que se produce una mayor brecha en los ingresos por género. El estudio concluye que, si bien desde mediados de la primera década de los 2000 se presentan elementos positivos como la elevación del salario, el cierre de la brecha salarial y el crecimiento de la participación femenina, la presencia de mujeres en la informalidad y el subempleo se mantienen e incluso se incrementan.

La persistencia de la informalidad o informalización urbana ha generado un volumen importante de literatura desde distintas aristas. En ella, el pequeño comercio ha ocupado un lugar destacado. Si bien en un primer momento encontramos estudios generales sobre el peso y el lugar estructural del sector informal en el capitalismo latinoamericano (Cardoso y Faletto, 1977; Tokman, 1987; Farrell, 1985; Pérez Sáinz, 1995), más tarde, y dada la enorme heterogeneidad del campo informal, surgen otros abordajes más situados y centrados en actividades y miradas específicas. Se analizan, por separado o de forma conjunta, las transacciones comerciales que conectan campo y ciudad en la economía popular y su creciente inmersión en redes globales (Carbonetto, 1985; Tassi, Arbona, Ferrufino y Rodríguez-Carmona, 2012); los modos de identificación étnica, de clase y de género, y su anclaje socioespacial (Godoy y Stecher, 2008; Pereira Morató, 2008; Barragán, 2004, 2009; Kingman y Muratorio, 2014); las condiciones de trabajo y la relación con el mercado laboral (Abreu y Sorj, 1993; Das Neves Bezerra, 2012); las formas de regulación, organización y contienda política (Cuti Martins, 2006; Silva Londońo, 2008; Veleda da Silva, 2003); o las tramas familiares y comunitarias que atraviesa la venta (Olivo Pérez, 2010; Gago, 2015). En Ecuador, y desde una perspectiva de género, destacan los aportes de Lourdes Benería y María Floro (2006) sobre economía informal y organización de los hogares a comienzos de los años 2000. La fluidez entre actividades pagadas y no pagadas, formales e

3 Expresión frecuentemente utilizada por el entonces mandatario ecuatoriano Rafael Correa durante sus alocuciones públicas como contraposición a la etapa neoliberal. 
informales, permite a las mujeres negociar las tensiones entre el cuidado de la familia y la necesidad acuciante del ingreso. ${ }^{4}$ La superposición de actividades produce una intensificación del trabajo que redunda en una menor calidad de vida.

Conectándose con este enfoque de género sobre informalidad y comercio de calle, y anclándose en el estudio de los procesos de identificación en el trabajo y el impacto de las regulaciones, en el presente artículo se interroga sobre el papel crucial que juega la apropiación del espacio en la ocupación y el modo en que condiciona la agencia femenina en esta actividad. A partir de una investigación cualitativa sobre las trayectorias de comerciantes en la avenida Martha Bucaram, situada en el sur de Quito, examinamos el papel que adquieren las estrategias espaciales en un entorno de regulación, repunte de la informalidad y fragilidad de las dinámicas gremiales y de la intermediación entre la administración zonal y las organizaciones barriales.

Ante las limitaciones para acceder a otro tipo de trabajos por las escasas oportunidades de formación, el comercio minorista aparece como una posibilidad de obtener un dinero inmediato. Como revelan las trayectorias, vender en la calle forma parte, en muchos casos, de una historia familiar que se hereda, mientras que en otros es una salida frente a acontecimientos sobrevenidos (violencia doméstica, separaciones, accidentes, etcétera) y un modo de afrontar las cargas familiares. Arraigar la venta al espacio y a las redes locales permite a estas comerciantes disputar algunas iniciativas de regulación, generar nuevas expectativas y afirmar su autonomía en un contexto adverso.

El texto está organizado de la siguiente manera. En primer lugar planteamos la perspectiva teórica que guía la investigación, situando el foco en la ocupación en tanto experiencia atravesada por la informalización y estrechamente vinculada a la movilidad y a la territorialización. Seguidamente presentamos el entorno del estudio en lo que se refiere al sector de venta autónoma, su composición social, su regulación y su anclaje en la ciudad y en la zona de estudio. Luego exponemos la metodología que ha guiado el trabajo con carácter previo al desarrollo del análisis en tres aspectos fundamentales: (i) la venta en las trayectorias de vida de las mujeres, (ii) las disputas y las intermediaciones en torno a la regulación, y (iii) las estrategias espaciales en la calle y los vínculos barriales. El texto finaliza esbozando algunas conclusiones que dan cuenta de los modos en que actualmente se construye un sentido propiamente femenino de la ocupación en estos entornos populares.

4 Para las autoras, el trabajo altamente informal, en el que figura la venta en la calle, sería aquel con jornadas extensas (de hasta 12 horas) e irregulares (no están pautados estrictamente los días de trabajo), con bajo ingreso (no llegan al salario básico) y condiciones precarias (exposición a condiciones climáticas y sin protección de seguridad social). A esto se añaden elevadas cargas de trabajo no remunerado. 
Los análisis sobre las metamorfosis del trabajo desde la sociología y la antropología han apuntado a la emergencia de nuevos "modos de ser en la informalidad", que conviven con otros previamente asentados (Antunes, 2011; Gómez y Pacheco, 2014). La informalización y la precarización del trabajo se vuelve una característica constitutiva y creciente de la acumulación del capital, que se intensifica en periodos de crisis. "Entender-como sugiere el autor- sus modos de expresión y sus significados es, por lo tanto, importante para que podamos tener una mejor comprensión de los mecanismos y de los engranajes que impulsan el mundo del trabajo hacia la informalidad" (Antunes, 2015: 71). Junto a asalariados sin registro que han perdido o fragilizado su estatuto contractual, a autónomos y/o a emprendedores, perviven los denominados trabajadores informales tradicionales, ${ }^{5}$ con trabajos estables, inestables u ocasionales, formas de inserción extremadamente precarias y caracterizadas por una renta muy baja y por la ausencia de garantía en cuanto al acceso a derechos sociales y laborales básicos. En ocasiones trabajan en solitario, pero habitualmente lo hacen movilizando fuerza de trabajo familiar. La heterogeneidad en este campo "tradicional" es considerable, pero, en todo caso, el protagonismo femenino y la condición precaria son elementos recurrentes.

Si bien los enfoques estructuralistas duales (formal versus informal), críticos y no críticos, de las décadas de 1970 y 1980 se centraron en los límites del sector moderno en el desarrollo capitalista en América Latina y en la persistencia de la pobreza y de la marginalidad urbana (Nun, 1969; Tokman, 1987; Portes y Haller, 2004), hoy el examen de las fusiones de lo formal y lo informal (Benería, 2006; Pérez Sáinz y Mora Salas, 2009), las distintas conceptualizaciones del sector informal (Neffa, 2009; Echebarría, Aguado y Barrutia, 2010; Coraggio, 2002; Singer, 2001; Hintze, 2010) o incluso el descentramiento epistémico de este binario (Denning, 2010) invitan a otro tipo de planteamientos. Estos contribuyen a incorporar al análisis una pluralidad de sujetos, instancias y procesos no laborales, a considerar trayectorias más que categorías estancas y a pensar el trabajo desde los actores y sus estrategias.

Entre ellos destaca la mirada sobre el trabajo ampliado, cuyo epicentro ha sido el "trabajo no clásico" (De la Garza, 2011). La propuesta no solo se limita a desplazar los trabajos industriales, estables y regulados, estudiando aquellos que quedan fuera de este esquema (call centers, vendedores

5 Estos están “insertos en las actividades que requieren baja capitalización, buscando obtener una renta para el consumo individual y familiar. Los que ejercen este tipo de actividad viven de su fuerza de trabajo, llegando a utilizar la ayuda del trabajo familiar o de empleados temporales" (Alves y Tavares, 2006, en Antunes, 2015: 71). 
ambulantes, taxistas, trabajadoras del hogar, trabajadoras del sexo, etcétera), sino que pasa a examinarlos en la encrucijada de distintos mundos de vida, territorios y tiempos que exceden el puesto, el entorno de la empresa o las relaciones laborales. La ocupación, en tanto vivencia y sentido del trabajo, en tanto apropiación del mismo, se puede gestar en las relaciones vecinales y familiares, en la calle, pero también en la casa y en el mercado, en el puesto y en la experiencia encarnada en el transporte; puede fraguarse en una historia estable de oficio o profesión que se transmite de generación en generación, en el entorno de la organización y el conflicto o en la vulnerabilidad, la intermitencia o la itinerancia de la actividad. ${ }^{6}$ Como advierten Laís Abramo y Cecilia Montero (2000), no se trata aquí de "perderse en la singularidad" de cada caso, sino de entender cómo distintas políticas, dinámicas de mercado y configuraciones simbólicas estructurantes median la construcción de la ocupación, al mismo tiempo que esta se configura según el género, la etnicidad o el origen, dando forma a distintas composiciones de clase.

Esta aproximación nos permite, además, atravesar la compartimentación entre actividades con y sin ingresos, "productivas" y "reproductivas", públicas y privadas, algo que (como indica la literatura feminista) es fundamental para entender el modo en que mujeres y hombres se relacionan con el mercado de trabajo y con los trabajos cotidianos que realizan, y el modo en que esto alumbra distintas atribuciones y valoraciones del hogar, la familia y los cuidados (Todaro y Yáńez, 2004; Díaz, Godoy y Stecher, 2005; Tarrés, 2007; Guadarrama, Hualde y López, 2012). En este sentido, las restricciones, intrínsecas e impuestas, y las estrategias para enfrentarlas presentan un claro carácter articulado de género y raza (Kabeer, 2001).

Para los efectos de nuestro estudio, la apropiación del trabajo en ocupaciones generalmente informales y feminizadas, como la venta callejera, está estrechamente conectada a la construcción de un territorio en y más allá del puesto de trabajo. ${ }^{7}$ En él confluyen vendedoras y compradoras junto con actores del

6 "La experiencia de trabajo para muchas gentes es todavía importante en el total de su tiempo de vida, pero el trabajo coexiste en los trabajadores con otros espacios de experiencia como los de la vida en el sindicato (cuando lo hay), con la reproducción externa al trabajo (familia, ocio, tiempo libre, relaciones de amistad y parentesco, la vida en el barrio), y en ocasiones con la experiencia en la política pública o en los partidos políticos" (De la Garza, 2011: 30).

7 En esta línea es en la que cobra sentido el desplazamiento hacia el concepto de precarización en tanto "conjunto de condiciones, materiales y simbólicas, que determinan una incertidumbre acerca del acceso sostenido a los recursos esenciales para el pleno desarrollo de la vida de un sujeto. Esta definición permitiría superar las dicotomías público/privado y producción/reproducción y reconocer y dar visibilidad 
municipio, de las juntas barriales, de las asociaciones, pero también con vecinos y transeúntes. El espacio no es aquí un telón de fondo sobre el que se desarrollan los acontecimientos, sino un elemento clave que es preciso conquistar, amoldar, pelear incluso, en el despliegue de la ocupación (Kingman, 2009). La venta en la calle es una estrategia de supervivencia fluctuante en la que con frecuencia se produce una pugna en torno a la ubicación espacial, tanto en el caso de los puestos semifijos como en el de los ambulantes (Veleda da Silva, 2003). Dicha pugna (que habitualmente se ha formulado en términos de seguridad, salubridad, riesgo ambiental, patrimonio, competencia comercial y regulación del trabajo) se relaciona con los proyectos de renovación urbana, con la emergencia de centros comerciales que buscan aglutinar el consumo y con los modos en que se ordenan, tipifican y segregan zonas, actividades y grupos sociales. Todo ello, a su vez, y como sugiere Eduardo Kingman (2014), da cuenta de la vitalidad de las culturas populares callejeras latinoamericanas y pone de relieve las tensiones que suscitan los procesos de modernización contemporáneos. Podemos decir entonces que en América Latina la experiencia de la no formalidad en la venta, con una fuerte presencia de mujeres, especialmente indígenas, es eminentemente una experiencia de movilidad y (des)territorialización que puede ser leída bajo la mirada de lo que, siguiendo a Henri Lefebvre, hoy llamamos "derecho a la ciudad".

El pesimismo sobre el desmoronamiento de colectividades y de vecindarios frente a las arremetidas fragmentadoras y segregadoras de la urbanización capitalista cede en el análisis ante la dimensión humana y las prácticas de apropiación creativa del espacio urbano (Harvey, 2013). Si bien en Ecuador, particularmente en Quito (Carrión, 2005; Kingman, 2014; Hanley y Ruthenburg, 2005), el foco ha estado puesto en la remodelación de los centros históricos urbanos, aquí, y en ocasiones vinculado a este mismo proceso, nos desplazamos a un barrio de la periferia para comprender los procesos de pugna y apropiación del espacio desde las prácticas del comercio minorista.

\section{La AVENIDA MaRTHA BUCARAM Y LAS VENDEDORAS MINORISTAS}

La avenida Martha Bucaram es la arteria que recorre 17 barrios pertenecientes a la Ciudadela Ibarra, en la parroquia La Ecuatoriana, en la zona suroccidental de Quito. Estos barrios, ubicados en un extremo del área metropolitana y pertenecientes a una antigua hacienda, se constituyeron a partir de la expansión urbana de finales de la década de 1970 mediante un proceso

a las interconexiones entre lo social y lo económico que hacen imposible pensar la precariedad desde un punto de vista exclusivamente laboral y salarial" (Colectivo Precarias a la Deriva, 2004: 28). 
de compra y de loteamiento durante la presidencia democrática de Roldós Aguilera, cuya esposa y operadora política da nombre a la avenida. Fue a través de la presión y de la autogestión de las cooperativas de vivienda, en este caso la Unión de Trabajadores Autónomos de Quito, ${ }^{8}$ y de una serie de intermediaciones político-partidarias legadas de una administración a otra, que se lograron equipamientos y servicios básicos.

Estos barrios fueron literalmente construidos por vendedores ambulantes del centro histórico de la ciudad, pobladores de origen rural que conformaron un "subproletariado" integrado por empleadas domésticas, peones de la construcción, pequeños artesanos, limpiadores de calzados, etcétera (Achig, 1983; Unda, 2000). Los efectos de la reestructuración agraria y la débil integración al mercado capitalista, junto a la existencia de un mercado interno, estimularon la migración y la inserción precaria en el sector informal (Farrell, 1985; Hanley y Ruthenburg, 2005). Después de un peregrinaje por el inquilinato y de la deambulación en la venta, lograr un suelo en la ciudad sobre el cual poder recrear lazos de propiedad, parentesco y paisanaje se convertió en uno de los hilos centrales de la identidad popular urbana durante este periodo (Ortiz y Martínez, 1999).

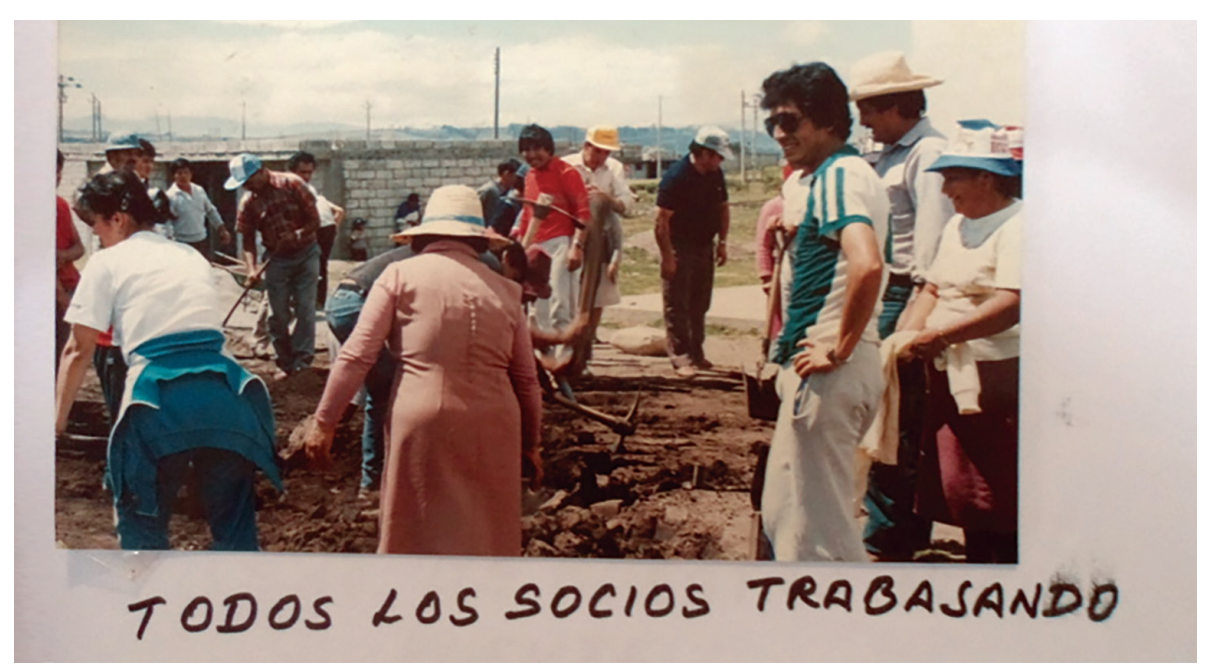

Minga en la avenida Martha Bucaram. (Archivo no fechado del Comité Pro-mejoras.)

8 Comandada por el ya difunto señor Lema, la Unión de Trabajadores Autónomos de Quito fue la cooperativa de vivienda que movilizó las energías de los residentes por varias décadas. Con el tiempo, el cariz de los vínculos clientelares generó conflictividad interna y fragmentación de la organización, dando paso a la conformación de pequeños comités menores. 
El esfuerzo colectivo para lograr lo básico, obteniendo así legalidad y sentido de ciudadanía, cede en años subsiguientes ante un esquema de reproducción crecientemente individualizado y familiar. El precio del suelo sube, algunos moradores venden sus viviendas y el transporte y las infraestructuras ganadas contribuyen a la llegada de nuevos habitantes que, como explica uno de los iniciadores, carecen de motivos para organizarse "porque todo está hecho". Algunos dirigentes y exdirigentes de Ciudadela Ibarra señalan entre los problemas actuales del barrio la delincuencia, mayormente centrada en la venta y el consumo de drogas, la limpieza y, en menor medida, el comercio en la calle. Las directivas barriales y los comités promejoras se activan en el contacto con agentes policiales, campañas institucionales y vecinos para la celebración de festividades, estrechamente entretejidas a partidos y campañas políticas. La Asociación de Vendedores Minoristas Martha Bucaram (en adelante AMB) ha sido convocada a diversas movilizaciones, generándose entre la dirigencia distintas visiones acerca de cómo deberían relacionarse con las formaciones partidistas.

La remodelación del centro histórico de la ciudad, un proceso que fue cobrando fuerza desde la declaración del casco histórico en 1978 como Patrimonio de la Humanidad (Carrión, 2005), que en una primera fase se llevó a cabo entre 1999 y 2003, ${ }^{9}$ condujo a muchos vendedores callejeros, especialmente indígenas, a desplazarse a zonas menos céntricas y a otros a ubicarse en mercados. Esto ha producido, ya en los años 2000, distintas oleadas de movilidad para la venta. Si ponemos atención a la procedencia de las vendedoras en la $\mathrm{AMB}$ veremos que en los últimos años confluyen en el barrio y en la avenida, tanto a través del desplazamiento residencial como del comercial, desde distintos puntos de la ciudad donde el acoso o la expulsión dificultó la venta y/o resultaba más cómodo vender cerca del domicilio. En general, se trata de población con bajos niveles de formación, en edad laboral, mayoritariamente femenina, sin permisos y sin afiliación al seguro social. ${ }^{10}$

9 Desde mediados de la década de 1990, de la mano de la nueva percepción del espacio público en el fortalecimiento de la identidad nacional, la relativa tolerancia hacia el comercio se tornó en acoso en un contexto de expansión de la informalidad. En 1994 se puso en marcha un plan municipal con un préstamo del Banco Interamericano de Desarrollo que incluía la regulación de la venta en la calle y la reubicación de 7.000 vendedores (Hanley y Ruthenburg, 2005). A pesar de las alabanzas que mereció la iniciativa, los requisitos exigidos dificultaron la vida de muchas personas migrantes, principalmente mujeres.

10 El Primer Censo de Comerciantes Autónomos (2011) para todo el distrito arroja algunos datos relevantes: el 62\% corresponde a población entre los 18 y los 53 años de edad; el $64,4 \%$ son mujeres y el $35,6 \%$ son hombres; la jefatura del hogar es del 
Desde mediados de la primera década de los años 2000, la venta experimentó una nueva fase regulatoria de mano de la gestión municipal de Augusto Barrera, de Alianza País. Si bien este impulso se desliga de la concepción patológica y delincuencial previa, recuperando la informalidad para la economía popular, y asume una visión modernizadora, también acarrea nuevos problemas. La reubicación y la ordenación de la venta minorista en la última década entraña profundos cambios, entre los que figura la erosión de las organizaciones formales e informales que existían en el centro histórico, así como el desplazamiento de la venta hacia otras zonas que se convierten en subcentros que pivotan en torno a las nuevas centralidades, en este caso del sur. Para las minoristas, las nuevas regulaciones implicaron el uso del carnet, capacitaciones, uniforme y pago de regalías, así como el aumento del control de la policía municipal.

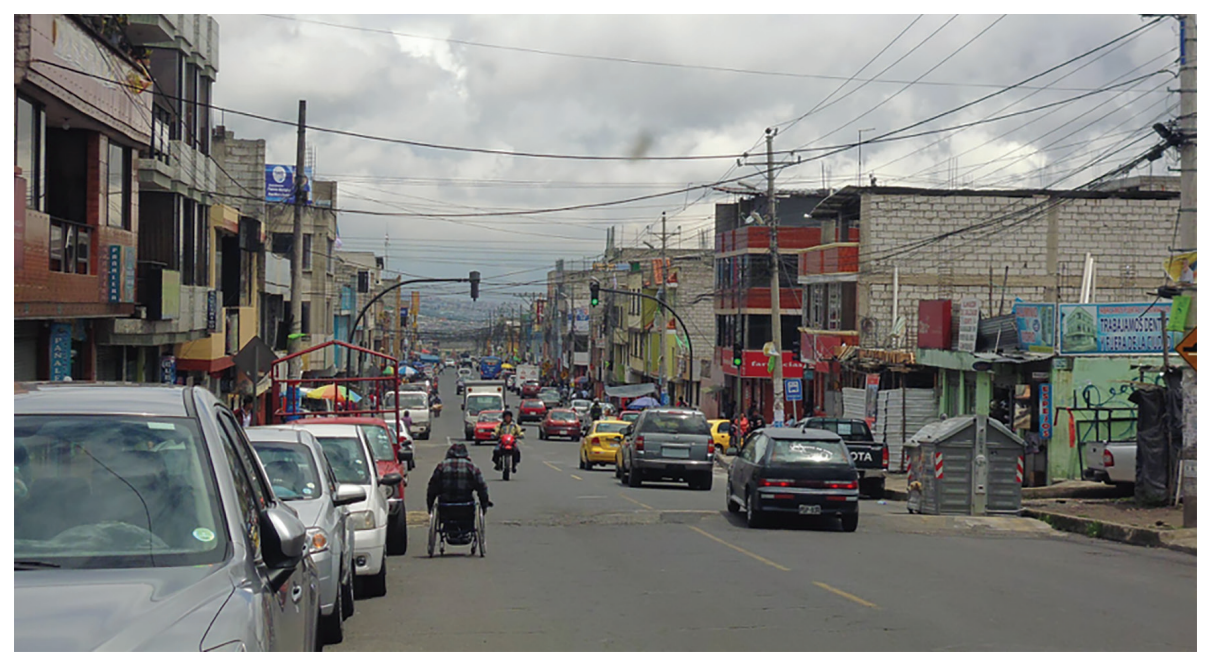

Avenida Martha Bucaram. (Fotografía de las autoras, 20 de enero de 2017.)

$40,2 \%$ en las mujeres y del 29,4\% en los hombres; el 92\% alcanza niveles de educación primaria y secundaria, aunque no siempre los culminen; más del 50\% vive en cuartos y mediaguas de arriendo; entre las administraciones que registran más vendedores (71\%) se encuentran Eugenio Espejo, Valle de Tumbaco, Eloy Alfaro y Manuela Sáenz; en Quitumbe se registra un 8\% (430 vendedores), el 49,2\% son fijos, el $13,9 \%$ son semifijos y el $36,8 \%$ con ambulantes. En cuanto al permiso, apenas el $17,5 \%$ lo poseen, en tanto que el $71,7 \%$ no cuenta con autorización; el $48,5 \%$ está asociado, frente al $51,5 \%$ de independientes; el $72 \%$ no posee certificado alguno extendido por una institución de salud; el 75\% no se encuentra afiliado al Instituto Ecuatoriano de Seguridad Social (IESS); apenas el 13\% está registrado en el Seguro Social; el grueso se dedica al giro (rubro) de alimentos procesados. 
En este tránsito de un tratamiento a otro a lo largo de los años 2000, la avenida Martha Bucaram se convirtió en un importante foco comercial estratégico que atrae a consumidores locales de los distintos barrios, quienes que atraviesan la avenida e incluso de otros puntos próximos durante los fines de semana. Cercano al mercado mayorista y al de Solanda, donde se abastecen las minoristas haciéndose con el remate, la avenida forma parte de un circuito al que se integran las zonas comerciales de Las Cuadras, La Aurora, Guamaní, La Ecuatoriana y La Arcadia. La avenida concentra comercios de muy distinto tipo, además de restaurantes, academias, supermercados y empresas medianas. Entre la calle 6 y la 10, tramo en el que se sitúa la asociación, existe además una alta densidad de puestos fijos, semifijos y ambulantes que se retroalimentan. Cabría hablar aquí de nueva centralidad no planificada en la medida en que la zona aglutina y atrae (además de residencias) servicios, empleo, comercio, ferias, pequeños negocios, talleres y otros lugares de interés para la población, entre los que destacan distintas canchas deportivas y el parque de la Unión de Trabajadores Autónomos de Quito (Beuf, 2011). ${ }^{11}$

En este como en otros sectores, la administración zonal ha promocionado una plataforma de venta (véase la siguiente fotografía), pero también aquí es rechazada por las minoristas, que prefieren mantener sus distintas mercaderías en las aceras más transitadas a falta de un centro comercial a su medida: "si no nos entregan un mercado comercial, nosotros de aquí no nos vamos a mover", sentencia Blanquita, vendedora en la Martha Bucaram. Algunas de las que se movieron volvieron a la calle, mientras que las que permanecieron se quejan de las que están fuera restándoles ventas.

11 No se trataría, en la Martha Bucaram, tanto de un proceso agudo de acumulación de capital en la periferia (Harvey, 2013) como de la conformación de pequeños subcentros que, gracias al comercio, las infraestructuras como también los transportes, como también a la disposición de una vía amplia a cuyos lados se puede parquear sin dificultad, atrae a residentes de sectores populares de barrios circundantes. Quitumbe, donde se sitúan el terminal y otras infraestructuras, sería el epicentro en esta jerarquización territorial; en él se sitúan, efectivamente, grandes superficies comerciales y empresas de mayor envergadura. 


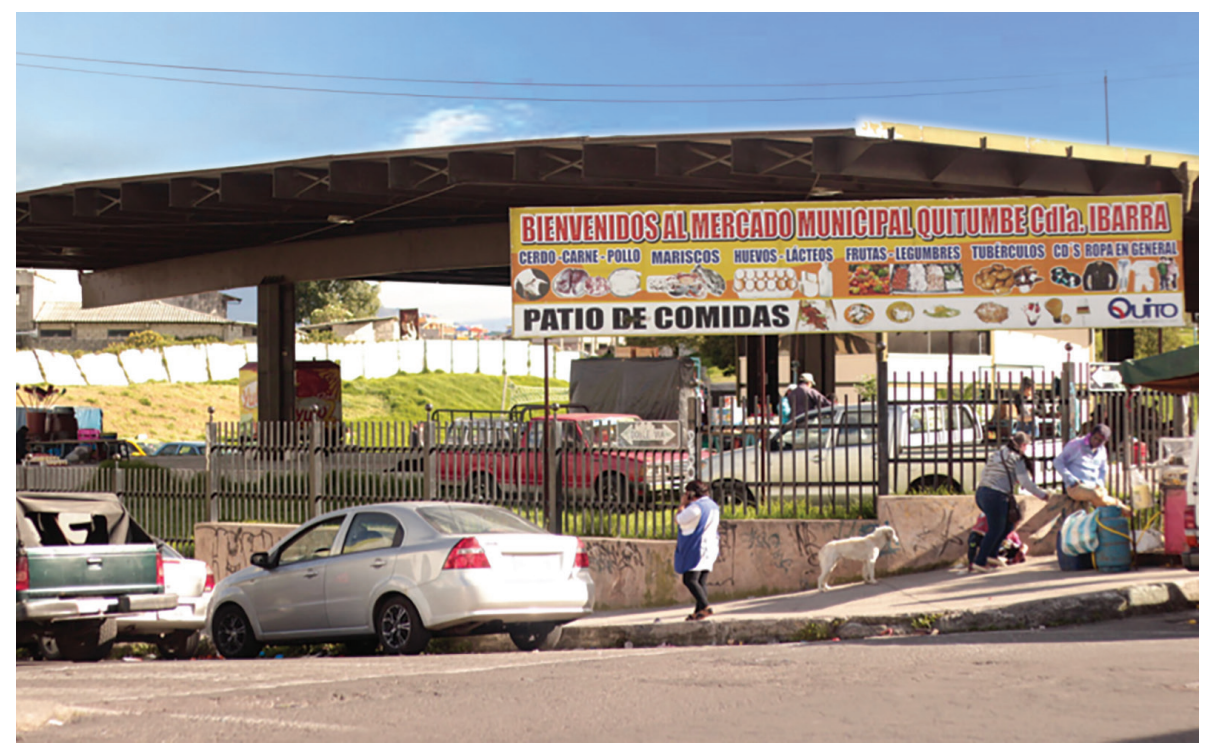

"La Plataforma". (Fotografía de las autoras, 20 de enero de 2017.)

La AMB es una organización de primer grado que se creó en 2012. Es parte de la Federación de Comerciantes Minoristas de Pichincha (FEDECOMIP), vinculada a su vez a la Confederación Unitaria de Comerciantes Minoristas y Trabajadores Autónomos del Ecuador (CUCOMITAE), de carácter nacional. La capacidad de estas organizaciones se reforzó en la década de 1990, en un momento de fuerte convulsión política y creciente precarización social. Desde entonces han visto debilitarse sus bases locales, aunque también han asistido a la emergencia de nuevas asociaciones que, como la AMB, nacen de las nuevas políticas urbanas. ${ }^{12} \mathrm{La}$ confrontación entre estas organizaciones y el gobierno de Alianza País ha sido una constante en los últimos años; este hecho acabaría minando el respaldo popular al partido de gobierno. A pesar de que la regulación en la Martha Bucaram es comparativamente más laxa que la del Centro, la AMB se conforma como un modo de "permanecer en la calle" (Graja Vizcaino, 2014) en un nuevo momento de ordenación. Se inicia con 40 asociadas y en la actualidad ronda las 100 personas asociadas, 70 mujeres y 30 hombres, aunque no todas asisten a las reuniones. A través de la misma, las vendedoras se resguardan de los controles, regulan el espacio entre sus integrantes y negocian con las autoridades del distrito. Si bien las nuevas reglamentaciones del comercio

12 En esta misma área se ubica la ASOEMPRO, una asociación más antigua y de menor tamańo, recogida en el Censo, también asociada a la FEDECOMIP. 
minorista ${ }^{13}$ desde 2008 reconocen y formalizan parcialmente la venta en la calle, como veremos, no están exentas de ambivalencias. La conformación del nuevo equipo municipal, con otro enfoque tras las elecciones de febrero de 2014, ${ }^{14}$ añade mayor complejidad a la cuestión, al poner freno al proceso y generar nuevas sinergias entre las dirigencias y el candidato de oposición (y futuro alcalde, Marcelo Rodas, de SUMA-VIVE), en un contexto electoral.

\section{Metodología}

El estudio se desarrolló en dos fases, entre mayo y diciembre de 2015, y entre febrero y mayo de 2016, ampliándose de enero a febrero de 2017. Se aplicó una metodología cualitativa basada en 24 entrevistas en profundidad a comerciantes, todas ellas de la asociación, así como en observaciones de la actividad de venta. ${ }^{15}$ Se entrevistó también a distintos dirigentes: dos de la AMB (uno de la CUCOMITAE y uno de la FEDECOMIP), el exalcalde Augusto Barrera, el actual director de la de la Administración Zonal de Quitumbe, junto a dos responsables municipales del comercio en esta área, a cinco dirigentes barriales y a otros actores del vecindario. ${ }^{16}$ Las entrevistas a las minoristas tenían

13 Desde la CUCOMITAE, próxima al extinto partido de orientación maoísta, Movimiento Popular Democrático, hoy Unidad Popular, se contribuyó a la redacción de la Ley de Defensa del Comerciante Minorista y el Trabajador Autónomo (2008) que, si bien fue aprobada en Asamblea Nacional en 2011, finalmente recibió el veto del presidente Rafael Correa. Esta sistematizaba algunos reclamos básicos como la cuestión del espacio público, la necesidad de estabilidad laboral, los créditos y el amparo de los comerciantes minoristas. La Ley Orgánica de Economía Popular y Solidaria (LOEPS) (2011) recuperó solo en parte algunos de ellos. A nivel municipal, las ordenanzas N. 0253 (2008) y N. 0280 (2012), esta última negociada con la CUCOMITAE, contribuyeron a tipificar a los vendedores, establecer zonas permitidas y no permitidas, conceder permisos y otorgar puestos en ferias y mercados.

14 Augusto Barrera, de Alianza País, es sustituido en el Gobierno por Mauricio Rodas, de SUMA-VIVE, una agrupación vinculada a las élites empresariales que se erigió en torno a significantes "postpolíticos", sintonizando con sectores medios y populares respecto a los impuestos locales (Ramírez y Coronel, 2014). Durante las elecciones de 2017, esta fuerza radicalizaría sus posiciones uniendo esfuerzos con la oposición de derechas liderada por el banquero Guillermo Lasso.

15 La segunda fase se llevó a cabo durante la campaña electoral, y tuvimos ocasión de asistir a la festividad del Carnaval auspiciada por el candidato de derecha.

16 Además de las entrevistas a responsables municipales, contamos con información de la Agencia de Coordinación Distrital del Comercio (ACDC), de la Administración 
por objeto abordar su experiencia en la venta, sus limitantes y sus estrategias para trabajar, además del modo en que todo ello se entreteje con otras actividades vinculadas al hogar, a la familia y también a la participación asociativa. Entendemos que una aproximación de género nos permite dar cuenta de la abrumadora presencia de mujeres, mestizas e indígenas, en las calles, muchas de ellas vecinas de la Ciudadela Ibarra. Las asociadas tienen en su mayoría puestos fijos y alquilan pequeños bajos para almacenaje; algunas llegan con camionetas en las que exponen su mercancía o se instalan en pequeños puestos bajo lonas. Hay quienes trasladan su mercadería en carros. Finalmente, encontramos vendedoras que lograron arrendar un local (muy pocas) u ocupan diminutas bodegas que les sirven como trastienda. Algunas llegan los fines de semana y establecen puestos semifijos, otras son "feriantes" que transitan a lo largo de la semana por el circuito ya aludido.

Entrevistamos a mujeres que se dedican a diferentes "giros", entre los que destacan, casi a la par, la venta de indumentaria y los alimentos y las comidas preparadas. Aproximadamente la mitad de las entrevistadas son casadas; el resto son jefas de hogar solas, divorciadas o viudas. Todas tienen entre dos y cuatro hijos. En cuanto al nivel de estudios, menos de la mitad ha concluido la primaria, algunas terminaron la secundaria y otras son analfabetas.

Enfocar las entrevistas desde la reconstrucción de sus trayectorias de vida y trabajo fue el medio para situar su ubicación actual y su vivencia de la venta. Entendemos con Sandra Harding que "las experiencias sociales características de las mujeres y de los hombres ofrecen bases diferentes para la elaboración del conocimiento" (1998: 8). En este sentido, comprender cómo y desde dónde llegan estas mujeres a la venta, qué restricciones enfrentan y qué salidas les dan, por qué se asocian y cómo actúan para defender su espacio social y su presencia simbólica son cuestiones vinculadas a las dinámicas articuladas en las que se configuran el género y la raza con relación a su particular modo de habitar la no formalidad. La inserción de las mujeres en el comercio da cuenta de una economía precaria que se juega en el día a día y que, como veíamos al inicio, sigue en pie e incluso da muestras de crecimiento.

Las entrevistas a dirigentes barriales y a responsables municipales buscaban, más bien, comprender los cambios, las negociaciones y las intermediaciones entre la dirigencia de la asociación y las bases y la política institucional vinculada a la regulación del comercio minorista en la ciudad. Como

Zonal de Quitumbe y del Censo del Comercio Autónomo en el Distrito Metropolitano de Quito (2011) encargado por la Secretaría de Desarrollo Productivo y Competitividad a la Pontificia Universidad Católica del Ecuador (PUCE) (Centro de Investigaciones Técnico-Sociales). 
decíamos, existen algunas investigaciones sobre el casco histórico de Quito y sobre sus mercados; sin embargo, y a pesar de estar conectadas con los procesos del centro, son pocas las que se desarrollan en los barrios del sur.

APROPIACIÓN ESPACIAL EN LA VENTA MINORISTA: ENTRE LA PRECARIEDAD Y EL NEGOCIO PROPIO

Para comprender el protagonismo femenino y la construcción de la ocupación por parte de las minoristas de calle, mediante sus estrategias de base territorial, proponemos tres entradas analíticas: (i) las movilidades y los asentamientos en la ciudad para la venta a través de las trayectorias; (ii) las políticas de regulación de la venta y el modo en que afectan la ubicación, las disputas por el espacio y la asociatividad; y (iii) los vínculos y las negociaciones localizadas en la calle (relaciones de las vendedoras con los locales, con el vecindario y su tejido asociativo).

Trayectorias de movilidad y asentamiento: migración, historia familiar y trabajo autónomo

Muchas vendedoras provienen de zonas rurales y están vinculadas con actividades de subsistencia agrícola y ganadera que, para ellas, desde niñas, se entretejieron con tareas domésticas. Observamos dos tendencias migratorias generacionales. La mitad de las entrevistadas tiene entre 20 y 30 años, y llegó a la Martha Bucaram durante el primer lustro de los años 2000. La otra mitad tiene entre 50 y 60 años, reside en el barrio desde hace unos 30 años y participó en su construcción.

Estas mujeres llegan desde parroquias rurales aledañas a Quito y provincias limítrofes, de ciudades como Riobamba, Cotacachi, Mitad del Mundo y Otavalo. Este patrón migratorio intergeneracional de género vinculado al trabajo (que teje un vínculo entre lo rural y lo urbano) no ha cesado, hecho que matiza una concepción rígida de la dicotomía entre trabajo urbano y trabajo agrícola. En la actualidad, aparece asociado con transformaciones del campo ecuatoriano que (con un impacto diferencial según el género) han suscitado una minifundización de las parcelas y una orientación hacia la agroindustria y, por tanto, hacia la proletarización del agro en la sierra (Martínez, 2014).

En el marco de las relaciones patriarcales, las mujeres han encontrado pocas oportunidades para estudiar, se han casado de forma temprana, han cargado con las responsabilidades domésticas aun en condiciones abusivas e, incluso, han subsidiado los estudios de sus hermanos. En la ciudad, encontraron en la venta una salida para mantenerse y mantener a sus hijos. Varias refieren haber llegado huyendo de situaciones de violencia por parte 
de padres o cónyuges. Alexandra migró en estas circunstancias y se encontró literalmente en la calle; poco a poco, y gracias a los vínculos que fue forjando, logró un espacio propio como vendedora:

Cuando yo tenía 18 años, no sabía de dónde darles de comer a los niños, porque estaba en la calle, vivía en la calle y dormí casi ocho días en la calle. Una amiguita, que tiene un ojito, me dijo: “¿por qué lloras?". "Porque no hay qué darles de comer a mis hijos" [...] [le respondí], "Yo te voy a enseñar", me dijo, "consíguete el charol, que es una madera con cajoncitos; anda al carpintero, píntale bien bonito y yo te presto la plata”. Y me fui, corrí y ya le hice el charolito, le cosí, lo puse aquí (señala su cintura). De ahí me prestó, me acuerdo que me prestó 10.000 sucres. Compramos tabacos, fósforos, mentas y los caramelos que más se venden y ya. Y yo me agachaba para vender, era así (se inclina). Mi amiga me decía: "no, mamita, jalza la cabeza!", y subíamos las dos así (se yergue), sube y baja. Y decía: "Señor, cómprele a ella porque ella no sabe vender".

Julia, una mujer indígena de 26 años, ayudaba a su madre en el campo y en la casa. Llegó a Quito con 18 años y trabajó en una panadería y un restaurante donde conoció a su esposo. Se fueron a vivir a la Martha Bucaram. Animada por su suegra, que ya vendía allí, armó un puesto de verduras y legumbres, que atendía tres días a la semana. Al enviudar comenzó a abrirlo a diario. La falta de educación, pero también el racismo, operan como fuertes restricciones:

La verdad que ya no, ya no había más. Para nosotros no hay trabajo, como no somos estudiados. Nada. Para nosotros no hay trabajo, mejor [...] [dedicarme] a [lo] que sea para dar de comer a mis hijas, mejor dedique aquí [sic]. Ya para no morir de hambre, ni tanto yo, ni tanto mis hijas. Para mantener. Mi esposo murió, ya no sabíamos a dónde ir, mejor dedique a mi negocio.

Otras mujeres tienen trayectorias urbanas en las que la venta forma parte de una historia familiar de largo recorrido. Melisa tiene 38 años, es madre de dos niños y está casada. Proviene de una familia de comerciantes que se dedicaba a la venta en el centro histórico y en Ambato, siendo su padre a la vez sastre. Él le enseñó a coser las carteras y los sacos que comercializaban. Mientras vivía en casa de sus padres se dedicaba a coser y así ayudaba con los gastos. Cuenta que puso su propio puesto en la Martha Bucaram porque su esposo tuvo problemas de columna y a ella "le tocó ayudarlo". Al inicio vendía en La Ecuatoriana, donde conoció a Bernardo, más tarde presidente de la AMB, y "tras las corridas" por parte del Municipio exploraron y se asentaron en la Martha Bucaram. 
Un caso similar es el de Beatriz, quiteña de 27 años, casada y con tres hijos. Desde los ocho años ayudó con la venta de frutas y legumbres en el céntrico mercado de San Roque. Al casarse se mudó a la Martha Bucaram. En 2012, estando sin trabajo, enfermó su hijo; su esposo ya vendía indumentaria allí, así que pidieron un préstamo y ella puso su puesto. Complementa sus ingresos con otras "chauchas", como lavar ropa a domicilio. "Vienen de todo lado", comenta Bernardo, y se quedan porque la venta funciona.

Para la mitad de las entrevistadas, la venta autónoma es una actividad en la que se iniciaron con la familia de origen, algunas desde los ocho años, llegando a ejercerla por su cuenta en distintos puntos de la ciudad. La vivencia de la ocupación se arraiga en un saber hacer que, combinado a un saber estar, permite ganarse un espacio en la calle. La otra mitad refiere trabajos, anteriores, ya sea en la agricultura o en otras actividades urbanas precarias como el empleo de hogar, que han ido alternando con la venta, y que las ha llevado a desplazarse por distintos barrios. Algunas probaron vender, les fue bien, y de ahí establecieron "su negocio". Para las mujeres, acontecimientos sobrevenidos como divorcios, enfermedades o viudez han sido decisivos a la hora de optar por la venta minorista, como también lo ha sido la maternidad, que han tenido que combinar para seguir garantizando ingresos mínimos. La necesidad de "coger el dinero diario" en caso de enfermedad o necesidades inmediatas da cuenta de que estas mujeres carecen de ahorros, ${ }^{17}$ y no pueden esperar a final de mes para recibir un sueldo. Pocas refieren empleos formales y estables previos, pero incluso para ellas entrar y salir de la venta ha sido una posibilidad altamente flexible que les permitió bandearse en situaciones complicadas. Ana, de 31 años, es madre soltera de una nena de cinco. Antes de tener su puesto de venta de indumentaria, trabajó como dependienta y cajera en el Dunkin' Donuts, con un contrato que estipulaba condiciones que difícilmente se cumplían. Su madre, con la que vive, le ayuda con la niña, pero esta se enfermó y la venta fue la estrategia para poder seguir cuidando de su hija. Mara, de 37 años, divorciada y con dos hijos, vive con su madre y su hermano, y trabaja como azafata en el trolebús por un salario básico. Los domingos ayuda a su madre en el puesto, con lo que también contribuye a la economía familiar.

Para las mujeres de sectores populares, el trabajo autónomo en el pequeño comercio se perfila como un mecanismo general de inserción laboral precaria. Como señalan Alison Vásconez y Elizabeth Espinosa (2014), esta opción, a diferencia de lo que sucede con los hombres, cobra importancia cuando se convierten en jefas de hogar al incorporarse a la división sexual del trabajo con

17 Según el Censo de Vendedores Autónomos (2011), el 86\% de los vendedores no accede a crédito alguno. 
$\mathrm{y}$ sin ingreso, fuera y dentro de casa. Se trata de una fuente de renta inmediata que, como señalan las vendedoras, puede ser regulada por ellas mismas "sin estar esclavizada al mando de otro". "Yo - dice María Rosa- me ordeno mejor, eso es mi beneficio porque no estoy ordenada de nadie". Cuando existen otras fuentes de ingreso se suele espaciar la venta; cuando estas decrecen o desaparecen, se intensifica.

El trabajo de campo reveló que las restricciones actúan con mayor fuerza cuando hay cargas familiares, menores ingresos, menor educación, migración rural e identificación indígena. Tanto el sentimiento de vulnerabilidad y la fragilidad ante eventualidades como la responsabilidad en el cuidado condicionan la inclinación por un modo de existencia en el que el ingreso es inmediato: "mientras no haya trabajo, usted no puede soltar". A pesar de la fragilidad, la idea de autonomía configura un fuerte sentir vinculado al negocio propio que da cuenta de una trayectoria de asentamiento progresivo. Se trata de un proceso de territorialización anclado a los derechos adquiridos a partir de la regularidad en el puesto (diario, de ciertos días, de fin de semana o incluso "de temporada"), así como al giro, el producto específico que además de la ubicación caracteriza al/la vendedor/a ante sus "vecis" (vecinos). Esto entraña reconocimiento, afianzando el derecho a permanecer, si bien es preciso advertir que la movilidad y la versatilidad siguen siendo rasgos prominentes en el comercio minorista. Si lo que se vende incorpora algún tipo de manipulación, por ejemplo de alimentos, la vivencia del negocio como propio se acrecienta. Así ocurre con Mario, que además de asociarse con su hijo para traer quesos de Manabí y armar el puesto a diario, confecciona licor, dulces y otros productos de su tierra en un pequeño almacén arrendado en una calle paralela no muy lejos de su casa. Al principio, según comenta, no conocían esos alimentos, pero ahora los distribuye "a pedido" por el sur de la ciudad.

Para las mujeres indígenas, la autonomía se mide, por ende, respecto a la memoria de explotación (y trabajo infantil) en otras actividades que, como el trabajo doméstico, implican un fuerte legado de servidumbre y racismo en sus trayectorias vitales. Aunque el testimonio de Alejandra se refiera a la venta, detrás se esconden sentimientos previos respecto al trabajo: "Si quiero salgo, si no quiero no salgo, y si quiero me como mis cosas, no tengo que decirle: 'señora, ¿̨puedo comer un poquito?', o estarme muriendo de hambre; me cojo, me sirvo, les sirvo y como".

No es que el comercio minorista se libre de esta carga, pero el "negocio" propio, término recurrente, sigue representando no solo una mayor flexibilidad para cuidar a los hijos y garantizar la subsistencia, sino un mayor grado de autonomía, reconocimiento y autoestima ante los suyos, en la calle y ante la sociedad. 


\section{"LA ALEGRÍA DEL BARRIO": ORDENACIÓN DE LA VENTA, DISPUTA CON EL MUNICIPIO E IMPULSO ASOCIATIVO}

Ganarse la venta y la calle forma parte del día a día. Este ejercicio de territorialización ha estado estrechamente vinculado a la regulación del comercio minorista en los últimos años, en la medida en que formaciones, permisos y patentes ${ }^{18}$ se convertían en un elemento crucial a la hora de establecerse. El periodo de la administración municipal de Alianza País (2009-2014) implicó un cambio al implementarse una política que, inspirada en la "despatologización” de la informalidad y el resguardo del derecho al trabajo, buscaba simultáneamente preservar el derecho al espacio público. Esto se tradujo en un ejercicio de ordenación de la venta mediante la emisión de permisos. Según explica el propio exalcalde Augusto Barrera, se creó un censo, se tipificaron las modalidades de venta y se establecieron adscripciones espaciales, al mismo tiempo que se impulsaban ferias y se creaban Centros Populares de Ahorro. Todo esto, que se experimentó con mayor intensidad en el centro histórico, contribuyó también, junto con otras medidas, a generar nuevas centralidades en barrios lejanos donde estas políticas llegaban con distintas intensidades. Frente a administraciones anteriores, la regulación apareció aquí vinculada al fortalecimiento de lo público y a la capacidad de la administración para repartir derechos y responsabilidades.

Para las vendedoras, la Martha Bucaram fue un destino interesante que comenzó a crecer, según cuentan, hace unos siete años, por los factores ya señalados. Como relatan las minoristas, con la apertura de nuevos comercios y puestos en la avenida se gestó un efecto de atracción que se fue retroalimentando hasta crear una rica trama de encuentros e interacciones. Así lo cuenta Gabriela:

Nosotros vinimos acá porque no vimos tanta competencia, tanto comercio. [...] A nosotros nos dicen vulgarmente que somos "la alegría del barrio", porque nosotros venimos, salimos viernes, sábado y domingo y esto está pintado, y aquí es una alegría que el barrio le da. Cuando nosotros no estamos, no hay nada.

Los efectos de la regulación y el control de la venta también se hicieron presentes en la $\mathrm{AMB}$, hecho que suscitó de parte de las vendedoras una actitud de pugna. Según narra un dirigente, ante las reiteradas batidas municipales, tres vendedores, más tarde dirigentes de la asociación, comenzaron a reunir firmas para presentar a la Administración Zonal de Quitumbe. De

18 La patente permite a las vendedoras ocupar el espacio a cambio de un pago de $\$ 11,25$ anuales. 
ahí, en asamblea, decidieron hacer un registro con el que abrieron una vía de reconocimiento y negociación con la administración, contrataron a un abogado y legalizaron la asociación, inicialmente con unas 40 socias, que en poco tiempo llegaron a ser 85 . Tal y como sentencia una líder de la $A M B$, una vendedora mestiza, refiriéndose a los reclamos de los permisos prometidos que hicieron entonces, la responsable "nos atropelló, nos dijo que eramos indios". "Nos engañaron -sostiene otra vendedora-, hicimos la formación de 15 horas, pero no nos dieron los permisos". A pesar del espíritu de desestigmatización y dignificación del comercio en el marco de la economía popular, y de la Ordenanza N.o 0280, la persecución y la incautación de mercadería siguió generando descontento. Para las vendedoras, la creación de la Asociación está directamente vinculada a este nuevo contexto en el que esta se convierte en un valioso recurso que les dota de una presencia y una voz ante el municipio que, como explicó Bernardo, quejándose de la actual dirigencia, es preciso mantener: "la dirigencia tiene que estar siempre en el municipio, estar al tanto de lo que está pasando para proteger a 'su gente".

Además del acoso en la calle y la emisión efectiva de los permisos, las entrevistas realizadas recogen el sentimiento de amenaza ante la posibilidad de ser confinadas en el Mercado Municipal Ciudadela Ibarra, más conocido como "la plataforma", ubicado junto al parque. Las vendedoras rechazaron desplazarse a esta ubicación por estar fuera del tránsito peatonal o salieron del allí su construcción en 2009, y nuevamente en 2013: "los ecuatorianos -afirma Marcia- somos muy vagos, queremos todo a la manita”. Esta idea de accesibilidad cotidiana basada en el regateo, el menudeo y la proximidad sería un rasgo distintivo de lo que Alice Beuf (2011), refiriéndose a los sectores periféricos de Bogotá, denomina centralidades populares, donde las prácticas de tránsito y de consumo se distancian de las de las grandes superficies comerciales, confiriendo carácter al lugar.

Bernardo, anterior presidente de la Asociación, explica que no están en contra de un centro comercial mixto como el que se hizo en la Michelena; de hecho, enfatiza que es una de sus aspiraciones, pero ha de reunir ciertos requisitos para transformarse en un espacio de venta diaria. Gabriela coincide con esta aspiración:

Claro, esa es una de las demandas principales. O sea, tener un lugar estable, seguro donde nosotros podamos estar y decir "esto ya es mío". O sea, un local, sí, un local se podría decir. Donde ya se pueda salir a trabajar y volverse a la casa [...]. Necesitamos un centro de comercialización para ya no estar cargando, vaciando, trayendo los palos, dejando los palos, en ese "vaivén". 
La idea del centro con locales mantiene a la dirigencia masculina en conversaciones y atrae a las vendedoras. Estas sospechan de cualquier iniciativa que en lo inmediato implique salir de la calle sin garantías según Bernardo:

[...] para llevar esa propuesta nosotros socializamos primero con nuestra gente, entonces dijeron ellos "perfecto". Incluso nosotros al municipio le propusimos, le dijimos "nosotros no queremos que nos regalen nada, queremos poner 50/50,70/30", no sé, llegar a un acuerdo. Entonces los comerciantes llegamos a un acuerdo igual, que nosotros no queríamos que nos regalen todo, que, si es de poner mano de obra, poníamos mano de obra, ponemos algo, que no sea gratis. Entonces el municipio aceptó todo esto y está aceptado, sino que, como le digo, con la última directiva que hubo se destruyó todo, no se destruyó, está planteado porque yo he hablado con las autoridades, es que eso tiene que seguir [...].

El anterior municipio no dio respuesta a este reclamo, mientras que el actual, con el que la AMB y la FEDECOMIP mantienen una relación de apoyo más o menos pactada que les ha brindado cierta laxitud en los controles, tampoco ha dado señales claras al respecto.

La dirigencia ha modulado la aproximación y el alejamiento del municipio y los partidos según la coyuntura; "tenemos relación con las autoridades competentes -explica Bernardo-, obviamente cada quien usa políticamente la cuestión”. Este tipo de intermediaciones políticas en el día a día, como señala Diana Silva Londoño (2008) para el caso de los ambulantes del centro histórico de la Ciudad de México, ponen en cuestión la interpretación estrecha en términos de clientelismo y hablan de las intersecciones entre vida cotidiana para la supervivencia y política partidaria. En Quito, han tenido una clara influencia en las movilizaciones por la base durante las elecciones presidenciales de febrero de 2017, en las que el avance de la derecha entre los sectores populares del sur formaba parte de la agenda de la oposición ante un escenario de pérdida de popularidad por parte de Alianza País, que encontró en el exceso de control un poderoso argumento. ${ }^{19}$ Más que una derechización de la población o una penetración de la lógica emprendedora individualista, lo que encontramos, más bien, es una larga historia de autogestión para la supervivencia que encuentra escasas contrapartidas en las propuestas planteadas. Esto se entreteje, por ende, con la tradicional desconfianza popular respecto al Estado, que ahora exige afiliaciones, patentes y otros requerimientos que se consideran como onerosos, además de una forma de exposición y vigilancia.

19 Durante la segunda fase del trabajo de campo, en un mismo fin de semana se dieron cita en la Martha Bucaram la sabatina del presidente saliente Rafael Correa y el Taita Carnaval de Guaranda, auspiciado por el candidato de derecha Guillermo Lasso. 
En definitiva, la formación de la AMB está directamente vinculada a la pugna por mantener el espacio a través de las intermediaciones de la dirigencia en el día a día con el municipio y la expectativa de lograr un centro. Respecto a esto último, algunas afirman haber perdido las esperanzas:

No sé, aquí hay algunas que quieren seguir aquí mismo en el negocio, algunas ya no quieren porque no hay esperanzas del municipio. Algunas ya se retiraron incluso; de tanta gente que éramos socios, como 100 éramos, ahora creo que apenas estamos 40 , ya se fueron decepcionados.

Los responsables de la Administración Zonal de Quitumbe, que hablan de la avenida como uno de los "puntos críticos" de la zona, justamente por el comercio "ilegal”, recrean de forma enfática el lenguaje de la "invasión" descontrolada, asociada a la migración internacional y nacional tras el terremoto, a la delincuencia, a la insalubridad y a la ocupación de la vereda. Además, acusan a los dirigentes de maniobrar políticamente y defender intereses personales:

Ahí es cuando entra el eje político, porque ellos defienden el comercio ilegal. El comercio ilegal ya se convierte en un derecho, y obviamente los presidentes de las asociaciones tienen acercamientos políticos para que defiendan el comercio ilegal, porque ellos viven de eso, cobrar el espacio público, obligan a los comerciantes a pagar y ellos viven de eso.

Desconsideran rotundamente la idea de un nuevo centro por la falta de recursos y plantean como alternativa hacer atractiva la plataforma (con un punto de recaudación de servicios básicos, subastas, ferias, actividades culturales, etcétera).

El hecho de que los presidentes de las asociaciones siempre hayan sido varones refuerza la naturaleza generizada de la representación y de los espacios de negociación municipal y partidaria, tema que merecería un desarrollo más detenido. ${ }^{20} \mathrm{El}$ salto a la política se ha producido desde este tipo

20 Cada vez que nos dirigíamos a las vendedoras, estas nos remitían al presidente, lo cual dificultó el trabajo de campo. Manejan, como también señala Silva Londoño (2008) el término "ayuda" para referirse a la actuación de los dirigentes. "El uso de los eufemismos permite que la solución de favores no sea entendida como un derecho sino como un favor que los líderes de comerciantes hacen a los comerciantes de base y de este modo, establecen las obligaciones para regresar el favor del que son beneficiarios. En este caso, además de las cuotas, mantener limpio el puesto, atender bien a los clientes, tener buenas relaciones entre compañeros" (ibid.: 60). 
de organizaciones. En esto las mujeres se ubican más bien en el terreno de la subsistencia y de la delegación. En todo caso, todas, particularmente las indígenas, coinciden en que la $\mathrm{AMB}$ ha implicado que las reconozcan y las respeten, tanto así que otros comerciantes de la zona se han hecho pasar por miembros de la misma, sin serlo. En la fotografía de abajo, la señora Blanca muestra con orgullo los sacos que han confeccionado para distinguirse tanto ante los oficiales del distrito como ante otros comerciantes. Por lo general, las vendedoras son reacias a la entrada de nuevos miembros que pudieran reclamar el mismo reconocimiento y los mismos derechos potenciales ante la administración. Han pasado de ser vendedoras cualesquiera a ser de la $\mathrm{AMB}$, una pertenencia que movilizan en las relaciones sociales que les permiten ganarse la calle.

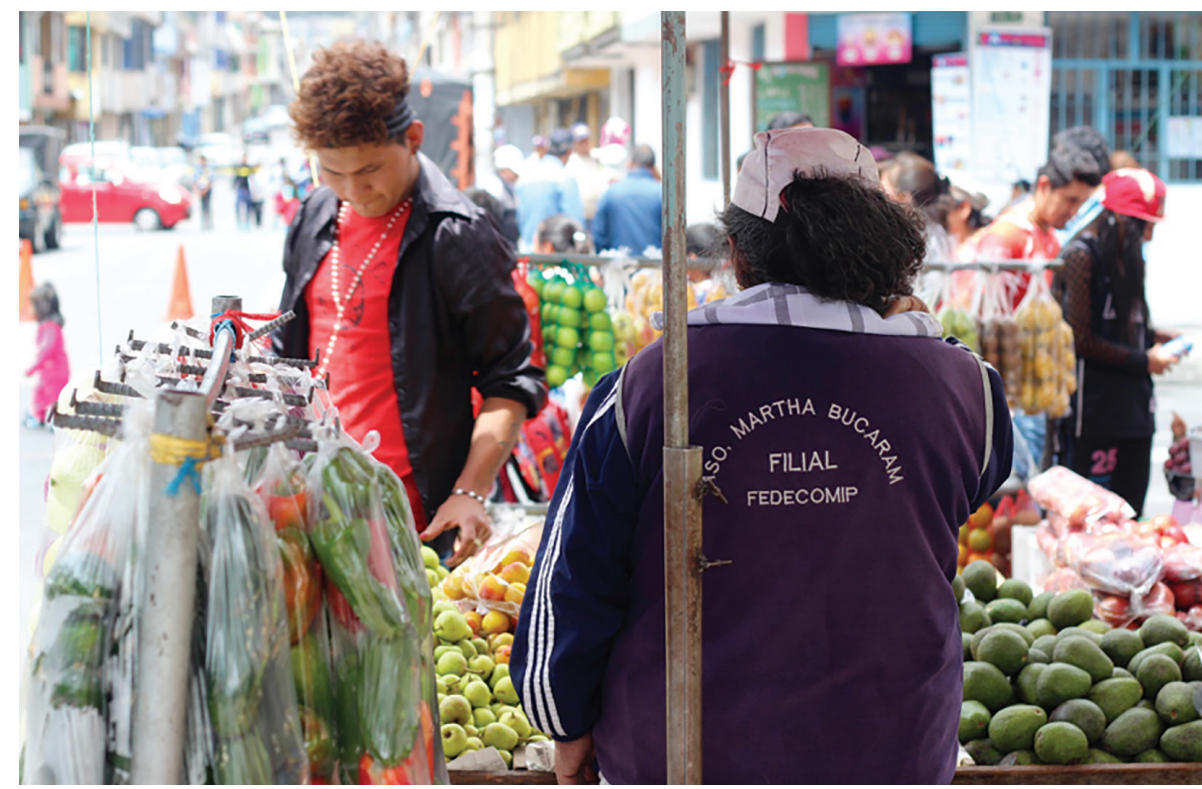

Vendedora de la AMB. (Fotografía de las autoras, mayo de 2016.)

Apelando a las nuevas normativas, las dirigencias evocan su identificación como trabajadoras "autónomas" o "por cuenta propia", mientras que las asociadas siguen refiriéndose a "su negocio", hecho que da cuenta de una vía particular en la apropiación tanto del espacio como de la ocupación. Bernardo, ya afincado en un local, presenta la relación de continuidad entre estar en la acera y haberse ubicado en un comercio de arriendo, cuyo precio alcanza los 500 dólares, con una fachada totalmente abierta a la calle, si bien otras vendedoras reconocen que se trata de otro escalón 
en la consecución del negocio. Haber plantado cara a la Administración Zonal de Quitumbe ha supuesto, para ellas, un lugar distintivo respecto del cual se miden con quienes recién llegan a la AMB. El hecho de que muchas sean residentes y hayan asistido al desarrollo del barrio no hace sino afianzar este sentimiento en la ocupación. El local propio cataliza las aspiraciones de ascenso de muchas de ellas. Se trata de una alternativa a los trajines cotidianos, aunque no acaban de confiar en su viabilidad y delegan en los varones las tareas de intermediación institucional.

\section{"Al puesto hay que cuidarlo": vínculos, conflictos y negociaciones de calle}

Tal y como sosteníamos en el punto anterior, ganarse la calle entraña un mundo de relaciones y de interacciones que se entablan entre vendedoras, con los locales y, en general, con el vecindario, de forma directa o a través de la AMB. Todo ello implica un saber hacer y un saber estar cuyos códigos, a pesar de no ser explícitos, emergen cuando preguntamos acerca de los procedimientos, los conflictos o las estrategias. Es ahí cuando las normas y las legitimidades ganadas sobre el espacio se hacen patentes, revelando (además de un singular modo de ser en la informalidad) la existencia de una esfera pública autoorganizada. ${ }^{21}$

El elemento central para pensar estos vínculos es la propia ubicación, el tipo de transacciones que ayudan a mantenerla y hacerla reconocible ante los demás. La antigüedad en la calle da prioridad para mantener el espacio, que en los mejores tramos de la avenida (en "la malla", lugar donde la Asociación coloca una pequeña carpa) ha sido marcado en la pared por las comerciantes, como se aprecia en la siguiente fotografía.

21 No afirmamos que se trate de una esfera ideal o exenta de relaciones de poder, ni mucho menos; tampoco que sus principios rectores estén desconectados de la moral inscrita en las ordenaciones oficiales. Su concepción, no obstante, se distancia en ocasiones de las concepciones de urbanismo y urbanidad propugnadas de forma unilateral, visible, integrada y aparentemente igualitaria sobre las que el Estado manifiesta su indiscutible autoridad (Delgado y Malet, 2007). 


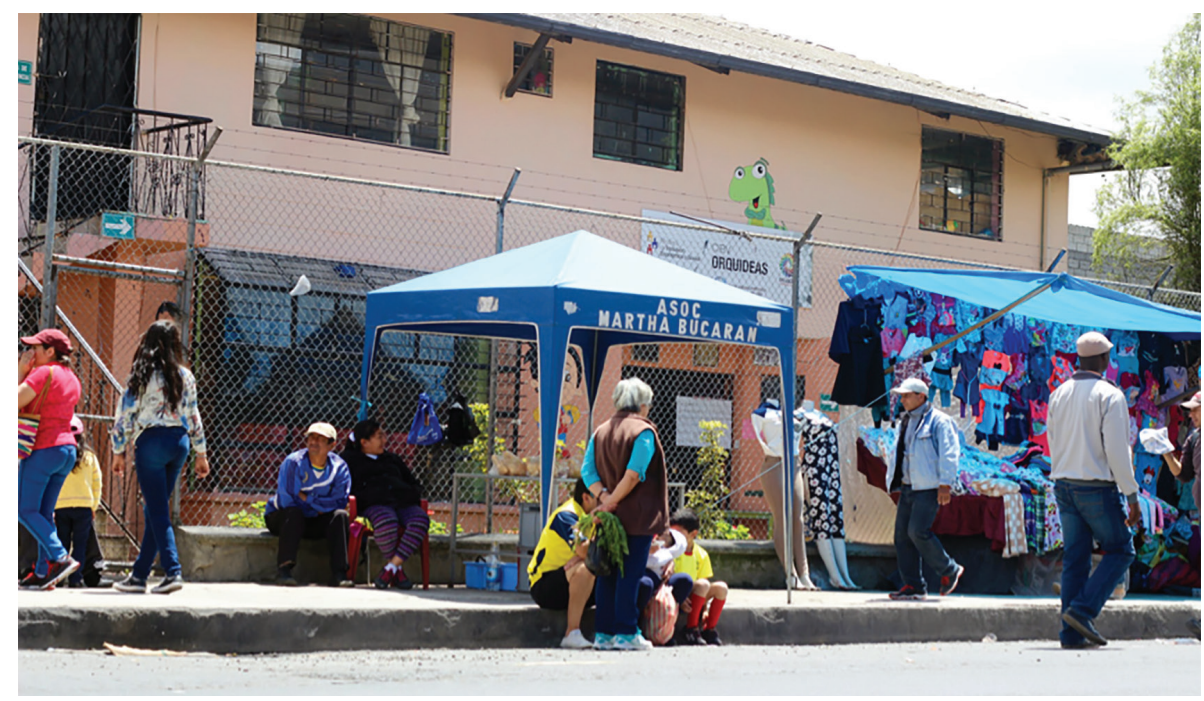

Carpa de la AMB en la malla frente al Centro Infantil el Buen Vivir. (Fotografía de las autoras, mayo de 2016.)

Es preciso entender que, además de las ambulantes, hay vendedoras que salen todos los días, otras que arman el puesto los fines de semana e incluso otras que aparecen regularmente ciertos días y circulan intermitentemente por distintos mercados y ferias donde ya han ganado un lugar. "Cuidar el puesto" implica, entonces, presencia y regularidad, al igual que participación en las negociaciones que se establecen entre los distintos actores. Asociarse, aparte de ser una estrategia de reconocimiento de cara a la administración, implica asimismo asumir ciertas normas de conducta, lo que se conoce como "trabajar bien". Algunas vendedoras dicen que la AMB ya no admite socias porque son muchas, pero no todas coinciden en este punto, y hay también quienes venden sin estar asociadas. En efecto, los pactos diarios operan más allá de la Asociación. Si bien esta es interpelada en caso de conflicto, la práctica habitual es que sean las propias vendedoras las que disputen el espacio, acudiendo a los argumentos que les permiten legitimar su presencia.

Además de antigüedad y de regularidad, un elemento clave para defender la ubicación es el tipo de producto comercializado. Existe un código implícito respecto al equilibrio entre la proximidad de giros idénticos, siendo esto una fuente de discordia. Cuando la señora Beatriz, vecina antigua del barrio, comenzó a vender en la avenida Martha Bucaram, tras moverse desde Chillogallo hace ya siete años, se situó en una de las mejores esquinas, frente a un local que también vendía verduras. Tras un periodo de tira y afloja logró quedarse. Ella misma insiste en que si llega alguien a su lado, con el mismo giro, llama al resto y "la echamos peleando". Esta vendedora ha ampliado el puesto en una red familiar con distintas ubicaciones. Dos hijas y un hijo venden al lado, 
ocupando todo el esquinazo, mientras que otra vende pinchos enfrente, en las tardes. Otro hijo está más arriba, en otro tramo de la calle.

$\mathrm{El}$ anterior presidente de la $\mathrm{AMB}$ mencionó un acuerdo tácito para prohibir el monopolio. El municipio acudió al censo de los comerciantes para depurar la lista; si se repite el apellido, se da prioridad a otra vendedora, solo se permiten dos puestos por familia. Tal y como comentó Bernardo, el municipio viene constantemente: “isaben quiénes somos cada uno!". Sin embargo, lo habitual es que las redes de comercio y parentesco se solapen, en ocasiones ganando espacio para el mismo puesto, en otras situándolo en otro emplazamiento y manteniendo un flujo de intercambios que recrean y fortalecen tanto a la familia como la venta. Diego, que coloca su mercadería junto a la de su hijo, ocupa los fines de semana un hueco, dos metros más arriba, en la confluencia con otra calle, un excelente punto de venta que ha ganado durante esos días. En este sentido, quienes "cuidan el puesto" pueden expandir su radio de acción mejorando su ubicación e incorporando a otros familiares.

Esta articulación entre venta minorista y familia resulta en una estrategia fundamental para las mujeres, especialmente para las jefas de hogar con niños pequeños, en la medida en que les permite cuidarlos y al mismo tiempo obtener un ingreso y algo de apoyo. Las hijas de Julia apoyan el trabajo de su madre y aprenden el oficio como ella lo aprendió previamente. A las 13 horas acuden a la escuela, pero antes han madrugado para ir al mayorista, trasladado la mercadería desde un almacén próximo, armado el puesto en la malla y ayudado a desgranar choclo y a vender.

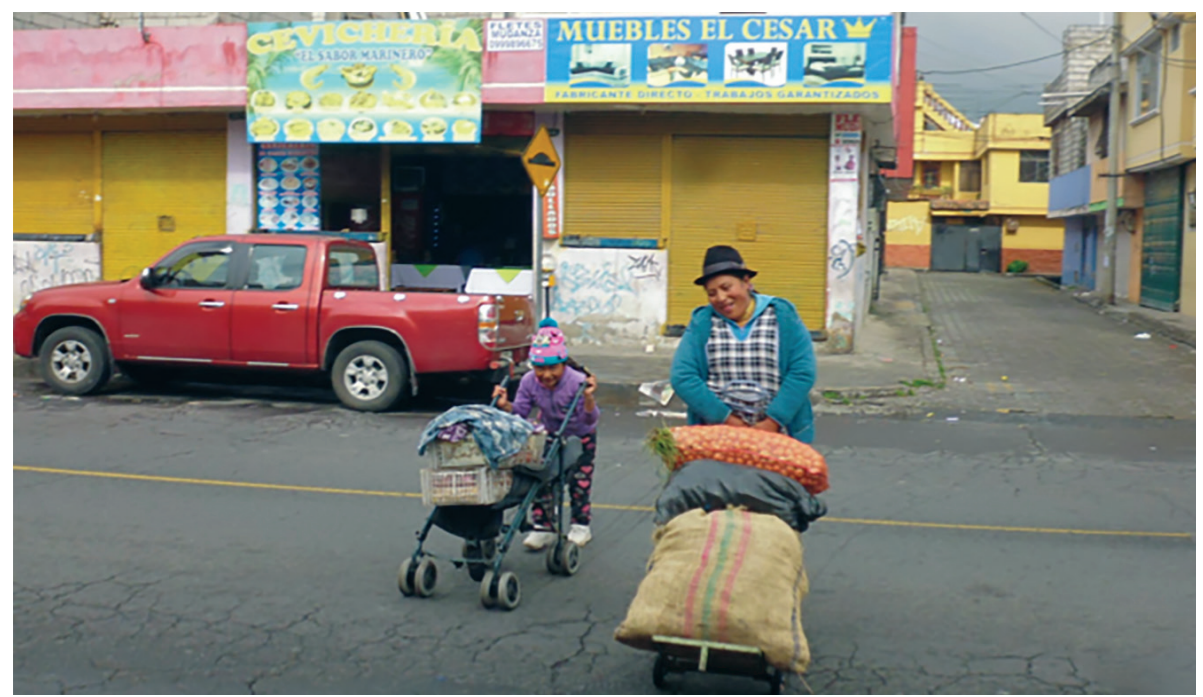

Julia y una de sus hijas, al fondo el portón del almacén. (Fotografía de las autoras, mayo de 2016.) 
El lunes es el día de descanso, pero el relato apenas revela un momento para detenerse. Los ingresos son bajos, y si los niños enferman no se puede salir, de modo que, como dice Melisa, "hay que estirar los piececitos hasta donde la cama nos dé", conjugando la atención a la familia y al negocio. Las comerciantes desarrollan un sentido de autonomía subsumida: valoran, como veíamos, la independencia que les brinda salir o no salir, no ser "mandadas", poder responder a eventualidades familiares o cuidar y contar con el apoyo de los hijos, pero esto implica intensificar el trabajo y estar expuestas a fuertes fluctuaciones en la venta (Saltzmann, 2016). En este orden de cosas, la subsistencia es un imperativo.

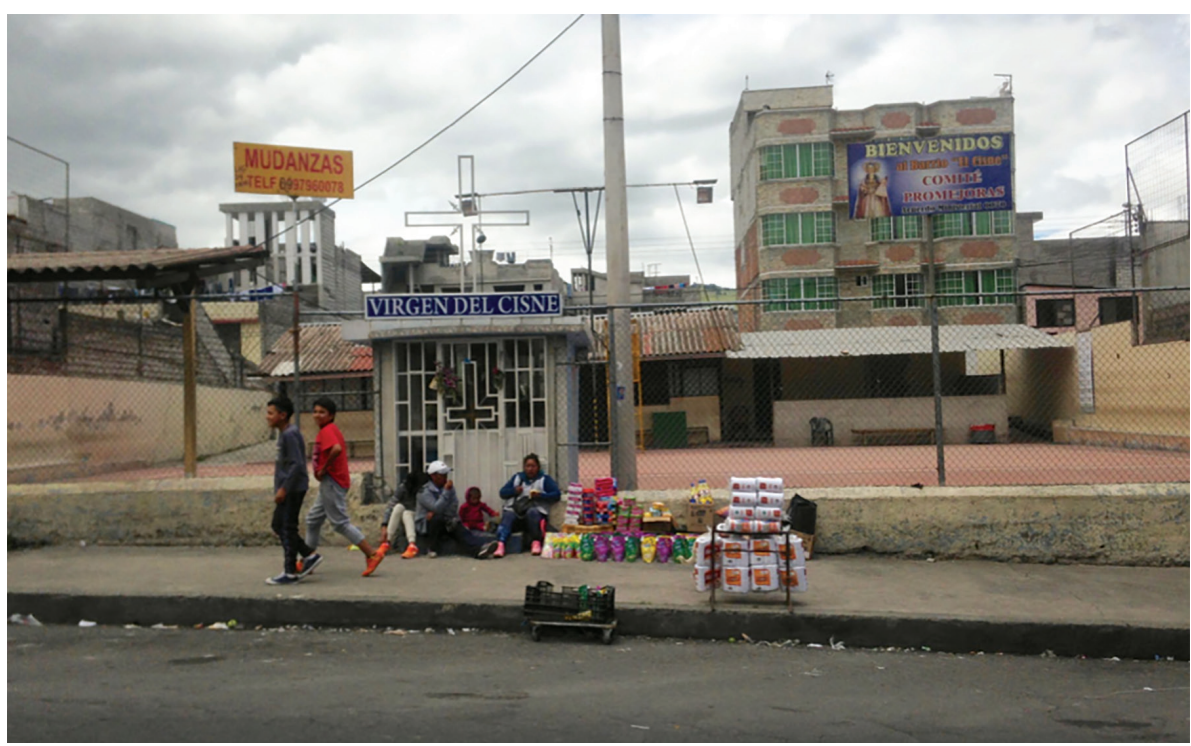

Vendedora con su esposo y sus hijos en la entrada de la cancha. (Fotografía de las autoras, mayo de 2016.)

Las que ocupan el espacio de la malla (contrariamente a lo que ocurre con la vendedora de la fotografía de arriba) disfrutan de una de las mejores ubicaciones. En la pared se pueden ver las marcas de los puestos en pintura amarilla. El nuevo director del Centro Infantil del Buen Vivir se opuso fuertemente a que las vendedoras estuvieran en la calle y mandó distintos oficios al municipio. Fue entonces cuando se abrió una negociación en la que también se hizo presente la AMB. Demostrar que se "trabaja bien" implicó en este, como en otros casos, establecer los términos de un intercambio material y simbólico: los comerciantes se ofrecieron a invertir y pavimentar la vereda para que esta fuera más accesible y aseada, 
para que luciera mejor, a cambio de poder seguir vendiendo. Esto y "mandar sacar a los del pescado", que se habían hecho pasar por miembros de la Asociación, fueron las bases del acuerdo. Ahí se saldó el conflicto, restituyendo un orden propio en la calle.

$\mathrm{Al}$ igual que la relación entre vendedoras, en la relación con los locales y los vecinos de la avenida se revelan expresiones de conflicto, pero también de cooperación. Beatriz narra su llegada a la AMB y los acuerdos a los que fue llegando:

Yo, antes..., me hacían problema porque yo no era de la Asociación, me decían que tengo que ser de la Asociación para permanecer en el lugar, si no que coja mis cosas y me busque otro sitio. Porque hay competencia entre compañeras mismo. Entonces cuando yo vine a ponerme me ponía en las mallas. Entonces había una compañera que era grosera y vino [a] hacerme alzar a la mala, y mi esposo dijo, "vámonos al frente, al frente no hay nadie del comercio de ropa”. Nos pasamos acá al frente y el dueño de la casa me permitió dejarme [quedarme] aquí. Igual cuando abrieron el local aquí, toda la planta baja es arrendada y la señora que alquila el local también me dijo "puede no más quedarse aquí". Me permitió ponerme acá, en este lado. Entonces dijo: "solo que le pido que no me tape las...". Entonces eso le trato yo de cumplir a la señora, para que no me mande, porque si es por la dueña de casa, me mandara. Hay otras gentes que es [son] dueñas de casa y no dejan que se pongan en las casas, ni las de los locales mismo.

A medida que se traban las relaciones, estas posibilitan nuevas oportunidades y recursos: uso de luz, arriendo de bodegas como almacén, limpieza y arreglos de la vereda, cuidado recíproco de puestos y locales, compra de alimentos, vigilancia, ayuda para armar el puesto, etcétera. Bernardo, que inicialmente vendía en el suelo, en la malla, acabó arrendando un local gracias a la amistad que entabló con una vecina. Tal y como reveló un estudio previo en la Martha Bucaram sobre venta directa (Vega y Bermúdez, en prensa al momento de escribir este artículo), la alianza entre estas vendedoras y los locales es una estrategia fructífera tanto para colocar la mercadería como para cuidar. También, en ocasiones, estas mujeres acaban situando pequeños puestos en las aceras. El acceso al local marca una jerarquía en cuyos extremos se hallan quienes venden en los autobuses, pasando calamidades, extorsiones, malos tratos y siendo tildados de delincuentes, y las caseras, que ya han ganado un puesto fijo en la avenida; aun estas últimas se quejan de los metropolitanos, así como de las fatigas de la calle; "es un desastre vender en la calle”, comenta Blanquita. Para Mara, la sociabilidad que entrańa la venta es una ayuda potencial en caso de necesidad: 
P: ¿Qué le gusta de este trabajo y qué no le gusta?

R: A veces lo que no me gusta es que no se vende todo. Y lo que me gusta, me fascina, es la atención al cliente. Soy sociable, me catalogo sociable. Tengo amistades. Me gusta socializar con la gente para [que] después de un tiempo haya o no haya alguna ayuda.

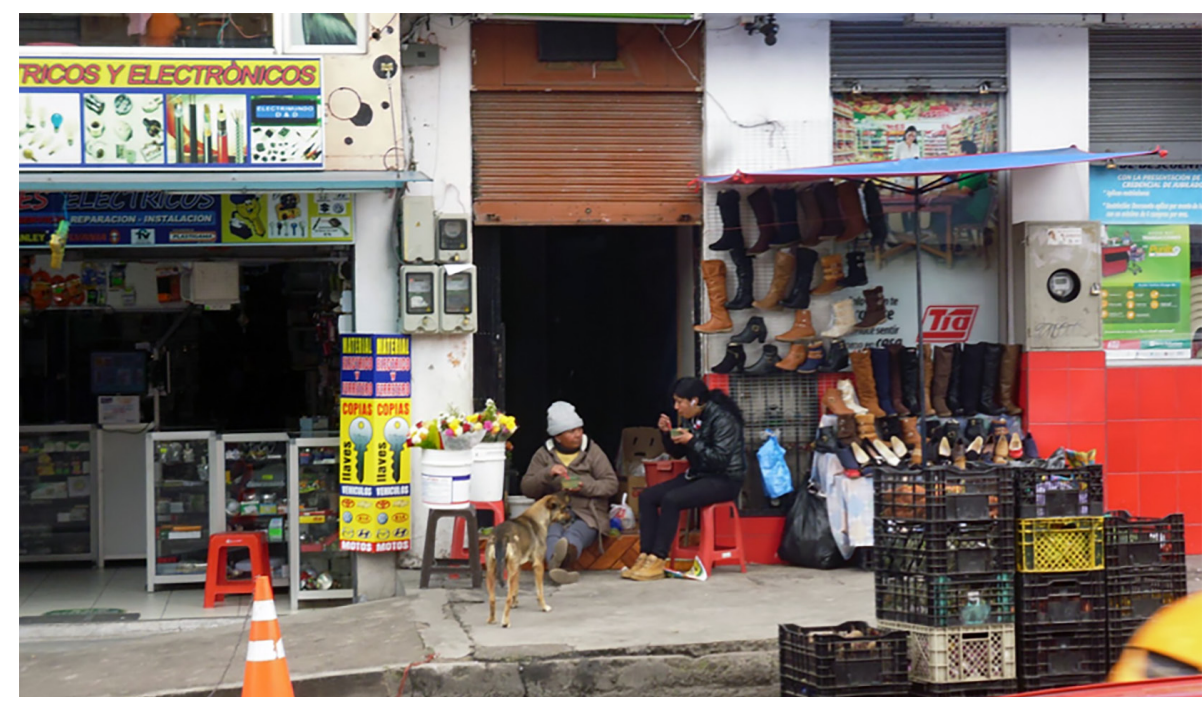

Vendedora instalada delante de locales. (Fotografía de las autoras, mayo de 2016.)

La calle está hecha de vínculos, negociaciones y conflictos que afianzan la familia y la atención a los hijos a través del negocio y viceversa, protegiéndolo frente a intrusos y garantizando una serie de recursos materiales y sociales que resguardan la actividad. Todo ello implica, como veíamos, "trabajar bien", una suerte de combinación entre la gestión pactada del espacio y el establecimiento de vínculos de cooperación y reciprocidad que garantizan la permanencia.

\section{CONCLUSIONES}

En los últimos años, la avenida Martha Bucaram se ha convertido en una nueva subcentralidad popular en el radio de acción de Quitumbe. Las minoristas han ido llegando a esta avenida atraídas por las conexiones y las posibilidades que ofrece el espacio o, por esto mismo, han optado por vender donde ya residían. Lejos de ser parte de una "invasión" descontrolada, una plaga que se expande por la ciudad y que debe ser frenada o desplazada, imagen evocada frecuentemente por la administración, la venta en la calle revela 
un universo de cooperación, conflicto y negociación que, como ponen de manifiesto otros estudios, incorpora sus propias jerarquías, códigos y valores desde los que se legitima el derecho a permanecer (o ser expulsado) y desde los que se traman acuerdos con el municipio.

Para las mujeres, ocupar y ocuparse en la calle es un modo de subsistencia, en ocasiones heredado, en ocasiones producto de la vulnerabilidad o las eventualidades de la vida, que se afianza a partir de la construcción de un territorio, así sea temporal o discontinuo. Marcar el puesto y llegar a acuerdos con locales, vecinas y entre vendedoras entraña una comprensión de lo que significa "trabajar bien", algo que forma parte de una cultura popular de calle que, como sugiere Eduardo Kingman, se erige en "una economía moral, capaz de garantizar un mínimo de recursos y solidaridad en condiciones de amenazas comunes" (1999: 16). Para las minoristas, afirmarse en "su negocio", arraigándolo en la ciudad, es una forma de contrarrestar tanto la falta de oportunidades en el mundo salarial (sobre todo entre las indígenas) como las explotaciones y las discriminaciones sufridas en otros sectores informales en los que se integraron, particularmente el servicio doméstico o la venta ambulante. Se evidencia así una autonomía subsumida que, si bien les permite obtener recursos al día, beneficiarse de una gran flexibilidad para atender a los suyos y algunos apoyos de proximidad, involucra precariedad en cuanto al ingreso y fatigas asociadas al trabajo a la intemperie y a la exposición a las políticas reglamentadoras de turno.

Con relación a esto último, se advierte que, si bien las iniciativas llevadas a cabo por el municipio de la Revolución Ciudadana plantearon un nuevo marco de comprensión sobre la venta de calle como parte del derecho al trabajo, compatible con el derecho a la ciudad, gracias a la regulación, esta no ha dado sus frutos en lo que se refiere a la efectividad de las medidas y, en un sentido más general, a la creación de la cultura política de lo público propugnada desde la institucionalidad. El hecho de que no se hayan emitido permisos en esta área, tras la realización de estudios, censos, capacitaciones y normativas, y de que las expectativas de lograr un centro de comercialización mixto se hayan visto frustradas, junto con la continuidad del acoso en la calle, han acrecentado el ya arraigado sentimiento de sospecha respecto al Estado y lo que se interpretan como mecanismos de vigilancia y control. Este ha sido, sin lugar a dudas, el caldo de cultivo en el que ha ganado posiciones la derecha, que se ha expresado en el plano electoral.

Si bien los dirigentes varones de la AMB han manejado estas diferencias para establecer un terreno de reconocimiento y tratos con los agentes municipales, y en ocasiones para proyectarse políticamente, las asociadas han delegado estas tareas, al mismo tiempo que se han mantenido al tanto para resguardar su puesto y poder optar, en caso de darse la posibilidad, a un espacio 
propio donde afincarse en mejores condiciones, una expectativa común a todas ellas. Entre tanto, su presencia en las veredas de la avenida, una "problemática" para quienes aspiran a "limpiar" las calles, se trama en redes de alcance familiar y local. Más que un "desborde económico popular indígena", como el descrito por algunos autores, cuyos protagonistas "negocian en los intersticios de la economía global desde sus propias historias y sus propias formas de relacionamiento", alentados por la experiencia "de nadar en las aguas de las reglas ambiguas y las 'seguridades jurídicas' cambiantes” (Tassi, Arbona, Ferrufino y Rodríguez-Carmona, 2012: 97), lo que encontramos aquí son expresiones locales de una ocupación para la supervivencia que tras una trayectoria de constante movilidad por la ciudad aspira a afincarse y a preservar su frágil autonomía ("no estar ordenada de nadie"). Este sentido de la ocupación, en sus declinaciones femeninas y masculinas, se legitima a partir de una densa trama familiar y vecinal de negociaciones y conflictos que, lejos de representar un desorden absoluto, apuntan a la existencia de una cultura popular urbana que se alimenta y enfrenta a las expectativas frustradas de casi una década de Revolución Ciudadana. 
568 | Trabajos y trabajadores en América Latina (siglos XVI-XXI)

BiBLIOGRAFÍA

Achig Subía, Lucas

1983 El proceso urbano de Quito (ensayo de interpretación). Quito: Centro de Investigaciones CIUDAD.

Abramo, Laís y Cecilia Montero

2000 "Origen y evolución de la sociología del trabajo en América Latina". En: Enrique de la Garza Toledo (comp.), Tratado Latinoamericano de Sociología del Trabajo. México D. F.: Fondo de Cultura Económica.

2004 "La sociologie du travail en Amérique Latine: un essai de périodisation". En: Sociologie du Travail, volumen 46, número 1. 12-26.

Abreu, Alice y Bila Sorj

1993 O trabalho invisivel. Estudos sobre trabalhadores a domicilio no Brasil. Río de Janeiro: Rio Fundo.

Antunes, Ricardo

2015 "Los modos de ser de la informalidad: ¿hacia una nueva era de la precarización estructural del trabajo? (tema central)". En: Ecuador Debate, número 94. 69-79.

2011 "La nueva morfología del trabajo y sus principales tendencias: informalidad, infoproletariado, (in)materialidad y valor". En: Sociología del Trabajo, número 74. 47-66.

Barragán, Rossana

2009 "Más allá de lo mestizo, más allá de lo aymara: organización e identidades de clase y etnicidad en el comercio callejero en la ciudad de La Paz". En: Eduardo Kingman (comp.), Historia social urbana. Espacios y flujos. Quito: Facultad Latinoamericana de Ciencias Sociales-Ecuador.

Benería, Lourdes

2006 "Trabajo productivo/reproductivo, pobreza y políticas de conciliación”. En: Nómadas, número 24. 8-21.

Benería, Lourdes y María Floro

2006 La persistencia de la desigualdad. Género, trabajo y pobreza en América

Latina. Quito: Consejo Nacional de las Mujeres / Facultad Latinoamericana de Ciencias Sociales-Ecuador / Secretaría Técnica del Frente Social / Rispergraf.

Beuf, Alice

2012 "Concepción de centralidades urbanas y planeación del crecimiento urbano en la Bogotá del siglo XX”. Ponencia presentada en el 
XII Coloquio Internacional de Geocrítica: "Las independencias y construcción de estados nacionales: poder, territorialización y socialización, siglos XIX-XX”, Bogotá.

2011 "Les centralités à Bogotá, entre compétitivité urbaine et équité territoriale". Tesis de doctorado en Geografía. Université Paris Ouest Nanterre La Défense, Nanterre, Francia.

Carbonetto, Daniel

1985 "Notas sobre la heterogeneidad y el crecimiento económico en la región". En: El sector informal urbano en los paises andinos. Quito: Instituto Latinoamericano de Investigaciones Sociales / Centro de Formación y Empleo para el Sector Informal Urbano.

Cardoso, Fernando Enrique y Enzo Faletto

1977 Dependencia y desarrollo en América Latina: ensayo de interpretación sociológica. Buenos Aires: Siglo XXI.

Carrión, Fernando

2005 "El centro histórico como objeto de deseo". En: Fernando Carrión y Lisa Hanley (eds.), Regeneración y revitalización urbana en las Américas: hacia un Estado estable. Quito: Facultad Latinoamericana de Ciencias Sociales-Ecuador.

Colectivo Precarias a la Deriva

2004 A la deriva, por los circuitos de la precariedad femenina. Madrid:

Traficantes de Sueños.

Coraggio, José Luis

2002 "La economía social como vía para otro desarrollo social". En: José Luis Coraggio, De la emergencia a la estrategia: más allá del "alivio de la pobreza". Buenos Aires: Espacio Editorial.

Cuti Martins, Cleber

2006 "Informalidade e conflicto: a Relação dos Vendedores Ambulantes com a Prefeitura e a Câmara de Vereadores de Porto Alegre". En: Elías Medeiros Vieira y Romério Jair Kunrath (coords.), Trabalho e ciudadanía no Brasil. Puerto Alegre, Brasil: Faculdade Cenecista de Osório, Universidade Federal do Rio Grande do Sul / Programa de Pós-graduação em Ciência Política, Universidade Federal do Rio Grande do Sul.

Das Neves Bezerra, Gustavo

2012 "Mercadores ambulantes das praias do Rio de Janeiro. Subjetividades e economia política". En: María Julia Soul (comp.), El mundo del trabajo en América Latina. Tendencias y resistencias. Buenos Aires: Consejo Latinoamericano de Ciencias Sociales. 
De la Garza, Enrique

2011 "Introducción: construcción de la identidad y acción colectiva entre trabajadores no clásicos como problema”. En: Enrique de la Garza (coord.), Trabajo no clásico, organización y acción colectiva. Tomo I. Ciudad de México: Universidad Nacional Autónoma de México.

Delgado, Manuel y Daniel Malet

2007 El espacio público como ideología. Jornadas Marx, siglo XXI. Universidad de la Rioja, Legroño / Institut Català d'Antropologia / Universitat de Barcelona.

Denning, Michael

2010 "Wageless Life". En: New Left Review, número 66. 79-97.

Díaz, Ximena; Lorena Godoy y Antonio Stecher

2005 Significados del trabajo, identidad y ciudadania: la experiencia de hombres $y$ mujeres en un mercado laboral flexible. Santiago de Chile: Centro de Estudios de la Mujer.

Echebarría, Carmen; Itziar Aguado y José María Barrutia

2010 "El desarrollo sostenible a lo largo de la historia del pensamiento económico". En: Revista de Economía Mundial, número 21. 87-110.

Instituto Nacional de Estadística y Censos (Ecuador)

2016 Reporte de Economía Laboral-Marzo 2016. Quito: Dirección de Estudios y Análisis de la Información.

Farrell, Joseph y Ernesto Schiefelbein

1985 "Education and Status Attainment in Chile: A Comparative Challenge to the Wisconsin Model of Status Attainment". En: Comparative Education Review, número 9. 490-506.

Gago, Verónica

2015 La razón neoliberal. Economías barrocas y pragmática popular. Buenos Aires: Tinta Limón.

Godoy, Lorena y Antonio Stecher

2008 "La experiencia de mujeres asalariadas en Santiago de Chile: sentidos del trabajo e identidades de género". En: Betty Espinosa (coord.), Mundos del trabajo: pluralidad y transformaciones contemporáneas.

Quito: Facultad Latinoamericana de Ciencias Sociales-Ecuador.

Gómez Solórzano, Marco y Celia Pacheco Reyes

2014 Trabajo informal, economía solidaria y autogestión: precariedad laboral y resistencia en la globalización. Buenos Aires: Ediciones Continente. 
Guadarrama, Rocío; Alfredo Hualde y Silvia López

2012 "Precariedad laboral y heterogeneidad ocupacional: una propuesta teórico-metodológica". En: Revista Mexicana de Sociología, volumen 74, número 2. 213-243.

Hanley, Lisa y Meg Ruthenburg

2005 "Los impactos sociales de la renovación urbana: el caso de Quito, Ecuador". En: Fernando Carrión y Lisa Hanley (eds.), Regeneración y revitalización urbana en las Américas: hacia un Estado estable. Quito: Facultad Latinoamericana de Ciencias Sociales-Ecuador.

Harding, Sandra

1998 Is Science Multicultural?: Postcolonialisms, Feminisms, and Epistemologies, Race, Gender and Science. Bloomington, Indiana, Estados Unidos de América: Indiana University Press.

Harvey, David

2013 Ciudades rebeldes. Del derecho a la ciudad a la revolución urbana. Madrid: Akal.

2004 El nuevo imperialismo. Madrid: Akal.

Hintze, Susana

2010 La politica es un arma cargada de futuro: la economía social y solidaria en Brasily Venezuela. Buenos Aires: Fundación Centro de Integración, Comunicación, Cultura y Sociedad / Consejo Latinoamericano de Ciencias Sociales.

Kabeer, Naila

2001 "Reflections on the Measurement of Women's Empowerment". En: Anne Sisask (ed.), Discussing Women's Empowerment: Theory and Practice. SIDA Studies, número 3. Swedish International Delopment Cooperation Agency, Estocolmo, Suecia.

Kingman, Eduardo

2014 La ciudad y los otros. Quito 1860-1940. Higienismo, ornato y policía. Quito: Facultad Latinoamericana de Ciencias Sociales-Ecuador.

2009 Historia social urbana. Espacios y flujos. Quito: Facultad Latinoamericana de Ciencias Sociales / Ministerio de Cultura.

Kingman, Eduardo y Blanca Muratorio

2014 Los trajines callejeros: memoria y vida cotidiana. Quito, siglos XIX-XX. Quito: Instituto Metropolitano de Patrimonio. 
572 | Trabajos y trabajadores en América Latina (siglos XVI-XXI)

Kingman, Eduardo y Ton Salman

1999 Antigua modernidad y memoria del presente: culturas urbanas e identidad. Quito: Facultad Latinoamericana de Ciencias Sociales-Ecuador.

Martínez, Luciano

2014 "De la hacienda al agronegocio: agricultura y capitalismo en Ecuador". En: Guillermo Almeyra, Luciano Concheiro Bórquez, João Márcio Mendes Pereira y Carlos Walter Porto-Gonçalves (coords.), Capitalismo: tierra y poder en América Latina (1982-2012) Bolivia, Colombia, Ecuador, Perú, Venezuela. Buenos Aires: Consejo Latinoamericano de Ciencias Sociales.

Neffa, Julio; Enrique de la Garza y Leticia Muñiz (coords.)

2009 Trabajo, empleo, calificaciones profesionales, relaciones de trabajo e identidades laborales. Buenos Aires: Consejo Latinoamericano de Ciencias Sociales.

Nun, José

1969 "Superpoblación relativa, ejército industrial de reserva y masa marginal". En: Revista Latinoamericana de Sociología, volumen V. Centro de Investigaciones Sociales del Instituto Torcuato Di Tella.

Organización Internacional del Trabajo

2016 Panorama Laboral 2016 América Latina y el Caribe. Lima:

Organización Internacional del Trabajo, Oficina Regional para América Latina y el Caribe.

Olivo Pérez, Miguel Ángel

2010 Vendedores ambulantes en el Centro Histórico de la ciudad de México: Estigmas y aprendizajes en su ocupación. México D. F.: Universidad Autónoma Metropolitana.

Ortiz, Santiago y Elvira Martínez

1999 "La propiedad, un sueño realizado: relato oral de los pobladores de La Argelia". En: Ton Salman y Eduardo Kingman (eds.), Antigua modernidad y memoria del presente. Culturas urbanas e identidad. Quito: Facultad Latinoamericana de Ciencias Sociales-Ecuador.

Pereira Morató, René; Eugenia Bridikhina, Jaime Montaño y Ramiro Blanco 2008 "Espacio compartido: espacio urbano y comercio informal en la ciudad de La Paz". Informe de medio término, Proyecto del Programa de Investigación Estratégica en Bolivia (PIEB). La Paz: PIEB. 
Pérez Sáinz, Juan Pablo

1995 "Globalización y neoinformalidad en América Latina". En: Revista Nueva Sociedad, número 135. 36-41.

Portes, Alejandro y William Haller

2004 La economía informal. Serie Políticas Sociales. Santiago de Chile: CEPAL.

Pérez Sáinz, Juan Pablo y Minor Mora Salas

2009 "Excedente económico y persistencia de las desigualdades en América Latina". En: Revista Mexicana de Sociología, año 71. 411-451.

Rodríguez Morató, Arturo

2008 "La emergencia de una capital cultural europea". En: Mónica Degen y Soledad García (eds.), La metaciudad: Barcelona. Transformación de una metrópolis. Barcelona: Anthropos.

Silva Londoño, Diana Alejandra

2008 "Comercio ambulante y su relación con el sistema político institucional en el Distrito Federal de México". En: Betty Espinosa (coord.), Mundos del Trabajo. Pluralidad y transformaciones contemporáneas. Quito: FLACSO-Ecuador.

Singer, Paul

2001 "Economía Social: posibilidades y desafíos". Charla presentada en el Sindicato de Ingenieros en Río de Janeiro. Evento promovido por el Núcleo de Trabajo y Renta de FASE Nacional y coordinado por Rosemary Gomes. Disponible en: http://www.dhl.hegoa.ehu.es/ ficheros/0000/0179/economia_solidaria_posibilidades_y_desafios.pdf

Tarrés, María

2007 "Las identidades de género como proceso social: rupturas, campos de acción y construcción de sujetos”. En: Rocío Guadarrama y José Luis Torres (coords.), Los significados del trabajo femenino en el mundo global. Estereotipos, transacciones y rupturas. Madrid: Anthropos.

Tassi, Nico; Juan M. Arbona, Giovanna Ferrufino y Antonio Rodríguez-Carmona 2012 "El desborde económico popular en Bolivia. Comerciantes aymaras en el mundo global”. En: Nueva Sociedad, número 241 (septiembreoctubre). 93-105.

Todaro, Rosalba y Sonia Yáñez

2004 El trabajo se transforma. Relaciones de producción y relaciones de género. Santiago de Chile: Centro de Estudios de la Mujer. 
574 | Trabajos y trabajadores en América Latina (siglos XVI-XXI)

Tokman, Víctor E.

1987 "El imperativo de actuar. El sector informal hoy". En: Revista Nueva Sociedad, número 90. 70-86.

Unda, Mario

2000 Como rayo en el cielo sereno. Reflexiones acerca de la participación popular en el Ecuador. Quito: Centro de Investigaciones CIUDAD.

Vásconez, Alison

2016 Mujeres ecuatorianas dos décadas de cambios 1995-2015. Quito: ONU Mujeres Ecuador.

Vásconez, Alison y Elizabeth Espinosa

2014 Ecuador: Empoderamiento económico de las mujeres. Producción y reproducción de sesgos de género en el mundo del trabajo. Quito: PNUD / AECID.

Veleda da Silva, Susana

2003 "Trabajo informal, género y cultura: el comercio callejero e informal en el sur de Brasil". Tesis de doctorado. Universidad Autónoma de Barcelona, España. 



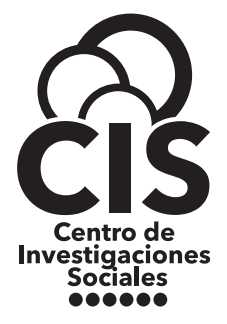

Este libro se terminó de imprimir en septiembre de 2019, en los talleres de Grupo Impresor, en La Paz (Bolivia). 

El trabajo es una experiencia multifacética que nos constituye en nuestra cotidianidad. Atraviesa los tiempos y, sin embargo, la "historia laboral" se ha restringido a la de los obreros de la industria (desde fines del siglo XIX), olvidando a los no asalariados permanentes y a los sujetos a diferentes grados de coacción, como también a las mujeres y sus múltiples modalidades laborales. Las reflexiones sobre el trabajo atraviesan igualmente las fronteras, aunque las establecidas entre los académicos del sur con los del norte pueden ser más habituales que las existentes entre los propios países de América Latina. No menos importante resulta subrayar que hay pocos espacios para compartir experiencias e investigaciones sobre la temática laboral entre historiadores, sociólogos o antropólogos, entre algunas de las miradas de las ciencias sociales.

Trabajos y trabajadores en América Latina (siglos XVI-XXI) busca sobrepasar esas limitaciones para repensar qué es trabajo, y sus fronteras, sistematizar las tendencias historiográficas existentes y revisar los conflictos en torno al trabajo, así como analizar la informalidad y la precariedad laboral. Son estos cinco ejes los que estructuran en las páginas de este libro los aportes y las reflexiones de más de 30 estudiosos de distintos países latinoamericanos, gracias a un largo esfuerzo colectivo de instituciones y de investigadores.

Rossana Barragán
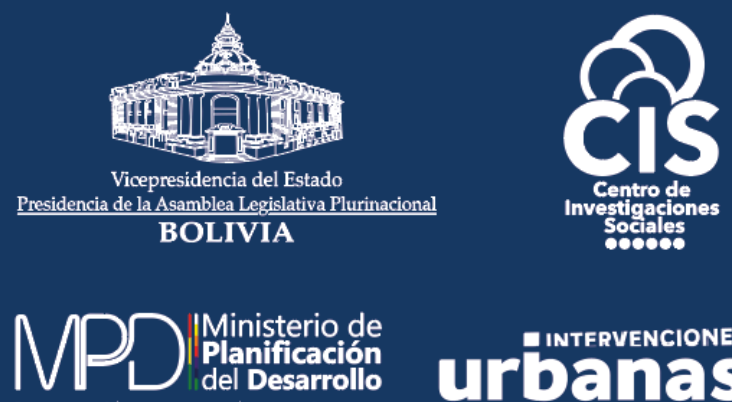

Ministerio de Planificación del Desarrollo

\section{urbannas}
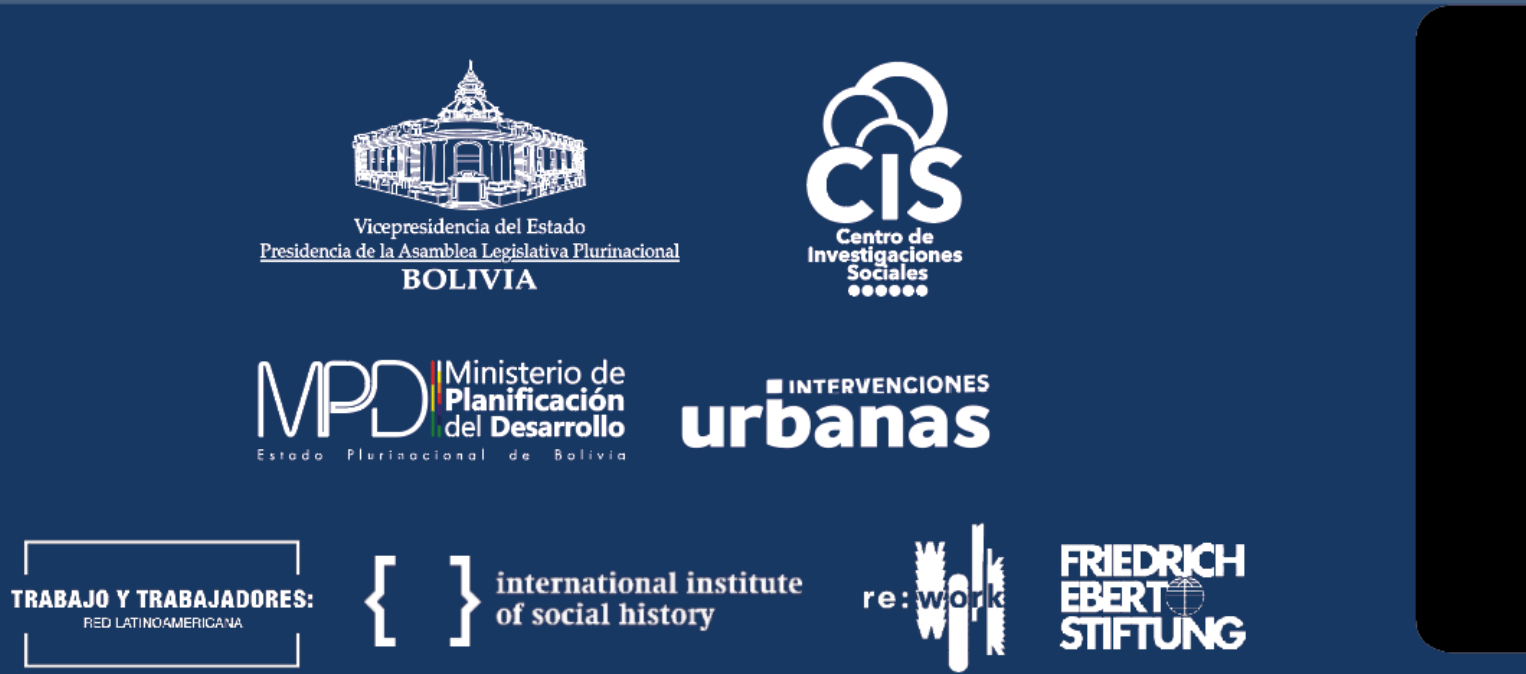